\title{
GOVERNANCE AND CITY REGIONS
}

\section{POLICY AND PLANNING IN EUROPE}

\section{Regional Studies}

A leading \& impactful community

REGIONS AND CITIES

KARSTEN ZIMMERMANN AND PATRICIA FEIERTAG

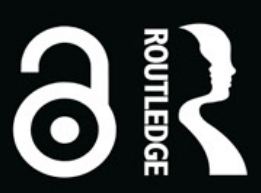




\section{Governance and City Regions}

City-regions are areas where the daily journeys for work, shopping and leisure frequently cross administrative boundaries. They are seen as engines of the national economy, but are also facing congestion and disparities. Thus, all over the world, governments attempt to increase problem-solving capacities in city-regions by institutional reform and a shift of functions.

This book analyses the recent reforms and changes in the governance of city-regions in France, Germany and Italy. It covers themes such as the impact of austerity measures, territorial development, planning and state modernisation. The authors provide a systematic cross-country perspective on two levels, between six city-regions and between the national policy frameworks in these three countries. They use a solid comparative framework, which refers to the four dimensions functions, institutions and governance, ideas and space. They describe the course of the reforms, the motivations and the results, and consequently, they question the widespread metropolitan fever or resurgence of city-regions and provide a better understanding of recent changes in city-regional governance in Europe.

The primary readership will be researchers and master students in planning, urban studies, urban geography, political science and governance studies, especially those interested in metropolitan regions and / or decentralisation. Due to the uniqueness of the work, the book will be of particular interest to scholars working on the comparative European dimension of territorial governance and planning.

Karsten Zimmermann is Professor for European Planning Cultures at the Faculty of Spatial Planning, Dortmund Technical University, Germany.

Patricia Feiertag is a postdoctoral researcher at the Faculty of Spatial Planning, Dortmund Technical University, Germany. 


\section{RSA Resisnal studes}

A leading \& impactful community

\title{
Regions and Cities
}

Series Editor in Chief

Joan Fitzgerald, Northeastern University, USA

Editors

Roberta Capello, Politecnico di Milano, Italy

Rob Kitchin, Maynooth University, Ireland

Jörg Knieling, HafenCity University Hamburg, Germany

Nichola Lowe, University of North Carolina at Chapel Hill, USA

In today's globalised, knowledge-driven and networked world, regions and cities have assumed heightened significance as the interconnected nodes of economic, social and cultural production, and as sites of new modes of economic and territorial governance and policy experimentation. This book series brings together incisive and critically engaged international and interdisciplinary research on this resurgence of regions and cities, and should be of interest to geographers, economists, sociologists, political scientists and cultural scholars, as well as to policy-makers involved in regional and urban development.

\begin{abstract}
About the Regional Studies Association (RSA)
The Regions and Cities Book Series is a series of the Regional Studies Association (RSA). The RSA is a global and interdisciplinary network for regional and urban research, policy and development. The RSA is a registered not-for-profit organisation, a learned society and membership body that aims to advance regional studies and science. The RSA's publishing portfolio includes five academic journals, two book series, a Blog and an online magazine. For more information on the Regional Studies Association, visit www.regionalstudies.org.

There is a $\mathbf{3 0 \%}$ discount available to RSA members on books in the Regions and Cities series, and other subject-related Taylor and Francis books and e-books including Routledge titles. To order, simply email Luke McNicholas (Luke.McNicholas@tandf.co.uk), or phone on +44 (0)20 70177545 and declare your RSA membership. You can also visit the series page at www.routledge.com/Regions-and-Cities/book-series/RSA and use the discount code: RSA225
\end{abstract}

146. The Confines of Territory

Edited by John Agnew

147. The Randstad

A Polycentric Metropolis

Edited by Wil Zonneveld and Vincent Nadin

148. Planning Regional Futures

Edited by John Harrison, Daniel Galland and Mark Tewdwr-Jones

149. Border Cities and Territorial Development

Edited by Eduardo Medeiros

150. Metropolitan Governance in Latin America

Edited by Alejandra Trejo-Nieto and José L. Niño-Amézquita

151. Governance and City Regions

Policy and Planning in Europe

Karsten Zimmermann and Patricia Feiertag

For more information about this series, please visit: www.routledge.com/Regions-and-Cities/ book-series/RSA 


\section{Governance and City Regions Policy and Planning in Europe}

\section{Karsten Zimmermann and Patricia Feiertag}




\section{Cover image: () Patricia Feiertag}

First published 2022

by Routledge

2 Park Square, Milton Park, Abingdon, Oxon OX14 4RN

and by Routledge

605 Third Avenue, New York, NY 10158

Routledge is an imprint of the Taylor \& Francis Group, an informa business

(C) 2022 Karsten Zimmermann and Patricia Feiertag

The right of Karsten Zimmermann and Patricia Feiertag to be identified as authors of this work has been asserted in accordance with sections 77 and 78 of the Copyright, Designs and Patents Act 1988.

The Open Access version of this book, available at www.taylorfrancis. com, has been made available under a Creative Commons Attribution-Non Commercial-No Derivatives 4.0 license.

Trademark notice: Product or corporate names may be trademarks or registered trademarks, and are used only for identification and explanation without intent to infringe.

\section{British Library Cataloguing-in-Publication Data}

A catalogue record for this book is available from the British Library

Library of Congress Cataloging-in-Publication Data

Names: Zimmermann, Karsten, author. I Feiertag, Patricia, author.

Title: Governance and city regions: policy and planning in Europe/Karsten

Zimmermann and Patricia Feiertag.

Description: Abingdon, Oxon; New York, NY: Routledge, 2022. I

Series: Regions and cities RSA I Includes bibliographical references and index.

Identifiers: LCCN 2021040868 (print) I LCCN 2021040869 (ebook) I

ISBN 9781032063645 (hardback) I ISBN 9781032063652 (paperback) I

ISBN 9781003201922 (ebook)

Subjects: LCSH: Metropolitan government-Europe. I Metropolitan

areas-Government policy-Europe. I Regional planning-Europe.

Classification: LCC JS3000.25.Z56 2022 (print) | LCC JS3000.25 (ebook) |

DDC 320.8/5094-dc23

LC record available at https://lccn.loc.gov/2021040868

LC ebook record available at https://lccn.loc.gov/2021040869

ISBN: 978-1-032-06364-5 (hbk)

ISBN: 978-1-032-06365-2 (pbk)

ISBN: 978-1-003-20192-2 (ebk)

DOI: $10.4324 / 9781003201922$

Typeset in Sabon

by Deanta Global Publishing Services, Chennai, India 


\section{Contents}

List of figures vii

List of tables

Acknowledgements $\quad \mathrm{x}$

List of abbreviations xii

About the authors xvi

1 Introduction: City-regions in Europe 1

K. ZIMMERMANN AND P. FEIERTAG

1.1 The rise of territorial reforms in Europe's city-regions? 1

1.2 Research question and research design 7

1.3 Comparing city-regions and local government systems 14

1.4 Short view on cases 18

1.5 Methods 21

Notes 26

References 26

2 France

P. FEIERTAG

2.1 City-regions and their governance in France 33

2.2 Multi-scaled governance of Nantes: métropole and bipolar metropolitan region 49

2.3 Lyon: powerful institution with a (too) small perimeter 70

2.4 Conclusion: recent changes of city-regional governance in France 98

Notes 109

References 111

3 Italy

K. ZIMMERMANN

3.1 Metropolitan policies and institutional reforms in Italy 118 
vi Contents

3.2 The Città Metropolitana di Bologna: frontrunner for territorial cooperation in Italy? 137

3.3 The Città Metropolitana di Firenze: mismatch of socioeconomic regionalism, territory and jurisdiction 154

3.4 Conclusion: recent changes of city-regional governance in Italy 174

Notes 177

References 178

\section{Germany}

P. FEIERTAG AND K. ZIMMERMANN

4.1 Metropolitan governance in Germany 187

4.2 Frankfurt/Rhine-Main: still a fragmented territory? 203

4.3 Stuttgart: well established showcase example of metro governance? 222

4.4 Interpretation and conclusion: the steady relevance of city-regions 252

Notes 255

References 257

5 Cross-country comparison

P. FEIERTAG AND K. ZIMMERMANN

5.1 Institutions 262

5.2 Functions 267

5.3 Ideas 271

5.4 Spatial relationships 273

References 275

6 Conclusion

K. ZIMMERMANN AND P. FEIERTAG

6.1 The three countries in a European context 277

6.2 City-regions and the consolidation state: what drives reforms and what are the results in terms of institutions, spatial relationships and functions? 288

Notes 293

References 294

Annex

Index 


\section{Figures}

1.1 City-Regions in Italy (Città Metropolitane), France (Métropole) and Germany (Metropolregionen and Planungsverbände) 22

2.1 Development of municipal groupings from 2007 to $2020 \quad 35$

2.2 Pôles métropolitains in $2017 \quad 38$

2.3 Map of métropoles by the French government 45

2.4 Planning regions for SCoT 49

2.5 Nantes in the multilevel system 61

2.6 Inter-SCoT area of Nantes 63

2.7 Constituencies for direct election of the metropolitan council 80

2.8 Spatial definition of the metropolitan region of Lyon 82

2.9 Métropole de Lyon 83

2.10 Institutional organisation within the Inter-SCoT area of Lyon 88

2.11 Map development axes from the common chapter of the Inter-SCoT de l'aire métropolitaine lyonnaise $\quad 90$

3.1 Città Metropolitane d'Italia 127

3.2 Municipalities and municipal unions in the CM Bologna, areas in white are non-associated municipalities 143

3.3 ATOs and municipal unions 146

3.4 Municipalities and municipal unions in the CM Florence 160

3.5 Piana Fiorentina 161

3.6 Piana Fiorentina, administrative boundaries with Pistoia, Prato and Florence 164

4.1 Metropolitan regions and Regionalverbände in Germany 190

4.2 Map competitiveness in the updated spatial vision 2016

4.3 Representation of metropolitan regions in Germany 1997 and $2006 \quad 201$

4.4 Evolving delimitation of metropolitan regions used by
IKM monitoring

4.5 Planning regions for regional plans 204 
viii Figures

4.6 Frankfurt/ Rhine-Main region 206

4.7 Frankfurt/ Rhine-Main region in the multilevel system 214

$\begin{array}{lll}4.8 & \text { Stuttgart Region } & 223\end{array}$

4.9 Stuttgart in the multilevel system of Baden-Württemberg 242

4.10 Imaginary of the metropolitan region 246

4.11 Area of validity of the Metropolticket 251 


\section{Tables}

1.1 Dimensions for comparison 13

1.2 Case study city-regions 18

1.3 Categories in the dimension of ideas 25

2.1 The 22 French Métropoles 36

2.2 Overview of compulsory responsibilities of municipal groupings according to the MAPTAM law 40

2.3 Enlargement of métropoles by additional member municipalities between 2010 and 2020 (March 2020) 46

2.4 Nantes in the multilevel system 61

2.5 Layers of planning documents in the city-region of Nantes 62

2.6 Lyon in the multilevel system $\quad 84$

2.7 Layers of planning documents in the city-region of Lyon 89

3.1 Milestones in metropolitan policy 123

3.2 Città Metropolitane 126

3.3 Unioni di Comuni in the CM Bologna 141

3.4 Unioni di Comuni in the CM Firenze 159

4.1 European Metropolitan Regions in Germany 191

4.2 Regionalverband Rhine Main in the multilayer system of the Regierungsbezirk Southern Hesse 207

4.3 Networks and initiatives with participation of planning authority 221

4.4 Layers of government 228

4.5 Shareholdings of Stuttgart Region 234

4.6 Layers of planning documents 243

5.1 Metropolitan authorities in the six city-regional case studies 265 


\section{Acknowledgements}

This book is the result of a three-and-a-half year long empirical research that was possible due to the generous support of the Deutsche Forschungsgemeinschaft (DFG) under grant number ZI 1164/8-1 (research project "Steuerung und Planung in Metropolregionen im Wandel. Ein internationaler Vergleich in den Ländern Deutschland, Italien und Frankreich"). The empirical work regarding cases studies in six city-regions and three countries was carried out by us, two German researchers with good French and Italian language skills. However, without the help of colleagues from France and Italy the results of this research would have been much more limited. The empirical work in the four city-regions in Italy in France benefitted from great support and invaluable help of colleagues and friends. Our words of thanks go to Camilla Perrone, Maddalena Rossi, Andrea Lippi, Ignazio Vinci and Valeria Fedeli for Italy and Christophe Demazière, Benoit Dugua and Isabelle Garat for France. They helped us finding interview partners, did some interviews together with us, responded patiently to our queries or read parts of the manuscript. The exchange with colleagues from Italy and France at all stages of the working process has greatly helped us to interpret recent development and debates in these countries. The section on European experiences of city-regional governance benefitted greatly from comments of Ivona Sagan, João Igreja and Lasse Gerrits. In order to get insights regarding city-regions in different countries we did interviews with Daniel Galland and Poul Erik Mouritzen (Denmark) and Andreas Hildenbrand Scheid (Spain). Catherine van Rijswijck helped us with the section on the Netherlands and Rogério Lopes with the section on Portugal.

Interim results of the book were presented at the meetings of the FrancoGerman working group of German Academy for Territorial Development in the Leibniz Association (ARL). We also used the opportunity to discuss preliminary results at a meeting of the AESOP French and British Planning Studies Group. We would also like to thank our colleagues from the international working group on "Planning \& Governing the Metropolis" for three years of collaboration and fruitful debates: Christophe Demazière, Valeria Fedeli, Daniel Galland, Evelyn Gustedt, John Harrison, Zafer Şahin, Peter Schmitt, Mark Tewdwr-Jones and Mariona Tomàs. This group was 
also supported by the Academy for Territorial Development in the Leibniz Association ARL.

A special word of thanks goes the numerous interviewees from regional governments, city-regional authorities and local governments. They all showed great interest into our work and dedicated a share of their scarce working time to us. In particular, we want to mention the colleagues of the Métropole de Lyon, Métropole de Nantes, Città Metropolitana di Bologna, Città Metropolitana di Firenze, Verband Region Stuttgart and Regionalverband FrankfurtRheinMain.

Fatbardha Gela helped us a lot with the manuscript and supported empirical work in Italy. She was always available and highly committed.

Karsten Zimmermann \& Patricia Feiertag 


\section{Abbreviations}

$\begin{array}{ll}\text { ADCF } & \text { Assemblée des Communautés de France } \\ \text { ADERLY } & \begin{array}{l}\text { Association pour le développement économique de } \\ \text { la région lyonnaise }\end{array} \\ \text { AGMA } & \text { Association of greater Manchester Authorities } \\ \text { AGRV } & \text { Arbeitsgemeinschaft der Regionalverbände } \\ \text { AMB } & \text { Àrea Metropolitana de Barcelona } \\ \text { AML } & \text { Área Metropolitana de Lisboa } \\ \text { AMP } & \text { Área Metropolitana do Porto } \\ \text { ANCI } & \text { Associazione Nazionale Comuni Italiani } \\ \text { ARPAT } & \text { Agenzia Regionale per la Protezione Ambientale } \\ & \text { della Toscana). } \\ \text { ATO } & \text { Autorità di ambiti territoriali ottimali } \\ \text { AURAN } & \text { Agence d'Urbanisme de la Région Nantaise } \\ \text { AVL } & \text { Abfallverwertungsgesellschaft des Landkreises } \\ & \text { Ludwigsburg mbH } \\ \text { BBR } & \text { Bundesamt für Bauwesen und Raumordnung } \\ \text { BBSR } & \text { Bundesinstitut für Bau-, Stadt- und Raumforschung } \\ \text { B-PLAN } & \text { Bebauungsplan } \\ \text { CA } & \text { Communauté d'agglomération } \\ \text { CAP ATLANTIQUE } & \text { Communauté d'agglomération de la Presqu'île de } \\ & \text { Guérande Atlantique } \\ \text { CARENE } & \text { Communauté d'agglomération de la Région } \\ \text { CC } & \text { Nazairienne et de l'Estuaire } \\ \text { CDM } & \text { Communauté de communes } \\ \text { CDU } & \text { Contrat de Développement Métropolitain } \\ \text { CGET } & \text { Christlich Demokratische Union Deutschlands } \\ \text { CHU } & \text { Commissariat général à l'égalité des territoires } \\ \text { CM } & \text { Centre hospitalier universitaire } \\ \text { COURLY } & \text { Città Metropolitana } \\ \text { CSS } & \text { Communauté urbaine de Lyon } \\ \text { CTAP } & \text { Consiglio Italiano per le Scienze Sociali } \\ & \text { Conférence territoriale de l'action publique }\end{array}$




\begin{tabular}{|c|c|}
\hline CTR & Contrats Territoires-Région \\
\hline $\mathrm{CU}$ & Communauté Urbaine \\
\hline DATAR & $\begin{array}{l}\text { Délégation interministérielle à l'aménagement du territoire et } \\
\text { à l'attractivité régionale }\end{array}$ \\
\hline DCM & Decreto Ministeriale \\
\hline DG & Direction Générale \\
\hline DGB & Deutscher Gewerkschaftsbund \\
\hline DGCL & Direction générale des collectivités locales \\
\hline DTA & Directive territoriale d'aménagement \\
\hline DTADD & $\begin{array}{l}\text { Directive territoriale d'aménagement et de développement } \\
\text { durable }\end{array}$ \\
\hline EMM & Europäische Metropolregion München \\
\hline EMR & Europäische Metropolregion/ European metropolitan region \\
\hline EMTA & European Metropolitan Transport Authorities \\
\hline EPCI & Établissement public de coopération intercommunale \\
\hline EPURES & Agence d'urbanisme de la région stéphanoise \\
\hline ERDF & European Regional Development Fund \\
\hline ESPON & European Spatial Planning Observation Network \\
\hline FDP & Freie Demokratische Partei \\
\hline FNP & Flächennutzungsplan \\
\hline FRI & Fondazione per la Ricerca e l'Innovazione \\
\hline GMBH & Gesellschaft mit beschränkter Haftung \\
\hline GRS & Gigabit Region Stuttgart GmbH \\
\hline HUR & Hovedstadens Udviklingsråd \\
\hline IBA & Internationale Bauausstellung \\
\hline IHK & Industrie- und Handelskammer \\
\hline IKM & Initiativkreis Europäische Metropolregionen in Deutschland \\
\hline IMC & Intermunicipal cooperation \\
\hline IMEG & Initiativkreis metropolitane Grenzregionen \\
\hline INSEE & Institut national de la statistique et des études économiques \\
\hline INU & Istituto Nazionale Urbanistica \\
\hline IPT & Imposta di trascrizione \\
\hline IRPET & Istituto Regionale Programmazione Economica Toscana \\
\hline ITI & Integrated Territorial Investment \\
\hline KAF & Kommunaler Arbeitskreis Fildern \\
\hline LEP & Landesentwicklungsplan \\
\hline MAPTAM & $\begin{array}{l}\text { Modernisation de l'action publique territoriale et } \\
\text { d'affirmation des métropoles }\end{array}$ \\
\hline METREX & Network of European metropolitan regions and areas \\
\hline MGZM & $\begin{array}{l}\text { Górnośląsko-Zagłębiowska Metropolia/ Metropolitan } \\
\text { Association of Upper Silesia and Dabrowa Basin }\end{array}$ \\
\hline MKRO & Ministerkonferenz für Raumordnung \\
\hline MORO & Modellprojekte der Raumordnung \\
\hline MOU & Memorandum of Understanding \\
\hline MRDH & Metropoolregio Rotterdam Den Haag \\
\hline
\end{tabular}


NUTS Nomenclature des Unités territoriales statistiques

OECD Organization for Economic Co-operation and

OREAM $\quad \begin{array}{ll}\text { Development } \\ \text { Organisation d'études d'aménagement d'aire }\end{array}$ métropolitaine

PDU Plan de déplacements urbains

PETR Pôle d'équilibre territorial rural

PIT Piano di indirizzo territoriale con valenza di piano paesaggistico

PLERT Piano di Localizzazione delle Emittenti RadioTelevisive

PLH Programme local de l'habitat

PLU Plan local d'urbanisme

PLU-H Plan local de l'urbanisme et de l'habitat

PLUI Plan local d'urbanisme intercommunal

PLUM Plan local d'urbanisme métropolitain

PM Pôle métropolitain

PON Programma operativo nazionale

PPI

PRG

Programme pluriannuel d'investissement

PSM

Piano Regolatore Generale

PSR

Piano Strategico Metropolitano

PTCP

Piano Sviluppo Rurale

PTM

Piano Territoriale di Coordinamento Provinciale

PUMS/SUMP

Piano Territoriale Metropolitano

PUR

Sustainable Urban Mobility Plan

RCT

Planungsverband unteres Remstal

RE-DLAB

Réforme des collectivités territoriales

\section{Architettura}

RER

RFNP

Laboratorio Regional Design del Dipartimento di

RKW

Regione Emilia Romagna

Regionaler Flächennutzungsplan

Rationalisierungs- und Innovationszentrum der Deutschen Wirtschaft e.V.

RMV Rhein-Main-Verkehrsverbund

RUL Région urbaine lyonnaise

RVFRM Regionalverband Frankfurt/ Rhein-Main

RVR Regionalverband Ruhr

SAMOA Société d'Aménagement de la Métropole Ouest Atlantique

SCOT Schéma de cohérence territoriale

SDAU Schéma directeur d'aménagement et d'urbanisme

SDCI

SDG

Schéma départemental de coopération intercommunale

SEMITAN Société d'Economie Mixte des Transports de

l'Agglomération Nantaise

SEPAL Syndicat d'Étude et de Programmation de l'Agglomération Lyonnaise 
SFM Servizio Ferroviario Metropolitano

SIMAN Syndicat intercommunal à vocation multiple

SNCF Société nationale des chemins de fer

SPD Sozialdemokratische Partei Deutschland

SRADDET Schéma régional d'aménagement, de développement durable et d'égalité des territoires

SRU Solidarité et renouvellement urbains

SUAP Sportello Unico delle Attività Produttive

SYTRAL Syndicat mixte des Transports pour le Rhône et l'Agglomération Lyonnaise

TGV Train à Grande Vitesse

UDC Unioni di Comuni

UNESCO United Nations Educational, Scientific and Cultural Organization

UPI Unione Province d'Italia

URBALYON Agence d'urbanisme pour le développement de l'agglomération lyonnaise

UVF Umlandverband Frankfurt/ Main

VRS Verband Region Stuttgart

WRS Wirtschaftsförderung Region Stuttgart GmbH

ZAC Zones d'aménagement concerté

ZO Zone omogenee 


\section{About the authors}

Since 2012, Karsten Zimmermann has been Professor at the Faculty of Spatial Planning at Technical University of Dortmund where he holds the chair for European Planning Cultures. He is educated as a political scientist and dedicated most of his academic work to the study of cities and regions. From 2012 to 2016 he was the president of the European Urban Research Association EURA. He is Editor of Urban Research and Practice. His list of publications includes numerous articles and books on metropolitan governance, European urban policy, knowledge and planning and local climate policies. Current research projects focus on comparative metropolitan governance and spatial planning in Germany, Italy and France, innovation in local mobility policies in German cities, national urban policies and regional governance of water infrastructures.

Patricia Feiertag is a postdoctoral researcher at the Faculty of Spatial Planning of Dortmund Technical University, Germany, interested in comparative planning studies, metropolitan planning and governance, policy advice as well as maps as representation of space. From 2016 to 2019 she has been part of the European working group "Planning \& Governing the Metropolis" of the German Academy for Territorial Development in the Leibniz Association (ARL). 


\title{
1 Introduction
}

\author{
City-regions in Europe \\ K. Zimmermann and P. Feiertag
}

\subsection{The rise of territorial reforms in Europe's city-regions?}

City-regions and their governance is a persistent topic in the planning sciences, urban geography and local government studies and it's no surprise that the reconfiguration of city-regional governance is seen as an ongoing process, sometimes as an element of national reform agendas, sometimes being a more local project of transformation of cross-jurisdictional relations (Keil et al. 2017a; Zimmermann et al. 2020; Tomás 2020). Often cityregions are considered to be the hubs of the globalised knowledge economy and, at least in some cases, this prompted the support of national governments in various ways (Moisio and Jonas 2018; Lang and Török 2017; see also Katz and Bradley 2013). The following quotes illustrate the conventional wisdom in the scholarly literature with regard to the narrative of competitiveness and city-regions:

Large urban agglomerations in the Global North in particular are often understood as sites of globalization. These cities are understood through their functions and substances and the degree of integration into the purportedly "global" economy.

(Moisio et al. 2018, 137)

Hence it

has become commonplace not only for urbanists, consultant companies, globalization boosters and businesses firms (which also construct and finance urban infrastructures) but also for nation-state policymakers and politicians to argue that the strategic role of cities and cityregions has grown fundamentally during the past two or three decades. In such a geopolitical imaginary, the growth of major cities and cityregions is conceived of as an inevitable global phenomenon orchestrated by market forces, one which proceeds beyond politics, political regulation and the territorial state. Policy analyst Parag Khanna's (2016) Connectography is one among the many attempts to tell a story about 


\section{Introduction}

the contemporary de-territorializing global processes and the related ways in which the future is being shaped less by states than by connectivities of urban hubs and flows.

(Moisio et al. 2018, 137)

City-regions, due to their role and function as "national champions" in economic development (Crouch and LeGalès 2012) are the target of territorialised national policies and, seen from the perspective of national governments, their governance is highly relevant in order to prevent failures in many public policies (such as transport, environmental protection, innovation, see Kübler and Lefèvre 2017; Gross, Gualini and Ye 2019; Keil et al. 2017b). Indeed, higher education and research institutes as well as private knowledge-based service providers are concentrated in city-regions and generate competitive advantages on an international scale. Against this background, some European states such as Germany and France as well as Poland have partially redefined the function of city-regions in their spatial development policies and have given more relevance to competitiveness and innovation - or defined city-regions for the first time at all in planning and policy documents (Moisio et al. 2018; Krukowska and Lackowska 2017; Geppert 2009; Blotevogel and Schmitt 2006).

However, the assumption that the growth and rising relevance of cityregions is mainly driven by economic globalisation is questionable and has ostensibly produced some all too schematic and even flawed theoretical insights (a position shared by Gualini and Gross 2019, 7). National reforms in France and Italy taking place in the years 2010-2015 and presented in detail in this book indicate that there is a new interest in city-regions that emerged in a period when these two states (as well as others) were facing the long-term effects of the financial crisis of 2008-2009. It seems that these conditions changed the way city-regions were seen by state governments. The assumption of the dominance of competition-oriented metropolitan policy seems to be somewhat biased. City-regions are still strategic projects of state-spatial restructuring but there are indications that the financial crisis of 2008 shifted the focus and brought metropolitan reform back to the agenda, but with a stronger focus on austerity, efficiency and cohesion policy. There is a stronger emphasis on the relevance city-regions have for the modernisation of the public sector and the coordination of public services. In addition, there is a stronger recognition of a pronounced and ongoing process of metropolitanisation and the effects this process has for effective and efficient public policies (Sellers et al. 2013; Balducci et al. 2017; Siedentop and Fina 2012; Dembski et al. 2019; Cardoso and Meijers 2021).

In a narrow sense, metropolitanisation refers to the growth of city-regions and respective processes of suburbanisation and post-suburbanisation (Dembski et al. 2019; Cardoso and Meijers 2021). In a wider interpretational frame, metropolitanisation is a multidimensional process referring to issues of scale selection, cross-jurisdictional governance and construction 
of space. This implies a rising relevance of city-regions as social, economic or even political entities with many direct and indirect effects (Scott 2001). City-regions are the targets of immigration and thus places of diversity and more or less successful social integration. They reveal high levels of environmental problems and produce new forms of large-scale social inequality (Sellers et al. 2017; Keil et al. 2017b). This poses a range of challenges for public policies and subnational politics, which touches upon questions about the territorial organisation of the state (i.e. devolution, decentralisation, regionalisation). In many cases, city-regions show inadequate forms of metropolitan governance, which points to parochialism and fragmented local government structures (Scott 2019; Rosan 2016). Coordination deficits in land use planning, infrastructure development, transport planning, environmental planning and other public services such as waste disposal, energy supply, housing policy or public transport services are the obvious result. These deficits have been discussed at greater length in the debate on metropolitan governance (Scott 2019; Keil et al. 2017a; Zimmermann, Galland and Harrison 2020; Rosan 2016; Heinelt et al. 2011; Sager 2006).

At least in some European countries, metropolitanisation and the quest for higher efficiency in the public sector has triggered a renewed debate on the social, political and economic significance of city-regions, which necessarily also provokes questions of good institutional design and the setting of priorities for national spatial development policy (Gross and Gualini 2019; Salet and Thornley 2007; Zimmermann and Heinelt 2012; Sellers et al. 2013). Territorial reforms usually pursue different objectives and move along institutionally determined national paths (Loughlin 2007; Lidström 2007; Baldersheim and Rose 2010). This holds true particularly for reforms in public administration as well as decentralisation and regionalisation reforms that took shape across Europe in recent years (Kuhlmann and Bouckeart 2016). In the following section we argue that the differentiation of production and social reproduction functions is a helpful heuristic for discussing the current changes in the governance of city-regions and this helps to answer the question of what drives city-regionalism.

\subsubsection{Production or social reproduction?}

The supposed one-sidedness in the orientation of the academic debate, the so-called neo-liberal plot, was the subject of a controversial debate about the question of what drives the agendas of city-regional politics in the International Journal of Urban and Regional Research (Harding 2007; Jonas and Ward 2007; see also Keil et al. 2017b). Is it the production function or the social reproduction function? These two different functions stand for two different sets of policy priorities and ideas of what is at stake in city-regions. The production function is primarily supported by measures that serve to strengthen the competitiveness and innovation capacity of cityregions. In Germany, for example, this was part of the national guiding 


\section{Introduction}

principles and action strategies of spatial development that allocated innovation, gateway and competition functions to a limited number of rather large metropolitan regions (BMVBS 2006; MKRO 2013).

The social reproduction function is defined very broadly by Jonas and Ward (2007, 174-175) and includes welfare policies such as housing, public services and childcare, but also refers to measures that promote quality of life, thus addressing open spaces (inner-city and regional parks) and environmental aspects (noise protection, air pollution control, climate adaptation). In a similar way, Kantor and Savitch (2005) in their comparative study on cities in the international marketplace made a distinction between marketoriented urban policies and socially oriented urban policies. In part, this refers to a distinction made in political science in the 1980s to describe the functional shift of urban policies (Hesse 1983; Harvey 1989). While cities (i.e. local governments) were responsible in the post-war period for the provision and implementation of social reproduction functions, it was national government that was in charge of innovation policies and economic development. In a shift often described as the transformation of the Keynesian Welfare State to the Schumpeterian Workfare State, this division of functions was renegotiated and re-scaled (Jessop 2002, 2010). Henceforth, cities started initiatives to create business-friendly environments and marketing campaigns and made investments in specific types of infrastructure such as airports or convention centres. Much of the literature about the re-scaling of the state described the impacts of this transition, i.e. the downscaling of innovation and competitiveness-oriented policies and the rise of cities and city-regions as actors in the globalised economy (Pinson 2020; Keil 1998).

In the view of many observers, the production function currently dominates the discussion on planning and governance in city-regions, while the social reproduction function receives less attention (Blotevogel and Schmitt 2006; Jonas and Ward 2007; Salet and Thornley 2007; Moisio and Jonas 2018; Wachsmuth 2017). However, according to our observations, the social production function is a long-standing theme for city-regions and much stronger as a facilitator of city-regional governance than it may seem when examining the mentioned literature. Hence, following Keil et al. (2017b), we want to find out if a consensus is possible between these diverging goals. In addition, we need to consider that there are new concerns potentially not covered so far (public health, digitisation, climate adaptation). Whether the attribution of new functions has actually replaced older ones as drivers for institutional change and institutional variation is empirically questionable, specifically when put into the perspective of an international comparison (Salet and Thornley 2007; Kuhlmann and Bouckaert 2016; Tosics 2019; Keil et al. 2017a).

In this respect, it is not only in Germany that the discussion on cityregions differs considerably from the discussion of the late 1960s and early 1970s. The "old" attribution of functions saw city-regions as conurbations facing problems of congestion and inner city decay. There was an urgent 
need for planning interventions and concerted action, not least because of a lack of inter-municipal burden-sharing for infrastructures of regional relevance. In particular, the public transport sector was considered to put a heavy burden on the budgets of the core cities and justified the demands of these cities for the fair sharing of costs. While city-regions were territories framed as problematic in the old nomenclature, city-regions have become the bearers of hope for a regionalised economy geared towards constant innovation, with European or global significance. Sometimes this shift finds its expression in new imaginaries such as metropolitan regions, indicating higher international relevance, bigness and symbolic power (Fedeli, Harrison and Feiertag 2020). ${ }^{1}$ These city-regions are supposed to develop new forms of governance such as voluntary and public-private self-organisation, also in anticipation of some form of devolution of statutory tasks or public policies. Is this interpretative frame still valid? Or are we entering a new period of city-regionalism where metropolitanisation and pressures to consolidate public budgets determine the agendas?

\subsubsection{Effectiveness of city-regional governance?}

There is a second anomaly in the debate on city-regions. We are puzzled by the discrepancy between the academic work on the rise of city-regions and the actual limited success of metropolitan governance arrangements - at least in the majority of cases (Scott 2019; Keil et al. 2017a; Rosan 2016; Heinelt et al 2011; ESPON 2018). In many states, the role of institutionalised city-regions in multi-level governance systems is far from being clear or city-regions as institutions have even been abolished. Rhetoric on the rise of city-regions and political practice fall apart and, in many cases, what seems to be a purposive designed arrangement for metropolitan governance is more a side effect of wider reforms of the state (Kuhlmann and Wollmann 2014; Jessop 2010). Decentralisation, regionalisation, shifts in the multi-level architecture of the state (including fiscal federalism or asymmetric decentralisation) have an impact on city-regions but this effect is not necessarily positive. Therefore, putting reforms of city-regional governance into context is relevant to avoid traps in the interpretation about the drivers of the rise of city-regions.

Without a doubt, due to fragmented and particularistic local government structures, most city-regions are in need of better and more coherent governance structures. However, for many public policies such as public transport, sewage, waste management and regional planning, city-regional solutions are in place. In both Germany and France, inter-municipal associations are a consistent and indispensable form of provision of services of general interest and spatial planning. In France and Italy, consolidated solutions for city-regional governance have been implemented since 2014-2015. The neo-liberal plot thus seems to be too simple as an explanatory scheme for the recent developments. The reason for this is that, with few exceptions, 


\section{Introduction}

the debate on city-regions has in recent years hardly taken the aspect of the performance of public policies into account but has instead concentrated on processes of institution-building and the emergence of regional regimes, without full reflection of the role city-regions have in the multi-level system of public administration (Heinelt and Zimmermann 2012; Blatter 2005). So, the question is: which role do city-regions play in the process of dealing with public problems (Sellers et al. 2013)? Can shifts be identified in an international comparison? It is worth mentioning that Fürst, Hesse and Richter addressed a similar question in the early 1980s under the title "Agglomerations in the process of federal problem processing" in relation to Germany (Fürst, Hesse and Richter 1984). One of the results of this study was the insight that changes are more likely in the realm of re-distribution of financial resources (including temporary side-payments). Territorial reforms are much more difficult to render because of vested interests and local identities (Fürst, Hesse and Richter 1984, 303). The authors also pointed out that the solving of distributional conflicts has a strong cognitive dimension (ibid. 298).

We feel that the discussion on metropolitan governance and re-scaling of territorial governance in geography and planning has paid little attention to the political and administrative science discussion on regionalisation, decentralisation, inter-municipal cooperation and fiscal relationships of state levels (Loughlin 2007; Teles 2016; Steen, Teles and Torsteinsen 2017; Kübler and Rochat 2018). Indeed, the debate on the territorial organisation of the state and the role of local government has been ongoing for many years if not decades. Contrary to the assumption that globalisation, Europeanisation and internationalisation homogenise institutions and policies, we find that the diversity of territorial and functional profiles of local governments in Europe is still high (Denters and Rose 2005; Baldersheim and Rose 2010; Kuhlmann and Bouckaert 2016). Although the definition of the functions and the territorial dimension of local governments as well as inter-municipal arrangements is often seen as a question of local political negotiations, national governments have a clear interest to intervene. Recent attempts of reterritorialisation of the state in France and Italy and initiatives on city-region level in other states demonstrate that more effective and more efficient local public policies are on the agenda of national and subnational governments (Kuhlmann and Bouckaert 2016). We may apply a range of heuristics to analyse these reforms:

- asymmetric decentralisation as a form of decentralisation that gives different degrees of autonomy to regions within a nation state (OECD 2018)

- austerity policies as a result of financial and economic instability, resulting in amalgamations of local governments for the purpose of cost-efficiency (Kuhlmann and Bouckeart 2016; see Streeck 2017) 
- the return of the nation state as a result of the financial crisis in 2008 (Jessop 2010).

Having said this, the well-established categories used in the long and ongoing debate on metropolitan governance in political science seem to be less and less appropriate to understand what is currently going on (Kübler and Rochat 2018). At least when referring to the distinction of metropolitan reform (consolidation), new regionalism (collaboration) and public choice (competition) as the three major theoretical positions that are often used to distinguish different periods with dominant institutional ideas of how best to govern city-regions (Nelles 2012; Tomàs 2020). Periodisation is very common in the studies on metropolitan governance but, as has been demonstrated by Galland and Harrison (2020), the temporal dimension is not necessarily a sequence of neatly separated phases. Many public tasks can be organised in different ways and we have only limited knowledge about the effectiveness of different organisational forms such as single-purpose associations, inter-municipal cooperation, interventions of upper tier governments, contracts and multipurpose organisations. Problems of metropolitan development can also be tackled in various institutional environments (regionalising states, federalism, unitary states). Scott highlights that,

an approximate template is occasionally detectable in the more successful efforts that have pushed in this direction, namely-and in sharp contradistinction to any unitary arrangement-a conglomerate structure made up of loose hierarchical relationships complemented by assorted crosscutting organizations wherever these can significantly enhance operational effectiveness. There is no compelling reason, moreover, why a well-designed structure of this type could not also enhance the democratic assets of the city-region.

(Scott 2019, 17)

The empirical chapters of this book will show if these kinds of arrangements mentioned by Scott are emerging or not. Quotes like this often suffer from a focus on a few successful cases (often Stuttgart, Lyon or Portland). But what happens in other medium sized city-regions such as Nantes or Bologna? These medium sized city-regions are relevant as socio-economic entities but not as large as the global city-regions often referred to. Do they display the same patterns of governance and politics (ESPON 2018)?

\subsection{Research question and research design}

Hence, in our empirical study we start from a more nuanced heuristic. As territorial and functional reforms have several dimensions, a cross-national comparison needs a selection of criteria and dimensions and this selection always depends on the cognitive interest of the research. As we want to 


\section{Introduction}

address motivations for reforms as well as design options (institutional, functional, territorial) we identified the following four dimensions: ideas, functions, institutions and space. The functional, territorial and institutional dimensions are widely used in comparative local government studies. These studies, for instance, distinguish political, functional and territorial profiles of local governments (Kuhlmann and Wollmann 2014, 21-22). We add the ideational dimension as we feel that discourse matters, in particular when analysing the effects of austerity measures taken as a reaction to the fiscal crisis post-2008. Each of these four dimensions, described in more detail in the next sections, refers to a specific aspect of metropolitan governance and allows us to answer the following questions with regard to the recent reforms:

1) Do city-regions increase in relevance as institutional sites of problemsolving? And, if this is the case, in which dimension can we observe this increase in relevance? Do reforms have a functional (more or less functions) or territorial focus (jurisdictions getting bigger) and which ideas drive these reforms (economic competitiveness (production), efficiency of public administration, social reproduction, cohesion or enhanced participation)?

2) Do we observe convergence, divergence or persistence of the national patterns of city-regional politics?

3 ) Is there a change in the arguments for reforms, from instrumental-analytic reflections in public administration (decentralisation, reform of the public sector, fiscal federalism) to political disputes about the role of city-regions in the context of globalisation and Europeanisation?

Although we are focusing on recent reforms (in particular in France and Italy), we see these in the context of longer trajectories of institutional change (Lowndes and Lempriere 2018).

\subsubsection{Functions}

We assume that a change in the allocation of functions between local government, the second tier of local government, city-region or the lower state levels is part of every reform of metropolitan governance. Functions refer to the tasks that are assigned in whole or in part to municipalities or cityregions in the multi-level system. As indicated above, we make a fundamental distinction between those functions that are more related to social reproduction or services of general interest and those that are more related to the function of competitiveness. The first group of functions is usually part of the functional profile of local government and the second tier of local government (i.e. counties, provinces, départements), but is often managed under inter-municipal responsibility. We think of tasks such as waste management, sewage treatment, secondary schools, public transport, social 
housing, spatial planning, planning and provision of all kinds of public infrastructure and green spaces for recreation. This dimension found strong recognition in studies on decentralisation and reallocation of functions in comparative public administration (Kuhlmann and Bouckeart 2016).

The dimension of functions also had significant repercussions in the German debate on Metropolitan Regions during the 2000s (Blotevogel and Schmitt 2006). In this national debate, emphasis was not on social reproduction but on the production function. A fourfold definition of metropoli$\tan$ functions was used in order to make a distinction between metropolitan regions and smaller city-regions (Blotevogel and Schmitt 2006). These four functions were innovation, connectivity (or gateway-functions), economic development and symbolic power (i.e. creation of new urban imaginaries and lifestyles). Exemplary functions are marketing, tourism, economic development and all kinds of support for gateway and innovation policies.

The two-fold distinction of social reproduction functions and production function takes up common lines of argumentation from the geographical and administrative science discussion on city-regions and inter-municipal cooperation (see above, Kantor and Savitch 2005). Furthermore, we assume that differences between the states and city-regions under scrutiny exist with respect to the relationship of the functional dimension and other dimensions such as institutions and spatial relations. Different functions call for different spatial scales and governance arrangements which - in turn - may create fragmentation.

Our guiding questions are:

- Which functions are performed at which level?

- Are there significant shifts upwards or downwards in this respect?

- Which functional profiles result from this?

- Which actors claim responsibility for which functions?

\subsubsection{Institutions and governance}

The dimension of institutions in comparative local government studies and comparative planning studies often refers to some well-known formal categories (Kuhlmann and Wollmann 2014):

1) The position of municipalities and the second tier of local self-government in the structure of the state (functional profile of municipalities; political and fiscal autonomy of municipalities; administrative culture)

2) The relationship between local, regional and national spatial planning (distribution of competences, interdependence).

The reforms in France and Italy changed the formal distributions of functions between local government, regional governments (in Italy) and city-regional organisations, and introduced new entities (if not institutions). Hence, the 
comparison of the formal aspects and operational rules in the multi-level governance system is highly relevant for our comparative study. However, as Lowndes and Lempriere (2018) point out: institutions are more than just organisations and formal regulations. They constitute the rules in use that may take the form of informal conventions, routinised practices and institutional narratives that guide the behaviour of individual and organisational actors. Therefore, we consider also

3) the formal and informal institutionalisation of the city-region and forms of organisation of inter-municipal cooperation according to the fields of activity and

4) institutional legacies and changing narratives of past forms of intermunicipal collaboration and metropolitan governance (as in all of our case-study regions, inter-municipal initiatives existed before the reforms).

With regard to institutional ideas, the discussion on metropolitan governance and territorial reforms is based on a simple dichotomy of two positions. One is the distinction between consolidation approaches and public choice (competition) (Baldersheim and Rose 2010, 8; Heinelt and Kübler 2005). Protagonists of consolidation (or in other words: metropolitan reformers) see the creation of a new jurisdiction or amalgamation of existing jurisdictions as the best solution to create economies of scale. Multi-purpose associations are also part of this system of ideas, which not only refers to effective problem-solving but also to legitimacy, as we often find a claim for the direct election of regional councils (Blatter 2005).

Public choice, in contrast, sees the virtue in keeping the autonomy of small units (i.e. local governments). Charles Tiebout and Vincent Ostrom, being the principal protagonists of this position, argue for competition between jurisdictions in order to create choice options for citizens and firms (Ostrom, Tiebout and Warren 1961). Despite being very influential in the debate surrounding metropolitan government and governance, the distinction between these two positions has been far too simple to catch the murky reality of territorial and functional reforms in city-regions. Collaboration takes place in various fields and on different scales, some functions are shared, some are sharply separated between the local and the regional level. Organisational forms include single-purpose associations, multi-purpose associations, agencies under private law, soft and voluntary associations and contracting. We may also find different organisational forms for different policies. Hence, when describing the institutional profile of city-regions, in addition to spatial planning, further fields of action will be taken into account. In particular, housing policy and services of general interest (e.g. water supply and waste disposal, energy, public transport) will be considered as these tasks contribute significantly to the reproduction function. In addition, municipal and regional economic development (incl. marketing, tourism) is also 
considered, as it articulates the production function. The main object of observation is city-regional institutions created by territorial and functional reforms, and a reflection about their role in the multi-level system.

\subsubsection{Ideas}

In addition to institutional and functional aspects, the ideational dimension is of interest as the financial crisis in 2008/2009 caused a window of opportunity for the re-articulation of a range of ideas for state modernisation and the rendering of public policies. Following Hall (1989), we understand ideas as catalysts which, in a given institutional framework, enable the formation of coalitions of actors that make their claims during the implementation of reforms (see also Bèland and Cox 2011). Baldersheim and Rose (2010) called this the framing of territorial choice: territorial and functional reforms need justification and this is done by referring to a specific set of frames and ideas. The dimension of ideas also refers to the different reform discourses in the states and takes into account the positions of the actors involved as well as the lines of conflict (Lieberman 2003). The notion of ideas captures the actors' beliefs, expectations, assumptions about cause and effects and knowledge that actors bring into the world of political reforms, or in other words "ideas, after all are a medium by which people can imagine a state of affairs other than the status quo and such imaginings might plausibly spur them to act to try and make changes" (Lieberman 2003, 698).

With regard to the reform of metropolitan governance, a set of ideas such as territorial equity, effectiveness, competitiveness or autonomy of local selfgovernment is frequently used as a point of reference in academic writings and actors' statements. In the debate on the modernisation of the public sector it is common to refer to at least three bundles of ideas: (a) cost-efficiency (partly influenced by New Public Management); (b) effectiveness of public services (simplification, decentralisation, subsidiarity, territorial coherence) and (c) democracy (i.e. bringing decisions closer to the citizens, the option of referendums, direct elections of regional councils). In the realm of spatial planning, effectiveness means the overcoming of local particularism with regard to land use decisions. This idea, however, is in conflict with the idea and value of the autonomy of local self-government. Other ideas are organised around generic principles such as territorial cohesion or urban-rural partnership. We add competitiveness and austerity since the financial crisis of 2008 caused massive austerity programmes, in particular in southern Europe. In addition, Europeanisation may be a frame that is used when justifying reforms (often in a narrower definition than the pressures of the common market, Fricke 2020).

The analysis of ideas also aims to describe the content of what we call metropolitan policy. The term metropolitan policy covers all initiatives of a state government that explicitly aim to promote (or prevent) improved capacity for action in city-regions. Examples are the initiative of European 


\section{Introduction}

metropolitan regions in Germany (Zimmermann 2017; Blotevogel and Schmitt 2006) or the initiative of the métropoles d'équilibre/décentralisation industrielle of the French spatial development policy of the 1960s (Geppert 2009, 253). Metropolitan policy thus refers to all government measures, laws and support programmes, but also to guiding principles and ideas for action, which in every respect have city-regions as their subject. The term metropolitan policy also expresses that metropolitan reforms are not only about forms of organisation (metropolitan governance), but also the result of political disputes, which essentially revolve around the question of what function city-regions should have for the social and economic development of a country. As elaborated by Heinelt and Zimmermann, this ideational dimension addresses the level of meta-governance (Zimmermann and Heinelt 2012, 93). Impulses of the meta-level are understood as actionguiding orientation and ideas that can influence debates on city-regions. This may be accompanied by changes in the institutional system (new competencies or formats) or funding programmes (using Germany as an example: Schmitt 2009; Zimmermann 2012).

\subsubsection{Spatial relations and territorial profiles}

In public administration science, the territorial dimension has found enormous recognition in the literature on reforms of local government (Kuhlmann and Wollmann 2014; Baldersheim and Rose 2010). However, space has become a contested academic notion, not least in the debate on city-regions (Cardoso and Meijers 2021). In planning science and geography, we know at least three different conceptual approaches for defining reasonable spaces for cooperation in city-regional politics (Tosics 2019, 3):

- The morphologic area (the continuously urbanised or built-up area);

- The functional urban region (often defined by commuter sheds or labour markets); and

- The larger economic area (usually vast areas constituted by a system of economic hubs and districts as well as transport infrastructures) (see OECD 2012; ESPON 2018; Dembski et al. 2019).

A fourth discourse partly takes up these definitions but sees city-space not bound to geographical boundaries but constituted by global capitalist relations or networked spaces (Paasi 2002). This body of work on relational space refers, among others, to the spatial theory of Henri Lefebvre. The TPSN-framework of Jessop et al. (2008) partly synthesises this discussion and distinguishes four categories of space: territory, place, scale and network. While territory describes jurisdictional spaces (government territories), the other three categories are in use for relational or socio-political geographies being much more in a state of flux. The consequence for our approach is that we, in addition to the conventional wisdom of the public 
administration literature on decentralisation and amalgamation of municipalities, will also consider soft forms of territorial politics, networked space and collaborative governance. It is particularly these practices that show that the constitution of metropolitan space is a contested process and jurisdictional boundaries are often more part of the problem than the solution as the construction of space is the result of a diverse set of social, cultural and economic practices (Löw 2016). What a reasonable scale of social or economic action or policy-intervention would be is far from clear. Hence, we also consider the discussion on post-metropolitan territories or the inbetween city (Balducci et al. 2017; Soja 2000). It is not necessary to refer to the debate on planetary or endless urbanisation to make clear that suburbanisation, post-suburbanisation and re-urbanisation - sometimes in parallel - create a new hierarchy of places in city-regions, even questioning in some cases where the city-region starts and where it ends (Dembski et al. 2019). This dimension does not merely refer to jurisdictional boundaries but also the space-constituting relationships between scales (Gualini and Gross 2019). A constructivist perspective is needed as actors try to establish new spatial scales by questioning others. Still, representative and accountable (local) governments exist on different levels and the formation of interest happens through the reference to (local) jurisdictions with clear boundaries.

In two of the three countries under observation in this book a reconfiguration of spatial levels happened recently and these emerging scales took different institutional shapes. These scales are not clearly related to each other in all cases. Rather, there are diffuse demarcations and overlaps. Instead of the clear differentiation of spatial levels, perforated and fragmented arrangements can also emerge. Table 1.1 summarises the four dimensions for the descriptive comparison.

Table 1.1 Dimensions for comparison

\begin{tabular}{|c|c|}
\hline Dimension & Criteria \\
\hline \multirow[t]{2}{*}{ Functions } & $\begin{array}{l}\text { Production function (marketing, regional development } \\
\text { agency, gateway function, innovation) }\end{array}$ \\
\hline & $\begin{array}{l}\text { Social reproduction function (Housing policy, public services, } \\
\text { public transport services, environmental protection) }\end{array}$ \\
\hline \multirow[t]{2}{*}{ Institutions } & $\begin{array}{l}\text { Multi-level Governance (local government system, } \\
\text { planning system) }\end{array}$ \\
\hline & Metropolitan Governance (forms) \\
\hline Ideas & $\begin{array}{l}\text { Justification of reforms in which the direction of change } \\
\text { is articulated (welfare state compensation, competitive } \\
\text { orientation); this becomes apparent in (national) spatial } \\
\text { mission statements, programmes, declarations, studies, } \\
\text { statements of networks of cities and regions such as IKM } \\
\text { in Germany, interviews, possibly newspapers }\end{array}$ \\
\hline Spatial relations & $\begin{array}{l}\text { Scaling and Re-Scaling, disputes about boundaries, soft } \\
\text { space, size of jurisdictions, relationship between scales }\end{array}$ \\
\hline
\end{tabular}




\subsection{Comparing city-regions and local government systems}

The new allocation of functions to city-regions described above takes place simultaneously and yet differently in the European states (Zimmermann 2017; Fürst 2010; Salet et al. 2003; see Chapter 6.1). These developments justify the need for a comparative analysis that can build on the ongoing discussion on the comparison of local governments and planning systems in Europe and beyond (Sellers 2019; Denters and Rose 2005; Nadin and Stead 2012). With regard to the state of research, it must be noted that despite the quite respectable number of publications on metropolitan governance, a systematic comparison at European level has yet not been conducted (Heinelt and Kübler 2005; Salet et al. 2003; Otgaar et al. 2008; Keil et al. 2017a; ESPON 2018).

Some elements of comparative local government research have already been discussed above (Wollmann 2008; Kuhlmann and Wollmann 2014). Still, the comparison of cities and local governments risks tapping into some pitfalls. In a very basic way, Kantor and Savitch (2005) see the problems of comparative urban analysis as follows:

To begin, there is no commonly accepted general theory of urban politics and policy that can provide direction and testable propositions for examining common political phenomena in cities across nations and cultures. Without some kind of theoretical construct that highlights common properties shared by cities, comparative analysis makes little sense. This vacuum leaves those seeking to do comparative urban research dependent on what Robert Merton called "theories of the middle range" to guide inquiry (Merton 1968).

(Kantor and Savitch 2005, 136)

Notwithstanding these problems, comparative urban research has experienced a boom in recent years, raising important methodological questions (Robinson 2016; Sellers 2019; Kantor and Savitch 2005). Particular attention has been paid to the consideration of the explanatory value of local contexts (Kantor and Savitch 2005; Sellers 2019). There is, however, a difference between cities as objects of comparison and local governments. Cities are complex social, spatial and political phenomena and this complexity creates heuristic and theoretical problems when seeing the city as the object of comparison (Robinson 2016). With regard to categories and principles of comparisons, the situation is more advantageous in the field of comparative local government studies. Here it is possible to build on a range of pertinent studies and well-tried typologies (Kuhlmann and Wollmann 2014). But even if comparative local government studies in Europe are somewhat more advanced than comparative global urban research, some of the fundamental methodological problems are similar (Kantor and Savitch 2005). These consist of: 
1) analysing a sizeable number of cities (or city-regions in our case) while still providing depth of analysis (scope versus depth)

2) accounting for different contextual meanings, especially across different political and administrative cultures

3) providing conceptual tools that can accurately address the same problem in different places (symmetry) and

4) accessing, retrieving and processing useful data from multiple jurisdictions (Kantor and Savitch 2005, 137).

In this study, we basically follow two strategies when comparing metropolitan governance in three states: variation-finding comparison (as suggested by Tilly 1984) and multi-level matched comparison as proposed by Sellers (2019).

By following what Tilly (1984) called a variational comparison, we want to find the gradual variation in the similar patterns of the emergence of cityregional governance in Germany, France and Italy. Such an international comparison usually shows how a comparable set of variables works in different contexts. The variation-finding comparison focusses on the anomalies and allows for contrasting observations within a group of systems that share some basic elements. In our case, these are three big and long-standing EU member states that experienced the post-war emergence of a welfare state that is now gradually transforming into something new and different, also with regard to territorial welfare policies (Jessop 2002; King and LeGalès 2017). Territorial re-configuration of regions and cities is one of the elements of this ongoing transformation. Variation-finding comparison can differ with regard to the way the gradual variation of a phenomenon is controlled. A similar systems design in local government studies would usually compare similar cases taken from a variety of national contexts (with the ultimate goal of finding universal principles). However, given the territorial diversity of reforms within and across nation states and the mutual feedback between local politics and national reform initiatives, the rigidity of variable-centred comparisons needs to be rethought. Many national governments implicitly or explicitly treat regions and cities asymmetrically when implementing national reforms. They choose pilot regions, give some regions more power than others or implement reforms in an incremental way (e.g. métropole in France, combined authorities in the UK, German city-regions). In addition, reforms are the result of ongoing negotiations between different levels of government. Hence, the interactions between local and national (or subnational) governments are part of the variation. This prohibits the application of national typologies that are part of the conventional wisdom in comparative local government studies. ${ }^{2}$ In these typologies local governments are largely seen as dependent variables but not as active agents in central-local relations. In addition, the groups that are used as an empirical reference for these typologies are less and less homogeneous due to several asymmetric reforms. Their explanatory value is therefore limited. 
In nested comparisons (Sellers 2019), the definition and use of variation in variation-finding comparison (i.e. similarity and difference) is handled in a more flexible way. In what Sellers calls multi-level matched comparison, variation is observable on both national and subnational levels (Sellers 2019). Hence, the goal is explicitly to "carry out a controlled examination of how both national contexts and subnational politics matter" (96):

Multilevel matched comparison offers a design to address subnational politics in countries that differ significantly, but along dimensions that offer a tractable basis for comparative analysis.

(Sellers 2019, 96)

This type of research has thus two components:

1) The combination of differences on local and national levels; and

2) The interactions of national and local governments.

Nevertheless, comparisons need to follow some of the basic principles defined in the literature (Tilly 1984; Sartori 1991; Kantor and Savitch 2005; Sellers 2019). In regard to what is compared, comparisons need to be discrete (i.e. identifying units or objects, dimensions or functions precisely). Comparisons also need to take into consideration the principles of symmetry and functional equivalence. The research programme (the scope of the study and the portfolio of methods) must be implemented in a similar way in all case studies. This sounds self-evident, but in an international comparison with fieldwork across different cultures and languages it is a relevant issue. Part of symmetry is also what is called functional equivalence in local government studies (Sellers 2019, 90). Although this depends very much on the interest of the researcher, it is common in local government studies to compare units that are similar in terms of status or formal responsibilities. Therefore, we excluded capital city-regions (Berlin, Rome, Paris) and the German city-states.

The comparison establishes relationships among the dimensions of comparison (functions, institutions, ideas, spatial relations) that can describe and explain the differences between the most recent developments in Germany, France and Italy. Such a multidimensional approach seems to be necessary in order to grasp the observable diversity in European city-regions. It also makes it possible to capture the trends of convergence and divergence more accurately.

Germany, France and Italy were selected as they display several commonalities as well as differences that allow for a combination of variations across the three states as well the six case studies.

- As described above, the function of city-regions has been discussed more intensively in all three countries in the last 10-15 years than in other European states and corresponding programmes are being set up. While 
in Germany, however, the importance of city-regions for economic and social development is being discussed, the current initiative in Italy is influenced by the consolidation constraints of a country severely affected by the financial crisis. In France, we find both of these arguments present. Furthermore, the three countries have different planning systems and local government systems, so that different framework conditions exist here. In all three states there is more than one or two city-regions that are affected by reforms, hence we have a critical mass (14 in Italy, 22 in France and in Germany about 10).

- France and Germany have a strong tradition of inter-municipal cooperation but represent different planning and local government systems and types of state (decentralised unitary state - federal state). In Italy, the regions are increasingly responsible for planning and local government (regionalised state). However, the current formation of city-regions is based on a national law.

- In their own way, Germany and France represent "successful models" of inter-municipal cooperation with strengths and weaknesses. In both countries, the question of linking new competition-oriented strategies with the classic inter-municipal institutions delivering services of general interest is also currently arising. Since Italy has only a limited tradition of inter-municipal cooperation and fewer incentives are provided in either the planning or the municipal system, the starting conditions here are more unfavourable. Nevertheless, a discourse is being conducted on the role of city-regions - with an uncertain outcome.

- France and Italy are often considered as having similar characteristics (i.e. they differ from the Northern and Anglo-Saxon models of local governments and are members of the so-called Franco or Napoleonic Group or represent the southern model), with centralised systems, weak local governments and a provincial tier (Hesse and Sharpe 1991, Loughlin 2003, Kuhlmann and Wollmann 2014). Germany is part of the northern continental model with strong local governments. These typologies have a heuristic value but a comparison of France and Italy with regard to city-regional governance will show significant differences.

- The choice of the cases also allows us to gain some knowledge about the eventual impact of policy transfer and diffusion. Three of our case studies are known internationally for their - relative - success of cityregional policies (Lyon, Stuttgart and Bologna). In particular, Stuttgart and Lyon are often referred to as best practice (Fricke 2020). In addition, France and Italy share a common administrative culture and Italian protagonists often refer to the French experience.

- We selected two city-regions in each country, which allows for a minimum of subnational variation (see Table 1.2). The selection criteria for the case study regions were some established patterns of inter-municipal coordination and metropolitan governance. We also wanted a forerunner in each country and one city-region where metropolitan 
Table 1.2 Case study city-regions

\begin{tabular}{llrrr}
\hline & City-Region & Size & Inhabitants & $\begin{array}{c}\text { number of } \\
\text { municipalities }\end{array}$ \\
\hline France & Lyon (Métropole) & $533.7 \mathrm{~km}^{2}$ & $1,402,326$ & 59 \\
& Nantes (Métropole) & $523.4 \mathrm{~km}^{2}$ & 658,356 & 24 \\
Germany & Stuttgart (VRS) & $3,654 \mathrm{~km}^{2}$ & $2,787,724$ & 179 \\
& Frankfurt/Rhine-Main & $2,458 \mathrm{~km}^{2}$ & $2,359,733$ & 80 \\
Italy & Bologna (CM) & $3,702 \mathrm{~km}^{2}$ & $1,014,619$ & 55 \\
& Florence (CM) & $3,514 \mathrm{~km}^{2}$ & $1,013,260$ & 41 \\
\hline
\end{tabular}

reforms display some implementation problems. The city-regions are comparable in terms of population size, territory and economic prosperity. However, due to territorial reforms in the 1970s, German cityregions tend to be bigger than their French and Italian counterparts. In addition, each city-region shows some specific features that we considered relevant for our study, i.e. the pôle métropolitain responsible for regional planning in Nantes Saint-Nazaire, the unsolved problem of regional governance in the piana fiorentina (Firenze-PratoPistoia) and the regional land use plan in the Frankfurt/Rhine-Main city-region.

\subsection{Short view on cases}

\subsubsection{France}

Since the 1980s, France has undergone various decentralisation reforms, and since 2003, France is called a decentralised unitary state in the French constitution (Borraz and LeGalès 2005; Kuhlmann 2009). The shifts in tasks that have taken place are important for the institutional formation of city-regions. They not only strengthened the regions and départements, but also forms of inter-municipal cooperation that have existed since the 1960s (Négrier 2005; Kuhlmann 2009; Geppert 2009). The formats provided for this purpose, EPCI (Établissements publics de cooperation intercommunale), addressed different scales and were intended to increase the effectiveness of public service provision by forming large units. The reason for this is the high number of small and very small municipalities. The EPCI, especially the most integrated types, métropoles and communautés urbaines, perform numerous functions in the fields of urban renewal, social housing, spatial planning and economic development, and have their own financial resources thanks to revenues from the business tax. Intermunicipal cooperation was thus primarily a question of the functional and territorial profile of the municipalities and the related effectiveness and efficiency of the performance of the public sector and gradual decentralisation. In addition, the relationship of Greater Paris to the other city-regions has always been a focus of French spatial development policy (Geppert 2009, 
252; Négrier 2005). Since the 1990s, the focus, which was primarily on the efficient performance of tasks and balancing of territorial disparities, has been partially reoriented (Geppert 2009, 256-257; Pinson and Galimberti 2013). In 2003, the French spatial planning authority DATAR published a call for inter-municipal cooperation, which addressed all city-regions outside Greater Paris and indicated a new orientation in many respects. Smaller urban regions were also able to participate. In terms of content, the keyword métropole was used to focus more on aspects of growth pole policy and competitiveness and less on territorial balance (Verhage et al. 2007, 88; Geppert 2009, 260). With regard to the forms of organisation, city networks such as Caen-Le Havre-Rouen and purely project-related forms of cooperation were now also possible alongside municipal associations. Some of those soft cooperation spaces continue to exist under the name of pôle métropolitain, but national metropolitan policy has shifted again after 2010 towards a metropolitan reform position. A new episode in French metropolitan policy emerged when the creation of métropoles started in 2010-2012 (Pinson and Galimberti 2013). Métropoles are one of the four types of EPCI and take on further tasks in the area of social reproduction and competition policy. However, contrary to initial plans (and unlike the provinces in Italy), the départements were not abolished. Only in the case of Lyon does a métropole fulfil the functions of the département on its territory.

\subsubsection{Italy}

Italy's local government system is characterised by many small municipalities, which in comparison have a limited functional profile (Bobbio 2005). Intercommunal cooperation in the form of special-purpose associations does not have the same status as in Germany or France. For some metropolitan policy initiatives, the provinces as the second tier of local self-government were particularly relevant in city-regions such as Milan, Bologna or Florence, as they at least partly represent and refer to a functional cityregion. However, it is only since the 1990s that these provincial governments have had limited resources and competencies for city-regional policy and planning.

A law passed in 1990 with the objective of promoting inter-municipal cooperation in metropolitan regions was in line with the European-wide trend at the time, but implementation was largely unresponsive. In the wake of the financial crisis in 2008 and the resulting consolidation pressures, the initiative was taken up again by the national government and reformulated as binding law in 2012. The plan was to abolish the provinces and create a new type of city-region governance in the biggest agglomerations of the country and city-regions on the islands of Sicily and Sardinia (which are regions with a special status). The provinces were to be transformed into a sort of city-regional government (Città Metropolitana) in those areas, while in the rural parts inter-municipal arrangements were expected to take over 
provincial tasks (d'Albergo 2012; Vinci 2019). The latter did not happen. The whole reform process was rather cumbersome but in 2014 the new entities came into life, though their functional profile remained in part open for interpretation and derogation in the national legislation. The regional governments, together with local actors, were called upon to make proposals for the structures and competences of the new entity. Still, as many commentators show, the problem of more effective coordination and strategic planning remains largely unsolved in most city-regions in Italy, for various reasons (Vinci 2019; Fedeli 2017; Tubertini 2015). In contrast to Germany and France, there is no comparable range of institutional formats that have been successfully tested.

\subsubsection{Germany}

Germany has a long tradition of inter-municipal cooperation in many areas of the public sector (especially spatial planning, services of general interest, public transport). Inter-municipal associations have proven to be a consistent solution for the provision of local public services (Lorrain 2005). Other solutions such as regional cities and districts have remained much-discussed exceptions. Since the 1990s, the repertoire of formats has expanded in the course of the governance debate. Associations (Regionalverbände), limited liability companies, other voluntary forms of cooperation and networks were considered the method of choice and sometimes combinations of them are used on various spatial scales. As a result, inter-municipal cooperation in city-regions happens in a wide variety of forms and is widely recognised as a solution to the problems of agglomerations. Territorial reforms and amalgamations were carried out in the 1970s, but are rare today. Only in a few cases, such as Stuttgart, Hanover or, to a lesser extent, Rhine-Neckar, do the many initiatives result in an integrated metropolitan policy in which a high degree of binding coordination of action is implemented and an extensive bundle of public tasks is performed at the city-regional level. In other metropolitan regions such as Hamburg, the Ruhr, Munich or Frankfurt/ Rhine-Main, structures remain fragmented or weakly institutionalised and thus unstable (Heinelt et al. 2011; Blatter 2005).

The content of inter-municipal cooperation has also changed. In addition to traditional tasks of spatial planning and services of general interest, additional metropolitan governance arrangements involving private actors are dedicated to international marketing and economic promotion, cultural policy, digitisation and innovation policy (Zimmermann 2012; Blatter 2005). All these forms of cooperation are usually the result of voluntary cooperation. In the case of the three city-states Berlin, Hamburg and Bremen, metropolitan policy is seeking to overcome state boundaries via contracts with the neighbouring states.

National government is less relevant as local government is a domain of the states and the states pursue different strategies with regard to the 
consolidation of city-regions. The struggle for adequate forms and scales of metropolitan governance is not a national policy-issue. There is no nationwide strategy or discourse except for the so-called European Metropolitan Regions. As an element of a metropolitan policy jointly pursued by the federal government, the states and some cities, initially seven, then 11 European metropolitan regions in Germany have received special attention for some years now (BMVBS 2006; MKRO 2013). The initiative is intended to highlight the importance of these metropolitan regions for economic and social development, although some observers note a one-sided focus on competitiveness (Blotevogel and Schmitt 2006). In contrast to France, however, these metropolitan regions do not receive any subsidies, but are supposed to realise synergies and mobilise resources by themselves.

\subsection{Methods}

In our study, we applied a comparative case study approach. The case study approach is applied at several levels according to the principle of casing (Ragin 1992; Gerring 2007). First, two city-regions in each state were considered as cases (in total six cases). In addition, we considered the three nation states as cases as nation states define frameworks and policies for city-regions. This allowed us to compare:

- City-regions in a cross-country perspective;

- National policy frameworks in a cross-country perspective; and

- Two city-regions within each nation state, as we expected regional differences.

Case study work in the city-regions included the analysis of the institutional framework, strategic planning approaches (if present) and policy processes. This is done in combination with the preparatory analysis of national metropolitan policy and through document analyses and interviews. The interviews allowed for the identification of the evaluation schemes of actors with regard to the functions of the city-region and the ideas that motivated the reforms. The document analyses are used to identify ideas in national reform discourse as well as the different spatial definitions of the city-regions used by local actors. In each case study, at least spatial planning, services of general interest, public transport and economic development (marketing) have been examined with regard to their regional significance. Other fields of action have been consulted on a case-by-case basis (e.g. regional parks in Stuttgart or digitisation in Frankfurt/Rhein-Main) as well as projects with relevance for the city-region (Île de Nantes in Nantes; trade fair, new main station Stuttgart 21, IBA 2027 in Stuttgart; Airport, Part-Dieu and Confluence in Lyon). Città metropolitane, métropoles and Regionalverbände are the institutions that have been closely analysed due to their key importance for city-regional governance. However, we observed in part the repartition of 


\section{Introduction}

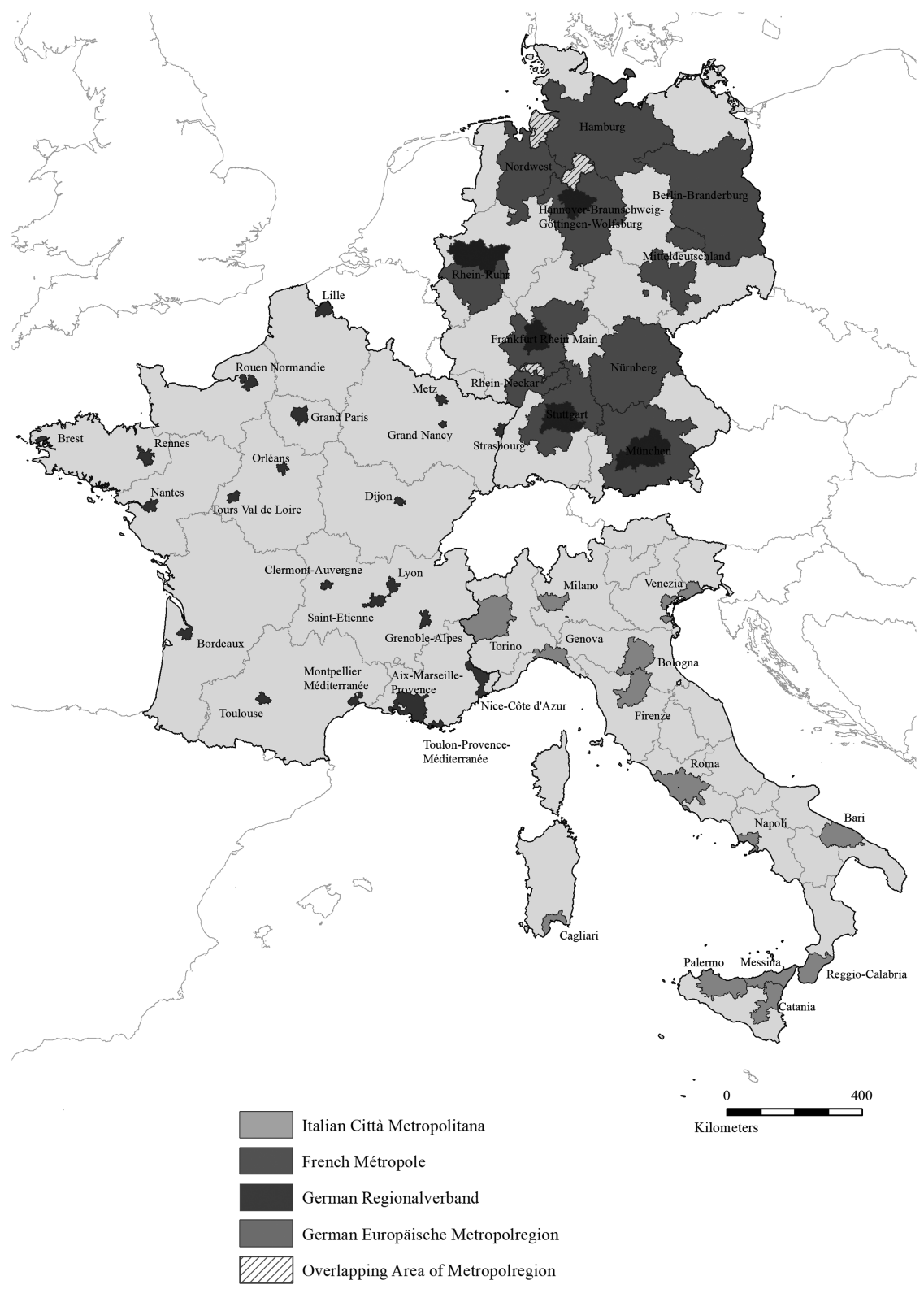

Figure 1.1 City-Regions in Italy (Città Metropolitane), France (Métropole) and Germany (Metropolregionen and Planungsverbände) 2018 Concept: P. Feiertag Cartography: F. Gela 
functions to several institutions (additional special-purpose associations, limited liability companies, voluntary networks) and on several spatial scales (variable geometry due to functional aspects; superimposition of a cityregional and a larger metropolitan scale). Thus, these various relevant governance arrangements in the six case-study regions were taken into account.

\subsubsection{Selection of case studies}

On the level of states, France and Italy were chosen because both states introduced a new legal framework for city-regions in the years 2012-2015 (see above). Germany, on the other hand, tends to show a pattern of incremental change and regionalised path dependency.

In each country, we excluded the capital city-regions and the city-states in Germany as they have more powers. We selected prosperous city-regions with manifest ambitions for city-regional cooperation or regional reforms, even when these ambitions partly date back to previous periods (as in the case of Bologna). In other words, we were searching for critical and meaningful cases with regard to a positive feature (city-regional governance).

\subsubsection{Interviews with experts}

The interviews were conducted as qualitative expert interviews, which are intended to provide information on the case studies as well as access to the cognitive frames of the reforms. The interview guidelines were adapted to the respective interviewee and his or her field of activity. Between seven and 11 persons were interviewed per case study region, in total 50 (see Appendix). The duration of the interviews was between 50 and 130 minutes. Most of the interviews took place in person during a field visit. Individual supplementary interviews were conducted by telephone or video conference. All interviews were recorded.

Different groups of experts were covered in each region:

- Representatives of regional governments (in particular relevant for Italy and France);

- Representatives of city-regional authorities and / or agencies;

- Representatives of local government (core city and surrounding municipalities), largely of the administration but also mayors;

- Other actors such as Conseil de Développement of Métropole in France, i.e. consultative body with actors from the civil society.

The interview questions covered the following aspects:

- Competences of the city-regional institution in different fields of action such as spatial planning, transport and economic development; sharing and repartition of functions with other levels; 


\section{Introduction}

- Strategic planning processes including inter-municipal land use planning, regional planning and informal development strategies;

- Projects with regional relevance including the involvement of different actors in the course of implementation;

- Decision-making processes, in particular the involvement of municipalities at the city-regional level;

- The evolution of the city-regional institutions as well as ideas justifying the strengthening or emergence of institutions;

- Functional interdependencies in the city-region;

- Competing spatial definitions of the city-region, shifting boundaries as well as the use of the term "metropolitan region".

In addition, we did expert talks, often with academics of local universities who had conducted research regarding planning and governance of their city-region.

\subsubsection{Document analysis}

For an overview of documents with regard to the national debate about metropolitan regions, crucial moments had to be determined. In France, métropoles have been introduced by the two laws RCT (16 December 2010) and MAPTAM (27 January 2014). The document analysis covered the discussion process from the announcement of the reform by the President (October, 2008) to the adoption of the second law in 2014. In Germany, the national debate concerns the introduction of Metropolitan regions in national spatial visions by the MKRO and subsequent debates about a paradigm shift in spatial planning. For Italy, the years 2009, 2012 and 2014 were essential as important laws or bylaws were issued.

The stock of documents reflecting national debates consisted of:

- National and regional laws and bylaws;

- Preparatory reports and policy papers;

- Parliamentary debates and speeches of ministers;

- Reports of association of cities;

- Academic publications.

Regarding the six city-regions, the stock of documents consisted of:

- Statutes, annual reports and budget plans;

- Strategic plans;

- Studies commissioned by city-regional institutions;

- Statements in consultation processes;

- Self-portrayal on homepages;

- Newspaper articles;

- Academic publications. 
Regarding spatial relations and territorial profiles, the use (or absence) of maps and descriptions of the city-regions as well as debates about boundaries were of particular relevance. The document analysis revealed whether the appropriate spatial dimension was debated or not, how the choice of perimeter of metropolitan institutions was justified and whether functional and morphological aspects of the city-region were taken into account. Regarding the national framework in the three states, the question is whether the spatial dimension of city-regions played any role in the reshaping of the multi-level system. At the local level, i.e. regarding the six city-regions, we identified competing and evolving spatial definitions of the city-region.

For the dimension of ideas, a selected number of documents has been coded. In the French case, for example, these were speeches of presidents and ministers regarding the two laws RCT and MAPTAM ${ }^{3}$ as well as the report of an expert commission (Comité pour la réforme des collectivités locales 2009) and a publication of the Ministry of the Interior explaining the reform (Ministère de l'Intérieur 2011). The intention was to show ideas used by the government to justify metropolitan reforms. As the laws concern all levels of territorial government, a two-step analysis was made, exploring in a first step ideas justifying the reform as a whole and in a second step identifying ideas directly related to metropolitan regions and to the creation of the métropole. For the German case, documents from the MKRO related to the national spatial vision as well as academic articles describing the discussion process were analysed. National spatial development reports presented to the parliament are also included in the stock of documents as they reveal the contemporary interpretation of major challenges to be tackled by national policy and the ideas related to metro regions.

In the coding process, we have coded sentences or words that evoke specific ideas (Saldaña 2016). The categories used for coding have been in part

Table 1.3 Categories in the dimension of ideas

\begin{tabular}{|c|c|}
\hline Category & Coding Indications (examplary) \\
\hline Cohesion & $\begin{array}{l}\text { Balanced territorial development, benefit for the } \\
\text { entire country, spill over to rural hinterland }\end{array}$ \\
\hline Austerity & Financial crisis, debts, cutbacks \\
\hline Welfare & $\begin{array}{l}\text { Services of general interest, housing, mobility, } \\
\text { sustainability }\end{array}$ \\
\hline $\begin{array}{l}\text { Democracy and social } \\
\text { participation }\end{array}$ & $\begin{array}{l}\text { Direct election, democratic legitimacy, } \\
\text { identification of citizens with territorial entities }\end{array}$ \\
\hline $\begin{array}{l}\text { Efficiency and functional } \\
\text { reforms }\end{array}$ & $\begin{array}{l}\text { Modernisation of the state, fragmentation, } \\
\text { decentralisation }\end{array}$ \\
\hline Equal treatment of territories & $\begin{array}{l}\text { Same treatment of all territorial authorities vs. } \\
\text { adaptation to the spatial diversity }\end{array}$ \\
\hline Local self-organisation & Top down vs. bottom up \\
\hline Economic competitiveness & $\begin{array}{l}\text { Economic growth, international competition, } \\
\text { marketing, large-scale projects }\end{array}$ \\
\hline
\end{tabular}


pre-defined on the basis of academic writings and in part added during the process of coding (see Table 1.3). As a result, we could interpret which have been the dominant ideas driving the national reform discourse.

\section{Notes}

1 We continue to use the notion of city-regions, not only to avoid confusion but also with regard to our empirical case studies.

2 Usually the Anglo-Saxon type, the Scandinavian type, the southern European or Napoleonic type and the continental type (Kuhlmann and Wollmann 2014).

3 Sarkozy 22.10. 2008 and 5.3.2009; Hortefeux 19.1.2010; Hollande 20.11.2012; Lebranchu 10.4.2013 and 29.1.2014.

\section{References}

Baldersheim, H. and Rose, L. (2010) Territorial Choice. The Politics of Boundaries and Borders. Palgrave Macmillan.

Balducci, A.; Fedeli, V. and Curci, F. (2017) Post-metropolitan territories as emergent forms of urban space. In: Post-Metropolitan Territories, Balducci, A.; Fedeli, V. and Curci, F. (eds.) London: Routledge, pp. 3-14.

Bèland, D. and Cox, R.H. (2011) Ideas and Politics in Social Science Research. Oxford: Oxford University Press.

Blatter, J. (2005) Metropolitan governance in Deutschland. Normative, utilitaristische, kommunikative und dramaturgische Steuerungsansätze. Swiss Political Science Review, 11(1), 121-157.

Blotevogel, H. and Schmitt, P. (2006) "European Metropolitan Regions" as a new discursive frame in strategic spatial planning and policies in Germany. Die Erde, 137(1-2), 55-74.

BMVBS (2006) Leitbilder und Handlungsstrategien der Raumordnung. Bonn/Berlin.

Bobbio, L. (2005) Italy. After the storm. In: Comparing Local Governance. Trends and Developments, Denters, Bas and Rose, Lawrence E. (eds.) London: Palgrave, pp. 29-46.

Borraz, O. and LeGalès, P. (2005) France: The intermunicipal revolution. In: Comparing Local Governance. Trends and Developments, Denters, Bas and Rose, Lawrence E. (eds.) London: Palgrave, pp. 12-28.

Cardoso, R. and Meijers, E. (2021) Metropolisation: The winding road toward the citification of the region. Urban Geography, 42(1), 1-20. DOI: 10.1080/02723638.2020.1828558.

Comité pour la réforme des collectivités locales (2009) Il est temps de décider. Rapport au Président de la République. 5 March 2009. Paris

Crouch, C. and Le Galès, P. (2012) Cities as national champions? Journal of European Public Policy, 19(3), 405-419. DOI: 10.1080/13501763.2011.640795.

Dembski, S.; Sykes, O.; Couch, C.; Desjardins, X.; Evers, D.; Osterhage, F.; Siedentop, S. and Zimmermann, K. (2019) Reurbanisation and suburbia in northwest Europe: A comparative perspective on spatial trends and policy approaches. Progress in Planning, 1-47. DOI: 10.1016/j.progress.2019.100462.

Denters, B. and Rose, L. E. (eds.) (2005) Comparing Local Governance. Trends and Developments. London: Palgrave. 
D’Albergo, E. (2012) When metropolitan reform and development policy are loosely coupled: Rome as a case of weak political rescaling, paper presented at the conference "Governing the Metropolis: Powers and Territories" Paris, November 28-30.

ESPON (2018) SPIMA: Spatial Dynamics and Strategic Planning in Metropolitan Areas. Luxembourg: ESPON.

Fedeli, V. (2017) Metropolitan governance and metropolitan cities in Italy: Outdated solutions for processes of urban regionalisation? Raumforschung und Raumordnung, 75(3), 265-274.

Fedeli, V.; Harrison, J. and Feiertag, P. (2020) Invoking new metropolitan imaginaries: What type of metropolitan region for what kind of metropolitan planning and governance? In: Metropolitan Regions, Planning and Governance, Zimmermann, K.; Galland, D. and Harrison, J. (eds.) Cham: Springer International Publishing, pp. 173-192.

Fricke, C. (2020) European Dimension of Metropolitan Policies Policy Learning and Reframing of Metropolitan Regions. Cham: Springer.

Fürst, D. (2010) Wie handlungsfähig sind die Deutschen Metropolregionen? Zeitschrift für staats- und Europawissenschaften, 3(3), 358-383.

Fürst, D.; Hesse, J.J. and Richter, H. (1984) Stadt und Staat. Verdichtungsräume im Prozess der föderalstaatlichen Problemverarbeitung. Baden-Baden: Nomos.

Galland, D. and Harrison, J. (2020) Conceptualising metropolitan regions: How institutions, policies, spatial imaginaries and planning are influencing metropolitan development. In: Metropolitan Regions, Planning and Governance, Zimmermann, K.; Galland, D. and Harrison, J. (eds.) Cham: Springer International Publishing, pp. 1-21.

Geppert, A. (2009) Polycentricity: Can we make it happen? From a concept to its implementation. Urban Research and Practice, 2(3), 251-268.

Gerring, J. (2007) Case Study Research. Principles and Practices. Cambridge: CUP.

Gross, J.S. and Gualini, E. (2019) The construction of metropolitan space: Comparative lessons. In: Constructing Metropolitan Space. Actors, Policies and Processes of Rescaling in World Metropolises, Gross, J.S.; Gualini, E. and Ye, L. (eds.) London: Routledge, pp. 213-224.

Gross, J.S.; Gualini, E. and Ye, L. (eds.) (2019) Constructing Metropolitan Space. Actors, Policies and Processes of Rescaling in World Metropolises. London: Routledge.

Gualini, E. and Gross, J.S. (2019) Introduction: Actors, policies and processes in the construction of metropolitan space: Conceptual and analytical issues. In: Constructing Metropolitan Space. Actors, Policies and Processes of Rescaling in World Metropolises, Gross, J.S.; Gualini, E. and Ye, L. (eds.) London: Routledge, pp. 3-28.

Hall, P.A. (1989) Conclusion: The politics of Keynesian ideas. In: The Political Power of Economic Ideas. Keynesianism across Nations, Hall, P.A. (ed.) Princeton, NJ: Princeton University Press, pp. 361-391.

Harding, A. (2007) Taking city regions seriously? Response to debate on 'cityregions: New geographies of governance, democracy and social reproduction. International Journal of Urban and Regional Research, 31(2), 443-458.

Harvey, D. (1989) From managerialism to entrepreneurialism: The transformation in urban governance in late capitalism. Geografiska Annaler, Series B, 71(1), 3-17. 


\section{Introduction}

Heinelt, H. and Kübler, D. (eds.) (2005) Metropolitan Governance, Capacity, Democracy and the Dynamics of Place. London: Routledge.

Heinelt, H. and Zimmermann, K. (2012) Metropolitan governance in Deutschland. Das Regieren in Ballungsräumen und neue Formen politischer Steuerung. Wiesbaden: Springer VS.

Heinelt, H.; Razin, E. and Zimmermann, K. (eds.) (2011) Metropolitan Governance. Different Paths in Contrasting Contexts: Germany and Israel. Frankfurt am Main: Campus Verlag

Hesse, J. J. (1983) Stadt und Staat - Veränderungen der Stellung und Funktion der Gemeinden im Bundesstaat. Das Beispiel Bundesrepublik Deutschland. In: Staat und Gemeinden zwischen Konflikt und Kooperation, Hesse, Joachim Jens U.; Ganseforth, H. U.; Fürst, Dietrich U. and Ritter, Ernst Hasso (Hrsg.) BadenBaden: Nomos, pp. 11-43.

Hesse, J.J. and Sharpe, L.J. (1991) Local Government in international perspective: Some comparative observations. In: Local Government and Urban Affairs in International Perspective, Hesse, J.J. (ed.) Baden-Baden: Nomos, pp. 603-621.

Jessop, B. (2002) The Future of the Capitalist State. Hoboken, NJ: Wiley.

Jessop, B. (2010) The 'return' of the national state in the current crisis of the world market. Capital \& Class, 34(1), 38-43.

Jessop, B.; Brenner, N. and Jones, M. (2008) Theorizing sociospatial relations. Environment and Planning. Part D, 26(3), 389-401.

Jonas, A.E.G. and Ward, K.G. (2007) Introduction to a debate on city-regions: New geographies of governance, democracy and social reproduction. International Journal of Urban and Regional Research, 31(1), 169-178.

Kantor, P. and Savitch, H. (2005) How to study comparative urban development politics: A research note. International Journal of Urban and Regional Research, 29(1), 135-151. DOI: 10.1111/j.14682427.2005.00575.x.

Katz, B. and Bradley, J. (2013) The Metropolitan Revolution: How Cities and Metros Are Fixing Our Broken Politics and Fragile Economy. Washington, DC: Brookings Institution Press.

Keil, R. (1998) Globalization makes states: Perspective of local governance in the age of the world city. Review of International Political Economy, 5(4), 616-646.

Keil, R.; Hamel, P.; Boudreau, J.-A. and Kipfer, S. (eds.) (2017a) Governing Cities Through Regions. Canadian and European Perspectives. Waterloo: WLU Press.

Keil, R.; Hamel, P.; Boudreau, J.-A.; Kipfer, S. and Allahwala, A. (2017b) Regional governance revisited: Political space, collective agency, and identity. In: Governing Cities Through Regions. Canadian and European Perspectives, Keil, R.; Hamel, P.; Boudreau, J.-A. and Kipfer, S. (eds.) Waterloo: WLU Press, pp. 3-26.

King, D. and LeGalès, P. (eds.) (2017) Reconfiguring European States in Crisis. Oxford University Press.

Krukowska, J. and Lackowska, M. (2017) Metropolitan colours of Europeanization. Institutionalization of integrated territorial investment structures in the context of past cooperation in metropolitan regions. Raumforschung und Raumordnung, 75(3), 275-289. DOI: 10.1007/s13147-016-0447-y.

Khanna, P. (2016) Connectography: Mapping the Global Network Revolution. London: Weidenfeld \& Nicolson.

Kuhlmann, S. (2009) Politik- und Verwaltungsreform in Kontinentaleuropa. Subnationaler Institutionenwandel im Deutsch-französischen Vergleich. BadenBaden: Nomos. 
Kuhlmann, S. and Bouckaert, G. (2016) Introduction: Comparing local public sector reforms: Institutional policies in context. In: Local Public Sector Reforms in Times of Crisis, Kuhlmann, S. and Bouckaert, G. (eds.) London: Palgrave Macmillan, pp. 1-20.

Kuhlmann, S. and Wollmann, H. (2014) Introduction to Comparative Public Administration. Cheltenham: Edward Elgar.

Kübler, D. and Lefèvre, C. (2017) Megacity governance and the state. Urban Research \& Practice, 11(4), 378-395.

Kübler, D. and Rochat, P. (2018) Fragmented governance and spatial equity in metropolitan areas: The role of intergovernmental cooperation and revenuesharing. Urban Affairs Review, 55(5), 1247-1279.

Lang, T. and Török, I. (2017) Metropolitan region policies in the European Union: Following national, European or neoliberal agendas? International Planning Studies, 22(1), 1-13.

Lidström, A. (2007) Territorial governance in transition. Regional and Federal Studies, 17(4), 499-508.

Lieberman, R.C. (2003) (December 2002) Ideas, institutions, and political order: Explaining political change. American Political Science Review, 96(4), 697-712.

Lorrain, D. (2005) Urban capitalisms: European models in competition. International Journal of Urban and Regional Research, 29(2), 231-267.

Loughlin, J. (ed.) (2003) Subnational Democracy in the European Union. Oxford: Oxford University Press.

Loughlin, J. (2007) Reconfiguring the state: Trends in territorial governance in European states. Regional and Federal Studies, 17(4), 385-403.

Lowndes, V. and Lempriere, M. (2018) Understanding variation in processes of institutional formation. Political Studies, 66(1), 226-244.

Löw, M. (2016) The Sociology of Space. Materiality, Social Structures, and Action. Cham: Springer.

Merton, R. (1968) Social Theory and Social Structure. New York, NY: The Free Press.

Ministère de l'intérieur (2011) Loi de réforme des collectivités territoriales. guide pratique. Paris: Ministère de l'intérieur.

MKRO / Ministerkonferenz für Raumordnung (2016) Leitbilder und Handlungsstrategien für die Raumentwicklung in Deutschland. Berlin: Bundesministerium für Verkehr und digitale Infrastruktur.

Moisio, S. and Jonas, A.E.G. (2018) City regions and city-regionalism. In: Handbook on the Geographies of Regions and Territories, Paasi, A.; Harrison, J. and Jones, M. (eds.) Cheltenham: Edward Elgar, pp. 285-297.

Moisio, S.; Luukkonen, J. and Jonas, A.E.G. (2018) Political geographies of globalization. In: Handbook on the Geographies of Globalization, Kloosterman, R.C.; Mamadouh, V. and Terhorst, P. (eds.) Cheltenham: Edward Elgar, pp. 135-147.

Nadin, V. and Stead, D. (2012) Opening up the compendium: An evaluation of international comparative planning research methodologies. European Planning Studies, 21(10), 1542-1561.

Négrier, E. (2005) The new French dice: Metropolitan institution building and democratic issues. In: Metropolitan Governance. Capacity, Democracy and the Dynamics of Place, Heinelt, H. and Kübler, D. (eds.) London: Routledge, pp. 29-46. 
Nelles, J. (2012) Comparative Metropolitan Policy: Governing Beyond Local Boundaries in the Imagined Metropolis. London: Routledge. DOI: $10.4324 / 9780203126745$.

OECD (2012) Redefining “Urban”. A New Way to Measure Metropolitan Areas. Paris: OECD.

OECD (2018) Asymmetric Decentralization: Trends and Policy Implications. Paris: CFE/RDPC.

Ostrom, V.; Tiebout, C.M. and Warren, R. (1961) The organization of government in metropolitan areas: A theoretical inquiry. American Political Science Review, 55(4), 831-842.

Otgaar, A.; van den Berg, L.; van der Meer, J. and Speller, C. (2008) Empowering Metropolitan Regions through New Forms of Cooperation. Aldershot: Ashgate.

Paasi, A. (2002) Bounded spaces in the mobile world, deconstructing 'regional identity'. Tijdschrift voor Economische en Sociale Geografie, 93(2), 137-148.

Pinson, G. (2020) Voracious cities and obstructing states. In: The City as Global Political Actor, Oosterlynck, S.; Beeckmans, L.; Bassens, D.; Derudder, B.; Segaert, B. and Braeckmans, L. (eds.) London: Routledge, pp. 60-85.

Pinson, G. and Galimberti, D. (2013) Métropole franches et regions agencifiées. Pouvoir locaux, 96(1), 48-55.

Ragin, C. (1992) "Casing" and the process of social inquiry. In: What Is a Case? Exploring the Foundations of Social Inquiry, Ragin, C.C. and Becker, H.S. (eds.) Cambridge: Cambridge University Press, pp. 217-226.

Robinson, J. (2016) Comparative urbanism: New geographies and cultures of theorizing the urban. International Journal of Urban and Regional Research, 40(1), 187-199.

Rosan, C.D. (2016) Governing the Fragmented Metropolis. Planning for Regional Sustainability. Philadelphia, PA: University of Pennsylvania Press.

Sager, F. (2006) Policy coordination in the European metropolis: A meta-analysis. West European Politics, 29(3), 433-460.

Saldaña, J. (2016) The Coding Manual for Qualitative Researchers. 3rd edition. Los Angeles, CA: Sage Publications.

Salet, W. and Thornley, A. (2007) Institutional influences on the integration of multilevel governance and spatial policy in European city-regions. Journal of Planning Education and Research, 27(2), 188-198.

Salet, W.; Thornley, A. and Kreukels, A. (eds.) (2003) Metropolitan Governance and Spatial Planning. Comparative Case Studies of European City Regions. London: Spon Press.

Sartori, G. (1991) Comparing and miscomparing. Journal of Theoretical Politics, 3(3), 243-257.

Schmitt, P. (2009) Raumpolitische Diskurse um Metropolregionen in Deutschland: Positionen, Kontroversen, Perspektiven. In: Metropolregionen Innovation, Wettbewerb, Handlungsfähigkeit. ARL Forschungs- und Sitzungsberichte, Knieling, J. (ed.) Hannover, pp. 60-100.

Scott, A. J. (2001) Globalization and the rise of city-regions. European Planning Studies, 9(7), 813-826. DOI: 10.1080/09654310120079788.

Scott, A.J. (2019) City-regions reconsidered. Environment and Planning. Part A, 51(3), 554-580. DOI: 10.1177/0308518X19831591. 
Sellers, J. (2019) From Within to Between nations: Subnational comparison across borders. Perspectives on Politics, 17(1), 85-105. DOI: 10.1017/S1537592718 002104.

Sellers, J.M.; Kübler, D.; Arretche, M. and Razin, E. (2017) Inequality and Governance in the Metropolis. Place Equality Regimes and Fiscal Choices in Eleven Countries. London: Palgrave Macmillan.

Sellers, J. M.; Kübler, D.; Walks, R. A. and Walter-Rogg, M. (2013) The Political Ecology of the Metropolis. Colchester: ECPR Press.

Siedentop, S. and Fina, S. (2012) Who sprawls most? Exploring the patterns of urban growth across 26 European countries. Environment and Planning. Part A, 44(11), 2765-2784.

Soja, E. (2000) Postmetropolis: Critical Studies of Cities and Regions. Oxford: Blackwell.

Steen,T.; Teles, F. and Torsteinsen, H. (2017) Improving local service Delivery: Increasing performance through reforms. In: The Future of Local Government in Europe, Lessons from Research and Practice in 31 Countries, Bouckaert, G.; Kuhlmann, S. and Schwab, C. (eds.) Baden-Baden: Nomos, pp. 53-78.

Streeck, W. (2017) A new regime: The consolidation state. In: Reconfiguring European States in Crisis, King, D. and LeGalès, P. (eds.) Oxford: Oxford University Press, pp. 139-157.

Teles, F. (2016) Local Governance and Intermunicipal Cooperation. London: Palgrave Macmillan UK.

Tilly, C. (1984) Big Structures, Large Processes, Huge Comparisons. New York: Russel Sage Foundation.

Tomàs, M. (2020) Metropolitan revolution or metropolitan evolution? The (dis) continuities in metropolitan institutional reforms. In: Metropolitan Regions, Planning and Governance, Zimmermann, K.; Galland, D. and Harrison, J. (eds.) Cham: Springer International Publishing, pp. 25-39.

Tosics, I. (2019) The metropolitan challenge in European Urban Areas, paper presented at the EURA-UAA Conference, in Dublin, June 20-22.

Tubertini, C. (2015) La città metropolitana tra Regione, Comuni ed Unioni. Analisi delle relazioni istituzionali. Roma. Working Papers. Rivista online di Urban@it. Available at http://www.urbanit.it/wpcontent/uploads/2015/09/BP_A_Tubertini .pdf.

Verhage, R.; Baker, M. and Boino, P. (2007) Strategic spatial planning at the metropolitan level. The case of Manchester and Lyon. In: Spatial Planning Systems of Britain and France. A Comparative Analysis, Booth, P.; Breuillard, M.; Fraser, C. and Paris, D. (eds.) London, New York: Routledge, pp. 83-98. DOI: $10.4324 / 9780203962244$.

Vinci, I. (2019) Governing the metropolitan dimension: A critical perspective on institutional reshaping and planning innovation in Italy. European Journal of Spatial Development, 70, 1-21. DOI: 10.30689/EJSD2018:70.1650-9544.

Wachsmuth, D. (2017) Competitive multi-city regionalism: Growth politics beyond the growth machine. Regional Studies, 51(4), 643-653.

Wollmann, H. (2008) Reformen in Kommunalpolitik und -verwaltung England, Schweden, Frankreich und Deutschland im Vergleich Wiesbaden: Springer VS.

Zimmermann, K. (2012) Institutionalisierung regionaler Kooperation zwischen strategischer Anpassung und kollektiven Lernprozessen: Das Beispiel Metropolregion Rhein-Neckar. Baden-Baden: Nomos. 


\section{Introduction}

Zimmermann, K. (2017) Re-scaling of metropolitan governance in Germany. Raumforschung und Raumordnung, 75(3), 253-263.

Zimmermann, K. and Heinelt, H. (2012) Metropolitan Governance in Deutschland. Das Regieren in Ballungsräumen und neue Formen politischer Steuerung. Wiesbaden: Springer VS.

Zimmermann, K.; Galland, D. and Harrison, J. (2020) Metropolitan Regions, Planning and Governance. Cham: Springer. 


\title{
2 France
}

\author{
P. Feiertag
}

\subsection{City-regions and their governance in France}

The preferred solution for addressing metropolitan issues in France is municipal groupings with their own taxation. Their administrative capacities have been gradually extended since the 1970s. The recent creation of métropoles as a specific form of municipal grouping is another step in a longer history of territorial reforms (Parnet 2016, 242-243). Départements, the second tier of local government, are highly visible for citizens because of their responsibility for social welfare funds. However, their function has been mainly reduced to the implementation of national social welfare policies and the growth of compulsory expenditure limits their possibilities to become active in other policy fields (Négrier and Nicolas 2011, 77; Desjardins and Geppert 2020,124). The régions created in the 1980s have become the leading level of government concerning economic development and transport, and cover large territories, in particular since their number was reduced from 22 to 13 in 2016 (without overseas territories). Due to their size, they are less relevant for city-regional governance.

In this section we will give an account of national metropolitan policy by focussing on the recent developments, i.e. the establishment of métropoles and pôles métropolitains. We will first explain the evolution of metropolitan groupings culminating in the creation of métropoles for joint policy-making in city-regions (2.1.1) and their extensive functions (2.1.2), and then we will discuss the ideas that guided the territorial reforms of the 2010s and that led to the creation of métropoles (2.1.3) as well as the spatial dimension of métropoles and pôles métropolitains (2.1.4).

\subsubsection{Metropolitan institutions: a long history of municipal groupings instead of amalgamation}

France is the country with the highest number of municipalities in Europe. Many of them are small or very small: about three-quarters (i.e. 25,059 out of 34,841 ) of the municipalities have fewer than 1,000 inhabitants (DGCL 2019). As attempts to amalgamate municipalities failed throughout the 20th century, multi-purpose associations were promoted to overcome 


\section{France}

municipal fragmentation (Hertzog 2018, 134; Borraz and Le Galès 2005). France has a rich history of inter-municipal cooperation that began in the 19th century with contribution-financed single-purpose unions (syndicats), mainly in rural areas for public services such as water supply, sewage, waste collection, electricity and gas. From 1959 onwards, multi-purpose unions as well as districts, ${ }^{1}$ which could levy their own taxes, were set up (Wollmann 2008, 58). The first wave of communautés urbaines was created by law in the 1960s, including Lyon, Lille, Bordeaux and Strasbourg, later followed by Brest in the 1970s, Nice and Nancy in the 1990s, Nantes and Toulouse in the 2000s and Dijon, Saint-Étienne and Clermont-Ferrand only between 2015 and 2017. A system of different types of groupings depending on the size of municipality was established in 1999 and complemented 11 years later by the métropole.

The creation of enlarged unions with more functions has accelerated throughout recent territorial reforms (see Figure 2.1). Since 2017, all $^{2}$ French municipalities have been engaged in one of the four forms of municipal groupings (Etablissement public de coopération intercommunale à fiscalité propre, EPCI): communauté de communes (CC), communauté d'agglomération (CA), communauté urbaine (CU) or métropole. Those municipal groupings have become an important pillar of French subnational government (Geppert 2017, 227). The difference between EPCIs and technical multi-purpose unions for water supply or sewage is that they have a number of compulsory functions and fiscal powers. Single-purpose and multi-purpose unions have been partly absorbed, but will continue to exist both inside and between EPCIs if their perimeters are more pertinent to their task than the EPCI (Hertzog 2018, 143). One example is the regional planning associations (syndicats de SCoT, see 2.2.3 and 2.3.3).

In analogy to rural and peri-urban areas, city-regions are organised as municipal groupings instead of merging the municipalities and creating new jurisdictions. The laws on reform of local government (RCT, 16 December 2010) and on modernising public territorial action and consolidating the metropoles (MAPTAM, 27 January 2014) created a specific kind of grouping called a "métropole" for city-regions. The main difference to the other types of EPCI is that métropoles have more compulsory functions and accordingly also a higher budget. Lyon is the only one with the status of a local authority, exerting the powers of the département over its territory.

Twenty-two métropoles have existed in France since 2018. All of them had been organised in some kind of municipal grouping before, meaning that there is a path-dependency of inter-municipal cooperation at the local level. Their trajectories, however, have been different as can also be seen in the two cases of Lyon (see 2.3) and Nantes (see 2.2). The pre-existing placespecific institutional structures had an impact on the recent metropolitan reform and its outcome, most notably in the case of the three métropoles with special status: Paris, Aix-Marseille and Lyon (Parnet 2016). The transformation of the former CUs and CAs into a métropole mainly took place in 2015, followed by a second wave of métropoles in 2018 (see Table 2.1). 

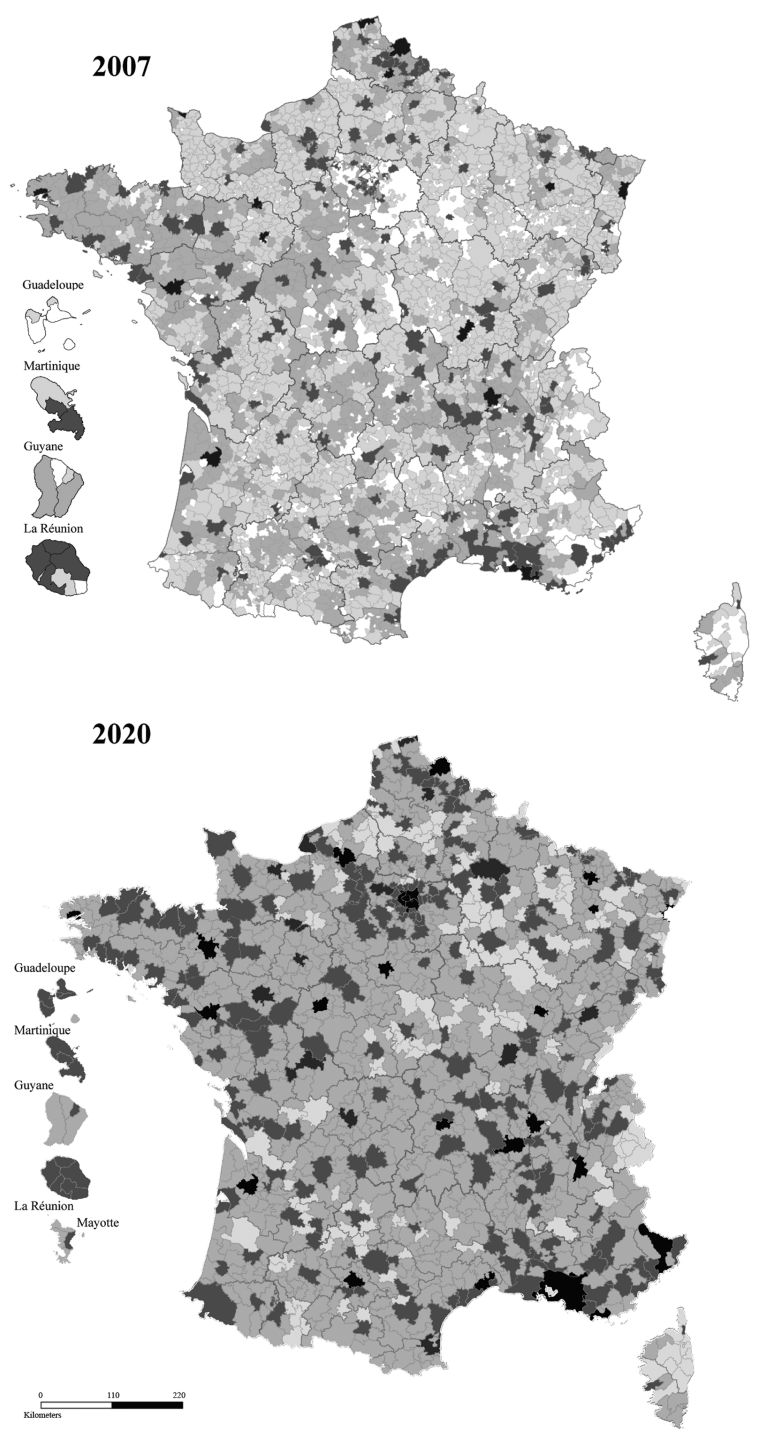

\begin{tabular}{llll}
\hline Type of municipal grouping & 01.01 .2007 & 01.01 .2015 & 01.01 .2020 \\
Métropole (incl. Lyon) & 0 & 11 & 22 \\
$\quad$ Communauté urbaine CU & 14 & 9 & 14 \\
Communauté d'agglomération CA & 169 & 226 & 222 \\
Communauté de communes CC & 2.368 & 1.884 & 997 \\
\hline
\end{tabular}

Figure 2.1 Development of municipal groupings from 2007 to 2020 (C) Cartography: DGCL - Banatic 


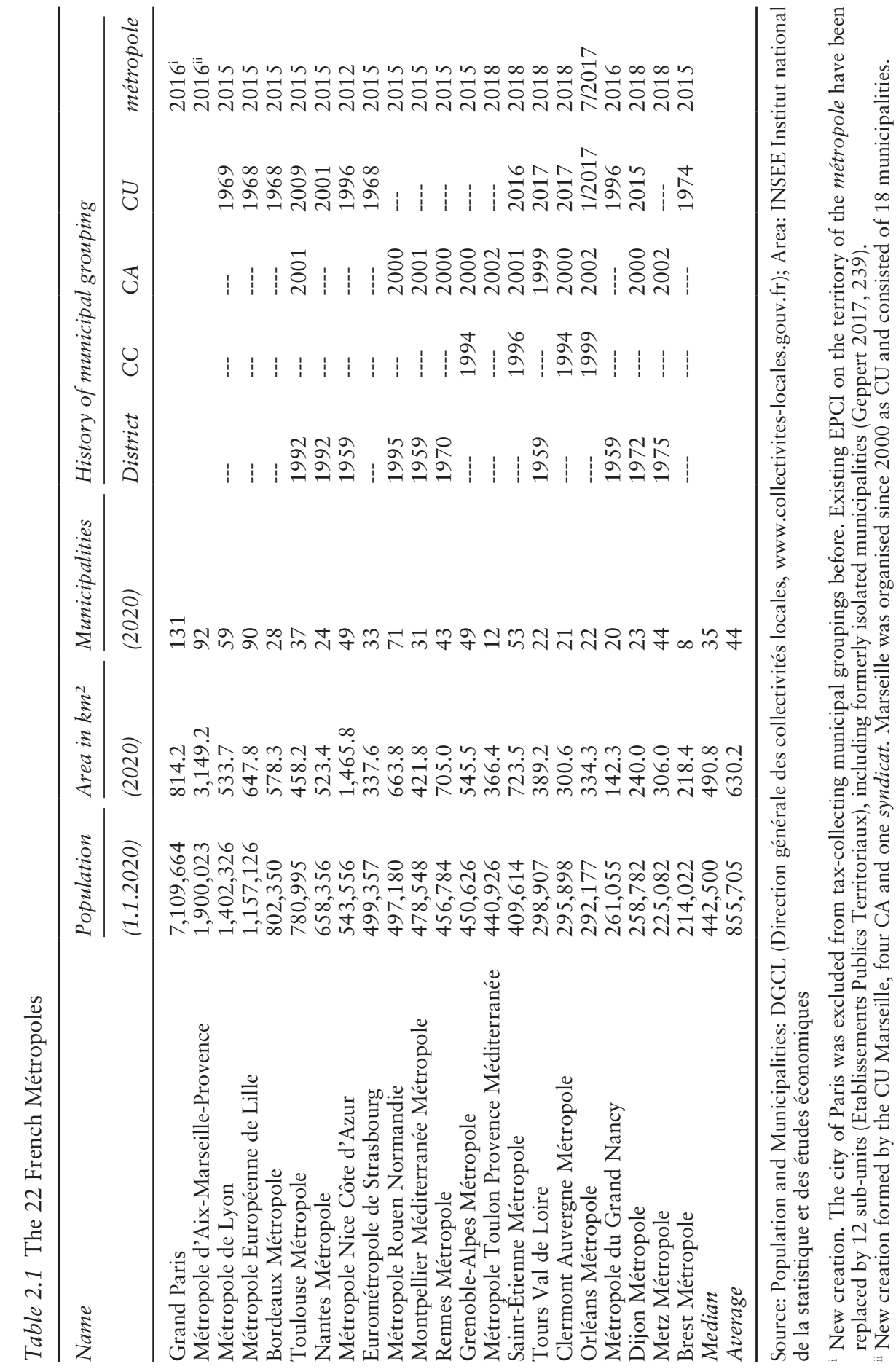




\subsubsection{Legitimacy}

Métropoles are governed by a council composed of municipal councillors (conseil de la métropole), a president elected out of the council (président de la métropole) and an executive body formed by the vice-presidents (bureau). A conférence métropolitaine formed by the mayors of all member municipalities has advisory status and a coordinating function between the métropole and its member municipalities. The conseil de développement is another body with advisory status. It is composed of members of the civil society, organises debates and formulates propositions and statements both at the request of the métropole (e.g. within planning processes such as the local land use plan) and to self-selected topics.

It is common practice to elect a mayor as president, though national law does not prescribe this as a rule. The president is often the mayor of the core city (e.g. in Toulouse, Bordeaux, Brest and Montpellier), leading to a concentration of power. Each member municipality is represented by at least one councillor (or a number of councillors corresponding to the demographic weight of the municipality), but the number of vice-presidents is restricted to 20 . It is noteworthy that the variation in the number of member municipalities is huge, ranging from eight to 131 municipalities (median of 35; see Table 2.1). Very large groupings are more challenging to manage, because governance is based on finding consensus. As councillors represent the interests of their municipality and mayors play a significant role as local leaders, finding consensus may be difficult. Four métropoles have more than 70 member municipalities: Métropole Rouen Normandie, Métropole Européenne de Lille, Métropole d'Aix-Marseille-Provence and Grand Paris.

Whereas the inter-municipal cooperation in the form of the métropoles is adopting the model of a hard, powerful institution, the urban-rural cooperation with their hinterland is either not institutionalised or happens through soft, flexible agreements (contrat de réciprocité) or light institutions dedicated to running the cooperation (syndicat mixte, association, pôle métropolitain; support of agences d'urbanisme). In 2018, 21 métropoles $^{3}$ indicated in a survey 173 partnerships with surrounding territories, i.e. an average of 8.2 each, including both multi-thematic and single topic cooperation (43\% single topic) as well as different degrees of institutionalisation (CGET 2019). This illustrates well that cooperation beyond the borders of the métropoles follows the logic of flexible geographies, with many different, overlapping perimeters of cooperation, depending on the topic. The pôle métropolitains are a case in point.

\subsubsection{Pôles métropolitains}

Pôles métropolitains are a soft form of voluntary inter-territorial cooperation introduced at the same time as the métropole by the RCT law in 2010. The legal definition is much more open in terms of members, spatial 


\section{France}

delimitation and competencies, leading to large diversity (Bariol-Mathais 2017). They are made up of municipal groupings, but can also involve the région and the département in a vertical cooperation, as well as other partners such as universities, port companies, economic development agencies, tourist offices, chambers of commerce and industry or agences d'urbanisme. In terms of spatial relationships they either cover a continuous area or form a network of cities (see Figure 2.2). One EPCI can be member of several pôles. The pôles métropolitains accomplish self-defined tasks in the common interest of the members. These common interests defined by the members differ from case to case, but mostly cover economic development, research and innovation policies, tourism, culture, mobility and in a few cases also regional planning ${ }^{4}$ (Bariol-Mathais 2017, 36; Hertzog 2018, 145). These tasks are partly delegated by the members without transferring them completely to the pôle and partly additional tasks for larger-scale coordination. However, the pôles métropolitains do not have their own source of income,

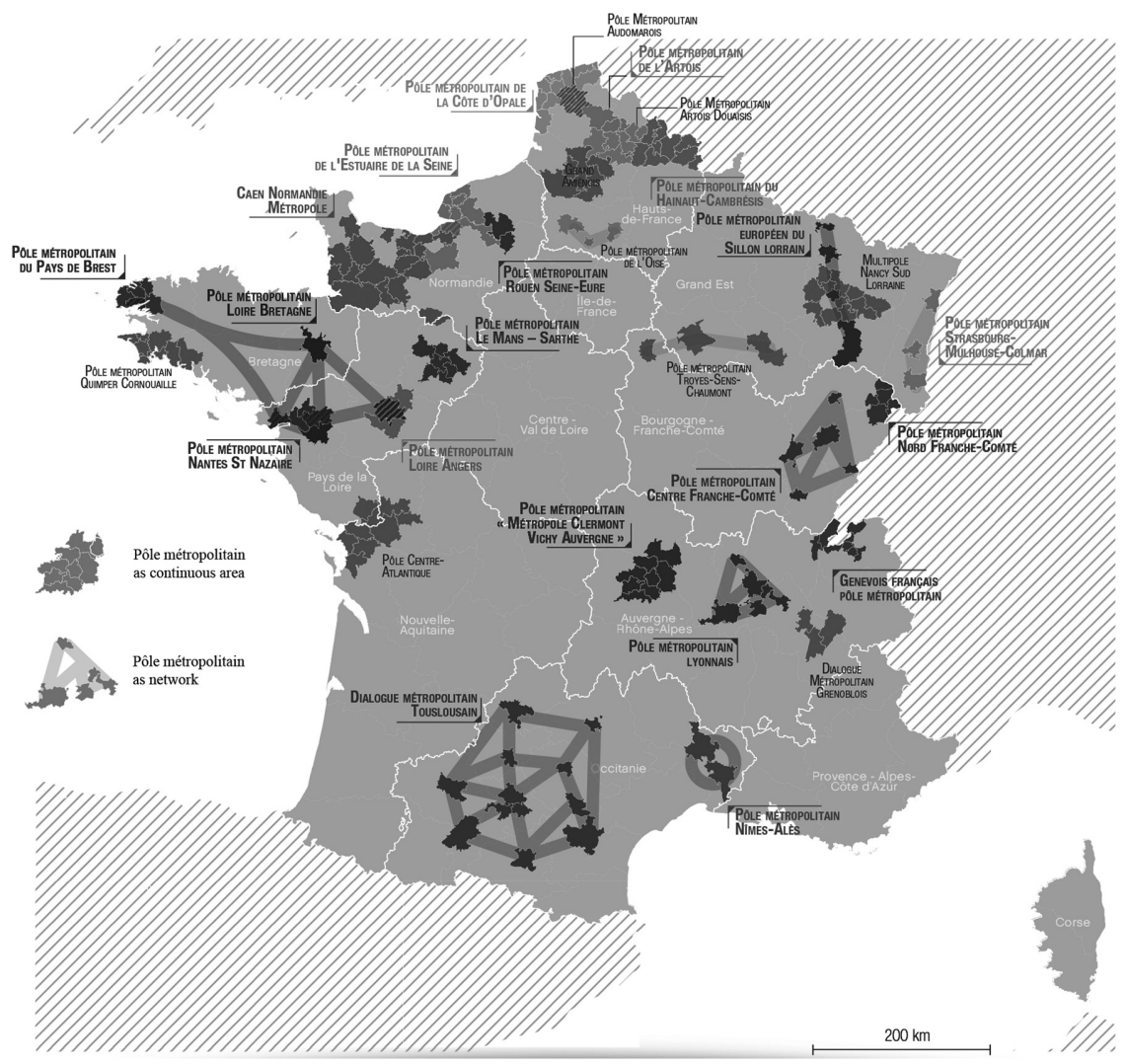

Figure 2.2 Pôles métropolitains in 2017 (C) FNAU, Source: Bariol-Mathais 2017, 39 
but are financed by membership fees and project-related funding from upper level government. They therefore depend on the commitment of their members, in particular the presidents of the largest EPCI.

On first sight, pôle métropolitains and métropoles may seem to be concurrent forms of metropolitan governance. In fact, after a phase of experimentation with soft metropolitan networks such as the pôles (call for cooperation issued by DATAR in 2004, see Motte 2007; Demazière and Sykes 2021; Megerle 2008, 26), the state favoured the model of métropoles, which became obligatory in 2014 (loi MAPTAM). However, the municipalities often sympathised with the more flexible model of the pôle métropolitain and established it in numerous city-regions. Between 2011 and 2013, only one métropole was created, Nice, but 11 pôles. Since 2014, the métropoles have dominated the national discourse, but numerous new pôles have emerged in areas with smaller urban centres. Measured in terms of incentives granted by the state, resources and attention, the métropoles can be considered as winners in the competition between the two models (Vanier 2017). Measured in terms of the number of pôles created, however, they have also been able to establish themselves. Since many large cities (Lyon, Nantes, Rouen, Strasbourg, Rennes, Saint-Étienne, Clermont-Ferrand, Nancy, Metz and Brest; and in a preliminary stage also Toulouse and Grenoble) are today part of both a métropole and a pôle métropolitain, both can be interpreted as complementary forms rather than competing models for the organisation of metropolitan spaces. In terms of administrative power, the métropole is much more relevant.

\subsubsection{Functions: redistributing responsibilities within the emerging multilayer system}

Throughout the history of inter-municipal cooperation in France, a gradual shift of municipal responsibilities to the inter-municipal level has taken place (Borraz and Le Galès 2005). Municipal groupings only have powers in matters that are explicitly listed in their statutes, whereas municipalities can act in any matter of municipal interest. However, today the responsibilities of the EPCIs are more important than the powers left to the municipalities. Hertzog $(2018,146)$ even anticipates, that they will in the long run become "the consistent municipal level, the old communes staying like the parishes in England." Out of the different types of municipal groupings in France, métropoles have the broadest portfolio of functions. Compared to intermunicipal cooperation in other countries, even communautés de communes "have an important list of compulsory competences and are incited to progressively absorb the technical unions" (Hertzog 2018, 148); this statement applies even more to the métropoles (see Table 2.2).

As a general rule, inter-municipal cooperation is more intense in urban areas than in rural ones, reflected by the functional profile of CCs, CAs, CUs and métropoles. However, local variation is possible. Member 


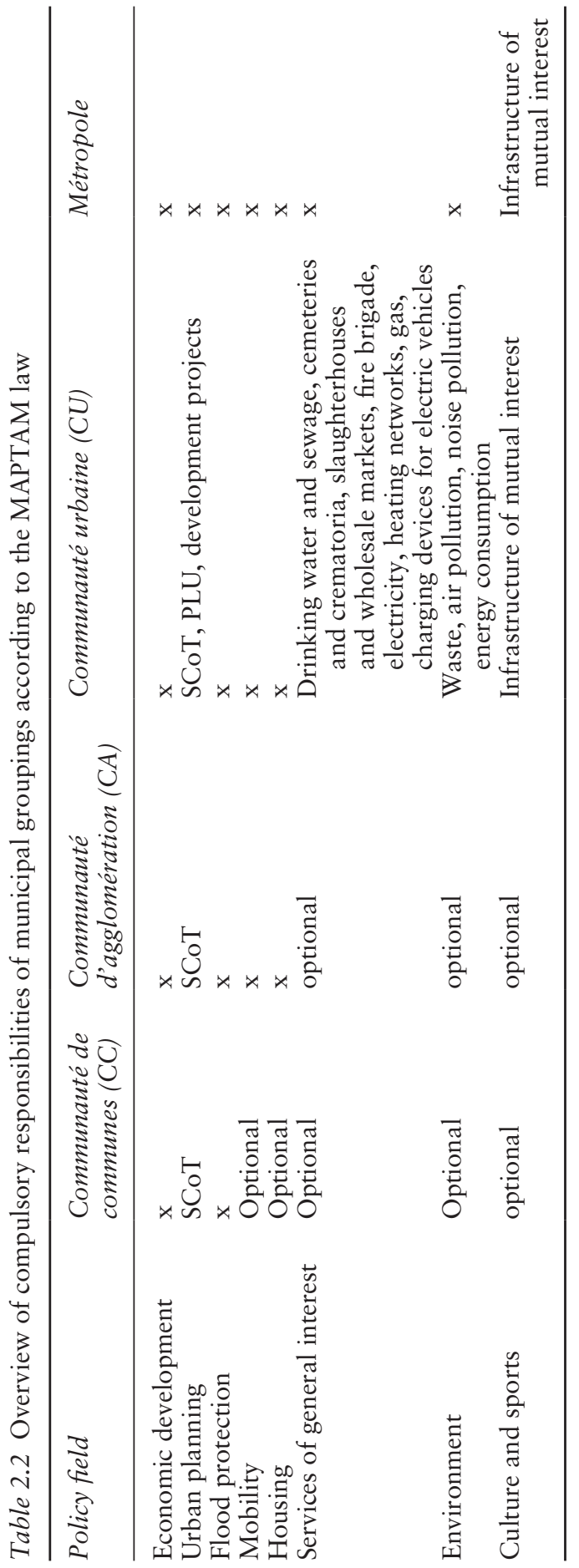


municipalities of each municipal grouping can delegate additional functions to the inter-municipal level, depending on local consensus and the willingness to pursue inter-municipal integration. Or, on the contrary, they can choose a type of municipal grouping with fewer compulsory functions if they do not wish to adopt them, e.g. a CA instead of a CU or a CC instead of a CA. Brest is an example of a city-region with a higher degree of integration despite the relatively small size of the city-region (Geppert 2017, 236). Whether the transformation into a métropole induces significantly enlarged competencies or not depends on prior integration. Changes in the functional profile were significant in the case of the former CAs such as Rennes or Grenoble and only minor in some former CUs (see section 2.2.1 and Table 2.1).

The redistribution of responsibilities within the multilayer system did not only apply to the municipalities and municipal groupings, but to all levels of territorial government. A key aim of recent French territorial reforms was to redefine the functions of each layer and reduce the overlap of powers (Parnet 2016, 241). The régions and the municipal groupings have been strengthened whereas départements and municipalities have lost functions, in particular in urban areas. The métropoles have acquired some former departmental functions. An entire delegation of functions of the département to the métropole within its territory has so far only happened in Lyon, where the transfer came about due to an alliance of the mayor of Lyon and the president of the Département Rhône (Geppert 2017, 237; see 2.3.1). The French government sympathises with the idea of expanding this model to all métropoles, but has met local opposition both from presidents of several métropoles (e.g. Nantes, see 2.2.1) and départements. So far, a mandatory transfer of responsibilities concerns only departmental roads and some minor tasks, whereas the départements keep their role concerning school education and social policy. Each métropole had to sign an agreement with its département about at least three responsibilities out of a list of eight to be transferred in January 2017. The most popular have been funds for housing and youth care. The same law (NOTR 2015) also abolished the general clause of competence for départements and régions. Previously, each level of government had the power to intervene in any policy field concerning its territory, without a hierarchy between them. The reform was supposed to clarify roles and define the main responsible level of government (Desjardins and Geppert 2020, 125). Regions have the leading role for economic development and intermodal transport, départements for social policies such as minimum income, job placement and social services for elderly people and youth care (Négrier and Nicolas 2011). There are still policy fields shared by all levels such as culture, sport, tourism, education and environment.

Régions and métropoles have overlapping responsibilities in the field of economic development and environmental protection. In the field of planning, a hierarchy of comprehensive plans developed at different levels of 


\section{France}

government below the state was introduced in 2015. The régions had to adopt a legally binding strategic plan until 2019, the SRADDET (schéma régional d'aménagement, de développement durable et d'égalité des territoires). The SRADDET replaces a range of sectoral plans and is binding for the lower scale regional plan SCoT (schéma de cohérence territoriale) developed by the municipal groupings. The SCoT was introduced in the year 2000 (law SRU), leading to a first generation of plans in the mid-2000s. This was an attempt to reintroduce a strategic dimension to spatial planning and to link land use, transport and housing (Verhage et al. 2007, 83; Wollmann 2008, 186). Inter-municipal cooperation was deepened by this joint task of developing a future vision for the territory and staff for spatial planning tasks was increased (Kuhlmann et al. 2011, 162). The subordination of the already existing SCoT to the SRADDET can lead to conflicts, because the métropoles have much more experience, know-how and manpower in the field of spatial planning whereas régions have in the past concentrated on regional economic development and the distribution of regional funds. Despite decentralisation, France continues to be a unitary state and régions remain rather weak in terms of budgets and decision-making power as they cannot formulate laws (Beyer 2017, 40). Due to the power of the métropoles, régions are tempted to focus their efforts on the compensation of non-metropolitan areas, while their competencies - innovation, regional rail transport, etc. - relate strongly to large agglomerations (Desjardins and Geppert 2020, 130).

\subsubsection{Ideas behind territorial reforms: efficiency in the public sector}

The simplification of the territorial organisation of the French state and the clarification of power relations between governmental levels were the main preoccupation of the territorial reforms of the years 2010 and 2014/15 (Geppert 2017, 234; Vanier 2017, 18; Négrier and Nicolas 2011). Terms such as "excessive number of levels", "confusion", "dysfunction and redundancies" used by president Sarkozy (2008) underline the need to intervene and to rationalise the distribution of responsibilities. In the speeches of presidents and ministers related to the RCT and MAPTAM laws, only limited parts concern the métropoles introduced by those laws. Pôles métropolitains are for the most not mentioned at all. This illustrates well that the reforms concerned the entire system of public administration and territorial representation, not just the metropolitan regions.

Although the main driver in terms of ideas is efficiency in the public sector, when speaking of métropoles, the main idea that is evoked by the government is the increased competition of cities on a European and global scale related to globalisation. This idea is used to justify the need for strong, integrated institutions to govern city-regions. Their new legal status and functions such as economic development, marketing and innovation are supposed to enable them to better ensure their international competitiveness 
and economic dynamism (Lebranchu 2014). The debate focuses on the distribution of functions between layers of government, whereas the spatial dimension of metropolitan regions is left aside. In consequence, the national laws favour institutional integration of the métropoles instead of addressing an enlargement or redefinition of perimeters.

Another idea often referred to is the provision of services of general interest. The argument is that city-regions are congested areas with an increased need for steering and coordination. The city-region is seen as an appropriate problem-solving level for housing, transport, education, social services and environmental issues related to the needs of the inhabitants. This argument justifies the transfer of additional responsibilities to the métropole. It also implies that métropoles are not only dedicated to production functions, but also to functions of social reproduction, which is in fact reflected in the profile of their compulsory responsibilities set by the legislator. The concentration of functions at the level of métropoles is justified in conjunction with efficiency arguments.

The idea of local self-government was relevant in 2009-2010. The issue was whether metropolitan governments should be created top-town by national law as argued by the expert commission Balladur (Comité pour la réforme des collectivités locales 2009) or based on voluntary inter-municipal initiatives. The interior minister Hortefeux (2010) argued at that time that "the dynamics must come from the territories themselves. State-imposed métropoles, from Paris, will guarantee useless polemics and certainly fail" (own translation). ${ }^{5}$ Accordingly, the legal status of métropole was first introduced as a voluntary option. But only one city-region, Nice, adopted it. This position was therefore partly revised with the MAPTAM law in 2014, when the transformation into a métropole became compulsory for the largest municipal groupings with at least 400,000 inhabitants located in a functional urban area (aire urbaine) of 650,000 or more inhabitants. Smaller ones may be granted this status on their request but only with the agreement of the national government.

The idea of national territorial cohesion (égalité du territoire) is related to the concern of rural areas and small towns about being disadvantaged by the reforms strengthening the territorial organisation of metropolitan regions. The counter-argument of the government follows the theory of spill-over, arguing that the entire country will benefit economically from strengthening metropolitan regions. This is related to the idea of competitiveness as metropolises are seen as engines of growth.

Participation has played a minor role when justifying the reforms. The idea of citizen involvement and strengthening local democracy was therefore not the driving force behind the legislative initiative, but was taken into account. It is related to decentralisation ("closer to the citizens") and accountability and concerns mainly the local level. Still, the democratic control of inter-municipal politics by the citizens is acknowledged as a weakness: "there is some anomaly in the fact that the EPCIs, some of which 
exercise almost general competence, remain indirectly elected, even though the expenditure they incur is equivalent to that of the regions" (own translation, ${ }^{6}$ Comité pour la réforme des collectivités locales 2009). At the same time, the representation of municipalities within the EPCI will be kept (Hollande 2012). Despite attempts to overcome the democratic deficit (Wollmann 2008, 45; Demazière 2018, 70) by introducing direct elections, the election of the metropolitan council is still tied to the municipal election. Since 2014, candidates that will represent the municipality in the metropolitan council have been separately listed on the ballots for municipal elections (Hertzog 2018, 147). The only exception, with different constituencies and electoral lists for the metropolitan council, is Lyon due to its status as a département (see 2.3.1). Therefore, the legitimacy of metropolitan governance and planning remains weak, whereas technical capacities are strong.

\subsubsection{Spatial relationships: partial enlargement based on population threshold}

The creation of the pôle métropolitain displays a multi-scaled logic of creating flexible spaces for governance. The dimension of space did not play any role in the process of creation of the métropoles. If any cartographic visualisation was used at the national level in the context of the creation of the métropoles, the city-regions were represented as dots on the map (see Figure 2.3). The debate centred on their number and their functions in the multilayer system. Regarding their sociospatial relations, métropoles were conceptualised as "scale" (Jessop et al. 2008, 293), meaning that the vertical differentiation between state institutions and scalar division of labour is emphasised. The national laws left the definition of the appropriate perimeter to the municipal groupings themselves. An exception was Aix-Marseille, where local actors could not reach a consensus to overcome institutional fragmentation, and the national government intervened by merging six municipal groupings (Parnet 2016; Douay 2013).

Instead of setting a perimeter, a minimum threshold of population was fixed to be eligible as a métropole. However, this criterion turned out to be flexible and was modified by various tailor-made exceptions at the request of local actors willing to acquire the status. This means that the criteria of eligibility have been adapted to the existing municipal groupings instead of forcing them to expand their territory to meet the population threshold. The category of métropole was initially intended for the largest agglomerations with at least 500,000 inhabitants (law RCT 2010) as well as the four CUs compulsorily created in the 1960s. ${ }^{7}$ In 2014 (law MAPTAM), the threshold was lowered to municipal groupings of 400,000 inhabitants with a functional urban area of 650,000 or more. During the elaboration of the law, Montpellier and Brest, which were below the population threshold, successfully campaigned to be granted the metropolitan status. Tailor-made additional criteria fitting each case were included (Geppert 2017, 235): 


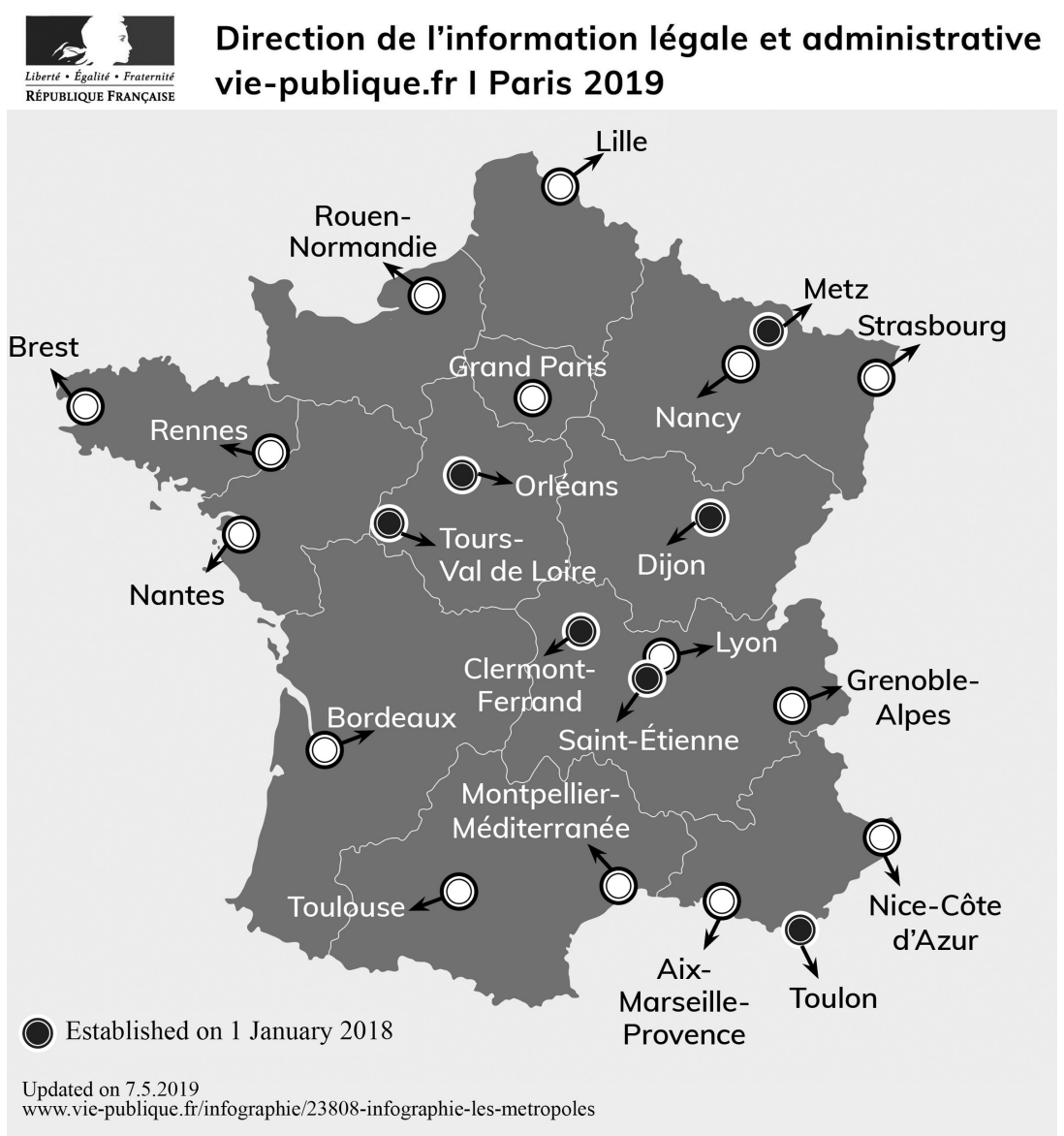

Figure 2.3 Map of métropoles by the French government

regional capitals as well as EPCIs, which already exerted the full powers of the métropoles when the law entered into force. In 2017, the criteria were relaxed again due to lobbying of the presidents of the municipal groupings (Demazière and Sykes 2021; Beyer 2017, 38) and enabled a substantial increase of métropoles from 15 to 22 (see Figure 2.3). Each municipal grouping can request to be granted the status of métropole if it has more than 250,000 inhabitants and is a regional capital with an employment zone of more than 400,000 inhabitants or a former regional capital ${ }^{8}$ with an employment zone of more than 500,000 inhabitants.

Apart from the first métropole Nice, none of the current 22 métropoles voluntarily changed their perimeter during the transformation into a métropole. They did not wish to integrate and enlarge at the same time. Since 


\section{France}

gaining the status of métropole, the spatial extension has been stable in 20 out of 22 cases; only Lille and Strasbourg added new member municipalities. Therefore, "instead of creating large alliances on the scale of broad urban areas, metropolises result in the increased integration of the urban cores of the municipalities, crystallizing pre-existing territorial structures" (Geppert $2017,235)$. However, in a few cases, an enlargement took place in the years before the creation of the métropole (see Table 2.3). The CAs of Rennes and Saint-Étienne had fewer than 400,000 inhabitants before their enlargement and thereby exceeded the threshold. All in all, eight métropoles did adapt their perimeter at all between 2010 and 2020, and three only in minor terms with one or two additional municipalities. The most significant changes of

Table 2.3 Enlargement of métropoles by additional member municipalities between 2010 and 2020 (March 2020)

\begin{tabular}{|c|c|c|c|}
\hline Métropole & $\begin{array}{l}\text { Enlargement in } \\
\text { preparation } \\
\text { (after 2010) }\end{array}$ & $\begin{array}{l}\text { Enlargement } \\
\text { simultaneous with } \\
\text { change to métropole }\end{array}$ & $\begin{array}{l}\text { Enlargement after } \\
\text { creation of métropole } \\
\text { (until 2020) }\end{array}$ \\
\hline Grand Paris & & 2016 New creation & 0 \\
\hline $\begin{array}{l}\text { Aix-Marseille } \\
\text { Provence }\end{array}$ & & 2016 New creation & 0 \\
\hline Lyon & $\begin{array}{l}2011+1 \text { municipality } \\
2014+1\end{array}$ & 0 & 0 \\
\hline Lille & 0 & 0 & $\begin{array}{l}2017+ \\
5 \text { municipalities }\end{array}$ \\
\hline Bordeaux & $2013+1$ & 0 & 0 \\
\hline Toulouse & $2011+12$ & 0 & 0 \\
\hline Nantes & 0 & 0 & 0 \\
\hline Nice & 0 & $\begin{array}{l}2012+ \\
22 \text { municipalities }\end{array}$ & 0 \\
\hline Strasbourg & 0 & 0 & $2017+5$ \\
\hline Rouen & 0 & 0 & 0 \\
\hline Montpellier & 0 & 0 & 0 \\
\hline Rennes & $\begin{array}{l}7 / 2012+1 \\
2014+5\end{array}$ & 0 & 0 \\
\hline Grenoble & $\begin{array}{l}2012+1 \\
2014+21\end{array}$ & 0 & 0 \\
\hline Toulon & 0 & 0 & 0 \\
\hline Saint-Étienne & $\begin{array}{l}2013+2 \\
2017+8\end{array}$ & 0 & 0 \\
\hline Tours & $2014+3$ & 0 & 0 \\
\hline Clermont & 0 & 0 & 0 \\
\hline Orléans & 0 & 0 & 0 \\
\hline Nancy & 0 & 0 & 0 \\
\hline Dijon & $2013+2$ & 0 & $\begin{array}{l}2019-1 \text { due to } \\
\text { merger of two } \\
\text { municipalities }\end{array}$ \\
\hline Metz & $2014+4$ & 0 & 0 \\
\hline Brest & 0 & 0 & 0 \\
\hline
\end{tabular}


perimeter took place in Aix-Marseille, Rouen (already in 2009 by merging two CAs and two CCs), Nice, Grenoble, Toulouse and Saint-Étienne. AixMarseille, Nice and Saint-Étienne are also among the métropoles with the largest area (see Table 2.1).

The dynamic of spatial redefinition and consolidation has been higher in spaces beyond the métropoles. Other types of municipal groupings have been considerably enlarged due to many mergers of small communautés de communes and the emergence of large communautés d'agglomération, partly in direct vicinity of métropoles or pôles métropolitains (see AdCF 2017, 22 and Figure 2.1). An example of a huge CA is Pays Basque with an area of 2,967 km², 159 member municipalities and about 300,000 inhabitants. Its territory is much larger than most métropoles (see Table 2.1). The CU Grand Reims with 144 municipalities was created out of seven CCs and the CA Reims Métropole. Both were established in 2017 as alternatives to a pôle métropolitain initially preferred by the municipalities.

The redrawing of the map of inter-municipal cooperation was pushed by the state and was largely accomplished by 2017 (Hertzog 2018, 142; Geppert 2017, 233). Since 2010, a representative of the government (préfet) has prepared a scheme (schéma départemental de coopération intercomunale, SDCI) after each municipal election which includes a proposition on how to redefine the boundaries of municipal groupings in the département. It is submitted to a committee of local representatives; they can deviate from the proposition, but only with a two-thirds majority. The second generation of SDCI was adopted in 2016 and induced significant changes, though not in all départements equally. The objective was to complete the coverage of the national territory by municipal groupings, reduce their number and upgrade them into more integrated categories in order to rationalise the territorial organisation and increase the efficiency of the local administration. As a result, the weight and technical capacity of municipal groupings has increased, but the very large groupings are running the risk of losing the proximity to their citizens (Geppert 2017, 234).

The upscaling also concerned planning perimeters. The more integrated groupings are obliged to take responsibility for land use planning. Even CCs and CAs are supposed to draw up inter-municipal land use plans (Plan local d'urbanisme intercommunal, PLUi) since 2010 (law Grenelle), because the national law foresees the PLUi as the desired standard and the municipal PLU as an exception (Molino and Allé 2013, 7). A PLUi with a regulatory part for the entire municipal grouping already exist in the métropoles such as in Lyon and Nantes (see 2.2.2 and 2.3.2) or are under preparation. They will become much more common in the near future in other areas as well. Until December 2017, only 22 PLUis were valid in France, but 324 were in the process of elaboration (Fédération des SCoT 2018, 4).

The city-regional strategic plan schéma de cohérence territoriale (SCoT) has also been up-scaled. As standard for the future, the SCoT has to be developed by several groupings forming a planning association instead 
of individual municipal groupings. In addition to that, the size of EPCIs increased and thus led to the revision of SCoT perimeters (Vanier et al. 2017, 34). Note that the institutional territory of a métropole and the territory for a SCoT do not coincide, with few exceptions. Whereas the métropoles themselves are mainly monocentric, covering one urban core and its adjacent built-up area, the planning regions are larger, mostly more polycentric, and include peri-urban areas. The functional area defined as aire métropolitaine is in most cases even larger than the SCoT planning region (see 2.3.2). Not all métropoles are yet part of a larger SCoT with surrounding municipal groupings. Montpellier (Moscarelli 2016), Rouen, Nice and Orléans still have a SCoT for the territory of the métropole and a more detailed PLUi for the same area under preparation.

The legal possibility of a PLUi having the function of a regional land use plan (SCoT) existed for a short period, but was revoked in 2017, meaning that their number is limited to the 13 plans already started and is not an option anymore. All urban regions are part of a SCoT. This is not the case for all rural territories. Though the number and size of planning regions have increased in the last decade, the plans do not cover the entire country yet (see Figure 2.4). The size of planning regions varies greatly and is defined at the local level. However, strong legal incentives due to limited possibilities of urban extension without a SCoT have led to a step-by-step implementation even in rural areas and to an enlargement of planning areas.

Hence, the French planning system foresees in the future a hierarchy of three planning documents with a SRADDET at the scale of the région, a SCoT at the scale of several EPCIs and a PLUi at the scale of each métropole. At the national level, a comprehensive spatial development plan does not exist, but several sectoral schemes (e.g. regarding flood risk management) define binding rules that have to be taken on in the subsequent planning instruments SRADDET, SCoT and PLUi (Desjardins and Geppert $2020,126)$. These changes in the planning system seek to ensure the coordination of spatial planning across different levels and thus to reduce the institutional fragmentation and the competition between municipalities for investments and tax revenues. Whether this aim is achieved or not varies from city-region to city-region and depends to a high degree on the maturity of inter-municipal cooperation, as Demazière (2018) argues.

The French state intervened in the 1990s by launching regional plans for some areas of national interest, the "directive territoriale d'aménagement" (DTA). They cover city-regions such as Lyon and Nantes (see sections 2.2 and 2.3), but also areas with high vulnerability (the Alps and river deltas) or difficult economic situations such as the former mining area of the Lorraine (Carpenter and Verhage 2014, 61). Six DTAs were approved by the state between 2003 and 2007..$^{9}$ Existing DTAs are still legally binding for local land use plans, but new ones after 2010 (Law Grenelle II) would only have a guiding character (and are called DTADD [directive territoriale d'aménagement et de développement durable]). After this legal change, no 


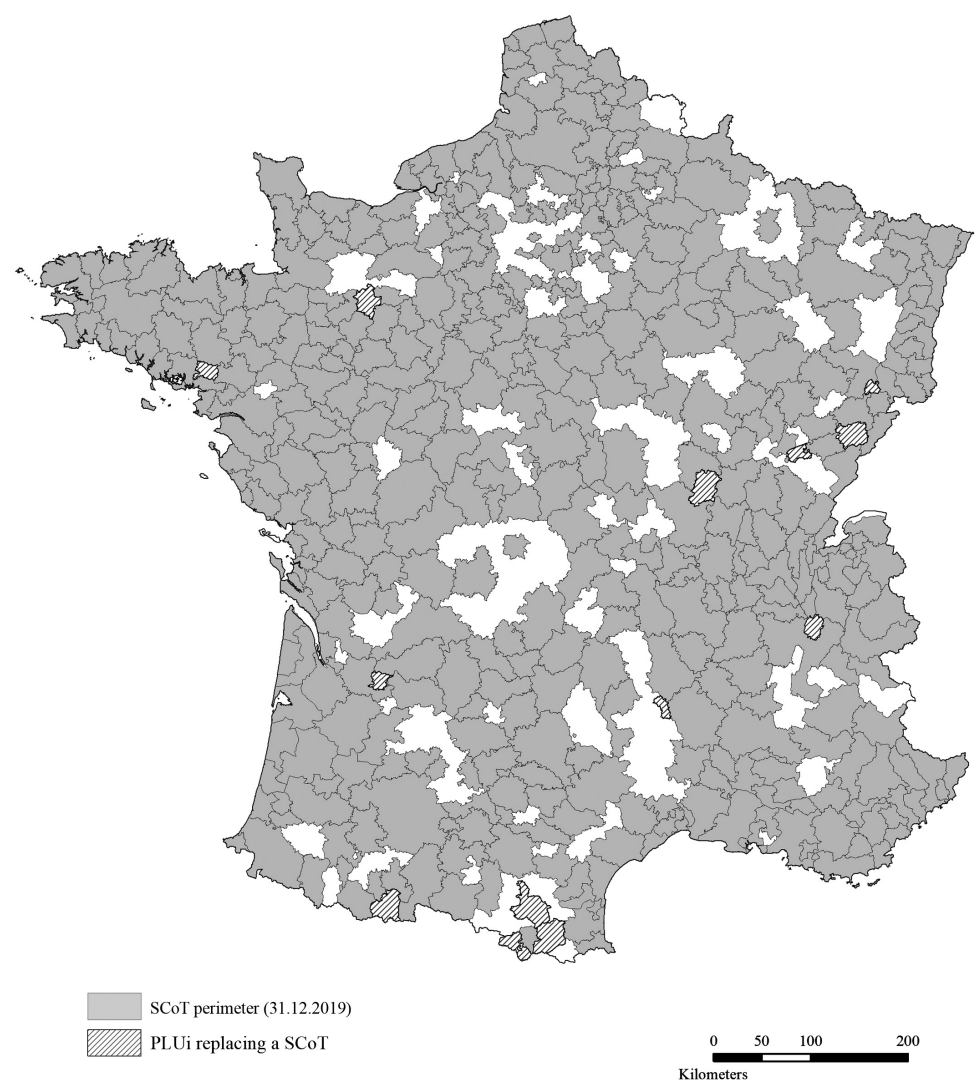

Figure 2.4 Planning regions for SCoT Data: DGALN/ BSCI SuDocUH

state-led regional plans have been developed. All in all, France is en route towards more consolidated forms of territorial governance for city-regions. The main components are the municipal groupings of the core of metropolitan regions (métropoles), supplemented by larger spaces for regional planning and soft coordination of policies.

\subsection{Multi-scaled governance of Nantes: métropole and bipolar metropolitan region}

Nantes is a regional capital and gateway city in Western France, a former working-class town (ship-building industry, agri-food industry) as well as an inland port city (Masson et al. 2013, 26). In addition, Nantes was the former residence of the dukes of Bretagne. Its economic structure, physical shape and image have been altered over time and especially in the course of a successful structural change. While the industry and port activities have been 
declining since the 1960s, the university reopened in 1962 and around 5,500 jobs in the tertiary sector were transferred to the city between 1970 and 1985 due to a deconcentration of the national administration, for example the services of the Ministry of Foreign Affairs (Devisme 2009, 23). Multiple transport connections have been enhanced in the last 40 years, increasing the gateway function of the city-region. Among these enhanced connections are the motorway to Paris (mainly constructed in the 1970s and 80s) and connections to Bordeaux and Rennes, a high-speed rail line (opened in 1989) as well as flight connections to various European destinations (Renard 2015). During the 1990s, Nantes was the French city-region with the highest population growth (Devisme 2009, 23). At the same time, large public and private companies such as the French Post and the railway company SNCF as well as the multimedia chain FNAC settled in Nantes (Masson et al. 2013, 12-13). Industrial working places have been replaced by higher service functions. Nowadays, the university hospital (CHU, to be relocated on the Île de Nantes), French Post, Airbus, public administrations (région, département, métropole and city), the university as well as banking services and regional headquarters of construction and insurance companies are large employers. Nantes' economy has proved to be reasonably resilient since the 2008 crisis (Griggs et al. 2018, 6). Alongside economic transformation, Nantes has succeeded in branding itself as an attractive, vibrant city with a high quality of life. This was mainly achieved through cultural events, international networking, large-scale urban projects, rankings and labels such as EcoCité (Griggs et al. 2018, 6; Garat et al. 2005, 149; Gravari-Barbas 2009).

When talking about metropolitan governance and planning, the following key characteristics should be mentioned, which will be unpacked throughout this chapter:

- Strong inter-municipal institution Nantes Métropole with the main integration phase in the 2000s;

- Specific governance arrangements such as pôles de proximité and merged administration show that the national laws only define a framework for the metropolitan institution, leaving space to adapt it to local conditions;

- Cooperation in the wider metropolitan region Nantes - Saint-Nazaire has been developed in parallel to the strong municipal grouping and relevant for local actors though less institutionalised;

- The mayor of Nantes has a leadership position within the city-region due to multiple positions as president of the métropole, of the pôle métropolitain and of the local development agency SAMOA;

- Importance of the successful flagship project regeneration of Île de Nantes and the SAMOA for the entire metropolitan region.

In this section, we will analyse governance and planning in the metropolitan region of Nantes as one of two French case studies in the book. We first focus on the core of the metropolitan region, organised in the form of the 
institution Nantes Métropole (2.2.1). Second, we will show institutional borders, planning perimeters and functional interrelations in the metropolitan region (2.2.2) and we will scrutinise governance arrangements covering larger spaces than the core area (2.2.3).

\subsubsection{The institution: Nantes Métropole}

Nantes was one of the 11 city-regions adopting the status of a métropole in January 2015 due to the national law MAPTAM (see 2.1.1). The transformation of the municipal grouping into a métropole was mandatory since it exceeds the threshold of 400,000 inhabitants. Nantes was not subject to special arrangements in the legislation, unlike Lyon, Aix-Marseille, Paris, Brest and Nancy (the latter two were exceptions due to their population size being below 400,000) or Lille and Strasbourg (appellation that refers to their cross-border character). Compared to the other 21 métropoles existing since 2018, Nantes is above the median in terms of number of inhabitants (7th largest) and in the middle position in terms of area (11th largest), but has a relatively small number of member municipalities (15th of 22 métropoles).

\subsubsection{From communauté urbaine to métropole}

In the case of Nantes, the intensification of inter-municipal integration started late compared to the first four communautés urbaines created in the 1960s (see 2.1.1). Nevertheless, it was one of the most integrated municipal groupings in the 2010s when the national metropolitan reform was established. The major step in its institutional development was the creation of the CU in 2001. The emergence of inter-municipal cooperation started in 1982 with the creation of a syndicat intercommunal à vocation multiple, the SIMAN, that became a district urbain with own tax revenues in 1992, but these predecessors were very light structures with few human resources, limited tasks and at that stage a poorly developed attitude towards intermunicipal collaboration. The transformation from a district urbain to a CU was fundamental, as a common policy was gradually put into place (Garat 2013, 99). The crucial impetus for the transformation towards a municipal grouping with substantial responsibilities and resources came from the national level (law Chevènement 1999) with the incentive of additional financial allocations. The mayors of the 24 member municipalities reached a compromise about governance rules through intensive debate. The compromise included tangible advantages for the municipalities through municipal projects realised by the CUs and a key role of the mayors in decision-making processes through a regular conference of mayors (conférence des maires). The governance rules were laid down in a charter (charte de fonctionement), which forms the foundation of today's governance mechanisms. The fundamental rules of the Nantes model of collaborative governance were 


\section{France}

the maintenance of a central role for mayors across the conurbation; negotiated outcomes, often between mayors; multicenter urban development not solely concentrated on Nantes; the multiplication of spaces of dialogue and engagement; and significantly, the investment in the "urban project" as a primary site for, and instrument of, urban governance.

(Griggs et al. 2018, 7)

Due to its late creation, the CU de Nantes deliberately transferred a larger number of responsibilities to the inter-municipal level compared to other CUs that had been created decades previously. These included urban planning, housing, transport, management of public space and economic development.

The municipal grouping has slowly progressed: in the first years municipal projects were put together, but later on collective objectives were defined to guide its public policies in a more transversal way. A significant step in the institutional development took place in 2008/2009. At that time the administration of the CU was pooled with the city administration of Nantes (see below), a plan for investment for the period 2008-2014 (PPI programmes pluriannuals d'investissement) was negotiated between the CU and each member municipality, and thematic conferences were started to prepare strategic documents on transport and housing (Garat 2013, 99-108).

In 2012, the presidency of the municipal grouping changed. Jean-Marc Ayrault, who had been mayor of Nantes for 25 years and president of the CU since its foundation, became Prime Minister ${ }^{10}$ in 2012 when the MAPTAM national law was passed and he did not stand as a candidate again afterwards. He had established a "consensual and pragmatic logic of decision making" (Griggs et al. 2018, 7) and had been crucial for intermunicipal integration. The handover of power to his successors Patrick Rimbert (interrim) and Johanna Rolland elected in 2014 cannot be seen as political disruption as both politicians belong to the left-wing party PS. Nevertheless, it caused some changes in terms of the leading positions, including a generational change, a surplus of women in power as well as a change in policy priorities, communication style and topics. During the era of Ayrault, community participation went hand in hand with highly visible redevelopment projects, and an agenda of internationalisation and growth orientation. Rolland, whose first mandate was shaped by a period of austerity, reinforced the culture of proximity associated with the Nantes model by highlighting citizen dialogue (Griggs et al. 2018, 6-15). Also, she directed the political work towards the everyday life of citizens, services of general interest in the neighbourhoods, schools, green spaces in the city and energy transition.

The legal status of métropole obtained in 2015 did not induce a significant institutional change in Nantes, in contrast to what has happened in many other métropoles. The municipal grouping already possessed all the 
competencies required by the MAPTAM law at that time. Only minimal changes of its functions took place on a voluntary basis, concerning the responsibility for some cultural and sports infrastructure such as the opera as well as financial support for inter-municipal company kindergartens. Due to a national law (Law NOTR 2015, art. 90) Nantes had to adopt an agreement (convention de transfert de competences) with the département about departmental responsibilities to be transferred until 1 January 2017 and took over the competence for departmental roads as well as the assistance for social housing, youth care and the elderly. According to the interviewees, the creation of the métropole felt like a natural step. This was mainly because it was not intensively debated on the political level and passed almost unnoticed by the citizens. The name of the institution did not change either as the term métropole had already been used since 2004 .

\subsubsection{Nantes Métropole in the multilayer system}

The métropole is part of the multilayer system and shares responsibilities with higher territorial authorities. Additionally, it seeks to coordinate public policies via soft institutions beyond its own boundaries (see 2.2.3). Nantes is the largest agglomeration and the capital of both the Région Pays de la Loire and the Département Loire-Atlantique, and has been growing in terms of its economy and population in the last 30 years. This has contributed to Nantes' economic relevance as well as to its self-confidence and claim for self-government, underpinned by the capacities of its institution. The described configuration could potentially lead to conflicts with the région whereas the sharing of responsibilities with the département is more consensual because of similar political majorities and fewer overlapping functions.

The département is mainly responsible for social reproduction functions, more specifically social policy, and has seen its responsibilities being diminished within the last decade (see 2.1.2). In the past, it has played a role in coordinating spatial development, but this is no longer the case. Nowadays it rather supports the inter-municipal level on a project base, e.g. concerning bicycle paths along the river Loire. According to the interviewees, a merger of métropole and département within the perimeter of the métropole such as in Lyon is unwanted. One of the main reasons is the high costs of social policy. The president of Nantes Métropole has explicitly proclaimed her objections against such ideas pushed at the national level, pleading instead for more agile soft cooperation beyond the métropole instead, e.g. in the form of contracts (Dubois 2018; see 2.2.3).

The perimeter of the Région Pays de la Loire remained unchanged during the reform of the regions in 2016. Due to decentralisation of some strategic competencies, the functions of all French regions have been increased. The region is supposed to have a strategic role concerning the production function (infrastructures, economic development), leading to an overlap of responsibilities and to potential tensions with the métropole. Both 
institutions have roughly the same budget (Devisme 2009, 37). In the field of economic development, the region is the leading territorial authority. Anyway, the territory of the métropole is to a certain degree excluded from the responsibility of the region: the métropole also has competencies in the field of economic development and can therefore deviate from the regional strategy. Besides that, the région has gained responsibilities in spatial planning and possesses for the first time in its history a planning instrument that is legally binding for local land use plans, the SRADDET. Nantes Métropole has outlined its role and expectations within the participation process, portraying itself as the economic engine of the region and outlining at the same time particular challenges in terms of social cohesion (Nantes Métropole 2017). Concerning its more traditional instruments of distributing funding for regional development, the Région Pays de la Loire signs co-financing contracts with all municipal groupings within its territory, using two instruments depending on the size and the type of grouping: the Contrat de Développement Métropolitain (CDM) for Nantes Métropole and the two communautés urbaines (CU Angers Loire Métropole and CU le Mans Métropole) as well as the Contrats Territoires-Région (CTR) with the CA and CC (see 2.3.2). The difference is that the amount of subsidies for each territory is, in the case of the CTR, calculated using a distribution key ${ }^{11}$ but has few thematic restrictions, whereas the choice of projects to be co-financed via CDM is more political. The distribution of funds among Nantes, Angers and Le Mans is negotiated after the local proposals have been handed in.

Apart from setting the legal framework, the state has a far-reaching influence on planning and governing the metropolitan region by taking infrastructure decisions. In the case of Nantes, the cancellation in January 2018 by the French Government of an airport project planned since the 1960s and located between Nantes and Rennes (Notre-Dame-des-Landes) has turned the development strategy of the region upside down. Due to these circumstances, the deadline for the SRADDET Pays de la Loire has been pushed to the end of 2020 to give the region sufficient time for the necessary reorientation and to organise a territorial dialogue. Secondly, the harbour of Saint-Nazaire with its considerable spatial dimension is currently under state responsibility but is no longer considered as one of the main ports of national interest according to the current national strategy. Both sites are not within the boundaries of Nantes Métropole, but have considerable importance for the metropolitan region and its spatial development (Terrassier 2012). In terms of strategic planning, the estuary of the Loire with Saint-Nazaire and Nantes is one of six territories of national interest covered by a directive territoriale d'aménagement (DTA Estuaire de la Loire, started in 1996 and approved in July 2006). The document has been particularly relevant for dealing with land use conflicts in the sensible river delta (Devisme 2009, 35). Today, the DTA is still formally binding for the SCoT, but is partially outdated and not likely to be renewed. 


\subsubsection{Functions of the Métropole}

The institution Nantes Métropole does not have the status of a territorial jurisdiction, but takes on a substantial number of municipal responsibilities on behalf of the member municipalities since 2001. The competencies that the member municipalities agreed on slightly exceed those prescribed by law as compulsory competencies for métropoles (see 2.1.2). These additional competencies concern both production and social reproduction functions, e.g. accommodation for Roma and travelling communities, actions in favour of disabled people, equipment for higher education and research as well as major equipment for transport, telecommunications, sports and culture.

Regarding production functions, Nantes Métropole is responsible for the following policies:

- Economic development;

- Marketing and tourism;

- Support of innovation, higher education and research;

- Major infrastructure for transport, telecommunications, sports and culture (e.g. the art museum, the stadium, the opera house).

Regarding social reproduction functions, Nantes Métropole is competent in the following policies:

- Housing;

- Public transport (via the public transport company Simetan);

- Public spaces and roads (except roads of national importance; planning and construction, cleaning, street lighting, video surveillance);

- Environmental protection;

- Energy (distribution of electricity, gas and heat; advancement of renewable energies and energy efficiency; climate plan);

- Waste collection and treatment as well as water distribution and wastewater treatment;

- Minor tasks concerning social policy, e.g. services for elderly people and disabled persons.

In the field of town planning and mobility, the mayors of the member municipalities have only kept minor responsibilities. Planning procedures as well as operational tasks are carried out at the inter-municipal level. The mayors are still signing building permits but are supported by the intermunicipal administration, if they wish to be. This service is much used by the smaller municipalities or for complicated cases. Mayors also have local police power and therefore sign decisions about road closures and whether street parking is charged or not. All other issues concerning mobility and transport are decided at the inter-municipal level. When an area is 
developed, the métropole establishes the roads, water and electricity supply as well as public spaces, whereas the municipalities have kept the responsibility for providing public facilities such as sports facilities, community facilities and schools. All in all, the remaining tasks of the mayors demonstrate their relevance to the citizens of their municipality, but technical know-how and complex administrative tasks have shifted to the administration of the métropole.

\subsubsection{The inter-municipal administration - large, decentralised, pooled with City of Nantes}

The métropole possesses substantial resources due to its vast responsibilities. The voted budget for 2019 amounts to 1.31 billion $€$, subdivided into a main budget (769 M€) and six annexed budgets for waste $(85 \mathrm{M} €)$, potable water (105.9 M€), wastewater (57.3 M€), industrial and commercial premises (e.g. business incubator; 3.3 M€), parking (44.3 M€) and public transport (293.7 $\mathrm{M€)}$. The revenues come from own taxation, fees for services, allocations from the state, compensation from the département (for the responsibilities fulfilled by the métropole) and co-financing by the région, the European Union or others. In terms of human resources, Nantes Métropole has about 3,300 employees, out of which $30 \%$ work in the administration (2017). ${ }^{12}$ The inter-municipal administration is marked on one hand by decentral organisation units called pôles de proximité (since the creation of the CU in 2001) and on the other hand by shared management together with the City of Nantes (since 2008).

The administration of the métropole and the City of Nantes are closely interwoven. A double leadership with the mayor of the core city as president of the métropole is a common model in French métropoles (Zimmermann and Feiertag 2017, 20-21) and is also practised in Nantes. ${ }^{13}$ In addition to that, since 2008 the entire leadership of the administration has been shared, including the heads of administrative units (Directions Générales DG) and the central services have been pooled, forming a joint administration of the métropole and City of Nantes with about 7,000 civil servants (Dèbre and Garat 2015, 30). Within the other DGs, some divisions are assigned to the City of Nantes, some to the métropole and some provide services for both. According to the organisation chart from January 2018, the only DG with predominantly municipal tasks is social cohesion (composed of the divisions "childhood \& education", "prevention \& solidarity" as well as "citizenship \& social activities"), whereas the units for "economic development \& international attractiveness", for "environment \& urban services" as well as the one for "territorial cohesion" have a large proportion of units dealing with metropolitan responsibilities. This reorganisation can be interpreted as a way to augment the influence of the City of Nantes on the administration of the métropole through strategic leadership positions, especially because its administrative director, Benoist Pavageau (2009-2014), had been head of the administration of the city of Nantes 
before and had been a collaborator of Ayrault since the 1980s (Masson et al. 2013, 92). On the other hand, the merger is strongly driven by the idea of efficiency and cost-saving, and was implemented in a tense financial situation (Masson et al. 2013, 91). The pooling of staff is a step-by-step process that has been expanded each year, with staff numbers increasing from 173 positions in 2008 to 1,514 in 2016, resulting in a constant reshaping of the organisation (Dèbre and Garat 2015,30). The process has not ended yet and has been extended to the other member municipalities. In the current phase of institutional development, the métropole and interested municipalities conclude individual arrangements for the pooling of municipal tasks that require special equipment or technical know-how (e.g. archives or video surveillance) instead of the transfer of additional competencies to the metropolitan level. This means to centralise the administration with the aim of providing efficient, professional services, but at the same time seeking to keep the political control partly at the municipal level.

The principle of proximity was called for by the mayors of the periphery in order to reduce the risk of hegemony of the core city, and was established from the beginning in the "charte de fonctionnement". Each of the seven pôles de proximité groups several municipalities or city quarters of Nantes based on common characteristics. They consist of units of the administration located in municipalities around Nantes with about 200 civil servants each, and are charged with missions of planning and maintenance of public spaces and streets, sanitation, urban development and relations with companies within their geographic area (Masson et al. 2013, 90). They are meant to be an interface between the metropolitan administration and the municipal administrations; their directors are direct contact persons for the mayors as well as department heads of the metropolitan administration (Dèbre and Garat 2015, 28).

On one hand the pôles de proximité form an intermediary level to discuss territorial strategies, such as the land use plan PLUm, the traffic plan PDU or the climate plan for an area sharing some similarities; on the other hand they have an operational function as the mayors, metropolitan councillors and technicians meet every two months to deal with detailed questions about the implementation of public policies within their area, such as lighting for public spaces or street trees (commission locale). The term "proximity" thus refers to a proximity between the decision-making process of the métropole and its member municipalities, whereas the citizens are less aware of the decentralised units and mainly continue to use the municipal administration as a contact point (Garat 2013, 96-98; Conseil de Développement de Nantes Métropole 2017). In the first years of their existence, the staff of the pôles de proximité mainly consisted of previous employees of the municipalities of their area who had been transferred to the municipal grouping, whereas the central administration of Nantes Métropole was mainly composed of former employees of the City of Nantes or the district urbain or newly recruited staff (Garat 2013, 97). This composition has been slowly changing over time. 


\subsubsection{Representation of municipal interests}

Political decision-making takes place in two deliberative bodies, the metropolitan council (conseil communautaire) with 97 members (election period 2014-2020) and the bureau with 47 members. The bureau is a body formed by members of the metropolitan council. They meet more often than the metropolitan council, i.e. seven or eight times a year instead of four times for the metropolitan council. The 20 vice-presidents elected by the council are responsible for different policy fields and form the executive power together with the president. The council of the métropole is indirectly elected; its members have to be municipal councillors at the same time. The parties flag those candidates they intend to send to the metropolitan council on the electoral lists for the municipal election. The mayors are usually members of the metropolitan council. The election campaign topics have so far concentrated on issues concerning the respective municipality, not on a political programme for the entire inter-municipal territory. This can be seen as problematic in terms of democratic representation because substantial functions have been transferred to the inter-municipal level.

The representation of the municipalities within the inter-municipal organisation depends on their demographic weight. However, each municipality has at least one seat in the metropolitan council and the bureau, regardless of its size. The smallest municipality St-Léger-les-Vignes had 1,640 inhabitants at the time of the 2014 election, i.e. $0.3 \%$ of the population against $1.0 \%$ of seats in the council and $2.1 \%$ in the bureau. The city of Nantes on the other hand dominates the metropolitan council with 48 out of 97 seats and also holds the presidency as well as seven vice-presidents. In the bureau, its proportion of members is lower with 11 members out of 47 (2014-2020). The socialist mayor of Nantes and president of the municipal grouping could in the past also rely on a solid socialist majority of above $80 \%$ in the council (Masson et al. 2013, 92). The model of representing every municipality even in the smaller bodies is possible in Nantes due to the relatively small number of 24 member municipalities. Métropoles with a similar number of municipalities are Nancy, Bordeaux, Tours, ClermontFerrand, Dijon and Orléans, whereas Lille, Aix-Marseille and Grand Paris have 90 or more member municipalities. Until 2014, each municipality of the CU even provided one of the vice-presidents (Masson et al. 2013, 90); Nantes Métropole had 33 vice-presidents at that time, but their number was reduced in 2014 to 20 due to national legislation.

The mayors of the member municipalities play an important role in decision-making processes within the métropole. According to the interviewees, they are the ones that express their opinions most during the council meetings, mainly speaking for their municipality. Furthermore, a conference of mayors with advisory status is a crucial mechanism to prepare council meetings and reach a consensus about political orientations beforehand (Masson et al. 2013, 89). The mayors are usually the ones occupying the position of 
vice-president or member of the bureau. They also conduct bilateral negotiations with representatives of the métropole, e.g. within the PLUm process or concerning contracts between municipality and métropole about projects that will be carried out in shared responsibility (contrats de co-développement). However, Masson et al. $(2013,91)$ argue that the practice of negotiation between mayors has been limited to some extent by formal procedures with quantified targets. This means that the inter-municipal administration provides a binding framework.

\subsubsection{6 Île de Nantes and SAMOA - cornerstone of metropolitan development}

When talking about the metropolitan ambition of the Métropole de Nantes, its major urban development project Île de Nantes and the public agency Société d'Aménagement de la Métropole Ouest Atlantique (SAMOA) created in 2003 to implement it must be mentioned (Devisme 2009, 59). The Île de Nantes is an island of about 350 hectares at the heart of the city. It was a fragmented area composed of industrial brownfields of the former harbour, functionalist administrative buildings from the 1960s-70s and a small residential district from the 19th century and has been transformed into a united space that is understood as an enlargement of the centre of the agglomeration. The mixed-use area for creative industry, culture, higher education, commercial and residential functions is the cornerstone of an overall strategy which follows the idea of increasing the attractiveness of the agglomeration through urban quality and the use of water as a design element in the city (Pinson 2009, 44; Violeau 2011, 88-89).

The planning process of the Île de Nantes is seen as innovative because of its openness: instead of a static master plan, the urbanist Chemetoff has developed an evolving "plan guide" that has been updated every three months and values the existing traces of the history as well as the activities of actors on the site (Pinson 2009, 44; Diedrich and Dahl 2016, 76). The regeneration of the area focussed on the emergence of a creative cluster in parallel to the urban development. The SAMOA achieved this by acting as a facilitator and by providing catalyst locations with cheap temporary rooms, co-working spaces and showrooms in unused warehouses (Nicolas and Roy 2015, 78-82). All in all, the Île de Nantes is a field of experimentation with a strategic relevance extending well beyond the site itself, also influencing the external image of the city-region. Nantes Métropole was very active in European networks and projects in the 2000s during the development of the area and hosted a meeting of the Eurocities network about creative economy in 2009, presenting itself as an innovative forerunner (Nicolas and Roy 2015, 77).

The SAMOA is a public developer owned by Nantes Métropole (58\%) and the municipal grouping CARENE around Saint-Nazaire $(5 \%)$, the City of Nantes $(17 \%)$ and the neighbouring city Rezé (5\%), the département 
$(5 \%)$ and the région $(5 \%)$ as well as the Syndicat mixte du SCoT Nantes Saint-Nazaire (5\%). It is headed by the mayor of Nantes and works closely with the administration of Nantes Métropole responsible for urban development. SAMOA represents a remarkable form of governance because stakeholders from different levels are responsible for different territories and meet and collaborate, with the concrete outcome of the Île de Nantes regeneration scheme. Though its primary mission is to develop this specific site, SAMOA has helped the larger territory of the metropolitan region Nantes Saint-Nazaire to emerge and to institutionalise by organising thematic conferences (conférences métropolitaines), applying for the label EcoCité obtained in 2009 and conducting feasibility studies (Ouvrard 2016, $91,108)$. This orientation towards the metropolitan scale was also linked to its first director, Laurent Théry. He had previously been head of the administration of the CU (Ouvrard 2016, 98; Devisme 2009, 59) and is seen as the crucial mediator of the city-regional plan SCoT 2007 (Violeau 2011, 88). In 2012, when the Pôle métropolitain Nantes Saint-Nazaire (see 2.2.3) was founded, part of the staff from SAMOA working on the metropolitan scale had been transferred to the pôle. Since then, the SAMOA has mainly concentrated on the regeneration of the Île de Nantes.

\subsubsection{Spatial relations within the wider metropolitan area of Nantes Saint-Nazaire}

The spatial dimension of the metropolitan area is defined in different ways. Viewed as a layer of governance, Nantes Métropole corresponds to an intermediary layer between municipality and département and is responsible for the local land use plan (PLUm), whereas in morphological terms it roughly corresponds to the urban agglomeration of Nantes and is the core of a wider functional urban region.

\subsubsection{Institutional perimeters: Nantes Métropole in the multilevel system}

The territory of Nantes Métropole fits in the multilevel system of the territorial authorities région, département and municipality without transcending administrative borders (see Figure 2.5 and Table 2.4). It is composed of 24 municipalities; the city of Nantes is by far the largest one with 319,284 inhabitants,${ }^{14}$ whereas all the others have fewer than 50,000 inhabitants. The four other municipalities with more than 25,000 inhabitants (SaintHerblain, Rezé, Saint-Sébastien-sur-Loire and Orvault) are directly adjacent to Nantes. The municipal grouping hosts $46 \%$ of the population of the département and is one of 17 EPCIs in the Département Loire-Atlantique: ${ }^{15}$ one métropole, four CAs and 12 CCs, but no CUs (since January 2017, dynamics see below). Nantes is the only one of the 22 French métropoles situated in the Région Pays de la Loire. The two next largest cities in the 


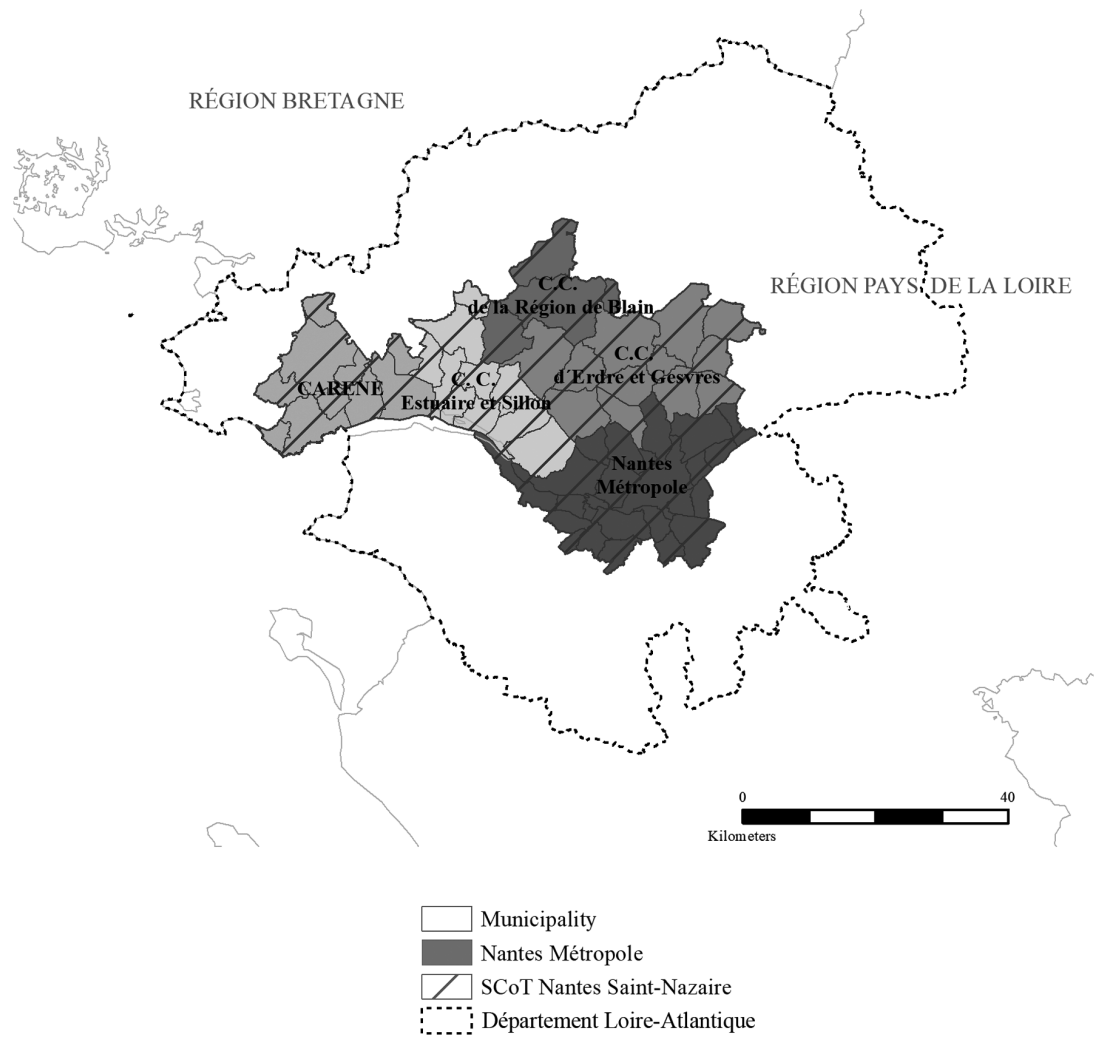

Figure 2.5 Nantes in the multilevel system 2021 Concept: P. Feiertag Cartography: F. Gela

Table 2.4 Nantes in the multilevel system

\begin{tabular}{llll}
\hline Level & Type of institution & Name & Composed of \\
\hline Région & Territorial Authority & $\begin{array}{c}\text { Région Pays de la } \\
\text { Loire }\end{array}$ & 5 départements \\
Département & Territorial Authority & $\begin{array}{c}\text { Département Loire- } \\
\text { Atlantique (44) }\end{array}$ & $\begin{array}{c}\text { 17 EPCIs } \\
(2017 / 01 / 01)\end{array}$ \\
Métropole & $\begin{array}{c}\text { Etablissement Public } \\
\text { de Coopération }\end{array}$ & $\begin{array}{c}\text { Nantes Métropole } \\
\text { 24 municipalities }\end{array}$ & \\
Municipality & $\begin{array}{l}\text { Intercommunale (EPCI) } \\
\text { Territorial Authority }\end{array}$ & Ville de Nantes & \\
\hline
\end{tabular}

region are Angers (158,000 inh.) and Le Mans (146,000 inh.), which are both part of a communauté urbaine (CU Angers Loire Métropole with 29 municipalities and 306,000 inh., CU Le Mans Métropole with 19 municipalities and 210,000 inh. $)^{16}$ and a pôle métropolitain that is also responsible for the regional plan SCoT (Pôle Métropolitain Loire Angers with four 


\section{France}

EPCIs and Pôle Métropolitain Le Mans-Sarthe with seven EPCIs). Another large city in close proximity to Nantes is Rennes, the capital of the region Bretagne.

The area covered by city-regional planning documents takes into account the estuary of the river Loire due to various shared issues at stake (Fritsch 2006, 27; Renard 2008, 136; Masboungi 2012). However, the two documents SCoT and DTA covering the bipolar metropolitan region of Nantes Saint-Nazaire use a different spatial definition and have a low degree of institutionalisation (see Table 2.5 and 2.2.3). The SCoT Nantes Saint-Nazaire includes three CCs between Nantes Métropole and the CARENE on the northern riverbank with 61 member municipalities in total (see Figure 2.5), whereas the DTA Estuaire de la Loire covers 199 municipalities (Renard 2008, 133). The latter has a significantly larger perimeter in the south and east as compared to the SCoT, is centred around the river delta and exceeds the département in the east, covering the municipalities Oree d'Anjou and Mauges-sur-Loire. Additionally, an informal Inter-SCoT dialogue is organised with all SCoTs within the Département Loire-Atlantique (Auran 2017; see 2.2.3). Thus, the SCoT du Pays des Mauges, which touches Nantes Métropole directly in the east, is not included because the territory is part of the neighbouring Département Maine-et-Loire. Six out of eight SCoT planning regions end at the administrative border of the Département LoireAtlantique (see Figure 2.6).

The municipal PLU within the territory of Nantes Métropole has recently been replaced by an inter-municipal land use plan, the plan local d'urbanisme métropolitain (PLUm). The municipalities continue to play an important role in the process of development and have opted to break down the orientations of the document for each municipality (cahier communal). This part of the PLUm is not legally binding and has rather a pedagogical character as its purpose it to make the implications of the PLUm more understandable for citizens, politicians and public servants of the municipalities.

Table 2.5 Layers of planning documents in the city-region of Nantes

\begin{tabular}{llll}
\hline $\begin{array}{l}\text { Planning } \\
\text { document }\end{array}$ & $\begin{array}{l}\text { Year of } \\
\text { approval }\end{array}$ & Institution & Area covered \\
\hline $\begin{array}{l}\text { SRADDET } \\
\text { Inter-SCoT }\end{array}$ & 2020 & $\begin{array}{l}\text { Région Pays de la Loire } \\
\text { Informal dialogue supported } \\
\text { by agences d'urbanisme }\end{array}$ & $\begin{array}{l}\text { Région } \\
8 \text { SCoTs of the } \\
\text { Département } \\
\text { Loire-Atlantique }\end{array}$ \\
DTA & 2006 & State & 199 municipalities \\
SCoT & 2016 & Pôle métropolitain Nantes & 5 EPCI (with \\
& 2019 & Saint-Nazaire & 61 municipalities) \\
PLUm & & Nantes Métropole & 1 EPCI (with \\
& & & 24 municipalities) \\
\hline
\end{tabular}




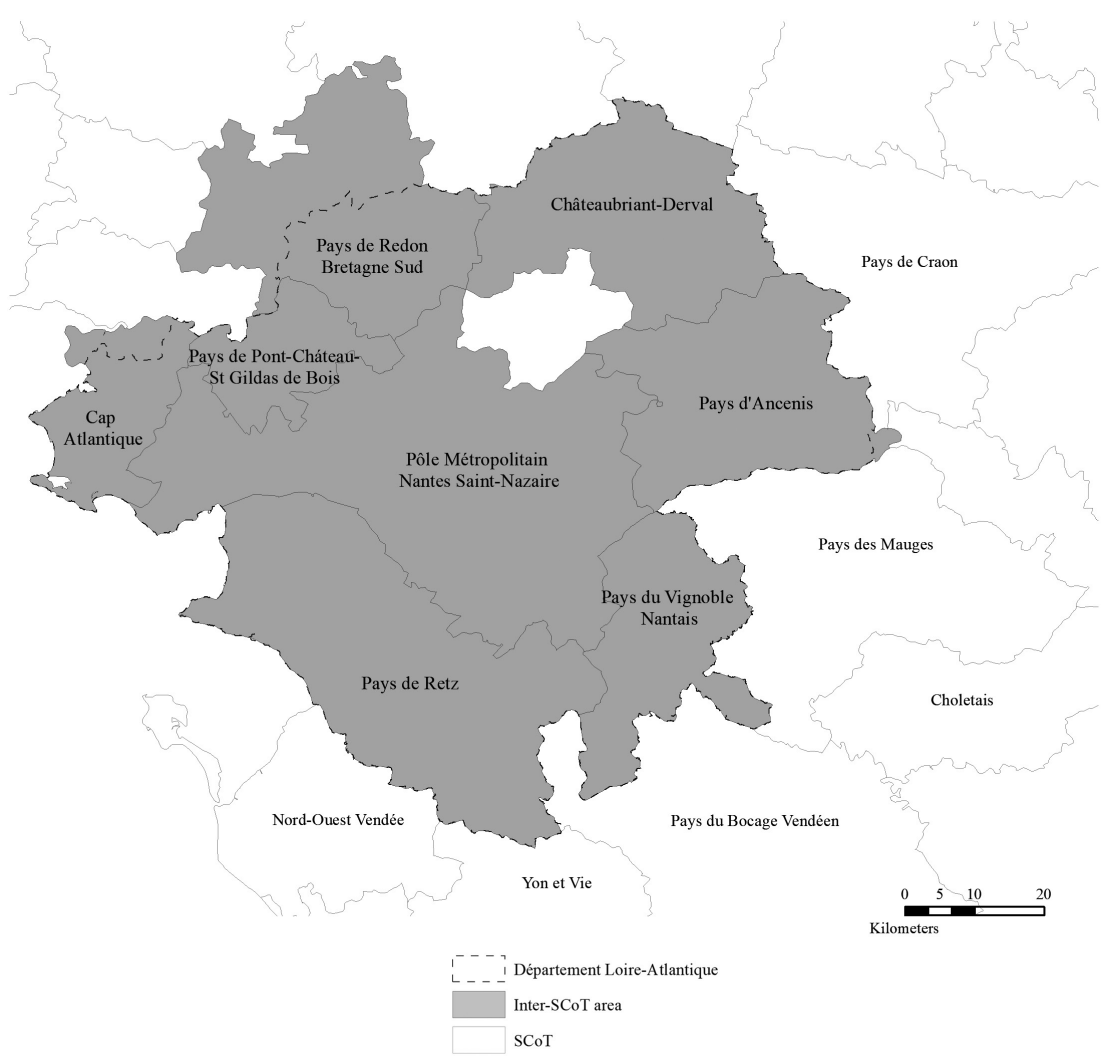

Figure 2.6 Inter-SCoT area of Nantes 2021 Concept: P. Feiertag Cartography: F. Gela

\subsubsection{Morphological and functional definitions: unité urbaine and aire urbaine}

The territory of the municipal grouping Nantes Métropole roughly corresponds to one continuous urban agglomeration ("unité urbaine"), meaning a built-up area without interruptions of more than 200 metres, as defined by INSEE ${ }^{17}$ Its size can therefore be seen as pertinent from a morphological point of view. Its exact delimitation, respectively the membership of some of the border municipalities, also depends on the political will to cooperate or not at the time the CU was formed rather than compelling morphological reasons. On one hand three member municipalities in the west (Le Pellerin, Brains) and east (Mauves-sur-Loire) along the river Loire are not part of the continuously built-up space; on the other hand three non-member municipalities on the south bank of the river Loire (Haute Goulaine, PontSt-Martin, Port-St-Père) are part of the urban unit according to the INSEE definition. 


\section{France}

The functional urban area defined by commuter relations ("aire urbaine" meaning a group of adjoining municipalities, where at least $40 \%$ of the employed resident population works in the centre or in the municipalities attracted by this centre) ${ }^{18}$ is much larger in the northern and southern direction. According to the INSEE definition it is made up of 108 municipalities, ${ }^{19}$ covers $3,405 \mathrm{~km}^{2}$ and has 961,500 inhabitants (2016). As reflected in regional planning documents, Nantes has strong functional relations to the neighbouring city of Saint-Nazaire due to the river and port activities and is described as bipolar (Mahé and Bois 2012, 18; Fritsch 2006, 26). The geographers Jean Renard (2015) and Claude Cabanne (Garat et al. 2005, 36) even define the functional territory as stretching to the sea on both river banks, thus also including the seaside resorts as well as vineyard areas south of Nantes. The two agglomerations have strong economic links and are connected by the industrial and logistics axis of the estuary, but Fritsch (2006, 26-27) argues that the two cities, separated by a distance of about 50 kilometres, do not yet form a unit in terms of household practices and each has its own catchment area. It can be concluded that functional relations as well as shared interests exist in a far wider area than the institutionalised perimeter of the métropole. This wider metropolitan region has fuzzy boundaries that can be defined in different ways.

\subsubsection{Boundaries: evolution of perimeters and their impact on cooperation}

Institutional boundaries of the metropolitan region have mainly been defined by local actors and are contingent on the political will of municipalities to be part of an inter-municipal cooperation. They evolved in several steps.

The inter-municipal grouping district urbain was established by 20 municipalities in 1992 and expanded its territory in two steps. First, in 1995, one additional municipality became part of it. Then, in 2001, three other municipalities joined the district urbain. Since the transformation to a $\mathrm{CU}$, there have been no additional changes to the territory. The perimeter is a political construction. Some adjacent municipalities with close links to Nantes have decided not to join, such as Treillières in a referendum in 2002. One of the reasons was the self-perception of being a rural municipality rather than part of the urban agglomeration and the wish to preserve this identity. Afterwards, the focus of the CU was on integration instead of extension. Today, an extension is unwanted by the members of the métropole, who argue that it is too late and too complicated because they have a well-established mode of collaborating with 24 members.

Whereas the territory of Nantes Métropole has solidified, a number of EPCIs adjacent to it merged and thus considerably enlarged their territory between 2010 and 2017. This was mainly done due to incentives from the national government and also to legislation defining minimum sizes of municipal groupings in terms of inhabitants (see 2.1.4). The SDCI for 
2016-2022 has led to six mergers of CCs, of which five neighbour Nantes Métropole. This means that a ring of larger groupings around Nantes has been created instead of enlarging the métropole itself. Two of the EPCIs adjacent to Nantes have become communautés d'agglomération as a result of the merger: CA Pornic Pays de Retz in the west and CA Clisson, Sèvre \& Maine with 16 communities and 54,000 inhabitants in the southeast. The departmental schéma had the explicit objective of creating CAs with additional competencies in the fields of mobility and social housing as a counterbalance to Nantes. They should contribute to a stronger complementarity between urban and rural areas (Préfecture de la Loire-Atlantique 2016, 24).

It can be concluded that there is consent among the member municipalities of the métropole as well as adjacent municipal groupings and the state representative prefet not to expand the territory of the municipal grouping of Nantes Métropole to its functional area because it would otherwise encompass wide parts of the département. The recomposition of municipal groupings within the département instead aims to create more similar territories in terms of area and competencies relevant for spatial development, relating to the idea of égalité $d u$ territoire. In consequence, negotiations about urban-rural relationships cannot be resolved within the more or less homogeneous municipal groupings themselves, but are shifted to another institutional layer, that of much softer cooperation between municipal groupings.

\subsubsection{Coordination of public policies beyond the métropole}

Given the relatively small size of the city of Nantes and of the métropole, a second scale of cooperation has developed in parallel to the strong municipal grouping: that of the bipolar metropolitan region of Nantes Saint-Nazaire. It has become widely accepted as a natural area of reference in the thinking of territorial actors (Fritsch 2006, 27) and has been institutionalised gradually in the form of the Pôle métropolitain Nantes Saint-Nazaire. In addition to this, a range of other soft forms of coordination between the métropole and adjoining territories as well as the région exist: the Inter-SCoT dialogue, reciprocity deals, a second pôle métropolitain in the form of a city network, and a territorial conference at the scale of the région.

\subsubsection{Pôle métropolitain Nantes Saint-Nazaire - strong imaginary, but light institution / "le projet avant l'institution"}

The pôle métropolitain Nantes Saint-Nazaire is based on a partnership between the two cities Nantes and Saint-Nazaire. It evokes the spatial imaginary of the estuary of the river Loire as an area with strong interdependencies. The metropolisation of Nantes and its ambition to be an economic and cultural hub of European relevance is conceptualised at the scale of the Nantes Saint-Nazaire estuary (Fritsch 2007, 118; Devisme 2009, 12; 
Gravari-Barbas 2009, 287; Masboungi 2012). Nantes defines itself as a harbour city, but the harbour has moved to the river mouth and both cities need each other to have a critical mass in terms of inhabitants and economic activities to reach a metropolitan dimension in national and European competition. Besides economic considerations, the vulnerable river delta has put ecological questions at the heart of metropolitan cooperation (Masboungi 2012, 30).

The construction of the large territory has taken place in parallel to the strengthening of the municipal grouping of Nantes Métropole, both driven by Nantes' mayor Ayrault, though the pôle métropolitain is much weaker in terms of functions and resources. Symbolic acts and cultural events such as the art festival Estuaire between 2007 and 2012 have been used to construct a collective imaginary that was meant to be shared not only by decisionmakers, business leaders and planning professionals but also by the general public (Gravari-Barbas 2009, 288). An important step towards metropolitan cooperation has been a territorial dialogue in the form of "conférences métropolitaines" held at irregular intervals between 1999 and 2011. It has had an open format including politicians, civil society actors and experts. The dialogue contributed to a common identity within the city-region and served to advance projects of common interest (Ouvrard 2016, 91).

The first step in formalising the dialogue was the creation of the planning association Syndicat Mixte du SCoT in 2003 and the development of the first regional plan SCoT approved in 2007. The association was transformed into a "pôle métropolitain" in July 2012, keeping its perimeter and members as well as its internal structure (Bariol-Mathais 2017, 48). The new name was intended to add to its visibility, but the continuity of the institution was high. The change of status became possible by national legislation (see 2.1.1.) and made it possible to adobt additional tasks beyond regional planning, including an operational dimension. This confirmed the existing practice as the syndicate had had the ambition to play an active part in implementing the SCoT since 2008 and had been launching studies to prepare operational projects with the support of the urban development company SAMOA (see 2.2.1). After becoming a pôle métropolitain, this became an official task and the way to debate and decide about operational projects changed from a one by one basis to a voted four-year action programme. However, the main task has remained regional planning, i.e. the SCoT, and the pôle clearly concentrates on topics with a strong link to land use, landscape and urban design.

The pôle métropolitain is an interface structure between existing municipal groupings and thus is dependent on the resources and political will of its five members for implementation. As the former mayor Ayrault puts it (2012, 173), it was more important for him to develop a shared territorial project and to commit to it than to build a new institutional layer. According to the annual report of 2016, its budget amounts to about 1.1 M€, financed by its members (thereof $75 \%$ Nantes Métropole) as well as additional funding 
from national programmes. Its office is composed of a small team of four employees. Its president is the mayor of Nantes and the deliberative bodies are constituted of representatives of each municipality.

According to the interviewees, the pôle métropolitain is mainly valued as a space for regular exchange, providing opportunities for meetings and coordination between decision-makers. The elected representatives of the municipal groupings are used to working together on issues of territorial development such as commercial development and interrelations due to their monthly meetings. The institution is also used for a joint positioning towards the region, e.g. for the SRADDET or towards the state. It seeks to mobilise funding from the national or EU level by preparing joint proposals, e.g. for the national label EcoCité. EcoCité is one of several programs launched by the French state with the aim of influencing urban agendas via competitive mechanisms rather than large amounts of funding (Demazière and Sykes 2021). The pôle conducts feasibility studies, e.g. concerning urban development around train stations, and has organised a landscape planning competition focused on the topic of water, with six sites spread across the territory. Its role is mainly to initiate projects, take care of the conceptual aspects and ensure consistency as part of an overall strategy as well as deal with communication and marketing, whereas the realisation is done by the municipal groupings or the concerned municipalities themselves (Bariol-Mathais 2017, 50). The municipalities between the two large groupings Nantes Métropole and CARENE particularly benefit from the project support and the know-how partly transferred from experience gained within Nantes' Urban Development Company SAMOA.

The governance arrangement is well established and valued by the local actors because it produces a benefit for its members without excessive costs in terms of additional administrative structures. However, its success is dependent on the consent of the two mayors of Nantes and Saint-Nazaire as the main drivers. The generational change in the two cities has caused a less dynamic phase for the pôle métropolitain, because the new mayors elected in 2014 concentrated first on their own cities and municipal groupings.

\subsubsection{Overcoming boundaries - Instruments of soft coordination with variable geographies}

In contrast to the bipolar space of Nantes, the following arrangements correspond to a more selective inter-territorial cooperation seeking to address issues beyond the boundaries of the pôle métropolitain.

\section{- Inter-SCoT dialogue - Coordination of regional plans}

The eight planning associations within the Département Loire-Atlantique are maintaining a dialogue, though without a regular frequency or any kind of formalisation. They do not have the same rhythm in preparing their SCoTs, 
meaning that some planning associations such as Nantes Saint-Nazaire had already approved their second generation of SCoT in 2016 whereas others had just started the process at that time or had recently approved their first regional plan. Furthermore, they do not use the same cartographic language or definitions, leading to high heterogeneity. The purpose of the dialogue is to avoid incompatibility and direct competition, e.g. concerning industrial sites. Meetings are focussed on topics with relevance to the scale of the entire territory, such as risks of flooding. Additionally, each planning association involves the neighbouring associations when developing a new regional plan.

The Inter-SCoT dialogue was initially driven by the département, which has withdrawn from the task due to changes of responsibilities between territorial layers (see 2.1.2). The Agence d'Urbanisme de la Région Nantaise (AURAN), which is working with several planning associations to support the development of the SCoT, has partly stepped in by taking the initiative to produce an overview of the orientations of the SCoT. This "Panorama des SCoT" (AURAN 2017) is meant to share information about the objectives in each plan, e.g. concerning the number of housing units and density. All in all, the coordination is rather loose and depends on occasions.

- Contrat de réciprocité with PETR (pôle d'équilibre territorial rural) du Pays de Retz - urban-rural relations

The reciprocity deals (contrat de réciprocité) are intended to be an instrument of mutual agreement between rural, peri-urban and urban territories and were launched by the interministerial committee of rurality in 2015, followed by an experimental phase in four territories, thereof only two (Brest and Toulouse) had actually agreed on a contract by 2018 (Bigay et al. 2018, 30). Nantes was not part of the experimental phase, but adopted the instrument afterwards.

One of the weaknesses of the Pôle métropolitain Nantes Saint-Nazaire is that it does not include the south bank of the river Loire, because no political consensus has been reached, either at the time of the creation of the SCoT perimeter, or in 2012 when transforming it into a pôle métropolitain. The seaside has a recreational function for Nantes, whereas Nantes provides jobs for the inhabitants of the Pays du Retz, leading to commuting activities. Instead of changing the institutional perimeters, the decision has been to conclude contracts about collaboration. Nantes Métropole and the PETR du Pays de Retz signed their first contract in April 2019 after one year of preparation, with four topics of cooperation: food provision, mobility, economy and tourism. Concrete projects will be, among others, traffic lanes dedicated to non-polluting vehicles and cars with several passengers, implemented in 2021. Further steps would be a contract between the agglomeration of Saint-Nazaire and the Pays du Retz as well as closer coordination between the two SCoTs. 
- Espace métropolitain Loire-Bretagne - city network focussing on competitiveness

The "Espace metropolitain Loire-Bretagne" has the legal form of a pôle métropolitain and consists of three métropoles (Brest, Nantes and Rennes) as well as two CAs (Angers and Saint-Nazaire), thus regrouping the largest agglomerations of north-western France in a city network with a rotating presidency. Initially, all five were cities with a socialist mayor, but this changed in Angers after 2014 and has had an impact on the cooperation with the other cities. The idea of a city network had already been discussed since the 1990s, but the historically difficult relation between the main cities Rennes and Nantes hampered stable cooperation. For decades they had been either turning their backs on each other or competing for influence instead of seeking to complement each other (Renard 2008, 115-124).

The pôle was created in 2012 and addresses the topics of accessibility, higher education and research as well as economic development (BariolMathais 2017, 120). Due to the distance between the cities, the focus is entirely different from the other pôle métropolitain where Nantes is a member. Instead of dealing with spatial planning or urban-rural relationships, it is a strategic alliance focussed on competitiveness and promotion of the territory at national and international scales (Bigay et al. 2018, 62). Examples of joint efforts are campaigning for better high-speed train connections and a joint presentation at an international real estate exhibition. Infrastructure alliances have lately been emerging on a much larger spatial scale than that of a city-region, as also observable elsewhere in Europe (Feiertag et al. 2020, 161).

- Vertical coordination - the new role of the région

In searching for potential mediating institutions for an inter-territorial balancing of interests, the region is seen as the most likely candidate rather than the département or national government (Bigay et al. 2018, 31). The region has become competent in spatial planning and has thus also become the host of a vertical territorial dialogue. This dialogue takes place on one hand as part of the development process of the planning document SRADDET and on the other hand due to a new instrument of territorial conferences (Conférence territoriale de l'action publique CTAP) introduced by the MAPTAM law.

During the development of the SRADDET, the Région Pays de la Loire first contacted the planning associations of SCoT, as there had been few thematic overlaps before. A consultation with each of the planning associations took place and a joint statement by all planning associations of the region was produced, formulating their expectations. Presentations in each département took place in 2017, but the territorial dialogue was opened up and intensified in 2019 after the cancellation of the airport 
project Notre-Dame-des-Landes (see 2.2.1) with a process called "my region in 2050".

The territorial conferences of the Région Pays de la Loire had its first session in February 2015. The CTAP are mandatory and include representatives of the region, the départements and the municipal groupings. Each EPCI with at least 300,000 inhabitants has its own seat whereas the smaller ones share one representative per département. According to the law, their purpose is to debate and give an opinion. However, the instrument has been criticised for being too formalised and heavy, and thus not inviting open debate (Acar and Reix 2017, 5).

\subsection{Lyon: powerful institution with a (too) small perimeter}

Lyon is located in the south-east of France and is the third largest French city in terms of inhabitants. It is situated on a north-south transport axis to the Mediterranean Sea (Marseille) and connected to Paris with a high-speed train (TGV) with two hours' travel time. This line was the first high-speed connection in France and was already inaugurated in 1981. Lyon has a strong industrial basis with large companies. Historically, the beginning of the industrial production was related to silk production, later on developing towards textile production in general, chemistry and mechanics and in the 20th century, as well as automotive, metallurgy and petrochemical industries (Galimberti 2015, 93).

The centre of the city-region is formed by Lyon and the adjacent city of Villeurbanne. Both cities together have roughly 650,000 inhabitants. The other municipalities within the city-regional institution Métropole de Lyon are significantly smaller and part of a continuous urban fabric. Thirteen of them have between 20,000 and 61,000 inhabitants, 21 between 5,000 and 20,000 and 24 municipalities have fewer than 5,000 inhabitants. The agglomeration is "marked by historical segregation between its western (residential, affluent, composed of single-family homes) and eastern (industrial, working-class, surrounded by large housing estates) suburbs" (Rousseau 2015, 624) and a high social homogeneity of its western suburbs. The agglomeration of Lyon is part of a wider metropolitan region including the city of Saint-Étienne as the second urban centre and several mediumsized cities such as Vienne and Villefranche-sur-Saône.

The following key characteristics concerning metropolitan governance and planning will be highlighted in this chapter:

- Since 2015, the strong city-regional jurisdiction Métropole de Lyon with additional responsibilities has been replacing the municipal grouping created in the 1960s;

- International competitiveness as an important driver for the mayors of Lyon and presidents of the inter-municipal grouping since the 1990s, becoming apparent in urban development projects, city marketing and efforts towards more powerful forms of city-regional governance; 
- Unusually long tradition of inter-municipal land use planning within the métropole;

- Steady urban extension as well as increased commuting distances, in contrast with the almost stable institutional perimeter of the city-region for half a century;

- Several governance arrangements for the wider metro region beyond the Métropole de Lyon, but with a low degree of institutionalisation.

In this section, we will analyse governance and planning in the metropolitan region of Lyon. We first examine the Métropole de Lyon covering the urban core of the metropolitan region (2.3.1). Second, we will elucidate institutional borders, planning perimeters and functional interrelations in the metropolitan region (2.3.2) and investigate different soft governance arrangements within the wider metropolitan area, including regional planning associations (2.3.3).

\subsubsection{The institution: Métropole de Lyon}

Lyon has the most integrated metropolitan governance arrangement of all French city-regions and is the only one with the status of a jurisdiction. Its special status is fixed by national law, but was negotiated by powerful local actors. Compared to the other 21 métropoles existing since 2018, Lyon is one of the largest in terms of inhabitants (third largest) and has more member municipalities than the median (fifth rank of 22). However, the métropole is only in the middle field concerning the area (10th largest) covering a territory similar to the métropoles Grenoble or Nantes. The area covered by the Métropole de Lyon is considerably smaller than the métropoles SaintÉtienne, Rennes and Rouen despite the fact that each of them has fewer than 500,000 inhabitants (see Table 2.1).

\subsubsection{Long-standing inter-municipal cooperation and planning}

The city-region of Lyon was among the first city-regions in France where a strong municipal grouping with responsibilities in spatial planning was created based on the need to think in terms of city-regions (Parnet 2016, 242). Inter-municipal cooperation in the city-region of Lyon started long before it adopted the status of métropole. Lyon is one of four city-regions that were obliged by national law to create a communauté urbaine in the 1960s with a perimeter defined by the state. The Communauté Urbaine de Lyon (COURLY) was created in January 1969, two years later than the other CUs of Lille, Bordeaux and Strasbourg because departmental boundaries had to be altered (Bariol-Mathais 2015, 27; see 2.3.2). Even prior to this imposed creation of a municipal grouping, Lyon had already had associations for joint service provision for water supply, electricity and public transport since the 1920s (Gardon and Meillerand 2007, 11). The early start of inter-municipal cooperation at the beginning of the 20th century 


\section{France}

is unique among French metropolitan regions. This early accumulation of experiences of cooperation has led to the emergence of a politically significant multi-communal territory (Aguiar Mol 2015, 128). By targeting topics such as urban transport, social housing and internationalisation, the $\mathrm{CU}$ became a veritable metropolitan institution in the 1980s.

In 1991, the COURLY was renamed "Grand Lyon" (Bariol-Mathais 2015 , 27). The key role of the CU was enhanced by the revision of the strategic planning document schéma directeur with the major participation of the economic actors. Its title "Lyon 2010, un projet d'agglomération pour une métropole européenne" underlined the focus on international competitiveness. During the terms of office of the two mayors Michel Noir (19891995) and Raymond Barre (1995-2001), economic development was a dominant concern, combined with city branding, emblematic urban projects (Cité internationale designed by Renzo Piano, congress hall) and traffic projects (metro line extension, northern ring road) (Aguiar Mol 2015, 129-132). Later on, the idea of the economic competitiveness of the city at the global scale centred on expanding the service sector also included a strategy of residential densification of the suburbs due to the scarcity of land within the boundaries of the métropole (Rousseau 2015, 624-626).

The ADERLY economic development agency was created as early as 1974 (Frébault and Sozzi 2010, 44; Galimberti 2015, 104). It was set up with the aim of promoting Lyon and to attract foreign investors (Ben Mabrouk and Jouve 2002, 92). ALDERLY also addressed issues of metropolisation and internationalisation and included public, private and semi-public actors (Aguiar Mol 2015, 129; Galimberti 2015, 108). Since 2015, it is co-financed by the métropole, but was steered in the first 15 years by the chamber of commerce and industry as the operator without the involvement of COURLY on the operational side. The early focus on competitiveness and economic development of the COURLY was not supported by the industrial sector at that time, but instead regarded with suspicion, because the economic policy of the president and mayor of Lyon Michel Noir focussed on the service sector as an element of urban modernity and considered industrial buildings to be harmful to the quality of life in urban areas, wishing to relocate them to the countryside outside the CU (Ben Mabrouk and Jouve 2002, 101).

Whereas the COURLY integrated more policy fields step-by-step, its territorial dimension remained unchanged over decades. Minor extensions occurred between 2007 and 2014, when four small municipalities successively joined the CU at their request (Fitria 2016, 172-173). Two of them were motivated by a difficult financial situation whereas the other two joined due to joint interests concerning opposition against a highway project; they saw a strategic advantage in joining the large municipal grouping with regard to negotiations with the state services. The new member municipalities were incorporated into the SCoT strategic planning document, but the extension had only minor effects on the municipal grouping due to their small number of inhabitants. When Lyon was a municipal grouping with a 
voluntary character it was possible to add single municipalities in case of agreement of the potential new member and Grand Lyon, but any extension has been made much more complicated since 2015 by the new jurisdictional status of the métropole because a national law would be needed (Galimberti et al. 2014, 201; Fitria 2016, 269). Further voluntary extensions are unlikely, because the representation of the municipalities has been altered since 2020, making it less attractive for smaller municipalities to ask for admission (Fitria 2016, 276). The métropole itself is not actively pursuing the integration of individual municipalities as changing its territory would only bring strategic advantages in the case of a substantial enlargement. Therefore, the current perimeter of the métropole has become rigid and could only be enlarged by state intervention. If such a law were passed (which is not a current preoccupation of the government), it would most likely only be prepared to annex a significant number of municipalities.

Lyon is a forerunner when it comes to spatial planning at a city-regional scale, both within the perimeter of the CU and beyond (see 2.3.3). Even before the creation of the CU, strategic plans for the metropolitan region were prepared in the 1960 s, covering a vast territory (Plan d'urbanisme directeur and Plan d'Aménagement et d'Orientation Générale PADOG; see Bariol-Mathais 2015, 32; Gardon and Meillerand 2007, 14; Verhage et al. $2007,86)$. Since its creation, the municipal grouping itself has developed a range of strategic spatial plans (SDAU 1978, schéma directeur 1992, SCoT 2010, modified in 2017). An inter-municipal planning association, the SEPAL, was first created in 1985, but dissolved in 1992 after finalisation of the plan and only reopened in 2003. Since 2001, municipal groupings have been legally obliged to keep their planning associations after finalisation of a plan; thus the planning associations can monitor and adapt their regional plans. Local land use plans have been developed for several municipalities since 1980, organised in five sub-territories, and the first inter-municipal land use plan PLUi covering the entire territory came into force as early as 2005. Even today, the two other municipal groupings within the regional planning area of Lyon still have separate municipal land use plans for each of their member municipalities. This long-standing tradition of inter-municipal land use planning is unusual in France.

The city-region is considered in the literature as a forerunner of cityregional governance in the French context, both concerning service provision and planning (Aguiar Mol 2015, 50; Galimberti et al. 2014, 191; Bariol-Mathais 2015). The organisation itself emphasises the linear character of its institutional history since the 1960 s, interpreting it as a logical progression. This smooth narrative of the métropole can partially be questioned according to Parnet $(2016,246)$ as it overlooks the question of the adequate perimeter (see 2.3.2) and sweeps conflicts with smaller municipalities, rural territories and the région under the carpet. Anyhow, the transformation of the former CU into a métropole certainly means a continuation and further integration of a long-established institution rather than a discontinuity. 


\subsubsection{Special status of métropole fixed by national law}

The transformation of the communauté urbaine Grand Lyon into the métropole was a turning point because of its special status. It led to substantially more functions, budget and staff as well as a direct election of the metropolitan council. The national law MAPTAM from January 2014 describes the general rules for the métropole and foresees specific tailor-made rules for the three largest in terms of population (Geppert 2017, 226): the capital Paris (art. 12-14), Aix-Marseille (art. 40-42) and Lyon (art. 26-39). Lyon is the only one that has become a full local self-government (collectivite territoriale à statut particulier) instead of only a legal public person (etablissement public) like all other métropoles (Hertzog 2018, 150). Hence, the new jurisdiction, in terms of functions is a combination of the competencies of the département that have been entirely transferred and the former municipal grouping CU. The additional responsibilities have also led to additional financial resources and the transfer of staff from the departmental administration. Geppert $(2017,237)$ describes the Métropole de Lyon as a "powerful entity" with "full control over its territory".

The making of a tailor-made status appears "in very different contexts: the crystallisation of a solid collaboration in Lyon, the authoritarian intervention of the national government in the conflict-ridden area of Aix-Marseille, a compromise between the numerous players of the Paris region" (Geppert 2017, 237). In the case of Lyon, the initiative came from the local level, driven forward by an alliance of Gérard Collomb, the mayor of Lyon and president of the municipal grouping at that time, and Michel Mercier, president of the council of the Département Rhône (Conseil Général du Rhône) via informal negotiations at the beginning of the parliamentary process. The first draft of the law assigned the status of EPCI to Grand Lyon like to the other city-regions (Parnet 2016, 252). Rather than a top-down intervention of the state, "two prominent local politicians who dominated the local scene" (Parnet 2016, 260) used the opportunity of the legislative process. The other municipalities of the Grand Lyon grouping were not involved in the decision-making process (Galimberti et al. 2014, 192). The métropole has been cut out of the Département Rhône, but the département continues to exist and to carry out its functions for the rest its territory. This was a win-win situation that both suited the métropole, which was strengthened, as well as the département, which became socially more homogeneous, slightly better off than the core city and got rid of responsibilities in social welfare for the urban area as well as the costly Confluence Museum (Geppert 2017, 238; Galimberti et al. 2014, 192). In the case of Lyon, the national legislative process created a window of political opportunity for an institutional solution that fitted the specific geographical and demographic situation of this particular cityregion (Hertzog 2018, 151).

A mayor difference compared to the former status as CU as well as compared to the other "métropoles de droit commun" is the direct election of 
its councillors, carried out for the first time in $2020 .{ }^{20}$ This changes the role of municipalities and the representation of the smaller ones. It also means a change in leadership from one super-president to two leading figures because the double role of mayor and president of the métropole is not allowed in this case. This concentration of power had been a frequent practice in Lyon for decades. The first president of the COURLY was the mayor of Lyon at that time, Louis Pradel ${ }^{21}$ (Bariol-Mathais 2015, 27), followed by Francisque Collomb, Michel Noir, Raymond Barre and Gérard Collomb. Most of them have also been influential on the national level like many mayors of large cities in France ("Grand Elus", see also Thoenig 2006, 55), providing them with additional power via shorter circuits to decision-making in Paris (Mallon et al. 2010, 88-92). Noir, Barre and Collomb have all been ministers at some point in their career. However, in the case of Gérard Collomb, becoming minister of the interior in May 2017 marks the end of its hegemony in Lyon as he ceased to be mayor and president of the métropole and could not restore this position after his return. He continued to be a councillor throughout all this time in both the municipal and metropolitan councils, as well as president of the SEPAL planning association, and was re-elected mayor of Lyon in November 2018 by the municipal council, but had to cede the position of mayor and failed to become the first directly elected president of the métropole in June 2020. The positions of president of the métropole and mayor of Lyon have been conquered by two members of the Green Party, Bruno Bernard and Grégory Doucet. The Green Party (Europe Ecologie-Les Verts) had an unprecedented success at the municipal elections in 2020 in many large cities such as Bordeaux, Strasbourg and Tours.

\subsubsection{Extensive functions of the Métropole de Lyon}

The functions of the Métropole de Lyon are more extensive than in any other French métropole, because they include all functions of the département along with many former municipal functions. The decades since the creation of the COURLY have been marked by a steady increase of functions, a model of concentration that is likely to have reached its limits due to a risk of sluggishness and reduced acceptance by the municipalities (Galimberti et al. 2014, 192-193). Due to its status as full local self-government, the métropole has the right to act in any kind of policy field (clause de compétence générale), but does not necessarily have the interest to do so. As one example from the field of housing policy, the métropole has not claimed the competence for the accommodation of the homeless, but rather leaves this task to the state.

Regarding production functions, the Métropole de Lyon is competent in the following policies:

- Economic development;

- Marketing and tourism; 
- Major events and equipment for transport, telecommunications, sports and culture (e.g. the Confluence Museum, the Gallo-Roman Museum Lugdunum).

Regarding social reproduction functions, the Métropole de Lyon is competent in the following policies:

- Housing policy and Social Housing including personal aid;

- Public transport (via the public transport association Sytral);

- Public space and roads (except roads of national importance; planning and construction, maintenance);

- Town planning and urban development (SCoT, PLUi, ZAC);

- Schools (collèges);

- Environmental protection;

- Energy (distribution of electricity, gas and heat; advancement of renewable energies and energy efficiency; climate plan);

- Waste collection and treatment as well as water distribution and wastewater treatment;

- Social services (services for families; financial support for low-income households);

- $\quad$ Fire and rescue services.

In the field of town planning and urban mobility, almost all former municipal functions are carried out at the metropolitan level. Concerning public transport in the wider metropolitan area, a high interdependence with the Région Auvergne-Rhône-Alpes (responsible for regional trains) as well as to some extent with the surrounding départements and municipal groupings exists due to shared responsibilities, and thus necessitates agreements and steering mechanisms for common action (Idt et al. 2012, 226). The mayors sign building permits, but planning instruments as well as projects of urban renewal are the responsibility of the métropole. The municipalities are still responsible for street lighting and the maintenance of green spaces. As mentioned above, inter-municipal planning was introduced long before the creation of the métropole, since the early days of the CU (Gardon and Meillerand 2007, 216). It has been one of the vehicles to create a sense of belonging to the same metropolitan territory among the member municipalities (Galimberti et al. 2014, 196). Urban development projects were linked to economic development and attractiveness of the city: "the priority given to the tertiary sector in Lyon was mainly organised around a series of major real estate operations in the town centre" (Ben Mabrouk and Jouve 2002, 102). Vast property developments for business with high quality public spaces and architecture, which were the joint responsibility of the COURLY and the chamber of commerce and industry, were seen as projects of metropolitan interest (Ben Mabrouk and Jouve 2002, 103). The connection of urban planning, economic development and metropolitan policies has been 
pursued in projects such as Confluence on the southern part of the peninsula where the river Rhône and Saône flow together, or the refurbishment of the Part Dieu business district in the making.

Compared to the former municipal grouping of the CU, social reproduction functions have been strengthened, in particular by adding social policies. This is a field where the metropolitan institution did not have much experience before (Galimberti et al. 2014, 192). The additional responsibilities also concern the field of housing policies. The former $\mathrm{CU}$ already had a strategic programme for housing (PLH), but the personal aid directly paid to the households had been administered by the département. A large number of civil servants working in this field were transferred to the administration of the métropole. The important place social policy takes now in terms of manpower is in contrast with the competitive agenda that has been driving the institutional development since the 1990s up to today (Galimberti et al. 2014, 193-196; Carpenter and Verhage 2014, 63). However, even the benefit seen by President Collomb in integrating the reproduction functions of the département was driven by a logic of competitiveness, because the metropolitan institution has become more powerful and autonomous by gaining full control of the territory without interference from other layers of government. As one interviewee put it, the unique status of Lyon also creates the opportunity to spread the image of the Métropole de Lyon as a strong metropolitan government. Whether the changed responsibilities will influence the agenda in the long run remains to be seen, but this was not perceptible in the first years of the métropole.

\subsubsection{Substantially enlarged administration of the métropole}

The Métropole de Lyon has a larger administration than any other French métropole and even slightly exceeds the staff of the city of Lyon (Demazière et al. 2022). At the time of the creation of the métropole in January 2015 it had about 8,700 employees, of which 4,800 civil servants were from the former CU Grand Lyon and a large number were transferred from the Département Rhône. This means that the change in status introduced by the MAPTAM law has also brought a considerable change for the administration of the Métropole de Lyon. The restructuring of the administration took time and was still ongoing in 2018. The two parts were largely working in separate divisions - and to some extent in different buildings - in their respective policy fields with the same staff and working culture as before.

For the contact with the citizens regarding social assistance, the métropole has inherited 18 deconcentrated units from the Département Rhône spread over the territory that have been renamed "Maisons de la Métropole". They provide services e.g. for the disabled, elderly, families or households facing housing difficulties.

The métropole already had another kind of territorial sub-unit introduced following deliberation by the metropolitan council in 2002, the nine 
conférences territoriales. Their main purpose is to organise the regular information flow between the mayors within those sub-territories and the metropolitan administration by a monthly meeting with the vice-presidents of the métropole. It is not a decision-making level, but allows discussion of aspects related to that territory in more detail than would be possible in the metropolitan council or the conference of all 59 mayors. Therefore, it is an important forum for opinion making, bridging the municipalities and the métropole. In addition, the responsibilities within the administration of the métropole are organised according to these sub-areas and the coordination between sectoral policies within these spaces. However, decentralised administrative units of the métropole based outside Lyon do not exist. The definition of the nine sub-territories (bassins de vie) is based on a mix of geographic characteristics, strong functional interrelation, and political habits of working together. They are also meant to break down the metropolitan policy to the specifics of the different areas and are picked up in strategic documents as relevant units for spatial planning. The SCoT strategic cityregional plan makes specifications on that territorial level instead of the scale of single municipalities, e.g. concerning the target for housing units to be built. The PLU-H inter-municipal land use plan adopted in 2019 also uses these sub-territories. It makes specifications on three scales: the entire métropole, the bassins de vie and each municipality. In the previous PLUi of 2005 , only the two levels of the metropolis and municipality were used, as the focus was on a common orientation for the entire métropole.

Although the mayors of Lyon have for a long time also been presidents of the grouping, the two administrations of the city and the municipal grouping have always been separate entities with different heads of administration, unlike in Nantes. Mixed teams with civil servants from métropole and city only exist for specific projects with shared responsibilities. Pooled services where the métropole carries out tasks for the municipalities are rare in Lyon. One example of such a service is to check if building permits can be approved for smaller municipalities lacking their own know-how in that domain. However, some groups of municipalities have created their own pooled services to prepare building permits rather than rely on the metropolitan administration. Large investments of the métropole in the municipalities are negotiated with each municipality and fixed in a multi-annual investment programme (PPI). The separation of the two administrations is also manifested spatially as the town hall of the city of Lyon is located in the old centre on the peninsula of the two rivers Rhône and Saône, whereas the administration of the métropole is located in the eastern part of Lyon in the office district Part Dieu. This separation is amplified by the direct election of the municipal council. Because both are full local self-governments, it is no longer possible to be mayor and president of the métropole at the same time. President Bruno Bernard, elected in 2020, is also the first president not to be part of the city council of Lyon at the same time. 


\subsubsection{Direct election of the metropolitan council leading to a lower political relevance of the municipalities}

After decades of each metropolitan councillor automatically having the double function of municipal councillor of one of the 59 member municipalities, this tie has been changed with the direct election of the municipal councils with separate election lists. Each party has to constitute a list with alternation of women and men. In each constituency, the list with the majority (either an absolute majority in the first round or a simple majority in the second round) obtains half of the seats, whereas the other half is divided proportionally between lists with at least $5 \%$ of the votes, including the winning list. Decisions in the council are taken with a majority vote.

Between 1983 and 2020, each member municipality was represented by at least one seat in the metropolitan council. Beforehand, a demographic threshold of 15,000 inhabitants was required to obtain a delegate, which was not reached by 41 out of 55 municipalities, leading to a political dominance of the core city obtained by its demographic weight. The number of councillors of the core city was reduced from half to one-third in 1983 (Galimberti et al. 2014, 197). The changed composition of the councils had become possible due to a modification of national laws (Fitria 2016, 140-141).

At the time of creation of the métropole in January 2015, the 165 councillors of the CU elected in March 2014 were automatically transformed into councillors of the métropole. Since the first direct election in June 2020, democratic representation has again been tied to demographic weight rather than to municipalities as basic units of representation. Representatives are now elected in 14 constituencies (see Figure 2.7). The new metropolitan council is composed of the slightly reduced number of 150 councillors with seven to 17 councillors from each constituency, depending on their demographic weight. Most constituencies are composed of several municipalities or of several districts (arrondissements) of the city of Lyon. The largest constituency in terms of area, "Val de Saône" in the north, corresponds to 25 municipalities, whereas the city of Villeurbanne forms its own constituency (see Figure 2.7).

The delimitation of the constituencies is similar to the nine sub-territorial units (e.g. Plateau Nord, Rhône Amont, Porte des Alpes, Portes du Sud) ${ }^{22}$ used in strategic documents and for regular meetings (conférences territoriales), but gives more importance to demographic weight. Accordingly, the conférence territoriale "Lyon Villeurbanne" corresponds to seven electoral constituencies, whereas by contrast the constituency "Val de Saône" consists of two territorial conferences. The representation of smaller municipalities is changed compared to the former regime. The small municipalities of the new circumscription Val de Saône has lost the most seats, as they are represented by 14 councillors instead of 26 formerly, but they are still slightly overrepresented in terms of demographic weight. The city of Lyon 


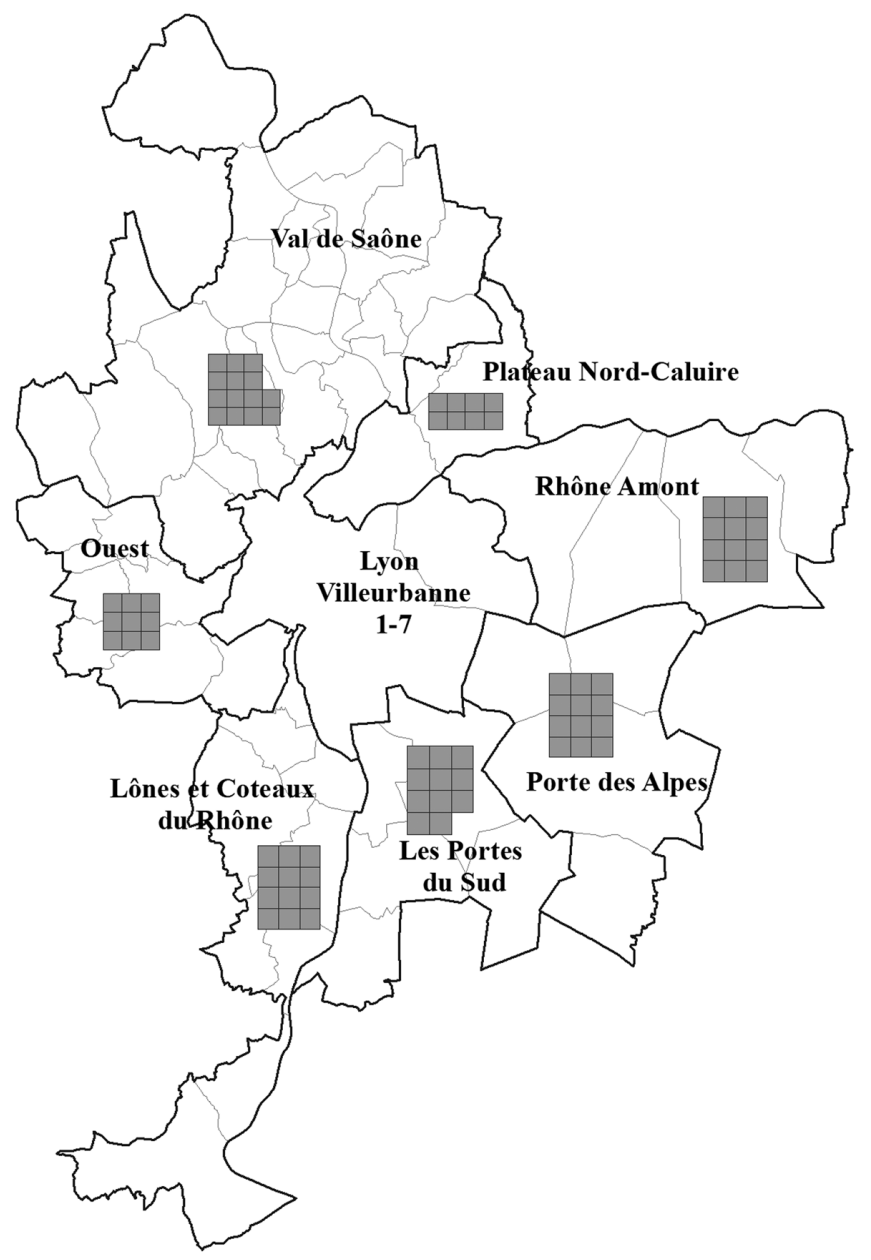

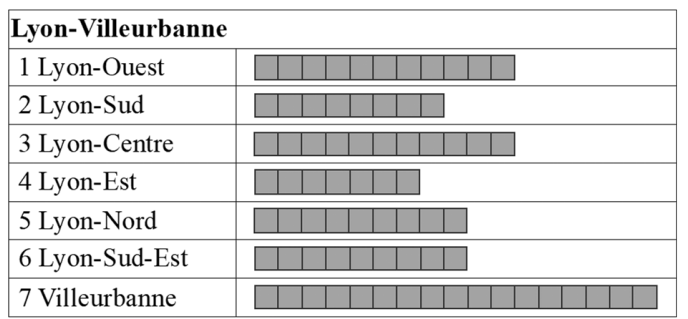

Constituencies

Municipalities

Seats in the metropolitan council per constituency

Figure 2.7 Constituencies for direct election of the metropolitan council 2021 Concept: P. Feiertag Cartography: F. Gela 
is represented with a similar proportion to before, with about one-third of the seats (55 out of 150 councillors).

The mayors are still involved in the governance of the métropole, but with a reduced role within the council and the executive bureau. The "bureau" composed of the president and his vice-presidents is the main place for decision-making (Galimberti et al. 2014, 198). Within the new council, only 24 out of 150 councillors are mayors. However, the mayors of the 14 cities with more than 20,000 inhabitants except Lyon and Saint-Genis-Laval are all part of the metropolitan council. The left-wing mayors of the three largest cities Villeurbanne, Vénissieux and Vaulx-en-Velin adjacent to Lyon are also vice-presidents of the métropole (being in charge of culture, combatting discrimination and territorial equality) and thus maintain a direct influence on metropolitan policies. Historically, a seat as vice-president has always been guaranteed to the second largest city Villeurbanne, but for decades it has been common practice to exclude the municipalities run by opposition parties (Fitria 2016, 144). The mayors of the medium-sized cities Vaulx-en-Velin and Vénissieux were first vice-presidents in 2001 and 2008 respectively, despite the fact that their communist mayors were still part of the opposition in the metropolitan council (Galimberti et al. 2014, 197-198). Compared to previous election periods, the proportion of mayors among vice-presidents was much reduced in 2020 with three out of 23 . Seventeen out of the 23 new vicepresidents are members of the Green Party, none of them being a mayor. Thus, the choice of vice-presidents is mainly based on the political party affiliation, but also takes gender and territorial representation into account. The vicepresidents have been elected in 13 different constituencies (all but Lyon-Nord).

\subsubsection{Spatial relations within the wider metropolitan area of Lyon}

How to define the metropolitan region of Lyon is ambiguous. There is no single, dominant conception of the territory; many coexist. This is perfectly illustrated by the book l'expérience métropolitaine lyonnaise (BariolMathais 2015,11), starting with six different answers on how to imagine the territorial dimension of the metropolitan region: as institutional territory (métropole or pôle métropolitain), as territory for strategic planning (Inter-SCoT or DTA) or as statistically defined area (aire métropolitaine lyonnaise or aire urbaine de Lyon) (see Figure 2.8). Out of those territorial definitions, the Métropole de Lyon is by far the smallest one and only covers the core of the metropolitan region.

\subsubsection{Morphological and functional definitions: unité urbaine, aire urbaine and aire métropolitaine}

The métropole and pôle métropolitain institutionalised territories as well as the SCoT and DTA territories for strategic planning are significantly smaller than the statistically defined aire métropolitaine (see Figure 2.8). 


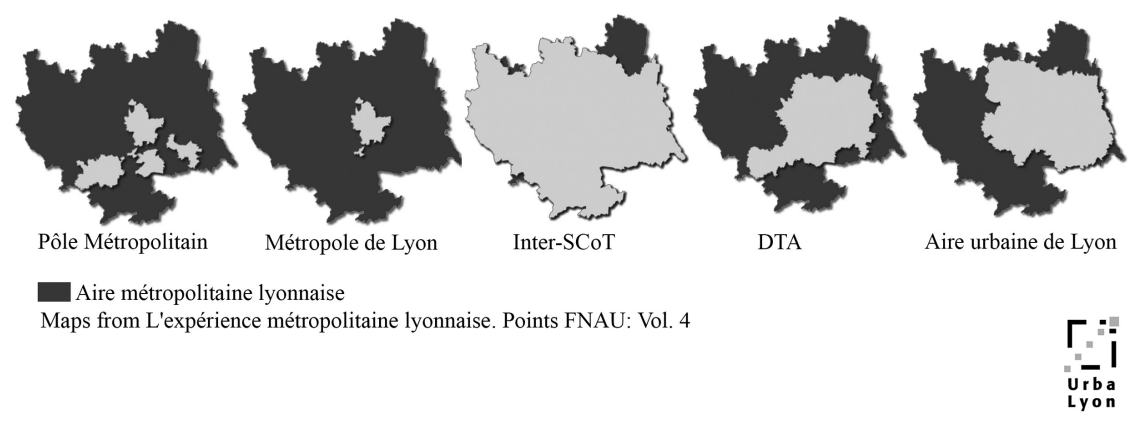

Figure 2.8 Spatial definition of the metropolitan region of Lyon (C) Urbalyon, 2015

The two informal arrangements of Inter-SCoT (formed of several SCoT) and the former Région Urbaine de Lyon (RUL) covered a similar territory, almost corresponding to the aire métropolitaine. The metropolitan area (aire métropolitaine) visualised in Figure 2.8 corresponds to 1,039 municipalities with about 3.4 Mio inhabitants and an area of $13,445 \mathrm{~km}^{2}$, roughly forming a square with sides $160 \mathrm{~km}$ in length (Bariol-Mathais 2015, 10). It is composed of several urban areas (aire urbaine) with strong interlinkage. Urban areas are calculated separately for each urban centre providing at least 10,000 jobs according to the national statistical institute INSEE on the basis of commuter relations between centres. ${ }^{23}$ According to this definition, the urban area of Lyon is formed by 498 municipalities with 2.3 million inhabitants and an area of $6,012 \mathrm{~km}^{2}$ and the neighbouring urban area of Saint-Étienne encompasses 117 municipalities with 0.5 million inhabitants and an area of $1,689 \mathrm{~km}^{2}$ (INSEE, data from 16 June 2020). Those areas of strong interrelation have been substantially growing in the last decades; in the case of the urban area of Lyon by about 200 municipalities since 1999 (Fitria and Charmes 2014).

A second statistical definition by INSEE concerns the urban form, the urban unit (unité urbaine) meaning the built-up area without interruptions of more than 200 metres. ${ }^{24}$ Even this much narrower definition of the urban agglomeration of Lyon would be substantially larger than the institution Métropole de Lyon. It corresponds to 128 municipalities and extends in the northern direction along the river Rhône even beyond the city of Villefranche-sur-Saône. Ben Mabrouk and Jouve (2002, 104) describe a "growing unsuitability of the territory of the Lyon urban community" since the 1970s. Due to topographic reasons, the plains east of the river Rhône have been the main direction of extension for centuries and have a peri-urban character, whereas the hilly landscape towards the west has prevented continuous urbanisation (Dugua 2015, 288). 


\subsubsection{High fragmentation of institutional perimeters}

The Métropole de Lyon includes 59 municipalities with 1.38 million inhabitants (1/2019; thereof 0.5 million in the city of Lyon) and an area of $533 \mathrm{~km}^{2}$ (see Figure 2.9). Its territory has been very stable over decades: the COURLY was founded with 55 member municipalities and kept its boundaries for 37 years. Since 2007, only the river Rhône connected the territory in the South. A strip of land along the river was conceded to the métropole in 2013 to formally fulfil the criterion of territorial continuity required by the law RCT (Fitria 2016, 254-61). Since the change to a métropole, the perimeter has not been altered and is unlikely to be extended in the near future.

Lyon is part of the Région Auvergne-Rhône-Alpes, one of the enlarged French regions created by amalgamation of two regions in 2016

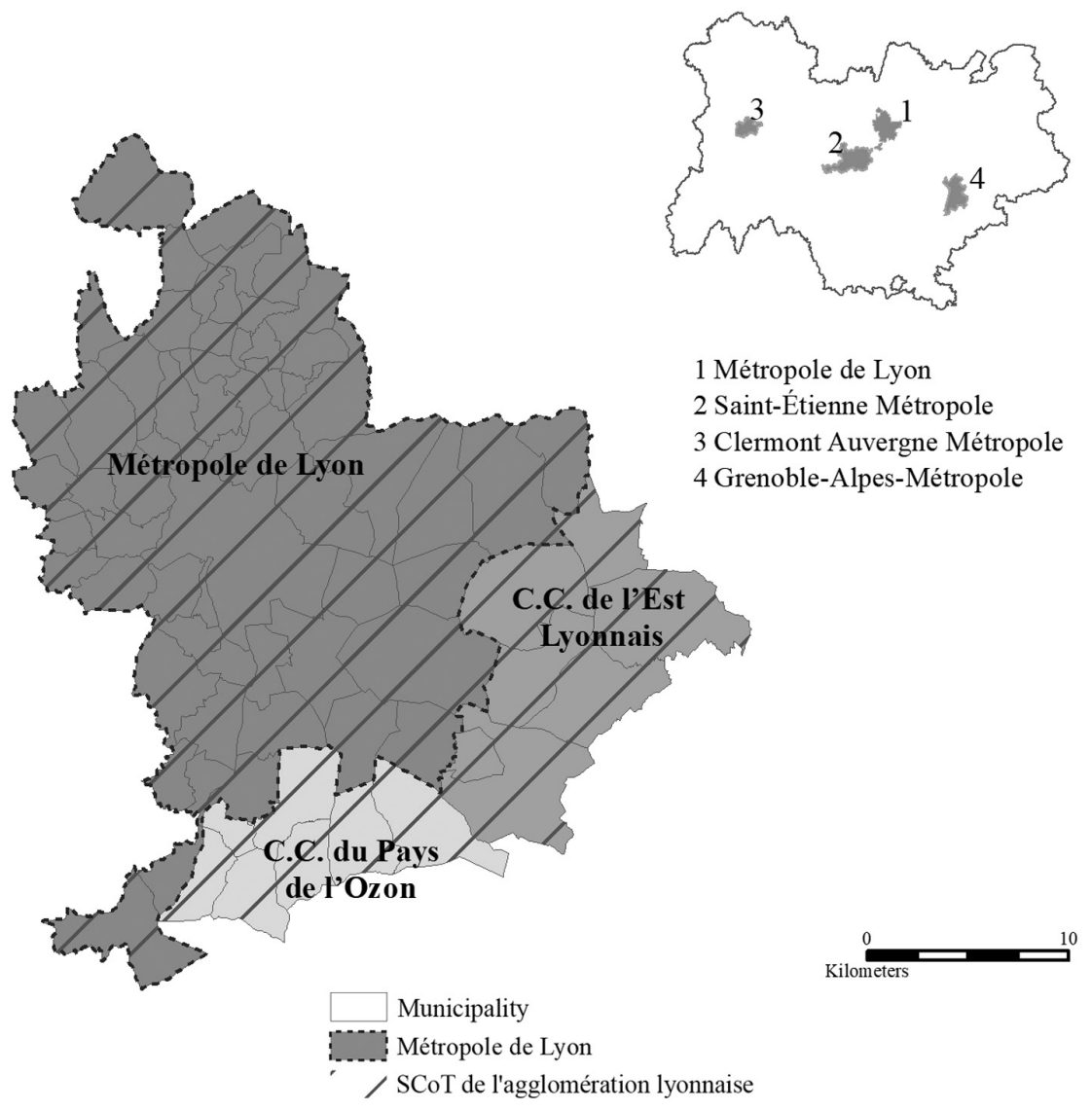

Région Auvergne-Rhône-Alpes

1 Métropole de Lyon 2 Saint-Étienne Métropole 3 Clermont Auvergne Métropole 4 Grenoble-Alpes-Métropole

Figure 2.9 Métropole de Lyon 2021 Concept: P. Feiertag Cartography: F. Gela 


\section{France}

Table 2.6 Lyon in the multilevel system

\begin{tabular}{|c|c|c|c|}
\hline Level & $\begin{array}{l}\text { Type of } \\
\text { institution }\end{array}$ & Name & Composed of \\
\hline Région & $\begin{array}{l}\text { Territorial } \\
\text { Authority }\end{array}$ & $\begin{array}{l}\text { Région } \\
\quad \text { Auvergne-Rhône-Alpes }\end{array}$ & 12 départements \\
\hline $\begin{array}{l}\text { Métropole with status } \\
\text { of département }\end{array}$ & $\begin{array}{l}\text { Territorial } \\
\text { Authority }\end{array}$ & Métropole de Lyon & 59 municipalities \\
\hline Municipality & $\begin{array}{l}\text { Territorial } \\
\text { Authority }\end{array}$ & Ville de Lyon & \\
\hline
\end{tabular}

(see Table 2.6). The new boundaries of the super-region do not correspond to the shape of the urban system. Instead, three urban networks with strong internal links are discernible: Clermont-Ferrand, Lyon and Grenoble (Desjardins and Geppert 2020, 128-129). All of them are organised as métropoles (see Table 2.1), just like Saint-Étienne which is part of the urban network of Lyon. In addition, the north-eastern border region is part of the cross-border urban network of Geneva (Région AuvergneRhône-Alpes 2020, 12).

As has been mentioned before, the Métropole de Lyon is the only métropole that has the function of a département at the same time, and has been cut out of its former département, Rhône. The département never formed a pertinent space for city-regional coordination of policies, but instead contributed to the institutional fragmentation despite continued adaptation of its borders (Boino 2007, 43). The functional city-region is divided into three départements: Ain, Isère and Rhône, or even four with Saint-Étienne located in the Département Loire. Historically, this administrative separation was deliberately chosen in 1793 to weaken the influence of the city of Lyon after an uproar. The Département Rhône has been enlarged three times (1852, 1967 and 1971) towards the east because of the extension of the urban agglomeration of Lyon. The original boundary was the river Rhône that runs through the city from north to south. The enlargement in 1967 was closely linked to the creation of the CU because its territory would otherwise have covered municipalities from three départements. To avoid this, the national government choose to shift the departmental boundaries and attached six municipalities of the Département Ain and 23 of the Département Isère to Rhône, though not all of them became part of COURLY in 1969. This shift of boundaries acknowledged the extensive urbanisation towards the east on the left bank of the river Rhône that had already taken place. The third enlargement of the Département Rhône involved only one municipality, Colombier Saugnieu, and was made to incorporate the area of the future airport Lyon-Satolas, later renamed Lyon Saint-Exupéry (Bariol-Mathais 2015, 26-27).

The municipal boundaries of the city of Lyon itself are rather narrow. The administrative territory was enlarged in the middle of the 19 th century 
but could not keep pace with its urban extension. At the beginning of the 20th century, the attempt to incorporate the city of Villeurbanne located in the north-east of Lyon, mostly within the first ring road (boulevard périphérique) failed. Afterwards, the first attempts at inter-municipal cooperation were undertaken as an alternative to annexation (Bariol-Mathais 2015, 24, 28).

The Métropole de Lyon is surrounded by small peri-urban communautés de communes. They were founded during the 1990s by municipalities with similar socioeconomic characteristics with the intent to prevent incorporation into Greater Lyon (Carpenter and Verhage 2014, 60). The main reasons to reject incorporation despite the advantage of better services were a good fiscal situation, the lack of visibility of small municipalities within the large métropole and most notably the lack of identification with the political project of Grand Lyon. Rather than seeing themselves as part of a metropolis of European rank, municipalities such as Millery seek to preserve a rural character and also to prevent the pressure to build social housing (Fitria and Charmes 2014). The existing structure of inter-municipal groupings thus contributes little to the solidarity between different territories - rich and poor, urban and peri-urban - intended by the legislator (Boino 2007, 49; Rousseau 2015, 623). This is still true despite the general reorganisation of inter-municipal groupings brought about by law and the schéma départemental de coopération intercommunale (SDCI) (see 2.1.4). The state services had proposed in the SDCI 2011 to add two municipalities (Jons and Millery) to Greater Lyon due to territorial discontinuities, but this was never put into practice because of the opposition of those municipalities. Greater Lyon also objected to it as the municipal grouping did not wish to integrate new municipalities against their will (Fitria and Charmes 2014). There were some dynamics regarding the merger of municipal groupings in the wider metropolitan area between 2011 and 2017, but the first ring around Lyon is still organised as CCs, many of them with unchanged perimeters. Within the functional aire métropolitaine lyonnaise (see Figure 2.8), two communautés d'agglomération with a larger area than each of the two métropoles Lyon and Saint-Étienne were created in January 2017: the CA du Bassin de Bourg-en-Bresse in the NorthEast (merger of seven EPCIs with 75 municipalities and $1,300 \mathrm{~km}^{2}$ ) and Loire Forez agglomération around Montbrison in the South-West with 88 municipalities (merger of four EPCIs). None of them is a member of the soft pôle métropolitain (see 2.3.3). One incentive to create larger groupings is a better visibility within the enlarged Région Auvergne-Rhône-Alpes. The municipal groupings are direct interlocutors of the région. The région concludes co-financing contracts with each of them based on a local development strategy and project propositions for any kind of investment of more than $60,000 €$ (apart from roads and sewage).

The municipal groupings (CA and CU) of the larger cities in the immediate surroundings of the Métropole de Lyon are organised within the soft 
cooperation space pôle métropolitain, forming a city network (see Figure 2.2 and 2.3.3). With about two million inhabitants, it is by far the largest pôle métropolitain in France and the only one including more than one métropole (Bariol-Mathais 2017, 35). Several other pôles organised as networks instead of a continuous space exist, but most of them have larger distances between the cities than in the case of Lyon (e.g. Loire-Bretagne, StrasbourgMulhouse or Centre-Franche-Comté).

All in all, institutional perimeters of territorial authorities have not been in line with the morphological and functional territory of the city-region for more than a century. This fragmentation has not been reduced by the emergence of municipal groupings. This also applies for the spatial dimension of the much weaker institution pôle métropolitain (see 2.3.3). The creation of the métropole, meaning a concentration of functions without enlargement of its perimeter rather aggravates the divide. According to Geppert (2017, 238), there is no entity that could ensure solidarity between a dynamic urban core area and a suburban residential periphery at the fringes of the agglomeration. Dugua $(2015,792)$ argues that overcoming the inter-territorial battle and opening up to a larger diversity of stakeholders beyond the public actors might eventually happen in the future, triggered by the pressure of an economic crisis or by a renewal of elected officials as heads of the main institutions.

\subsubsection{Perimeters for regional planning}

During the 1960s, state initiatives for strategic spatial planning covered a large metropolitan area: the plan d'aménagement et d'orientation générale (PADOG) developed by the Ministry of Construction and the Schéma d'Aménagement de la Métropole Lyon-St Étienne - Grenoble (OREAM 1971). However, the introduction of the SDAU planning instrument in 1967 led to "a shift in scale from the level of the metropolitan area to the level of the agglomerations" (Verhage et al. 2007, 86). The inter-municipal communauté urbaine was created in the same period and took over the task of strategic planning, though for a smaller perimeter (Bariol-Mathais 2015, 35-39). The development took ten years in the agglomeration of Lyon and was completed in 1978, but other parts of the metropolitan area did not succeed in producing an SDAU. Thus spatial planning at the level of the larger metropolitan area disappeared at that time (Verhage et al. 2007, 86). The state launched the development of another city-regional plan, the directive territoriale d'aménagement (DTA; see 2.3.3) at the end of the 1990s. Its perimeter was fixed based on morphological definitions and corresponded to the aires urbaines of Lyon, Saint-Étienne and Bourgoin Jallieu/ NordIsère (see Figure 2.8). The east of Lyon was seen as an important development area, whereas the more rural western side towards the city of Roanne was not included (Dugua 2015, 670). The DTA was smaller than the space covered by the RUL and not coherent with SCoT-boundaries defined shortly 
after by the local actors themselves: it cuts across eight of ten affected SCoTs (Préfecture de Région Rhône-Alpes 2006, 12).

Today's SCoT de l'agglomération lyonnaise has a limited perimeter and does not correspond to the metropolitan region (Aguiar Mol 2015, 310). It includes two small municipal groupings in the south-east of Lyon, CC de l'Est Lyonnais with 40,000 inhabitants and CC du Pays de l'Ozon with 25,000 inhabitants (see Figure 2.9). This area has particular relevance for spatial development because the airport Saint-Exupéry is located there and encourages important economic activities in its surroundings (Fitria and Charmes 2014). Since a minor extension in 2016, the SCoT covers 74 municipalities with an area of $756 \mathrm{~km}^{2}$. Two small municipalities have been added because they had joined the municipal grouping of Lyon. This extension, which is insignificant in terms of demographic weight $(6,200$ inhabitants), does not increase the coherence of the perimeter. The informal Inter-SCoT dialogue (see 2.3.3.) first covered nine SCoT territories, i.e. the ring directly adjacent to Lyon and was later enlarged towards the west; today it encompasses 13 SCoT territories (Dugua 2015, 317; Verhage et al. 2007, 87) with 914 communes, 3.1 million inhabitants and an area of $10400 \mathrm{~km}^{2}$. Since 2004, it has also covered the agglomeration of SaintÉtienne, and since 2006 the medium-sized city of Roanne. The rural space in-between (SCoT Loire Centre and Mont du Lyonnais) was integrated in 2011 (Dugua 2015, 317; see Figure 2.10). Cooperation on this spatial scale is not entirely new, as it is similar to the association Région Urbaine de Lyon (RUL) created in 1989 (see 2.3.3.). The RUL has treated questions of spatial development and produced a charter for planning and development, but does not possess a formal planning instrument.

\subsubsection{Coordination of public policies beyond the métropole}

The inability of traditional institutional perimeters to handle the reality of metropolitan dynamics (Dugua 2015, 282) has led to the creation of several additional soft spaces with different perimeters. Three other bodies are relevant for metropolitan politics: the RUL, the Inter-SCoT and the pôle métropolitain (Aguiar Mol 2015, 138). The Métropole de Lyon is a powerful actor present in all of them. Furthermore, the state and the région intervene in this strategic territory of high national relevance.

\subsubsection{Regional planning: Inter-SCoT, DTA and SRADDET}

Regional planning at a metropolitan scale has a long tradition in the metro region of Lyon, although without institutionalised planning association at that scale (see 2.3.1 and 2.3.2). As the SCoT planning document only covers the core of the metropolitan region, its potential to bring coherence into metropolitan policies is limited. It is complemented by three other processes of regional planning that have taken place in the last two decades. All three 


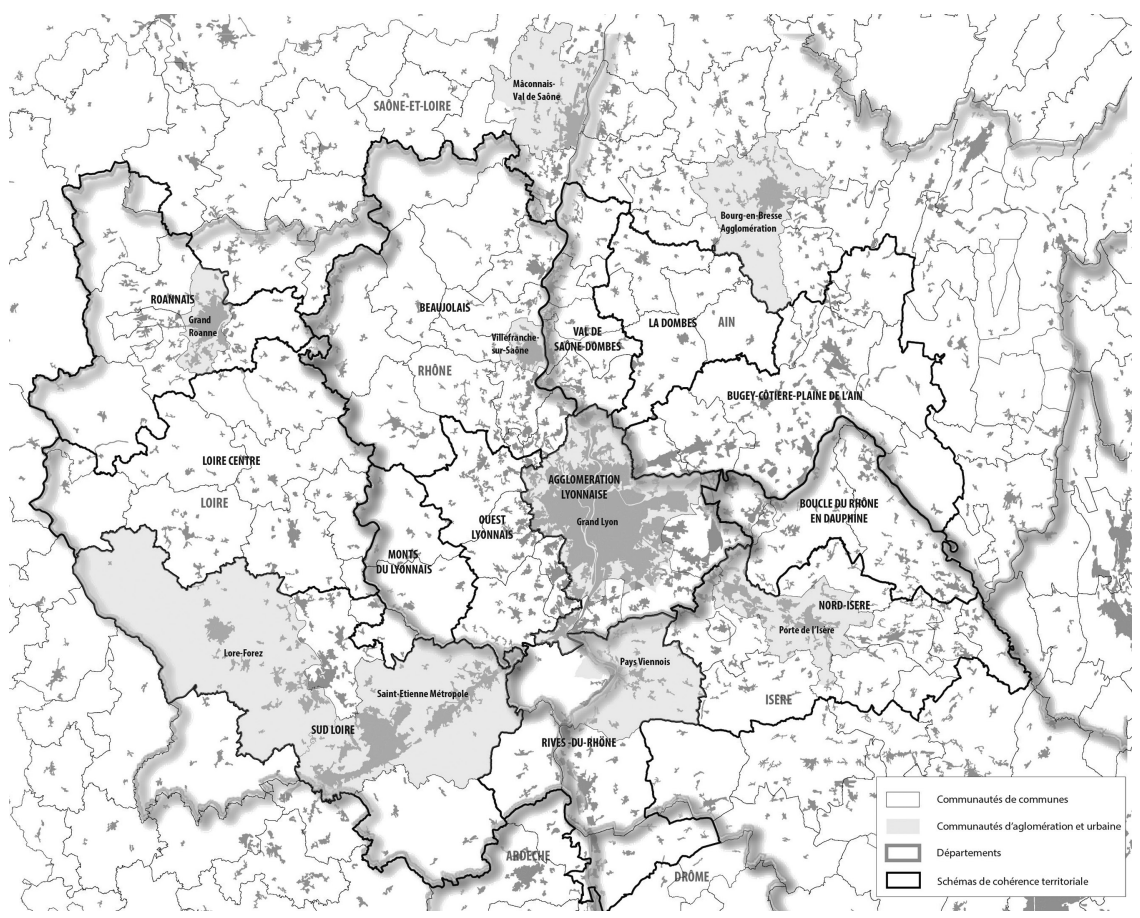

Figure 2.10 Institutional organisation within the Inter-SCoT area of Lyon (C) Dugua, Source: Dugua 2015, 309)

cover the wider metropolitan region of Lyon, though with different perimeters, at different times and piloted by different actors (see Table 2.7). The DTA as an instrument for areas of national interest was launched by the state and developed between 1998 and 2007; the SRADDET is a new planning instrument of the région first developed between 2016 and 2020; and the Inter-SCoT is a continuous dialogue between inter-municipal planning associations started in the 2000s. All three are binding for the SCoT de l'agglomération lyonnaise: DTA and SRADDET in legal terms as part of hierarchical vertical coordination and the Inter-SCoT due to a self-binding commitment as part of vertical coordination between bodies of local self-government.

The Inter-SCoT dialogue in the region of Lyon is an informal process, but is more intense and engaging than in most other French city-regions due to the necessity induced by the small size of the SCoT de l'agglomération lyonnaise (see Figure 2.9) compared to the functional area of interdependence (Interviews; Dugua 2015, 318). However, its governance arrangement has remained weak. The Inter-SCoT dialogue started in parallel to the development of the first generation of SCoT and was initiated in 2002 by the 
Table 2.7 Layers of planning documents in the city-region of Lyon

\begin{tabular}{|c|c|c|c|}
\hline Planning document & Year of approval & Institution & Area covered \\
\hline SRADDET & 2020 & $\begin{array}{l}\text { Région Auvergne- } \\
\text { Rhône-Alpes }\end{array}$ & Région \\
\hline Inter-SCoT & Since 2002 & $\begin{array}{l}\text { Informal dialogue } \\
\text { supported } \\
\text { by agences } \\
\text { d'urbanisme }\end{array}$ & 13 SCoT \\
\hline DTA & 2006 & State & 382 municipalities \\
\hline $\begin{array}{l}\text { SCoT de l'agglomération } \\
\text { lyonnaise }\end{array}$ & $\begin{array}{l}\text { 2010, updated } \\
\text { in } 2017\end{array}$ & Syndicat de SCoT & $\begin{array}{l}3 \text { EPCIs (with } \\
74 \text { municipalities) }\end{array}$ \\
\hline $\begin{array}{l}\text { PLUi including housing } \\
\text { programme PLH }\end{array}$ & 2019 & $\begin{array}{l}\text { Métropole de } \\
\text { Lyon }\end{array}$ & $\begin{array}{l}\text { Métropole (with } \\
59 \text { municipalities) }\end{array}$ \\
\hline
\end{tabular}

Agence d'Urbanisme pour le développement de l'agglomération lyonnaise (UrbaLyon) after the creation of a large SCoT for the entire metro region had failed (Aguiar Mol 2015, 142; Boino 2007, 55; see also 2.3.2). Even two decades later, there is no political will to reduce the number of SCoTs. The leading role of the president of UrbaLyon was crucial for convincing the municipal groupings around Lyon to participate in this less obligating, flexible form of coordination, because the agency was seen as neutral and valued due to its know-how (Aguiar Mol 2015, 205). For the project leaders of the first generation of SCoT, the possibility to exchange with other syndicats de SCoT about the practices that had to be established was a high incentive to engage in the dialogue (Aguiar Mol 2015, 188). The two agences d'urbanisme of Lyon and Saint-Étienne have produced over 50 studies on the scale of the metropolitan region as part of the Inter-SCoT dialogue as well as indicators for monitoring of residential development, transport, green and blue infrastructure as well as commercial development (Bariol-Mathais 2015, 48; Verhage et al. 2007, 87; Dugua 2015, 317). An important outcome is that the exchange has led to a common chapter at the beginning of each SCoT, introducing the main principles of the development for the entire metropolitan region. ${ }^{25}$ The topics treated on the scale of the entire metro region were centrality and transport, housing and urban forms, economic development as well as agriculture and environment (Dugua 2015, 368-382). The Inter-SCoT itself has no legal quality, but the content becomes legally binding once it is integrated into the SCoT of its members (Aguiar Mol 2015, 157). The common chapter also includes a schematic map showing development axes and the main green spaces (see Figure 2.11).

The Inter-SCoT is a useful platform for exchange and consultation, but with some restrictions. A real coordination of spatial policies is made difficult by the fact that the development of the SCoT has not been synchronised since the beginning: whereas the first SCoT in the metropolitan region was already approved in 2003, the SCoT for the core area was launched as last one and only approved in 2010 (Boino 2007, 56; SEPAL 2010). This time 


\section{Chapitre commun inter-Scot, axes de développement}

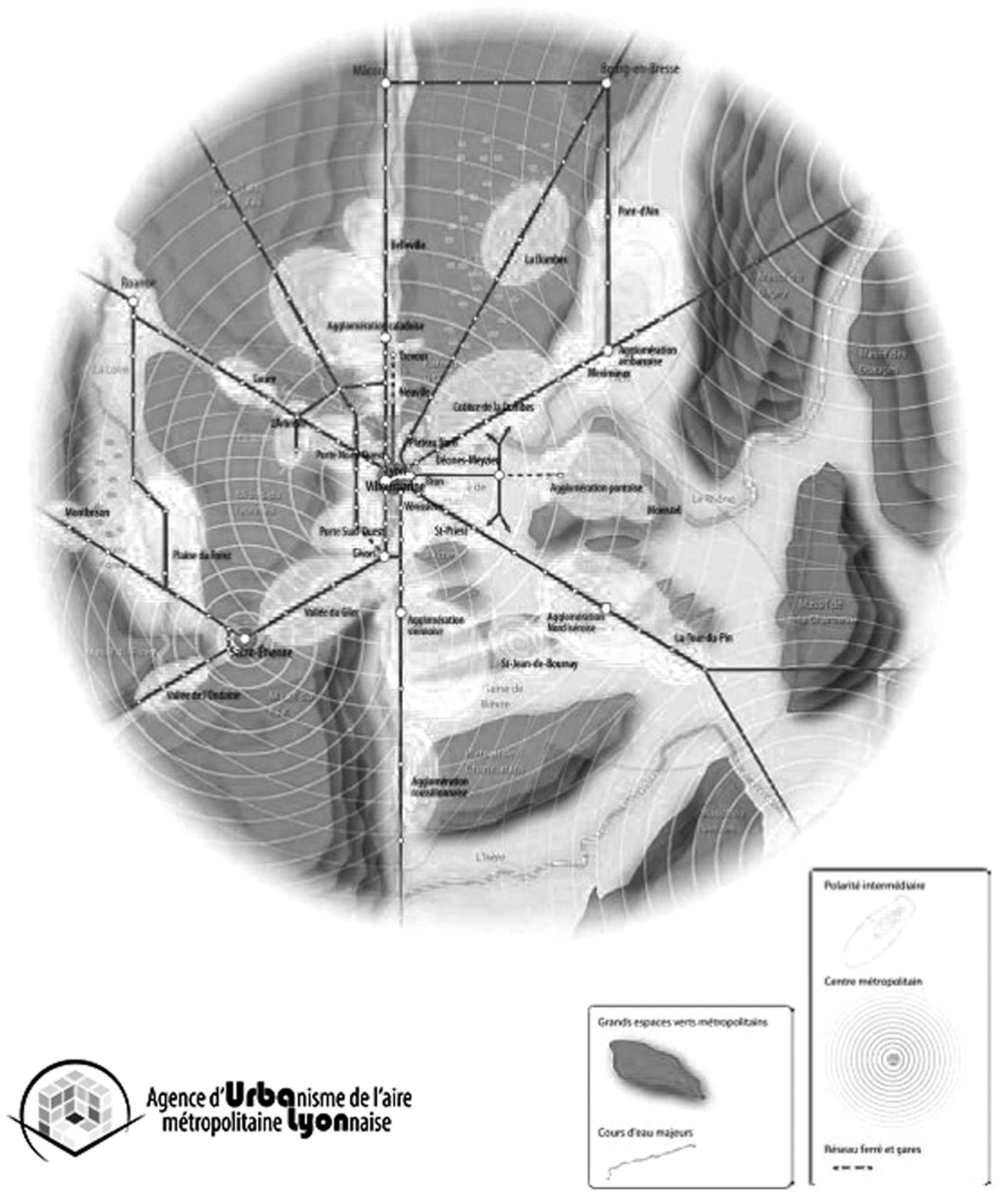

Figure 2.11 Map development axes from the common chapter of the Inter-SCoT de l'aire métropolitaine lyonnaise

lag has persisted in the updating process. Secondly, one of the reasons for its success is its voluntary character, but it does not allow to treat highly conflictual topics (Aguiar Mol 2015, 322; Dugua 2015, 319). The InterSCoT remains an informal dialogue without any decision-making power. A formalised governance arrangement was pushed on several occasions by 
some SCoT presidents, but rejected both by Grand Lyon and many of the peripheral SCoT associations (Dugua 2015, 394). The Inter-SCoT is an expert dialogue between planners of the planning associations "syndicat de SCoT" and the two agences d'urbanisme, but also an arena for exchange of the elected representatives of the member EPCIs. The planners responsible for the 13 SCoTs meet at six-week intervals, share know-how and discuss common problems (Interviews; Aguiar Mol 2015, 168-169). The presidents of the EPCI meet once or twice a year to decide the missions to be developed for the following year, but also to discuss a specific topic relevant to metropolitan planning (Dugua 2015, 317). This personal contact has been helpful to build trust and facilitates other forms of informal cooperation within the larger metropolitan region such as the pôle métropolitain (Aguiar Mol 2015, 319). These meetings are one of the rare occasions where the influential political representatives of the core cities meet face to face with the presidents of small municipal groupings in the periphery of the metropolitan region (Dugua 2015, 318). At the beginning of the dialogue, the smaller municipal groupings mistrusted the dominant Lyon (Fitria 2016, 99) and feared losing power, but working together has helped to acknowledge common interests and to build a climate of confidence within this arena characterised by low political visibility (Aguiar Mol 2015, 173174). The Inter-SCoT dialogue enables the local actors to reason and act on a metropolitan scale (Aguiar Mol 2015, 186). The Inter-SCoT dialogue was partly triggered by the development of the binding directive territoriale d'aménagement (DTA) for the aire métropolitaine lyonnaise by the state to keep a say in the process of defining the spatial strategy of the metropolitan area (Dugua 2015, 316). Today, a strong motivation for the Inter-SCoT dialogue is to express common points of view, e.g. concerning railway connections or the SRADDET and to produce agreements on a unified position towards investors, e.g. concerning large-scale commercial developments.

Lyon is one of six territories of national interest covered by a regional plan established by the state, the DTA. The metropolitan region of Lyon was chosen because of its importance for the national economy, but also because of the high institutional fragmentation. According to the DTA,

the implementation of real "governance" for this metropolitan territory requires strong action by the state, in its own areas of competence but also as a partner of the local authorities which are responsible but which, locked within their own limits, cannot meet the requirements of regional or national interest. The initiatives observed are still too slow and not sufficiently binding for the coordination of public policies (own translation, ${ }^{26}$ Préfecture de Région Rhône-Alpes 2006, 11).

The process started in 1998 with a preparatory analysis and the document came into force in January 2007 (Bariol-Mathais 2015, 40; Dugua 2015, $315)$. It formulates the state's priorities in the medium and long term, in 


\section{France}

particular regarding large-scale infrastructure such as highways, high-speed rail connections, harbours and intermodal hubs (Carpenter and Verhage 2014, 61; Bariol-Mathais 2015, 42). Its main impact was to keep potential sites for infrastructure free from other land uses (Dugua 2015, 691). In the area surrounding the airport, building restrictions are related to noise protection, expansion plans of the airport as well as a multimodal platform and a planned high-speed connection to Turin. A modification was made between 2013 and 2015 to allow for additional sites for cargo and economic activity zones. Today the content of the DTA is partly outdated because infrastructure projects such as a new highway bypassing Lyon in the west have been rejected. This creates a paradoxical situation because the DTA continues to be formally binding for the SRADDET and SCoT planning documents. They therefore have to integrate infrastructure projects programmed 15 years ago even though all actors agree that they will never come about. Thus, the DTA has mainly become an inconvenient constraint in the eyes of local actors rather than an instrument that helps to structure the future development of the metro region.

Although the state is not developing regional plans anymore, the régions have had the duty to develop a strategic document for their entire territory since 2015, the SRADDET (schéma régional d'aménagement, de développement durable et d'égalité des territoires). In the case of Auvergne-RhôneAlpes, the objective of the region was to define a unified, coherent vision of the new regional territory created by the amalgamation of two regions. The development process of the SRADDET included a territorial dialogue in each département as well as thematic consultations, both at the beginning and after drafting the document. For both the participation process and the document, the title "Ambition Territoires 2030" was chosen as it was believed to sound less technocratic and be easier to communicate than "SRADDET". The planning document entered into force in April 2020 and is binding for the already existing SCoT, but is not likely to cause modifications. It defines general principles concerning territorial development, transport, climate, air and energy, biodiversity and waste management, but no quantitative aims concerning land consumption, densification or reservation of agricultural land. Territorialised specifications are only made with a low level of precision: it contains a list of infrastructure projects that the région is willing to co-finance such as high-speed rail connections, and indicates ecological corridors and biodiversity reservoirs schematically. Thus, the région defines a frame, but its impact on land use planning is low in the first generation of SRADDET.

\subsubsection{The région urbaine de Lyon (RUL) and its dissolution}

The association Région Urbaine de Lyon (RUL) was “a permanent forum for dialogue and debate, with the aim of providing a clearer vision of the challenges facing the metropolitan area of Lyon and Saint-Étienne, proposing 
strategy plans for development and planning, and being a catalyst for coordinated action by both local authorities and local stakeholders" (Bideau 2003, 108). It was created in 1989 and dissolved in April 2015. The association was based on the voluntary action of members to address issues of metropolitan development and transcend administrative boundaries within an area close to the functional metropolitan region. According to Aguiar $\operatorname{Mol}(2015,141)$, it was the only arena where all actors of the metropolitan region came together. Other authors refer to it as a unique institutional solution that did not exist in any other metropolitan area in France (Bideau 2003, 108; Verhage et al. 2007, 87). What made it so special apart from its early creation and its perimeter was the horizontal as well as vertical coordination across different layers of the state. The association has brought together the départements, the région as well as the largest municipal groupings of the metro region. Its founding members were the three départements Ain, Rhône and Isère as well as the Communauté Urbaine de Lyon. Two years later, it was enlarged towards Saint-Étienne with the fourth département Loire, though without the municipal grouping of Saint-Étienne. The Région Rhône-Alpes became a member in 1996 and held the co-presidency from 2002 together with the president of Grand Lyon. In the same year, the other EPCIs representing the urban centres of the metropolitan region became associated members (Bideau 2003, 108; Boino 2007, 54; Aguiar Mol 2015, 141). Thus, Grand Lyon, and the mayor of Lyon as its president, had a key role within the RUL and was far more influential in agenda setting than the other municipalities and municipal groupings of the metro region.

The RUL had some similarity to the Inter-SCoT dialogue existing in parallel for about ten years. Both were soft, dialogue-oriented forms of metropolitan cooperation with a similar perimeter, and both had the role of producing knowledge and joint strategies. They involved slightly different actors and topics, though with overlaps (Aguiar Mol 2015, 191). The work of the RUL was coordinated by a small team of four employees. The core activity of the RUL was an annual forum as a basis for producing common ideas and developing propositions that were then validated by the members. Each year, another topic was addressed: 1997 logistics, 1998 sustainable development, 1999 metropolitan functions, 2000 peri-urban areas, 2002 leisure, etc. (Bideau 2003, 108-109).

The main merit of the RUL was to reach consensus about some questions and to develop a common vision for spatial development of the metropolitan space despite a very fragmented institutional landscape (Bideau 2003, 108; Boino 2007, 54). According to its former director, it was a place for open dialogue, because of low media exposure. In the annual conferences the members agreed on a charter for planning and development (Charte d'aménagement et de développement 1994) as well as several strategies (e.g. schéma logistique in 1997). During the term of office of Raymond Barre, comprehensive planning processes were regarded as too heavy and time-consuming and the activities were turned towards specific sites, e.g. 


\section{France}

in the logistics sector (Aguiar Mol 2015, 131). One of the successes of the RUL has been the establishment of a partnership between the public transport companies of the metro region in 2000 (Bideau 2003, 108-109, Boino 2007, 54). Thus the RUL contributed to multimodal pricing, a web tool for public transport route planning on the perimeter of the RUL, and the creation of a logistics cluster (Dugua 2015, 310). Although it has been an incubator for some projects, the main activities of the RUL remained reflection, dialogue and networking. Activities in the last years of its existence included the topics of economic development, intermodal transport, logistics and the metropolitan dimension of tourism (Aguiar Mol 2015, 141-142). Today, intermodal transport is the responsibility of the région, whereas the pôle métropolitain pursues the work regarding tourism.

Despite positive acknowledgements in the literature (Bideau 2003; Verhage et al. 2007; Boino 2007; Aguiar Mol 2015), some shortcomings have to be mentioned to explain the disappearance of the RUL. The outcome in terms of concrete project implementation was rather limited and slow. Like any other form of soft governance, the RUL did not possess any decision-making power (Aguiar Mol 2015, 198) and its low formalisation caused fragility and a lack of democratic legitimacy (Boino 2007, 54). In addition, the boundaries of the départements remained very present (Aguiar Mol 2015, 183; Dugua 2015, 310), and political conflicts between the actors persisted (Aguiar Mol 2015, 130). A certain amount of mistrust and distance from the presidents of the intercommunal bodies (Aguiar Mol 2015, 142) as well as rivalries between Grand Lyon and the région about metropolitan leadership (Dugua 2015, 310) complicated the process. The RUL also lacked good relations with the local economic sphere. Most large companies with industrial plants in the metro region had their headquarters in Paris and were involved very little in local politics whereas the chamber of commerce and industry mainly supported the interests of small and mediumsized businesses (Ben Mabrouk and Jouve 2002, 101). Thus, despite its longstanding existence as part of metro governance in Lyon, the RUL was called into question by the emergence of other metropolitan institutions. Although it coexisted with the Inter-SCoT dialogue, it was dissolved in favour of the pôle métropolitain due to a unilateral decision of the mayor of Lyon not to support it anymore. Two years after the formalisation of the pôle métropolitain as an association, its members withdrew from the RUL on the initiative of Gérard Collomb and thus caused its dissolution in November 2014 as it made no sense to pursue it without Lyon (Dugua 2015, 311). Thus, the RUL ceased to exist at the moment Grand Lyon became a métropole.

\subsubsection{The Pôle métropolitain as alternative to the RUL}

The pôle métropolitain is slightly more formalised than the former RUL and the Inter-SCoT dialogue because it has a legal form defined by national law (see 2.1.1). However, it remains a light form of cooperation based on 
dialogue and voluntary action of the members, with all the advantages and disadvantages of soft governance arrangements. With a headquarters with six employees and a budget of 1.8 Mio $€$ (i.e. about $0.05 \%$ of the budget of the Métropole de Lyon), it does not have significantly more capacities than the former RUL. Creating a new organisation instead of formalising the governance of the Inter-SCoT or using the long-standing RUL for metropolitan projects was a unilateral choice of Grand Lyon, justified by the argument to be more action-oriented instead of focussed on reflection and strategy formulation. The Inter-SCoT is portrayed as complementary (Dugua 2015, 394), restricted to reflections on spatial planning within the SCoT procedures and with the main value of a regular exchange between planners, whereas the pôle is a more political arena and totally free in the definition of its topics and actions, as long as a consensus among its members can be reached. Compared to the RUL, the crucial difference is the circle of actors since the new association is only formed of municipal groupings representing the urban centres of the metropolitan region (see Figure 2.2). This reduction to horizontal cooperation without the région, the départements and the state was seen as an advantage by the cities and can be interpreted as one of the aims of the institutional change (Aguiar Mol 2015, 187). It reflects fundamental changes in the multilayer system in the three decades since the creation of the RUL with the rise of the largest municipal groupings and the marginalisation of the départements (see 2.1), but means that a shared forum with the région has disappeared, despite mutual fields of action such as intermodal transport, economic development and regional planning (SRADDET).

The aspiration behind the pôle métropolitain was to create a more potent organisation that would be able to advance concrete projects quicker and be more politically visible. The driving idea behind the pôle was to enhance the competitiveness of the metropolitan region at a European scale. This idea was mainly related to the symbolism of having more weight due to a higher number of inhabitants within this larger area as compared to the métropole (Interviews; Dugua 2015, 313). Its fields of action are not so different from the agenda of the RUL. The initial topics formulated in a first cooperation agreement signed in 2010 were the economy, culture, transport and spatial development (Dugua 2015, 312). Concrete actions that were implemented until 2018 mainly concerned tourism (booking destinations within the entire region in each tourism office), marketing (joint presentations at real estate fairs) and regional food cycles (use of local products for large events) as well as two sites of particular relevance: the airport Saint-Exupéry and the Valley of the river Gier between Saint-Étienne and Lyon. In the field of transport, some ideas about reduction of car traffic in the centre of Lyon by creating park and ride car parks with carpooling services as well as ferry transport on the river Rhône have been proposed, but the implementation of joint solutions has been difficult.

The airport was initially not part of the pôle, which is called illogical by Carpenter and Verhage $(2014,60)$. The association was officially created by 
prefectoral decree in April 2012 with four members, the municipal groupings of Lyon, Saint-Étienne, Vienne and Bourgoin Jallieu (see Figure 2.8). The patchworked territory acknowledges the role of the large urban EPCI as key actors due to shifts of responsibility in the past decade, but also poses problems because the topics addressed at the metropolitan scale are not only restricted to these territories. One obvious example is urban agriculture and regional consumer cycles, as production areas are to a large part located in those municipalities that are not members of the pôle. In 2016, after the dissolution of the RUL, Villefranche in the north of Lyon and the CC de l'Est lyonnais with the airport joined the pôle.

The airport is the symbol of the difficulty of the various bodies of metropolitan governance in making the link between strategies on the scale of the large territory and local actions (Dugua and Trotta 2012). Since 2016, the pôle métropolitain has taken over the responsibility to coordinate the development of activity zones in the institutionally highly fragmented area around the airport, cutting across three départements and four SCoTs. The process includes only three of the six members of the pôle, but a wide range of other actors such as state services, EPCIs and SCoTs covered by the study area, départements, région, chambers and economic development agencies. The urgency of coordinated action in this area had already been recognised by the Inter-SCoT in 2010. As a first step the UrbaLyon had been mandated to carry out a survey as the basis for a joint strategy initially piloted by the state, also leading to a modification of the DTA. It was under discussion to create a new association for the Saint-Exupéry plain to implement the strategy, but the task was instead entrusted to the pôle métropolitain (Dugua 2015, 440-448).

The mode of operation of the pôle métropolitain is incremental, i.e. based on the preparation and initiation of innovative projects that would add to overall goals of metropolitan development. It is a place for experimentation and dissemination of good practice (Bariol-Mathais 2017, 119) as well as dialogue between the elected representatives of the members. Each of the six municipal groupings provides one vice-president and sends members to the council composed of 88 members (thereof 43 Métropole de Lyon). The crucial element of governance is to bring the presidents of the six municipal groupings together. Their meetings take place every second month and are prepared by a meeting of their heads of administration with the director of the pôle. The head office has the means to initiate processes by bringing actors together and financing smaller studies, but larger investments have to be financed by each of the members and thus must be deliberated by their democratic bodies. The pôle has already raised funds to a smaller extent, but is not made for this and does not have the capacity for EU funding applications.

The pôle métropolitain launched promising projects in its first years, but entered a phase of lower activity between 2015 and 2018. The lower interest of the members was caused by a fundamental restructuring within all 
of the municipal groupings themselves as well as political change after the municipal election of 2014 with new mayors. Conflicts of interest persist despite the seemingly more heterogeneous circle of actors as compared to the RUL, but can be addressed. The voluntary status and light structure is a precondition for its existence and allows for flexibility, but is seen by most interviewees as a step in the right direction rather than as an entirely satisfactory solution of metropolitan governance. Concerning future perspectives, the conceptions range from an enlarged territory of the pôle, i.e. more coherent soft space, to a much larger métropole, i.e. replacement by a hard institution. Thus, rather than conducting debates on its form, it seems more auspicious to concentrate on concrete projects with joint benefits that can be launched within the given institutional frame.

\subsubsection{Saint-Étienne - second hub of the metropolitan region or a metropolis in its own right?}

Saint-Étienne is the core city of a municipal grouping that acquired the status of métropole in 2018. It is one of the largest French métropoles in terms of area, but has only about one-third of the population of the Métropole de Lyon (see Table 2.1). The centres of the two métropoles are only about $50 \mathrm{~km}$ away from each other and their borders now almost touch each other since the municipality of Givors joined the Métropole de Lyon (see Figure 2.10). The two cities are part of one urban network with strong internal links (Desjardins and Geppert 2020, 129). Saint-Étienne is the second largest centre whereas the others are medium-sized cities (Vienne, Bourgoin Jallieu and Villefranche-sur-Saône).

The state-led regional plan PADOG from the 1960s interpreted Lyon and Saint-Étienne as two city-regions (régions urbaines) that are both part of the metropolitan region of Lyon (aire métropolitaine de Lyon) (BariolMathais 2015, 33). The DTA calls for a multipolar urban development and also describes Saint-Étienne as a separate agglomeration (agglomération de Saint-Étienne) within the metropolitan region of Lyon (Préfecture de Région Rhône-Alpes 2006, 15). It can be argued that the subsystem of Saint-Étienne is more coherent in terms of planning than the one of Lyon because SaintÉtienne is part of the SCoT Sud Loire covering a vast area of 116 municipalities. The agglomeration of Saint-Étienne has been part of the three soft networks on the metropolitan level, RUL, Inter-SCoT and pôle métropolitain. However, it was not a founding member of the RUL or the Inter-SCoT. In both cases its territory was soon included in the considerations due to the strong functional interrelation, but Saint-Étienne was first invited only as an observer (Boino 2007, 54-56). Within the governance of the pôle métropolitain, the Saint-Étienne Métropole has a more equitable role, at least symbolically: according to the statutes, the presidency rotates every three years between Lyon and Saint-Étienne and its headquarters is located in-between the two centres. The ADERLY economic development agency 
has extended its radius of action to the municipal groupings of Saint-Étienne and Capi in 2015 (Bariol-Mathais 2017, 117). Furthermore, the universities of Saint-Étienne and Lyon have started an alliance within a national initiative for excellence. All in all, competitiveness functions are carried out at a larger scale including Lyon and Saint-Étienne, whereas services for the population are provided by each of the métropoles.

Regarding the terminology, most actors refer to the urban or metropoli$\tan$ region of Lyon. However, in the context of the Inter-SCoT-dialogue, documents refer to the "aire métropolitaine Lyon - Saint Étienne", emphasising a bipolar character. The pôle métropolitain has been named only "pôle métropolitain" without referring to Lyon in its name and thus avoiding the question of the relevance of the agglomeration of Saint-Étienne in the partnership.

\subsection{Conclusion: recent changes of city-regional governance in France}

In the chapter on French metropolitan governance and planning, two métropoles created in January 2015 have been the main objects of investigation. The Métropole de Lyon has a special status as full local self-government, whereas Nantes is one of the "ordinary" métropoles organised as a legal public body (EPCI). The main differences between the two cases are that the Métropole de Lyon fulfils functions of the département and has had a directly elected assembly since 2020 . Lyon also has a longer history of intermunicipal cooperation and regional planning, whereas the main integration process in Nantes took place in the 2000s. In both cases, the mayors of the core city have had a key role in governance of the metropolitan region in the last two decades, both within the métropole and beyond. However, this concentration of mayoral power ended in Lyon after 2020, as the métropole became an independent layer of governance.

In terms of a functional definition of the metropolitan region, i.e. aire urbaine defined by commuter sheds, Lyon is significantly larger. However, the institutionalised space of the two métropoles is almost the same with an area of a little more than $500 \mathrm{~km}^{2}$. With regard to city-regional planning, Lyon even has a smaller SCoT than Nantes (compensated by a more committed Inter-SCoT dialogue including the surrounding planning associations). In Nantes, the wider metropolitan area of Nantes - Saint-Nazaire forms a second, albeit weak, level of metropolitan governance (pôle métropolitain responsible for SCoT) composed of several EPCIs. With regard to vertical cooperation, actors from different levels responsible for different territories meet and collaborate within the SAMOA development agency with the concrete outcome of the Île de Nantes regeneration scheme. In Lyon, coordinated action from a multitude of actors is needed for the area around the airport Saint-Exupéry located outside the métropole; this task has been delegated to the pôle métropolitain after preparatory analysis by state services. 
The case of Nantes shows that the existing instruments create capacities to act despite persistent institutional fragmentation of the metropolitan region. Lyon has succeeded in establishing one of the most powerful cityregional governments in Europe (Galimberti et al. 2014, 192) for the core of the metropolitan region. In France, it is an experimental case that receives much attention and is often seen as the most advanced, most exemplary model of metropolitan government. The full impact of its transformation will only become assessable in the years to come, namely the impact of direct elections, the dissociation of the mayor of Lyon and the president of the métropole as well as the political shift to the Green Party in 2020. On the wider scale of the large functional urban region, the metropolitan region of Lyon is still a highly fragmented space. It has a rich, long-standing tradition of metropolitan dialogue, though the definition of metropolitan space remains fluid and coordinated action is split into several arenas with low degrees of institutionalisation. Their fragility and dependence on the goodwill of the métropole is shown by the dissolution of the RUL. Strengthening the métropole institution has rather intensified the "fronts of the interterritorial battle" in the Lyon metropolitan area (Dugua 2015, 395) and the realisation of concrete projects with a multitude of actors, interests and rivalries remains cumbersome. For the field of public transport Idt et al. (2012) argue that collective action can be reached even without a shared vision or the existence of common interests, if actors assume their interdependence and if steering mechanisms for inter-institutional cooperation are able to manage the competition between territorial administrations.

This comparative section is organised according to the four dimensions of institutions, functions, ideas and space that form the analytical framework of the book. It synthesises the three previous sections on national territorial reforms and the two in depth case studies of Nantes and Lyon, and interprets on this basis recent changes of city-regional governance in France.

\subsubsection{Institutions}

Métropoles have become a powerful layer above the municipalities and are key institutions for metropolitan governance. They are the result of many decades of inter-municipal cooperation. The new status granted by the national government is not particularly exclusive, given the number of 22 métropoles since 2018. Whether the status of métropole came with important changes or not depends greatly on the individual city-region and its history of inter-municipal cooperation. Regarding the two cases of Nantes and Lyon, the impact of the MAPTAM law has been quite different: in the case of Nantes, the transformation was minor, whereas it triggered great institutional change in Lyon. This was primarily related to Lyon's special status, i.e. to the transfer of all departmental responsibilities within its territory and the direct election of its council. The two métropoles were preceded by a $C U$ and already possessed most of the municipal responsibilities prescribed 
by the MAPTAM law. This does not apply to all French métropoles, e.g. Grenoble.

The national laws set the framework for the métropoles, such as mandatory responsibilities and rules for political representation. Therefore, a similar type of metropolitan institution exists in all French city-regions. Nonetheless, we can observe some heterogeneity and variation. On one hand, tailor-made rules for some métropoles such as Lyon have already become part of the legislative process. On the other hand, specific local arrangements are possible within the framework of the national law such as in the case of Nantes (pooled administration with deconcentrated units, additional responsibilities, key role of the local development agency, SAMOA).

Both métropoles have established sub-units regrouping several municipalities or city-quarters of the core city, although the national law does not include them. These are called "pôles de proximité" in Nantes and "conférences territoriales" or "bassin de vie" in Lyon. In the case of Lyon, their outline is largely consistent with the boundaries of the new electoral constituencies of the métropole. The idea behind them is to create spaces with similar characteristics and issues. An advantage is that those spaces are more alike in size than the municipalities and partly overcome the dichotomy between a large core and small peripheral units. They do not form an official decision-making level, but are used in strategic documents (e.g. for diagnosis and formulation of the development strategy "projet territorial" within the land use plan PLUi/PLUm) ${ }^{27}$ and for coordination of concrete questions regarding the implementation of public policies in the particular area (interface between métropole and municipalities). Both in Nantes and Lyon, this intermediary level for consultation guarantees regular communication among the mayors within those sub-territories and the heads of the metropolitan executive. In Nantes, the pôles de proximité also correspond to deconcentrated units of the metropolitan administration, and their establishment was one founding principle of the CU. In neither of the two métropoles are they used for contact with the citizens, neither for consultation nor for administrative procedures. The municipalities remain the main interface between the local administration and the citizens. For example, the citizen participation during the preparation of inter-municipal land use plans took place in each municipality individually and was jointly organised by the municipal administration and the métropole.

Municipalities also remain the basic unit for democratic representation in the métropoles, with the exception of Lyon. Direct election without a simultaneous mandate in a municipal council was much discussed but never implemented in the national legislative process. In the case of Lyon, the transformation into a jurisdiction with directly elected council has reshaped the relationship between the Métropole de Lyon and the municipalities within its perimeter. They are no longer members of a voluntary municipal grouping. Instead, the métropole, which fulfils many functions of local self-government and raises its own taxes has become a layer of 
territorial government without asking its former members for their consent. Direct elections strengthen the democratic legitimacy of the métropole and match the high influence of the political decisions of the metropolitan council on living conditions in the agglomeration. At the same time, the status of the municipalities and their mayors within the decision-making process has changed, causing internal conflicts between the métropole and the municipalities. Representation of interests is especially an issue for the small municipalities in the north-west, run by mayors of parties that are in the opposition in the current metropolitan council and have also lost all seats as vice-presidents of the métropole.

Whether Lyon will remain a single case or is a forerunner of the future reorganisation of the multilevel system will be seen in the long run. Extending the institutional arrangements to other large city-regions has been favoured by president Macron among others, but is opposed by many métropoles such as Nantes. Whether it would really increase their problem-solving capacities or rather add to hyperintegrated bodies that collapse under their own weight (Demazière et al. 2022) has to be scrutinised. The social services responsibilities of the départements are heavy in terms of budget and staff, but the exercise of these responsibilities is largely framed by national regulations and therefore has few additional possibilities to shape policy (Galimberti et al. 2014, 200). The benefit of the proposed reorganisation also highly depends on the boundaries of the départements. If they cut across the metro region and are thus hampering city-regional coordination of policies as was the case in Lyon, or are almost identical to the territory of the métropole, as in Aix-Marseille-Provence, it makes sense to merge métropole and département.

When analysing the spatial relations it becomes apparent that territorial coordination beyond the borders of the métropole is needed to address shared issues. This is already done by a range of soft territorial alliances, using different instruments, partially introduced by law (CGET 2019, 11). Municipal groupings are the main actors for territorial coordination as they negotiate shared strategies and common projects between each other. This has the advantage that the number of interlocutors is significantly lower than in case of negotiations between municipalities. In addition, the dialogue is more balanced than it would be when a small suburban municipality with 2,000 inhabitants negotiates with a city. However, important asymmetries in size, responsibilities, resources and political weight remain. The restructuring of municipal groupings around the métropoles has been seeking to amend this partially but has in the short term led to stagnation of interterritorial cooperation because of new positioning, internal reorganisation and construction of a common territorial project within the EPCI in both case study regions. A discontinuity in leadership in the largest cities (Nantes and Saint-Nazaire as well as Lyon and Saint-Étienne) has also slowed down soft cooperation, as cooperation is largely built upon personal contact and trust among the presidents of the most influential municipal groupings. 


\section{France}

The institutional form of pôle métropolitain (PM) has far from the same importance as the métropoles nor the same attention in national discourses. They remain difficult to grasp for many due to their heterogeneity in terms of fields of action (freely defined on the basis of a common interest) and territorial coverage (either continuous or discontinuous, with the possibility to overlap with other pôles métropolitains), and appear weak due to their very small budget compared to that of métropoles as well as the lack of exclusive responsibilities. The instrument PM has been picked up both in Lyon and in Nantes with the aim of formalising inter-municipal cooperation beyond the métropole, but is only one of several mechanisms for soft coordination. Those pôles métropolitains have in common that they were created with the expectation of being an action-oriented format that would facilitate joint projects. Both are devices for horizontal cooperation between EPCIs with rather small headquarters. The regular meeting of the presidents of EPCIs is their key governance mechanism. Their cooperation space is more polycentric than the métropoles themselves and a step towards cooperation among equals with the second largest cities. However, major differences exist between the pôles. Whereas the PM Nantes Saint-Nazaire covers a continuous area, both the pôle métropolitain of Lyon and the second pôle of Nantes, PM Loire-Bretagne are organised as city networks with the EPCIs of the largest centres. The fields of action defined as common interests as well as the type of projects are different as well. In Lyon, the pôle has been an alternative replacing an existing forum, whereas the PM Nantes SaintNazaire represents a deepening of an existing association and the PM LoireBretagne is an entirely new format.

\subsubsection{Functions}

All 22 French métropoles perform a wide range of functions and form the local level of self-government together with the municipalities. Most of their functions have been transferred from the member municipalities. Fulfilling functions at the inter-municipal level takes place as an alternative to the forced merger of municipalities. Today, the métropoles fulfil more functions than the cities themselves. This is in particular true for the field of spatial planning as the responsibilities both for land use planning and large urban projects have been transferred to the level of the métropole. The administration of the métropoles in some cases such as Lyon or Bordeaux even exceeds the staff of the administration of their core city (Demazière et al. 2022). This shift of functions has not happened overnight, but was a gradual process over several decades. In Lyon, this process started three decades earlier than in Nantes due to the creation of a CU in 1969. In addition, the Métropole de Lyon has performed all functions of the département since 2016. In Nantes, the process of delegating municipal tasks to the inter-municipal administration has not ended yet, but took place recently mainly in the form of individual agreements between municipalities and the métropole. Unlike Lyon, 
the administrations of the Métropole de Nantes and of the city of Nantes have become deeply entwined, forming one pooled administration with joint departments. The functions of the métropole and of the city of Nantes are carried out under the same head. Deliberation takes place in separate councils for municipal or metropolitan competencies. However, important overlaps exist there as well, because each metropolitan councillor has to be a member of one of the municipal councils of the 24 member municipalities and it is common practice that the mayor of Nantes is president of the métropole.

Social reproduction functions have been the starting point of intermunicipal cooperation, initially in the form of single-purpose associations for technical services such as water supply, waste treatment and energy supply. Those functions have been absorbed by the métropoles of Lyon and Nantes. Both are also responsible for urban planning, strategies for housing and transport, building and maintaining roads and public spaces as well as for environmental protection. Public transport is also under the responsibility of the métropole but is carried out by a transport company (Sytral in the case of Lyon, Semitan in the case of Nantes) with majority ownership of the métropole. In the case of Nantes, the métropole has almost no functions regarding social policy and health; those services are divided between the département and the municipalities. In Lyon, since 2015, substantial social functions, including financial support for low-income households, have changed the functional profile. Social assistance is organised in a decentralised way with buildings in different quarters of Lyon and other municipalities (Maison de la Métropole). In all French métropoles, substantial parts of the services of general interest for the citizens are today provided by the métropole.

With regard to production functions, the métropoles are responsible for economic development, marketing and tourism as well as large projects and events of city-regional relevance. The individual municipalities cannot provide production functions alone due to their small size. Municipalities join forces when addressing investors and visitors in order to have a better chance of attracting attention and promoting their city-region. In the case of Lyon, the CU started activities in the field of economic development at an early stage. At the same time, even the métropoles are small in a European comparison with other city-regional governments. Therefore, production functions are in part addressed in wider networks such as pôle métropolitains and joint business development agencies. Functions related to economic competitiveness are partially shared with the région. Métropoles have the right to deviate from regional strategies concerning economic development. However, a main lever of influence is the co-financing of projects, as enhancing the production functions is often related to extensive investments that cannot be financed by the local level alone.

Functions of soft institutions on the scale of the wider metropolitan region concern both social reproduction and production. Regarding the 


\section{France}

pôles métropolitains, the focus lies more on production functions in the case of Lyon, e.g. the joint representation of the city-region at real estate shows. However, the topics of joint interest defined by the members are not limited to production functions. One of the topics treated successfully is regional food cycles. In Nantes, given the responsibility for strategic planning, the focus on the Pôle métropolitain Nantes Saint-Nazaire is more on the coordination of land use in the city-region. This task touches both upon production functions (e.g. sites for industry, business and logistics) as well as reproduction (e.g. landscape protection). Projects for landscape design launched by the pôle via a design competition rather concern local recreation and can therefore be attributed to the social reproduction function. However, the pôle also uses the image of a green sustainable city-region for marketing purposes, e.g. by applying for a national label (EcoCité). Thus, the ideas of sustainability and attractiveness both for citizens and externals are linked together. The second Pôle métropolitain Loire-Bretagne, which consists of a city network, more exclusively targets competitiveness with the common interests of accessibility by high-speed rail, university cooperation and joint marketing at real estate shows.

\subsubsection{Ideas}

In both the cases of Lyon and Nantes, the idea of competitiveness of cityregions on a European scale is central to metropolitan policy. It becomes manifest on several spatial scales: one being the métropole, but also at the larger scale of the metropolitan region beyond its institutional boundaries as well as on the smaller scale of specific places within the city-region with symbolic value for the image of the metropolis (i.e. Lyon Confluence and Île de Nantes). The idea of European competitiveness prompted the mayors of the core cities to act long before the métropole was invented as an institutional form by the French government. In Lyon, an orientation towards competitiveness goes back to the 1990s and guided the actions of the successive mayors Noir, Barre and Collomb. However, the recent election of the summer of 2020 might mean a reorientation of priorities; the Green Party has won both positions of mayor of Lyon and president of the métropole, and its political programme stands for sustainability rather than having a growth orientation.

In Nantes, the aspiration to transform the city into a metropolis of European importance started a decade later and is mainly attributed to the long-term mayor and first president of the CU Jean-Marc Ayrault. He is also seen as the driving force behind inter-municipal cooperation such as the creation of the CU, support of the national legislation concerning métropoles (as prime minister during the development of the MAPTAM law), rapprochement with the mayor of the former rival city Saint-Nazaire, creation of the planning association for the SCoT including both cities and later on transformation into a pôle métropolitain. In the competition with 
other cities, Nantes has been successfully branded as a sustainable, liveable city, e.g. as the first French city that has reintroduced the tramway as a transport system. The self-understanding and image combine attractiveness, participation and sustainability (Griggs et al. 2018, 15). Ayrault's successor, Johanna Rolland, is pursuing the political legacy with regard to inter-municipal cooperation, but with an even greater focus on the quality of life for citizens in all city quarters beyond showcase projects. The ideas of proximity to the citizens, participation and welfare have gained importance.

In both city-regions, competitiveness has been an argument to justify the step-by-step integration of the municipal grouping towards a strong institution (métropole) and to claim for the integration of policy fields related to the production function. This logic corresponds to the metropolitan reform position (see Chapter 1). In Nantes, the creation of the CU was a major step towards a stronger inter-municipal institution. In Lyon, the métropole has started early activities regarding economic development and has broadened the functions of the municipal grouping. Both cities have used strategies of festivalisation, i.e. culture and big events to change the image of the city-region (not only marketing campaigns of the economic development agencies).

Due to the logic of a "critical mass" needed in comparison to other European city-regions, competitiveness has also been a reason for interpreting and describing the metropolitan region as a larger space, beyond the métropole itself. This is obvious in the case of Nantes as the city itself is not among the large cities of Europe in terms of inhabitants. Rather than size, the positioning of the city-region is justified by quality of life, good economic development and innovation. The imaginary of a bipolar metropolitan region Nantes Saint-Nazaire has been cultivated in parallel to the consolidation of the inter-municipal grouping Nantes Métropole. Still, the institution Pôle métropolitain Nantes Saint-Nazaire contributes to social reproduction rather than production functions, with the key focus on regional planning, water and landscape. Although Lyon is the third largest French city (after Paris and Marseille), the idea of a critical mass in terms of inhabitants is very present in the mind of local actors. Due to the French urban system with a huge gap between Paris and all other cities as well as narrow administrative boundaries of the core cities, the demographic size of French cities is much lower than the demographic size of the European cities with similar importance that they wish to be compared with (Megerle 2008, 26). However, by presenting benchmarking numbers of the metropolitan region for the pôle métropolitain or even the entire aire métropolitaine, this critical mass in quantitative rankings is attained.

The competitiveness strategies of both city-regions are closely related to large urban projects. Thus, metropolitan policy focussed on competitiveness and city branding is manifested within the city via high quality urban design, (star)architecture and place-making. According to Pinson (2009), urban projects such as the Île de Nantes enable the European cities of second 
rank (beyond global cities such as Paris, between 300,000 and three million inhabitants) to position themselves in a more competitive environment. "lls [les projets urbains] sont l'occasion de la definition de strategies de developpement economique, de la redecouverte et de la mise en valeur d'avantages competitifs. L'occasion aussi de doter les villes des amenites et des equipements censés y attirer les activites economiques et les classes sociales les plus valorisees dans le capitalisme globalisé" (Pinson 2009, 404). The close interrelation of the economic development strategy and urban development was already observable in Lyon at an early stage. The promotion of the tertiary sector was pursued through the construction of attractive business districts. Given its size, Lyon has several sites implementing urban projects with strategic relevance for the city-region, recently Confluence in the southern part of the peninsula, along with the old city centre and the refurbishment of the second central district Part Dieu. In Nantes, the emblematic project Île de Nantes is closely related to creating favourable conditions for creative industry. The SAMOA development agency had from the beginning a double role of developing the site and promoting the economy. The innovative approach of flexible development via a constantly evolving master plan, temporary use (Dietrich and Dahl 2016), art projects as well as favourable conditions for the creative industry has been actively promoted in international networks.

In order to avoid a distorted perspective, it has to be stressed that competitiveness is certainly not the only idea guiding the emergence of inter-municipal métropoles. Just like in the national discourse related to the territorial reforms (laws RCT and MAPTAM), efficiency has been an important justification for transferring more and more functions from the municipalities to the inter-municipal level. The idea behind this is that the administration of the métropole can provide a higher quality of service at lower costs as compared to a multitude of very small municipalities or a large number of single-purpose associations. This logic is also driving the merger of the municipal administration of the city of Nantes with the inter-municipal administration of the métropole, resulting in joint heads of administration responsible for both jointly used central services as well as the continued pooling of municipal tasks.

\subsubsection{Space}

French city-regions are institutionally fragmented. None of the three layers of territorial government région, département and municipality corresponds to the functional space of city-regions. Municipalities are for the most part very small, also in the first and second ring around large cities, and urbanisation expands way beyond the administrative borders of the core cities. The boundaries of départements were defined in the 18th century and in part cut across contemporary city-regions. Régions in turn are much bigger territories than city-regions and have recently been enlarged. This fragmentation 
is in part addressed by the strengthening of inter-municipal cooperation. However, the métropoles only cover the urban core of the metropolitan regions, especially in the case of the larger ones in terms of inhabitants (see Table 2.1). This applies for both case study regions Lyon and Nantes, but is more pronounced in Lyon. With regard to boundaries of municipal groupings, there was dynamic change in the 2010s regarding the ring of small CCs around the métropole as well as regarding municipalities without municipal groupings. By contrast, the perimeter of the métropole and the previous $\mathrm{CU}$ has been rather stable (see 2.1.4). What is more, a voluntary accession of further municipalities has become even less likely after the creation of métropoles, as the two case studies show.

The spatial definition of metropolitan regions is contested and remains blurred. The term "metropolitan region" (literally translated "région métropolitaine") is rarely used in French. Instead, authors speak of "agglomération lyonnaise/nantaise", "région urbaine", "aire urbaine/ métropolitaine", "territoire métropolitain" or even the plural "territories métropolitains" referring to the co-existence and evolution of several institutionalised perimeters for planning and soft cooperation (e.g. used by Bariol-Mathais 2015, 45). ${ }^{28}$ What is more, they use these terms in parallel. Among a sample of academic publications in the French language about the two city-regions Nantes and Lyon (sample composed of five $\mathrm{PhD}$ and two book chapters: Aguiar Mol 2015; Boino 2007; Dugua 2015; Fitria 2016; Galimberti 2015; Fritsch 2007 and Ouvrard 2016), all authors used each of the terms "agglomération", "région urbaine", "aire urbaine" and "territoire métropolitain" in their publication, with the only exception being Arie Fitria who did not speak of "territoire métropolitain". Apart from Deborah Galimberti (speaking as often of "région urbaine"), all have in common that "agglomération" is the by far most used appellation. This multifaceted use of terms shows the complexity and fuzziness of describing the spatial dimension of French metro regions. The terms have different connotations and in part refer to a different perimeter defined by spatial analysis (aire urbainel métropolitaine, see 2.2.2 and 2.3.2) or institutions (territoire(s) métropolitain(s)). The more general term "city-region" (région urbaine) relates to a specific institution and its perimeter - in the case of Lyon, the RUL (see 2.3.3) - whereas agglomeration (agglomération) relates to the urban form, but does not have a clear spatial delimitation in either of the two cases Nantes and Lyon. Dugua uses the term "agglomération" for the core of the city-region.

Those spatial definitions have in common that the centre of the metro region is clearly denominated and name giving, but that the external boundary is subject to change over time, more precisely to enlargement. In the case of the institutional territories (métropole, planning association, pôle métropolitain), the perimeter is defined by membership, but can be extended. In the case of the functional definitions, they are calculated based on statistical definitions, but change when they are reviewed due to ongoing urbanisation and longer commuter distances. The blurriness of the fringe is even more 


\section{France}

evident when superimposing the various coexistent spatial definitions. Thus, the French metropolitan regions have a clear core and maybe a number of medium-sized cities where most citizens, politicians and scientists would agree that they are part of the metropolitan region. However, for the periurban and rural municipalities between and at the fringes, no shared definition exists, whether they are part of the metro region or not. What is more, the exact spatial delimitation does not play any role because the metropolitan region is not a container space with a clear inside and outside.

Rather than as territories with explicit boundaries, the spatial dimension is conceptualised as a network of places with several layers. This is true both from the national perspective and from the local perspective. From the national perspective, métropoles are dots on the map (see Figure 2.3), linked by the high-speed rail network (TGV). From the local perspective, metropolitan regions are either a network of urban centres or a network of places with relevance for metropolitan functions. This can be the case due to their gateway functions (e.g. having an airport or central train station), symbolic functions related to the image of the city-region (e.g. iconic buildings), decision-making role (e.g. public administration or headquarters) or innovation (e.g. having universities) (for more examples see Blotevogel and Schmitt 2006, 62). When representing the metropolitan region visually, this is done by pictures of places, not by showing boundaries.

Admittedly, jurisdictions have a clearly defined territory, which is constitutive for democratic representation, accountability and financing of public services. This is also valid in the case of the métropole as the dominant (most powerful and most recognised) institution in French metropolitan regions. Their budget stems from the taxes paid by the citizens within their boundaries and their political executive is elected in the member municipalities. Nevertheless, their perimeter is not constitutive of the way the spatial dimension of the metropolitan region is conceptualised, not even for themselves. Although a voluntary enlargement was not possible in the past, local actors acknowledge the functional interdependencies stretching way beyond the institutional territory. In their development strategies, they take into account interdependencies, strategic places outside their territory as well as the additional weight of an enlarged definition in benchmarking. They also act outside the restricted territory of the métropole. In fact, the president of the métropole is the only inevitable actor in all forums concerned with the future of the metropolitan region. He or she in turn has a range of different partners and instruments at his or her disposal to pursue the interests of the core territory. Thus, policy-making beyond territorial boundaries i.e. despite institutional fragmentation, is possible but highly complex due to the multitude of actors. Furthermore, it is restricted to consensus finding and thus contingent on steering mechanisms and the possibility of creating win-win situations.

Key foundations for city-regional cooperation are shared knowledge about the spatial development of the entire area and a shared vision of the desired future development. Regional planning seeks to create common 
spatial knowledge and a shared vision, and in both case study regions is done on a larger scale than the territory of the métropole. Instruments of regional planning are adding to coherent spatial development in those regions with high development pressure. However, the success in limiting sprawl depends on the extent to which municipal groupings adhere to self-limitation in their SCoT and PLUi. The Inter-SCoT is purely voluntary; the first generation of SRADDET essentially fixes general principles of development and the state withdraws from the task of coordinating spatial development. Beyond the regulatory impact within the formal planning system, regular spatial observation and cartographic representation as well as forums to discuss the spatial dynamics of the wider metro region have an effect on the mental map of local actors. If members of municipal and metropolitan councils regularly meet within the committees of planning associations (syndicat de SCoT and Inter-SCoT dialogue) or other associations targeting the spatial development (Lyon: formerly RUL, today pôle métropolitain; Nantes: SAMOA), their own spatial positioning (Williams 1996, 97) within the metropolitan region is likely to change. The shared conception of the spatial development is even more pronounced between planners working in planning departments of the EPCIs as well as the syndicats de SCoT. The publicly financed agences d'urbanisme ${ }^{29}$ have an important supporting role in that regard (Ouvrard 2016; Bendjador 2007).

\section{Notes}

1 All Districts were transformed into communautés after 1999 and do not exist anymore. Their maximum number was 324 in 1995 (Hertzog 2018, 137).

2 With the exception of four geographically isolated municipalities located on an island.

3 Aix-Marseille-Provence did not participate because cooperation is mainly established within the métropole itself given the large size of the recently created territory.

4 In three cases, the pôle is responsible for the regional plan schéma de cohérence territoriale (SCoT), namely in Nantes Saint-Nazaire, Pays de Brest and Loire Angers. In one case, it corresponds to the cooperation area of several SCoT (Inter-SCoT), namely Le Mans - Sarthe (Bariol-Mathais 2017).

5 "je suis convaincu que la dynamique doit venir des territoires eux-mêmes. Des métropoles imposées par l'Etat, depuis Paris, c'est l'assurance de polémiques inutiles et c'est la certitude de l'échec."

6 "il y a quelque anomalie à ce que les établissements publics de coopération intercommunale (EPCI), dont certains exercent une compétence quasi générale, demeurent issus du suffrage indirect, alors que les dépenses qu'ils exposent équivalent à celles des régions."

7 This exception was designed to include Strasbourg.

8 This applies to cities that lost the status of regional capital in 2016, when the number of regions was reduced from 22 to 13: Metz (former capital of the region Lorraine) and Clermont-Ferrand (former capital of the region Auvergne).

9 Alpes Maritimes adopted by decree 2.12.2003, Bassins Miniers Nord-Lorrains 2.8.2005, Estuaire de la Seine 10.7.2006, Estuaire de la Loire 17.7.2006, Aire métropolitaine lyonnaise 9.1.2007, Bouches du Rhône 10.5.2007. 
10 In France, being mayor of a large city is an important power base for a national political career. Since 1958, only four prime ministers out of 22 have not been mayor before heading the national government (Demazière and Sykes 2021).

11 Criteria: the lower the density of population and the lower the tax income per inhabitant, the higher the basic subsidy; additional funds are given for places of higher centrality, islands, the coast and UNESCO heritage sites.

12 Nantes Métropole (2017). Retrieved from: https://www.nantesmetropole.fr/ institution-metropolitaine/institution/l-organisation-22934.kjsp, accessed 14 March 2018, last update 12 June 2017.

13 With one exception: the mayor of Rezé was president in the intermediary phase when Ayrault became prime minister in 2012 until the next election in April 2014. He retired afterwards and announced in September 2013 that he would not be a candidate in the next elections, leaving the floor to Johanna Rolland.

14 On 1 January 2021, data from INSEE (population totale).

15 Three EPCI cross-departmental borders, namely CAP Atlantique and Redon Agglomération in the north and the CC du Pays d'Ancenis in the east.

16 On 1 January 2021 (population totale), data on composition of EPCI from DGCL.

17 Definition INSEE see www.insee.fr/en/metadonnees/definition/c1501 (30 July 2019).

18 Definition INSEE see www.insee.fr/en/metadonnees/definition/c2070 (30 July 2019).

19 see https://www.insee.fr/fr/metadonnees/cog/aire-urbaine/AU2010008-nantes (30 July 2019).

20 The first round of municipal elections took place on 15 March 2020 despite the Corona pandemic, but the second round needed in all constituencies without an absolute majority was postponed to 28 June 2020.

21 Mayor of Lyon from 1957 to 1976.

22 Only one municipality west of Lyon, Sainte-Foy-lès-Lyon, is attributed differently. It is part of the southern conférence territoriale "Lônes et Coteaux du Rhône", but is attributed to the circumscription "Ouest", otherwise identical to the conférence territoriale "Val d'Yzeron".

23 Definition INSEE see www.insee.fr/en/metadonnees/definition/c2070 (30 July 2019).

24 Definition INSEE see www.insee.fr/en/metadonnees/definition/c1501 (30 July 2019).

25 First version in 2006, updated in 2013 (Dugua 2015, 394).

26 'La mise en oeuvre d'une réelle 'gouvernance' pour ce territoire métropolitain exige une action forte de l'Etat, dans ses compétences propres mais aussi en tant que partenaire de collectivités responsables mais qui, chacune enfermée dans ses seules limites, ne sauraient répondre aux exigences de l'intérêt régional ou national. Les initiatives constatées demeurent trop lentes et trop peu contraignantes pour que la coordination des politiques publiques mises en oeuvre par des acteurs dont les intérêts individuels sont parfois contradictoires soit à la hauteur des enjeux et des ambitions de la métropole."

27 In the city-region of Nantes, the inter-municipal land use plan has been called "Plan local d'urbanisme métropolitain (PLUm)" instead of "Plan local d'urbanisme intercommunal (PLUi)" to highlight the aspect of being a joint plan for the métropole with a shared vision for the development of the entire metropolitan territory.

28 Map "Les territoires métropolitains lyonnais, 2000-2006" showing the perimeter of the DTA regional plan and three different spatial definitions of the RUL

29 Agences d'urbanisme have been created since the 1960s with the mission to provide services regarding spatial analysis and development of formal planning 
instruments to municipalities and municipal groupings within a large city-regional area. Thus, they are involved in many planning procedures in metro regions (Kuhlmann et al. 2011, 162). They are co-financed by municipal groupings, cities, départements, the région, the state, planning associations and semi-public partners such as transport companies or chambers of commerce. In 2019, 49 agences existed in France and all métropoles had an agence d'urbanisme at their disposal. With regard to the two case study regions, both agences d'urbanisme UrbaLyon and AURAN were founded in 1978. Both cover much larger areas than the métropoles with their work, and their perimeter of intervention has greatly evolved since the year 2000 (FNAU 2012, 4, map périmètres statutaires des agences d'urbanisme). With regard to the wider metropolitan region, a second agence exists in both cases: the Agence d'Urbanisme de la région de Saint-Nazaire (ADDRN) and the Agence d'Urbanisme de la Région Stéphanoise (EPURES). Today, those agences cooperate and produce joint spatial analysis for the larger space of their joint territories.

\section{References}

\section{Laws}

Loi No. 99-586 Du (12 juillet 1999) relative au renforcement et à la simplification de la coopération intercommunale (Loi Chevènement).

Loi No. 2000-1208 Du (13 décembre 2000) relative à la solidarité et au renouvellement urbains (Loi SRU).

Loi No. 2010-788 du du (12 juillet 2010) loi portant engagement national pour l'environnement (Loi Grenelle II).

Loi No. 2010-1563 Du (16 décembre 2010) de réforme des collectivités territoriales (Loi RCT).

Loi No. 2014-58 Du (27 janvier 2014) de modernisation de l'action publique territoriale et d'affirmation des métropoles (Loi MAPTAM).

Loi No. 2014-366 Du (24 mars 2014) pour l'accès au logement et un urbanisme rénové (Loi ALUR).

Loi No. 2015-29 Du (16 janvier 2015) relative à la délimitation des régions, aux élections régionales et départementales et modifiant le calendrier électoral.

Loi No. 2015-292 Du (16 mars 2015) relative à l'amélioration du régime de la commune nouvelle, pour des communes fortes et vivantes.

Loi No. 2015-991 du, 7 août, 2015 portant nouvelle organisation territoriale de la République (Loi NOTR).

Loi No. 2017-257 du 28 février 2017 relative au statut de Paris et à l'aménagement métropolitain.

\section{Literature}

Acar, B. and Reix, P. (2017) Délégation de compétences et conférence territoriale d'action publique, de nouveaux outils au service de la coopération territoriale. Paris: Inspection générale de l'administration (16119-R).

Aguiar Mol, N. (2015) “La production de la métropole: quel rôle jouent les documents de planification? Les cas de la Région Métropolitaine de Belo Horizonte au Brésil et de la métropole lyonnaise en France.” PhD. Paris: Université Paris-Est (Architecture, aménagement de l'espace). HAL Id: tel-01357936. 


\section{France}

Assemblée des Communautés de France (AdCF) (2017) Fusions 2017 Bilan des SDCI et nouvelle typologie des communautés. Paris: Assemblée des Communautés de France.

AURAN (2017) Panorama des SCoT de Loire atlantique. Premier inventaire des objectifs et orientations. Nantes: AURAN.

Ayrault, J.M. (2012) Gouvernance: “je ne crois pas à la structure unique”. In: Estuaire Nantes - Saint-Nazaire. Écométropole, mode d'emploi, Masboungi, A. (ed.) Paris: Éditions du Moniteur (Collection projet urbain), p. 173.

Bariol-Mathais, B. (ed.) (2015) L'expérience métropolitaine lyonnaise. Paris: FNAU. Gallimard (Collection Alternatives).

Bariol-Mathais, B. (ed.) (2017) Les pôles métropolitains, accélérateurs de coopérations territoriales. Paris: FNAU. Gallimard (Collection Alternatives).

Ben Mabrouk, T. and Jouve, B. (2002) Building a new territory: The urban region of Lyon. In: Local Power, Territory and Institutions in European Metropolitan Regions, Jouve, B. and Lefèvre, C. (eds.) London: Routledge (The Cass series in regional and federal studies, 6), pp. 82-106.

Bendjador, Y. (2007) “Les agences d'urbanisme en France métropolitaine: des outils évolutifs?” PhD. Tours: Université François Rabelais Tours (Géographie). HAL Id: tel-00235072.

Beyer, A. (2017) Die Metropolisierung und ihre historisch-Politische Interpretation in den gegenwärtigen Gebietsreformen Frankreichs. Europa Regional, 23(4), 30-43.

Bideau, A. (2003) Un partenariat original pour un territoire métropolitian. La Région Urbaine de Lyon. disP: The Planning Review, 152(152), 108-110. DOI: 10.1080/02513625.2003.10556841.

Bigay, M., Devillard, T., Perez Inigo, L. and Sainclair, J. (2018) Les environnements territoriaux des métropoles: Quelles stratégies de coopération au service $d u$ développement local. Analyse comparée des systèmes de Lille, Nantes et Toulouse. Paris: École Urbaine de Sciences Po.

Blotevogel, H. H. and Schmitt, P. (2006) "European Metropolitan Regions" as a new discursive frame in strategic spatial planning and policies in Germany. Die Erde, 137(1-2), 55-74.

Boino, P. (2007) Lyon: Le territoire comme facteur de métropolisation. In: Les agglomérations françaises face aux défis métropolitains, Motte, A. (ed.) Paris: Economica; Anthropos (Collection Villes), pp. 42-61.

Borraz, O. and Le Galès, P. (2005) France: the intermunicipal revolution. In: Comparing Local Governance. Trends and Developments, Denters, B. and Rose, L. (eds.) London: Palgrave Macmillan, pp. 12-28. HAL Id: hal-02100010

Carpenter, J. and Verhage, R. (2014) Lyon city profile. Cities, 38, 57-68. DOI: 10.1016/j.cities.2013.12.003.

Comité pour la réforme des collectivités locales (2009) Il est temps de décider. Rapport au Président de la République. Paris: République Française.

Commissariat général à l'égalité des territoires (CGET) (2019) Les coopérations interterritoriales. Zoom sur les coopérations entre métropoles et territoires environnantes. Paris: République Française.

Conseil de Développement de Nantes Métropole (2017) Contribution de Michel Jouvet. Contribution au groupe de travail citoyenneté métropolitaine: "La métropole de la proximité". Nantes: Conseil de Développement de Nantes Métropole. 
Dèbre, C. and Garat, I. (2015) Huiler la mécanique métropolitaine: L'exemple nantais. In: Faire métropole. De nouvelles règles du jeu?, Lefeuvre, M.-P. (ed.) Paris: Éditions du Moniteur, pp. 23-46.

Demazière, C. (2018) Strategic spatial planning in a situation of fragmented Local Government: The case of France. disP - the Planning Review, 54(2), 58-76. DOI: 10.1080/02513625.2018.1487645.

Demazière, C. and Sykes, O. (2021) Acting for cities and towns? The perpetual reinvention of categories and tools of national urban policies in France. In: A Modern Guide to National Urban Policies in Europe, Zimmermann, K. and Fedeli, V. (eds.) Cheltenham, UK: Edward Elgar, pp. 34-57. DOI: $10.4337 / 9781839109058$.

Demazière, C., Feiertag, P., Paris, D., Zimmermann, K. and Dubois, J. (2022) Métropoles et organisation du développement métropolitain en Allemagne et en France. In: Villes et métropoles en Allemagne et en France: Les défis actuels pour l'aménagement du territoire et l'urbanisme, Gustedt, E., Grabski-Kieron, U., Demazière, C. and Didier, P. (eds.) Hannover: Akademie für Raumentwicklung in der Leibniz-Gemeinschaft (ARL). In print.

Desjardins, X. and Geppert, A. (2020) Governance rescaling and regional planning in France. Is big really beautiful? In: Shaping Regional Futures: Designing and Visioning in Governance Rescaling, Lingua, V. and Balz, V. (eds.) Cham: Springer International Publishing, pp. 121-132. DOI: 10.1007/978-3-030-23573-4_9.

Devisme, L. (2009) Nantes. Petite et grande fabrique urbaine (Ville en train de se faire). Marseille: Parenthèses.

Diedrich, L. and Dahl, C. (2016) Ile de Nantes 2000-2010: A method for the meantime?. Journal of Landscape Architecture, 11(2), 72-83. DOI: 10.1080/18626033.2016.1188576.

Direction générale des collectivités locales (DGCL) (2019) Les collectivités en chiffres 2019. Paris: DGCL.

Douay, N. (2013) Aix-Marseille-Provence: Accouchement d'une métropole dans la douleur. Métropolitiques. Available at: www.metropolitiques.eu/Aix-MarseilleProvence.html.

Dubois, C. (2018) Agglo nantaise et Pays de Retz. Ils veulent jouer collectif. Ouest France from 7 October 2018.

Dugua, B. (2015) "Entre mise en oeuvre et mise à l'épreuvre de la planification territoriale. Dynamique des lieux de Projets dans l'inter-Scot de l'aire métropolitaine lyonnaise.” PhD. Grenoble: Université Grenoble Alpes. HAL Id: tel-01348271.

Dugua, B. and Trotta-Brambilla, G. (2012) Les «lieux transactionnels» de la planification territoriale. Géocarrefour, 87(2). DOI: 10.4000/geocarrefour.8706.

Fédération des SCoT (2018). SCoT et PLUi. Panorama au 1er janvier 2018. Paris.

Fédération nationale des Agences d'Urbanisme (FNAU) (2012) Les agences d'urbanisme. Une ingénierie en réseau pour les politiques territoriales. Paris: FNAU.

Feiertag, P.; Harrison, J. and Fedeli, V. (2020) Constructing metropolitan imaginaries: Who does this and why? In: Metropolitan Regions, Planning and Governance, Zimmermann, K., Galland, D. and Harrison, J. (eds.) Cham: Springer International Publishing, pp. 155-172. DOI: 10.1007/978-3-030-25632-6_9.

Fitria, A. (2016) "Services urbains, urbanisme et aménagement. Analyse géopolitique des relations entre une communauté urbaine et les collectivités voisines: le cas du 


\section{France}

Grand Lyon.” PhD. Lyon: Université Lumière Lyon 2 (Géographie Aménagement Urbanisme). HAL Id:. tel-01739492.

Fitria, A. and Charmes, E. (2014) Redécoupages territoriaux: La métropole lyonnaise face à ses périphéries. La revue foncière, (1), 15-19. HAL Id: halshs-01170641.

Frébault, J. and Sozzi, C. (2010) Lyon 2010. Repères chronologiques. Revue urbanisme, 371, 43-45.

Fritsch, B. (2006) Nantes -Saint-Nazaire, métropole exemplaire ? L'Information Géographique, 70(4), 25. DOI: 10.3917/lig.704.0025.

Fritsch, B. (2007) Nantes - Saint-Nazaire face aux défis métropoitains. In: Collection Villes. Les agglomérations françaises face aux défis métropolitains, Motte, A. (ed.) Paris: Economica; Anthropos, pp. 118-134.

Galimberti, D. (2015) “Gouverner le développement économique des territoires: entre politique et société. Une comparaison des régions de Lyon et Milan (19702011).” PhD. Saint-Étienne: Université de Lyon, Université Jean Monnet.

Galimberti, D., Lobry, S., Pinson, G. and Rio, N. (2014) La métropole de Lyon. Splendeurs et fragilités d'une machine intercommunale. Hérodote, 154(3), 191209. DOI: 10.3917/her.154.0191.

Garat, I. (2013) La Place du logement et de l'habitat dans un système territorialisé. In: Nantes Axe thematique regulations territoriales et métropolitaines. Rapport Final (POPSU II), Bossé, A. et al. (eds.) Paris: PUCA, pp. 95-121.

Garat, I., Pottier, P., Guineberteau, T., Jousseaume, V. and Madoré, F. (2005) Nantes. De la belle endormie au nouvel Eden de l'ouest. Paris: Economica (Villes). HAL Id: halshs-00006856.

Gardon, S. and Meillerand, M.-C. (2007) La construction d'une réflexion métropolitaine. Espaces et structures qui précèdent la mise en place de l'agence d'urbanisme de Lyon. Territoire en Mouvement, 2(2), 4-17. DOI: 10.4000/ tem.601.

Geppert, A. (2017) Vae victis! Spatial planning in the rescaled metropolitan governance in France. Raumforschung und Raumordnung, 75(3), 225-241. DOI: 10.1007/s13147-017-0492-1.

Gravari-Barbas, M. (2009) La « ville festive » ou construire la ville contemporaine par l'événement. (The "festival city". Urban events and contemporary city building). Bulletin de l'Association de Géographes Français, 86(3), 279-290. DOI: $10.3406 /$ bagf.2009.2673.

Griggs, S., Howarth, D. and Feandeiro, A. (2018) The logics and limits of "collaborative governance" in Nantes. Myth, ideology, and the politics of new urban regimes. Journal of Urban Affairs, 9(2), 1-18. DOI: 10.1080/07352166.2018.1516508.

Hertzog, R. (2018) Inter-municipal cooperation in France: A continuous reform, new trends. In: Inter-Municipal Cooperation in Europe: Institutions and Governance, Teles, F. and Swianiewicz, P. (eds.) Cham: Springer International Publishing, pp. 133-155. DOI: 10.1007/978-3-319-62819-6.

Hollande, F. (2012) Déclaration De M. François Hollande, Président de la République, sur la politique du gouvernement en faveur des collectivités territoriales. 95ème Congrès des Maires et présidents de communautés de France. 20 October 2012, Paris: République Française. Available at: http://discours.vie-publique.fr/notices/ 127002190.html.

Hortefeux, B. (2010) Déclaration De M. Brice Hortefeux, ministre de l'intérieur, de l'outre-mer et des collectivités territoriales, sur les piliers du projet de loi de réforme des collectivités territoriales. émergence d'un pôle département région, 
renforcement du pôle commune intercommunalité, création d'un réseau de métropoles, clarification des compétences et des co-financements. Sénat. Paris: République Française. Available at: http://discours.vie-publique.fr/notices/1030 00159.html.

Idt, J., Arab, N. and Lefeuvre, M.-P. (2012) Metropolitan collective action. When the project is not linked to common interest. The case of the intermodal transit network in the Lyon metropolitan area. Urban Research and Practice, 5(2), 223238. DOI: 10.1080/17535069.2012.691619.

Jessop, B., Brenner, N. and Jones, M. (2008) Theorizing sociospatial relations. Environment and Planning. Part D, 26(3), 389-401. DOI: 10.1068/d9107.

Kuhlmann, S., Bogumil, J., Ebinger, F., Grohs, S. and Reiter, R. (eds.) (2011) Dezentralisierung des Staates in Europa. Auswirkungen auf die kommunale Aufgabenerfüllung in Deutschland, Frankreich und Großbritannien. Wiesbaden: Springer VS (Stadtforschung aktuell, 117).

Lebranchu, M. (2014) Déclaration de Mme Marylise Lebranchu, ministre de la réforme de l'Etat, de la décentralisation et de la fonction publique sur la mise en œuvre de la loi de modernisation de l'action publique territoriale et d'affirmation des métropoles. Conseil des Ministres. 29 January 2014. Paris: République Française. Available at: http://discours.vie-publique.fr/notices/146000233.html.

Mahé, S. and Bois, S. (2012) Naissance d'un grand territoire. In: Estuaire Nantes Saint-Nazaire. Écométropole, Mode d'Emploi, Masboungi, A. (ed.) Paris: Éditions du Moniteur (Collection projet urbain), pp. 18-25.

Mallon, I., Vogel, M., Authier, J.-Y. and Grafmeyer, Y. (2010) Sociologie de Lyon. Paris: la Découverte (Repères Sociologie). DOI: 10.3917/dec.authi.2010.01

Masboungi, A. (ed.) (2012) Estuaire Nantes - Saint-Nazaire. Écométropole, mode d'emploi. Paris: Éditions du Moniteur (Collection projet urbain).

Masson, P., Cartier, M., Le Saout, R., Retière, J.-N. and Suteau, M. (2013) Sociologie de Nantes. Paris: la Découverte (Repères Sociologie). DOI: 10.3917/dec.masso. 2013.01

Megerle, H. (2008) Von der "ville en crise" zur Metropolitan European Growth Area. Aktuelle Transformationsprozesse der Metropolregion Marseille - Aixen-Provence. Raumforschung und Raumordnung, 66(1), 23-35. DOI: 10.1007/ BF03184044.

Molino, M. and Allé, C. (2013) Plans locaux d'urbanisme intercommunaux. Témoignages, enquête et analyse des pratiques communautaires. Paris: AdCF.

Moscarelli, F. (2016) La Place de la biodiversité dans les documents de planification urbaine en France. Urbe, 8(3), 407-424. DOI: 10.1590/2175-3369.008.003.AO09.

Motte, A. (ed.) (2007) Les agglomérations françaises face aux défis métropolitains. Paris: Economica; Anthropos (Collection Villes).

Nantes Métropole (2017) Contribution au SRADDET adressée à la présidente $d u$ Conseil Région des Pays de la Loire. 4 December 2017. Nantes: Nantes Métropole.

Négrier, E. and Nicolas, F. (2011) France. In: Second Tier of Local Government in Europe. Provinces, Counties, Départements and Landkreise in Comparison, Heinelt, H. and Bertrana, X. (eds.) London: Routledge, pp. 73- 89. DOI: $10.4324 / 9780203180846$.

Nicolas, A. and Roy, E. (2015) La «clusterisation» du projet urbain de l'ile de Nantes. In: Faire métropole. De nouvelles règles du jeu?, Lefeuvre, M.-P. (ed.) Paris: Éditions du Moniteur. HAL Id: halshs-02193877, pp. 71-97. 


\section{France}

OREAM Rhône-Alpes (1971) Schéma d'aménagement de la métropole Lyon Saint-Étienne - Grenoble. Métropoles d'équilibre et aires métropolitaines. Paris: DATAR.

Ouvrard, P. (2016) "Le nouvel esprit de l'urbanisme, entre scènes et coulisses. Une ethnographie de la fabrique du territoire de Saint-Nazaire à Nantes.” PhD. Nantes: ENSA Nantes.

Parnet, C. (2016) Two faces of the city: Varieties of metropolitanisation in Lyon and Marseilles. In: Cities as Political Objects. Historical Evolution, Analytical Categorisations and Institutional Challenges of Metropolitanisation, Cole, A. and Payre, R. (eds.) Cheltenham, UK, Northampton, MA: Edward Elgar Publishing (Cities series), pp. 241-264. DOI: 10.1111/1468-2427.12619.

Pinson, G. (2009) Gouverner la ville par projet. Urbanisme et gouvernance des villes européennes. Paris: Presses de Sciences Po (Gouvernances).

Préfecture de Région Rhône-Alpes (2006) Directive territoriale d'aménagement de l'aire métropolitaine lyonnaise. Lyon: Préfecture de Région Rhône-Alpes.

Préfecture de la Loire Atlantique (2016) Schéma départemental de la coopération interommunale. Nantes: Préfecture de la Loire Atlantique.

Région Auvergne-Rhône-Alpes (2020) Ambition Territoires 2030. Schéma régional d'aménagement, de développement durable et d'égalité des territoires AuvergneRhône-Alpes. Rapport d'objectifs. Lyon Région Auvergne-Rhône-Alpes.

Renard, J. (2008) Nantes à la croisée des chemins. Rennes: Presses Universitaires de Rennes (Collection Espace et territoires).

Renard, J. (2015) Nantes dans le big-bang territorial. Revue d'économie régionale et urbaine (Blog Big Bang Territorial 2. La consultation scientifique nationale de la RERU). Available at: http://bigbangterritorial.unblog.fr/2015/10/26/jean-renard -nantes-dans-le-big-bang-territorial/.

Rousseau, M. (2015) 'Many Rivers to Cross'. Suburban densification and the social status quo in greater Lyon. International Journal of Urban and Regional Research, 39(3), 622-632. DOI: 10.1111/1468-2427.12197.

SEPAL (2010) Scot de l'agglomération lyonnaise 2030. Rapport de présentation. Lyon.

Terrassier, N. (2012) Notre-Dame-des-Landes, un aéroport jugé stratégique sur le plan économique. In: Estuaire Nantes - Saint-Nazaire. Écométropole, Mode d'Emploi, Masboungi, A. (ed.) Paris: Éditions du Moniteur (Collection projet urbain), pp. 86-89.

Thoenig, J.-C. (2006) Modernizing sub-national government in France: Institutional creativity and systemic stability. In: State and Local Government Reforms in France and Germany. Divergence and Convergence, Hoffmann-Martinot, V. and Wollmann, H. (eds.) Wiesbaden: Springer VS (Urban and regional research international, 7), pp. 39-58. DOI: 10.1007/978-3-531-90271-5_2.

Vanier, M. (2017) Le soldat pôle métropolitain: Iténeraire d'un rescapé. Le point de vue d'un chercheur. In: Les pôles métropolitains, accélérateurs de coopérations territoriales, Bariol-Mathais, B. (ed.) Paris: FNAU. Gallimard, pp. 18-19.

Vanier, M., Faure, A., Dugua, B., Loisel, M. and Martin-Gousset, C. (2017) La planification à la croisée des chemins: Les SCoT comme cas d'école. Pouvoirs Locaux, 109, 33-38. HAL Id: halshs-01469713. 
Verhage, R., Baker, M. and Boino, P. (2007) Strategic spatial planning at the metropolitan level. The case of Manchester and Lyon. In: Spatial Planning Systems of Britain and France. A Comparative Analysis, Booth, P., Breuillard, M., Fraser, C. and Paris, D. (eds.) London, New York: Routledge, pp. 83-98. DOI: $10.4324 / 9780203962244$.

Violeau, J.-L. (2011) Nantes, l'invention d'une l'île. Paris: Autrement (Le Mook).

Williams, R. H. (1996) European Union Spatial Policy and Planning. London: Chapman.

Wollmann, H. (2008) Reformen in Kommunalpolitik und -verwaltung. England, Schweden, Frankreich und Deutschland im Vergleich. Wiesbaden: Springer VS.

Zimmermann, K. and Feiertag, P. (2017) Governance and territorial regulation of the metropolis in Germany and France Appel à candidatures "A la lumière des expériences étrangères, que nous disent les résultats du programme de recherche Popsu 2?” POPSU2 (Plate-forme d'observation des Projets et Stratégies Urbaines). Paris: PUCA. 


\title{
3 Italy
}

\author{
K. Zimmermann
}

\subsection{Metropolitan policies and institutional reforms in Italy}

Over the last 15 to 20 years, Italy has undergone numerous institutional reforms, affecting the division of responsibilities and fiscal relationships between the different levels of government (Brunazzo 2010). In principle, the direction of the reforms can be described as a form of regionalisation since the 20 regions gained significantly in relevance from the 1970s onwards. ${ }^{1}$ Regional governments are an important actor with regard to the supervision of local government and the implementation of the national law on metropolitan cities. Especially in the late 1990s and early 2000s, the regions were strengthened politically and also in terms of functions (Behnke 2010; Brunazzo 2010; Cotta and Verzichelli 2007; Grasse 2005). The 20 regions are not constituent states of the Italian republic but rather administrative levels with some political autonomy. For a long time, they were financially dependent on the central government. Only in recent years have they incrementally developed into institutions of regional self-government. The regional parliament (Consiglio) is elected for five years; the regional committee (Giunta regionale) is made of elected members of the parliament or experts without any political affiliation. The regional president, who is directly elected by the people, leads the Giunta. Regionalisation is the notion used most often for this ongoing process of institutional change. Federalism and devolution, on the other hand, are not entirely appropriate as a description, but are in use (Köppl 2007, 179-180; Behnke 2010).

With regard to the separation of powers between regional and central government, the principle of framework legislation applies (although it is called competing legislation). A positive catalogue is used to determine the areas in which the regions were given additional legislative and executive powers. These included the administrative structure of the regions, provinces, città metropolitane and municipalities, health care, schools, welfare services, urban development, spatial planning and regional policy, transport policy (infrastructure) and tourism. However, the possibilities for derogation remained within narrow limits until the 2001 constitutional reform. On the one hand, a government commissioner exercised preventive control. On 
the other hand, regional laws were (and still are) not allowed to contradict the principles of the constitution, basic state norms, national interests and the interests of other regions (Köppl 2007, 180-181; Cotta and Verzichelli 2007). In addition, the corresponding norms were often formulated in an imprecise manner, so that in many cases there were repeated legal disputes that had to be decided by the constitutional court (this has happened also with the law on metropolitan cities). The result was and still is an overlap of competences (both executive and legislative) between the regions and the state.

The constitutional reform in 2001 changed the situation considerably. The reform was the result of a longer-lasting process that began in the 1990s. In 1997, the Bassanini Acts initiated a process of change strongly influenced by the ideas of subsidiarity, efficiency and better coordination of state levels (Köppl 2007, 182; Behnke 2010; Bolgherini and Lippi 2016). More competences and a share of the tax revenues were allocated to the regions. The constitutional law introduced by a centre-left government in 2001 followed on seamlessly and is widely considered a far-reaching reform of the state (Cotta and Verzichelli 2007). In particular, Chapter V of the Constitution, which regulates the matter of regions, provinces and municipalities, has been significantly amended and città metropolitane have been introduced as an additional level of the state. Art. 114 defines regions, provinces, città metropolitane and municipalities as levels of the Republic (Köppl 2007, 183). Hence, the Italian state, as defined in 2001, has four levels: central government, regions (20), provinces (today 89) or città metropolitane (10 plus 4 in the regions with special status) and municipalities (about 8,100). The relationship between the 14 città metropolitane and the provinces was not clearly defined at this moment but the substitution of provinces in cityregions was envisioned. Article 117 of the reformed constitution refers to the term "territorial governance" (Governo del territorio) as being part of competing legislation between the regions and the state (Fedeli 2012). This is more than a change of words and indicates a stronger recognition of European debates on territorial development in the field of spatial planning. The principle of framework legislation was restricted and formulated more clearly. A clearer distinction was made between exclusive legislation of the state and competing legislation (the latter usually takes the form of implementation and enforcement laws, so the notion competing legislation is a bit misleading, Schefold 2010).

In a process that started in the 1980s, the increasing relevance of the regions became visible in particular in the areas of urban development, spatial planning, environmental planning and nature conservation, regional development, infrastructure planning and local government (Grasse 2005). Within the framework of national normative principles, the regions can enact independent laws for urban and regional planning and they make use of these options in very different ways (Fedeli 2012). The field of industrial and economic policy falls within the exclusive legislative competence of the 
regions. Since then, many authors use formulations such as differentiated or asymmetrical regionalism in order to describe the relationship of central government and the regions (Zwilling and Alber 2019). It has to be mentioned that these reforms of the multi-level governance system in Italy did not follow a clear strategy but were influenced by frequent changes of governments in a fragmented political landscape (Bolgherini and Lippi 2016, 267). Over the last 15 years, many amendments, revocations and delays happened with the result of a permanent re-allocation of functions and the re-shaping of inter-institutional relations. Overall, the sluggishness of these reforms can be explained by the still existing centralism and the government's pronounced distrust of downstream levels.

Italy's local government system is characterised by many small municipalities, which in comparison still have a limited functional profile (Bobbio 2005; Bolgherini and Lippi 2016, 268). For a long time, they were seen merely as administrative bodies and were strictly controlled by upper-level government. In the 1990s, however, numerous far-reaching reforms took place that gave municipalities more political, administrative and financial leeway (especially the Bassanini laws in 1997). With the introduction of the direct election of the mayor in 1993, municipalities were gradually upgraded to genuine units of local self-government (Magnier 2003; Bolgherini and Lippi 2016, 270; Citroni et al. 2013).

The role of the provinces (second tier of local government) in the Italian multi-level system has also been under discussion in Italy for a longer period and national government and the regions did not always have the same opinion. The government partially upgraded provinces and their role has been debated in particular with regard to the governance of city-regions. There were, however, considerable differences in the way the regions dealt with the provinces.

Central government withdrew more and more and left the field to the regions, which in turn established a range of different working relationships with the provinces. Only some regions have used the provinces as a level of strategic spatial development policy. Baccetti (2011) sees territorial coordination of services and planning as a core task of the provinces but as has been said before some regions delegated additional functions to the provinces. Within these reform discourses, the provinces had a strong institutional self-interest but faced two parallel institutional developments. Firstly, the regions became stronger due to the regionalisation of the state, accumulating more and more functions and legislative competences. Secondly, the municipalities benefited from the introduction of the directly elected representatives and decentralisation reforms. The European financial stability rules as defined in the treaty of Maastricht resulted in a change in the fiscal relationships of the governmental layers, with greater financial autonomy of the local level (Bolgherini and Lippi 2016, 271). In connection with the collapse of the former party system in the Tangentopoli crisis and the implementation of New Public Management tools, a new generation of 
political leaders took office in the 1990s in many cities and initiated a period of considerable policy change (especially in Bologna, Turin, Rome, Naples and Palermo). The direct elections were also introduced on a provincial level and led to a temporary revival of the provinces but the effect was less strong (Baccetti 2011). In addition, the provinces received some planning functions (Balducci 2003, 62) and at the same time some new provinces were created (e.g. in Greater Milan and Prato). Some of these new provinces were rather small, hence aggravating the problem of territorial fragmentation of these city-regions.

With the Delrio Law from 2012, however, the provinces were considerably weakened as the città metropolitane (CM) replaced them in the cityregions and inter-municipal Unioni di Comuni were given more relevance in the rural parts (Bolgherini and Lippi 2016). The still existing provinces will have to give up $50 \%$ of their staff (instead of $30 \%$ for the CM, Legge 190/2014; Legge di stabilità 2016, Legge 208/2015). The council and the president are no longer directly elected and they are reduced to basic functions (Bolgherini and Lippi 2016, 275). Already in 2012, the Monti government had plans to abolish or re-organise the provinces (spending review act, D1 35/2012 or Legge 135/2012). The final abolishment of the still existing provinces and the subsequent substitution by inter-municipal unions was part a legislative proposal in 2016 that failed in a referendum. Hence, there would be no second tier of local government with constitutional status except the città metropolitane. For the following governments of Gentiloni and in particular Salvini, Di Maio and Conte (who took over the government in 2018), these plans were no longer a priority. Hence, the provinces still exist outside the city-regions, but, as we will see later, the provinces can be seen as the losers in this stream of reforms.

Spatial planning and urban development fall within the scope of national framework or competing legislation, ${ }^{2}$ with the regions being granted considerable scope for derogation here. The national planning law dates from 1942 (Law 1150/1942) and has never been completely revised, though intense debates have been going on since the mid 1990s (Fedeli 2012; Servillo and Lingua 2014). The most relevant binding plan laid down in the law is the local general plan (Piano Regolatore Generale - PRG). The PRG must be drawn up by all municipalities and defines land use for the entire urban area in the sense of zoning, and also contains statements for urban design (height, density, building typologies, etc.). ${ }^{3}$ It thus combines land use planning and development planning. The resulting considerable effort is probably one of the reasons for the implementation deficits of this plan.

Some regions have adopted independent planning laws and introduced a two-tier urban planning system consisting of a structural plan and an implementation plan (Piroddi 2009; Fedeli 2012). ${ }^{4}$ Further levels of supra-local or strategic spatial planning were not initially planned, with the exception of a state regional plan that was hardly used. In the 1990s, provinces were granted the function of provincial territorial planning. Some provinces have 


\section{Italy}

taken up the task of strategic spatial development planning in the 2000s and this has also been introduced in supplementary regional laws. However, these plans, the provincial PTCP (Piano Territoriale di Coordinamento Provinciale) in particular, are not plans in the sense of a comprehensive control of spatial development, but rather a coordination of local land use plans. As a result, they are descriptions of a state to be aimed at by defining development axes, infrastructures and environmental protection zones. The concepts or mission statements primarily bind the level at which they were drawn up.

The higher scale territorial plans of the regions usually do not address the scale of city-regions and make only limited prescriptions for settlement development. Only the environmental plans relating to nature conservation and flood risks have an effect here in the sense of a plan hierarchy through the binding designation of protected areas (Colavitti et al. 2013). Since the regions are responsible for tourism, economic development, environmental planning and some infrastructures, the effect in terms of implementation is high. On the other hand, no binding statements were made for settlement development (in the sense of growth rates, centralities, cartographic definitions, caps for settlement development). As we will see later, the recent legislation and the new generation of regional plans in Tuscany and Emilia Romagna demonstrate more ambition with regard to the reduction of land consumption and control of settlement but they do this by defining general rules for the reduction of land consumption.

\subsubsection{The role of city-regions in the Italian multi-level governance system}

A profiled national policy for city-regions or metropolitan areas is a rather recent phenomenon in Italy (Vinci 2019; Fedeli 2017). One of the few national initiatives targeting city-regions was the so-called Progetto 80 (Project 80 ) that was published in the late 1960s. Project 80 (full name Rapporto preliminare al secondo programma economico nazionale 197175) was a comprehensive socio-economic development programme for the whole nation. Progetto 80 defined spatial development priorities for the first and second half of the 1970s and defined a range of territories to be the target for funding and sectoral policies. Besides tourism areas and rural parts of the county, numerous city-regions were defined as metropolitan systems (sistemi metropolitani) that were supposed to be the basis for Italian industrial development and coordinated infrastructure planning in the 1970s (Allulli 2010, 24; Renzoni 2012, 40). In particular, scenario $\mathrm{P}$ (modello programmatico $P$ ) described a national system of separated polycentric city-regions well connected by a nation-wide system of infrastructure (Renzoni 2012, 87). Like similar national planning initiatives in many European states, the economic crisis of the early 1970s stopped Project 80. 
City-regional governance and inter-municipal planning remained a rare phenomenon in Italy, although there have been numerous attempts in cityregions such as Milan and Torino (in part forced by national legislation, Tortorella and Allulli 2014, 25). In Milan, an inter-municipal master plan was debated and elaborated in the period between the mid-1950s and 1967 (Balducci 2003; Gualini 2003). The final document, however, included several compromises and was more a general statement with uncertain prospects for implementation.

With regard to metropolitan policies and planning, the provinces as the second level of local self-government are particularly relevant in city-regions, since they at least partly represent a functional urban region. However, it is only since the 1990s that the provinces have had limited resources and competencies in urban-regional policy and planning and took initiative in city-regions such as Milan or Bologna (see below).

The more recent history begins in 1990 with a national law (legge 142/1990 Ordinamento delle autonomie locali), which aimed to promote inter-municipal cooperation in metropolitan regions (so-called aree metropolitane) (see Table 3.1). As the regions were called upon to implement the law and define perimeters, this law is considered to be a top-down initiative. Although this law was in line with the European-wide trend at the time (renaissance of city-regions), some regional and many local governments largely ignored it (Riboldazzi 2017; Vinci 2019; Vandelli and Vitali 2014, 80 ). In the following years, the state government reacted to this implementation deficit of the 1990 law. A new law from 1993 provided for the establishment of city-regions as a more voluntary task of the municipalities but left the role for the provinces unclear (Law 436/1993). The effect was

Table 3.1 Milestones in metropolitan policy

\begin{tabular}{|c|c|}
\hline Act & Content \\
\hline $142 / 1990$ & Obligation to form city-regions (aree metropolitane) \\
\hline $436 / 1993$ & $\begin{array}{l}\text { Obligation is transformed to voluntary cooperation, } \\
\text { aree metropolitane as arenas of voluntary } \\
\text { cooperation of cities, regional conferences }\end{array}$ \\
\hline 265/1999 & $\begin{array}{l}\text { Initiative for } \mathrm{CM} \text { is assigned to the municipalities } \\
\text { and provinces, but remains voluntary }\end{array}$ \\
\hline Title V Constitution 2001 & $\begin{array}{l}\mathrm{CM} \text { are described as equal constitutive units of the } \\
\text { state (next to municipalities, provinces, regions) }\end{array}$ \\
\hline $\begin{array}{l}\text { 42/2009 Law on fiscal } \\
\text { federalism }\end{array}$ & $\begin{array}{l}\text { Provides for the creation of the CM, with the } \\
\text { simultaneous abolition of the provinces }\end{array}$ \\
\hline 2012 Spending & Provides for the creation of the CM, but was \\
\hline Review Act /135/2012 & declared invalid by the Constitutional Court in \\
\hline adjusted in 2013 & $\begin{array}{l}2013 \text { because of concerns about the electoral } \\
\text { arrangements (judgement No 220/2013) }\end{array}$ \\
\hline $56 / 2014$ & $\begin{array}{l}\text { Delrio law provides for the formation of the } \mathrm{CM} \text { as } \\
\text { of } 1 \text { January } 2015\end{array}$ \\
\hline
\end{tabular}

Source: Tortorella and Allulli 2014, 33-41; Balducci 2003, 62-64 


\section{Italy}

again a cumbersome implementation. A few attempts were made to establish regional conferences as a format for inter-municipal coordination and concerted action for strategic development (Debernardi and Rosso 2008). Only in some city-regions such as Turin, Milan, Bologna and, to a limited degree, also in Florence did city-regional initiatives emerge in the 1990s (Bologna) or later (Torino, Milan in the 2000s) as more stable arrangements (Balducci 2003; Vandelli and Vitali 2014, 80). The case of Bologna is often referred to as a pioneer because in this city-region, 48 mayors concluded a kind of contract and founded a regional conference (1994) that produced significant outputs (see section 3.3; Vandelli and Vitali 2014). However, it was not until the end of the 1990s, with the adoption of Law 265/1999, that the municipalities were given a more binding responsibility for the establishment of city-regions together with the provinces (Balducci 2003).

This ambiguity reflects a more general contradiction between administrative decentralisation and regional centralism. Law 265/1999 attempted to overcome this ambiguity by giving municipalities and provinces the task of establishing the metropolitan city.

(Allulli 2010, 9)

In fact, in some city-regions inter-municipal initiatives were taken. A process of strategic planning began in Turin in 2000, which also led to the creation of a Conferenza Metropolitana. This was followed in 2008 by a kind of round table, to which the city of Turin invited 17 mayors from the surrounding municipalities (Tortorella and Allulli 2014, 64). The province of Milan initiated a city-regional dialogue (città di città - city of cities) in 2005 (Balducci et al. 2011). All these initiatives remained isolated and temporary initiatives and did not provide for any institutional changes.

\subsubsection{The Delrio Law and the Città Metropolitana}

Despite the isolated approaches of city-regional planning and governance in Bologna, Turin and Milan, the problem of more effective coordination and strategic planning remained largely unsolved in most city-regions, for various reasons. Firstly, in contrast to Germany and France, there is no comparable offer of institutional formats for inter-municipal cooperation that have been successfully tested (such as the French Intercommunalité or the Regionalverbände in Germany). Unioni di comuni (municipal unions) have existed since at least the 2000s in most city-regions, but were less relevant because of a lack of incentives. Secondly, institutional immobility is evident, which makes reforms in the area of city-regional cooperation rather unlikely (D'Albergo 2012). As already mentioned, the new constitution of 2001 recognised city-regions (città metropolitane) as a constituent level of the state alongside municipalities, provinces and regions but attempts to create city-regions were not taken immediately. In the wake of the financial 
crisis and the need to consolidate public budgets, the initiative was taken up again in 2009 in the Fiscal Federalism Act with the ultimate goal to replace provinces with città metropolitane. The provincial governments and the biggest city of the province were requested to make proposals for the territorial demarcation and functional profile of the new entity. In 2012, the introduction of the città metropolitane was made more binding. The background was the spending review act passed by the Monti government in July 2012, which included città metropolitane as a measure of budgetary consolidation (Tortorella and Allulli 2014, 33-41; Donati 2018). As part of a decree that was basically dedicated to the revision of public expenditure and approved in August 2012, Article 18 introduced the institution of metropolitan cities, due to be implemented on 1st January 2014, as an accompanying measure to the reduction of the number of the provincial tiers all over Italy (Bolgherini and Lippi 2016, 275-276). The law aimed at the reduction of the number of provinces from 110 to 50. A province should have a minimum size regarding area and population $\left(2,500 \mathrm{~km}^{2}\right.$ and 350,000 inhabitants) (Barbieri 2012; Kuhlmann and Wollmann 2014, 127).

The declared aim of the national government was to abolish the provinces in the metropolitan regions and replace them with a new kind of second tier of local government (città metropolitana) (D'Albergo 2012; Camagni 2014). The legislative initiative, named after the then Minister Delrio, was enacted as early as 2012 in the course of a series of legislative acts (DecretoLegge 6 luglio 2012, n. 95. see above), ${ }^{5}$ but was then classified in part as unconstitutional (at the request of the provinces) (Fedeli 2017; Vandelli and Vitali 2014). Despite this (temporary) victory of the provinces and the delay of the reform, the introduction of the città metropolitana was seen as inevitable and the next two years were used intensively by local actors to discuss the functional profile and competences of these new bodies.

After amendments, the law came into force on 1 January 2015 and had to be substantiated in regional laws in accordance with the joint legislation of the state and the regions, whereby there was some room for manoeuvre (Mobilio 2018; Tubertini 2015). ${ }^{6}$ The Delrio law had to be implemented by the regions in their respective laws (e.g. Lombardia Regional Law. no 19, 2015; Toscana Regional Law no 22, 2015). Following the national law, the regional governments were invited to make proposals for the structures and competences of the new city-regions as well, which led to intensive discussions between the regional governments, provinces and local governments, often with participation of local university departments (D'Albergo 2012; Fedeli 2012; Camagni 2014). Questions of financing (how to deal with debts of the provinces, takeover and redistribution of personnel, etc.) were problematic. It was not necessary to stick to the previous borders of the province. However, the hurdles for changing territorial boundaries were set very high in Law 42/2009 (with reference to Article 133 of the Constitution).

As a result, in ten city-regions the provinces ceased to exist. Some provincial functions were to be transferred to the regions, some to the new 


\section{Italy}

entity. Strategic planning was defined as an essential new function of the città metropolitana. A total of 14 metropolitan areas are affected, although for the four city-regions in the semi-autonomous regions of Sardinia and Sicily (Cagliari, Palermo, Catania, Messina-Reggio-Calabria) discussion of regional laws took much longer, not least because of the disputed option of the direct election. A special provision has been made for the Roma Capitale city-region in the draft law. In the original text, the Città Metropolitana di Roma coincided with the city of Roma Capitale and the province would continue to exist for the rest of the territory. Municipalities of the province would have the option to join the città metropolitana until the end of February 2014. However, the national parliament (Camera dei deputati) did not follow this suggestion (Tortorella and Allulli 2014, 44). As can be seen in Table 3.2, the size, number of municipalities and number of inhabitants of the $14 \mathrm{CM}$ differs considerably (with Torino being exceptionally big). This is a result of the delimitation of the provinces and institutional policies of the early 1990 s.

\subsubsection{Inter-municipal cooperation and territorial reforms - an alternative?}

Besides the creation of the città metropolitana, the Delrio Act had a second goal: facilitating amalgamations of municipalities and inter-municipal cooperation (unioni e fusioni di comuni). Intercommunal cooperation in

Table 3.2 Città Metropolitane

\begin{tabular}{|c|c|c|c|}
\hline & $\begin{array}{l}\text { Number of municipalities } \\
\text { and inter-municipal unions }\end{array}$ & $\begin{array}{l}\text { Inhabitants total and } \\
\text { core city (2014) }\end{array}$ & $\begin{array}{l}\text { Surface (in } \\
\mathrm{km}^{2} \text { ) }\end{array}$ \\
\hline Bari & 41 (1 Union) & $1,246,297 / 313,213$ & $3,862.88$ \\
\hline Bologna & 55 (8 Unions) & $990,681 / 380,635$ & $3,702.3$ \\
\hline Firenze & 42 (4 Unions) & $987,354 / 366,039$ & $3,513.69$ \\
\hline Genova & 67 (7 Unions) & $851,283 / 582,320$ & $1,838.5$ \\
\hline Milano & $\begin{array}{l}134 \text { ( } 5 \text { Unions, } \\
7 \text { Homogeneous zones) }\end{array}$ & $3,075,083 / 1,262,101$ & 1,575 \\
\hline Napoli & 92 & $3,055,339 / 959,052$ & $1,178.93$ \\
\hline $\begin{array}{l}\text { Reggio Calabria } \\
\quad \text { (est. 2016) }\end{array}$ & 97 (1 Union) & $550,323 / 180,686$ & $3,210.37$ \\
\hline Roma Capitale & 121 (6 Unions) & $4,039,813 / 2,638,848$ & $5,363.28$ \\
\hline Torino & $\begin{array}{l}315 \text { (27 Unions, } \\
11 \text { Homogeneous zones) }\end{array}$ & $2,254,720 / 872,091$ & $6,830.3$ \\
\hline Venezia & 44 (3 Unions) & $847,983 / 259,263$ & $2,472.91$ \\
\hline Cagliari (est. 2016) & 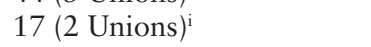 & $431,657 / 154,083$ & 1,248 \\
\hline Catania & 58 (2 Unions) & $1,115,535 / 311,402$ & $3,573.68$ \\
\hline Messina & 108 (15 Unions) & $640,675 / 229,565$ & $3,266.12$ \\
\hline Palermo & 82 (19 Unions) & $1,271,406 / 657,960$ & $5,009.28$ \\
\hline
\end{tabular}

${ }^{\mathrm{i}}$ The CM of Cagliari is the only case where the number of municipalities does not coincide with that of the former province (17 instead of 71).

Source: www.urban@it.it; Tortorella and Allulli 2014, 55 


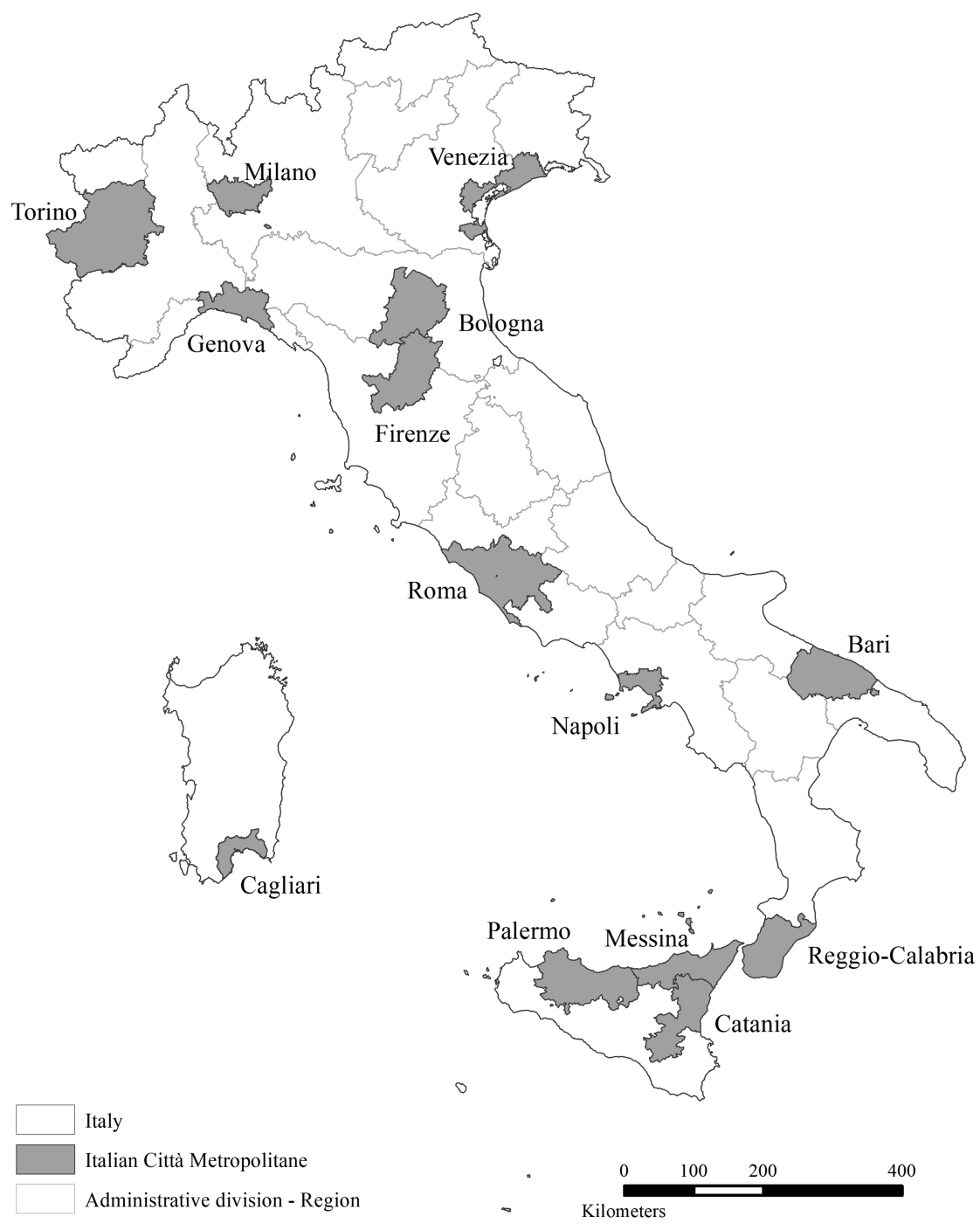

Figure 3.1 Città Metropolitane d'Italia (creative common licence) 2021 Concept: K. Zimmermann Cartography: F. Gela

city-regions in the form of special-purpose associations does not have the same status in Italy as in Germany or France. It is, however, well established in the sparsely populated mountainous areas and also in rural areas (Fedeli 2017; Kuhlmann and Wollmann 2014, 161). Since a territorial reform has never been carried out, almost 7,000 out of the more than 8,000 municipalities have less than 10,000 inhabitants (see for figures Bobbio 2005, 31). Four thousand, six hundred municipalities have less than 3,000 inhabitants 


\section{Italy}

(see also Riboldazzi 2017; Bolgherini et al. 2016). To solve the problem of size and efficiency, the instruments of consortia and unioni di comuni were introduced long before the Delrio Law. Since the early 2000s, unioni di comuni as a form of inter-municipal cooperation has been strengthened by national and regional laws and more precisely defined in terms of its status (Bolgherini and Lippi 2016, 273).7 Unioni di comuni are special-purpose associations that can be set up on a voluntary basis for the provision of public services (social services, local public transport). This is increasingly being used, also in city-regions (Riboldazzi 2017). ${ }^{8}$ Within 13 out of 14 $\mathrm{CM}$, unions have been established, but cover only parts of the territory (with CM Bologna being the most advanced case, see Table 3.2). The number differs from one (Bari, Reggio Calabria) to 27 (Torino). The core-cities are usually not part of a unione. With the Delrio Law and the subsequent regional laws, inter-municipal cooperation was to be strengthened, with the unioni di comuni being the ultimate instrument of choice.

\subsubsection{Institutional aspects and legitimacy of the Città Metropolitana}

The Italian expert discourse distinguishes two institutional models for the città metropolitana (Tubertini 2015, 10; Mobilio 2018):

a) a federal model, which ultimately remains more of a coordinating body, with relations between the municipalities being more horizontal (inter-municipal association model)

b) a territorial model that is a sum of municipalities and represents a metropolitan community (with the consequence of direct elections and a stronger role for the strategic plan).

Mobilio sees most CMs as mixed forms, with Milan, Rome and Naples forming one pole due to the possibility of direct election of the metropolitan council and Bologna, Florence and also Genova corresponding to the more federal model (Mobilio 2018, 5). In terms of institutional status, the establishment of the CM is a big change as provinces were a genuine level of selfgovernment, while the $\mathrm{CM}$ are a derivative entity with local governments being the constituent parts. This is reflected in the legitimacy structures and the functional profile.

In all CM, the mayor of the core city, which will keep its status as a municipality, is automatically the mayor of the new entity. Hence, the mayor is elected by the population of the core city but not by the citizens of the entire città metropolitana. The mayor has the authority to issue directives and is the head of the executive. He chairs the meetings of the metropolitan council, which varies in size depending on the size of the city-region: 24 members for city-regions with more than 3 million inhabitants, 18 for city-regions with 800,000 to 3 million inhabitants and 14 for city-regions with less than 
800,000 inhabitants. The Delrio Law explicitly allows for the direct election of the council and the mayor but defines conditions for that. Direct election is only possible if the core city is divided into subunits (de-amalgamation). For the city-regions with more than 3 million inhabitants (Rome, Milan and Naples) slightly different rules apply. The law stipulates that homogenous zones (zone omogenee $\mathrm{ZO}$, see below) have to be established and, in addition, the core city needs to establish decentralised subunits with some administrative autonomy. Hence, the conditions for the big three cities are less demanding. In fact, the big three voted for this option and aimed at direct election of the mayor and the metropolitan council. In addition, the statute of Genova mentions that the metropolitan mayor can be directly elected. However, in order to realise the direct election, the national electoral law has to be changed which is still pending (Vandelli 2015; Camera dei Deputati 2020a). Hence, in all CM the members of the metropolitan council are delegated municipal councillors or mayors. The direct election of the council has also been abolished for the remaining provinces.

The Metropolitan Conference forms the second chamber and consists of all mayors of the city-region. It must be consulted in several matters, but may also make proposals that must be adopted or rejected by qualified majority. In some cases, the matters are determined in a positive list (Tubertini 2015, 11). A local referendum and civic initiatives are possible but not all statutes mention this option explicitly (i.e. Florence). Some statutes underline the necessity of additional initiatives of participation and suggest a range of measures of participation (Genova, Milan, Naples) such as a metropolitan forum (Naples, Milano) and a youth forum (Naples). The statute of Bologna gives more emphasis to the role of municipalities as the appropriate sites for civic involvement. All statutes highlight the role of digital citizen involvement.

With regard to financing, the composition of the budget is similar to the ones of the provinces. As part of the decentralisation reforms and the (incomplete) introduction of fiscal federalism, every level of government in Italy has its own sources of income. In the case of the provinces and città metropolitane, this is mainly a fee for the registration of vehicles (imposta di trascrizione, IPT), a share of the liability insurance fee (for cars, imposta assicurazioni contro la responsabilità civile), a share of the income tax and an environmental fee (tributo ambientale) (Camera dei Deputati 2020b). Other sources are transfers from the region and the state. The proportion of these different sources varies from region to region but on average the independent sources constitute more than half of the budget (Garganese et al. $2018,36)$. In general, the income of the provinces and CM has decreased (ibid. 32; Agnoletti et al. 2015). It is important to note that the subnational levels of government had to make a large contribution to the fiscal consolidation of the Italian state as the debts of central government are much higher than the debts of the subnational levels (Garganese et al. 2018, 23). ${ }^{9}$ However, in the same period (2013 onwards) national government paid for 
back payments of local governments in order to relaunch local economies (Ambrosanio et al. 2016). Financial help for provinces and città metropolitane continued in 2017 (CM Milano 2020, 9-10).

Within the CM there is the possibility of introducing a kind of city district as decentralised units (homogeneous zones, zone omogenee or $\mathrm{ZO}$ ) which can also take over tasks (specifiche funzioni, con organismi di coordinamento) of the CM. So far (as of 3 September 2020) this has been done in two of the 14 metropolitan cities: Milan (7) and Turin (11). Note that the CM Turin is much bigger in terms of territory and number of municipalities than other CM (see Table 3.2). In Naples, five zone omogenee have been identified but the final decision is to still to be made; in Reggio Calabria and in Rome this is still under discussion. In Bari, Cagliari, Florence, Genova and Venice their formation is possible according to their respective statutes, but there are no plans for implementation. ${ }^{10}$ In terms of function and institutional status, the $\mathrm{ZO}$ are a mix of a territorial framework for policies of the $\mathrm{CM}$ and a unit for coordination of services in the area. The delimitation of the zones is done based on common spatial, social or cultural characteristics. Hence, one can assume that the zone can be referred to as soft intervention space for specific policies in the strategic plan. The strategic plan (piano strategico) for the CM Milan sees the zone omogenee as an instrument for the perpetuation and inspiration of further inter-municipal cooperation in addition to already existing cooperation between surrounding municipalities (CM di Milano 2016, 21-23). In the case of Milan, the zones are represented by an assembly of mayors of the municipalities being part of the zone. One of the members of the assembly (called coordinator) is chairing the assembly and represents the zone in the conference of all the $\mathrm{ZO}$. The assembly is a consultative body with regard to decisions of the metropolitan council. Decentralisation of administrative capacities is possible but institutional effects of the $\mathrm{ZO}$ have not yet been observed: neither do the $\mathrm{ZO}$ have their own administrative capacities nor are there any political effects on the Metropolitan Council or Assembly. The ZO have a different spatial delimitation than the unioni di comuni and cover the whole territory of the città metropolitana, whilst only 17 of the 134 municipalities of the CM Milano are organised in one of the five unioni di comuni (UdC).

\subsubsection{Functions and competences}

The Italian literature usually identifies two models for the re-distribution of tasks between the regions and the città metropolitane (Bolgherini et al. 2016, 348): a more conservative model that sees the CM as a continuation of the provinces plus the new task of strategic planning (i.e. Lombardia); a more residual model that foresees a substantial transfer of former provincial functions to the regions (Emilia-Romagna, Toscana). This may also include a transfer of provincial functions to municipalities or unions of municipalities (the latter being the preferred solution). 
Among the former provincial functions that often have been up-scaled or re-centred to the regions are agriculture, fishing and hunting, tourism, vocational education and labour market policy, management of hydrological risk and in some cases social services (Bolgherini et al. 2016, 348). The staff attached to these tasks has been transferred to regional governments. The loss of staff in this transition process was in most cases substantial (Vandelli and Morisi 2016, 187). As a result, the competences of the città metropolitane include three bundles of functions.

1) The basic function as defined by the Delrio Law (applies for all CM).

2) In addition, and unless otherwise provided for by regional laws, all the basic tasks of the provinces (so-called funzioni fondamentali provinciali).

3) In addition, regional governments may delegate more non-basic tasks (funzioni non fondamentali).

In particular with regard to the latter two bundles of functions, significant differences exist between the regions. Even the core tasks as defined in the national law have been taken up in the statutes in a variety of ways.

An essential element of the basic functions and new tasks is strategic planning. The strategic plan is supposed to be the central document for the coordination of spatial, social and economic development of the city-region and is to be renewed every three years. The coordinating effect and binding nature of this plan with regard to the municipalities is still not entirely clear as the prescriptions made in the law are minimal. The strategic plans already available show a high degree of diversity in terms of content and methods applied. They should serve to describe a future state of territorial, social and economic development and indicate the steps that need to be taken together with the municipalities and other actors.

Furthermore, the portfolio of basic tasks inherited from the provinces include:

- A regional territorial plan (pianificazione territoriale al livello metropolitano), which defines land use in the areas of infrastructure, environment and green spaces and can also give guidelines to the municipalities;

- The coordination of public services of regional relevance (waste management plans, transport infrastructures such as provincial streets, in some cases also regional streets as delegated tasks);

- Mobility (public transport planning and coordination, usually busses but also bicycle highways, creation and implementation of Sustainable Urban Mobility Plans - SUMP);

- Coordination and promotion of economic and social development;

- Communication networks, technology and digitalisation;

- Maintenance and planning of school buildings. 


\section{Italy}

Further tasks are environmental planning (parks and protected areas, forests, risk management) and nature conservation, tourism as well as energy but this varies from region to region. The national as well as the regional laws and the statutes underline the option of increased cooperation between the $\mathrm{CM}$ and the municipalities or unions of municipalities. The municipalities and municipal unions can make use of the $\mathrm{CM}$ and delegate tasks via agreements, but conversely, the CM can also delegate the execution of functions to the unions. The further assignment of municipal tasks has been explicitly highlighted as a possibility in many regional laws. In the case of Florence, the $\mathrm{CM}$ can also draw up the structure plan for all or some of the municipalities (piano strutturale $=$ a kind of land use plan), if municipalities so wish.

The implementation of strategic planning and territorial planning reveals a great variety of forms and procedures. Reduction of land consumption, for instance, is mentioned in some but by far not all statutes (in Torino and Milan in the first article of the statute). With regard to the execution of territorial planning, Vandelli sees some options for hierarchical interventions that are possible due to the Delrio Law: article 1, Comma 44 stipulates that the Piano Territoriale Metropolitano may "fissare vincoli e obiettivi all'attivita e all'esercizio delle funzioni dei comuni compresi nel territorio metropolitano" (Vandelli and Morisi 2016, 189). ${ }^{11}$

As mentioned above, the regions followed different paths when implementing legislation. The law on the CM Florence makes hardly any statements on the contents, procedures and objectives of the Piano Strategico (even the Delrio Law remains vague here), except that it must be in line with the objectives of the region (which are expressed, among others, in the regional territorial plan (PIT) of the Region of Tuscany). The law of the Liguria Region (Genova), on the other hand, emphasises economic development and infrastructure planning as core elements (Tubertini 2015).

With regard to territorial planning, the instrument piano territoriale metropolitano is defined in the national law but has to be used and implemented according to regional planning laws. Similar to the former provincial territorial plan (PTCP), the piano territoriale metropolitano should serve for the implementation of the CM's objectives. At the same time the plan sums up and include the intentions of the municipalities in urban development and sectoral planning. On the basis of the law, the $\mathrm{CM}$ can issue directives that the municipalities must implement within the scope of their planning competences. It is still unclear, however, whether the $\mathrm{CM}$ will be able to assert itself as a level of strategic territorial governance. CMs have yet to find their exact function and role, in particular with regard to strategic planning.

Some of the matters mentioned in the Delrio Law have been defined more precisely in bylaws. Sustainable urban mobility plans are a case in point. A decree of the national ministry for transport in 2017 made the elaboration of a sustainable urban mobility plan (following the principles of a SUMP as promoted by the European Commission) more or less obligatory for the CM (see also Legge n. 232/ 2016). The Decree of 4 August 2017 of the Ministry of Infrastructure and Transport adopted the guidelines for the 
drafting of a SUMP and established, in particular, that metropolitan cities need to elaborate a SUMP in order to access state funding for infrastructure, in particular for new interventions for rapid mass transport, such as metropolitan railway systems, metro and tram. This regulation is valid for the period 2019-2033. One third of the funding of this type available is reserved for the core city.

\subsubsection{EU structural funds (2014-2020)}

In the course of the programming of the Structural Funds period 2014-2020, city-regions were explicitly taken into account by the government. The programme PON Città metropolitane (PON Metro, stands for Programma operativo nazionale plurifondo Città metropolitane 2014-2020) allowed for the application for projects in five priority axes: digital agenda, urban mobility and sustainable public services, services for social inclusion, infrastructures for social inclusion and technical assistance. The programme provided roughly $892 \mathrm{M} €$ for the funding period 2014-2020 (Ministero Economia 2016, 6). The national programme makes a difference between the CM in terms of eligibility and identifies three groups: well off, in need, heavily in need (Agenzia per la Coesione Territoriale 2019). The national operational programme emphasised that integrated programmes should be designed, but that the core city should be preferred (Ministero Economia $2014,2)$. In addition, the metropolitan mayor was responsible for the process of selecting projects (Ministero Economia 2016, 6). The reality shows, however, that in the later course of the implementation of PON Metro by no means only the core-cities were preferred. Therefore, the effect can also be assessed as ambivalent: the CM only defines the territorial framework by using the strategic plan and the metropolitan mayor moderates the selection process together with the municipalities and the region. The $\mathrm{CM}$ as an organisation does not implement the projects itself but acts as an interlocutor for national and regional government. Hence, the CM exerts an administrative and moderating function. In Bologna, a certain degree of content and spatial control was achieved through the link with the Sustainable Urban Mobility Plan (SUMP).

To conclude this section on functions, the $\mathrm{CM}$ is responsible for some of the services of general interest inherited from the provinces (largely reproduction functions and administrative tasks). Economic development is present in the strategic plans but not very profiled. In addition, there is no specific governance form or instrument for implementation of economic development policies.

\subsubsection{Ideas: discourse on services of general interest, competitiveness, territorial and functional reforms}

The analysis of the ideational dimension of the reform reveals a sort of schizophrenic situation. On the one hand, the national law and regional laws 


\section{Italy}

underline the overall responsibility of the new entity for the coordination of social and economic development in the territory of the 14 city-regions. On the other hand, this initial idea (already present in the national legal initiatives of the 1990s) was totally overwhelmed by the management of the financial and economic crisis post-2008. The private sector did not play a great role during the reform (Assolombarda/Rete Associazioni Industriali Metropolitani 2014).

Administrative simplification with regard to the territorial entities has been a topic of the political discourse for a very long time in Italy. In the corresponding documents of the Senate and the Camera dei Deputati in 2010, the CM plays an important role with regard to the balanced allocation of functions between municipalities, municipal unions, provinces and regions. The national discourse of these years is clearly shaped by the quest for administrative simplification (semplificazione) and fiscal federalism (federalismo fiscale). At the level of the regions, subsidiarity is emphasised. In 2011, 2012 and 2013 the focus is clearly on austerity measures (Spending Review Act, Decree Salva Italia, Stability Acts). The Salva Italia decree of 5 December 2011, which came into force at the height of the financial crisis and was followed by further regulations, provided for specific measures to reduce costs. The provinces were in particular a target (abolition of the Giunta, transfer of functions). The Delrio Act was preceded by other legislative initiatives, most notably the one on fiscal federalism (law 42/2009), which reorganised the financial relations of local authorities (towards financing in line with needs) (Bolgherini and Lippi 2016; Ambrosio et al. 2016). In this law, the CM was already treated on an equal footing with municipalities and provinces and in some articles $(15,23)$ it was specifically described in terms of a transitional regulation of function and scope. The $\mathrm{CM}$ were supposed to finance themselves through fees (tributi) and probably would have no tax revenues of their own.

With regard to the relevance of ideas, there are also substantial differences between the different levels of government as the regions and the local statutes underline the relevance of social and economic development with the strategic plan being the main instrument whereas on national level there is much more emphasis on austerity and simplification of the public sector. It is striking that the statutes and regional laws deal much more clearly with issues of competitiveness and socio-economic regional development, without, of course, forgetting the aspect of territorially evenly distributed quality of services in the field of social services (as well as cultural heritage and nature conservation).

The same applies for the aspect of enhancing accountability and legitimacy. On national level discourse, this dimension was not very relevant with exception of the option for the direct election in Milan, Rome and Naples. However, as has been shown above, most of the statutes do offer much more than that. 


\subsubsection{Spatial relationships}

The scholarly debate on spaces of flows and flexible geographies in Italy is rich and full of inspirations (Balducci et al. 2017; CSS 2011). There is also a long debate on so-called large areas (aree vaste) and the optimal size of functional territories in public administration. However, in terms of spatial relationships, the reform was a simple substitution of the provinces with the CM. Other municipalities may join voluntarily, but municipalities may also withdraw (depending on the regional law, with mandatory reference to Article 133 of the Constitution, which already provided similar provisions for the provinces). Accordingly, a municipality would have to express its interest, the state would have to enact a law and consult the regional government on it. So far, this has not been the case in any CM and is unlikely to happen in the futures as this procedure is quite complex and time-consuming.

At the time of the reform process, with few exceptions, no spatial analyses (i.e. with reference to the perimeters of functional urban regions) were included in the preparation of the legislation at all. The eventual territorial management of rescaled relationships and the in-between spaces of metropolitan areas such as Torino - Milan, Milan - Bologna or Firenze Bologna, the so-called metropolitan question, was not discussed. A white paper by the Consiglio Italiano per le Scienze Sociali (CSS and Dematteis 2011, 387), which dealt with the administrative paradox in Italy, meaning that no differentiation is made between small and large cities regarding their competences, had no influence either. At least the Spending Review Act (2009) suggested a reorganisation of the provinces in November 2012. The province of Milan, for example, was supposed to be merged with the Province of Monza and Brianza and the province of Florence would have been merged with Pistoia and Prato. These regulations were later declared unconstitutional. ${ }^{12}$

In the case of Torino this neglect of functional spatial relationships means that a lot of small municipalities in the mountainous areas in the west of Torino are part of the CM but have only limited functional relationships with the core city (Voghera 2017). Other CMs, such as Genova are very small in terms of jurisdictional territory. The Italian planning system does not foresee any format or instrument for territorial cooperation at a larger scale (i.e. a portfolio of different governance forms for a variety of territorial scales that differ in institutional strength). The neglect of concepts such as soft spaces or relational space has been criticised by scholars at greater length (Fedeli 2017; Paba et al. 2017; Paba and Perrone 2018).

Besides the question of the role and perimeter of the provinces, in public administration in Italy there is an ongoing discussion about the optimal size for territorial forms of state action. The large areas (aree vaste) are thought for the provision of public services (Bolgherini et al 2016; Donati 2018). These so-called ATO (Autorità di ambiti territoriali ottimali $=$ optimal 


\section{Italy}

territories for public policies) are a form of functional territories that have been introduced from 1994 onwards for policies such as health services, waste management and wastewater management (Bolgherini et al. 2016; Kuhlmann and Wollmann 2014, 161).

A minimum of internal spatial flexibility and scaling is possible through the use of the zone omogeene (see Table 3.2). ZOs exist or are planned in several CM, but are used differently. In CM Turin, the largest CM in terms of surface area und number of municipalities, they have so far served exclusively to represent their member municipalities in the Conferenza Metropolitana. In addition, some municipalities cooperate in unioni di comuni, mostly in the fields of human resources development, with combined use of IT infrastructure and office space, economic development, environmental services and local police, but also to some extent in the field of spatial planning. In contrast to $\mathrm{ZO}$, unioni di comuni do not cover the entire $\mathrm{CM}$ and have a different perimeter. In this respect, the various regions seem to have different degrees of close ties: while in Bologna almost all the municipalities of the CM (except Bologna) are organised in unioni di comuni (no $\mathrm{ZO}$ exist here), in Venice this is the case only for 12 of the 44 municipalities, although there are no ZO (yet) here either. In Turin, there are 11 ZOs covering all municipalities and 27 unioni di comuni covering most of the 315 municipalities. However, 17 of the unioni di comuni are successors of the unioni montane, which were dissolved as an association in 2014 (cf. the respective websites of the $\mathrm{CM}$ at http://osservatorio.urbanit.it/).

\subsubsection{Interpretation and conclusion}

The start of the CM was anything but smooth. From the perspective of the municipalities, the new CMs were initially seen as successors to the provinces and not accepted as a new level of city-regional policy-making. The $\mathrm{CM}$ were also not strongly supported discursively as expected by the regions and the central government. Thus, they inherited many weaknesses and problems of the provinces (budget problems, unpopularity with the municipalities and regions etc.) (Fedeli 2017). The main problem of the provinces was the lack of acceptance vis-à-vis the other levels of government. The provinces were first grade entities working within their own framework of goals that were not in all cases well-coordinated with other levels of government. The CM, in contrast, follows a more utilitarian model of legitimacy as they have to prove that they are useful and effective. However, some of the functions are not well defined in national law.

Seen against the background of the ad hoc legislation in the period 20092012 with many laws and decrees on fiscal consolidation with frequent changes of government, Bolgherini and Lippi (2016) state that the Delrio Law was at least successful in giving the reform a more comprehensive outlook, bringing the different ends of the various reform ideas together (austerity, simplification, better coordination of social, economic and territorial 
development in city-regions). The Delrio Law did not create a strong institution but highlighted better horizontal and vertical coordination of levels (regions, CM, municipalities, municipal unions), decentralisation, and the integrated perspective on territorial forms of government. Most of the previous legal initiatives were purely focussed on austerity measures and took a very fiscal-technical view. It was only the second passing of the law under Matteo Renzi in 2014 that allowed for a broader range of arguments and overcame the purely technocratic character of the reform at least in its initial stages (planning, modernisation of the state through further territorial and functional reforms also beyond the $\mathrm{CM}$, combating the economic crisis, etc.).

The dominance of the core city is also criticised. Automatically designating the mayor of the core city as mayor of the CM has failed to create a balanced system of representation between sometimes very small municipalities and the core city (Riboldazzi 2017, 93). The homogeneous zones form an intermediary level in some of the CM but are not suitable for achieving a balance. They are not used to pool the interests of municipalities in their perimeter. It is not clear whether these zones will actually be given tasks. The CM can also hardly be described as a unit of local self-government. First of all, the metropolitan mayor is always the Lord Mayor of the core city, which he will primarily take care of, since he (or she) was directly elected by its inhabitants. Furthermore, the council is only indirectly elected. However, the mayor can delegate tasks to the second mayor or other councillors (as happened in Milan).

\subsection{The Città Metropolitana di Bologna: frontrunner for territorial cooperation in Italy?}

Our intention for the metropolitan city is to be a body with a light structure, but with a strong ability to guide and coordinate the municipalities, a body that performs mainly planning and programming functions, with a vision in which the metropolitan city is first and foremost a federation of municipalities. ${ }^{13}$

Virginio Merola, Sindaco metropolitano di Bologna

(Preface of the PSM 2.0)

The political debate about a potential metropolitan government for the cityregion of Bologna is not new. A process of collaboration between Bologna and 15 surrounding municipalities started already in the late 1960s with the inter-municipal plan Piano Intercomunale del Comprensorio Bolognese. ${ }^{14}$ In 1967, an inter-municipal land-use plan was elaborated, trying to define a general outline for the territorial development of the city-region. The plan was indicative for the local plans of Bologna and 16 surrounding municipalities (Gabellini et al. 2017, 178-179). This initiative found a successor in the inter-municipal urban plan in 1984 (Piano Urbanistico Intercomunale) 
(Fabbricatti 2016, 94). Still being an informal instrument for the coordination of local urban development (mobility, settlements), the perimeter was bigger as a reaction to suburbanisation. However, the impact was weak due to the voluntary character of the plan (Gabellini et al. 2017, 183). While the city of Bologna considered a city-regional dimension in its local plans (in particular with regard to the extension of infrastructure), it was the province of Bologna that took over a city-regional planning function from the 1990s onwards. At the same time, the regional government of Emilia Romagna renewed its territorial policies, taking into account the polycentric urban structure of the whole region Emilia Romagna but this initiative was only partly coherent with the initiatives taken by the province of Bologna (ibid. 185).

An important step was taken in 1994 when the agreement on the Metropolitan City of Bologna was signed by 37 mayors and the province of Bologna (Accordo per la Città Metropolitana di Bologna; Tubertini 2018, 2; Gabellini et al. 2017; Jouve and Lefèvre 2002). This agreement established the Metropolitan Conference, where mayors and managers of the involved municipalities collaborated on a voluntary basis for the creation of common development plans (CM Bologna 2016, 5; see also Jouve and Lefèvre 2002). The idea of a city-regional railway system was on the agenda since then. The idea of an enforced inter-municipal cooperation has also been supported by the regional government of Emilia Romagna since the late 1990s and early 2000s through the approval of several laws promoting inter-municipal cooperation (not only in the Bologna city-region). The existing inter-municipal associations in the Bologna city-region (unioni di comuni) are partly the result of this period. With the approval of Regional Law Nr. 33 in 1995 on the territorial boundary of the metropolitan area of Bologna and reallocation of functions, the regional government delimited the functional area of the city-region of Bologna by referring to the jurisdictional boundary of the province of Bologna (Fabbricatti 2016, 94).

The regional government tried to improve the cooperation between the city of Bologna and surrounding municipalities and supported the concept of a polycentric development in the regional territory. Several initiatives can be mentioned: the signature of the inter-institutional agreement (Accordo Quadro per la Città Metropolitana di Bologna) by the Region, Province and City of Bologna in 2009 or the creation of the first voluntary strategic metropolitan plan between 2011 and 2013 (Fabbricatti 2016, 92). At the same time, the regional government continued to support inter-municipal cooperation on a smaller scale. Since 2012, a regional law has existed that enforces inter-municipal collaboration even more strongly for smaller municipalities (RER 2012). ${ }^{15}$

This demonstrates that, in the case of Bologna, during the several politi$\mathrm{cal}$ (and economic) moments of crisis that have happened in Italy in the last decades (Regalia and Valbruzzi 2016, 55-56), the idea of creating a cityregion did not lose its relevance and appeal. The city-region of Bologna is considered to be one of the rare cases in Italy where the idea of metropolitan 
governance has met continuous and considerable support by different levels of government (local, provincial, regional). Hence, the implementation of the Delrio Law met some pre-existing structures and attitudes that were in favour of inter-municipal cooperation.

In the course of the implementation of the Delrio Law, the Province of Bologna has been replaced on 1 January 2015 by the new entity, Città Metropolitana di Bologna, which took over the former provincial boundary and also quite a few of its tasks (Tubertini 2015). However, relevant tasks in environmental policies and planning have been shifted to the region (Tubertini 2015, 2018; RER 2015a), together with a significant number of employees (almost 500 out of 900, CM Bologna 2017, 5). The Metropolitan City of Bologna comprises 55 municipalities differing in population and size. The size of the area is $3.703 \mathrm{~km}^{2}$, the number of inhabitants is 1,006 million (2016). The biggest city is Bologna with 389.261 inhabitants and a surface area of $140 \mathrm{~km}^{2}$.

\subsubsection{The institution Città Metropolitana di Bologna}

The current statute of the Metropolitan City of Bologna has been approved by the Metropolitan Conference on 23 December 2014 (CM Bologna 2016c). The document defines the main principles, roles and functions of the new institution. According to the Delrio Law and the statute, the Metropolitan City has different ruling bodies: the metropolitan mayor, the metropolitan conference and the metropolitan council. In addition, the statute of the Metropolitan City includes the presidency office which is a unique element.

- As defined by national law, the mayor of the city of Bologna is simultaneously the mayor of the Metropolitan City of Bologna (Virginio Merola from the Democratic Party). He has been in office since June 2011, re-elected in 2016. He is the political head of the metropolitan city by convening and presiding over the metropolitan council and the metropolitan conference. Moreover, his tasks are the supervision and execution of actions, the implementation of guidelines and other functions assigned to the metropolitan city by laws or regulations in force (CM Bologna 2016c, art. 33).

- The metropolitan council consists of 18 councillors: they are elected based on party lists by councillors of all 55 municipalities. As a result of the 2016 elections, the Democratic Party has the majority of seats with 13, followed by the Uniti per l'Alternativa and Rete Civica which have two seats each, and the Five Stars Movement with a single seat. Five councillors are from the city of Bologna, two from Casalecchio di Reno. The other councillors are from one municipality, and in total the councillors represent 13 municipalities out of 55. The distribution of seats is to the benefit of the bigger municipalities whereas smaller municipalities are not well represented (but see the representation of the 
unione di comuni in the institutional fabric of the $\mathrm{CM}$ in the following section). The situation provoked a discussion about a lack of territorial representation and the advantages of a direct election of the Consiglo (council), which is also prevalent in other city-regions (Tubertini 2015). Seven of the councilors have a thematic responsibility (consiglieri delegati) but the CM has no collegial organ or managing board with full time assignments (giunta or Mayor's cabinet).

- The Metropolitan Conference is a collegial body that encompasses the metropolitan mayor and all mayors of the 54 municipalities within the Metropolitan City. It has advisory and consultative powers set by the Delrio Law and the statute of the Metropolitan City of Bologna (CM Bologna 2016c, art. 31). The metropolitan mayor may consult the Metropolitan Conference on every matter. The main responsibility is, however, an eventual change of the statute. The metropolitan conference has only weak supervisory and control functions. Veto options are limited.

- With regard to the territorial governance structure, the CM Bologna differs from the other Italian metropolitan cities. Besides the council and the metropolitan conference, all involved parties agreed to establish a consultative body (Art. 32 of the statute): the Ufficio di Presidenza della Conferenza metropolitana. The Presidency Office of the Metropolitan Council is a body specifically set out by the statute of the Metropolitan City of Bologna. The body is part of the metropolitan conference and brings together the presidents of the seven municipal unions (unioni di comuni). The tasks are to support the work of the Metropolitan Conference. More importantly, the presidency office serves as a link between the seven unions of municipalities and the policies of the Metropolitan City.

Unioni di comuni are associations of municipalities and are responsible for services they accomplish on behalf of their members (RER 2012). The range of responsibilities and organisational forms of the seven unioni di comuni differs (CM Bologna 2018a). Some have joint offices and their own staff, others use offices and staff in different municipalities, mainly for the purpose of cost savings. Unioni di comuni have existed in Bologna for 20 years (since the late 1990s) and are an important pillar of metropolitan governance, both in terms of bundling and representation of local interest as well as implementation of public services (CM Bologna 2016b). Fifty-one municipalities form seven unions (Unione di Comuni dell'Appennino Bolognese, Unione di Comuni Savena-Idice, Unione Valli del Reno, Lavino e Samoggia, Unione Terre di Pianura, Unione Reno Galliera, Unione di Comuni Terre d'acqua and Nuovo Circondario Imolese, see Table 3.3). The strongest one in terms of functions and organisational capacities is Reno Galliera with eight member municipalities and the responsibility for the following functions: civil protection, social services, ICT services, local police, territorial governance 
Table 3.3 Unioni di Comuni in the CM Bologna

\begin{tabular}{lccc}
\hline Name & Municipalities & Size $\mathrm{km}^{2}$ & Inhabitants \\
\hline Unione Terre d'Aqua & 6 & 375 & 82.904 \\
Unione Reno Galliera & 8 & 296 & 73.996 \\
Unione dei Comuni Terre Pianura & 6 & 333 & 70.712 \\
Nuovo Circondario Imolese & 10 & 787 & 133.205 \\
Unione Savena - Idice & 5 & 378 & 44.987 \\
Unione dei Comuni Valle del Reno, & 5 & 404 & 11.608 \\
$\quad$ Lavino e Samoggia & & & \\
Unione dei Comuni Appenino Bolognese & 11 & 742 & 49.246 \\
\hline
\end{tabular}

Source: CM Bologna 2017, 14

and environmental services (one stop shops) (CM Bologna 2018a). Only six municipalities are non-associated municipalities. Besides the regional capital of Emilia Romagna, the City of Bologna, these are Budrio, Castenaso, Alto Reno Terme, San Lazzaro di Savena and Molinella (CM Bologna 2018, updated July 2021). The municipalities Molinella and Alto Reno Terme are situated in the western and eastern periphery of the CM; San Lazzaro borders directly with Bologna. Alto Reno Terme was part of an Unione until 2017 but this association collapsed. ${ }^{16}$ Two of the neighbouring municipalities of Alto Reno Terme were also not part of a union but joined the Unione di Comuni Appenino Bolognese in 2018. The regional government and the $\mathrm{CM}$ promote the amalgamation of municipalities and strengthening of the unions. Almagamations happened in 2013/14 and in 2016 when five municipalities merged and created the new municipality of Valsamoggia in the north-west of Bologna and two municipalities merged to create the municipality Alto Reno Terme (CM Bologna 2017, 14).

The creation of unioni di comuni is mandatory for smaller municipalities and voluntary for bigger ones but the regional government offers financial incentives, defines optimal cooperation areas and gives procedural help (RER 2018). Regional law 21 of 2012 defined the conditions and minimum size for unioni and follows national guidance on this matter. In addition, regional laws and guidance define a minimum portfolio of functions (see section 3.1). Municipalities can make a choice but have to organise joint services for at least four out of the following public tasks: staff management, social services, one-stop-shops for enterprises, spatial planning, local police and civic protection (RER 2018). The law also defines minimum thresholds for the population size.

Each municipal union has a president, usually one of the mayors of the member municipalities, a giunta (a collegial body made of the other mayors) and a council made of local councilors. The idea of creating stronger forms of inter-municipal collaboration in the territory of the former province of Bologna for a specific portfolio of functions was already part of Regional Law. Nr. 6 of 2004, which defined rules for the partial unification of local 


\section{Italy}

administrations within the provincial boundary (RER 2004, art. 22, 23). The law defined the forms of unions of municipalities and the special form of inter-municipal cooperation of the Nuovo Circondario Imolese. ${ }^{17}$

Within the governance arrangement of the Metropolitan City, the municipal unions are a sort of consultative organ but they are also relevant as representational bodies (Tubertini 2015). In fact, several policy documents as well as the statute state that "municipal Unions represent the priority reference for the territorial articulation of the Metropolitan City's policies and actions" (CM Bologna 2018a, 9, own translation).

In a way, they perform the function of the zone homogeene mentioned in the Delrio Law (implemented in CM Milan, see section 3.1)

The unioni di comuni have several advantages with regard to the governance of the city-region. They bundle interests of the member municipalities and are also involved in the distribution of national and ERDF funds (Bando Periferie, CM Bologna 2016a, 3). The mayor of the CM Bologna and the presidents of the seven unioni (themselves being mayors) have the opportunity to speak on equal terms, which is not possible with many of the mayors of smaller municipalities. However, the mission of the unions is not totally clear and they also differ in terms of organisational strength and joint execution of functions. In terms of politics, there is also a certain risk as some of the unions are of the opinion that the level of inter-municipal cooperation and planning realised is sufficient, so that there is no need for a CM. This is valid for the Nuovo Circondario Imolese where the Five Star Movement won the majority in 2019 but this general concern was not shared by all interviewees.

Also in spatial planning, inter-municipal land use plans gained in relevance. The regional government gives financial support to those municipalities who decide to elaborate an inter-municipal structure plan. The municipal union Reno Galliera established a joint office for urban planning which means that the local plans are elaborated by one body and that some inter-muncipal coordination for territorial development exists. The Unione di Comuni Valle del Reno, Lavino e Samoggia opted for an inter-municipal structure plan in 2017 (under preparation in 2020). Inter-municipal land use planning raises the question of the appropriate level of supra-local planning, but this issue was interpreted differently by interviewees. However, when larger groups of municipalities decide to cooperate on this matter, one is inclined to ask what a city-regional general plan will add. At least this demonstrates how, as well as the fact that a multi-level system of governance and planning is emerging.

\subsubsection{Forms of cooperation between municipalities, the municipal unions and $C M$}

Shortly after the inauguration of the CM, the municipalities and the municipal unions signed a sort of framework regulation for different types of 
cooperation between the $\mathrm{CM}$, the municipalities and unions of municipalities (CM Bologna 2016c). The document refers to regional legislation that defines three forms of inter-municipal cooperation: joint metropolitan offices (Ufficio in comune metropolitano), delegation (the CM is doing a service for a municipality and gets paid) and other forms of informal cooperation.

Joint offices have been used already in the past for the elaboration of the provincial territorial plan (PTCP). Since the CM started, joint offices have been installed for the Urban Sustainable Mobility Plan (PUMS, see below), which is one of the core projects of the CM, and for housing policies. Other jointly executed tasks are statistics and data management, tourism, information technology and economic development. More joint offices are planned, for example for the implementation of the bicycle plan (Ufficio Unico Metropolitano Bici) (CM Bologna 2019b, 101). Joint offices establish continued cooperation between the technical staff of the municipalities

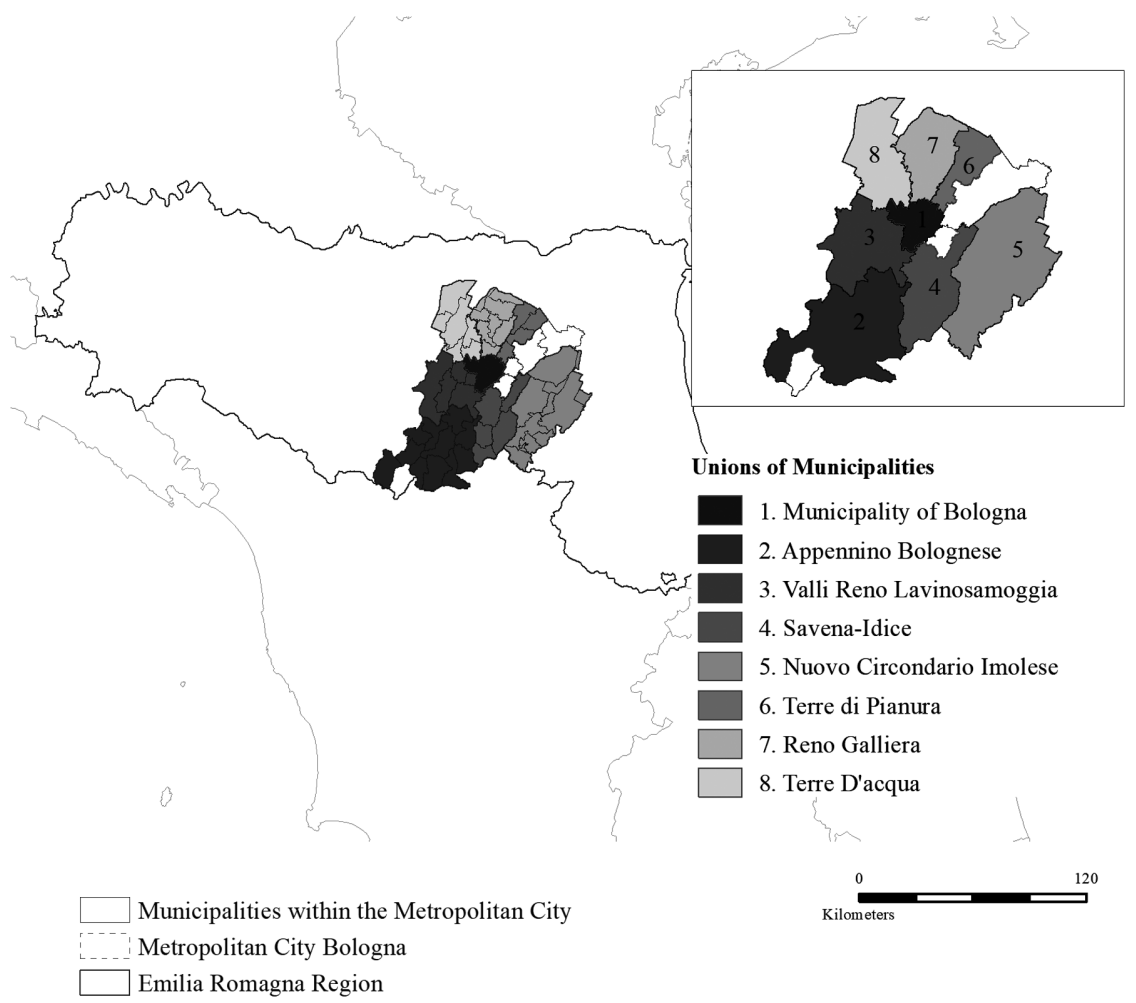

Figure 3.2 Municipalities and municipal unions in the CM Bologna, areas in white are non-associated municipalities 2021 Concept: K. Zimmermann Cartography: F. Gela 


\section{Italy}

and the CM. CM, municipal unions and municipalities signed a series of agreements that establish joint offices or other forms of cooperaton (joint office for legal issues / ufficio unico avvocatura civica), housing, EU Programmes, public procurement, social services). However, the joint office for tourism is restricted to Bologna and the CM and, in fact, the relationships between the $\mathrm{CM}$ and Bologna seem to be closer compared to the other municipalities, which is in part the result of the fact that the metropolitan mayor leads both organisations. Also the secretary general (secretario generale) is responsible for both the city administration and the CM. Usually a city, CM or province would have a secretary general of its own but for reasons of cost efficiency the position is shared in Bologna (as well as in Florence). Another form of inter-institutional collaboration between the CM and the municipal unions are round tables of higher administrative staff members for different policies (Tavolo di coordinamento dei vertici amministrativi, CM Bologna 2018b, 18). Municipalities may also use the services of the $\mathrm{CM}$ on a case-by-case basis. The municipality of Molinella did this for a change in the local land use plan (Giglioni 2016, 9). There is, however, a clear indication that the CM will give priority to cooperation with the municipal unions, instead of the municipalities (Tubertini 2018, 3).

Another inter-institutional body is the committee for urban planning (Comitato Urbanistico Metropolitano). This is an obligatory institution (according to regional planning law, RER 2017). ${ }^{18}$ It is composed of representatives of all the entities involved in planning matters of the city-region with the ultimate goal of bundling and simplification of planning procedures and permissions (municipalities, unioni di comuni, CM, regional government). The committee also examines the conformity of local and city-regional plans with the legal requirements and goals of the regional planning law (reduction of land consumption in particular).

\subsubsection{Inter-institutional relationships}

The introduction of the $\mathrm{CM}$ also reorganised the institutional relationship between the second tier of local government and the regional government. The former province was an independent governmental layer being able to define its own priorities. At the same time, this autonomy resulted in a certain degree of isolation with regard to institutional relationships with the region. Currently, a so-called "inter-institutional conference" (Conferenza interistituzionale) exists that gathers the president of the Region Emilia Romagna, the metropolitan mayor of the CM Bologna, the presidents of the other still existing provinces of Emilia Romagna and the president of the regional branch of ANCI (Italian association of municipalities and cities) (Tubertini 2018, 4; RER 2015a, art. 10). The terms of trade are part a of so-called "Patto interistituzionale tra Regione, Città metropolitana di Bologna, Province, ANCI e UPI" (inter-institutional 
agreement) that seeks to establish a multi-level governance arrangement. The inter-institutional conference agrees upon a document (documento unitario di strategia istituzionale e di programmazione degli obiettivi del governo territoriale) which defines the basic goals for territorial development. These are binding for other territorial plans (including the PSM and PTM of Bologna). With reference to this inter-institutional conference, the regional government and the CM also signed a general framework agreement in 2015 (Intesa Generale Quadro, RER 2015b). This document clearly defines the instruments and fields of activities of the $\mathrm{CM}$ and shows ways for collaboration and co-decision-making with the regional government. A predecessor of this body was part of an agreement between the region, the province and the city of Bologna which had the foreseen task to define functions to be dedicated to the potential Città Metropolitana (l'accordo del 2006 tra Regione, Provincia e Comune) (Tubertini 2018, 2).

In addition, the CM is now also a beneficiary of national government programmes partly funded by the EU (Presidenza del Consiglio dei Ministri $2017 \mathrm{~b})$. One of these programmes is the programme for urban regeneration and security in the periphery of city-regions with a total sum of funding available for the CM Bologna of $40 \mathrm{M} €$ (Bando Periferie, CM Bologna 2016a). The CM coordinated the selection of the projects on the basis of the strategic plan (PSM) and in accordance with the municipal unions. The CM is not the beneficiary itself, implementation is done by the municipalities. The former province was less relevant in this regard.

\subsubsection{Spatial relations}

The perimeter of the CM is the old province and this applies to all newly created CM in Italy. While there are ongoing discussions about the mismatch between functional urban regions and the now-existing jurisdiction in the metropolitan cities of Torino, Florence and Milan, the spatial delimitation of the CM Bologna reveals a higher congruence between the jurisdiction and the functional urban region. None of the interviewees saw any need to discuss this. For the process of creating the CM Bologna this consensus on the spatial delimitation was a big advantage.

The aspiration for better territorial coherence and cost-efficient structures is significant in Emilia Romagna. Regional laws prescribe collaboration for municipalities that are part of a pre-defined optimal collaboration area (ATO - Ambito territoriale ottimale, see Figure 3.3). These areas are primarily designed for social services and health care but in Emilia Romagna the ATO should also serve as a territorial framework for other inter-municipal services in order to increase territorial coherence and reduce fragmentation as well as functional overlaps (see the section on municipal unions above). In fact, five out of seven municipal unions in the territory of the CM Bologna are also a social service area or ATO ${ }^{19}$ Regional law no. 


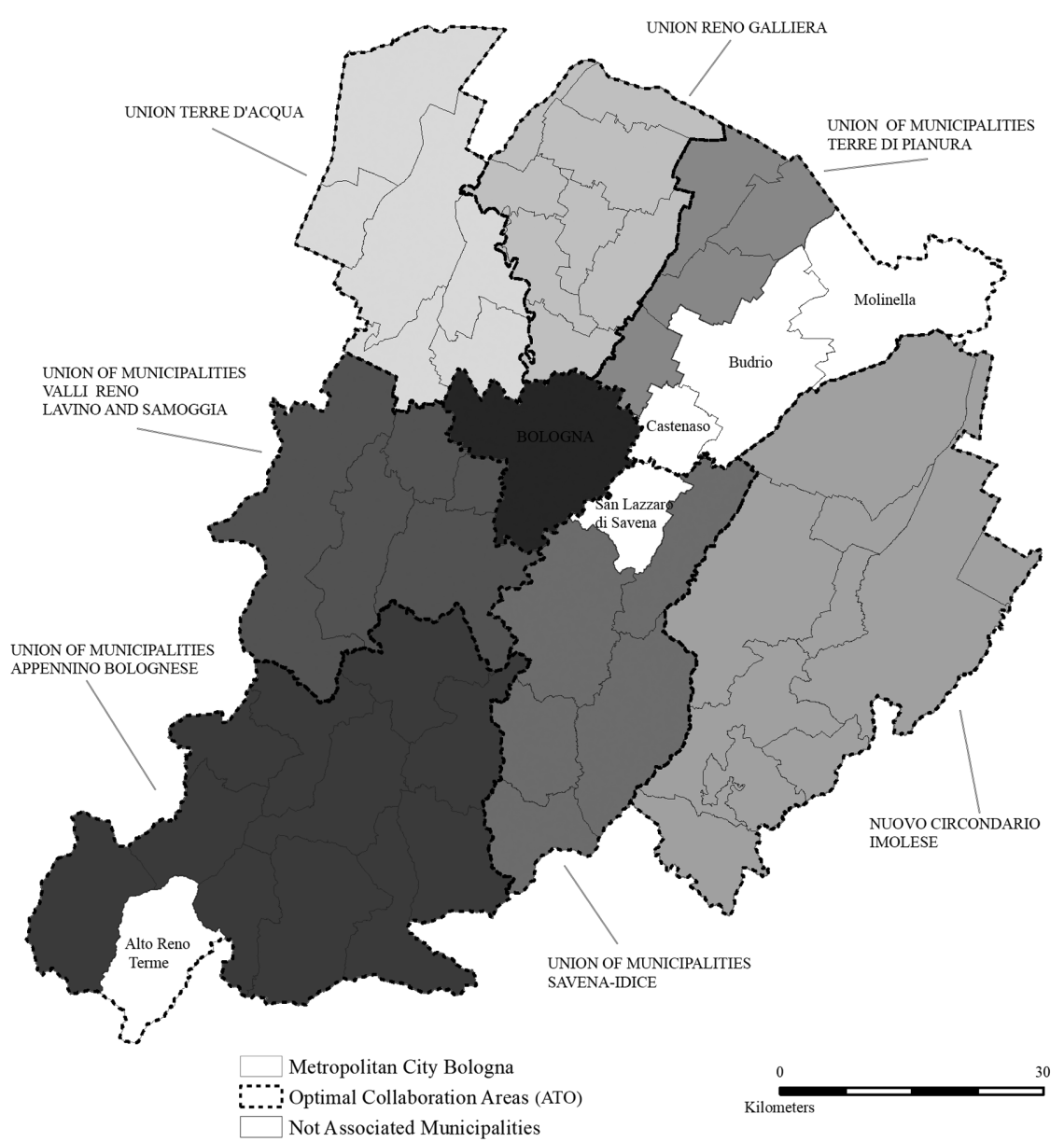

Figure 3.3 ATOs and municipal unions 2021 Concept: CM Bologna Cartography: F. Gela

21/2012 prescribes functional areas and defines that within these areas only one municipal union should be present.

The CM Bologna is not as polycentric as many other metropolitan cities in Italy (Presidenza del Consiglio dei Ministri 2017a). The core city has 390,000 inhabitants, the second largest city is Imola with 70,000 inhabitants. In terms of territorial development, big differences exist between the first ring municipalities (such as Casalecchio di Reno or San Lazzaro) and the smaller municipalities in the hills of the Appenin mountains or the plains in the north-east of Bologna. The municipalities in the Appenin are smaller and less growth oriented. There is, however, a functional polycentrism 
in terms of planning. The provincial regional plan (PTCP) as well as the territorial plan of the CM (PTM) define more than 20 regional poles or hubs (poli funzionali) as a means for structuring the territory and channelling funding (CM Bologna 2020b; CM Bologna 2018b, Ch. 6). These are, among others, the airport, the trade fair, the main station, the university as well as commercial zones. They are considered as places with higher mobility needs and in part form the backbone for the metropolitan railway system.

Emilia Romagna is considered a region with a polycentric urban structure and the role of the CM Bologna within this system of hubs and nodes is shortly adressed on the first pages of the PSM where cooperation on wider territorial scales is mentioned (CM Bologna 2018b, 2). Again, incentives come from above. The regional government of Emilia Romagna enforces cooperation (if not amalgamation) of provinces, so-called aree vaste inter-provinciale (large inter-provincial cooperation areas). This was part of the implementation of the Delrio Law for instance in the area of Piacenza, Parma and Modena and includes also the CM Bologna. The PSM mentions this larger scale cooperation with the provinces of Modena and Ferarra (so-called triannual protocoll, signed last time in November 2017) (CM Bologna 2018b, 28). On a wider scale, the two mayors of the metropolitan cities of Bologna and Florence signed an agreement (Memorandum) in 2017. They agreed to cooperate in the field of tourism and rural development in the Appenin mountainous area. This area is the border zone of the two city-regions. In fact the Florence Bologna metropolitan cities are the only ones that share a border. In a similar way, the CM Bologna also signed an agreement on tourism with the province of Prato in November 2017 (Tubertini 2018)..$^{20,21}$

To sum up this section: although there are spatial relationships beyond the territory of the CM that found institutional or policy repercussions, the focus of territorial policy clearly is on Bologna and the 54 municipalities. Larger scale cooperation is not as strong as in France and Germany.

\subsubsection{Coordination of public policies}

In terms of functions formally assigned to the new body, the CM Bologna does not differ significantly from the other CMs in Italy. However, the weight given to the new division of work between regional government, $\mathrm{CM}$ and municipal unions differs. The CM is responsible, in general, for the promotion and strategic coordination of socio-economic development. The main instruments that the CM can use for this purpose are the strategic plan (PSM), the general territorial plan (PTM) and the urban mobility plan (PUMS). The CM is in charge of the provincial streets and secondary schools and shares some tasks with municipalities and the region (tourism, economic development, mobility services, see below). There is a range of further tasks where the $\mathrm{CM}$ has a moderating and coordinating function (housing, urban regeneration) but implementation is in the responsibility 
of the municipalities. Functions that have been transferred in part or full to the region or regional agencies are agricultural and environmental policies, energy policy, culture, vocational education and civil protection (Tubertini 2018, RER 2015a).

The functions are mainly mirrored in the plans the CM is expected to elaborate, the more relevant plans being the PSM and the PTM. The third essential plan is the PUMS (sustainable urban mobility plan). We will start with the latter one as the preparation of this plan was a priority for the CM.

\subsubsection{Mobility}

The CM Bologna gives high priority to mobility policies and is involved in the implementation of a metropolitan railway system (servizio ferroviario metropolitano-SFM). Bologna shows a mix of excellent connectivity (motorways, airport, high-speed rail) and congested inner city routes due to high numbers of commuters (Delpiano and Ferroni 2016). The result is a considerable high level of air pollution and noise. The CM Bologna started preparing a sustainable urban mobility plan (SUMP / PUMS in Italian) in 2016 and the plan was approved in 2019 (CM Bologna 2019b). The metropolitan mobility plan for the CM of Bologna was the first inter-municipal SUMP in Italy. This indicates the priority that $\mathrm{CM}$ and City of Bologna give to mobility policy. The plan is a collection of priority projects with detailed steps and measures for implementation. The voluminous plan defines goals and suggests projects for the different transport modes (walking, cycling, public transport).

The implementation of the plan depends to a certain degree on EU funding, in fact without a SUMP there is no access to national and European funding. Additionally, the funds of the PON Metro programme were used for mobility projects. Although not necessarily a programme for mobility policies, the $\mathrm{CM}$ decided that projects financed through this programme must implement ideas taken from the SUMP.

The envisioned mobility policy for Bologna also includes larger infrastructure projects: a new tram system with four lines is planned and the system of metropolitan trains will be extended. The idea of a metropolitan railway system (SFM) emerged in the 1990s and implementation started in 1994. Some of the main components are an extension of the existing regional railway lines and an increase in the number of stations within the city-region. The main station of Bologna would be the central hub but this caused capacity problems as the high-speed and long-distance trains have priority. Hence, a tunnel with an underground station for the high-speed trains was constructed to give enough space for the SFM. The project had to face considerable delays and as a consequence the CM recognised that, in terms of metropolitan public transport, Bologna is lagging behind other city-regions in Europe and Italy (CM Bologna 2019b, 25, 110). In 2019, most of the investments for the SFM have been completed, although further improvements are envisioned (integrated ticket system, upgrading of existing stations, acquisition of new trains, 
15 min sequence of trains). In addition, the creation of 30 inter-modal mobility hubs is seen as the main task for the future. Since the 1990s, regional government, city of Bologna and the province of Bologna collaborated closely and the CM continues with this project. However, the CM is not the service provider. As a longer section on governance in the PUMS indicates, the $\mathrm{CM}$ would have welcomed a bundling of planning, management and service provision of all city-regional public transport services but for the moment this task is shared between the region (regional railways), the municipalities (local busses) and other service providers (CM 2019b, 110):

In materia di trasporti, l'intesa prevede inoltre che la programmazione del servizio ferroviario metropolitano sia fatta d'intesa tra Regione e Città metropolitana, mentre è rinviata al riordino della legislazione regionale la previsione di funzioni di promozione e coordinamento della mobilità e delle infrastrutture da parte della Città metropolitana, nonché la gestione del servizio ferroviario metropolitano.

With regard to transport, the agreement also provides that the planning of the metropolitan railway service is to be carried out by agreement between the Region and the metropolitan city, while the provision of functions to promote and coordinate mobility and infrastructure by the metropolitan city, as well as the management of the metropolitan railway service, is postponed to the change of regional legislation. (own translation)

The reintroduction of the tram is a more recent project and partly will substitute busses and give higher priority to public transport instead of cars. The tram certainly will be the major infrastructure project of the CM Bologna and the city of Bologna for the next decade.

The envisioned regional bicycle route system is a mix of a tourism project and an enhanced offering for residents of the region. The goals of the plan are ambitious in this regard. The major infrastructure projects and investments are all done with the financial help of and in coordination with the region.

\subsubsection{Metropolitan Strategic Plan (PSM)}

According to the specifications of the Delrio Law, the metropolitan cities are responsible for the creation of a compulsory and binding three-year Strategic Metropolitan Plan (Piano Strategico Metropolitano PSM), which must be updated every year (National Law n. 56/2014, Art.44). In Bologna, a strategic plan has been prepared on a voluntary basis already before the implementation of the CM. The process goes back to the formation of a civic platform (Comitato Promotore Bologna 2021 in 2011)22 that gathered various stakeholders that wanted to join forces for the socio-economic promotion of the city-region of Bologna. These were the chamber of commerce 
and industry, the university, firms and civic associations, the province and the municipalities. The first strategic plan was published in 2013. However, the continuity between the two strategic plans is not given, although, for marketing purposes, many people speak of PSM 1.0 and PSM 2.0. The first strategic plan was a list of wishes and projects that a group of private and public actors collected and handed over to the politicians of the province and the municipalities (Bologna in particular). The plan was voluntary and there was no real strategy, i.e. a priority given to some issues or projects instead of others. There was also no clear mechanism for implementation. The Comitato Promotore still exists but in terms of relevance it has been replaced by an advisory board (largely academics) and a consiglio di sviluppo (Advisory Board for Economic Development) which is composed of a range of high-ranking public and private leaders. ${ }^{23}$ Both bodies are new and need to find their roles in the current PSM process.

The new strategic plan is compulsory and was elaborated under the guidance and leadership of the CM. The character of this plan is very different compared to the previous one. The CM considers the PSM to be the main policy document for the city-region, providing a framework also for other plans and policies.

The plan-making process started in January 2016 and the final plan was adopted in 2018. During this period, several preparatory documents have been created ( $\mathrm{La}$ Voce delle Unioni, Le Linee di indirizzo del PSM 2.0, Documento Preliminare, Resoconto Fase Preparatoria) and after six meetings with the councils of the different unions of municipalities and the municipality of Bologna, the consultation phase with the presidency office, advisory board for economic development, advisory board and the involved stakeholders, and the final consultation, the PSM was approved in July 2018 (CM Bologna 2018b, 2-3). Other CM in Italy presented the PSM earlier (Milan, Firenze) but Bologna gave more priority to the elaboration of the PUMS.

With regard to the content, the PSM 2.0 Bologna differs from many other PSM in Italy that have their origin in urban design (i.e. Firenze). The PSM Bologna has no maps but is structured around the three principles of inclusivity, sustainability and attractiveness (CM Bologna 2018b, 9). Within these cross-cutting principles, the PSM clearly has two thematic priorities: mobility and urban regeneration. A third focus is on the governance of implementation and inter-municipal coordination. This refers also to the involvement of stakeholders through committees and round tables (Consiglio di Sviluppo und Tavolo delle Società Participate) which are part of an extended governance arrangement. The PSM puts a significant emphasis on the improvement of the quality of government (homogenous public administration, quality of government must be the same for the whole territory). In general, there is a strong consideration of sustainability goals (SDGs) which have been defined in a separate document called Charta Bologna (CM Bologna 2019a). Some goals are steep, such as the increase of green space by $45 \mathrm{~m}^{2}$ per capita by 2030 which 
would be, according to CM sources, a 50\% increase (CM Bologna 2018b, 36; CM Bologna 2019a, 60). Social inclusion and welfare is mentioned but is less significant. The consideration of the relaunch of the economy mirrors the adverse effects of the Covid-19 crisis. Digitisation is considered to be the new paradigm for the economy but also for public administration and mobility.

\subsubsection{The Metropolitan Territorial Plan (PTM)}

Spatial planning is not a totally new function for the second tier of local government in Italy as the provinces have been responsible for the elaboration of territorial plans (Piano Territoriale di Coordinamento Provinciale - PTCP) since the 1990s. The territorial plan of the former province of Bologna was valid until the new PTM came into force in December 2020. The provincial plan has been in force with a small number of modifications since 2004. The PTCP was considered to be a well elaborated plan, hence nobody felt that it needed to be replaced quickly. The PTCP was a voluminous document and defined the regional territorial structure by indicating functional poles such as the railway station, fairground, airport, university hospitals and the logistics interport (poli funzionali - an idea that is kept in the PTM, CM Bologna 2020b). In addition, larger zones for commercial development have been defined together with the municipal unions. The main instrument used for the implementation of the goals of the plan are called Accordi Territoriali and Accordi di Programma. These are agreements between the regional government, municipalities and the province that were part of the PTCP. They largely define the conditions for financing any kind of territorial development projects.

Further sectoral plans have been inherited from the province, such as the Piano di Commercio (a plan for retail and commercial uses), plans for towers for mobile communications (PLERT Piano di Localizzazione delle Emittenti RadioTelevisive) and plans for surface mining (Piano dello attivita Estrattive). The new PTM has a stronger ambition to integrate these sectoral plans into one coherent document. The PTM constitutes a new type of regional plan. Differing from the largely coordinative PTCP, the PTM will also be an urban design plan and should achieve more (according to interview results). It can also prescribe limits for local development.

One important element in this regard is a new regulation of the region Emilia Romagna for territorial planning and the reduction of land consumption. The new spatial planning law of the Emilia Romagna region of 2017 sets the goal of reducing land consumption to zero in 2050 (RER 2017). ${ }^{24}$ Until then, a growth of $3 \%$ is allowed (reference is the actual urbanised area, including the intended land activations in municipal plans as of the cut-off date 31 December 2017) (CM Bologna 2020c, 94). The impact of the $3 \%$ goal depends on the definition of urbanised territory and the rules for exceptions. In the course of the plan development, an inventory was carried out with the municipalities in order to find out which 


\section{Italy}

areas are provided for in the plans and are thus considered urbanised and which are not. The $3 \%$ growth potential was calculated with reference to the current state of consumed land based on existing plans and satellite images $\left(755 \mathrm{~km}^{2}\right)$. In addition to the already urbanised areas, building areas activated in the plans but not yet built on are added on top. ${ }^{25}$ Excluded from the $3 \%$ limitation are public infrastructures (social housing) and commercial areas that are considered strategically important for the city-region (CM Bologna 2020a). Expansion of commercial areas is still possible if it takes place as an extension at the existing well-connected functional poles identified in the PTM. In any case, the goals and priorities of the PSM apply.

The mechanism allows for some flexibility in the distribution of growth: as long as the $3 \%$ target is kept, some municipalities may grow stronger while others will not grow at all. The specification of which municipality is allowed to grow beyond $3 \%$ will be in the hands of the planners of the CM. Hence, the CM Bologna has an important role to play in the implementation of the $3 \%$ target which makes a difference to the former province. Since an equal allocation of $3 \%$ growth to all 55 municipalities of the CM would lead to very small new building areas in some cases, the CM has been given the task of defining criteria in the new PTM that distribute growth in such a way that $3 \%$ is achieved for the area of the CM as a whole and at the same time reasonable lots can be realised from a spatial planning perspective (concentration, public transport connection). Thus, in individual cases, new development areas larger than $3 \%$ can be realised in a municipality. The CM does not conclusively define these areas in the plan. Also the cartographic presentations of the plan do not define precisely which territories will be allowed to grow and which will not. But the PTM defines clear rules and territorial priorities that the municipalities must follow when they take corresponding initiatives. The CM moderates this selection with the municipalities according to the PSM and PTM criteria.

However, these regulations and priorities clearly show that some smaller municipalities would not benefit from growth as commercial areas and housing of strategic regional relevance are not realisable in the periphery. Realisation of growth is only reasonable in the centre or the plain (pianura) along the main transport axis (railway in particular). As a complementary measure, a compensation fund already provided for in the region's planning law (and national planning law) has been created to the benefit of those municipalities that cannot participate in the $3 \%$ growth target (Fondo perequativo metropolitano). The use of this fund must be in line with the objectives of the PSM, the mobility plan and the charter for a sustainable Bologna and will be used primarily in municipalities in the periphery to balance disadvantages or to reward these areas for their provision of eco-system services (CM Bologna 2020c, 96). The fund is financed by urban planning levies $(10 \mathrm{M} €)$ and is a tool for solidaric development as the levies will at least in part originate from the growing municipalities. This compensates 
for disadvantages insofar as these are compatible with the objectives of the PTM, the PSM and PUMS.

\subsubsection{Conclusion}

The new governance arrangement in Bologna certainly shows a higher level of inter-institutional and inter-municipal coordination and collaboration. However, the CM is only in part an independent layer of policy-making as the organisational autonomy in terms of financing and also in terms of legitimacy is low. Nevertheless, the PSM and the PUMS are the instruments that express the political will and priorities of the CM. The PTM, in contrast, is embedded in a new hierarchy of territorial plans and goals defined by the regional government. Whether the $\mathrm{CM}$ is equipped to solve the most pressing problems and issues is debatable. The following challenges have been mentioned in the interviews:

- Transport infrastructure: Bologna is a node of several important national highways and hub for logistics (Delpiano and Ferroni 2016). The system of highways and tangential roads is overstrained and needs investment. Bologna has a big freight distribution centre (interporto).

- The extension of the metropolitan railway system (FSM) in combination with the re-introduction of a tram.

- Housing policy and urban regeneration (not being a full competence of the CM but some supportive initiatives are done in collaboration with municipalities, Bologna in particular). A joint metropolitan office for housing policies has existed since 2015 (in terms of organisation the office is part of the city administration of Bologna).

The status quo of plans and inter-institutional arrangements between the region and the $\mathrm{CM}$ and the $\mathrm{CM}$ and the municipal unions at least indicates that these problems will be addressed according to their priority.

In the first years of the $\mathrm{CM}$, some conflicts emerged between the $\mathrm{CM}$ and municipalities when strategic decisions on mobility infrastructures and amendments of local plans were made (Tubertini 2018, 6). The cause was the indirect legitimacy of the council of the CM and the lack of territorial representation: there are not enough councillors and these probably follow local interests but not a genuine regional rationality. This is partly compensated by the representation of municipal unions (ufficio di presidencia).

The big advantage of the reform is the merger of political power. The mayor of the biggest city is also the mayor of the CM. Hence, he or she can facilitate more cooperation and cost-efficient structures between the two biggest administrations in the city-region. There is also no competition any longer between the political head of the province and the mayor of the biggest city. The result of the previous structure with two full levels of 


\section{Italy}

policy-making and planning were limited integration and lack of coordination (there was no city-regional mobility strategy and no joint strategy for tourism). This is now possible.

Another advantage is that the CM now has direct contacts and working relationships not only with the region but also with the national government and is considered the addressee for programmes. This was less the case before and the $\mathrm{CM}$ performs a mediating role with regard to the municipalities. This is important for the EU programme PON Metro and the national programme for the peripheries (bando periferie). The CM was in the leading position in the awarding of the programme for the peripheries (EU funding) and organised the selection according to criteria (the focus was on sustainable transport and territorial coherence or regional significance). A steering effect was thus achieved here.

The provinces were strong in Emilia Romagna as a result of decentralisation. Now, after a range of austerity measures have been implemented, the situation is different because many functions can no longer be fulfilled by the provinces. With regard to the territory outside the metropolitan city (i.e. the remaining provinces) there will be an unbalanced situation as the $\mathrm{CM}$ Bologna is stronger in terms of policy-making capacity. Compared to the provinces in the rural areas, the $\mathrm{CM}$ has partly kept its role and position and is given a role for strategic planning. The $\mathrm{CM}$ has a better standing because it communicates directly with the region and is seen as an institution of the municipalities. This federal model results in a better position although the $\mathrm{CM}$ also had to face a loss of resources. The mobility plan PUMS, for example, is actually a municipal plan that has been up-scaled in Bologna and also in other CMs. The CM organises all the consultation and participation with citizens and stakeholders, on behalf of the municipalities. Here, the $\mathrm{CM}$ plays a positive role.

The field of mobility, however, shows the limits of this new arrangement with a lot of shared responsibilities. In the area of transportation, the creation of the CM in combination with the PUMS and changed legal requirements has created a certain spirit of optimism and sense of relaunch. However, the CM largely remains a coordinating body in a network of agents, while the actual responsibilities for planning, financing and service provision remain distributed. There is only limited integrated management of public transport. All in all, the relevance of the city-region level in Bologna has risen, in terms of functions. At the same time, the cuts and shifts of tasks (in environmental planning, in particular) limit the capacity to act in specific fields. There is certainly a focus on socio-economic development and a sense of pro-active intervention.

\subsection{The Città Metropolitana di Firenze: mismatch of socio- economic regionalism, territory and jurisdiction}

The need for a change of the governance structures in the urban network of northern Tuscany and, closely linked to this, the establishment of large-scale 
spatial planning in the settlement areas of Florence, Prato and Pistoia has been the subject of ongoing debates in recent decades (Giovannoni and Innocenti 2010; Paba et al. 2017; De Luca 2017). Corresponding intermunicipal plans have repeatedly been drawn up and submitted to political consultations, and forms of cooperation have been established on an experimental basis (see below). However, a spatially coherent solution was never found. In 1992, Prato was founded as a separate province, thus adding another territorial entity between the Province of Florence and the Province of Pistoia (Giovannoni and Innocenti 2010, 72). Institutionally and spatially, this redesign of the provinces in the 1990s increased institutional fragmentation in the area.

The evolution of inter-municipal planning and cooperation in the Florence city-region goes back to the 1950s but throughout the whole period, intermunicipal cooperation has been less intense compared to other city-regions in Europe and also Italy (Giovannoni and Innocenti 2010; De Luca 2017). The major periods and milestones were:

- 1951-1966: discussion of an inter-municipal plan according to national law 1150/1942, Art. 12, which was intended as an official plan based on the initiative of Florence but never came into force (De Luca 2017, 215). In this period, 13 municipalities were involved. A conference of mayors was established in 1962 but reached no consensus (Paba et al. 2017, 109; Giovannoni and Innocenti 2010, 597).

- 1966-1978: second Florence inter-municipal plan, focussing on the area Piana Fiorentina (i.e. the Florence-Prato-Pistoia area), but this plan was only an informal scenario with analytic maps; the number of municipalities involved increased to 21 (Vannucchi 2008; De Luca 2017, 220).

- 1983-1990: structure plan (schema strutturale) for the metropolitan area Florence-Prato-Pistoia (19 municipalities) according to regional law 74/1984, art $8^{26}$. This was an initiative of the regional government (Giovannoni and Innocenti 2010, 598). The structure plan (schema strutturale con valenza di piano territoriale di coordinamento) came into force in 1990 through a regional law and largely covered infrastructures and environmental planning; implementation would happen through municipal directives.

- 1990: a regional law (n. 42/1990) creates Conferenza pianificazione territoriale dell'area, a coordinating body that should strengthen the structure plan (Giovannoni and Innocenti 2010, 599).

- During the process of reorganising the provinces in the early $1990 \mathrm{~s}$ (creation of province of Prato), the provinces were given supra-local planning competences (based on law 42/1990). As a consequence, the structure plan and the Conferenza pianificazione territoriale dell'area lost relevance, inter-municipal initiatives ebbed away, although being defined in the same law (Giovannoni and Innocenti 2010, 599; De Luca 2017, 224). 


\section{Italy}

- 1996: Patto per il governo dell'area metropolitana and creation of the Conferenza Metropolitana by the regional government as a minimal response to the national law 42/1990 on creating the Città Metropolitana (signed by the Region, the city of Florence, the Province of Florence and some municipalities and municipal associations (Mugello, Valdarno)) (Giovannoni and Innocenti 2010, 599).

- In the 2000s, initiatives of strategic planning were taken under the leadership of the city of Florence. The strategic plan was supported by the 11 municipalities of the first ring and a range of private actors (Giovannoni and Innocenti 2010, 600). The first strategic plan was published in 2002. For the implementation, an agency called Firenze 2010 was established in 2003. In parallel to the strategic plan, in 2006, 11 municipalities (Florence and the first ring municipalities) started a collaborative process for better planning of public transport (called PINCO). The ultimate goal was the creation of a municipal union (URBACT 2009, 34), which did not happen in the end. The re-introduction of the tram in Florence was partly connected to this as the tram connects (or will connect) Florence and some of the adjacent municipalities. This has been realised in the case of Scandicci, plans are made for Sesto Fiorentino where a branch of the University of Florence is located. The strategic plan was renewed in 2009 (Firenze Futura).

- In 2007, the three provinces of Pistoia, Prato and Florence and the regional government signed a pact for development of the metropolitan area.

Summing up these developments, we can say that several initiatives were taken over the last decades but remained fragmented and had weak implementation power. The city of Florence focussed on the municipalities of the first ring while the regional government tried to establish cross-jurisdictional collaboration on a wider scale. The creation of the province of Prato in the early 1990s, which is basically an extension of the city of Prato, increased institutional fragmentation. Institutional changes happened only with the implementation of the Delrio Law in 2014.

The population of the CM Florence is about $1,000,000(27 \%$ of the Region of Tuscany), of which 366,039 live in the core city of Florence (CM Florence 2018, web). The size of the territory is $3,514 \mathrm{~km}^{2}$. With regard to demographic development, the city-region is growing more in the suburban areas and less in the core city. The CM comprises 42 municipalities, some of which are grouped together in municipal unions.

\subsubsection{The Institution Cittá Metropolitana Firenze}

With the final adoption of the Delrio Law in 2014, the Città Metropolitana had to be created in the greater Florence city-region on 1 January 2015. Since the national law made in part vague specifications with regard to the organisational form and functions, it was left to the municipalities concerned and 
the regional government of Tuscany to develop an appropriate and accepted organisational form. For that purpose, in 2014, several workshops were held, also with the participation of academics of the University of Florence, in order to discuss these aspects. At one of these workshops, the mayor of Florence, Dario Nardella, made clear how he envisioned the CM: as a coordinating body that, following the principle of administrative simplification, should try to share administrative services and act as a service provider for the municipalities that set the objectives. Offices should be used together or merged, which has been partly realised. For example, just as in the CM Bologna, the position of the Segretario Generale of the administration was created as a joint position of the CM and the city of Florence. Also, some other staff work for both administrations. This measure saves costs and provides a certain effectiveness.

The CM Florence was created quite quickly, which is also reflected in the very rapid development of the strategic plan. Although the plan preparation process produced a considerable volume of preparatory documents, the plan was already adopted in 2017 and updated in 2018 and 2019 (DCM n. 26 del 5.4.2017).

In line with the Delrio Law, the three organs of the CM are the mayor of the CM (the lord mayor of Florence), the council (Consiglio Metropolitano), which in the case of Florence has 18 members, and the conference of mayors as a consultative organ (Conferenza Metropolitana). Seven members of the Consiglio Metropolitano are mayors, 11 are delegates of the local councils. ${ }^{27}$ Six members (one third) represent the city of Florence. The mayor presides over both the Consiglio and the Conferenza Metropolitana. The Consiglio meets monthly, the metropolitan conference only twice a year (but then on the same day as the Consiglio). The metropolitan conference decides in particular on changes of the statute and must be consulted on certain issues. The Città Metropolitana does not have a Giunta (mayor plus deputies) as is common in local politics in Italy. Some of the members of the Consiglio, however, have a similar function and form professional profiles for one or several of the various tasks of the CM (schools, mobility, environmental issues, etc.).

The statute of the CM Florence is 12 pages long and was adopted on 16 December 2014. The option of creating homogeneous zones is briefly mentioned in Art. 2 but not implemented. According to the statute, the CM's task is strategic regional development, integrated management and coordination of services of supra-local relevance, infrastructures and communication networks, and management of institutional relations (towards the regional government and national government). According to the regional law, the CM takes over the functions of the province, unless they have been transferred to the region. Specifically, the CM has the responsibility for:

- The elaboration of the strategic plan (PSM);

- Territorial planning on a city-regional scale (PTM); 
- School transport, school buildings and locations;

- Public transport and roads (provincial roads and planning of public transport (busses), traffic information system and the elaboration of the urban sustainable mobility plan (PUMS)). The former province was in charge of $1,071.9 \mathrm{~km}$ of provincial roads and of $276.6 \mathrm{~km}$ regional roads;

- Economic development and tourism, the latter shared with the region and municipalities (Regione Toscana 2018, 63);

- Digitisation and communication networks;

- Waste management ${ }^{28}$ (shared with service providers);

- A limited number of tasks in the field of labour market policy (antidiscrimination policies);

- Support of the municipalities in data processing and statistics;

- In addition, maintenance and preservation of a limited number of parks and monuments owned by the CM (the majority of which, however, have been transferred to the region).

Numerous functions of the former province were transferred to the region. Most of them are environmental and nature conservation policies (environmental assessments, noise abatement planning, air pollution control, water pollution control, agriculture, responsibility for nature reserves and parks). Additionally, labour market policy and energy policy are now a regional task (Regione Toscana 2018; Regional Law 22/2015, art. 2). In the field of infrastructures, some responsibilities have been transferred to the region but are now partly managed by the CM on a contractual basis (regional roads). This transfer of functions was accompanied by a significant reduction in the number of staff and most of the former provincial staff members were reallocated to the region (Regione Toscana 2018, 74). The municipalities did not have to hand over functions to the CM (or vice versa).

In regional law, provisions are made which regulate the takeover of functions of the remaining provinces outside the CM by municipalities and municipal associations. The strategy of the region is thus becoming apparent, namely to dispense the provinces in the medium term and to hand over the tasks to the municipalities or municipal unions.

\subsubsection{Forms of cooperation between municipalities, the municipal unions and CM}

The CM Florence can delegate functions to municipalities if this is in accordance with the principle of subsidiarity. In addition, the CM can conclude agreements with individual municipalities or associations of municipalities for the provision of services. In contrast to Bologna, the municipal unions do not have an institutional role in the CM Florence and were also not formed region-wide. The unions in the CM Florence are rather less recognised and used as partners of the CM. The existing ones are Mugello, Empolese-Valdelsa, Chianti Fiorentino, Valdarno e Valdisieve 
Table 3.4 Unioni di Comuni in the CM Firenze

\begin{tabular}{lclc}
\hline Name & Municipalities & Size $\mathrm{km}^{2}$ & Inhabitants \\
\hline $\begin{array}{l}\text { Unione Comunale del Chianti } \\
\quad \text { Fiorentino }\end{array}$ & 2 & 277.21 & 30,962 \\
$\begin{array}{l}\text { Unione di Comuni Del Circondario } \\
\text { dell'Empolese Valdelsa }\end{array}$ & 11 & 735.08 & 174,762 \\
$\begin{array}{l}\text { Unione Montana dei Comuni del } \\
\quad \text { Mugello }\end{array}$ & 8 & $1,131.13$ & 63,847 \\
$\begin{array}{l}\text { Valdarno e Valdisieve } \\
\text { Total CM }\end{array}$ & 6 & 495.02 & 55,165 \\
\hline
\end{tabular}

Source: http://www.comuniverso.it/index.cfm?Unioni_di_Comuni_della_Toscana\&menu=547, 26 August 2020

(see Table 3.4). The municipal unions in the Florence area differ in size and institutional strength. They perform mainly a limited coordination of public services. Two of them, Mugello and Empolese-Valdelsa, are responsible for an inter-municipal structural plan (Piano Strutturale Intercomunale). In particular, the unione di comuni Mugello has developed an inter-municipal planning level that covers a considerable part of the territory of the CM. It is striking that the four municipal unions cover only the second ring of the $\mathrm{CM}$ while the first ring municipalities are not organised in unions (https:// osservatorio.urbanit.it/unioni-di-comuni-firenze/).

\subsubsection{Inter-institutional relationships}

The relevant law for the constitution of the Città Metropolitana of Florence also provides for a coordination body with the region (Conferenza RegioneCittà Metropolitana), in which basic policy goals and concerted actions are to be discussed (Regione Toscana 2018, 11). The efficacy of this instrument was questioned by interviewees. The regional government defines the framework for territorial development in different documents and plans. The "Integrated Regional Spatial Planning and Landscape Plan" (Piano di indirizzo territoriale con valenza di piano paesaggistico - PIT, 2015) and the Regional Development Programme (Programma di Sviluppo Regionale, Regione PRS, Regione Toscana 2017) are the more relevant ones. The laws stipulate that agreement is reached on this (Regional Law 22/2015, 6; Regional Law 9/2016). It is stated that the subsequent plans must comply with the objectives and principles of the regional plans. However, the scale of the PIT is rather imprecise in its maps, but it lays down general principles for settlement development that severely restrict growth. The main purpose is, however, environmental protection, landscape planning and management of risks. In the relevant area of the CM (Ambito 06 Firenze Prato Pistoia in terms of the document) cartographic presentations include existing industrial sites, settlements, tourist zones and infrastructures. These 


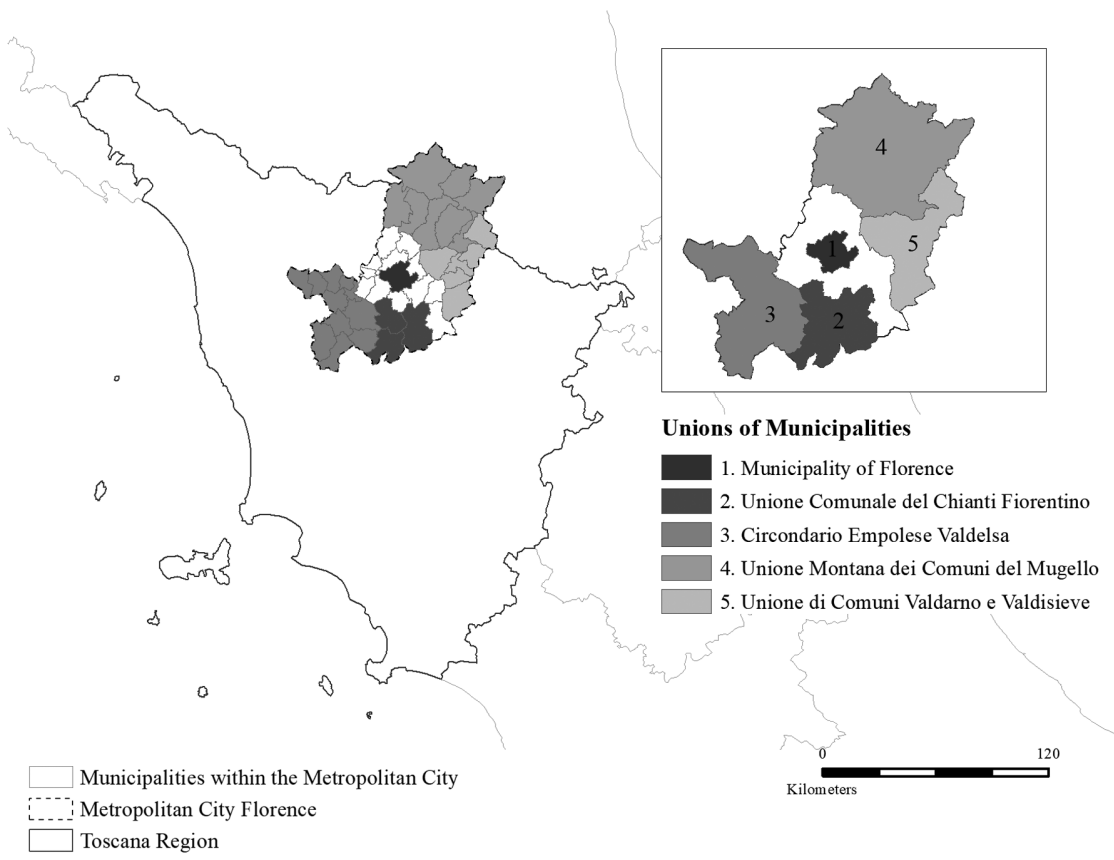

Figure 3.4 Municipalities and municipal unions in the CM Florence 2021 Concept: K. Zimmermann Cartography: F. Gela

cartographic presentations, however, are indicative and demonstrate criticalities (Regione Toscana 2015b, 60).

Beyond that it is open for procedural arrangements on how the relationship between the region and the CM will be structured and which role the spatial development plan Piano Territoriale Metropolitano (PTM) of the CM will play in the regional system of spatial planning (De Santis 2015). ${ }^{29}$ With the current planning legislation (Regional Law 65/2014) the region expressed stronger leadership in regional planning with the ultimate goal of reduction of land consumption.

\subsubsection{Spatial relations}

Central Tuscany is a polycentric space with complex functional and territorial relationships. The ongoing process of suburbanisation, post-suburbanisation and metropolisation has produced a patchwork of settlements and infrastructure corridors with in-between space seemingly being the dominant form of territorial development (Paba and Perrone 2018). This applies for the Piana Fiorentina (Figure 3.5) but also for the wider area reaching from Florence to the coast (Pisa, Livorno) (Paba et al. 2017). 


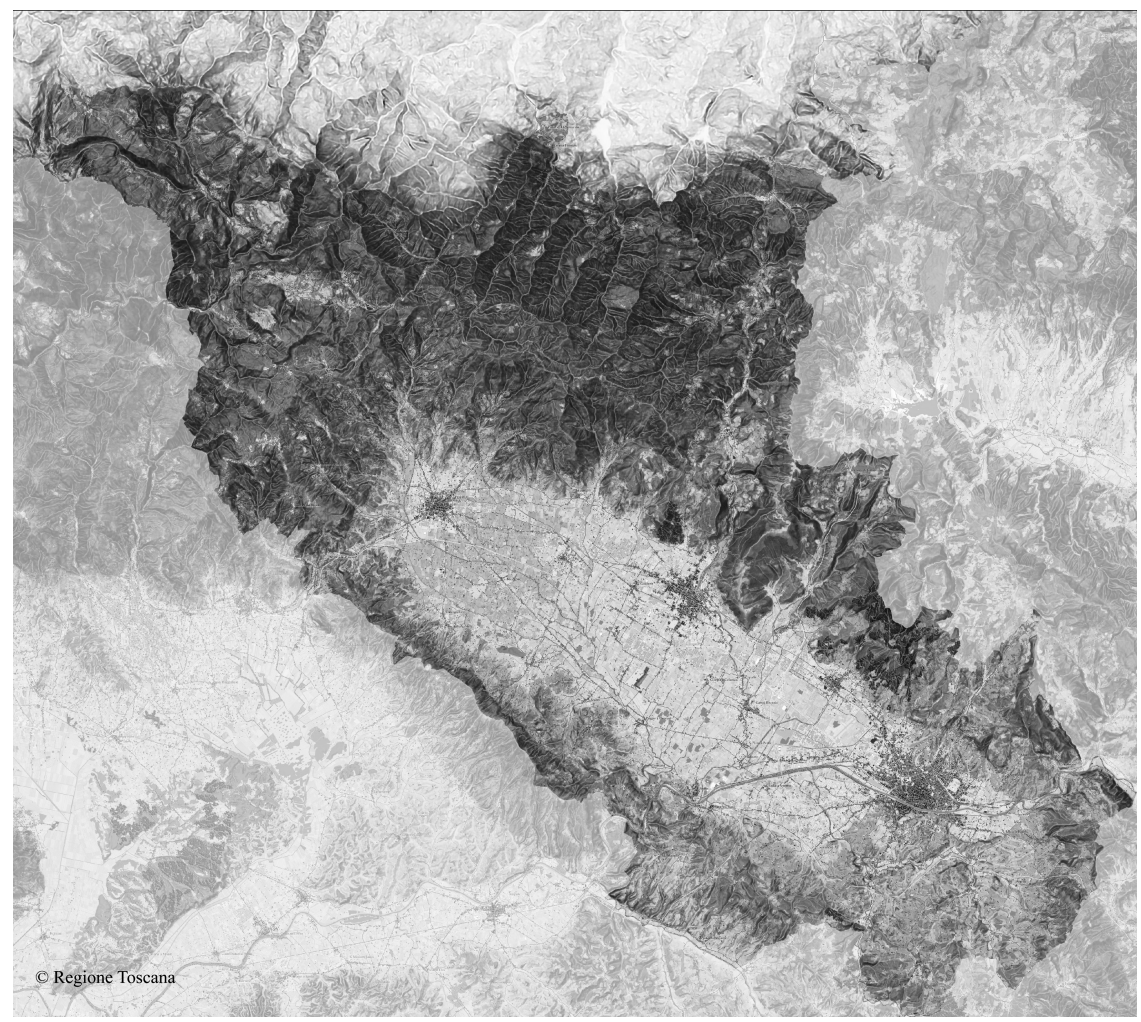

Figure 3.5 Piana Fiorentina. Source: Regione Toscana PIT 2015b, 16

Functionally and also with regard to the settlement structures, Prato and Florence had long since grown together, which was already expressed in the PIT of the Tuscany Region from 2015 (see Figure 3.5). In particular, the municipalities of Campi Bisenzio and Sesto Fiorentino are equally suburbs of Florence and Prato, but in terms of territorial planning administration are part of the CM Florence. Similar constellations can also be found on a larger scale. As a consequence, the role of Florence in the polycentric city-network of northern Tuscany (Pisa, Livorno, Lucca, Pistoia, Prato) has been discussed for a longer time (Paba et al. 2017; De Luca 2017). Florence is the largest city in Tuscany and it is the seat of the regional government and thus historically, politically and economically in an outstanding position; on the other hand, it is functionally and structurally part of a larger polycentric network of cities in northern and central Tuscany and also has close functional relations with the neighbouring CM Bologna. In the past, the regional government certainly pursued the goal of a balanced structure of cities. In 1978, the decision was made not to expand Florence airport, but to develop Pisa as an international 
hub and to connect Florence by rail (Florence-Peretola airport was intended as a regional airport). However, given the importance of Florence as a magnet for international tourist flows and a trade fair location (fashion), the size of the airport is no longer appropriate and the runway is too short for larger aircrafts. The city of Florence has repeatedly raised the issue of expansion, but the spatial situation has become complicated by settlement and commercial developments and designation of protected areas in the Piana Fiorentina. Municipalities and cities of the area (Prato) repeatedly raised their concerns.

The discussion on cooperative strategic planning in the early 2000s revived this debate on territorial re-organisation of territorial relationships. However, this only affected Florence and the municipalities of the first ring (Bagno a Ripoli, Calenzano, Campi Bisenzio, Fiesole, Impruneta, Lastra a Signa, Pontassieve, Scandicci, Sesto Fiorentino, Signa) (De Luca 2017). The strategic plan was adopted in 2002, being the result of a cooperative process involving many social groups. For the purpose of implementation, an association was founded in 2003 with the title "Firenze 2010: Associazione per il piano strategico dell'area fiorentina" (Giovannoni and Innocenti 2010, 603). The plan fully corresponded in its aspiration and content to the then current idea of collaborative strategic planning. It was a collection of 32 project ideas and 49 interventions but the initiative was strongly focussed on Florence and lost momentum in the following years.

In the second half of the 2000s, the larger spatial dimension of the cityregion was again discussed. For the area vasta (greater area) of Florence, Prato, Pistoia, workshops were organised in 2008. Discussions continued on other levels as well, although Florence has since then concentrated on the borders of its province or the first ring of municipalities. In the same period, so-called aree vaste (larger cooperation areas) of the region of Tuscany were under debate. Proposals for larger administrative areas were on the agenda, of which three to five for the whole of Tuscany were discussed in more detail. This could have been done by strengthening and enlarging the provinces. This was at least the position of the Regional President Rossi, but it was rejected by numerous municipalities such as Prato. However, the aree vaste are not completely new, but are already practised in the field of health services and nature conservation (ARPAT areas - Agenzia Regionale per la Protezione Ambientale della Toscana). The multitude of territorial frameworks for waste management, water management and social services is taken up in the strategic plan (CM Florence 2017, 24-25).

In the opinion of all interviewees, the keeping the borders of the old province of Florence in the creation of the CM means that a perimeter is chosen that is too small and does not reflect the functional interdependencies. The perimeter is therefore not appropriate for planning settlement development or operating integrated infrastructure development, especially with regard to mobility. This became apparent when in the summer of 2018, the efforts of the municipality of San Giovanni Valdarno became clear to become part 
of the CM. Up to now this town belongs to the province of Arezzo, but borders the CM (Figline - Incisa). Due to resistance in the Metropolitan Council, the process came to a standstill. The mayor of San Giovanni hoped to gain access to resources (EU funding) and argues that his municipality is part of the Florence labour market region (commuter shed).

The question of the adaptability of the spatial layout arises on several levels:

1) A recurring theme is the clarification of the relationship between $C M$ Firenze and the province of Prato, and the cities of Prato and Pistoia. The interdependencies between these places are so dense that a solution is needed to avoid further conflicts and to increase territorial coherence.

2) What forms of cooperation are required for the network of cities in northern Tuscany (Pisa, Empoli, Lucca, Pistoia, Prato, Florence) but also for area south of Florence (Val d'Arno) (Paba et al. 2017)?

3) How to integrate the mountainous and rural area of Mugello functionally and politically into the CM (north-east towards Bologna)?

4) The two CMs of Florence and Bologna are adjacent and have functional links (rail and motorway, alternative airport). Will a stable cooperation with the CM Bologna emerge?

The regional government clearly sees the advantage of cross-jurisdictional cooperation on a larger scale and intervenes in several ways. The region uses funding to give incentives for cooperation. The Piana Fiorentina is a case in point.

\subsubsection{The Piana Fiorentina project}

The Piana Fiorentina is a plain in the north of Florence, stretching beyond the boundaries of the CM (see Figure 3.6 and Figure 3.5). The area extends from Florence to Pistoia and thus encompasses a functionally and naturally well delimited area. Functionally, because there are dense functional interdependencies between the three large cities and the smaller towns (commuters, infrastructure), which should be managed through the collaboration of municipalities and provinces. Naturally, in the sense that it is a plain surrounded by mountains, which is used for agriculture, with conflicts of land use arising because of new settlements, commercial zones and infrastructure development. Last but not least, there are objectives of environmental and nature conservation and for the management of risks (flooding).

The regional government has a territorial instrument called PIT (Progetti integrati territoriali) that is thought to bring public and private actors together and offers some funding for projects at the intersection of environmental planning and regional development. The implementation is delegated to local authorities. In the case of the CM Florence there are three of them: the PIT Piana Fiorentina (a regional landscape planning project), and 


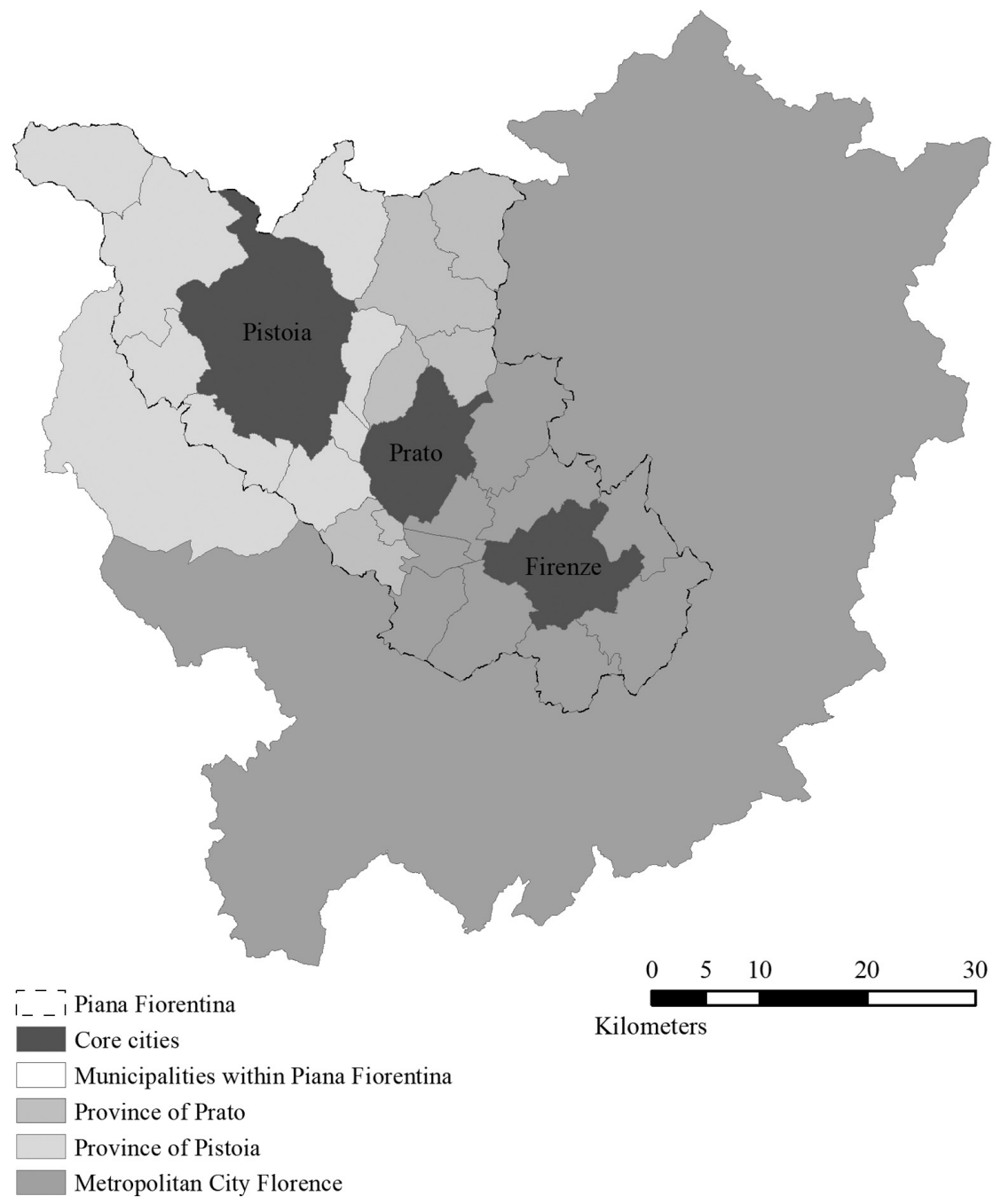

Figure 3.6 Piana Fiorentina, administrative boundaries with Pistoia, Prato and Florence 2021 Concept: K. Zimmermann Cartography: F. Gela

two projects referring to biodiversity and watershed management along the river Arno (CM Florence 2018d, 145; Regione Toscana 2016). The regional government has handed over the implementation of the PIT for the Piana Fiorentina to the CM; for the other two, the CM is just a partner as several other provinces are included. ${ }^{30}$

In cooperation with the province of Prato and other municipalities outside the CM, a kind of landscape park (parco agricolo), in the sense of green 
infrastructure and reduction of land consumption is to be created. The programme is part of the Rural Regional Development Plan (Piano Sviluppo Rurale PSR 2014-2020) of the Tuscany Region, in which the participating municipalities concluded an agreement. Plans for the Piana Fiorentina have a history that goes back to the 1970s (Regione Toscana 2015b, 16). It is, on the one hand, a piece of land with valuable environmental qualities. On the other hand, the piecemeal extension of settlements and transport infrastructures over the last decades has resulted in a situation of loss of green spaces and increasing hydrological risks. In fact, in the regional development plan, the Piana Fiorentina is characterised as an area of incomplete metropolisation or a peri-urban zone with scattered mobility infrastructure and economic development competing with agricultural land use and parks (Regione Toscana 2017, 112).

In terms of governance, a form of cooperative and project-based planning has been created for the area and the process is in the moderating hand of the CM.

The PIT Piana Fiorentina can be characterised as a supra-municipal initiative based on a grant from the region. Interventions should happen in these areas:

- Soil protection and flood prevention;

- Water protection;

- Biodiversity;

- Landscape planning;

- Sustainable energy;

- Agriculture (Regione Toscana 2016).

Since 2018, a bicycle highway has also been promoted as part of the Piana Fiorentina project and this is also one of the pilot projects of the strategic plan of the CM. Participants are the Province of Prato, the City of Prato, various municipalities and CM Florence. The participating parties have concluded an agreement (accordo territoriale) with the other actors and agricultural enterprises. There are direct beneficiaries (receiving funding) and indirect participants (affected in a broader sense and involved in the implementation). However, the map of interventions shows that the PIT Piana Fiorentina is a selection of bigger and smaller projects and less a comprehensive strategy. Financial support started in the 2000s.

This is thus an incentive-based cooperative planning process, which has been promoted for a longer time period, particularly by the Province of Prato, because it owns large parts of this area. From the perspective of the regional government, it is an attempt to give an impulse to this unplanned area on an intercommunal basis. In the past, Florence, in particular, considered this area as a backyard where waste incinerators, landfills, the airport and industry were located. This helped to protect the areas in the south-west of the city that are of great touristic value. This led to conflicts (between 
Prato and Florence, but also Campi Bisenzio, Sesto Fiorentino), especially in connection with the expansion of the airport, which has been under debate for some time. ${ }^{31}$

\subsubsection{Intercommunal land use planning below the CM}

The regional government of Tuscany supports inter-municipal cooperation and, with limited success, the amalgamation of smaller municipalities. The elaboration of inter-municipal structure plans is part of this strategy as the region gives a financial incentive for the elaboration of these plans. In the territory of the CM Florence, there are three cases. The neighbouring municipalities of Sesto Fiorentino and Calenzo have developed an inter-municipal structure plan (adopted in 2019); the unione montana di comuni Mugello with a total of eight municipalities has a joint planning office that drew up an inter-municipal structure plan (adopted in 2018, see Figure 3.4 Nr. 4). Another municipal union is about to finish the work on the inter-municipal structure plan (L'Unione dei comuni della Valdisieve, see Figure 3.4 Nr. 5) As a result, almost half of the territory of the CM will be covered by three inter-municipal structure plans. This emerging intermediate level of land use planning raises the question of what the territorial plan of the CM (PTM) would add or regulate (De Santis 2015).

\subsubsection{Cooperation with CM Bologna}

In March 2018, an MoU (Memorandum of Understanding) was signed between CM Bologna and CM Firenze (Patto Bologna - Firenze). This MoU aimed at enhanced cooperation in the fields of tourism, transport, EU projects (PON) and the Apennine area (mountain region between the cities, Mugello). In fact, the two CMs are the only ones directly bordering with each other. The two city-regions are well connected by rail and the motorway, which has been greatly improved in recent years.

We can conclude that several territorial reference frameworks exist within and beyond the territory of the CM. In particular, the region uses and refers to different territorial perimeters (including the Piana Fiorentina) but these are not institutionalised.

\subsubsection{Coordination of public policies}

As a result of the reform, the region took over many of the functions of the former province, but did not hand over significantly more functions to the CM (Regione Toscana 2018). The CM thus remains relatively weak compared to the former province. Although the new obligatory function of strategic planning is highlighted, the CM has a limited functional 
portfolio. With regard to the functional coordination of policies, the statute of the CM Florence clearly makes reference to the idea of integrated regional development. That is to say that the "mission statement" goes beyond the functions formally assigned to the $\mathrm{CM}$ as many goals have to be implemented with partners (i.e. the region and/or the municipalities and the private sector). This ambition (and broad interpretation) for integrated regional development is even stronger in the strategic plan and the activities of the $\mathrm{CM}$ in the first years since its foundation show that strong emphasis is given to the strategic plan which has been constantly debated and updated.

\subsubsection{The strategic plan-PSM}

The strategic plan (Piano Strategico Metropolitano) is referred to in Art. 5 of the statute as "atto di indirizzo" (i.e. indicative and only coordinating) for the municipalities and municipal unions. This means that the plan may indicate goals and directions for municipal action but rather as a framework that depends also on regional policies and plans. The strategic plan should express which priorities in regional development are set jointly, i.e. it takes up problems and proposes projects. The plan sets development priorities, chooses methods and instruments and indicates resources (if available). It is binding for the $\mathrm{CM}$; the municipalities can voluntarily orient themselves to the plan.

In terms of content, the PSM touches upon a wide range of issues without giving too clear priorities. These are urban regeneration and inner peripheries, brownfield development and reduction of land consumption (as requested by the regional planning law), economic development through incubators and new spaces for manufacturing, bicycle highways, an integrated metro ticket for public transport and green infrastructure. However, some important topics such as affordable housing, renewable energies, resilience and sustainable tourism are underrepresented. The topics and policies addressed in the various documents of the strategic plan are organised in three priority axes (or visions as they are called): (1) universal accessibility (referring to space and mobility but also to services); (2) distributed opportunities (or opportunities for all); (3) territories for well-being (referring to ecological values and urban-rural linkages). Although there is one document called strategic plan, the strategic plan consists of a variety of documents and contributions (preparatory documents, an atlas with indicative maps and graphics, analytical documents, a synthesis report and visions) (CM Florence 2017a-f; 2018a-d). All other plans, PTM and PUMS in particular are in a way inferior as they are means of implementation of what is defined in the PSM as being the priority.

The plan defines 11 sub-areas that are supposed to be territorial frameworks for cooperation between $\mathrm{CM}$, municipalities and private actors in 
various fields. These areas are defined based on the assumption of some homogeneity in terms of socio-economic and spatial structures. They are not granted with any institutional status or governance form.

In terms of implementation, the regional government declared that the PSM will be part of the regional development programme (PSR) which increases the relevance in terms of funding (CM Florence 2018a). In fact, the PSR refers quite often to the Città Metropolitana and mentions a range of planned interventions.

The PSM foresees additional measures for those policies that are not part of the formal responsibilities of the CM. These are a round table for all actors and institutions in the realm of social policies and, even more important, a round table called EasyMetroCity as a voluntary unit for coordinating all municipal services. This round table would be a sort of self-governing unit and will be open also for private actors and neighbouring municipalities (CM Florence 2017b, 25).

The implementation and the regular update of the plan is accompanied by a promotion committee, in which the CM, the University of Florence, the chamber of commerce, a local bank and a few other actors are involved. This is a sort of soft governance mechanism because the committee also supervises an agency called "Laboratorio per l'Operatività del Piano Strategico Metropolitano". This lab is the agent of the promotion committee and brings together staff of the university, the CM and several private and public agencies (Fondazione per la Ricerca e l'Innovazione (FRI), Laboratorio Regional Design del Dipartimento di Architettura (Re-DLab), Istituto Regionale Programmazione Economica Toscana (IRPET)). It is the task of this lab to evaluate and monitor the progress of plan implementation (annual reports) but this group of experts also elaborated and designed the plan. The triannual update of the plan started in 2020 and puts an emphasis on the connections between the three major plans (CM Florence 2021). The three priorities (or visions) of universal access, general opportunities and areas of well-being have not been changed so far. The short sequence of updates of the plan demonstrates that measurement of progress is rather difficult in such a complex environment. The process of drawing up the plan is evaluated differently by interviewees in terms of inclusiveness, prospects for implementation and territorial priorities.

\subsubsection{The territorial plan-PTM}

The second instrument is the metropolitan territorial plan (Piano Territoriale Metropolitano - PTM) with the ultimate task of coordinating the communication structures, service networks and infrastructure being in the competence of the CM. This may include setting constraints and objectives for the activity and functions of the municipalities within the metropolitan territory (according to Art. 6 of the statute that defines the scope of the PTM in the context of the regional law on spatial planning, Regional Law 
no 65/2014). The plan is intended to be the reference framework for the municipal land use plans. The statute of the $\mathrm{CM}$ mentions municipal structure plans that can be issued by the CM (according to regional law, but not yet implemented). With a similar intention, directives can be issued that refer to the operational plans ( $\$ 95$ Regional Law no 65/2014). The council decision to start the plan preparation process was taken on 18 December 2018. According to the initial documents the plan will make specifications for mobility infrastructures and services of regional relevance, urban regeneration and reuse of existing settlements (brownfields), regional economy (industry, craft industry), preservation of natural heritage, territorial equalisation, digitisation and rural development (CM Florence 2018e, 5-6). The PTM will in addition include an atlas of brownfield sites, the indication of bioregions, zones of conflict and transports networks (cycling in particular) (CM Florence 2018e, 18). There will be less detailed specifications for settlement development, but the draft of the plan includes some conceptual elements that give guidance in this regard (CM 2019). These are brownfield sites as intervention zones for urban regeneration, biodistricts and their functional relationships, intermodality of transport and cycling routes and declarations of intended projects in the sub-territories.

It is questionable whether the $\mathrm{CM}$ will have the instruments and resources to implement all the specifications made in this plan that is largely indicative. Particularly with regard to settlement development, hardly any specifications are likely to be made. In general, regional plans in Italy do not specify densities or growth rates for municipalities. There is no binding planning of the structure and hierarchy of centres and only a weak prescription for the distribution of functions in space. With regard to the process, the PTM takes up the initiatives of the municipalities and seeks to form them into something spatially coherent. With regard to the territory of the $\mathrm{CM}$, the PTM largely uses the existing municipal unions as reference for the analysis for the environmental assessment and the consultation process ( $\mathrm{CM}$ Florence 2018e, 23; CM Florence 2018c, 54). However, as many municipalities are still in the process of adapting their local plans to new regional planning legislation, the whole process is delayed (CM Florence 2018e, 20).

The specifications with regard to settlement development are made in the regional plan and regional planning law. Art. 4 of the Regional Planning Law (2014) stipulates that settlement development and infrastructure development on undeveloped land may only take place in the contiguous builtup area (urbanised area, this area is defined by the municipalities in the local plans, which in turn are approved by the region). The Conferenza di Copianificazione, consisting of representatives of the region, the CM and the affected municipalities, decides on exceptions. The PTM must meet the requirements of the PIT of the region and the latest planning law of Tuscany that stipulates the cessation of land consumption. The PTM should make use of the territorial reference frameworks of the PIT which do not correspond with the territory of the CM (CM Florence 2018a, 16). For the Piana 
Fiorentina planning area (Ambito 06), for example, a risk map is shown in the PIT accordingly, which shows the disadvantages and criticalities of the settlement development to date: loss of open spaces and agricultural land, fragmentation and interruptions, underused railway lines, flood risks (Regione Toscana 2015b). In total, there are six territorial reference frameworks in the regional plan PIT that overlap with the territory of the CM (ibid). ${ }^{32}$

The PIT of the region is also the landscape plan and thus the sectoral plan for nature conservation (including agriculture, forestry, flood protection) (Regione Toscana 2015a). It is clear from the preparatory documents that this aspect is given a great deal of weight, while settlement development is given rather little importance. The PTM documents attempt to clarify the status and content. This gives the impression that the plan is more a concretisation of the statements of the PIT and less a product of local selfadministration. It is not yet clear whether the municipalities of the CM want to / should use the plan to give themselves a joint binding guiding principle for spatial development or whether only requirements from "above" are fulfilled. In any case, the aim is to draw up a holistic spatial development plan based on the objectives of the strategic plan PSM and to implement them.

The interviewees see the task of spatial planning mainly in the hands of the region and less in the CM, even if they speak of an emerging integrated planning system. In the past, each level made a plan, but only for itself. Now they are basically working top down. The new planning law from 2014 has created the conditions for this and has treated settlement development restrictively and has given priority to internal urban development. The combination of PIT and landscape plan sets clear limits for settlement development through environmental planning. The regional planning law establishes the principle of zero growth and the priority for internal development (reduction of land consumption). This is justified in so far as the region is only growing slightly and there is still potential for internal development on brownfield sites (in particular in Florence). ${ }^{33}$ This means that regional planning in the sense of controlling settlement development is not left to the CM (or the municipalities in general) but is restricted due to regional legislation and related supervisory functions. The territorial plan of the former province (PTCP) made only indicative statements about the settlement structure and environmental protection.

\subsubsection{The mobility plan-PUMS}

In the field of mobility, the CM created an integrated mobility plan (PUMS) in a cooperative process with the municipalities. The PUMS is supposed to take up the basic principles and suggestions of the PSM and, in fact, the PUMS partly reads as a copy of the PSM (sections on tram, multimodal hubs and cycling infrastructure). Unlike in Bologna, this plan was drawn up much later than the PSM (resolution was September 2019, CM Florence 
2019). The PUMS of the CM Florence is a strategic document with a validity of ten years. It is intended to form and bundle supra-communal initiatives such as the extension of the tram of Florence, a metropolitan cycling system or an integrated metropolitan tariff system for public transport. The PUMS is binding (National Law n. 232 2016, updated in 2017). ${ }^{34}$ Still, concrete decisions in the field of mobility and digitalisation and services require supra-local (metropolitan) importance (di interesse della Città Metropolitana). The PUMS takes as a territorial reference the municipal unions, the city of Florence and the municipalities of the first ring.

The first part of the mobility plan is analytic, describing the major challenges of the area. The second part makes suggestions for a number of projects and measures. These include bicycle way systems (which is more a collection of information with regard to the legal background and opportunities, the measures are not very concrete but the chapter on cycling is very long). A region-wide integrated tariff system is also one of the measures foreseen in the PUMS. An integrated metro ticket for Florence and the municipalities of the first ring exists already and includes busses, trams and regional railways in the area of Florence and a limited number of municipalities (but not for the whole territory of the CM) (Firenze, Calenzano, Fiesole, Sesto Fiorentino, Lastra a Signa, Signa and Campi Bisenzio and additional service in the municipalities Impruneta, Vaglia, Bagno a Ripoli and Scandicci). The re-introduction of a tram system in Florence is a great success story in particular for the first ring municipality of Scandicci. Previously the bus connection to the centre of Florence was rather poor. The tram was actively used in Scandicci to develop the centre of this town. However, the introduction of the tram was pushed by the city of Florence long before the introduction of the CM. The tram will be extended to Sesto Fiorentino, Revezzano and Bagno a Ripoli within the next years.

Another important project is the integration of the regional railway into a metropolitan train system (in connection with inter-modal hubs tramway - railway, cycling). Again, this idea had already been planned previously, largely financed by the municipalities and the region. Regional rail transport, which is very important for commuter networks, is the responsibility of the regional government.

In general, although the plan has several hundreds of pages, it is a plan of goals and strategies and a collection of existing initiatives (i.e. the tramway). Concrete measures are rare (except for the streets). It is more an indicative plan with scenarios (which is a significant difference in contrast to Bologna).

\subsubsection{Special funding: PON Metro and PeriMETRO}

The moderating and coordinating function of the CM can be illustrated by the responsibility of the $\mathrm{CM}$ in the context of the implementation of the PON Metro programme. PON Metro was part of the national operational programme in the EU funding period 2014-2020 and specifically targeted 


\section{Italy}

at the Città Metropolitane. The focus was on urban renewal as part of European territorial cohesion policy. In the first call for projects, however, only the core city was eligible to apply for funding, presumably due to the fact that in 2014 the CMs were not yet capable to act and the intention was no longer to hand over implementation to the provinces as the abolition of the provinces was basically done. But even with the second call, a tendency to give preference to the core city is evident. The CM is not a direct recipient of the subsidies and does not implement any projects itself. This is in the hands of the municipalities. However, the CM organises the selection process together with the municipalities and acts as an interlocutor for the government in Rome. PON Metro has significantly increased the municipalities' attention with regard to the role of the CM. Fifty projects with a total funding of about $52 \mathrm{M} €$ ( $39 \mathrm{M} € \mathrm{EU}$ funding) for schools, cycle paths and green infrastructure have been selected.

PeriMetro is a funding programme of the Italian government to support the development of the so-called peripheries. This relates to a recent discourse about disadvantaged areas in Italy. Fifty projects are supported in the territory of the CM Florence (in the three categories of social and cultural infrastructures, cycling and walking infrastructure and public spaces, in total ca. $50 \mathrm{M} €)$. The selection process is similar to PON Metro. The importance of EU funding is also evident in the Piana Fiorentina project (see above).

In summary, it can be said that the planning competences of the CM are largely indicative. Only schools and transport infrastructure (provincial and regional roads, recently bicycle highway) fall within the scope of competence of the CM. However, the CM essentially acts in a coordinating and subsidiary manner and collaborates with the municipalities.

\subsubsection{Conclusion}

When comparing the factual competences of the $\mathrm{CM}$ and the answers of the interviewees to the question of the important and urgent subjects of inter-municipal politics, it is noticeable that some of the mentioned urgent problems of city-regional development are part of the functional portfolio of CM. This is true for mobility and sustainable transport and urban regeneration, whereas there are large gaps with regard to topics such as circular economy (waste management) or tourism (for which there is no real control so far), climate adaptation and the coordinated promotion of the regional economy. In particular, the aspect of housing is hardly addressed at all although urban regeneration is one of the priorities.

With regard to the classification of functions, it is also clear that, according to the statute, the law and the existing plans, the CM Florence is assigned more functions in the area of reproduction and services of general interest (e.g. provincial roads, schools, infrastructure), but at the same time a coordination function for strategic regional development is indicated. The regional government of Tuscany, however, sees regional development as a 
joint matter of the region and the CM. Moreover, at least the region and the $\mathrm{CM}$ itself emphasise the attempt to support socio-economic development. Although the idea of competitiveness is present in the strategic plan, the possibilities for implementation (resources, instruments, actors such as development agencies) are lacking. The region's expectations of the CM are quite high: it should implement regional policy and at the same time form a level of horizontal self-regulation. Municipal actors expect investments in infrastructure (maintenance and extension of the roads, bridges) from the CM.

The strategic plan is the new instrument of the CM, a comparable instrument was previously not available to the province. With the new instrument, the development function is emphasised and clearly separated from the rationale of the former province, which acted in a regulatory way. However, the CM can only give development impulses to a limited extent: in the area of infrastructure and through the PON / PeriMETRO programmes. In contrast to the PTM, the PSM is intended to be a holistic and process-oriented instrument, with which spatial and sectoral projects of regional development are defined and steps of implementation are indicated. It is procedurally designed and is to be renewed every three years and updated annually. The PSM is supposed to form the basis for the objectives of the PTM and the PUMS and in fact at least on a declaratory level, there is a certain degree of coherence between the three documents. But the PSM is largely coordinative and indicative, i.e. makes suggestions but prospects for implementation are vague or depend on some unknown variables. All three plans are, to a great extent, compilations of projects and measures that were on the agenda before (extension of the tramway, new train station for high-speed trains, landscape park Piana Fiorentina). The frequent update of the PSM also may create problems of coherence as the other plans (PUMS, PTM) are not updated so frequently.

The guiding idea of the Delrio reform on the national level was that of administrative simplification (both procedural and institutional), efficiency and cost reduction in the public sector. This is visible in some of the projects such as the sportello unico delle attività produttive (SUAP) - Unitary counter for economic activities. The idea of decentralisation can be seen as ambivalent, because in the end the regional government has gained personnel and functions and in fact some observers see the Delrio reform as an act of re-centralisation as the regions gained a lot of functions. However, both the interviewees and the documents speak of decentralisation. At least as a level of inter-municipal interest-mediation and coordination, the CM is more important and effective than the province. The latter was an independent level, which often enough worked in a rather contrary way to the region and municipalities. The interviewees confirmed that the CM is weaker than the former province. They see the benefit in the formation of a forum of mayors, which is now no longer to be shared with the provincial president. The province thus developed its own interests and was more an institution of the state (as an independent level), it acted top down. The CM, in contrast, can be understood as an organ of horizontal self-regulation. However, 


\section{Italy}

conflicts are naturally on the increase. ${ }^{35}$ At the same time a concentration on Florence can be observed (politically) as many smaller municipalities do not feel sufficiently included in the plan-making processes. This points to problems of internal territorial coherence. In fact, in June 2021, the Mayor of Florence announced that there would be closer cooperation with the 12 communities of the first ring. This implies in principle a splitting of the territory of the $\mathrm{CM}$ into a core and a periphery and this splitting was already observable in the past. The unstable or unclear functional as well as political relationships of the sub-territories (Mugello in particular) and the core city have been an issue from the beginning in the Città Metropolitana of Florence.

Overall, the CM Florence lacks the possibilities and instruments for implementation. The wealth of information and ideas contained in the strategic plan is inspiring, but contrasts with the abilities and possibilities of implementation. It remains to be seen whether the CM will succeed in forming specific alliances with municipalities and regions. All in all, the implementation of the Delrio Law in Tuscany is an act of centralisation, since in addition to the creation of the $\mathrm{CM}$, the provinces have been decisively weakened. Many functions and the personnel have been transferred to the region, especially in the field of environmental planning and landscape protection.

\subsection{Conclusion: recent changes of city-regional governance in Italy}

The introduction of the new entity was also not part of a visionary idea or a national reform strategy of the multi-level governance system that would give a greater role for $\mathrm{CM}$ or at least give clearer functional profiles for the different levels (in terms of avoiding redundancy). The creation of the $\mathrm{CM}$ is only one element of a wider stepwise and fragmented process of the modernisation of the public sector that is largely guided by ideas of decentralisation, cost efficiency, simplification and, to a lesser degree, territorial coherence. In fact, it's questionable if we can use the notion "reform" as most of the changes were rendered on an ad hoc basis and did not follow a coherent and comprehensive design (also due to the frequent changes of governments, with technical interim governments in power and changes required by the Constitutional Court). In Italy, various motives are mixed, such as decentralisation and local autonomy, desire for greater coherence of socio-economic development policies (vs. fragmentation), simplification of the public sector and austerity.

In view of current socio-spatial developments in Italian city-regions a new form of cooperative territorial action is actually needed (Fedeli 2017; Perrone and Rossi 2018). In the end, the reform was limited to a purely constitutional territorial reform; planning issues were not considered very strongly. The top-down implementation of the city-regions is a logical development, since the voluntary regional conferences of the 1990s were not very successful. However, the debate of the 1990s created a certain path 
dependency (Vandelli and Vitali 2014, 80). New ideas (governance), apart from the discussion on strategic planning, were not considered. Flexible forms of cooperation in different spatial settings for different tasks would be more appropriate for the issues that have to be addressed at the city-regional level (Riboldazzi 2017, 96).

In a way, the Delrio reform was also an attempt to design a system of territorial public administration that was rather uniform in a more flexible way. The openness of the Delrio law would in principle allow for contextspecific arrangements in each metropolitan city but the regions did only in part interpret the creation of metropolitan cities in this way. There are, nevertheless remarkable differences and these can in part be explained by path-dependencies. In those city-regions where the former province took a more pro-active role for regional development as Milan or Bologna, the $\mathrm{CM}$ as successor (also on terms of staff and implicit knowledge) follows a similar pattern of action. Other provinces / CM were less prepared for a role change. There are also differences with regard to the autonomy that is given to the $\mathrm{CM}$ by the respective regional government. Emilia-Romagna and Toscany display a more centralised approach while Lombardy followed the principle of decentralisation and this is not only a question of size (Mobilio 2018; Tubertini 2015). The national funding schemes PON Metro and Bando Periferie have had a limited homogenisation effect as this extra funding was very relevant for all $\mathrm{CM}$. As the $\mathrm{CM}$ had to face serious budget cuts in the years 2015, 2016 and 2017, these funding schemes made an important contribution to the implementation capacity of the metropolitan cities.

\subsubsection{Comparison Firenze - Bologna}

The two metropolitan cities of Florence and Bologna have a lot in common but there are also remarkable differences with regard to the factual practice of city-regional governance. From an institutional perspective both $\mathrm{CM}$ share a lot, largely because the national law defines the framework. As they are similar in size, the number of councillors is identical and also the conditions for the eventual introduction of the direct election of the metropolitan council are similar. In both city-regions, this is not a priority. Also, both regional governments opted for a pattern of recentralisation as more functions were shifted to the region. Differences are observable with regard to the institutional legacies. What happened in Bologna since the 1990s in terms of city-regional initiatives and inter-municipal cooperation (unioni di comuni) had a big impact for the start and performance of the CM. In a way this is a seamless continuation. As a result, there is closer collaboration between the municipalities (and their unions) and the CM, and in particular the administration of the core city has close working relationships with the $\mathrm{CM}$. Coordination with the regional government seems to be more regular in Bologna. In any case, the Delrio reform did strengthen the core city as the provincial counterpart does no longer exist and the mayor of the core city is 


\section{Italy}

also the political and administrative leader of the CM. This may have two antagonistic effects: greater effectiveness and better coordination between the core city and the CM or suspicion of the other member municipalities of the CM because the core city extends its influence.

A major difference exists, also in terms of institutional design, with regard to the use of municipal unions as an instrument for coordinating local interests and services. In Bologna, the municipal unions cover almost the whole territory of the CM and their representation forms an institutional pillar next to the council and the metropolitan conference. In Florence, there is no such role and function for municipal unions and the existing unions do cover only the peripheral territories (although representing large parts of the territory). The municipalities of the first ring are not organised in municipal unions.

In both city-regions, issues of territorial political representation emerged at the beginning because the composition of the metropolitan council with only 18 members represents political parties but not communities. In Bologna, however, this is mitigated at least in part as the municipal unions are an important pillar of the arrangement (in terms of territorial representation and as implementation agencies for policies and programmes of the $\mathrm{CM}$ ). If output legitimacy (i.e. effective problem-solving) or other means of political communication directly addressing citizens can soften this lack of territorial representation remains to be seen.

In terms of functions, it's clearly visible that both CM interpret the general task of strategic planning and coordination in a different way. Bologna gives a clear emphasis on mobility and (public) transport and the PSM has large parts dedicated to governance issues and joint public administration. This is largely absent in the PSM of the CM Florence. The PSM in Florence is more an urban design plan that gives greater emphasis on the differences of territorial subunits as soft spaces. The city-regional sustainable mobility plan (PUMS) of CM Florence is a collection of projects that were partly planned before. In Florence, the PTM is not yet finished. The plans of both city-regions share a great concern for urban regeneration and the support of the peripheries but Bologna established an equalisation scheme. In both $\mathrm{CM}$, the PSM is seen as the superordinate plan and the other plans and documents (PUMS, PTM) are in a way an implementation tool of the PSM. The sequence of adaptations of the PSM is higher in Florence which probably may cause temporal inconsistencies with the other plans that are not adapted so frequently.

With regard to questions of space and scale, bot CM are identical with the jurisdictional boundaries of the former province but this is less a problem in Bologna than in the greater Florence area where there are several spatial inconsistencies (Piana Fiorentina, city-network of northern Tuscany). There are also differences with regard to the internal territorial coherence as can be demonstrated by the splitting up of the territory of the CM Florence. There is a difference in terms of closer cooperation between Florence and the 12 communities of the first ring and the rest of the CM. 


\section{Notes}

1 Five regions have a special status with higher autonomy (Sardinia, Sicily, Valle d'Aosta, Friuli-Venezia Giulia and Trentino).

2 Article 117 of the Constitution decrees that the matter of territorial governance is the object of competing legislation between state and regions. This means that the central government sets the main guidelines and the general principles, while the regions determine specific laws and rules.

3 There are, however, implementation deficits. Many municipalities have outdated plans or the plan never came into force.

4 These include, besides others, Emilia Romagna, Lombardy, Tuscany.

5 Decree-Law no. 95 of July 6, 2012 provided - in art. 17 - for the reduction and reorganisation of the provinces (a topic known to the public debate as Dossier no. 9 "suppression of the provinces") and - in art. 18 - the establishment of metropolitan cities and the suppression of the provinces in their territory.

6 see a complete report on http://www.upinet.it/4692/istituzioni_e_riforme/lattuazione_della_legge_56_in_ambit_regional/ (29 June 2016).

7 The union of municipalities is an Italian body governed by legislative decree no. 267 of 18 August 2000, which implements law no. 265 of 3 August 1999, in particular article 32 . The entity is made up of two or more municipalities for the joint exercise of functions or services falling within the municipal competence. The union is endowed with statutory autonomy within the framework of the principles established by the Constitution and by the community, state and regional rules. Legislative Decree no. 267/2000 defines it as a local authority, but the Constitutional Court ruling no. 50 of 2015 specifies that it is an institutional form of association between municipalities.

8 Riboldazzi (2017) refers to figures from ANCI and mentions 448 inter-municipal unions, 60 of which are in Lombardy. 2,387 municipalities are involved.

9 As part of several fiscal consolidation measures that have been rendered postcrisis, the budget cuts for the provinces and CM defined by national decrees were 300 million in 2011 and 500 million in 2012 (CM Milano 2020, 7). The Stability Act in 2015 requested additional budget cuts (Agnoletti et al. 2015, 248).

10 http://osservatorio.urbanit.it/pianificazione-territoriale-e-urbanistica/.

11 "setting constraints and objectives for the activity and performance of the functions of municipalities within the metropolitan territory", own translation.

12 Draft law on the reorganisation of Provinces n. 3558, conversion into law of Decree Law n. 188 of 5 November 2012, on the subject of Metropolitan Provinces and Cities http://www.senato.it/japp/bgt/showdoc/16/DDLPRES/0/ 683012/index.html?part=ddlpres_ddlpres1.

13 Nei nostri propositi la Città metropolitana vuol essere un ente leggero nella struttura, ma forte nella capacità di indirizzo e di coordinamento dei Comuni, un ente che svolge in prevalenza funzioni di pianificazione e programmazione, in una visione in cui la Città metropolitana è innanzitutto una federazione di Comuni.

14 https://www.bibliotecasalaborsa.it/cronologia/bologna/1959/piano_intercomunale_del_comprensorio_bolognese.

$15 \mathrm{https}$ ://autonomie.regione.emilia-romagna.it/unioni-di-comuni/approfondiment i/attuazione-del-riordino-territoriale.

16 The smaller municipalities in the mountainous areas used a similar format for an even longer period.

17 The notion circondario is an older notion for a subdivision of a province. The circondario Imolese existed since the 1990s as an expression of a limited autonomy of this area. In 2010 the regional government of Emilia Romagna abolished the circondari and the circondario Imolese became a unione di comuni but kept the name. 
18 https://www.cittametropolitana.bo.it/pianificazione/cum.

19 https://www.ctss.bo.it/I_componenti_e_la_governance/Mappa_della_governance_della_Citta_metropolitana_di_Bologna.

20 https://www.cittametropolitana.bo.it/portale/Home/Archivio_news/Firmato_ il_Patto_tra_Bologna_Modena_e_Ferrara_L_obiettivo_e_rendere_quest_area_ ancor_piu_competitiva.

21 On a wider scale, an ESPON project investigates options for the creation of a space between Milan and the southern area of Lombardy and the CM Bologna. https://www.espon.eu/imagine.

22 http://www.fondazioneinnovazioneurbana.it/bologna/piano-strategicometropolitano.

23 http://psm.bologna.it/Consiglio_di_sviluppo.

24 With strong reference to the Carta di Bologna. The goal of sustainable development and reduction of land consumption was already defined in the period 2016-2020, but this was a voluntary commitment.

25 This is done because the plans have an expiry date (CM Bologna 2020a).

26 http://www.legislazionetecnica.it/18164/fonte/lr-toscana-31-12-1984-n-74.

27 Two councillors are from Sesto Fiorentino and Pontassieve each. The other councillors are from Lastra a Signa, Empoli, Barbarino di Mugello, Bagno a Ripoli, Scandicci, Campi Bisenzio, Greve in Chianti, Vinci, Marradi.

28 Following a decision of the administrative court, http://www.cittametropolitana. fi.it/ambiente/ (15 April 2021).

29 The spatial development plan of the old province (PTCP) is still valid until the new PTM will come in force.

30 PIT “Acque e Biodiversità - Tutela e valorizzazione delle risorse ambientali del Padule di Fucecchio e delle colline delle Cerbaie" with 12 municipalities and four provinces (CM Florence 2018d, 115).

31 Due to a government decision in 2019, the prospects for the start of construction works for the new (and longer) runway became more realistic. However, as there were some doubts about the results of environmental assessment, the implementation is still pending.

32 n. 5 Val di Nievole e Val d'Arno Inferiore, n. 6 Firenze-Prato-Pistoia e n. 7 Mugello, parte degli ambiti paesaggistici n. 9 Val d'Elsa, n.10 Chianti e n. 11 Val d'Arno Superior.

33 In March 2021 the final document of the PTM was not yet available.

34 A decree law from 4 August 2017 (Ministero delle Infrastrutture e dei Trasporti) defined guidelines for the metropolitan mobility plans and stipulated that access to funds would not be possible without such a plan.

35 The PSM, like the CM, cannot solve the conflicts of territorial development that emerge between Florence and Scandicci on a smaller scale. These are numerous and arise on the immediate border where infrastructure of Florence is used by citizens of Scandicci and retail centres of Scandicci attract citizens of Florence: a joint development of projects is obviously not conceivable, neither is coordination of larger retail centres. It was once thought to agree on a joint protocol between the two cities, but this has not come about.

\section{References}

\section{Laws}

Constitutional Judgment No. 220 of 2013 Constitutional legitimacy judgment. Official Gazette of Republic of Italy of 24.07.2013 - 1st Special Series No. 30.

Constitutional Law No. 3 of 8 October 2001. Amendments to Title V of the second part of the Constitution (articles 114-132 of the Constitution), Regulation of 
local autonomies. Official Gazette of Republic of Italy, General Series No. 248 of 24.10.2001.

Decree Law No. 267 of 18 August 2000. Consolidated text of the laws governing local authorities. Official Gazette of Republic of Italy, General Series n. 227 of 28.09.2000 - Ordinary Supplement n.162.

Decree Law No. 188 of 5 November 2012. Urgent provisions on provinces and metropolitan cities. Official Gazette of Republic of Italy, General Series n. 259 of 06.11.2012.

Decree Law No. 4 of 8 August 2017. Individuazione delle linee guida per i piani urbani di mobilita' sostenibile, ai sensi dell'articolo 3, comma 7, del decreto legislativo 16 dicembre 2016, n. 257. (17A06675) (Official Gazette of Republic of Italy of 1 05-10-2017, No. 233) Ministero delle Infrastrutture e dei Trasporti.

National Law No. 1150 of 17 August 1942 on Urban Planning. Official Gazette of Reign of Italy No. 224 of 16.10 .1942$.

National Law No. 142 of 8 June 1990 on the Ordering of local autonomies. Official Gazette of Republic of Italy, General Series No. 135 of 12.06.1990 - Ordinary Supplement No. 42.

National Law No. 436 of 2 November 1993 on Deferral of certain terms provided for by law no. 142 of 8 th June 1990, regarding metropolitan areas and the establishment of new provinces. Official Gazette of Republic of Italy, General Series No. 262 of 08.11.1993.

National Law No. 265 of 3 August 1999 on Provisions regarding autonomy and ordering of local bodies, as well as modifications to the law no. 142 of 8 th June 1990. Official Gazette of Republic of Italy, General Series No. 183 of 06.08.1999 Ordinary Supplement No. 149.

National Law No. 232 of 2016. Bilancio di previsione dello Stato per l'anno finanziario 2017 e bilancio pluriennale per il triennio 2017-2019. Official Gazette of Republic of Italy of 21.12. 2016, Series No. 297.

National Law No. 42 of 5 Mai 2009 on Delegation to the Government on tax federalism, in implementation of article 119 of the Constitution. Official Gazette of Republic of Italy, General Series No. 103 of 06.05.2009.

National Law No. 135 of 7 August 2012 on Conversion into law, with amendments, of the Decree Law No. 95 of 6 July 2012, containing urgent provisions for the revision of public spending with unchanged services to citizens. Official Gazette of Republic of Italy, General Series No. 189 of 14.08.2012 - Ordinary Supplement No. 173.

National Law No. 56 of 7 April 2014 on Provisions on metropolitan cities, provinces, unions and mergers of municipalities. Official Gazette of Republic of Italy, General Series No. 81 of 07.04.2014.

National Law No. 190 of 23 December 2014 on Provisions for the formation of the annual and multiannual state budget (Stability Law 2015). Official Gazette of Republic of Italy, General Series No. 300 of 29.12.2014 - Ordinary Supplement No. 99.

National Law No. 208 of 28 December 2015 on Provisions for the formation of the annual and multiannual state budget (Stability Law 2016). Official Gazette of Republic of Italy, General Series No. 302 of 30.12.2015 - Ordinary Supplement No. 70.

Regione Emilia Romagna (RER) (2004). Regional Law, 24/2004. Riforma del sistema amministrativo regionale e locale. Unione Europea e relazioni internazionali. Innovazione e semplificazione. Rapporti con l'università. Bologna. 
Regione Emilia Romagna (RER) (2012). Regional Law 21/2012. Misure per assicurare il governo territoriale delle funzioni amministrative secondo i principi di sussidiarietà, differenziazione ed adeguatezza. Bologna.

Regione Emilia Romagna (RER) (2015a) Intesa Generale Quadro Regione e Città metropolitana di Bologna (art. 5 L.r. n. 13/2015). Bologna.

Regione Emilia Romagna (RER) (2015b). Regional Law 13/2015. Riforma del sistema di governo regionale e locale e disposizione su città metropolitana di Bologna, province, comuni e loro unioni. Bologna.

Regione Emilia Romagna (RER) (2017). Regional Law 24/2017. Disciplina regionale sulla tutela e l'uso del territorio. Bologna.

Tuscany Regional Law No. 65 of 10 November 2014 on Rules for the government of the territory. (442) Official Bulletin n. 53, part one, of 12 November 2014.

Tuscany Regional Law No. 22 of 3 March 2015 on Reorganization of the provincial functions and implementation of the Law No. 56 of 7 April 2014 (Provisions on metropolitan cities, provinces, unions and mergers of municipalities). Amendments to the regional laws 32/2002, 67/2003, 41/2005, 68/2011, 65/2014. Official Bulletin of Region Tuscany, Part 1, No. 10 of 06.3.2015.

Tuscany Regional Law No. 9 of 5 February 2016 on Reorganization of the functions of the provinces and the metropolitan city of Florence. Amendments to regional laws 22/2015, 70/2015, 82/2015 and 68/2011. Official Bulletin n. 4, part one, of 10 February 2016.

\section{Literature}

Agenzia per la Coesione Territoriale (2019) Programma operativo nell'ambito dell'obiettivo "Investimenti in favore della crescita e dell'occupazione" Versione 5.0. Available at: http://www.ponmetro.it/wp-content/uploads/2016/11/Progra mme_2014IT16M2OP004_5_0_it.pdf.

Agnoletti, C., Ferretti, C. and Lattarulo, P. (2015) Strumenti di finanziamento della Città metropolitana. In: La finanza territoriale. Milano: Franco Angeli, pp. 241-254.

Allulli, M. (2010) La riforma metropolitana e i suoi dilemmi. Paper. Cittalia. Fondazione ANCI ricerche.

Ambrosanio, M.F.; Balduzzi, P. and Bordignon, M. (2016) Economic crisis and fiscal federalism in Italy. In: Multi-Level Finance and the Euro Crisis. Causes and Effects, Ahmad, E.; Bordignon, M. and Brosio, G. (eds.). Cheltenham: Edward Elgar, pp. 212-246.

Assolombarda/Rete Associazioni Industriali Metropolitani (2014) Manifesto delle Città Metropolitane italiane Available at: https://www.assolombarda.it/servizi/ assolombarda-e-confindustria/informazioni/manifesto-delle-citta-metropolitaneitaliane (accessed 15 August 2020).

Baccetti, C. (2011) Italy. In: The Second Tier of Local Government in Europe, Bertrana, X. and Hubert, H. (eds.). London: Routledge, pp. 164-183.

Balducci, A. (2003) Policies, plans and projects. Governing the city region of Milan. DISP, 152, 59-70.

Balducci, A.; Fedeli, V. and Pasqui, G. (2011) Strategic Planning for Contemporary Urban Regions. City of Cities: A Project for Milan. London: Routledge.

Balducci, A.; Fedeli, V. and Curci, F. (2017) Post-Metropolitan Territories. London: Routledge. 
Barbieri, C.A. (2012) Sul riordino accelerato delle Autonomie territoriali. Coglierne le potenzialità per il governo del territorio. Available at: http:/www.inu.it/wpcontent/uploads/Barbieri_Sul_riordino_accelerato_delle_Istituzioni_territoriali. pdf (accessed 11 November 2020).

Behnke, N. (2010) Politische Dezentralisierung und administrative Dekonzentration in Italien. In: Kommunale Aufgabenwahrnehmung im Wandel, Bogumil, J. and Kuhlmann, S. (eds.) Wiesbaden: Springer VS, pp. 299-322.

Bobbio, L. (2005) Italy. After the storm. In: Comparing Local Governance. Trends and Developments, Denters, Bas and Rose, Lawrence E. (eds.) London: Palgrave, pp. 29-46.

Bolgherini, S. and Lippi, A. (2016) Italy. Remapping local government. From re-allocation and re-shaping to re-scaling. In: Theoretical Foundations and Discussions on the Reformation Process in Local Governments. IGI Global; Sadioglu, U. and Dede, K. (eds.), pp. 265-288.

Bolgherini, S.; Lippi, A. and Maset, S. (2016) In mezzo al guado. La governance subregionale tra «vecchie» province e «nuove» aree vaste. Rivista italiana di politiche pubbliche, 16(3), 341-372.

Brunazzo, B. (2010) Italian regionalism. A semi-federation is taking shape: Or is it? In: Territorial Choice. The Politics of Boundaries and Borders, Baldersheim, $\mathrm{H}$. and Rose, L. (eds.) London: Palgrave MacMillan, pp. 180-197.

Camagni, R. (2014) Città metropolitane? No, solo province indebolite. lavoce.info from 18 February 2014. Available at: https://www.lavoce.info/archives/17288/ citta-metropolitane-delrio-province/.

Camera dei deputati (2020a). Città Metropolitane e province. Roma: Servizio Studio.

Camera dei deputati (2020b) Le entrate delle regioni e degli enti locali. Roma: Servizio Studio.

Citroni, G.; Lippi, A. and Profeti, S. (2013) Remapping the state: Inter-municipal cooperation through corporatisation and public-private governance structures. Local Government Studies, 39(2), 208-234. DOI: 10.1080/03003930.2012. 707615 .

Città metropolitana (CM) di Bologna (2016a) Convergenze metropolitane Bologna, relazione generale, allegato $a$. Bando per la riqualificazione e la sicurezza delle periferie (DPCM 25/5/2016). Bologna.

Città metropolitana (CM) di Bologna (2016b). Convenzione Quadro per la Collaborazione Istituzionale fra Città Metropolitana, Unioni e Singoli Comuni. Bologna: dell'area Bolognese.

Città metropolitana (CM) di Bologna (2016c). Statuto della Cittá Metropolitana di Bologna. Bologna.

Città metropolitana (CM) di Bologna (2017) Le linee di mandato 2016-2021 della città metropolitana. Bologna.

Città metropolitana (CM) di Bologna (2018a) Le Unioni di Comuni dell'area metropolitana bolognese. Lo stato di salute. Report e analisi degli incontri sul territorio. Bologna.

Città metropolitana (CM) di Bologna (2018b). Piano Strategico Metropolitano di Bologna (PSM 2.0) 2018. Bologna.

Città metropolitana (CM) di Bologna (2019a) Agenda Metropolitana per lo sviluppo sostenibile. Bologna.

Città metropolitana (CM) di Bologna (2019b) Piano urbano della mobilità sostenibile. Bologna: Relazione. 


\section{Italy}

Città metropolitana (CM) di Bologna (2020a) Obiettivi Metropolitani. Allegato 4 Il consumo di suolo. Bologna.

Città metropolitana (CM) di Bologna (2020b) Obiettivi Metropolitani. Allegato 13 I poli funzionali e le eccellenze. Bologna.

Città metropolitana $(\mathrm{CM})$ di Bologna $(2020 \mathrm{c})$ Regole. Le norme della proposta di Piano Territoriale Metropolitano. Bologna.

Città metropolitana $(\mathrm{CM})$ di Firenze (2016) Deliberazione del consiglio metropolitano 115 del 28/12/2016 "Progetto Integrato Territoriale "Piana Fiorentina” Consortium Agreement. Approvazione Schema di Accordo”. Firenze.

Città metropolitana (CM) di Firenze (2018a) Piano territoriale metropolitano. Relazione di avvio del procedimento. Florence.

Città metropolitana (CM) di Firenze (2018b) Rinascimento Metropolitano. Rinascimento Metropolitano. Stati generali della Città Metropolitana. (Report June 2018). Florence.

Città metropolitana (CM) di Firenze (2018c) Rinascimento Metropolitano. Piano Strategico 2030 Scenario attuale tendenziale - Approfondimenti. Florence. (updated document, December 2018).

Città metropolitana (CM) di Firenze (2018d) Rinascimento Metropolitano. Piano Strategico 2030 Visione strategica. Florence. (updated document, December 2018).

Città metropolitana (CM) di Firenze (2018e) Rinascimento metropolitano. Piano strategico 2030 (documento approvato 19 December 2018). Florence.

Città metropolitana (CM) di Firenze (2019) Piano Urbano de la Mobilità SostenibileRelazione Progetto completa. Florence.

Città metropolitana (CM) di Firenze (2021). Evento conclusivo. Presentazione dei resultati complessivi del percorso partecipativo (Report). Florence.

Città metropolitana $(\mathrm{CM})$ di Firenze / comitato scientifico del piano strategico (2017a). Atlante del piano. Florence.

Città metropolitana $(\mathrm{CM})$ di Firenze / comitato scientifico del piano strategico (2017b). Piano strategico. Visione strategica. Florence.

Città metropolitana $(\mathrm{CM})$ di Firenze / comitato scientifico del piano strategico (2017c) Rinascimento metropolitano. Piano strategico 2030 (documento di sintesi). Florence.

Città metropolitana $(\mathrm{CM})$ di Firenze / comitato scientifico del piano strategico (2017d) Rinascimento metropolitano. Verso il Piano Strategico Metropolitanao (Documento di Lavoro). Florence.

Città metropolitana $(\mathrm{CM})$ di Firenze / comitato scientifico del piano strategico (2017e) Rinascimento Metropolitano. Visione e Prospettive. Piano Strategico 2030 (documento di lavoro). Florence.

Città metropolitana $(\mathrm{CM})$ di Firenze / comitato scientifico del piano strategico (2017f). Verso il Piano Strategico. SCENARIO Attuale. Florence.

Città metropolitana (CM) di Milano (2016). Milano - Metropoli Reale - Metropoli Possibile. Piano Strategico. Milan: Città metropolitana (CM) di Milano.

Città Metropolitana (CM) di Milano (2020) Nota integrative al bilancio di previsione 2020 - 2022. Milan. Available at: https:/www.cittametropolitana.mi.it/portale/ amministrazione-trasparente/bilanci/bilancio_previsione/Bilancio-di-previsione2020 (accessed 18 August 2020).

Colavitti, A.M., Usai, N. and Bonfiglioli, S. (2013) Urban planning in Italy: The future of urban General Plan and governance. European Planning Studies, 21(2), 167-186. DOI: 10.1080/09654313.2012.722913. 
Consiglio Italiano per le Scienze Sociali (CSS) and Dematteis, G. (ed.) (2011) Libro Bianco sul Governo delle città italiane. In: Le grandi città italiane. Società e territori da ricomporre, Venice: Marsilio, pp. 379-423.

Cotta, M. and Verzichelli, L. (2007) Political Institutions in Italy. Oxford: Oxford University Press.

D’Albergo, E. (2012) When metropolitan reform and development policy are loosely coupled: Rome as a case of weak political rescaling. Paper presented at the Conference "Governing the Metropolis: Powers and Territories", Paris, November 28-30.

Debernardi, L. and Rosso, E. (2008) Governance and Sistemi Urbani. Roma: Carocci.

Delpiano, A. and Ferroni, L. (2016) Dalla Provincia alla Città metropolitana di Bologna: Il caso del Passante autostradale. Working papers. Rivista Online di Urban@it-2/2016.Urban@it.

De Luca, G. (2017) La Città Metropolitana di Firenze. In: Pianificare le città metropolitane in Italia. Interpretazioni, approci, prospettive, De Luca, G. and Moccia, F D. (eds.) Roma: INU edizioni, pp. 207-240.

De Santis, F. (2015) Il rapporto tra Pianificazione Strategica e Pianificazione Territoriale della Città Metropolitana nella legislazione della Regione Toscana. Osservatoriosullefonti.it, fasc, 2/2015, pp. 1-10.

Donati, D. (2018) Ex uno plures. The new models of Government for the "Large Area" in the recent reforms in Italy. In: Italien zwischen Krise und Aufbruch, Grasse, A.; Grimm, M. and Labitzke, J. (eds.) Cham: Springer, pp. 85-125.

Fabbricatti, K. (2016) Bologna. Smart community e Smart governance. In: Città metropolitane e Smart governance. Iniziative di successo e nodi critici verso la Smart City, Papa, R.; Gargiulo, C. and Battarra, R. (eds.). Napoli: fedOAPress, pp. 92-130. DOI: 10.6093/978-88-6887-005-8.

Fedeli, V. (2012) Planning in Italy, seventy years after the first national planning law. DISP: The Planning Review, 48(2), 106-113.

Fedeli, V. (2017) Metropolitan governance and metropolitan cities in Italy: Outdated solutions for processes of urban regionalisation? Raumforschung und Raumordnung, 75(3), 265-274.

Gabellini, G.; Proli, S. and Tondeli, S. (2017) Città metropolitana di Bologna. In: Pianificare le città metropolitane in Italia. Interpretazioni, approci, prospettive, De Luca, G. and Moccia, F.D. (eds.) Roma: INU edizioni, pp. 159-206.

Garganese, R.; Di Stefano, R.; Iary, I.P. and G. (2018) La finanza degli enti territoriali nel 2017. In: La finanza territoriale. Rapporto 2018. Soveria Mannelli: Rubettino, pp. 21-41.

Giglioni, F. (2016) La regolazione del consumo di suolo nelle prime esperienze delle città metropolitane Working papers. Rivista Online di Urban@it-2/2016.

Giovannoni, G. and Innocenti, R. (2010) Dallo schema strutturale al secondo Piano strategico. Il governo dell'area metropolitana. In: Firenze. Il progetto urbanistico. Scritti e contributi 1975-2010, Giorgieri, P. (ed.) Alinea editrice: Firenze, pp. 595-609.

Grasse, A. (2005) Modernisierungsfaktor Region: Subnationale Politik und Föderalisierung in Italien. Wiesbaden: VS-Verlag.

Gualini, E. (2003) The region of Milan, In. In: Metropolitan Governance and Spatial Planning. Comparative Case-Studies of European City-Regions, Kreukels, A.; Salet, W. and Thornley, A. (eds.). London: Spon Press, pp. 264-284. 
Jouve, B. and Lefèvre, C. (2002) The metropolitan city of Bologna: from the 'Third Italy' to the Second Republic. In: Local Power, Territory and Institutions in European Metropolitan Regions, Jouve, B. and Lefèvre, C (eds.) London: Routledge, pp. 35-56.

Köppl, S. (2007) Das Politische System Italiens. Eine Einführung. Wiesbaden: VS-Verlag.

Kuhlmann, S. and Wollmann, H. (2014) Introduction to Comparative Public Administration: Administrative Systems and Reforms in Europe. Cheltenham: Edward Elgar.

Magnier, A. (2003) Subsidiarity: Fall or premise of local government reforms. The Italian case. In: Reforming Local Goverment in Europe. Closing the Gap between Democracy and Efficiency, Kersting, N. and Vetter, A. (eds.) Wiesbaden: Springer VS, pp. 183-196.

Ministero Economia (2014) Programma operativo nell'ambito dell'obiettivo "Investimenti in favoe della crescita e dell'occupazione", PON Metro 20142020. Roma. Available at: http://www.pongovernance1420.gov.it/wp-content/ uploads/2017/01/Punto_2b_-_PON_GOV_2014-2020_Rev_post_CdS.pdf.

Ministero Economia (2016) PON Città metropolitane 2014-2020 - Documento di sintesi. Roma. Available at: http://www.ponmetro.it/wp-content/uploads/2016/ 10/SINTESI_PON_METRO_bozza_9_maggio_2016R-2.pdf.

Mobilio, G. (2018) I diversi “modelli” di Città metropolitana a partire dai primi quattro anni di esperienza istituzionale. In: Osservatorio Sulle Fonti(2/2018). Available at: http://www.osservatoriosullefonti.it.

Paba, G.; Perrone, C.; Luchesi, F. and Zetti, I. (2017) Territory matters: A regional portrait of Florence and Tuscany. In: Post-Metropolitan Territories: Looking for A New Urbanity, Balducci, A.; Fedeli, V. and Curci, F. (eds.) London: Routledge, pp. 95-116.

Paba, G. and Perrone, C. (eds.) (2018) TRANSIZIONI URBANE Regionalizzazione dell'urbano in Toscana tra storia, innovazione e auto-organizzazione. Il futuro delle cittá. Milano: Edizioni angelo Guerini e Associati SpA.

Perrone, C. and Rossi, M. (2018) La regionalizzazione della governance in Toscana. In: TRANSIZIONI URBANE Regionalizzazione dell'urbano in Toscana tra storia, innovazione e auto-organizzazione. Il futuro delle cittá, Paba, G. and Perrone, C. (eds.) Milano: Edizioni Angelo Guerini e Associati SpA, pp. 155-191.

Piroddi, E. (2009) Riflessioni sullo stato dell'arte. In: Nuovo Manuale di Urbanistica, Piroddi, E. and Cappuccitti, A. (eds.) Rome: Mancosu, sections D2, D3.

Presidenza del Consiglio dei Ministri (2017a) I dossier delle Città Metropolitane. Città metropolitana di Bologna. Roma: Dipartimento per gli Affari Regionali e le Autonomie (DARA).

Presidenza del Consiglio dei Ministri (2017b) Programma straordinario di intervento per la riqualificazione urbana e la sicurezza delle periferie delle città metropolitane e dei comuni capoluogo di provincia. Governo Italiano: Roma.

Regalia, M. and Valbruzzi, M. (2016) Vent'anni di elezione diretta del Sindaco di Bologna. Quaderni dell'Osservatorio Elettorale, 76, 55-56. Available at: http://www.regione.toscana.it/documents/10180/14170355/Interno+Quaderni+ Osservatorio+Elettorale+76+web+03+50-85.pdf/cabb1831-938c-4860-81ce9d91b9ede0f6. 
Regione Toscana (2015a) Piano di indirizzo territoriale con valenza di piano paesaggistico (PIT). Documento di piano. Florence: Regione Toscana.

Regione Toscana (2015b) Piano di indirizzo territoriale con valenza di piano paesaggistico (PIT). Scheda di ambito paesaggio 06. Florence: Firenze Prato Pistoia.

Regione Toscana (2016) Bando multi-misura "Progetti Integrati Territoriali - PIT" Annualità 2016. Florence: Regione Toscana.

Regione Toscana (2017) Programma regionale di sviluppo 2016-2020. Bollettino ufficiale della regione toscana, 13, 3.4.2017. Florence: Regione Toscana.

Regione Toscana (2018) La Regione dopo la Riforma. Riordino delle funzioni, procedimenti, progetti e interventi. Firenze: Agenzia Toscana Notizie.

Renzoni, C. (2012) Il progetto 80. Un'idea di Paese nell'Italia degli anni Sessanta. Firenze: Alinea Editrice.

Riboldazzi, R. (2017) Local Government Innovation in Italy and its impact on Urban and Regional Planning with a focus on the Milanese context. In: Local Government in Europe, Nunes-Silva, C. (ed.) Cham: Springer, pp. 89-109.

Schefold, D. (2010) Italiens Verfassungsentwicklung zwischen Regionalismus, Devolution und Föderalismus - Parallelen zu Deutschland? IEV-Online, 2/2010. FernUniversität Hagen: Hagener Online-Beiträge zu den Europäischen Verfassungswissenschaften ISSN: 1868-6680 Hagen.

Servillo, L. and Lingua, V. (2014) The innovation of the Italian planning system: Actors, path dependencies, cultural contradictions and a missing epilogue. European Planning Studies, 22(2), 400-417. DOI: 10.1080/09654313.2012.752443.

Tortorella, W. and Alluli, M. (2014) Città Metropolitane - La lunga attesa. Venezia: Marsilio.

Tubertini, C. (2015) La città metropolitana tra Regione, Comuni ed Unioni Analisi delle relazioni istituzionali. Roma. Working papers. Rivista online di Urban@it. Available at: http://www.urbanit.it/wpcontent/uploads/2015/09/BP_A_Tubertini .pdf.

Tubertini, C. (2018) La Città metropolitana nelle prime esperienze applicative: Il caso di Bologna. Available at: https:/www.urbanit.it/wp-content/uploads/2018/ 07/04-la-citta-metropolitana-nelle-prime-esperienze-applicative-tubertini.pdf.

URBACT (2009) Joining Forces. Metropolitan Governance \& Competitiveness of European Cities. Seminar Working Document. Paris: URBACT.

Vandelli, L. (2015) L'innovazione del governo locale alla prova: Uno sguardo comparato agli Statuti delle Città metropolitane. Rivista di Studi Giuridici e Politici, Numero Extraordinario 1, 213-238.

Vandelli, L. and Morisi, M. (2016) Città Metropolitane e nuove aree vaste: Dinamiche e prime esperienze. In: Secondo Rapporto sulle città. Le agende urbane delle città italiane, Pasqui, G.; Briata, P. and Fedeli, V. (eds.) Bologna: Il Mulino, pp. 179-196.

Vandelli, L. and Vitali, W. (2014) Il cammino accidentato verso le città metropolitane. In: Universen'agenda per le città. Nuove visioni per lo sviluppo urbano, Vitali, W. (ed.) Bologna, pp. 75-90. DOI: 10.978.8815/319920

Vannucchi, P.M. (2008) Le fasi delle pianificazione urbanistica a Prato. Prato: Lalli Editore. 


\section{Italy}

Vinci, I. (2019) Governing the metropolitan dimension: A critical perspective on institutional reshaping and planning innovation in Italy. European Journal of Spatial Development, 70, 1-21. DOI: 10.30689/EJSD2018:70.1650-9544.

Voghera, A. (2017) Città metropolitana di Torino. In: Pianificare le città metropolitane in Italia. Interpretazioni, approcci, prospettive, De Luca, G. and Moccia, F.D. (eds.) INU Edizioni, pp. 57-67.

Zwilling, C. and Alber, E. (2019) Italiens Spagat zwischen Einheit und Differenzierung: Reformen und differenzierter Regionalismus unter der "Regierung der Veränderung”. In: Jahrbuch Föderalismus 2019, Europäisches Zentrum für Föderalismusforschung (ed.) Baden-Baden: Nomos, pp. 313-328. DOI: $10.5771 / 9783748910817$. 


\title{
4 Germany
}

\author{
P. Feiertag and K. Zimmermann
}

\subsection{Metropolitan governance in Germany}

In Germany, metropolitan governance can hardly be discussed as a national or nationwide uniform phenomenon. A preference for flexible and placebased institutional solutions for metropolitan regions is observable instead of a nationwide approach (Zimmermann 2017, 254; Schmidt 2013; Fürst 2005, Blatter 2006). Instead of one type of metropolitan institution introduced by national law, various forms have developed via voluntary cooperation of local self-governments or by state law (or contracts between states when the city-region crosses state borders). The three city-states Berlin, Hamburg and Bremen are themselves strong metropolitan governments, but functional interdependencies with the adjacent cities and counties due to commuter relationships and settlement development induced the need for an additional layer of governance (Zimmermann 2017, 255). Hence, in the case of the three city-states, the creation of metropolitan governance arrangements implies cooperation between local self-governments and between state governments at the same time.

National government has only a weak influence on governance and planning in city-regions as spatial planning, regional policies and local government are a domain of the 16 states. One of the rare nationwide initiatives in the field of metropolitan policies is the concept of "European metropolitan regions" as new spaces for governance that was introduced in spatial planning (Raumordnung) as a joint initiative of states and the federal government in the late 1990s (Harrison and Growe 2014; see below). This indicated a change in the way city-regions and agglomerations were seen. Before this initiative, the policy discourse referred to smaller city-regions as agglomerations or densely populated areas (Ballungsraum or Verdichtungsraum) (Fricke 2017, 299).

\subsubsection{Metropolitan institutions: place-specific models of multi-scaled metropolitan governance}

This decentralised and non-uniform way of dealing with problems of metropolitan development is well accepted in Germany. Thus, it is up to 
each city-region to find institutional solutions for a stable coordination of municipalities as well as private actors. This laboratory-like situation has both produced outstanding cases of effective metropolitan governance as well as fragmented regions with a rather weak degree of integration and coordinated action. There is a broad consensus in academia as well as in the world of practice that more effective inter-municipal coordination in most of the German city-regions is needed, but in contrast to many other European states changes happen by way of continuous and flexible adaptations of existing legal frameworks and institutions instead of nationwide frameworks (Zimmermann 2017; Priebs 2019).

Inter-municipal associations (kommunale Zweckverbände or Regionalverbände) are the most frequently used instrument for the organisation of public services and planning functions in city-regions (Zimmermann 2017, 254). They are characterised by binding inter-municipal decisionmaking structures and have their own administration (Priebs 2019, 105106). First experiments took place since the beginning of the 20st century in the Ruhr area and Berlin. The early 1970s (e.g. Frankfurt, see 4.2.1) and 1990s (e.g. Stuttgart, see 4.3.1) was a period where the establishment of metropolitan governments was very much en vogue. A more recent example is the Rhine-Neckar region (2004). The portfolio of tasks and institutional strength varies between city-regions.

Throughout history, the amalgamation of municipalities or municipalities and counties has also been used to cope with issues of rapidly growing agglomerations. One example is Berlin with the creation of a regional city (Groß-Berlin) through the annexation of the smaller municipalities contiguous with the core city in 1920 (Priebs 2019, 55). Much more recent cases are the Hanover region and the city-region Aachen. In 2001, the county of Hanover and the former regional planning association were amalgamated with broad consensus of the local actors. In addition, several of the tasks of the government office for the region of Lower Saxony and the city of Hanover have been shifted to the region (e.g. environmental planning) (Blatter 2008, 147-148; Priebs 2019, 114-115; Zimmermann 2017, 258). The city-region Aachen, founded in 2009, is smaller and has fewer functions compared to Hanover. Similar solutions have been discussed for other cityregions as well, e.g. Frankfurt during the 1990s, but a consensus was never reached. Therefore, the Hanover region and city-region Aachen remain exceptional cases for Germany.

Territorial reforms to reduce the number of municipalities and counties by mergers were frequent in the 1970s in western Germany, ${ }^{1}$ but not to the extent to form city-regional entities. In some cases, e.g. Stuttgart (see 4.3.2), the core city was even excluded from enlargements. Another wave of territorial reforms took place in some federal states in the 2000s, motivated by attempts to reduce costs and to increase the efficiency of the administrative structure of counties by "economies of scale". In less populated areas, this upscaling came into conflict with the principle of local self-government 
guaranteed by the German constitution: the state's constitutional court of Mecklenburg-Vorpommern stopped the amalgamation of counties in 2007 and pointed out that the new entities with a size between 3,000 and 7,000 $\mathrm{km}^{2}$ would not correspond to what is considered the everyday world of residents (Heinelt and Egner 2011, 120).

Amalgamated city-regions such as Hanover have a directly elected council, just like a county. Direct election of the assembly can also be established in regional associations, if their statutes provide for it. In Germany, this is only the case in Stuttgart Region (see 4.3.1), the city-region Aachen, the regional association Saarbrücken and starting from 2020 also in the Ruhr Area. The difference to the Hanover region is that the counties still form a tier of local self-government within the Stuttgart Region and the Ruhr Area and that the regional assembly does not have the political function as a representative body of local self-government. Nevertheless, it can be regarded as a strong form of input legitimacy that differs significantly from governance-like forms of metropolitan politics (Zimmermann 2014, 187, 195).

Despite the creation of metropolitan institutions, counties continue to exist as a second tier of local self-government in city-regions. The amalgamation of counties and core cities is rare. Counties act at the same time as "(1) a multi-purpose state administration, (2) an association of municipalities and (3) a territorial unit exercising local self-government beside (above) the level of municipalities" (Heinelt and Egner 2011, 107). Large cities, however, have the status of county-exempt city, meaning that they fulfil all functions of a county and of a municipality. All cores of metropolitan regions are either county-exempt cities (Kreisfreie Stadt) or city-states (Stadtstaat), the latter ones with even more autonomy as they are sovereign states. Apart from a few exceptions, all cities with more than 100,000 inhabitants have the status of a county-exempt city, but there are also numerous cities with only 40,000-50,000 inhabitants that have this status. This depends on the settlement structure in the federal state, but there are also historical reasons. All in all, 107 cities in Germany have the status of county-exempt city (see Figure 4.1). The 301 German counties vary enormously with regard to population size, surface and population density. The biggest counties such as the Uckermark $\left(3,060 \mathrm{~km}^{2}\right)$ even exceed the size of the federal state Saarland (Heinelt and Egner 2011, 109).

\subsubsection{The nationwide initiative "European Metropolitan Regions"}

In many German metropolitan regions several regional scales of governance have emerged over the last decades (see Figure 4.1). They are the result of local initiatives and / or incentives provided by other governmental layers (Zimmermann 2017, 262). One of those incentives was the joint "Initiative European Metropolitan Regions in Germany" (Initiative Europäische Metropolregionen in Deutschland) taken by the Federal and State Ministers responsible for Spatial Planning (see Table 4.1). 


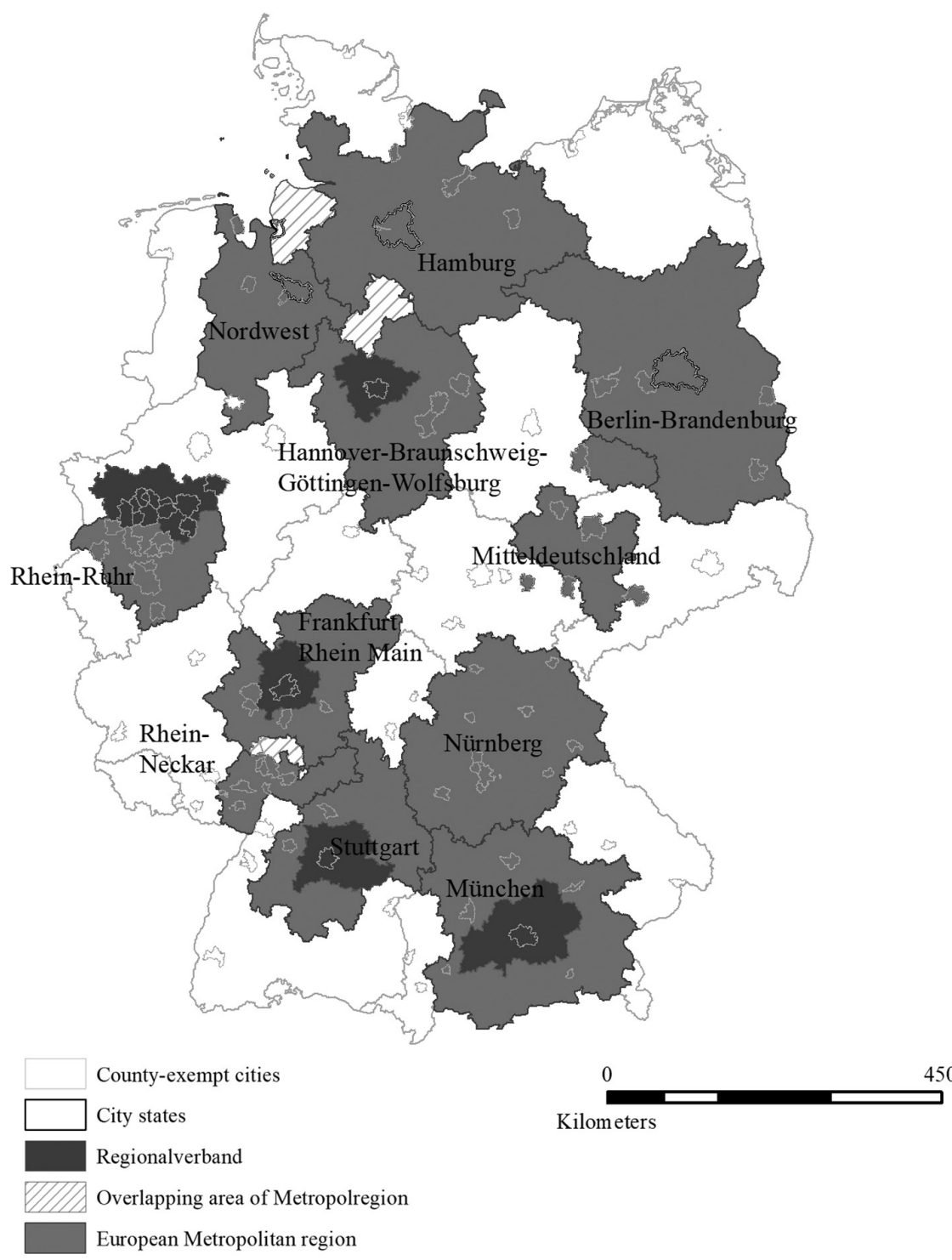

Figure 4.1 Metropolitan regions and Regionalverbände in Germany 2018 Concept: P. Feiertag Cartography: F. Gela

The concept of "Europäische Metropolregion in Deutschland" was first mentioned as a new spatial category in the action framework (Raumordnungspolitischer Handlungsrahmen) enacted by the Standing Conference of Federal and State Ministers responsible for Spatial Planning (Ministerkonferenz für Raumordnung, MKRO) in 1995 (MKRO 1995, 27). 
Table 4.1 European Metropolitan Regions in Germany

\begin{tabular}{lll}
\hline European Metropolitan Region & $\begin{array}{l}\text { Population } \\
\text { (million, 2017) }\end{array}$ & $\begin{array}{l}\text { Area }\left(\mathrm{km}^{2},\right. \\
2019)\end{array}$ \\
\hline Rhein-Ruhr & 12.8 & 15,425 \\
thereof Regionalverband Rubr & 5.1 & 4,439 \\
thereof Rheinland & 8,7 & 12,278 \\
Berlin-Brandenburg & 6.1 & 30,546 \\
München & 6.1 & 25,545 \\
Frankfurt Rhein-Main & 5.8 & 14,753 \\
Regionalverband Frankfurt Rhein-Main & 2,4 & 2,674 \\
Stuttgart & 5.4 & 15,425 \\
thereof VRS & 2.8 & 3.654 \\
Hamburg & 5.4 & 28,529 \\
Hannover Braunschweig Göttingen Wolfsburg & 3.8 & 18,623 \\
Hanover Region & 1,1 & 2,290 \\
Nürnberg & 3.5 & 21,781 \\
Nordwesten & 2.8 & 13,771 \\
Mitteldeutschland & 2.7 & 10,563 \\
Rhein-Neckar & 2.4 & 5,637 \\
\hline
\end{tabular}

Source: Website IKM

Initially being six regions (Berlin/Brandenburg, Hamburg, München, RhineMain, Rhine-Ruhr, Stuttgart), the number increased to seven in 1997 (including Halle/Leipzig-Sachsendreieck) and 11 in 2005 (including Hannover-Braunschweig-Göttingen, Nuremberg, Rhine-Neckar and Bremen-Oldenburg) (Blotevogel 2005, 642). Since 2005, this number of metropolitan regions has not changed and is not likely to grow any further, though the Rhine-Ruhr Region is de facto split up into three cooperation spaces and no longer exists as a territorial framework for policies and politics (Zimmermann 2017). However, cross-border regions with metropolitan functions have been introduced as an additional category (see Figure 4.2). They have been targeted by two calls for model projects ${ }^{2}$ and were encouraged to build their own network IMeG (Initiativkreis metropolitane Grenzregionen), which was founded in 2011. These regions were included in the revised national spatial vision for spatial development from March 2016 (Hager 2016).

The initiative to label European metropolitan regions nationwide cannot be considered as reconfiguration of the existing formal arrangements for metropolitan governance and does not change the diversity of institutional solutions (Zimmermann 2017, 254). Metro regions have been included in the national spatial vision and in state plans of the Länder but they have not been the cause of a territorial or functional reform granting them any competencies or financial resources. It is more an affirmation of the function of a metropolitan region relevant in terms of location marketing. Fricke (2020, 240) describes them as "rhetoric label related to positive expectations". In part, existing organisational bodies have been labelled as European metropolitan region or at least nominated as a representative within the national 


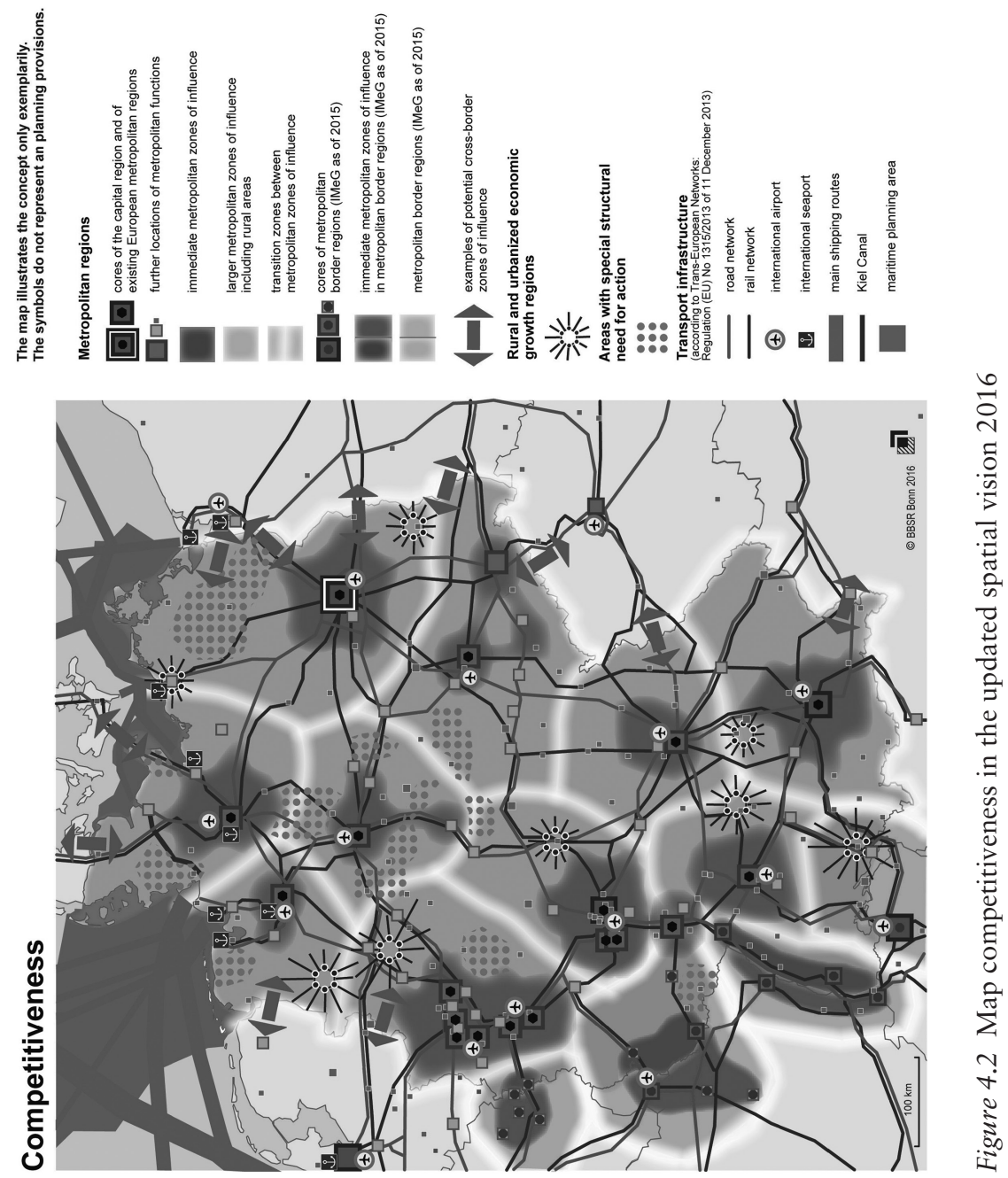


network of metropolitan regions, whereas at the same time additional regional and inter-municipal initiatives for cooperation have emerged on different scales. Apart from putting them on the European map, the support of the national ministry and its agency are limited to including the metropolitan regions as new spatial category in spatial strategies and spatial observation and monitoring as well as encouraging cooperation in form of calls for model projects (Modellprojekte der Raumordnung MORO).

\subsubsection{Multi-scaled governance}

The European metropolitan regions described in federal documents mostly have a larger spatial dimension than existing city-regional institutions (see 4.1.4) and therefore lead in Stuttgart, Frankfurt, Hanover, Munich and Bremen to multi-scaled arrangements with an additional level of regional cooperation. As can be seen in Figure 4.1, a likely pattern is the combination of county-exempt cities, a strong institutional core on a smaller scale (usually a regional planning authority or Regionalverband in city-regions) and softer forms of governance on larger scales (European metropolitan region). Hence, the multi-scaled arrangements consist of two or even three levels of governance and cooperation. In Stuttgart and Frankfurt, strong core regions with statutory planning functions and equipped with further tasks are supplemented by an additional layer of the larger European metropolitan region. In Munich, the regional planning authority is a less crucial part of the governance arrangement because its competence is limited to regional planning while we have a multi-purpose association in Stuttgart. An additional voluntary association of municipalities and counties covering a larger "Großraum München" exists since the 1950s: the "Planning Association for the Wider Economic Area" (Planungsverband Äußerer Wirtschaftsraum). Its role is a service provider for smaller municipalities but takes at the same time a regional perspective by coordinating traffic and settlement development on a voluntary basis and articulating interests in the region (Zimmermann 2017, 259). The association "Europäische Metropolregion München EMM e.V.” constitutes a third layer and is even larger. This voluntary cooperation between local governments, partners from the business sector, universities, research institutes and civil society organisations is financed through membership fees and has the aim to promote the economic development of the whole region and to increase its attractiveness and quality of life (Zimmermann 2017, 260).

In some cases, such as Stuttgart (see 4.3.3), the larger metropolitan scale remained a weak layer with low problem-solving capacities. In smaller and polycentric regions, where a single city cannot mobilise the critical mass to become internationally visible, local actors perceived mutual benefits that can be realised through cooperation (Zimmermann 2017, 257). City-regions such as Nuremberg and Rhine-Neckar used this opportunity to establish new metropolitan governance structures in the context of the national 
European Metropolitan Regions initiative. The Rhine-Neckar region is worth mentioning in this context because this region spans over the borders of three states (Hesse, Rhineland-Palatinate and Baden-Württemberg). Though being an association made of cities and counties, the creation made the signature of an inter-state treaty necessary because the task of statutory regional planning will be accomplished by the cross-border planning association (Nelles 2012).

Note that these multi-scaled metropolitan governance arrangements exist in addition to the five levels of the German multilevel system (Heinelt and Egner 2011, 107):

- Federal level (Bund);

- Federal states (Länder);

- Government offices for the regions (Bezirksregierungen; in eight out of 16 states $) ;^{3}$

- Counties (Landkreise) and county-exempt cities (kreisfreie Städte);

- Municipalities (Städte und Gemeinden).

Thus, they add to the complexity of territorial administration (see 4.3.1). The only exception is Hanover as in that case, the region has substituted the county and the former planning authority.

\subsubsection{Functions: production functions, regional planning and mobility}

As we have seen in the previous section, metropolitan governance in Germany is implemented in various organisational forms, policy sectors and scales. As the institutions show high variations, the number of functions they fulfil diverges as well. There are no compulsory functions delegated to all German city-regions. Functions are either defined by the members on a voluntary basis depending on agreed common interests or fixed on a caseby-case basis by state laws (e.g. Stuttgart, see 4.3.1). German city-regions are an institutional level above the counties and for the most are not responsible for social production functions such as social housing, schools, social public services and environmental policies.

The federal states have almost total responsibility for organising their internal structure and this includes local government and inter-municipal arrangements. The local level has the right of self-government guaranteed by the constitution and is formed by municipalities as well as counties as second tier (Zimmermann 2017, 254; Heinelt and Egner 2011). Over the last decade, the Länder governments have decentralised a number of tasks. Thus, municipalities and counties play a vital role in administering and implementing both national and state policies. Also, a high share of employees in the public sector are working for municipalities or counties apart from teachers, the police and university staff employed by the states. The tasks and competences of municipalities and counties as well as the 
grants they receive to fulfil those tasks differ from Land to Land (Heinelt and Egner 2011, 106-108). The local level was originally mainly responsible for social reproduction functions such as social services, housing and recreational facilities, planning and urban regeneration. The functional portfolio of the municipalities was expanded in the period of deindustrialisation, so that the municipalities were given financial and legal means to take action, for example to promote the renewal of old urban quarters or to expand public transport (Zimmermann 2020). Whereas production functions, i.e. measures to promote competitiveness, were more likely to be articulated at state and federal level. This separation of scale-specific functions became blurred in the 1980s and 1990s when cities, and later on city-regions, gained relevance as the main sites of economic globalisation (Mayer 1996; Brenner 2004).

When describing the functions delegated to city-regional institutions, we have to keep in mind that many city-regions are nowadays characterised by multi-scaled governance arrangements and, in addition, single-purpose associations for tasks such as public transport, water supply or waste treatment have not necessarily been absorbed by other more comprehensive metropolitan institutions. Therefore, functions carried out at the city-regional level can be split between several institutions and these may refer to variable geographies.

Functions depend on the scale and type of institution. The initiatives of the 1970s focussed on planning issues, public transport and other public services, whereas governance forms created during the new regionalism period of the 1990s or triggered by the Initiative European Metropolitan Regions had a focus on economic development and internationalisation (Zimmermann 2017, 261-262). According to Blatter (2008, 157-158), the integrated steering of regional settlement development and burden-sharing for investment in regional infrastructure demand formalised regional institutions, whereas light, performative forms of governance with a flexible, project-oriented geometry and the inclusion of private actors, particularly from the business sphere are suitable for production functions oriented towards large-scale competitiveness such as regional marketing, promotion of economic development and attraction of investors. Hamburg metropolitan region is a prototype of the latter functional profile, that corresponds best to the concept of a European metropolitan region:

The ahead of time self-designation as a metropolitan region, the successful establishment of the metropolitan region as a "brand", the clear focus on major flagship projects and a joint bid for the Olympic Games are clear indicators of such a form of governance (own translation). ${ }^{4}$

(Blatter 2008, 143-144)

Water supply and wastewater treatment (since the 1920s) as well as public transport and waste disposal (since 1970s) are organised via inter-municipal associations in most city-regions. However, apart from public transport 
associations these types of single-purpose inter-municipal cooperation often only concern a small number of adjacent municipalities and are not extended to the city-regional level. Hanover and Stuttgart are exceptions in this regard. In Hanover region, waste disposal as well as public transport is carried out by the region (Zimmermann 2014, 186). Stuttgart Region has the responsibility for regional public transport, i.e. construction and operation of the light rail system $(S-B a h n)$ and also a limited competence in waste management.

Recently, some city-regions have taken up new activity fields such as broadband networks (and digitisation), wind energy and electro-mobility. They are not the responsible level for authorising, constructing or operating these infrastructures, but support the municipalities and help to establish common framework conditions in the city-region. In the cases of Stuttgart and Frankfurt (see 4.3.3 and 4.3.4), the regional associations facilitated a joint tender for broadband expansion. Potential sites for wind energy are indicated in the regional plan (Stuttgart) or regional land use plan (Frankfurt). E-mobility is, among others, supported by a masterplan for fast-charging infrastructure.

Social services, education (kindergartens, schools) and health care (hospitals, local health authorities) are provided by the local level, either by the cities or the counties. Social benefits for the unemployed, handicapped or elderly people as well as health services account for a large share of the counties' expenditure (Heinelt and Egner 2011, 117). Hanover region is also responsible for the management of public hospitals (Zimmermann $2014,186)$ but it is an exceptional case as it has replaced the county within the area of the city-region.

Regional planning and regional landscape planning are well established in Germany (see Figure 4.5), but political relevance and organisational forms differ from state to state (Schmidt 2009, 1915). In some states such as Hesse or North Rhine-Westphalia the government offices of the regions are responsible for statutory regional planning. Many other states have created single purpose inter-municipal authorities responsible for statutory regional planning (Planungsverbände) (Zimmermann 2017, 254). The authorities Verband Region Stuttgart, Verband Region Rhein-Neckar, Regionalverband Rubr, Regionaler Planungsverband München and Region Hannover elaborate statutory regional plans. In some city-regions, the tasks of the planning authority have been expanded, combining regional planning with other tasks such as public transport, regional parks, regional business development and tourism (Stuttgart, see 4.3.1). The city-states are specific cases with regard to regional planning, because their local land use plan replaces the regional plan as well as the state plan. The federal states of Berlin and Brandenburg have established a joint state planning agency (Gemeinsame Landesplanung Berlin-Brandenburg). In the case of Bremen, an informal regional development concept as well as projects for implementation for a wider city-region have been developed by the inter-municipal association Kommunalverbund Niedersachsen Bremen e.V. (Blatter 2008, 145). In 
Hamburg metropolitan region, the elaboration of a joint spatial vision was discussed in the mid-2010s, but was not supported by all partners. As an intermediary step, thematic maps regarding demographic development and building activity with data from 1990, 2000 and 2010 have been elaborated for monitoring purposes and joint understanding of the spatial structure.

Local land use planning is a municipal task in Germany, carried out by the cities themselves or several small inter-municipal associations within a city-region. For example, the Stuttgart Region consists of 179 municipalities and is covered by 79 land use plans (see 4.3.2). Frankfurt is one of the few exceptions with a regional land use plan (RFNP) for the entire city-region (see 4.2). The instrument of a regional land use plan has been introduced in national planning law in 1998 (ROG $\mathbb{S} 13$ Abs. 4) with the objective of reducing deficits in the interaction of the local and regional planning levels for meeting the complex challenges in city-regions (Domhardt and Hilligardt 2011, 398). However, 20 years later it has remained a niche solution with only two approved RFNP in the entire country.

Germany's city-regions are also active in the field of green and blue infrastructure, either via shared responsibility for the maintenance of green spaces in-between municipalities (e.g. regional corridors or green belts) or by co-financing municipal projects (e.g. regional landscape park in Stuttgart). Creating a network of green corridors (Grünzüge) and bicycle paths both for residents and tourists has been one of the core tasks of the regional planning authority in the Ruhr Area (RVR).

The functions of regional marketing, business development and tourism are usually carried out at a city-regional scale, either by the core institution or a development agency organised as a public-private partnership. Associations with public and private partners such as the Europäische Metropolregion München EMM undertake voluntary actions with the overarching goal to promote the visibility, the economic development and the quality of life of the city-region (Zimmermann 2017, 260).

Large cultural or sports events such as the Olympics, the European Capital of Culture or an International Building Exhibition (IBA) also have the function of raising international awareness. City-regional institutions are often involved in these voluntary initiatives and bring local actors together. In the case of the European Capital of Culture 2010, the regional planning authority of the Ruhr region played an essential role during the process of application and implementation (Schmidt 2013). In the Stuttgart Region, the planning authority VRS was part of the consortium that submitted a bid for the Olympics.

\subsubsection{Ideas behind the concept of European metropolitan regions: competitiveness among global cities despite a polycentric urban system}

The introduction of metropolitan regions as a spatial category has been discussed in Germany as a paradigm shift in spatial planning (Raumordnung) and regional development. German spatial planning followed the principle 
of equal and balanced living conditions (Gleichwertige Lebensbedingungen) for decades. It is linked to a good standard of services of general interest in the proximity of citizens and the central-places concept as well as balanced economic growth. Regional development policy was (and still is) concentrated on peripheral or economically underdeveloped regions. Priority for metropolitan regions was a relatively new idea in this context.

The name "European metropolitan regions in Germany" already evokes that those city-regions are supposed to be able to compete with other large city-regions on a European if not a global scale. In response to the challenges of European integration and the intensification of globalisation, spatial planning at the federal level centred in the middle of the 1990s on the task of positioning major cities and regions within European and global circuits of capital accumulation by emphasising the importance of a limited number of metropolitan regions due to their competitiveness (both nationally and internationally) and their role as economic drivers of the national economy (Harrison and Growe 2014, 29). Germany has a polycentric urban system instead of one global city. Still, several city-regions were well positioned within European circuits of capital (Harrison and Growe 2014, 30).

The European metropolitan regions have been included in the national spatial vision (Leitbilder der Raumentwicklung) of 2006 and its updated version from 2016. The Leitbilder 2016 contain four thematic vision maps: "Enhance competitiveness", "Ensure the provision of public services", "Control and sustainably develop land uses" and "Shape climate change and the transformation of the energy system". Metropolitan regions are the key element visualised in the map on competitiveness and are interpreted as main engines of economic growth: "The German metropolitan regions of European importance are the essential national economic areas with a high productivity and are facing international competition" (MKRO 2016, 8 ). This increased relevance given to metropolitan regions triggered massive resistance against the concept from the Associations of German Counties and Municipalities (Kawka and Staats 2016, 535), fearing a redistribution of subsidies towards metropolitan regions at the dispense of rural spaces and towns. It was discussed if a paradigm change neglecting the equal provision of public services was about to happen (Blotevogel and Schmitt 2006; Harrison and Growe 2014, 32). In fact, the vision acknowledged the enhanced role of metropolitan regions, but there was a reluctance to actively push them and they did not receive any specific funding from the federal level.

The national spatial vision from 2006 and its update in 2016 (see Figure 4.2) show the attempt to reconcile both principles of competitiveness and equal living conditions by depicting larger metropolitan zones of influence including rural areas (weitere metropolitane Verflechtungsräume einschließlich ländlicher Räume). The entire country is divided into such zones of influence of metropolitan cores in order to avoid left-over spaces (Hesse and Leick 2013, 353). Of course, the distance between Berlin and 
the coast of Mecklenburg-Vorpommern or Munich and the Czech border is huge and that the interlinkage is not that strong can be illustrated by the main transport infrastructure, at least when not thinking in terms of daily commuters (see Figure 4.2). Metropolitan regions are depicted in a multi-scaled way, consisting of a metropolitan core and further locations of metropolitan functions linked by transport networks, the immediate metropolitan zones of influence (engere metropolitane Verflechtungsräume) and the larger zones of influence that have been attributed to the metro regions. Thus, analytical elements regarding metropolitan functions, population density and transport axes are combined with a normative interpretation of desirable spatial relations. On this new map of Germany,

the territorial boundaries of the politico-administrative Länder are nowhere to be seen. What we see instead is an idealized structure of more networked forms of regional cooperation and collaboration on a regional level. Identified as "large-scale areas of responsibility", each area is shown to comprise an existing metropolitan region and a wider "area of influence". Of particular note is how the boundary lines remain ambiguous. They also do not correspond to any known administrative or functional boundary. (Harrison and Growe 2014, 33)

The concept of large-scale partnerships for territorial cohesion (großräumige Verantwortungsgemeinschaften) was introduced in 2004 during the workshops for the preparation of the national spatial vision, although some doubts were raised as to whether these supra-regional partnerships were a mere rhetoric for appeasement (Hesse and Leick 2013, 353). How they could be realised in practice was explored later on by a national call for model projects for supra-regional partnerships (2007-2013) issued by the Federal Institute for Research on Building, Urban Affairs and Spatial Development (Bundesinstitut für Bau-, Stadt- und Raumforschung, BBSR). Despite a dominance of the metro regions in the discourse (Hesse and Leick 2013), the federal initiatives to support the implementation of the national spatial vision did not target the institutional organisation of metropolitan cores, but instead addressed the cooperation with their hinterland and urban-rural-partnerships.

A proposal of recommended competences for metropolitan institutions was part of the national spatial development report (Raumordnungsbericht) 2005, though without any binding impact (BBSR 2005, 189). The report included a chapter on metropolitan regions in Germany as part of a chapter on spaces with particular need for intervention. The federal government is responsible for spatial observation and has the obligation to present national spatial development reports at regular intervals to the parliament. The shift in focus of the following reports show that metropolitan regions have lost momentum in the national discourse. The following spatial development report (BBSR 2012) did use the term of metropolitan region, but 
already far less prominently. Their importance for growth and innovation was confirmed without addressing their internal organisation. The most recent report, dating from 2017, has the title "Daseinsvorsorge sichern" (securing services of general interest), clearly confirming the idea of equal living conditions as central concern for Germany's future spatial development. The report focuses on the central-places system and speaks of regional centres (Oberzentrum) and big cities, not of metropolitan regions. Overall, metropolitan regions are today well established in the thinking of professionals and academics, but political attention has shifted again towards peripheral areas where services of general interest are under pressure due to a shrinking and ageing population, tight public budgets and privatisation. In urban agglomerations, the key issue, which receives a lot of media coverage, is housing shortage and rising rents, producing higher living costs and gentrification.

\subsubsection{Spatial relationships: fuzzy boundaries of metropolitan regions}

How many city-regions should be called "metropolitan regions" has been defined based on political decisions at national level, but their exact delimitation has been left deliberately open. Schematic cartographic representations are used to leave the decision of the appropriate governance space to the Länder and the local actors themselves (Kawka and Staats 2016, 537; Fricke 2020, 237-240). Despite the blurry boundaries in the national vision maps (see Figure 4.2), some indications were given due to cities represented on the map. This has already been the case in earlier official representations from 1997 and 2006 adopted by the conference of ministers MKRO (see Figure 4.3).

The seven, or respectively 11 , metropolitan regions are depicted in a very schematic way as a hexagon or network of several hexagons in case of the polycentric metropolitan region Sachsendreieck, later re-named Central Germany. Apart from the core cities of the metro region, other cities at the fringes are represented either as part of the metro region - or outside of it. Although the national vision maps themselves do not have any direct binding power, these choices had an impact on the local spatial definition of the European metropolitan regions, if they were supported by the Land. For example, in Stuttgart the national maps represent the metropolitan region larger than the pre-existent city-regional institution Region Stuttgart and therefore called for an additional layer of metropolitan governance (see 4.3.2). In contrast, Rhine-Ruhr has never been institutionalised as one single metro region such as suggested by the national representation. The large metro region had initially been picked up by the state plan of North RhineWestphalia but did not have the full political support of the Land because of the unfavourable split of the Land. The municipal actors did not endorse the idea either due to too heterogeneous interests and mentalities. Therefore, this 

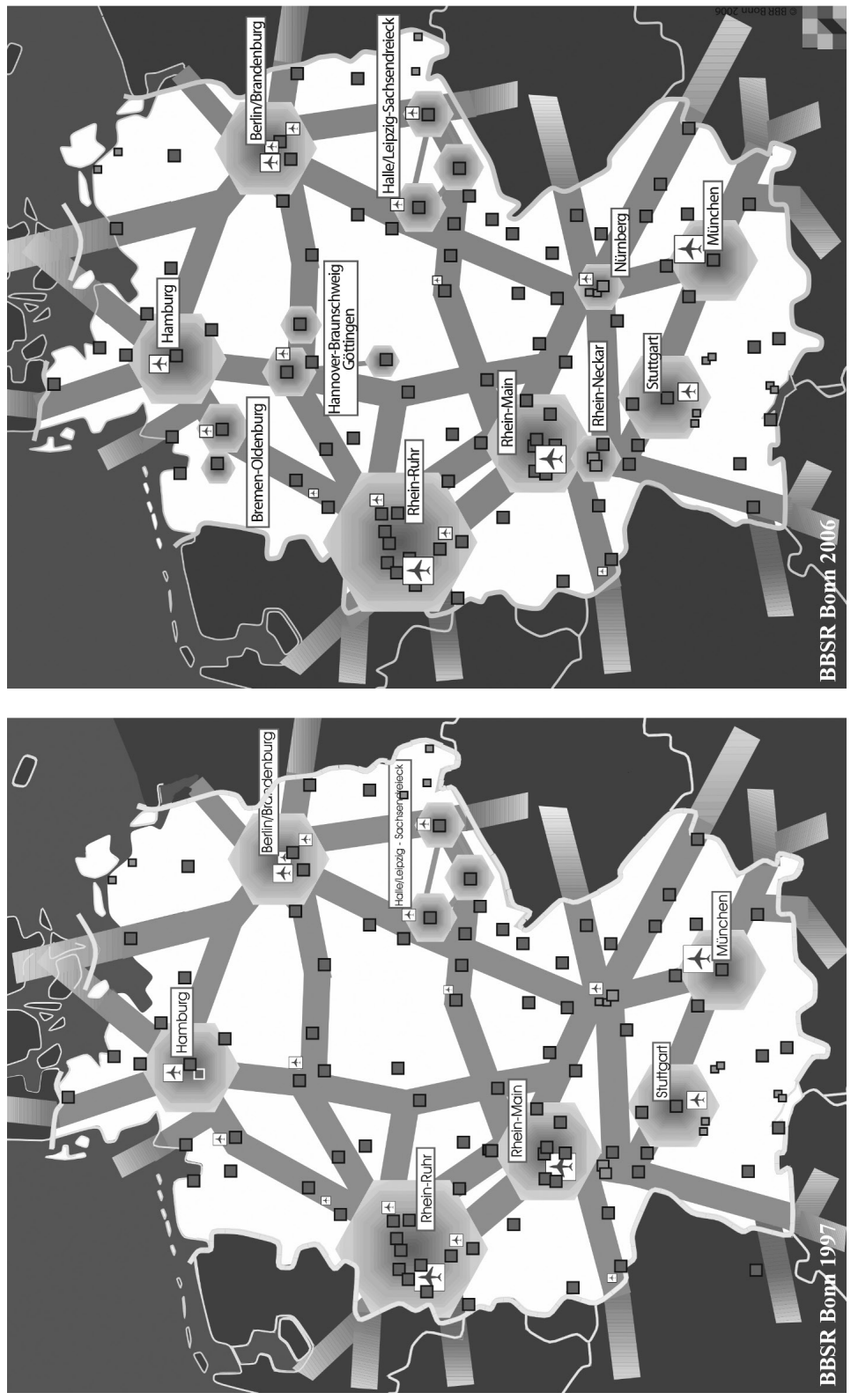

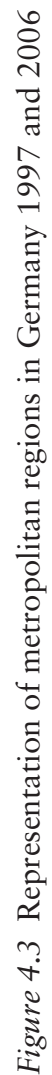




\section{2}

Germany

large area formed of ten counties and 22 county-exempt cities never became a governance space (Blotevogel and Schulze 2010, 256-257). Instead, the two subspaces Ruhr and Köln/Bonn have been formed and are both part of the network of German metropolitan regions (Initiativkreis Europäische Metropolregionen in Deutschland IKM) (see Figure 4.4). Düsseldorf is left as a stand-alone city.

The European metropolitan regions did not initially have a clear spatial reference, but resembled variable geometries of cooperation (Fricke 2020, 240). The necessity of a clear boundary first arose due to monitoring activities of the network of metro regions IKM, supported by the federal agency BBSR (Pütz 2016). The delimitations used in subsequent monitoring reports (see Figure 4.4) show, however, that the spatial outline of the metro regions is not definite. The evolution is most obvious in the case of Hamburg, where additional partners successively joined the club or in the EMR Central Germany. Changes also occurred in Munich, Nuremberg, North-West
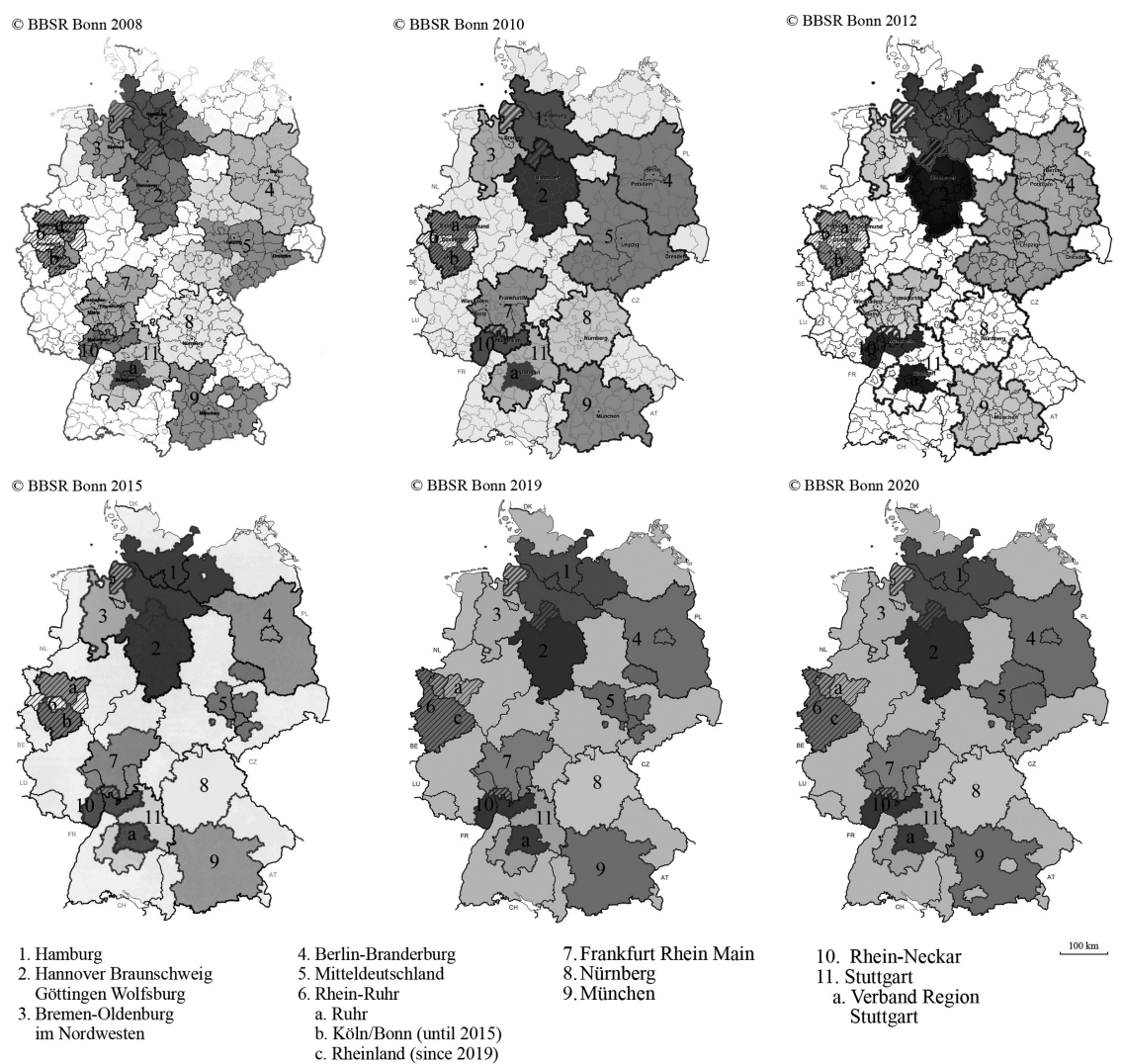

Figure 4.4 Evolving delimitation of metropolitan regions used by IKM monitoring 
(Bremen) and Köln/Bonn. In addition, those delimitations chosen by the local actors themselves deviate significantly from the spatial imaginary of the national vision map (see Figure 4.2). Both clearly show, however, that the concept of European metropolitan region does not correspond to the territory of a new jurisdiction with container-like boundaries. The cooperation spaces of European metropolitan regions partially overlap, meaning that some counties and municipalities are partners of two different metropolitan cooperation spaces. In addition to that, they cross administrative borders, especially in the case of the three city-states Berlin, Hamburg and Bremen. Seven out of 11 metropolitan regions cross the borders of federal states.

Europäische Metropolregionen such as defined by the organisations representing them in the network IKM are large entities, ranging from 5,637 to $30,546 \mathrm{~km}^{2}$ (2017, Monitoring IKM). In contrast, planning regions for regional plans only cover between 525 and $8,291 \mathrm{~km}^{2}$, depending on the federal state (Schmidt et al. 2018, 646). Lower-Saxony has small planning regions compared to the other federal states: apart from Braunschweig region (Regionalverband Großraum Braunschweig, see Priebs 2019, 116), they correspond to the counties. Ten European metropolitan regions are much larger than the regional planning regions of their core cities (see Figure 4.5). Rhine-Neckar is an exception, where regional planning association and European metropolitan region are congruent. Some European metropolitan regions are composed of several regional planning regions such as Stuttgart (see 4.3.2) or Berlin-Brandenburg with a joint state plan for both federal states. The smaller core regions Ruhr (6a on Figure 4.4) and Verband Region Stuttgart (11a) correspond to the territory of a regional plan and the responsible planning association.

As additional larger scales of metropolitan cooperation have emerged due to the initiative European metropolitan regions, we can speak of a partial re-scaling of metropolitan governance (Zimmermann 2017, 261), whereas planning scales have not been modified. The differentiation of scaled metropolitan policies as well as openness and frequent change of cooperation spaces renders the notions "metropolitan region" and "city-region" fuzzy.

\subsection{Frankfurt/Rhine-Main: still a fragmented territory?}

The Frankfurt/Rhine-Main region is a fuzzy political concept with a flexible geography and a range of collaborative arrangements (Nelles 2012; Hoyler et al. 2006; Schmidt 2013). As we will show later, there are several spatial delimitations present but for various reasons there is no commonly accepted understanding of the perimeter of the Rhine-Main region. In part, this is due to the fact that cooperation is based on actors and functions and not necessarily on congruent space. We refer predominantly to the territory of the planning authority because membership of the 80 municipalities is mandatory and the planning authority is an agency with a high degree of centrality within the network of regional initiatives. We will, however, demonstrate 


\section{Germany}

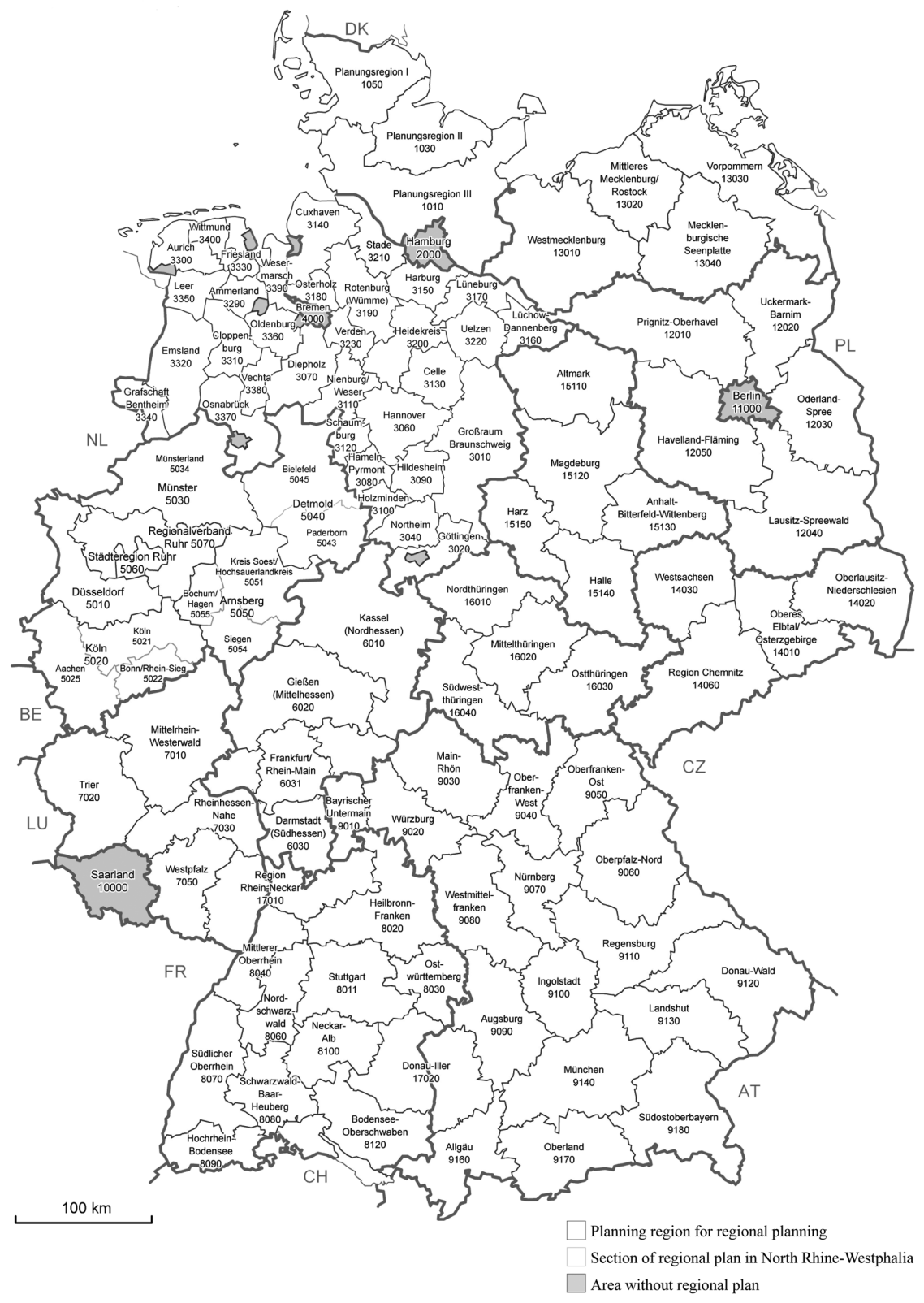

Figure 4.5 Planning regions for regional plans CBBSR Bonn 2019 
that the scales, perimeters and actor composition for cooperation vary in this region, mostly depending on the task.

The core city (Frankfurt am Main) is the dominant urban centre with 747,000 inhabitants. The territory of the planning authority, which is responsible for a special type of regional land use plan, has 2.4 million inhabitants meaning that the core city has a $31 \%$ share of the regional population. The second and third biggest cities in the planning region are Offenbach (127,000, directly bordering Frankfurt) and Hanau (96,000). The size of this region is $2,460 \mathrm{~km}^{2}$ (Regionalverband FRM 2019). It is usually called an "agglomeration" (Ballungsraum).

The region for statutory regional planning is the territory of the government district southern Hesse (size: 7,444,82 km², 4 million inhabitants, ten counties, four county-exempt cities and three cities with a special status).

On a larger scale, it has become quite common to refer to a metropolitan region. This is a huge area with a polycentric structure and fuzzy boundaries. Besides Frankfurt am Main, there are a number of cities with a population between 100,000 and 250,000 inhabitants, like Offenbach and Hanau, Darmstadt and Wiesbaden (which is the capital city of Hesse) as well as Aschaffenburg and Mainz which are in the federal states of Bavaria and Rhineland-Palatinate (Mainz is the capital city of the latter). This area comprises 18 counties and seven county-exempt cities with roughly 5.8 million inhabitants and crosses the borders of three states: Hesse, RhinelandPalatinate and Bavaria.

\subsubsection{The institutional arrangement}

The relevant institutional actors in the region of southern Hesse are the district government of the region (Regierungspräsidium Darmstadt), responsible for statutory regional planning, the planning authority (responsible for a regional land use plan), the counties and the county-exempt cities.

The history of regional planning and inter-municipal cooperation in this region goes back to the late 1950s and 1960s. In 1965, the Regional Planning Association Untermain (Regionale Planungsgemeinschaft Untermain) was established as a more formal arrangement with a rather small perimeter. Its successor, the Umlandverband Frankfurt was established in 1975 and was much stronger. The Umlandverband or UVF had a directly elected regional assembly and a broader portfolio of functions (Scheller and LanghagenRohrbach 2004). Forty-three municipalities around the city of Frankfurt were members of this association. Among the responsibilities of the Umlandverband were (Freund 2003, 133):

- Inter-municipal land use planning and coordination of land use (including landscape planning);

- Provision and management of leisure facilities of regional importance; 


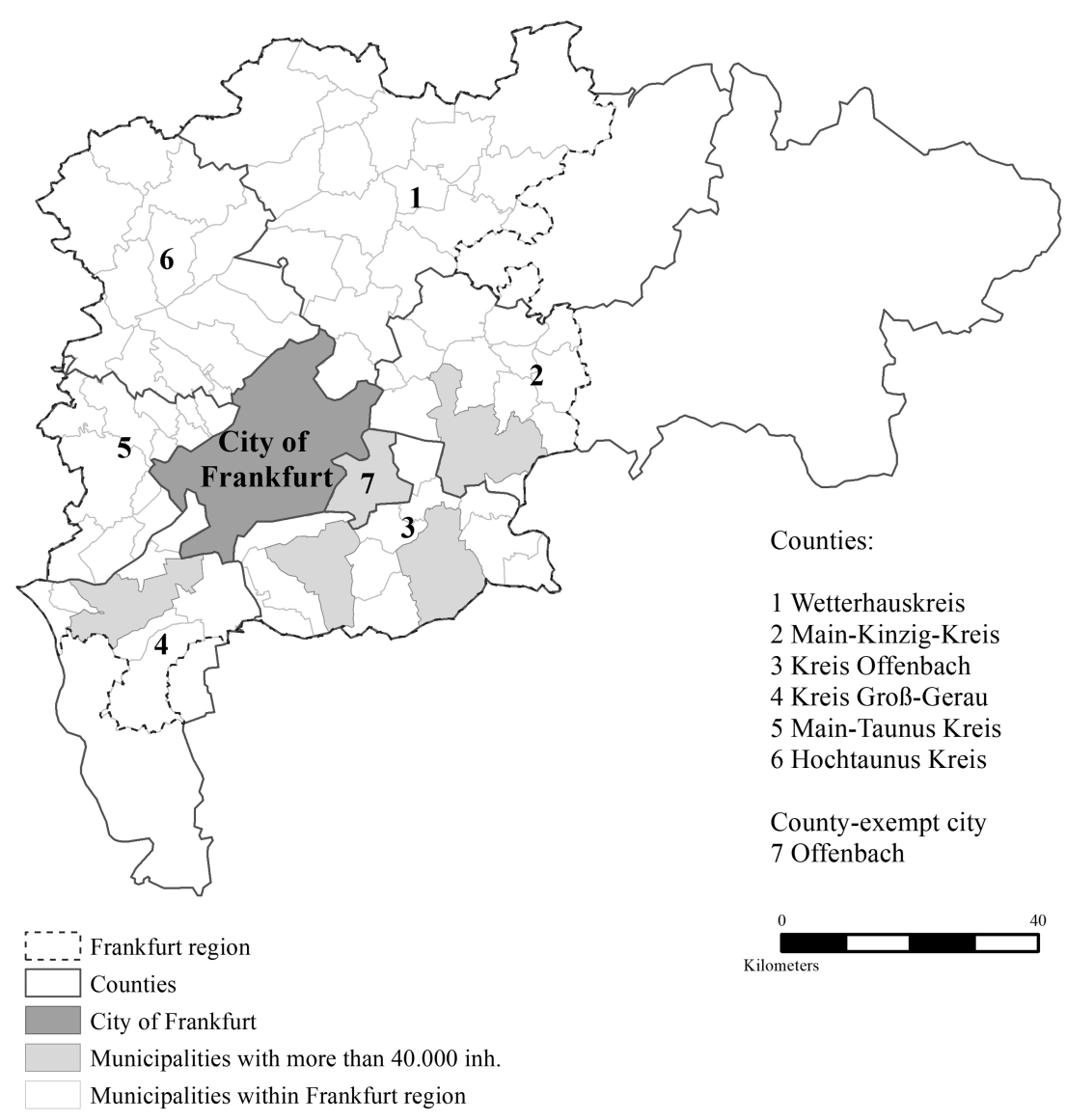

Figure 4.6 Frankfurt/ Rhine-Main region 2021 Concept: K. Zimmermann Cartography: F. Gela

- Technical infrastructure, traffic planning and the public transportation system, water supply, energy provision, sewage treatment, waste disposal.

The UVF was, therefore, a kind of multi-purpose association and met the zeitgeist of the metropolitan reform era (Heinz 2007). In fact, in the 1970s it was the metropolitan organisation that was considered to be the most innovative one in Western Germany. However, the power of the UVF was limited by its internal structure. Apart from the directly elected council, a municipal chamber existed, composed of representatives of its member municipalities. The municipal chamber was necessary as land use planning is a municipal task. Hence, every municipality needed to be provided with 
Table 4.2 Regionalverband Rhine Main in the multilayer system of the Regierungsbezirk Southern Hesse

\begin{tabular}{|c|c|c|c|}
\hline Level & $\begin{array}{l}\text { Number of } \\
\text { institutions }\end{array}$ & $\begin{array}{l}\text { Directly } \\
\text { elected } \\
\text { assembly }\end{array}$ & Name of institution \\
\hline Land (federal state) & 1 & yes & Hesse \\
\hline $\begin{array}{l}\text { Regierungspräsidium } \\
\text { (district government) }\end{array}$ & 1 & no & $\begin{array}{l}\text { Regierungspräsidium } \\
\text { Darmstadt }\end{array}$ \\
\hline $\begin{array}{l}\text { Regionalverband } \\
\text { (regional planning } \\
\text { authority) }\end{array}$ & 1 & no & Regionalverband \\
\hline Landkreis (county) & $5(10 / 18)$ & yes & Hochtaunuskreis, etc. \\
\hline $\begin{array}{l}\text { Kreisfreie Städte } \\
\quad \text { (county exempt) }\end{array}$ & $3(4 / 7)$ & & $\begin{array}{l}\text { Frankfurt, Offenbach } \\
\text { Wiesbaden, Darmstadt, } \\
\text { (Mainz, Aschaffenburg, } \\
\text { Gießen) }\end{array}$ \\
\hline Gemeinde (municipality) & $80(184 / \mathrm{ca} .300)$ & yes & \\
\hline
\end{tabular}

Note: numbers in brackets refer to the district and the metropolitan region

participation rights during the plan preparation process. Both chambers rather competed and unfortunately, the UVF's performance varied significantly between the various fields of interest (see Freund 2003, 133).

As a result, criticism of the UVF never stopped and during the 1990s the debate on an appropriate and effective metropolitan governance arrangement in the Frankfurt/Rhine-Main region gained considerable momentum and the UVF was in the middle of this turmoil. It was, however, not only the underperformance of the UVF but also the wider concern about economic competitiveness of the region that triggered the debate.

In any case, the gap between formal competence and actual capacity to implement policies provoked claims for the abolition of the UVF rather than calls to equip it with more powers. As a first step of change in the governance of Frankfurt/Rhine-Main the state government of Hesse took waste management away from the competence of the UVF. At the same time some classical conflicts emerged: the city of Frankfurt focussed on the fight for a financial equalisation scheme for the city and its surroundings, whereas the economic elite and the press (Frankfurter Allgemeine Zeitung) concentrated increasingly on issues of competitiveness (especially on raising the attractiveness of the metropolitan region for investors; see Blatter 2005, 145).

As a result, and separate from the changes which were undertaken by political-administrative actors, the private sector initiated activities on behalf of the metropolitan area. These joint activities grew out of a growing consciousness of challenges resulting from worldwide competition and the creation of the European Common Market in 1993. In the middle of 1991, the chambers of commerce (in short IHKs) of the Frankfurt/RhineMain area intensified their cooperation and established the IHK-Forum 
Rhine-Main. This Forum has a catchment area larger than the planning authority (Blatter 2005). ${ }^{5}$

In 1995, another organisation for economic cooperation was established: the Economic Development Agency for the Region of Frankfurt/RhineMain (Wirtschaftsförderung Region Frankfurt/Rhein-Main). This time the UVF was the initiator and established this agency as a kind of counterweight to the IHK-Forum. But it quickly lost its ideological stance and turned into a marketing-association of a considerable capacity to attract new municipal members (Blatter 2005, 145).

Only a year later, in 1996, about 150 enterprises established the Economic Initiative Frankfurt/Rhine-Main (Wirtschaftsinitiative Frankfurt/RheinMain). The main reason for founding this initiative was a shared concern about the lack of a "unified regional image" (Hoyler et al. 2006, 130). The creation of - at least - three initiatives from the business sphere (IHK-Forum, Economic Initiative Frankfurt/Rhine-Main and the Economic Development Agency for the Region of Frankfurt/Rhine-Main) indicates that economic development and competitiveness of the region in comparison with other regions worldwide was a reason for concern in the late 1990s. At the same time, it is justified to ask why there are three initiatives with partly overlapping but also competing agendas.

The 1999 elections for the Hesse parliament (Landtag) brought significant change for the governance of Frankfurt/Rhine-Main as the result of the election led to change of government (Christian Democrats (CDU) and Liberals (FDP)). According to the coalition's position the best way to deal with the administratively fragmented metropolitan region was by means of sector specific municipal cooperation. As the metropolitan area is in any case polycentric and as the residents still retain their local identity, voluntary cooperation between the municipalities was seen as the best and only possible way of coordinating decentralised and fragmented activities. The government issued a law on the "strengthening of the inter-municipal cooperation and planning in the Rhine-Main Region". ${ }^{6}$

The law abolished the Umlandverband and transferred in April 2001 the planning responsibilities to a newly created planning authority (Planungsverband Frankfurt/Rhein-Main). This new planning authority comprises a much wider catchment area than its predecessor $(75$ municipalities instead of 43), but this geographic extension went hand in hand with less powers. At least at the beginning, the association was in fact more a single-purpose association, whereas the UVF had formally (and early on in reality) a wide range of responsibilities. The new planning association is responsible for the preparatory land use plan (Regionaler Flächennutzungsplan) and for the landscape plan (Landschaftsplan) for the area covered by its members. In German planning law, the preparatory land use plan is a municipal plan, but in the region Frankfurt/Rhine-Main this task has been shifted to the planning authority. Because the territory of the new planning association included 75 rather than 43 municipalities, ${ }^{7}$ the 
plan exhibits a stronger regional dimension and was therefore considered to be an innovative instrument for the coordination of land use in metropolitan areas.

Apart from its limited range of competencies the new planning association also lacks - in comparison with the UVF - direct democratic legitimacy, as the regional chamber is not composed of directly elected members but of 93 representatives from the 75 municipalities who are the members of the planning association. Each municipality sends one representative, but the vote is weighted according to size (note that this describes the situation before the accession of five municipalities in April 2021):

$\begin{array}{ll}\text { Votes (according to inhabitants) } \\ \text { Frankfurt } & 12 \\ \text { Offenbach } & 4 \\ \text { Hanau } & 3 \\ \text { Bad Homburg } & 2 \\ \text { Rüsselsheim } & 2 \\ 70 \text { other cities } & 1\end{array}$

The chamber is organised into four fractions, currently the Social Democratic Party (SPD) has a majority (44 votes), followed by the conservative CDU (32), an independent list (11) and the Green party (6) (Regionalverband FRM 2020, 8).

The law also defined a list of public tasks of regional importance but not to be accomplished by the planning authority and gave one year for the municipalities to find collaborative new solutions for these tasks on a voluntary basis (MetropolG Land Hessen 2018). If this is not done, the federal state was empowered to impose an obligatory association. The tasks covered were waste disposal, water management, social and cultural infrastructure, regional parks, marketing and attracting investment and public transport.

The body being responsible for this process of finding voluntary solutions was the "council of the region" (Rat der Region) that gathered the county presidents and mayors of cities with more than 50,000 inhabitants. The voluntary character of this process was put into question as the Hesse government preserved the right to force the municipalities to cooperate if this did not occur in a bottom-up way. The restriction of federal state intervention is couched in vague terms. Cooperation should be imposed only for key policy areas (listed in the law). This issue of the possible intervention of the federal state government led to a strong reaction from the municipalities (Heinelt et al. 2011), which argued that the law was unconstitutional, i.e. it cut across the constitutional guarantee of local self-government. The main reason for such a strong reaction was the fear of being forced to give up some competencies (as well as a share of financial resources) and the non-voluntary inclusion of 32 municipalities that had not previously been 
members of the UVF. The appeal was rejected by the Hesse Constitutional Court in May 2002 and the law came into effect.

Apart from the two bodies created by the law, various other initiatives in the metropolitan area have flourished since the year 2000. This can be seen to be a result of the underperformance of the organisational setting established by the law of 2000 .

The council of the region was not very welcomed by the political leaders of local governments and their engagement in this context of forced voluntary collaboration was rather low. Instead, in May 2000, the mayor of Frankfurt initiated a regional conference that brought together the mayors of the big cities and the presidents of the counties of the area. The composition of the conference emphasised the extended boundaries of the metropolitan region insofar as it reached much further than the council of the region (i.e. beyond the boundaries of Hesse). The principle of dialogue characterising the interactions of this body is underpinned by the fact that the host of the conference was rotating.

The success of council of the region in finding arrangements for all the mentioned tasks of regional importance was limited and where solutions were found, the state government played a facilitating role (i.e. in the field of culture). The state government did not use the option of a top-down intervention but instead, in 2011, changed the whole setting again. The ineffective council of the region was replaced by a board of the region. This board has similar tasks but fewer members and a more effective mode of decisionmaking (i.e. the representatives of a municipality are not obliged anymore to vote concordantly). In addition, the planning authority and the board of the region should cooperate more closely which gives the planning authority more influence. The current structure is as follows: the board of the region (Regionalvorstand) is the main body in terms of leadership and decisionmaking $(\mathbb{S} \mathbb{S} 14,15$ MetropolG). Members of the board are the director of the planning authority and up to two deputy directors. In addition, up to eight honorary members (representatives of the civil society but in reality, mayors as well as members of the parliament of Hesse), the six county presidents and the lord mayors of Frankfurt am Main and Offenbach are full members of the board. The board also has members with a guest status (no right to vote). These are the mayors of adjacent cities that are not formal members, such as Darmstadt and Wiesbaden. There is also an advisory board and the members are the chamber of commerce, the regional transport association (RMV), the chamber of crafts, the economic initiative and the German Trade Union Federation (DGB). In other words, the regional board fulfils two functions: it leads the planning authority and defines the regional key tasks as suggested by the law in a more concrete manner. At the same time, the board has the mission to find arrangements for these key regional tasks (so-called Ballungsraumaufgaben) if the board does not consider the planning authority to be the appropriate agency. Hence, the board of the region has the clear mission to find arrangements for the accomplishment 
of regional key task but has considerable leeway to do this. This may imply that a function is delegated to a private agency.

Besides the planning region with two levels (regional land use plan, statutory regional plan), several other initiatives exist in different sectors. As these initiatives coincide with specific tasks or functions (culture, mobility, economic development, regional landscape park) we will introduce them in section 4.3.3. on coordination of public policies.

\subsubsection{Spatial relations within the metropolitan region of Frankfurt/Rhine-Main}

As has been mentioned, the Rhine-Main region is characterised as polycentric and in terms of its governance spaces as fuzzy. It has become common for many actors from the region to distinguish between the metropolitan region and the agglomeration (Metropolregion and Ballungsraum). The latter is the planning region for the regional land use plan, with Frankfurt and Offenbach being the dual urban core, surrounded by a polycentric system of cities, towns and suburban settlements. The notion metropolitan region indicates that there are many public policies that need coordination and collaboration on a larger scale (across the borders of the three states).

In addition, there is the statutory regional planning region which covers the entire territory of the government district of southern Hesse.

The metropolitan region emerged in the 2000s (see section 4.1) but initially found only limited response in the Frankfurt/Rhine-Main region. The territorial frame crosses two state borders (Rhineland-Palatinate, Hesse and Bavaria) and represents about 5.8 million inhabitants. In terms of governance, it is weakly institutionalised. Following a longer period of debates, in 2018 a strategy forum (Strategieforum) was founded as a result of an initiative of the chamber of commerce and industry Frankfurt. ${ }^{8}$ It found support of the state governments, hence it is not a genuine municipal initiative. Today, representatives of four state governments (Hesse, RhinelandPalatinate, Baden-Württemberg und Bavaria), the lord mayors of Frankfurt and Mainz, the county presidents of Hochtaunuskreis, Rhein-Neckar-Kreis and the region Bayrischer Untermain (Aschaffenburg) (i.e. a representative of local government from each of the four states) and the regional planning authority (the latter also represents municipalities) and the presidents of six chambers of commerce and industry are members of the steering board. The agenda of the forum clearly is economic development (entrepreneurship, smart region).

Although this arrangement is more stable now, clear boundaries of the metropolitan region do not exist. To give an example: in 2010, the chamber of commerce, the chamber of crafts and the Federation of Associations of Entrepreneurs of Hesse (Vereinigung der hessischen Unternehmerverbände $e . V$.) financed a study on functional and territorial interdependencies of the region. The report suggested to take also areas in the far north of Frankfurt 


\section{Germany}

into consideration as being part of the functional region (Prognos 2010). Hence, there are flexible spaces for cooperation and delimitation depends on the perspective and interest of the actors (see next section). It is possible to divide the region into economic functional sub-regions and clusters but this does not necessarily transform into political cooperation (Hoyler et al. 2008; FrankfurtRheinMain GmbH International Marketing of the Region 2018; Ebert 2016).

In order to describe the spatial pattern of the Rhine-Main region we may refer to the TSPN framework (Jessop et al. 2008). The core of the region is covered by a territory (the planning authority with obligatory membership). Besides the territory there is a range of functional networks and scales, some are more stable, some are more in a state of flux and they also refer to different spatial frameworks (flexible geographies). There are largely two dynamics: expansion (metropolitan region, now also including the Rhine-Neckar-County of Baden-Württemberg) and concentration (planning authority as institutional core). In fact, in 2019, the mayor of a smaller municipality in the north-east of the planning region (Limeshain) expressed the desire to became a full member of the planning authority. Accession is possible for municipalities that share a border with the planning region and this is the case in Limeshain. During the process three further villages (Echzell, Glauburg, Ranstadt) and the town Nidda followed and in April 2021 these five municipalities acceded the planning authority that has now 80 members.

\subsubsection{Coordination of public policies within and beyond the perimeter of the planning authority}

As has been mentioned already, the case of Frankfurt/Rhine-Main displays several task-specific arrangements that differ in terms of organisational form, actor composition and territorial outreach. In fact, it is the subject of a long debate where the region ends and which areas belong to it (Hoyler et al. 2006). As the planning authority is at least to a certain degree the organisational core of this arrangement, we will start with the policies coordinated by the planning authority. The functional portfolio of the planning authority is defined in the law but the law opens an opportunity to allocate more functions to the planning authority when the board of the region agrees upon this (see above). For the time being the planning authority has the genuine task of regional land use planning and landscape planning. In addition, the law mentions a number of key regional tasks calling for better inter-municipal coordination. The law specifies that the board of the region is encouraged to find solutions for these tasks. This does not necessarily mean that the planning authority will accomplish these tasks in full competence. Many options are possible and the planning authority may just be a partner but is allowed to take the initiative as long as the board of the regions decides this. ${ }^{9}$ 
These are:

- Sports and recreational facilities;

- Cultural facilities of regional relevance;

- Marketing and economic development;

- Regional landscape park Rhine-Main;

- Regional transport planning and management.

In 2018, after a regular evaluation of the law, some additional remits have been added. The new tasks that are mentioned now in the law are housing and spaces for new settlements, sustainable sourcing of water, preparation of a regional energy and climate protection concept, and the design as well as implementation of a digitisation strategy. Note that this means that the board of the region may take the initiative in a variety of forms. As we will see in the following sections, the board and the planning authority became active in a variety of policies such as energy, mobility and digitisation.

\subsubsection{Regional land use planning}

The Regional Authority (Regionalverband) FrankfurtRheinMain is responsible for the regional preparatory land use plan (regionaler Flächennutzungsplan) (Regional Authority FRM, 2014; Schmidt 2013). In German planning law, the preparatory land use plan usually is a municipal plan, being the structural element in a local two-tier system of land use planning. In the Frankfurt/Rhine-Main region this task was shifted to the Regional Authority in 2001. The regional land use plan controls the location of function in space (settlements, business zones, infrastructure, green spaces), but does not regulate details of urban design. The Regional Authority seeks to implement the general principles of German land use planning and gives priority to brownfield development and the inner cities along the major public transport axes.

The plan has to be developed in collaboration with the government office of the region responsible for the regional plan. Therefore, a tension between regional planning and inter-municipal land use planning (Regionaler Flächennutzungsplan) is not surprising. The new planning association was criticised by interviewees for its narrow delimitation and for responsibilities which overlapped with the competencies of the government office for the region. Since 1980, the government office for the region in Darmstadt has been responsible for the regional plan (Regionalplanung), the planning association (as mentioned above) for land use planning (Flächennutzungsplan) and for landscape planning (Landschaftsplan).

The former Umlandverband rendered a plan similar in character already before, but since 2001 it covers 75 municipalities instead of 43 (80 in 2021). This increase in size of this plan intensified the need for coordination with regional planning (Regierungsbezirk). Hence, the regional land use plan has 


\section{Germany}

to be developed in collaboration with the government office of the region. The planning region "Southern Hesse" is much bigger than the territory of the Rhine-Main planning authority but the latter forms the densely urbanised core (see Figure 4.7). Both plans operate with different scales (1:50,000, $1: 100,000)$. As part of the technical solution, the regional land use plan becomes part of the regional plan, or to be more precise: it substitutes the

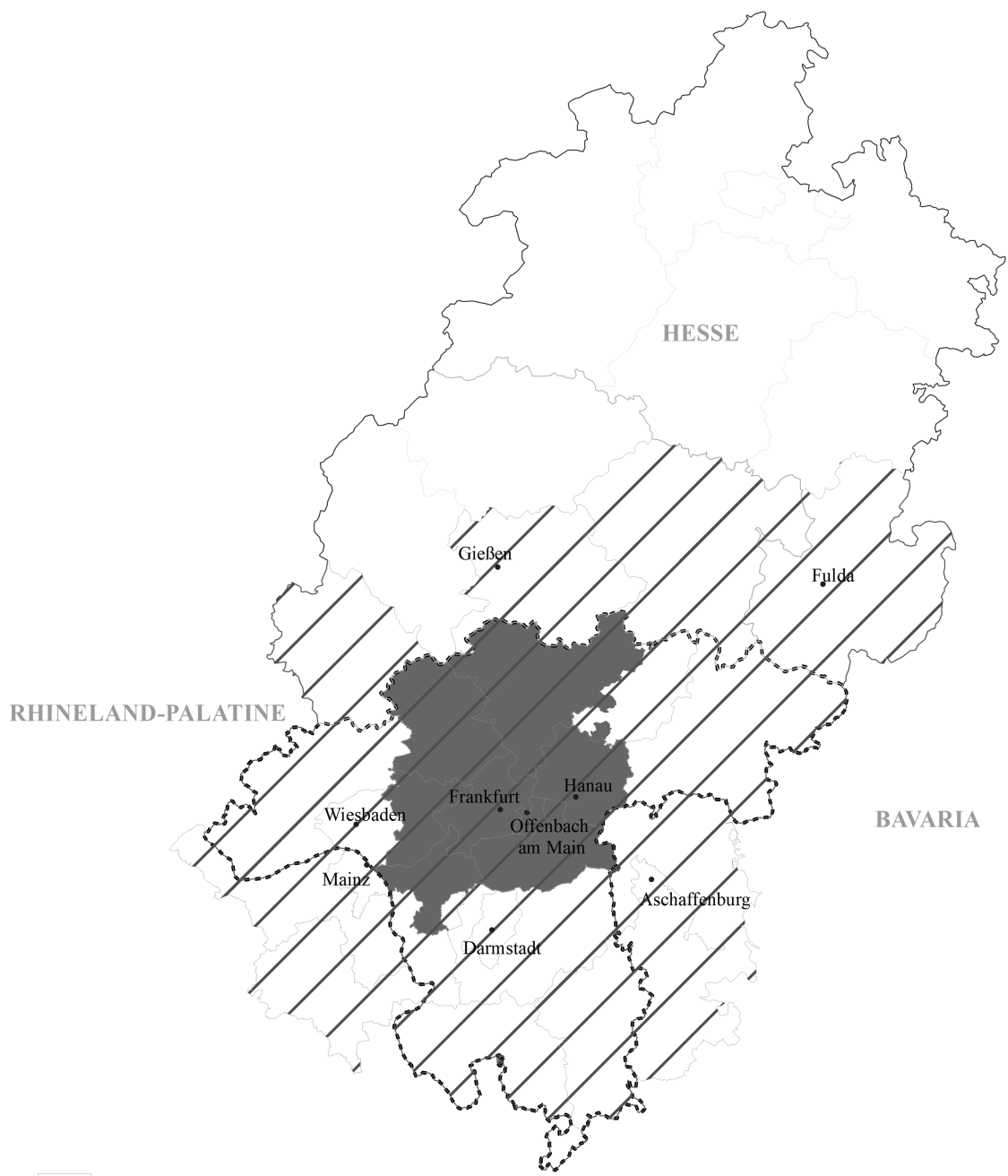

Counties

BADEN-WÜRTTEMBERG

Frankfurt region

Administrative district Darmstadt

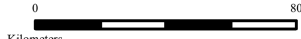

European Metropolitan region Frankfurt

Federal State Hesse

Figure 4.7 Frankfurt/ Rhine-Main region in the multilevel system 2021 Concept: K. Zimmermann Cartography: F. Gela 
regional plan in the area of the planning authority. Although this sounds technically complex, the experts can manage to prepare the two plans in a coherent way. Still, this solution is unique in Germany.

When the elaboration of the new regional land use plan started in 2018, municipalities and planning authority and the government office of the region agreed to change the scale of the new plan from 1:50,000 to 1:25,000. Hence, it will be more detailed and the difference between the regional plan and the regional land use plan becomes clearer. Major issues of for regional planning are large shopping centres and finding enough space for housing. For the regulation of shopping centres, a regional retail concept (Einzelhandelskonzept) is in use. This concept tries to protect the (small-scale) retail business of the inner city from the adverse effects of large shopping centres outside the city. Mobilising space for affordable housing is an unsolved problem.

\subsubsection{Regional Landscape Park}

In the mid-1990s the former planning authority UVF promoted the idea of a regional landscape park as a connected system of green space for recreational purposes. The motivation for this was twofold: on the one hand there was a lack of high-quality green areas that can be offered for recreational activities such as cycling and hiking. On the other hand, the planning authority wanted to protect green spaces and agricultural land. The planning authority followed an idea of decentralised implementation already in 1997: the planning authority did the strategic coordination and smaller groups of municipalities were envisioned to take the responsibility for a subarea of the park (in terms of implementation and maintenance). The implementation of this idea was taken away from the planning authority in the context of the reform in 2000/2001 and delegated in 2003 to a new special purpose governance form. This organisation started operation only in 2005 and is organised as a two-level system. Six decentralised agencies (usually municipalities and / or a county) are responsible for the management and maintenance of the park in a defined subarea. In total, 45 municipalities and two counties are active on this implementation level and the planning authority is involved in two of these operational partnerships. All these implementation agencies work together in an umbrella organisation (a limited liability firm, seven counties, six cities, the planning authority and the state government of Hesse are the stakeholders, also financially). The umbrella organisation is responsible for marketing but also for financing. The regional park is a highly valued initiative as there is a lack of high-quality green space and leisure facilities. Substantial financial support derives from Fraport, the owner of the airport.

\subsubsection{Digitisation}

Digitisation and the extension of broadband access has been added to the list of tasks of regional importance in 2018. Since 2019 the planning authority moderates a process called "Gigabit region" that includes nine counties 


\section{Germany}

and three county-exempt cities, in total more than 161 municipalities. Again, this is more municipalities than the authority has in terms of members, hence this is seen more as a task for the metropolitan region but the process is moderated by the staff of the planning authority. Joining forces makes sense as a larger group of municipalities can negotiate for better conditions with the firms. Another goal is the extension of the $5 \mathrm{G}$ standard that is necessary for some measures and projects in the area of mobility.

A letter of intent was signed in May 2019, a feasibility study has been published, and a public procurement process started in late 2019. The next step is the foundation of a limited liability company $(\mathrm{GmbH})$, which will be led by the director of the planning authority.

\subsubsection{Cultural policies}

Culture is another task that is mentioned in the law as one of the pending issues where the board of the region was encouraged to find a joint solution. Again, there are several initiatives active in the region and they differ in terms of membership and spatial reach. The Cultural Region (Kulturregion) is a voluntary association of 52 municipalities and counties and the planning authority. It was established in 2005 (www.kulturregion-frankfurtRheinmain.de). The Cultural Region is built up from below by municipalities (together with the planning authority) and tries to coordinate their specific interests (especially in respect of joint financing). The Cultural Region organises events and exhibitions and supports cultural initiatives that are active the region.

In 2006, yet another cultural initiative came about - the Kulturfonds Frankfurt Rhein-Main GmbH (www.kultur-fonds-frm.de). This is an initiative bringing together the federal state government, larger cities such as Frankfurt, Wiesbaden and Darmstadt and two counties for supporting high-level cultural offers that are seen as crucial locational factor. ${ }^{10}$ The Kulturfonds is stronger compared to the Cultural Region due to financial help of the state government but membership is smaller. Initially it was the state government, Frankfurt, Wiesbaden, Darmstadt and the two counties Hochtaunuskreis und Main-Taunus-Kreis as these are places where high culture events usually take place. In 2020, the city of Offenbach and the smaller towns of Oestrich-Winkel and Bad Vilbel joined the association. Therefore, currently there are ten members (Hanau joined earlier). The municipal members pay two euros per resident, the counties 1.60 euros per resident and the state government contribute a similar sum. Overall, the goal of this initiative was enhancing the attractiveness of the region.

A third actor is the Cultural Initiative Frankfurt/Rhine-Main (Kulturinitiative Frankfurt Rhein-Main) that was established in 1998 and then converted into an association in 2003 (www.kirm.de/kirm/satzung .htm). The Cultural Initiative gathers representatives of culture-related organisations in the region (as well as individual actors) in order to jointly 
run cultural activities and by these means, support the development of a cultural identity for the metropolitan area. The Cultural Initiative is more an organisation for people being active in culture and the media. Municipalities are less relevant.

\subsubsection{Economic Development and Marketing}

Economic development and marketing is a shared task between the municipalities and several special-purpose associations. In particular, the smaller municipalities see a great benefit in inter-municipal cooperation as they can mobilise more resources and critical mass. Economic competitiveness became an issue in regional policy in the early 1990s. The initiation of the IHK-Forum Rhine-Main by the chambers of commerce and industry of the Frankfurt/Rhine-Main region was a clear reaction to this. The chambers of commerce and industry usually operate locally. The Forum is a sort of platform that allows the various IHK to have more political weight and influence and bring regional topics on the agenda. The main motivation was a shared concern about a lack of coordination of local policies (infrastructure in particular, but also land use planning) and a lack of a common vision for the economic development of the region. The IHK Forum presents ten chambers covering a large area spanning from Mainz to Aschaffenburg.

The Economic Development Agency for the Region of Frankfurt/RhineMain (Wirtschaftsförderung Region Frankfurt/Rhein-Main), established in 1995 with the support of the UVF, has a different mission. It represents the interests of municipalities and also offers services for the member municipalities. Today also other actors such as technology clusters and Fraport are involved. ${ }^{11}$ Thus, membership is broad and the weight of the organisation is considerable. The aim of the agency, now connected to the planning authority, is the coordination and fostering of metropolitan-wide cooperation in the field of economic development. ${ }^{12}$

The Economic Initiative (Wirtschaftsinitiative), founded in 1996, is still active but focuses more on the bundling of interests within the region (agenda setting).

In 2021, we can see a more consolidated situation and increasing culture of effective division of work - although on first sight the actor constellation still seems to be complex and initiatives can hardly be separated. The following actors and initiatives are relevant:

- FrankfurtRheinMain International Marketing of the Region is responsible for the attraction of foreign firms and investors (https://www.frmunited.de/ueber-uns/). Hence, the agency is very active internationally (Southeast Asia and North America). Stakeholders are 34 towns and counties, the chambers of industry and commerce and various other affiliated organisations (the agency is operational with direct contact to firms). 


\section{Germany}

- The Association for the Promotion of the Frankfurt Rhein/Main region (Verein zur Förderung der Standortentwicklung, http://www.verein-frm. de) is an agency that acts also within the region. This association has a slightly different actor composition (state government of Hesse, City of Frankfurt am Main, Planning Authority (representing the other municipalities and countries), the Economic Initiative and Deutsche Bank). Its main purpose is agenda setting and it is also operational but with a focus on structural aspects of regional development.

- The international attraction of high skilled workforce is the task of the FrankfurtRheinMain International Office (Willkommensportal). This agency is organisationally part of the planning authority but a joint venture of the chamber of commerce Frankfurt and the planning authority (www.find-it-in-frm.de).

- Perform is a digital spin-off of the IHK-Forum and was established in 2016. Perform is an open online platform for the generation and promotion of ideas (together with Chambers of Crafts / Handwerkskammern). It is an open digital forum and follows the principle of crowdsourcing and bottom-up initiatives. The success is questionable until today but its visibility is high. One success, according the interviewees, is the higher recognition of congested streets and traffic jams on the commuter routes. This issue has been raised for a long time, but it gained recognition and wider support once it was placed as a project suggestion on the Perform platform. This is a form of digital regionalisation.

The economic initiatives and organisations were partly competing in the late 1990s and early 2000s, or at least they presented different visions and organisational solutions for the region. Today it is a network of initiatives with different but interwoven membership structures. A good example is the project FRM2030 (FrankfurtRheinMain GmbH International Marketing of the Region 2018). The purpose of this project was the creation of one or several visions for the metropolitan region. The final report also included measures and initiatives that would contribute to the implementation of the vision. The project was initiated by the planning authority and the association for the promotion of the Frankfurt Rhine/Main region (Verein zur Förderung der Standortentwicklung FrankfurtRheinMain). The FrankfurtRheinMain $\mathrm{GmbH}$ International Marketing of the Region was coordinating the project on behalf of the planning authority. In addition to the above-mentioned institutions, the Business Initiative, the state government of Hesse, the city of Frankfurt, the Frankfurt Chamber of Industry and Commerce and the Perform Initiative were also members of the FRM 2030 steering committee.

\subsubsection{Mobility}

The UVF had the responsibility for a mobility master plan but with the abolition of the planning authority in 2000 the task has become void as the 
new planning authority is primarily responsible for land use planning. As a consequence, although there are a range of mobility-related problems in the region, there is no overall planning authority or integrated mobility concept for the area since 2000. Besides this lack of coordination, major problems are the high number of commuting people and lagging investments in rail infrastructure.

In 2011, a mobility masterplan has been published as a study by an agency called ivm. As the task of public transport has been mentioned as one the tasks waiting for regional coordination in the law of 2000, the establishment of ivm in 2005 can be considered as a trial to organise the task of regional mobility planning in a more flexible way. The agency is a limited liability company owned by a large group of municipal shareholders and the state government of Hesse. The number of shareholders increased over time but not all municipalities of the planning region are involved. It is not a planning authority and has no implementation or planning powers. It is more a think tank that municipalities can hire for the elaboration of plans and mobility concepts when needed. Hence, the masterplan of 2011 was not a binding plan but a document giving recommendations and found limited attention.

In 2021, however, the planning authority published a mobility strategy as mobility has been added to the task of regional importance in 2018 . Although the planning authority calls this document SUMP (with reference to European standards) this is not an integrated transport plan but a collection of measures and priority projects. For most of the suggested projects the authority has no competence for implementation as the state government declined the request to give the legal competence for a binding mobility master plan (Generalverkehrsplan) back to the planning authority. An exception is the regional bicycle highway system. The municipalities delegated the coordination of this project to the planning authority. In terms of spatial reach, it is important to note that besides the legal members of the planning authority also the other municipalities of the counties GrossGerau, Wetterau and Main-Kinzig-Kreis participated in the process (in total 108 instead of 75 municipalities). The concept includes 22 measures and the overall goal is: a $65 \%$ share of environmentally friendly mobility in the regional modal split and the realisation of the so-called five minute region (i.e. the availability of a public mobility option within a reach of five minute walking distance). Many of the proposed measures are feasibility studies, including an expertise on the viability of more restrictive mobility policies (Regionalverband FRM 2021, 17).

The planning authority has no competence for busses or regional railways. This is in the competence of the counties and cities that collaborate within a single-purpose association (RMV). The RMV is responsible for an area much bigger than the planning region and manages regional railway connections ( $S$-Bahn and regional trains). The RMV covers 15 countries and 11 cities and these counties and cities are also the stakeholders together with the state government of Hesse. Hence, the RMV is 
not an association of transport providers but of local governments. They delegated the planning, managing and financing of public transport to the RMV. The members order a service and the RMV coordinates the implementation.

Infrastructure planning is done on a case-by-case basis. For the S-Bahn, for instance, this is done on an inter-municipal level through the creation of planning agencies for each new route. Usually this is a complex process that takes long time. A tangential connection in the west of the region has been under debate for about 30 years. The planning agency (Regionaltangente West Planungsgesellschaft) was founded in 2008 and encountered quite a few problems in coordinating the municipal stakeholders. The new line will start operation in the late 2020s.

\subsubsection{Energy}

In 2016, the planning authority published an energy concept for the region. This is a voluntary initiative and service for the municipalities as the planning authority gives advice, promotes renewable energy projects and identifies the sites for wind turbines in the regional land use plan.

Several of the organisations mentioned in this section are gathered in an umbrella organisation called "Arbeitsgemeinschaft der Dachgesellschaften" (Working Party of Regional Associations) which is moderated by the regional planning authority. This is more a voluntary forum of knowledge exchange and coordination, but it is the only arena where all the initiatives come together, though only for knowledge exchange and a minimum of strategic coordination. At the same time, this demonstrates that the planning authority has gained recognition as a central actor in the networked governance of Rhine-Main (see Table 4.3).

\subsubsection{Conclusion}

After years of conflicts and competing regional initiatives, there is a more consolidated and pragmatic approach of metropolitan governance in the Frankfurt/Rhine-Main region. The arrangement is still multipolar and more a "network of networks" with thematic overlaps and flexible geographies of cooperation. But it seems that all the initiatives have found a modus operandi that avoids double work and concurrence. Instead, a mutual acceptance and task-specific division of work seems to be in place.

The last moment in time, when a more consolidated solution was a disputed issue, was 2015 when the lord mayor of Frankfurt invited a wide range of actors on his own initiative to the Frankfurter Paulskirche to celebrate "The day of the metropolitan region". A declaration was signed but not much has happened in terms of consolidated governance (Bender et al. 2015). During this event, a treaty on the metropolitan region Rhine-Main between the states of Hesse, Bavaria and Rhineland-Palatinate was also discussed but never formalised. 
Table 4.3 Networks and initiatives with participation of planning authority

\begin{tabular}{|c|c|c|}
\hline Organisation / Initiative / Agency & $\begin{array}{l}\text { Role and relationship of planning } \\
\text { authority }\end{array}$ & Since \\
\hline $\begin{array}{l}\text { Economic Initiative / } \\
\text { Wirtschaftsinitiative }\end{array}$ & Member & 2005 \\
\hline $\begin{array}{l}\text { Association for the promotion of } \\
\text { the region / }\end{array}$ & $\begin{array}{l}\text { Foundation of the association } \\
\text { Wirtschaftsförderung Region }\end{array}$ & 1995 \\
\hline $\begin{array}{l}\text { Verein zur Förderung der } \\
\text { Standortentwicklung }\end{array}$ & Frankfurt RheinMain & \\
\hline Regionalpark & Joined the Regionalpark- & 2005 \\
\hline \multirow{4}{*}{$\begin{array}{l}\text { Durchführungsgesellschaften/ } \\
\text { Implemenation Agencies }\end{array}$} & Dachgesellschaft Share: $6,7 \%$ & \\
\hline & $\begin{array}{l}\text { Regionalpark RheinMain Südwest } \\
\text { GmbHShare: } 11,76 \%\end{array}$ & \\
\hline & $\begin{array}{l}\text { Regionalpark RheinMain Taunushang } \\
\text { GmbH Share: } 11,11 \%\end{array}$ & \\
\hline & $\begin{array}{l}\text { Gesellschaft zur Rekultivierung der } \\
\text { Kiesgrubenlandschaft Weilbach } \mathrm{mbH} \\
\text { Share: } 25,0 \%\end{array}$ & \\
\hline Strategieforum Metropolregion & Authority represents municipalities & 2015 \\
\hline Cultural Region / Kulturregion & Shareholder & 2005 \\
\hline Standortmarketinggesellschaft & Share: $3 \%$ & 2005 \\
\hline Frankfurt Rhein Main GmbH & $\begin{array}{l}\text { Dierctor of planning authority is } \\
\text { member of the governing board }\end{array}$ & \\
\hline Gigabitregion & $\begin{array}{l}\text { Planning authority leads the process, } \\
\text { Director is head of limited liability } \\
\text { company }\end{array}$ & 2019 \\
\hline
\end{tabular}

Even the IHK Frankfurt Rhine-Main, which was certainly a driver in the public debate on a potentially consolidated metropolitan government (i.e. the bundling of tasks in one organisation) changed its mindset and accepted the strategy forum. This is a soft form of collaboration between the states and local and economic actors (instead of a treaty), that nevertheless operates on a high political level (the state chancelleries).

Voluntary collaboration in different constellations and formats instead of never-ending debates about the appropriate metropolitan government seems to be an appropriate description of the mindset of actors. The metropolitan region is better established as a territorial frame than it used to be ten years ago (Heinelt et al. 2011). However, due to the abstract scale this territorial frame does not prevent conflicts when municipalities litigate about a location of a commercial development area or a large retail centre. The strategy forum has no powers here.

As a result, the only two remaining issues are infrastructure and mobility and strategic territorial development (housing in particular).

1) Mobility planning is less well coordinated. There have been attempts to create a regional vision in 2011 (without resonance) and there is an organisation addressing mobility issues for the municipalities (ivm $\mathrm{GmbH})$. But there is no binding mobility plan or body coordinating 


\section{Germany}

infrastructure planning. There is also no informal platform or arena or joint vision or commitment for coordinating the individual mobility strategies of cities (streets in particular). The planning authority is now responsible for the masterplan mobility but this seems to be only little more than a plan for regional bicycle lanes. However, the service in public transport (regional trains, local busses and trams) is coordinated well by the RMV. But the fact that there are so many commuters is not reflected in a regional mobility policy. The RMV is doing a good job in coordinating the service but some infrastructure projects are lagging behind (Extension of the S-Bahn) and there is also no link to the strategic dimension of the regional land use plan (pro-active coordination of territorial development, housing and mobility policies). Though some interviewees saw the problem they don't see the need for an authority taking care of the mobility problems. Problems of coordination are addressed when they occur or project-based (as has been shown by reference to the RTW Planungsgesellschaft).

2) Strategic territorial development. The planning authority is responsible for the land use plan and the landscape plan but not for the strategic coordination of regional development, hence the integration of transport and land use planning is weak. Also other issues such as climate change and economic development are only seen through the land use plan. Hence, we cannot speak of integrated spatial or strategic planning.

In terms of ideas guiding the policies we can say that effectiveness and efficiency are less relevant than in France and Italy. Economic development in a way is an important factor. Everybody (including the state government of Hesse) agrees that a successful region needs some coordination of land use (zoning of commercial areas). But detailed policies and projects are not on the agenda, this is done by the municipalities. The joint promotion of commercial zones is not foreseen but this is done implicitly with the support of the planning authority as they have a database. Still the municipalities compete and practice a kind of venue hopping.

The overall evaluation of the relevance of regionalisation in the Frankfurt/ Rhine-Main for public policies is nevertheless cumbersome. Effective single purpose arrangements such as the RMV (public transport) and promising initiatives such as the Gigabit Region (digitisation) stand in contrast to complex arrangements in land use planning and the regional landscape park.

\subsection{Stuttgart: well established showcase example of metro governance?}

Stuttgart, the capital of the federal state of Baden-Württemberg, is located in south-western Germany. Since decades, the region is renowned for its automotive and engineering industry. Its geographic location was however seen as being peripheral during industrialisation in the 19th century 
(Basten 2011, 276), whereas today the region has a higher centrality and connectivity due to a dense highway infrastructure, European integration, air traffic and investments in rail infrastructure (Frank and Marsden 2016, 259). The core city of Stuttgart is by far the dominant urban centre with 630,000 inhabitants out of 2.8 million in the city-region. With $23 \%$, the share of the regional population is however relatively low. The region, as defined by the regional planning authority Verband Region Stuttgart (VRS) comprises $3,654 \mathrm{~km}^{2}$. It has a polycentric urban structure as the core city is surrounded by several medium-sized cities of 40,000 to 95,000 inhabitants within a 25-kilometre radius (Esslingen, Böblingen, Sindelfingen and Leonberg, see Figure 4.8). The region is also characterised by many small cities and villages.

The Stuttgart Region experienced enormous population growth after the second world war, almost quadrupling its population between 1950 and 1960 (Basten 2011, 276). During the 1960s up until 1998, the city of Stuttgart lost residents with a temporary exception of the first years after German unification. This trend changed at the end of the 1990s and population growth has accelerated since 2010. Today, the city of Stuttgart has reached the population it had at the beginning of the 1960s (Website

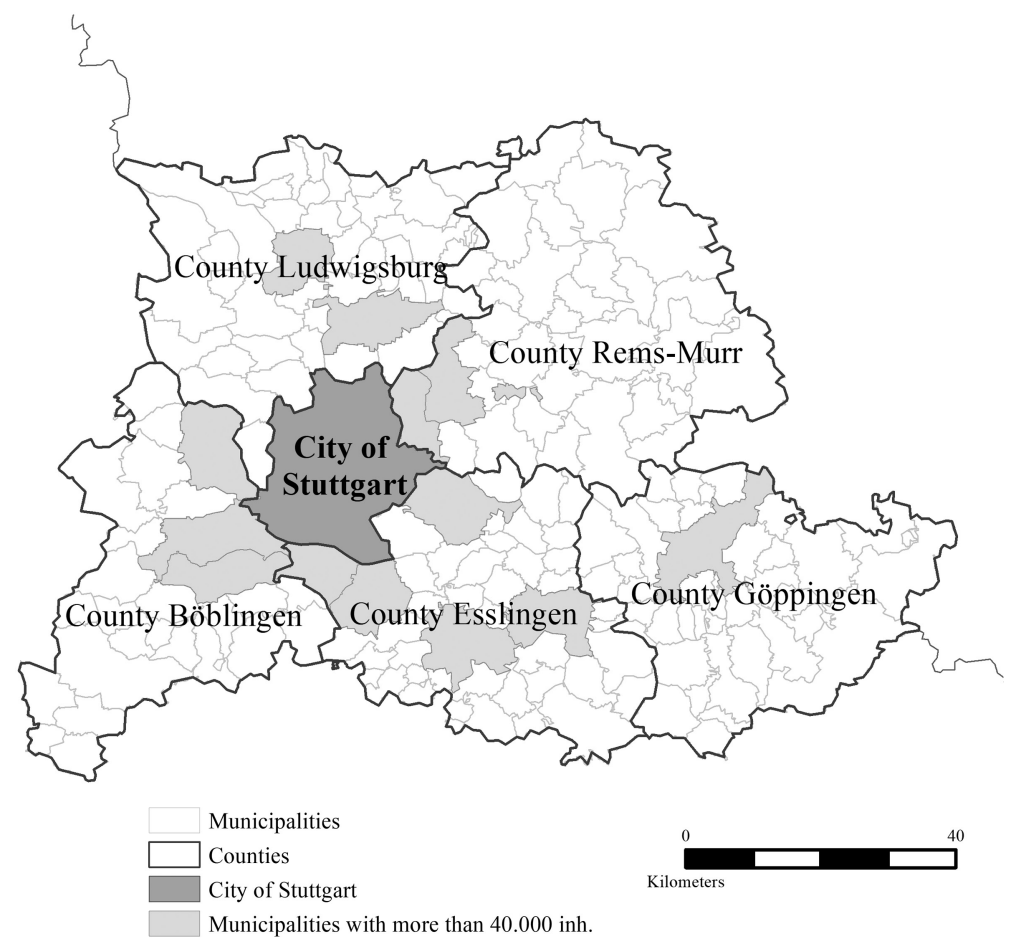

Figure 4.8 Stuttgart Region 2021 Concept: P. Feiertag Cartography: F. Gela 


\section{Germany}

Statistisches Landesamt Baden-Württemberg 2019). The population loss was in part due to suburbanisation and particularly households with higher incomes and families leaving the city (Heeg 2003, 164). Accordingly, population dynamics in the city-region varied with continued population growth until the 1970s and an overall population gain of over 500,000 inhabitants between 1961 and 1998. During the last decade, both core city and the region as a whole have been growing, but both population growth and building activity in terms of new housing units have been substantially higher outside the city of Stuttgart. Statistical data confirms that the core city gained young citizens in the education phase (18-25 years), whereas adults in the family phase (30-50 years) moved out of the city (ILS 2019). Before the creation of the regional planning authority, the rapid settlement development was scarcely controlled and led to massive land consumption and increase in car traffic. Land consumption was decoupled from population growth and the settlement area in the Stuttgart Region grew about $88 \%$ between 1965 and 2000 (Stark 2009, 73). Today, the settlement area is still expanding but growth rates have considerably slowed down despite population growth (VRS 2016, 19).

The Stuttgart Region has a strong automotive industry, engineering and mechanics sector with Mercedes/Daimler, Porsche and Bosch as large, internationally known companies as well as many small and medium-sized companies (Basten 2011, 273, 277). The highly export-oriented manufacturing industry was hit by a recession in the 1990s, leading to a job loss of over 100,000 between 1990 and 1997 (Heeg 2003, 166). However, the economy recovered in the 1990s and 2000s with job loss going hand in hand with a massive increase of productivity. The secondary sector continues to be highly significant for the regional economy despite tertiarisation, also in terms of well-paid jobs and its contribution to the regional GDP (Basten 2011, 277).

An essential feature of the governance arrangement in Stuttgart is its multi-scaled character where a strong institutional core (Verband Region Stuttgart) with a directly elected regional assembly and a bundle of functions (regional planning, public transport, etc.) is complemented by softer forms of voluntary cooperation. The core is organised as public authority and has along with Hanover the highest degree of institutionalisation of all city-regions in Germany (Fricke 2020, 157). In addition, strategic decisions are implemented by means of network building and network management (Benz 2003, 509).

The following key characteristics concerning metropolitan governance and planning will be highlighted in this chapter:

- Regional planning authority Verband Region Stuttgart with directly elected assembly created in 1994;

- Lean administration complemented by agencies with additional shareholders as partners; 
- High stability of the governance arrangement, functional profile and spatial dimension over more than 25 years;

- The idea to strengthen the economic competitiveness was a key driver during its foundation, but is no longer the central legitimation for its existence;

- The wider metropolitan region (Europäische Metropolregion Stuttgart) has never fully materialised as an additional layer.

\subsubsection{The institutional arrangement Verband Region Stuttgart}

The Stuttgart region as we see it today was created during the "second golden age of Metropolitan Government Reforms" (Lefèvre 2001, 16) in the 1990s and has remained stable since. It is one of the most integrated metropolitan institutions in Germany (Walter-Rogg 2018, 132). Even internationally, the Stuttgart Region is one of the rare examples with a directly elected assembly (Tomàs 2019, 35) and is acknowledged in academic contributions as a model for city-regional management (Priebs 2019, 263; Fricke 2020, 157; Frank and Marsden 2016, 248; Klinkenberg 2010, 392).

\subsubsection{The emergence of a unique governance model for Stuttgart Region}

The governance arrangement for Stuttgart Region is different from other city-regions in the federal state of Baden-Württemberg and resulted out of a combination of the state's reform policy (regionalisation "from above") and several political issues within the region that were pending since the 1970s (regionalisation "from below"). The fact that it came about was due to the exploitation of a favourable opportunity for reforms and the commitment of local actors (Benz 2003, 512).

Inter-municipal cooperation and regional planning started with voluntary municipal planning associations in the 1950s and included the City of Stuttgart since 1967 (Priebs 2019, 255). During the 1970s, territorial reforms strengthened the medium-sized cities in the surroundings of Stuttgart by increasing their size and administrative capacity, whereas the core city itself was not enlarged. The federal state created compulsory regional planning associations in 1972 throughout the entire state, replacing the voluntary municipal associations (Zimmermann 2011, 192-193). In addition to these large regions, six smaller neighbourhood associations were created in 1974 in the agglomerations of Baden-Württemberg with the task to elaborate inter-municipal land use plans, in case of Stuttgart for the core of the agglomeration (Stuttgart and the first ring). The first regional plan (Regionalplan) for Stuttgart came into force in 1977 and the inter-municipal land use plan in 1984 (Priebs 2019, 255). However, both the regional planning associations and the neighbourhood associations were limited to spatial planning tasks without any competences for implementation and were 


\section{Germany}

not able to address the bundle of problems of the metropolitan development in policy fields such as transport successfully (Zimmermann 2011, 193). Distribution conflicts between the municipalities concerning the financing of regional infrastructure were common (Benz 2003, 505).

At the beginning of the 1990s, the pressure to take action increased due to rising unemployment in Stuttgart caused by an industrial crisis, the growing awareness of competition between regions in the European common market and pending infrastructure investments of regional relevance (Basten 2011, 279). The mayor of Stuttgart as well as CEOs from large firms called for an intervention and the state government accepted these queries (Zimmermann 2011, 195; Benz 2003, 506; Priebs 2019, 256; Walter-Rogg 2018, 133). The former regional planning association was transformed by law ("Gesetz über die Errichtung des Verbands Region Stuttgart” (VRS) from 7 February 1994) into a regional jurisdiction (Körperschaft öffentlichen Rechts). The main changes of the reform were a directly elected assembly with a first election in June 1994 and some additional tasks beyond regional planning, particularly concerning regional transport and economic development. Hence, the VRS has gained democratic legitimacy and additional possibilities for implementation of the development strategy defined by the statutory regional plan. The latter is the main legal instrument of the VRS with the possibility to enforce projects of regional relevance if cooperative problem solving fails (Planungsgebot) and to align municipal plans to the aims of the regional plan. As the municipal neighbourhood associations in the Stuttgart Region has been dissolved when the VRS was created (Priebs 2019, 257), i.e. the local land use plans (Flächennutzungsplan) were since then again elaborated by the individual municipalities.

This strong position of the VRS increases the chances of achieving a negotiated solution with the municipalities (Benz 2003, 505-506). The first regional plan has been approved in 1998 and partially updated in 2002 with focus on large-scale retail (Priebs 2019, 258). The current one dates from 2009. A regional transport plan (Regionalverkehrsplan, 2001, updated in 2010 and 2018) as well as a landscape plan (Landschaftsrabmenplan) is elaborated in complementarity to the regional plan. In addition to those formal plans, an informal development strategy (Leitbild für den Wirtschaftsund Wissenschaftsstandort Region Stuttgart) has been elaborated by a broad range of actors including municipalities, counties, universities, companies, churches, etc. under coordination of the economic development agency (WRS) and approved by the regional assembly in 2012.

Within the 25 years since its creation, the governance arrangement of today's regional authority Verband Region Stuttgart has persisted without fundamental transformation. New projects, networks and topics such as wind energy and digital infrastructure (high-speed internet connections) emerged and were integrated into the existing governance arrangement. Additionally, the challenges have changed in character due to a good economic situation and demographic change. Now, a shortage of skilled 
workforce and affordable housing are considered pressing problems. At the same time, most municipalities in the region provide less building land than needed or do not activate plots foreseen for settlement development in regional and local plans for various reasons (Hemberger and Kiwitt 2018, 37). Whereas restrictive regional planning tools are well established, the German planning law has limited tools for pro-active settlement planning. The VRS is seeking to adapt by expanding soft activities such as information and advice, financial incentives and networking (Hemberger and Kiwitt 2018, 38-39).

Debates about extending the competencies of the regional authority have focussed on competencies of the counties, in particular regarding public transport. Due to the resistance of the counties, only a minor shift has taken place. Since 2015, the responsibility for regional express busses and park-and-ride services as well as a regional traffic control centre has been committed to the VRS, but not the competence for the local bus systems that are still in the competence of the counties (Priebs 2019, 258). The dispute has been settled by the federal state government with the agreement ÖPNV-Pakt 2025 signed by the federal state, the VRS, the counties and the city of Stuttgart (Beuttler-Bohn 2017, 116). The agreement fixes competencies, quality standards and the repartition of revenues. The head office of VRS has abandoned ambitions to expand its formal functions afterwards. A shift of functions from the municipal level is not debated, as the intermediary county level or the cooperation of neighbouring municipalities would be considered as a solution first. The state government is not willing to devolve more competencies either. The institutional arrangement of the VRS has remained unique in Baden-Württemberg, as the federal state has not expanded the model to other regions.

\subsubsection{Verband Region Stuttgart in the multilevel system}

Baden-Württemberg is a federal state with a multilayer system that has remained mostly unchanged for decades despite long-lasting debates about the high number of layers (Wahl 1998).

The Verband Region Stuttgart represents a city-regional level that is situated between the governmental levels of the state government and the counties. The federal state, the VRS, the counties and the municipalities all have a directly elected assembly or council. In addition to that, deconcentrated government offices of the regions of the state government (Regierungspräsidium) and different forms of joint administration at the municipal level exist such as single-purpose associations or voluntary cooperation (see Table 4.4). This means that the number of administrative levels varies between six, in the case of small municipalities, and four, in the case of county-exempt cities such as Stuttgart. ${ }^{13}$ The most influential levels of territorial government are the federal state government with legislative power and the cities with substantial rights of self-government. The capacity of 


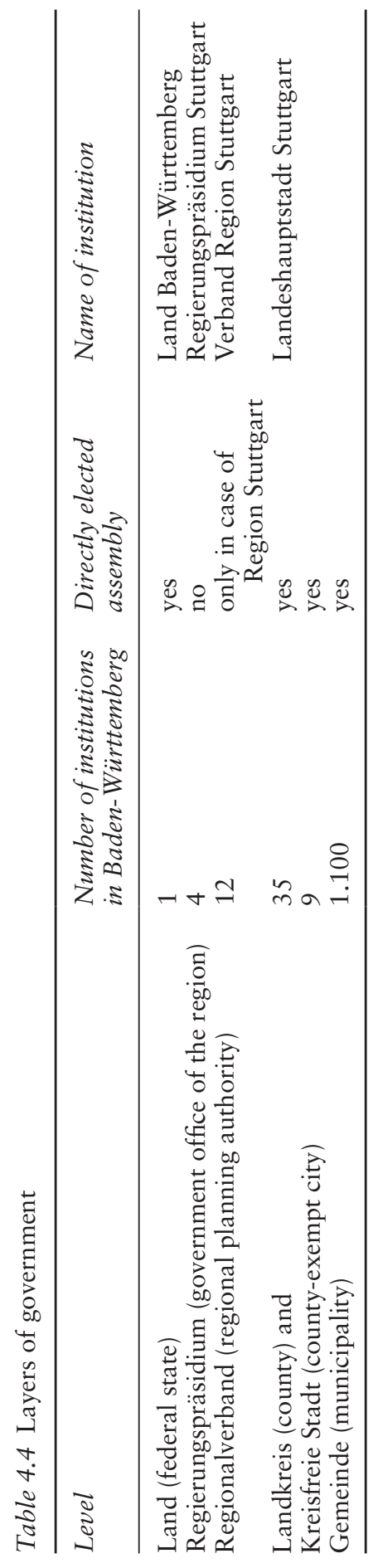


self-government varies depending on the size of the municipalities; municipalities with less than 20,000 inhabitants partially rely on the counties. With regard to the spatial planning system, the federal state, the regions and the municipalities are the three levels with statutory planning functions (see Table 4.6). The Stuttgart Region is not relevant in all public policies due to its narrow profile, e.g. not covering health care, education or social services and should therefore not be seen as a full-fledged level of administration, i.e. it is not a county (Wahl 1998, 210). This is all the more true for the other regional planning associations (Regionalverbände) in Baden-Württemberg as their functions are limited to regional planning and landscape planning.

The counties have a combined role of local self-government and multipurpose state administration (see 4.1). They are responsible for some services such as waste disposal and public transport (busses) and act at the same time as lower state authority with supervisory functions over the municipalities, e.g. concerning environmental protection, emission control and in case of small municipalities even building permission. Five counties are constituting members of the VRS. They have nevertheless limited significance in the daily work of the administration of the VRS. The contact is by far less frequent than with the municipalities because they are responsible for different policy fields. Collaboration is necessary when environmental issues in the regional plan are at stake or when the adaptation of timetables between busses and light rail needs to be done. Rivalries about the distribution of competences, in particular for public transport, had let to a chilly relationship at the beginning of the 2010s, but the relationship has improved since the issue has been settled. In the field of regional business development, the development agency (Wirtschaftsförderung Region Stuttgart, WRS) has managed to establish close contact and information flow via a model of shared staff: the responsible persons for business development in each county (Kreiswirtschaftsförderer) are employed by the WRS but have their main workplace within the county administration. In addition, WRS, counties and municipalities have launched a cooperation for broadband network expansion (organised as Gigabit Region Stuttgart limited liability firm).

Regierungspräsidien are lower state administrations responsible for nature conservation, environmental policies and road construction and have to approve the preparatory land use plans of the cities. The role of the Regierungspräsidien in everyday planning business is low because preparatory land use plans are only renewed every 15 years at best. They share key positions about land consumption, air pollution and large retail with VRS and can therefore potentially be supportive for the region.

The municipalities are the main partners of the VRS and the key level of implementation of policies. This is particularly true for the planning departments of cities. The planners in the head office of VRS are in frequent contact with the municipal planning departments, both via bilateral exchange about municipal planning processes and regular network meetings with the heads of planning offices of the cities. Due to a large number of 
municipalities (179), the collaboration is less intense with the small ones. The VRS uses a mix of regulatory tools (binding regional plan), incentives (co-funding), persuasion (information events), advice, and provides services in the field of public transport.

The federal state has a high influence on the city-region both via legislation and financing. Planning and financing of large infrastructure projects such as the trade fair, the airport or the railway project Stuttgart 21 depend on the federal state. Institutional reforms such as the territorial reforms of the 1970s concerning the enlargement of municipalities and counties, the creation of VRS in 1994 and the decision about additional competences in 2015 were enacted by the federal state. The state plan LEP defines general aims for spatial development with binding character for the region (Ministerium für Wirtschaft, Arbeit und Tourismus Baden-Württemberg 2002). The LEP 2002 had introduced the concept of a Europäische Metropolregion Stuttgart beyond the perimeter of the planning region (see 4.3.2 and 4.3.3). During the current legislative period (2016-2021) neither institutional reforms nor renewal of the state plan are scheduled. Instead, the federal state seeks to influence decision-making of the region in the devolved field of regional transport via financial incentives, namely concerning the frequency and pricing of light rail trains.

\subsubsection{Decision-making and leadership}

The governance structure of the VRS separates the political and executive power in a system of dual leadership. The assembly is presided over by a chairperson, whereas the administration is headed by a regional director. Both are elected by the regional assembly. The regional director is appointed for an eight-year term of office, thus longer than the assembly and its president. The president chairs the committees, prepares the agenda and is the director's supervisor. Throughout the history of VRS, the role of president has been interpreted differently. In the period from 1994 to 2008, the founding director Bernd Steinacher was very influential, whereas the changing presidents had mainly representative functions and the role of chairperson of the meetings (Priebs 2019, 257). Afterwards, the president Thomas Bopp (re-elected in 2019 for the third time despite a change of majority in the assembly) became the key personality for agenda setting and future projects of the region. In 2013, he took both positions of regional director and president for an interim period (Beuttler-Bohn 2017, 154).

The regional assembly meets five to six times a year. The transparency of the decision-making process is generated by opening the meetings to the public and reporting of local media. Its three committees deal with economy and administration, regional planning as well as transport and meet more often, especially transport as well planning with monthly meetings. The Christian Democrats (CDU) had the majority of seats since the assembly's foundation up to 2014, but were narrowly defeated by the Greens in 
2019. This result is in line with the political majority in the state government (minister-president from the Green party since 2011) and the city of Stuttgart (mayor from the Green party since 2013). The regional assembly has between 80 and 96 members (i.e. fewer than municipalities; 2014-2019: 87 members, since May 2019: 88) and is directly elected for five years. The regional assembly's work is organised along party-political lines in fractions (Fricke 2020,158). A minimum of $5 \%$ of votes is necessary to secure a seat and send any candidate from the party lists to the assembly. The six electoral districts correspond to the counties and the city of Stuttgart (represented with 18 seats). The election is held simultaneously with the European, county and municipal elections. It is noteworthy that the voter turnout is higher than for the municipal elections with $52,6 \%$ as historically lowest result in 2014 (Beuttler-Bohn 2017, 107) and 65.5\% in 2019. These good voter turn out show that the region is seen as a relevant institution by the citizens and give a strong legitimacy to the region. Still, interviewees argue that the topics where the region is competent are not suitable for election campaigns and that the multilevel system is too complex for the ordinary citizen to understand who is responsible for what. Thus, the direct election does not guarantee an identification with the city-region (Beuttler-Bohn 2017, 212). However, Walter-Rogg $(2018,141)$ argues that the opportunity to vote for the regional assembly seems to have a positive impact on the citizen's attachment to the region because of the unexpected empirical findings that older people who had the opportunity to vote for several times feel more attached to the Stuttgart Region than younger people.

The directly elected regional assembly is unanimously regarded as effective by interviewees and in the literature (Zimmermann 2014, 188; Benz 2003, 509; Beuttler-Bohn 2017, 108-109; Frank and Marsden 2016, 253), i.e. able to take a region-wide perspective and orient strategic decisions to it. It is seen by the municipalities as necessary counterpart to the networked forms of governance such as the public-private regional development agency (WRS), ensuring input legitimacy and democratic control (Zimmermann 2014, 195). The quality of the debates in terms of content and commitment is considered high as well (see also Beuttler-Bohn 2017, 109). The VRS is forced to be responsive to local interests and work towards regional consensus (Basten 2011, 281), but takes its decisions independently of special interests according to the majority principle based on parliamentary groups (Benz 2003, 511). Instead of government-opposition thinking, directly elected regional assemblies tend to be consensus-oriented; this mechanism can also be observed in the Stuttgart Region (Zimmermann 2014, 196; Kübler 2012). Local politicians can hold more than one mandate, meaning that some regional councillors have a double function as mayors, municipal or county councillors, members of the German federal parliament or the federal state parliament. In the current period 2019-2024, 16 mayors and five former mayors are regional councillors. Many of them are members of the parliament group of "Freie Wähler" (independent voters) which 


\section{Germany}

explicitly acts as stakeholders of municipal interests as a whole, but not necessarily of their individual municipality. Interviewees argue that mayors are valuable members as long as their share is limited and does not dominate the assembly, because most of them have much political expertise and professional competence.

The mayor of Stuttgart Fritz Kuhn (2013-2020) is part of the regional assembly and acts as vice-president. According to Stuttgart's municipal administration, this double position is an important link that ensures the alignment of strategic decisions between Stuttgart and the Region. At the same time, Kuhn sees its role in cautiously strengthening regional cooperation rather than being the figurehead of the Region. He could have run for the presidency after the Green Party won the regional elections in 2019, but deliberately refrained from it because he anticipated that the double mandate of being mayor of Stuttgart and President of the assembly of VRS would provoke conflicts and create harm in the spheres of metropolitics (Kuhn in Durchdenwald and Schwarz 2019). In fact, at the beginning of the 2000s there have been leadership conflicts between Stuttgart's mayor Schuster (1997-2013) and the regional director Steinacher as both claimed to represent the metropolitan region (Klinkenberg 2010, 394-396; Zimmermann and Heinelt 2012, 106; see 4.3.3).

\subsubsection{Functions}

The functions of the VRS have been either devolved from the federal state or upscaled from the counties. In addition to the compulsory tasks determined by state law, ${ }^{14}$ the VRS can render voluntary tasks in case that a majority of two-thirds of the assembly votes for this. This has been the case for the trade fair, the coordination and organisation of congresses, cultural events and big sport events as well as an external representation of the region and the co-funding of projects related to the implementation of the landscape park.

With regard to production functions, the VRS is competent in the following policies:

- Regional business development (via agency WRS, partly owned by the VRS);

- Tourism and regional marketing (via agency Regio Stuttgart Marketing und Tourismus $\mathrm{GmbH}$ );

- Building and management of new trade fair complex (via agencies Projektgesellschaft Neue Messe GmbH \& Co. Kg and Projektgesellschaft neue Messe Verwaltungs-GmbH; since 1998);

- Coordination and organisation of congresses, cultural events and big sport events with regional relevance, e.g. application to host the Olympic games in 2012 or IBA 2027 (via agencies for application; associations SportRegion Stuttgart e.V. as well as KulturRegion Stuttgart e.V.); 
- The external representation of the region (own office in Brussels since 2002, together with WRS) and participation in international networks (e.g. Metrex, EMTA for transport).

Regarding social reproduction functions, the VRS is competent in the following policies:

- Statutory Regional Planning;

- Regional public transport (responsibility for regional light railway since 1996 and express busses, park \& ride as well as a regional traffic control centre since 2015);

- Landscape planning (Landschaftsrabmenplan);

- Planning and implementation of regional landscape parks (since 2006);

- Identification of potential sites for wind energy (as part of the regional plan);

- Waste management of mineral waste and toxic soils (delegated to agency AVL in the county Ludwigsburg).

Although enhancing the economic competitiveness of the region at European and international level was the main motivation justifying the creation of the VRS (Zimmermann 2011, 195; Heeg 2003, 163; Fricke 2020, 160; Frank and Marsden 2016, 253), all functions related to competitiveness have been outsourced to autonomous agencies. This means that the Verband Region Stuttgart is shareholder together with other public and private partners such as the Chamber of Commerce and Industry (see Table 4.5). Its regional assembly takes strategic decisions in those policy fields, but the operational activities are not carried out within the administration of the VRS itself.

Regional planning, landscape planning and regional transport planning as well as the provision of regional light rail transit are the core tasks of the region. The regional-level coordination of both land use planning and transport creates good conditions to foster more sustainable urban settlement patterns (Frank and Marsden 2016, 243). Land use planning and urban development projects have remained in the responsibility of the municipalities, but the aims formulated in the regional plan as well as the spatial extent of green areas depicted in the plan are binding for local land use planning. This means that the region has regulative power concerning urban development. Those formal instruments are used more stringently than in other planning regions in Baden-Württemberg, in particular regarding retail, green spaces, density and transport-oriented development along rail stations and enforced by court decision, if necessary (Priebs 2019, 260; Benz 2003, 506).

In terms of implementation, the VRS has more options than the other regional planning authorities in Baden-Württemberg but is largely reliant on the municipalities, counties and the federal state (in case of large infrastructure projects such as the trade fair or the central train station of Stuttgart). The only exclusive responsibility concerns the regional light railway, 


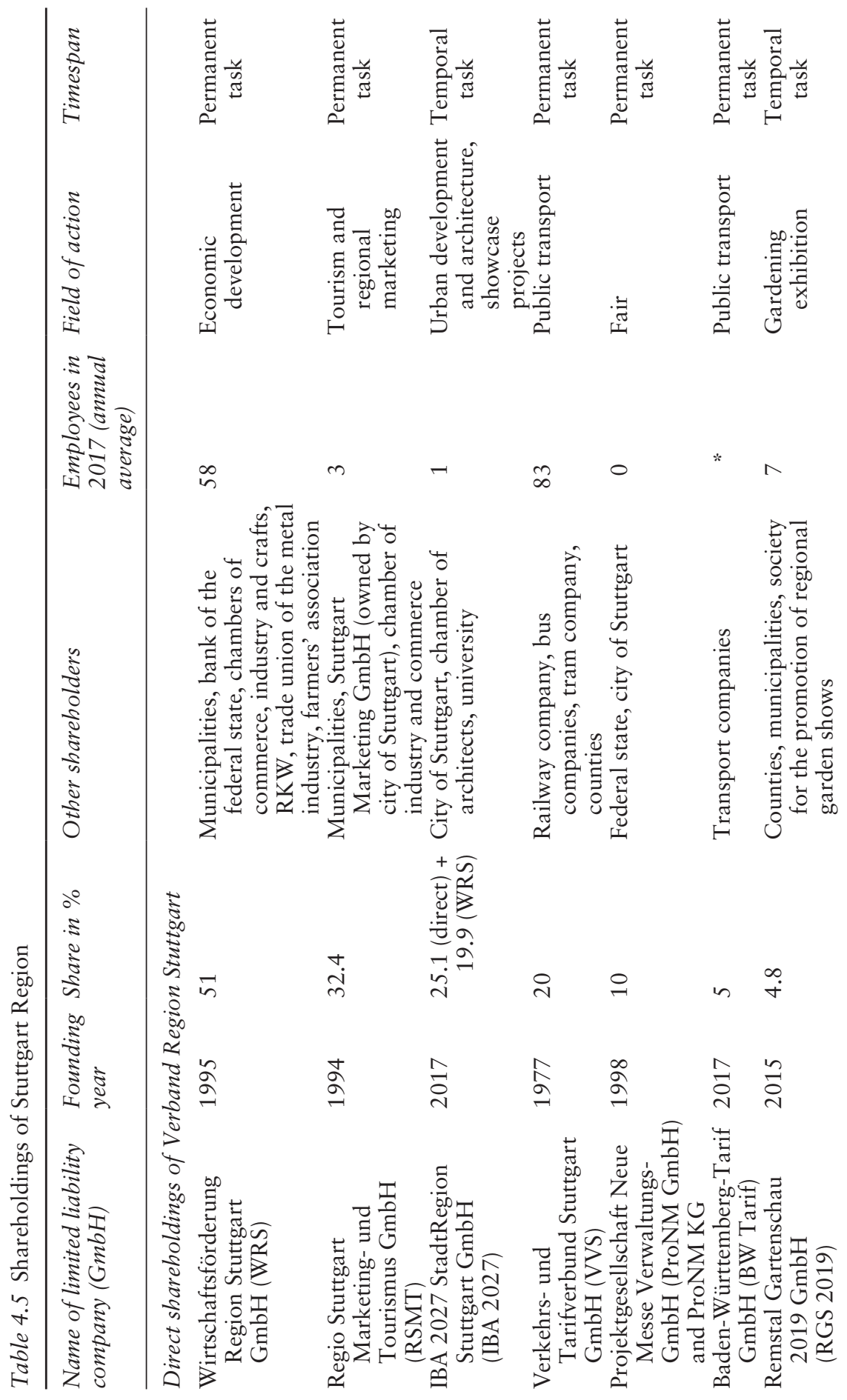


Germany 235

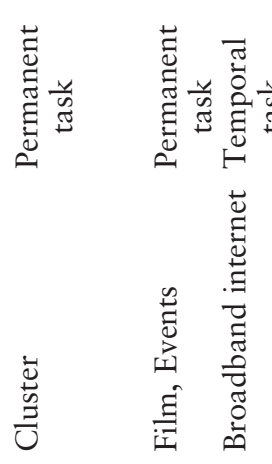

$\frac{\sqrt{2}}{3}$

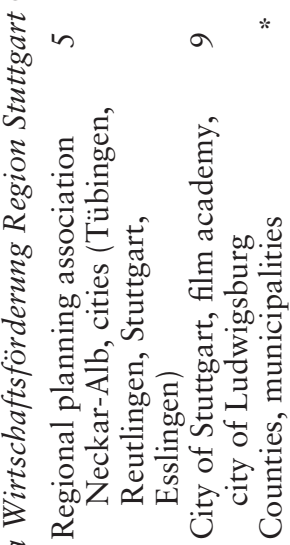

$\cdot \frac{2}{2}$

章

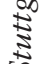

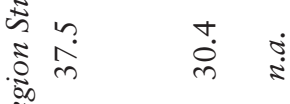

a

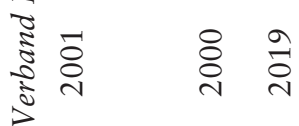

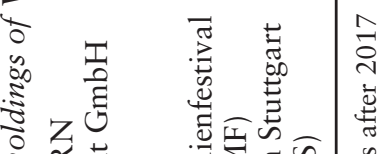

竞苞

$\rightarrow \circ$

ษั0

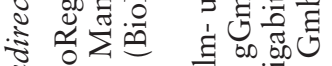

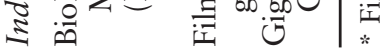




\section{Germany}

including the contracting, and express busses. Close coordination with the counties and the city of Stuttgart is still needed as they are responsible for local public transport.

The VRS supports the municipalities with small funding programmes for inter-municipal industrial parks and brownfields of regional relevance (since 1997, see Benz 2003, 50) and projects in areas designated as regional landscape park. The landscape park is composed of sub-regions with detailed implementation plans and combines measures of landscape protection (e.g. river renaturation) and recreation (e.g. bicycle path connections) and aims to enhance the quality of life in the region (Frank and Marsden 2016, 261; Basten 2011, 284). Since 2016, an action program for housing has been launched (Hemberger and Kiwitt 2018, 37). VRS has extended the cofinancing for green spaces in new housing areas with the aim to make dense, affordable housing forms more attractive for municipalities. Attempts to play a more active role in the provision of housing by supporting municipal land management are seen as unnecessary by the medium-sized cities with large professional planning departments, whereas the city of Stuttgart is in favour of it as it has an interest in more building activity outside its own territory to solve the problem of housing shortage. Small municipalities can benefit from information offers, e.g. from good examples meeting the density requirements of the regional plan; however they argue that it is not enough to support the administration, because the council and the citizens have to be convinced in order to raise the acceptance for other building typologies than single-family houses and terraced houses.

In addition to that, the VRS has become the representative of the cityregion with regard to external relations at the national and European level by means of lobbying, networking and participation in EU funded projects (Hunds 2011). Stuttgart has been the first German region to establish an office in Brussels and is very active in the Network of European metropolitan regions and areas (METREX) (Zimmermann 2011, 202). This is still the case despite leadership changes: the current director of VRS Dr. Nicola Schelling is president of METREX, and Stuttgart hosted a METREX conference about "Modern infrastructures for growing metropolitan regions" in autumn 2019. Stuttgart's European activities are exceptional compared to other German metropolitan regions (Fricke 2020, 37).

\subsubsection{Administration, development agencies and additional networks to include private actors}

The administrative core of the regional organisation is formed by a head office (Geschäftsstelle) with about 70 employees consisting of planners and technical staff. The small size is seen as a positive characteristic by representatives of the regional assembly (VRS 2004). According to the interviewees from the municipalities, the head office has built up a good reputation as a competent and committed partner. Its resources and possibilities for 
action are markedly higher than in the 11 other planning regions in BadenWürttemberg; with the exception of the Rhine-Neckar region. ${ }^{15}$

According to the budget plan of the Stuttgart Region, the budget for 2020 amounts to $442.4 \mathrm{M} €$, of which the lion's share of $410.9 \mathrm{M} €$ is dedicated to public transport (light rail operation, transport association, new vehicles, investments, rail project Stuttgart 21, etc.). The other budget positions are economic development (12.3 M€), personnel (6.1 M€), debts (4.9 M€), administration and IT $(4.3 \mathrm{M} €)$, planning $(3.1 \mathrm{M} €$ ) as well as culture and sports $(0.8 \mathrm{M} €)$. Main revenue sources are fees for public transport, allocations from the federal state and contributions paid by the counties and the 179 municipalities. The contribution for public transport is only paid by the members of the traffic association, i.e. Stuttgart and the four counties adjacent to it, not by the county of Göppingen. The region cannot levy taxes of its own and is therefore financially dependent from other territorial authorities. Voluntary activities and additional investments have to be financed by acquisition of funding or by the municipalities, who are also the beneficiaries of co-funding programs. The region has the means to kick of projects and initiatives via small amounts for studies, events and organisational support. It can also ensure a joint financial effort of the municipalities in case of large projects with regional relevance such as the trade fair. The municipal contribution to the budget is voted by the regional assembly and has to cover everything nobody else is paying for. It amounts to about 23.4 M€ in 2020 (thereof 1.5 M€ City of Stuttgart) and has increased between 2016 and 2019 after several stable years. The share per municipality depends on their tax income. The budget of the City of Stuttgart amounts to $€ 4.1$ billion for 2020 according to the budget plan. Thus, the city's contribution to the region's budget only represents a minor share of the expenditures.

The head office is seeking to mobilise the potentials of the region by supporting self-organisation and can be seen as central node in a network of cooperation (Zimmermann 2011, 203; Beuttler-Bohn 2017, 139). Operational tasks are carried out in public-private cooperation and via development agencies connected to the core organisation (Benz 2003, 508). These agencies function independently, but are controlled at a distance by the regional assembly (strategy, core projects, budget) and by the regional director (Benz 2003, 507-511). The most important one is the economic development agency Wirtschaftsförderung Region Stuttgart GmbH (WRS) established in 1995. It focuses on the promotion of industry and technology networks and started cluster policies such as the regional network MedienInitiative Region Stuttgart already in the 1990s. The WRS regularly reports to the committee of the regional assembly. In addition, the regional director of the VRS is part of its advisory board. In terms of administration and budget, the head office of VRS and the WRS are separately organised, though being in the same building. They coordinate their actions and exchange information via regular meetings. Most of their tasks and fields of action are clearly separated. Intersections exist concerning mobility as well 


\section{Germany}

as locations for industry and commercial use. The office in Brussels is a joint activity. Just like VRS, the WRS is shareholder of companies together with other public and private partners, meaning that the VRS as mother organisation is indirect shareholder in these cases. In 2017, the VRS was direct or indirect shareholder of 11 companies and supported two associations financially in a substantive way, KulturRegion Stuttgart e.V. and SportRegion Stuttgart e.V. In addition to that, the VRS and WRS are members of about 50 associations or networks (VRS 2018). In most of the cases, the region is not holding the majority of the limited liability companies (see Table 4.5); partners are especially the city of Stuttgart, other municipalities, counties, the federal state Baden-Württemberg, chambers, trade unions, transport companies and Stuttgart University. Which municipalities are involved depends on their interest in the topic and is different for each company.

Today, economic actors are mainly involved via the chambers of commerce and industry representing their interests. None of the large companies is a stakeholder of the WRS nor are CEOs standing for the regional parliament. Individual companies might contact the VRS if they feel affected by changes in the regional plan, but do not play a leading role in defining regional strategies anymore. This has been different in the 1990s when leading personalities of the business community have been influential in supporting regional reforms and launched a public debate about development perspectives of the region with stakeholders from culture, media, politics, social affairs, economy and science under the umbrella of the association Forum Region Stuttgart (Beuttler-Bohn 2017, 132-134; Zimmermann 2011, 199; Benz 2003, 508). The Forum existed for about 20 years, but was dissolved in 2015 due to the lack of a clear task, active members and financial contributions. Its mission has been fulfilled as the VRS is able to launch projects of regional importance and takes care of economic development and marketing via its agency WRS. In addition, the economic difficulties that hit the region in the 1990s could be overcome.

\subsubsection{Key projects: trade fair, Stuttgart 21, IBA 2027, Gigabit Region}

Stuttgart's large projects with regional importance have been either infrastructure projects or events, rather than a new city quarter or large-scale urban development area. The infrastructure projects depend on political and financial support from the state and the federal government (Basten 2011, 282). Current new housing areas seldom exceed 50-100 units and are spread over the city-region. This is caused by the polycentric structure of the city-region with a range of urban centres with a size of 40,000 to 95,000 inhabitants as well as the lack of available space in the core city due to topographic reasons, a strict political decision against outward extension and few remaining conversion areas. The new railway station (Stuttgart 21) 
and the former German headquarter of IBM (Eiermann Campus) are the largest conversion areas under development.

One of the key projects of the founding years was the relocation of the trade fair in the southern part of the region next to the airport. This large infrastructure project was one of the triggers for a more integrated form of metro governance (Blatter 2008, 149; Basten 2011, 284), because it could not be planned and financed by one municipality alone. The regional assembly voted for a financial contribution of the region in 1997 (Priebs 2019, 257). The VRS was responsible for the planning process and is still a shareholder of the company which manages the trade fair. The exact site of the new building was fixed in the regional plan and enforced by court decision; this was the first time the VRS actually used the legal instrument of planning obligation (Planungsgebot) (Priebs 2019, 260). The VRS was also in charge of mediating between the affected municipalities (Heeg 2003, 172). The new fair was inaugurated in 2007. The area next to the airport and trade fair is still a hotspot of urban development and will experience even more development pressure in the future because an additional train station will be built there, connecting it both via long distance and regional express trains. Land use conflicts are high in this area called Filder because it has very fertile soils, which still produce good yields despite climate change and drought.

The second key infrastructure project Stuttgart 21 concerns the transformation of Stuttgart's central railway station from an end station to a subterranean through station as well as a quicker connection to the city of Ulm located about $80 \mathrm{~km}$ southeast. This connection is part of a European high speed magistrale from Paris to Bratislava. This large-scale project involves the national government, the state government, German Railway (Deutsche $B a b n$ ) and the city of Stuttgart as partners (Basten 2011, 283). It clears an 85 hectares inner-city area from railway use and enables its redevelopment into a dense mixed-use quarter with about 7,000 housing units. The project name Stuttgart 21 has become a synonym for citizen protest against megaprojects. Reasons for heated protest from environmental activists and civil society groups were the cost explosion, limited gain of travelling time compared to alternative solutions, expected environmental damage and the cutting down of old trees in a part of the palace park. ${ }^{16}$

Regarding events, the VRS supported an application for the Olympic Games 2012. The candidature was prepared at the regional level in the form of a public-private partnership (Benz 2003, 509). However, Stuttgart's application did not pass the national selection process.

Another large project regarding an event is the international building exhibition (IBA) StadtRegion Stuttgart 2027. The specifically German format of an international building exhibition creates a laboratory situation for a limited period of time of typically ten years, has a thematic focus adapted to a local problematic and aims to give innovative answers to contemporary questions of urban development by building high-quality showcase projects 
(Niemann et al. 2011, 314). After a preparatory phase, the IBA was officially launched in 2017 and is organised by a development agency owned by the city of Stuttgart, the VRS and WRS as well as the chamber of architects and Stuttgart University. The process was initiated by the economic development agency of the Stuttgart Region (WRS), where the idea was born in search for a mobilising project for the whole region. The WRS had a key role in the preparatory phase as it engaged local stakeholders and took the risk to finance and organise a platform for a regional process of deliberation. Furthermore, one of its staff members became first director of the IBA agency. The IBA StadtRegion Stuttgart has four thematic priorities, addressing architectonic quality, functional mix, new technologies and the regional dimension ("Region ist Stadt und Stadt ist Region") (WRS 2016, 9). It is composed of many individual projects spread all over the region with high engagement of the middle-sized cities around Stuttgart. Contrary to other IBAs such as IBA Emscher Park, the federal state only gives minor financial support, meaning that municipalities have to finance the showcase projects themselves or apply for other sources of co-funding such as EU-funds. The IBA process triggers a competition for innovative ideas between the municipalities and is a stimulus for starting projects even if they might not be ready until 2027 or not part of the official IBA-exhibition. Even though the big picture of the IBA is still blurry due to the thematic diversity, the process is inclusive taking all interested actors on board. In that sense it can be said that the initial idea of a large project that brings the region together and gives a positive impetus after years of controversies around Stuttgart 21 is working.

Regarding infrastructure, the region is currently involved in the construction of a high-performance broadband network via glass fibre cable and $5 \mathrm{G}$. This is seen as precondition for digitalisation and future competitiveness. The Regional Assembly has decided to appoint the WRS with the task to launch a joint tender in order to reach a common standard and equal framework conditions for all municipalities in the region. The WRS and the counties have joined forces. Each county has established a single-purpose association ${ }^{17}$ together with all interested municipalities. The task of the single-purpose associations is to prioritise areas within the county and to support the municipalities with planning data, advice and help regarding applications for funding. In addition, the Gigabit Region Stuttgart GmbH (GRS) created in 2019 coordinates the processes and has concluded a contract with the telecommunication firm German Telekom regarding the broadband expansion in May 2019. High priority is set on the connection of business parks and industrial zones: according to the aims agreed on by the region and the Telekom, all of them shall be connected to glass fibre cable until $2025.90 \%$ of the private households shall be connected up to 2030. The step-by-step expansion is fixed in yearly plans in close coordination between Telekom, GRS, the single-purpose associations and the city of Stuttgart. 


\subsubsection{Spatial relations within the metropolitan region of Stuttgart}

The institutional perimeter of the Stuttgart Region is the dominant spatial definition for the city-region (Fricke 2020, 158). There is a surprising spatial congruence of the various regionalisations, particularly concerning economic actors. The chamber districts correspond to the territory of the VRS and even the labour union IG Metall has adapted to this by appointing a regional spokesperson. The term "Stuttgart Region" is seen as unambiguous and linked to a distinct territory and organisation; it is therefore also used for regional marketing. In contrast, the term "metropolitan region" is fuzzy and contested in its spatial outline and potential institutionalisation and therefore not used by local actors.

\subsubsection{Institutional perimeters: Stuttgart Region in the multilevel system}

The spatial dimension of the Stuttgart Region is based on county boundaries. Its territory is composed of the county-exempt city of Stuttgart and the additional 178 municipalities of the five counties Böblingen, Esslingen, Göppingen, Ludwigsburg and Rems-Murr-Kreis. These county and municipality boundaries have been a result of territorial reforms in the 1970s. Despite the mergers, the number of municipalities is still high and about two-thirds of the municipalities have less than 10,000 inhabitants. The city of Stuttgart itself has not been enlarged at that time in a deliberate decision of the federal state not to strengthen Stuttgart (Priebs 2019, 255). Four out of five counties of Stuttgart Region border the city of Stuttgart, but also extend far into the hinterland (see Figure 4.8).

Stuttgart Region is one of 12 planning regions in the federal state of BadenWürttemberg. It does not transcend administrative borders, either of the federal state or of its government office of the region (Regierungspräsidium Stuttgart) (see Figure 4.9). This spatial delimitation has been fixed by federal legislation (Regionalverbandsgesetz from July 1971) and has not been altered since. Neither an extension nor reduction are likely to happen in the future either. Some municipal councils of rural municipalities on the edge of the region flirt with an exit with the argument to save costs and get rid of restrictive regulations of the regional plan, but are not pursuing this as a serious option. Leaving Stuttgart Region would only be possible if a municipality changes the county it belongs to with the consent of the federal state; this is seen as an entirely hypothetical scenario by local actors. Rather than changing the boundaries, the functional fit of the cooperation area is attained by variable geometries beyond and within the boundaries if needed (see 4.3.3).

The perimeter of the Stuttgart Region also corresponds to one regional plan. It is the middle layer in the hierarchical system of planning documents between the federal LEP and the local land use plans (see Table 4.6). The preparatory land use plans partly constitutes another level of inter-municipal 


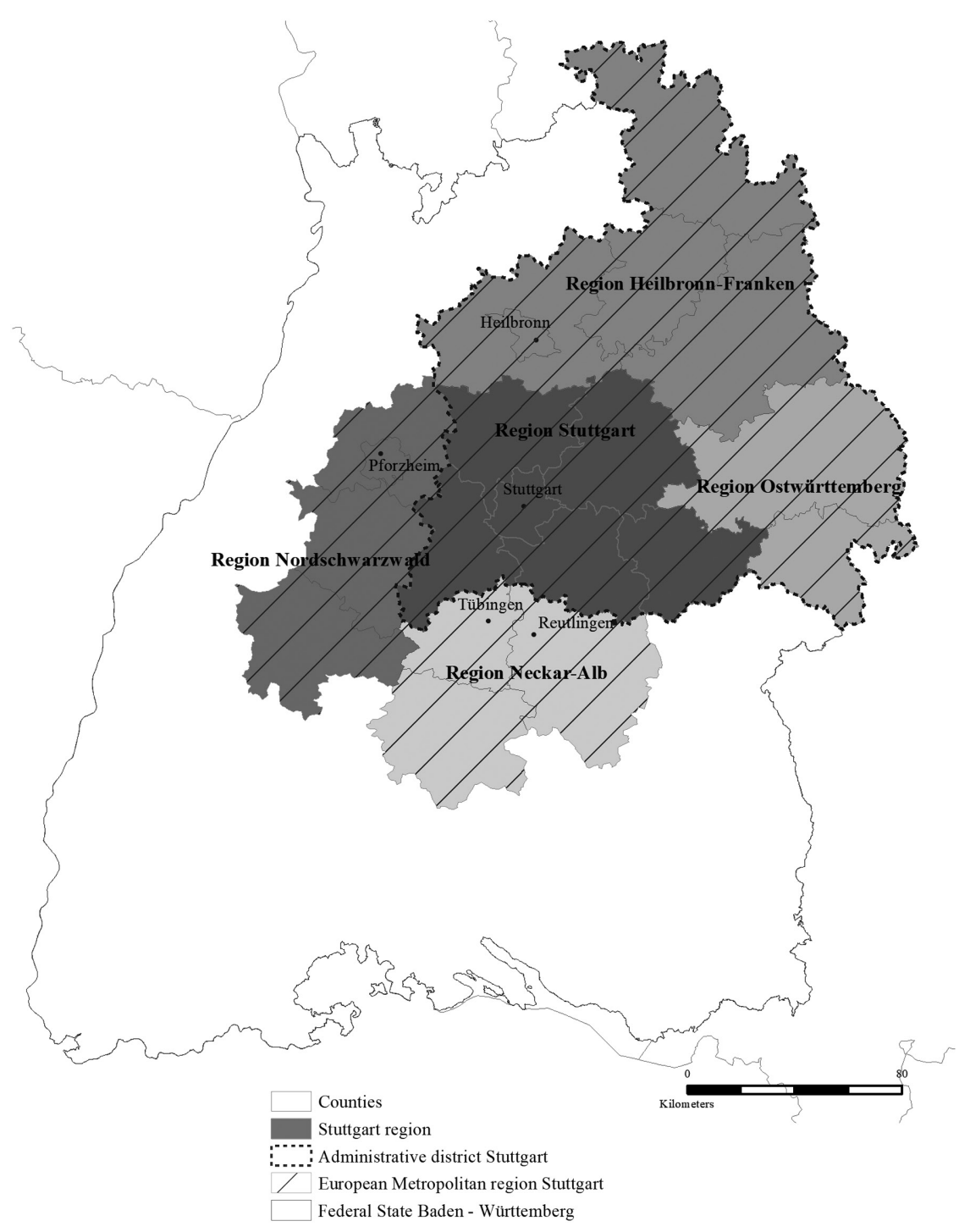

Figure 4.9 Stuttgart in the multilevel system of Baden-Württemberg 2021 Concept: P. Feiertag Cartography: F. Gela

cooperation. In particular, the smaller municipalities within the Stuttgart Region have an inter-municipal FNP. In total, the Stuttgart Region is covered by 79 FNP. One of the larger examples of an inter-municipal FNP is the Planungsverband unteres Remstal (PUR) with five municipalities, whereas others only cover two municipalities (e.g. Verwaltungsgemeinschaft Welzheim/Kaisersbach). The German planning law has also introduced the 
Germany 243

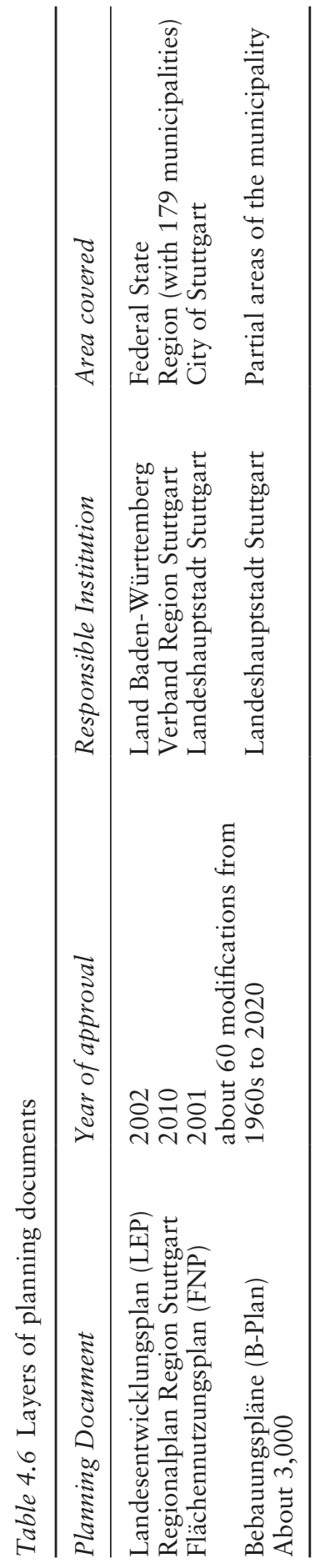




\section{Germany}

option of a regional FNP (see section 4.2 Frankfurt) but this is not in use in Stuttgart, because as land use planning is a municipal task it would have been necessary to directly involve the municipalities in decision-making, e.g. via a second chamber composed of mayors. The regional planners in Stuttgart argue that a regional FNP would not bring a considerable gain in control compared to a consistently applied regional plan. They see instead a risk to create a weaker instrument, because the mayors would most likely be less inclined to pass a restrictive regulation limiting their own development possibilities than the current regional assembly.

\subsubsection{Morphological and functional definitions}

Stuttgart Region covers a vast, heterogeneous area that is much larger than the continuously built-up space of the region. It includes rural areas, particularly in the northeast of the region. The continuously built-up space expands beyond the administrative borders of the city of Stuttgart. Due to its location in a basin surrounded by hilly terrain with forests, the settlement extension is limited in the west and also to a limited degree in the south. Continuity exists along the transport axes of rail, roads and rivers, e.g. in the south east along the river Neckar. These interrelations and green cuts are taken up by the regional plan in order to structure the regional space.

The delimitation of German regional plans is supposed to follow a functional logic by reflecting the areas of interdependence of the urban nodes with high centrality (Priebs 2019, 255). According to the regional planners themselves, the territory of the region does include the functional area of Stuttgart. Commuter flows decrease beyond the border. Boundary problems have existed in the past as some municipalities outside the region have benefitted from less restrictive planning rules in neighbouring regions and have been growing more, but this is not the case anymore. Although the perimeter was established in the 1970s and has not changed since then, the Stuttgart Region is still large enough in functional terms. The light rail train under the responsibility of VRS covers large parts of the region except the county Göppingen (connected by regional train) and less densely populated areas such as the eastern part of the county Rems-Murr. An extension beyond the region is under discussion and has already been the subject of feasibility studies, but has not been decided yet. A considerable part of the budget of the VRS is dedicated to investments into the light rail network. In 2019, the VRS decided to buy new trains to enable a switch to 15 -minute intervals (which is an investment of about $420 \mathrm{M} €$ ).

Intense connections to the surrounding urban nodes do exist, in particular with Tübingen, but also Heilbronn. Bosch, one of the manufacturing global companies and major employers in the region, has its headquarter in a small town near Heilbronn. The cities of Tübingen/Reutlingen, Pforzheim and Heilbronn (see Figure 4.9) have their own area of functional interdependence, 
though overlapping with Stuttgart. Accordingly, the LEP 2002 displays them as part of a continuous agglomeration (Verdichtungsraum). Verdichtungsräume are defined as large areas of municipalities with settlement density well above average (minimum $120 \%$ of federal state average) and intense internal commuter interdependences ( $75 \%$ of all commuters). The delimitation of spatial categories in the LEP is however not purely based on statistical indicators. In order to avoid patchworks, planning contexts and spatial proximity have been taken into account and local actors have been heard before the final definition (Ministerium für Wirtschaft, Arbeit und Tourismus Baden-Württemberg 2002, B8).

\subsubsection{The evolving spatial definition of the metropolitan region}

Stuttgart is one of the 11 city-regions labelled as a "European metropolitan region" by the Standing Conference of Federal and State Ministers responsible for Spatial Planning (MKRO) (see 4.1). As the the Verband Region Stuttgart had already been created, a discussion (if not dispute) started whether the metropolitan region would be identical with the Stuttgart Region or not. The cartographic representation produced at the national level (see Figure 4.3, section 4.1) is schematic and leaves the spatial delimitation mostly to the local level. The metro regions are depicted as hexagons. However, some of the larger cities are included in the map, suggesting that the cities of Heilbronn, Tübingen and Reutlingen would be part of the metro region, but not Pforzheim and Karlsruhe. The state plan LEP BW 2002 picks up this definition by specifying that the European metropolitan region includes the agglomerations Stuttgart, Heilbronn and Reutlingen/Tübingen (Ministerium für Wirtschaft, Arbeit und Tourismus Baden-Württemberg 2002). This means that the federal state had the position that the metro region should be interpreted larger than the planning regions and based on a functional definition as network of urban nodes, not on existing administrative boundaries. Unlike the national spatial vision, the LEP is a binding plan that cannot be ignored by the lower planning levels. It sets specific objectives for each spatial category. In the case of the Europäische Metropolregion Stuttgart as well as the Verdichtungsraum Karlsruhe/Pforzheim, these are "development tasks" (Entwicklungsaufgaben) such as a better integration into national and international transport, energy and communication networks.

The federal definition has been picked up and reinterpreted from the bottom-up perspective of regional actors (VRS et al. 2003). The outline of the metro region was soon extended. The regions Nordschwarzwald and Ostwürttemberg joined the informal cooperation of planning regions discussing how to translate the stipulations of the LEP into their regional plans. The five regions (see Figure 4.9) have agreed upon the interpretation that the LEP roughly fixes a minimum extension but leaves the exact shape by purpose vague and thereby avoids to oblige or exclude any municipality 


\section{Germany}

(Europäische Metropolregion Stuttgart 2008, 4). They highlight the fuzziness of the spatial delimitation as well as the voluntary and network character of cooperation within the European metropolitan region.

The planning regions were unwilling to draw an internal boundary between urban spaces that would belong to the metro region and rural parts that would be excluded (Klinkenberg 2010, 394). They therefore opted for a wider cooperation space formed by the entire regions Neckar-Alb, Nordschwarzwald, Heilbronn-Franken, Ostwürttemberg und Stuttgart (Europäische Metropolregion Stuttgart 2008, 5). However, their own representation used as a logo for the European metropolitan region (see Figure 4.10) shows that it has remained a juxtaposition of the former planning regions. It was in the end not possible to spatially redefine and institutionalise the metropolitan region on the basis of functional criteria. The federal requirement to create a larger cooperation space was reinterpreted by the regional associations and adapted to their existing borders. The resulting potential soft cooperation space is heterogeneous concerning population density, but also with regard to the composition of the population in terms of level of education and of non-German residents (Pütz 2016, 552).

\subsubsection{Sub-regional spaces and inter-municipal cooperation: Kommunaler Arbeitskreis Fildern (KAF)}

Due to the large size of the Stuttgart Region and the existence of many small municipalities, a wide range of inter-municipal collaborations below the VRS exists. Apart from the counties, there is no systematic subdivision in subspaces covering the entire region. Inter-municipal cooperation takes place in weakly institutionalised working structures, mostly created for a single purpose. Some of them have a decades-long history even older than the region itself. Their continuity depends very much on personal relations of local politicians and mayors. Those small municipalities who have managed to keep their independence during territorial reforms have fought for it

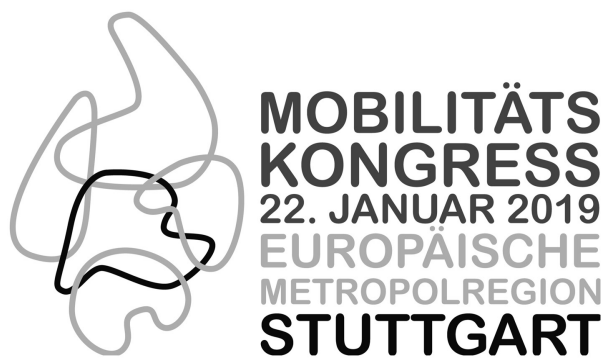

Figure 4.10 Imaginary of the metropolitan region (C) Landeshauptstadt Stuttgart and VRS 2019 
and tend to have a strong local identity. The decision to fulfil tasks together with other neighbouring municipalities is mainly motivated by financial constraints or a lack of know-how or has served as counter-argument against amalgamation. These small-scale inter-municipal structures have not become obsolete by the establishment of a strong city-regional level of governance because of the functional profile of the Stuttgart region (see 4.3.1). Service provision for the citizens as well as local land use planning and urban development continue to be municipal tasks covered by their right of local self-government.

Beyond pragmatic reasons, some inter-municipal activities have a more strategic dimension and are based on the idea of a shared territory related to the landscape. One of them is Grüne Nachbarschaft north of Stuttgart around the city of Ludwigsburg. The cooperation has been initiated by a landscape architect in the 1990s. Its activities consist of inter-municipal landscape planning and the implementation of over 100 projects for ecological landscape design, water body renaturation, local recreation as well as environmental education. One of the six member municipalities resigned in 2019 after 23 years of membership despite a positive assessment by the administration and the mayor as well as many implemented projects. The decision was made by the municipal council over the course of the budgetary discussions. This example shows that this kind of voluntary inter-municipal cooperation depends on the commitment of individuals and how volatile it can be.

The most institutionalised example is the Kommunaler Arbeitskreis Fildern (KAF) in the Filder area south of Stuttgart, a plain with very fertile soils. The KAF has been founded in 1967 and includes the municipalities of Filderstadt, Leinfelden-Echterdingen, Ostfildern, Denkendorf, Neuhausen and Steinenbronn as well as some quarters of the cities Stuttgart and Esslingen. It has a semi-formal structure based on a statute, a financial contribution of the member municipalities, a rotating chair, a board of mayors for decision-making and a purely advisory assembly with representatives of the municipal councils. The main topics are landscape protection, a network of bicycle path, flood prevention and noise protection from the airport Stuttgart located in that area. The original common interest behind the association was to join forces in defence of a planned airport expansion. Recently key principles for settlement development have become a topic because the area is confronted with high development pressure due to the trade fair and a new train station next to the airport (see 4.3.1). As a joint basis for discussion, KAF and VRS have commissioned a well-known architectural firm to carry out a study ("Filderstudie", presented in autumn 2018) assessing the additional demand triggered by the station and make propositions for the future development. The outcome has been debated, but it is up to each municipal council to draw conclusions and eventually take binding decisions. Some municipalities are in favour of a joint land use plan, but not all of them, meaning that the KAF will not be transformed into a planning association. 


\subsubsection{Coordination of public policies beyond the perimeter of the Verband Region Stuttgart}

It could be shown that the perimeter of the Stuttgart Region is widely used as a spatial reference for public policies. It is not fuzzy. Regional actors perceive it as suitable for functions such as economic development and regional planning. The Stuttgart Region is a hard space with an inside-outside divide based on the logic of joint financing within the region. Topic-specific soft spaces within and beyond the perimeter of the region do exist, but there is no comprehensive strategy for a larger metropolitan area. In many of them, the VRS is a key actor who has initiated and enabled them due to its capacities, e.g. via preparatory studies, application for funding or by bringing different actors together.

\subsubsection{Networks with variable geometries}

The governance model of the VRS with a small core for strategic decisions combined with more flexible networks and semi-public limited liability companies for operational tasks enables the Verband Region Stuttgart to expand cooperation within those networks beyond the boundaries of the Stuttgart Region itself. Despite this potential flexibility, institutions expanding beyond the region are rare due to an asymmetry of competences and resources between the VRS and the neighbouring regional associations as well as issues of co-financing. The VRS and its economic development agency WRS are shareholders of several limited liability companies with partners beyond the region: the biotechnology and medical technology cluster BioRegion Stern, the regional marketing agency Regio Stuttgart and a temporal consortium for an inter-municipal gardening exhibition in the valley of the river Rems.

- BioRegion STERN Management GmbH: BioRegion STERN is a biotechnology and medical technology cluster promoted together with the neighbouring Region Neckar-Alb (Tübingen). Its origin goes back as early as 2001 to a successful application in a competition of the Federal Ministry of Research (Benz 2003, 509; Priebs 2019, 257). Shareholders are the regional planning association Neckar-Alb as well as the cities Tübingen, Reutlingen, Stuttgart and Esslingen (see Table 4.5). The longstanding cluster operates completely autonomously; shareholders receive an annual report, but are not involved in the day-to-day business.

- Regio Stuttgart Marketing- und Tourismus GmbH: Tourism and city marketing activities of the region are organised together with the city of Stuttgart and include towns outside the region. Interested municipalities are organised in the association Regio Stuttgart Marketingund Tourismus e.V. which holds the same share as VRS and city of 
Stuttgart (each $32.4 \%$ ). The number of municipalities has gradually grown to 43 and is open for new members. From the tourism perspective, Stuttgart is interpreted as a larger area or network of places of interest. The tourism marketing presents both the core city, attractions in the region and beyond such as castles or outlet centres. This cooperation functions well due to common interests (Beuttler-Bohn 2017, 130).

- Remstal Gartenschau: The inter-municipal gardening exhibition along the valley of the river Rems with $80 \mathrm{~km}$ from the source to the mouth took place between May and October 2019. The federal state had given its approval in 2010. Gardening exhibitions nominated by the federal level or the states are common practice in Germany since the 1950s, but usually only one single municipality is entitled to apply. An inter-municipal cooperation is therefore a novelty (Beuttler-Bohn 2017,115 ) and would not have come about without the support of the VRS in the application and conception phase. The VRS has provided support in terms of content (idea and expertise), finance (co-financing of projects as part of its landscape park programme) and organisation (bringing the actors from different counties together). The partnership involves 16 municipalities and three counties as well as the VRS and private partners from the professional field of gardening and landscaping (organised in a society for the promotion of regional garden shows, Förderungsgesellschaft für die BW-Landesgartenschauen $\mathrm{mbH}$ ). One of the counties, Ostalbkreis, and five municipalities are not part of the Stuttgart Region. Each partner holds equal shares of the limited liability company responsible for running the gardening exhibition.

These examples established at different times with different members and topics show the logic of variable geometry. It is possible to involve partners from outside the region in concrete projects with a clear common interest that justifies the choice of partners. Partners mainly are cities on the edge of the region as well as neighbouring counties or regional associations as umbrella for smaller municipalities or co-financer. The organisation model as joint limited liability company allows for shared financing and a clear description of tasks and responsibilities. However, those examples have an exceptional character, whereas the large majority of activities of WRS and VRS as well their network of companies and associations operate within the area of the Stuttgart Region.

Small-scale inter-municipal partnerships across the border of the region also exist without involvement of the Stuttgart Region. These concern municipalities on the edge of the region. One example is the single-purpose association for drinking water supply Zweckverband Wasserversorgung Menzlesmüble formed by six municipalities. 


\subsubsection{Europäische Metropolregion Stuttgart as additional layer of governance?}

The concept of Europäische Metropolregion was meant to create a new mental geography (Blotevogel and Schmitt 2006, 61). The spatial definition of a wider metropolitan region beyond the Stuttgart Region at a national and federal level (see 4.3.2) raised the question of the appropriate form of governance for this new cooperation space and of the role of the VRS within it.

Stuttgart was labelled as Europäische Metropolregion in 1995 (see 4.1), shortly after creation of the VRS (see 4.3.1). The existing Verband Region Stuttgart saw itself as a legitimate institution to represent the metropolitan region and became its representative in the national network of metro regions IKM. This interpretation was challenged by the mayor of Stuttgart at the time, Wolfgang Schuster. The establishment of the European Metropolitan Region was accompanied by leadership conflicts to the extent that some cities and counties saw an opportunity here to pursue a municipally dominated form of regionalisation alongside the Verband Region Stuttgart in order not to further strengthen it (Zimmermann and Heinelt 2012, 106; Blatter 2008, 159). Both started attempts to put the Europäische Metropolregion into practice. On one hand, the regional associations met and elaborated a joint strategy paper including potential fields of action (VRS et al. 2003, 9-10) as well as a regional development concept as basis for their regional plans (Europäische Metropolregion Stuttgart 2008; Zimmermann 2011, 204). On the other hand, the Mayor of Stuttgart invited from July 2005 on representatives of the larger cities to the so-called Steering Committee "SchusterRunde" (Fricke 2020,164). Some cities within Stuttgart Region (Esslingen, Ludwigsburg, Sindelfingen) did not join the committee, because they did not wish to weaken the VRS. The informal network met quarterly and set up thematic working groups on "tourism and marketing", "science and education", "business and innovation" and "Neckar as a connecting link". The purpose was to develop concrete project proposals, but the network was unable to act because it lacked competences for key projects with regional relevance such as the trade fair or Stuttgart 21 (see 4.3.1) and was unable to solve distribution conflicts concerning costs (Klinkenberg 2010, 394-397).

Leadership conflicts between the mayor of Stuttgart and the director of the Stuttgart Region were settled in 2007 by the newly elected president of VRS Thomas Bopp. The result of the compromise is a coordinative committee involving both parties; it is hosted by the VRS and chaired by the mayor of Stuttgart. However, the involved actors had a low interest in the new model from the beginning and voluntary cooperation reached its limits (Klinkenberg 2010, 396-398; Zimmermann 2011, 204; Zimmermann and Heinelt 2012, 106). The committee still exists today, but has not met regularly for several years (Beuttler-Bohn 2017, 98). Interviewees state that a joint ticket for regional transport called "Metropolticket" as its 
only concrete output. It was introduced in January 2012 and involves nine transport associations (see Figure 4.11). The savings for the users are not huge, ${ }^{18}$ but it contributes to a metro-regional identity, because travellers from Tübingen or Esslingen to Heilbronn, for example, now feel that they are travelling "in the metropolitan region". Yet, the area of validity is not entirely identical with the spatial dimension defined as metro region (see Figure 4.9): the north of the region Heilbronn-Franken is not included and it stretches more to the south beyond the border of the region Neckar-Alb. The current mayor of Stuttgart, Kuhn, was not pushing the cooperation in the early years of his tenure, but has relaunched it in 2019 by initiating a

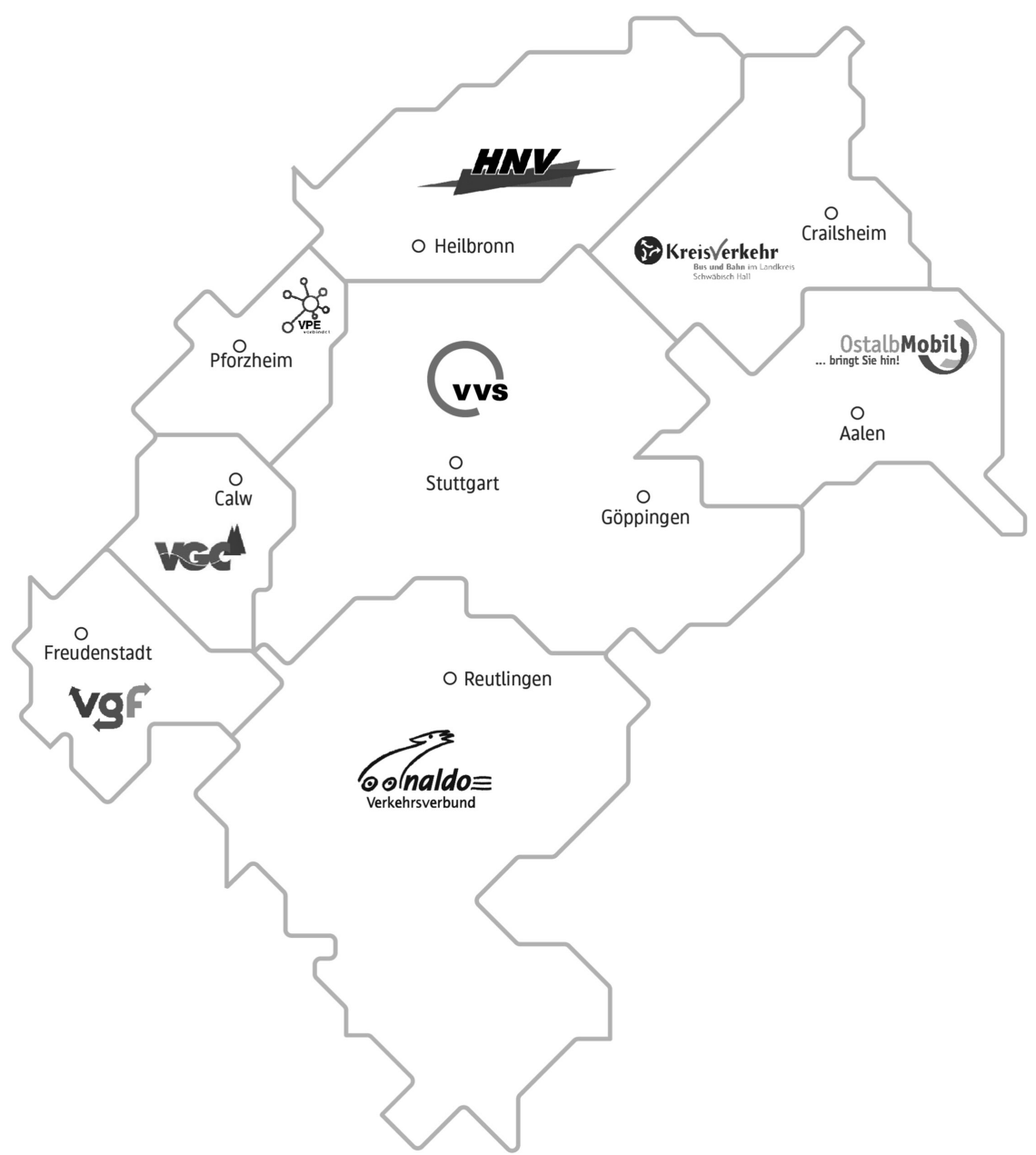

Figure 4.11 Area of validity of the Metropolticket (C) Verkehrsministerium BadenWürttemberg 


\section{Germany}

regional conference concerning mobility which took place in January 2019 under the label of Europäische Metropolregion Stuttgart. Yearly metropolitan conferences as forums for discussions are planned for the future.

All in all, in terms of functions, territory and governance, the Europäische Metropolregion has remained vague and fuzzy. The concept was not able to challenge the Stuttgart Region as the key player for the coordination of public policies. The struggle about the appropriate form of governance for the European metro region has, however, tied up political forces of the Stuttgart Region for several years and therefore rather hampered its institutional development (Blatter 2008, 159). Single-topic cooperation beyond the core of Stuttgart Region exists on a case-by-case basis, though not necessarily under the label of the metropolitan region (see above). None of the existing activities exactly covers the territory of the five regions defined as cooperation space (see Figure 4.8). The area is considered as being too heterogeneous and too big to specify common interests and projects (Interviews; see also Priebs 2019, 262). Another argument put forward against the European metropolitan region as an additional layer is that the multilevel system is already complex and that there are not enough topics left for yet another level between a strong federal state and a strong Stuttgart Region. A range of networks do already exist at the scale of the federal state BadenWürttemberg such as a working group of the 12 regional planning associations (Arbeitsgemeinschaft der Regionalverbände AGRV) or a network of planners as part of the Association of German Cities (Deutscher Städtetag). These are not the forums to discuss metro-regional issues, but the professional exchange and personal contacts make it easier to address the relevant actors if necessary.

\subsection{Interpretation and conclusion: the steady relevance of city-regions}

From a general point of view, not much has changed in the way the governance of city-regions is handled in Germany. Local government and regional policies are largely in the hands of the states and even in the states cityregional governance is decentralised and context-specific, voluntary rather than imperative (Heinelt and Zimmermann 2016). The state governments intervene from time to time (Stuttgart in the 1990s and 2015, Frankfurt/ Rhine-Main in the early 2000s and 2018) but as the case of Frankfurt/RhineMain demonstrates this is rather a definition of procedures and frameworks but not necessarily a clear functional prescription. In the case of Frankfurt/ Rhine-Main, despite the statutory planning functions, local governments have to fill the institutional voids that are defined in the law for so-called regional key tasks. In the case of Stuttgart, the state government intervened regarding the distribution of functions between the counties and the VRS.

On the other hand, Germany has a long tradition and rich experience with inter-municipal cooperation, in particular in city-regions. Inter-municipal 
associations (Planungs- und Regionalverbände) are quite common but differ in strength and with regard to the functions. In many city-regions, they are an implementation instrument for the more effective and cost-efficient provision of public services of general interest but in some cases (such as Stuttgart), the regional associations are stronger in terms of organisational autonomy and combine different functions. These very flexible systems are usually under control of the member municipalities. The inter-municipal associations are financially as well as politically dependent. Direct election such as in Stuttgart Region is a rare exception and even in that case, the financial contribution for any additional tasks depends on the municipalities. German city-regions may have own revenues in terms of fees for service provision, but no own taxes. The core cities do have a crucial role for decision-making within the city-regions; however, the mayors of the core city are not the heads of the city-regional associations.

Economisation of city-regional governance has happened but most of the associations are responsible for reproduction functions and planning. Historically they have been created to solve coordination problems of large agglomerations such as congestion, sprawl, environmental problems and inefficient service provision. Joint external representation and international marketing of the city-region have gained importance, but the big cities and their mayors continue to be relevant players in that regard. Transport is a task that is usually organised separately (Verkehrsverbünde) with Stuttgart being an exception. Counties and county-exempt cities are still main actors, being responsible for the bulk of public policies. Inter-municipal cooperation is widely spread, both in form of single- and multi-purpose associations, but mostly for smaller areas than the entire city-region.

A specific German phenomenon is the emergence of multi-scaled arrangements (e.g. Köln/Bonn) and larger scale cooperation areas (European metropolitan regions in Germany). This means that larger soft cooperation spaces have been added to persisting regional associations. Both have been identical only in a few regions such as Rhine-Neckar. The approach is an effort of a joint strategy for metropolitan regions by the ministers for spatial planning. This is an invitation to regional actors to find solutions, partly picked up by specific aims for those areas in state plans (LEP). But it does not constitute a specific institutional model.

Consolidation pressures do exist but city-regions are not the hotspots of state-modernisation or territorial and functional reforms. Nevertheless, reforms such as in the Ruhr may happen. The introduction of the direct election in the Ruhr indicates a return to the metro model. However, there is hardly any nationwide trend visible.

\subsubsection{Comparison of Stuttgart and Frankfurt/Rhine-Main}

Stuttgart and Frankfurt/Rhine-Main represent the two poles in a wide spectrum of city-regional governance. In both city-regions, regional planning 


\section{Germany}

authorities are in a way the organisational core of a broader governance arrangement, but the planning authority Region Stuttgart is stronger in terms of functions (mobility) and legitimacy. Frankfurt displays the principle of variegated cooperation (different formats and actor constellations) and the municipalities still hesitate to hand over more functions. Nevertheless, over the last years trust in the planning authority has risen and the authority became a partner of more and more networks and initiatives. Both are by and large seen as satisfactory governance solutions by local actors. Thus, they rather represent effective metropolitan governance among German city-regions whereas some other regions have remained even more fragmented than Frankfurt/Rhine-Main with a weaker degree of integration and coordinated action.

In terms of institutional ideas, Stuttgart is closer to the metropolitan reform model. It is a multi-purpose organisation with directly elected assembly and there is also a high degree of territorial coherence for most of the functions, though with low financial autonomy. It is also important to point out that it has a very lean organisational core, combined with semi-autonomous agencies. The planning authority Frankfurt/Rhine-Main is different in this regard. Opportunistic cooperation is an appropriate description. The law has been amended and so-called regional key functions have been added but the planning authority is more a moderator and shares regional policy with many other organisations. Over the last decade, the planning authority established different working relationships with these initiatives.

Also, in terms of spatial relations, the two regions differ. Frankfurt/ Rhine-Main is a large polycentric area that crosses the borders of three federal states. The territory of the planning region has been adapted in 2001 (75 instead of 43) and in 2021 (five new municipalities) and cuts across county boundaries (see Figure 4.6). Stuttgart region is even larger in terms of surface and population (see Table 4.1). However, its territory fits into the hierarchy of territorial authorities in the sense that is cuts neither across county boundaries nor across state boundaries and is one of 12 regional planning regions covering the state of Baden-Württemberg. Stuttgart is by far the biggest city in the city-region, but is surrounded by self-confident mediumsized cities. The number of municipalities in the region is much larger than in Frankfurt/Rhine-Main as municipalities in Baden-Württemberg are on average smaller. The spatial delimitation both of counties and planning regions was set by the state in the 1970s and never altered since. Stuttgart region has become a common spatial reference for local actors. The rigidity is not seen as problematic, first because it is perceived as pertinent for regional planning by the regional planners themselves and second, because the organisational model allows to form subspaces or integrate external actors for specific topics and projects if necessary. Varying cooperation spaces are, however, the exception in Stuttgart region whereas they are the norm in Frankfurt/Rhine-Main due to the principle of variegated cooperation. In Frankfurt/Rhine-Main, it is a question for open debate for each 
regional task if the planning region is the suitable area and format to take care of it.

With regard to the second layer of European metropolitan region in Germany, both are similar with $14,753 \mathrm{~km}^{2}$ (Frankfurt/Rhine-Main) and $15,425 \mathrm{~km}^{2}$ (Stuttgart). However, this spatial configuration is more meaningful in Frankfurt/Rhine-Main because it facilitates cooperation across the borders of the federal states. Even though it is a very weak, voluntary mechanism, the delimitation of the EMR Stuttgart is bound to pre-existing boundaries of counties and regional planning associations. This has prevented the creation of a meaningful space of action, because the EMR Stuttgart formed by five planning regions (see Figure 4.9) is too heterogeneous and has trouble formulating common interests and priorities. The marketing activities of the economic development agency WRS clearly focus on Stuttgart Region and not on the EMR, because the region is seen as a known brand and less ambiguous in terms of space and institution.

In terms of functions, there are some similarities between the two regions. In both, spatial planning (the regional plan in case of Stuttgart and the regional land use plan in case of Frankfurt) and landscape planning, regional landscape parks, economic development and marketing, external representation, digitisation, wind energy and large cultural or sports events are regional tasks. In Stuttgart, the portfolio also includes regional public transport, tourism and the trade fare. In Frankfurt, culture is a more prominent task with three complementary initiatives at the city-regional scale. The German city-regions are more open for economic development purposes and this applies for Stuttgart in particular. In Stuttgart, however, economic development and marketing are main tasks of a regional development agency (WRS), not of the VRS itself, but both are closely interrelated and steered by the regional council. In Frankfurt, economic development is less concentrated in one agency but accomplished by a mix of operational agencies and lobby organisations.

In both cases, we find continuous and flexible adaptations of existing legal frameworks and institutions. Adaptations in the case of Stuttgart Region have been minor, mainly affecting a few additional competences and topics as well as projects-based initiatives (IBA). But overall, the institutional arrangement has been very stable since the creation of the VRS in 1994. Over the last decades, the Frankfurt region was more in a flux, including spatial adjustments.

\section{Notes}

1 Most eastern federal states reduced the number of counties in the middle of the 1990s (Heinelt and Egner 2011, 110).

2 MORO "Überregionale Partnerschaften in grenzüberschreitende Verflechtungsräumen” 2008 with Lake Constance (see Harrison and Growe 2014, 36) and MORO IMeG 2011-2013 with four project areas. 


\section{Germany}

3 Do not exist in Schleswig-Holstein, Saarland, Brandenburg, MecklenburgVorpommern, Lower Saxony (abolished in 2004) as well as in the three city-states.

4 "Die frühe Selbstbezeichnung als Metropolregion, die erfolgreiche Etablierung der Metropolregion als 'Marke' sowie die klare Ausrichtung auf große Leitprojekte und eine gemeinsame Olympia-Bewerbung sind klare Indikatoren für eine solche Governance-Form."

5 The Forum brings together ten chambers of commerce from Southern Hesse, the region of Mainz and Worms in Rhineland-Palatinate and the region of Aschaffenburg in Bavaria.

6 The full title of the law of 19.12.2000 (in force since 2001) is: Gesetz zur Stärkung der kommunalen Zusammenarbeit im Ballungsraum Frankfurt/RheinMain, in short: Ballungsraumgesetz.

7 The increase by five municipalities happened only in April 2021.

8 https://strategieforum-frankfurtrheinmain.de.

9 Darüber hinaus hat er die Mitwirkungsbefugnis an der Wahrnehmung der Ballungsraumaufgaben nach $\mathbb{S} 1$ MetropolG sowie die Möglichkeit, sich an regionalbedeutsamen Angelegenheiten zu beteiligen ( $\mathbb{8}$ MetropolG), erhalten.

10 The strategy was adapted in 2020-21; projects supported by the fonds cover now a broader spectrum.

11 This economic development agency comprises 203 municipalities, 12 counties, five chambers of commerce, two chambers of craft, the Association of Hesse Enterprises (Vereinigung der hessischen Unternehmerverbände), seven research centres, Fraport (the company owning Frankfurt airport) and some other infrastructure companies in the region (http://www. region-frankfurt-rhein main.de/).

12 At the outset, the main aim was limited to "attracting investments and inform about available industrial real estate and office space in the region" (Hoyler et al. 2006, 130).

13 Baden-Württemberg has in total nine county excempt cities, namely BadenBaden, Freiburg im Breisgau, Heidelberg, Heilbronn, Karlsruhe, Mannheim, Pforzheim, Stuttgart and Ulm. With the exception of Baden-Baden, all of them have more than 100,000 inhabitants.

14 Gesetz über die Errichtung des Verbands Region Stuttgart vom 7. Februar 1994.

15 Regional planning authorities usually have about five to ten employees and their financial resources are strictly limited to their regional planning tasks.

16 The protest coalition organised weekly demonstrations with several thousands of participants starting in 2006, which escalated in September 2010 between police and protestors, when the north wing of the old station was torn down. Pictures of violence against protestants caught nationwide attention. Despite the vehement protests, a majority of citizens voted for the project in a statewide referendum held in November 2011 and obliged the Green party to continue with the megaproject notwithstanding their own opposition (Nagel and Satoh 2019).

17 Zweckverband Breitbandausbau Landkreis Böblingen, Zweckverband Breitbandversorgung Landkreis Esslingen, Zweckverband Gigabit Landkreis Göppingen, Zweckverband Kreisbreitband Ludwigsburg, Zweckverband Breitbandausbau Rems-Murr.

18 A day ticket for the metropolitan region costs $21 €$ compared to $24 €$ for regional transport in the entire state Baden-Württtemberg. 


\section{References}

Basten, L. (2011) Stuttgart. A metropolitan city-region in the making? International Planning Studies, 16(3), 273-287. DOI: 10.1080/13563475.2011.591146.

Bender, W. et al. (2015) Erklärung zur Zukunft der METROPOLREGION. Frankfurt: Frankfurt Rhein Main.

Benz, A. (2003) Regional Governance mit organisatorischem Kern. Das Beispiel der Region Stuttgart. Informationen zur Raumentwicklung, 8(9), 505-512.

Beuttler-Bohn, S. (2017) Identifikation der Bürger mit ibren Metropolregionen durch Metropolitan Governance. Ballungsräume Stuttgart und Rhein-Neckar im Vergleich. Berlin: Lit.

Blatter, J. (2005) Metropolitan Governance in Deutschland. Normative, utilitaristische, kommunikative und dramaturgische Steuerungsansätze. Swiss Political Science Review, 11(1), 119-155.

Blatter, J. (2006) Geographic scale and functional scope in metropolitan governance reform: Theory and evidence from Germany. Journal of Urban Affairs, 28(2), 121-150.

Blatter, J. (2008) Metropolitan Governance. Theoretische Formen, vielfältige Reformen und der aktuelle Nivellierungsdruck in deutschen Großstadtregionen. In: Lokale Politikforschung heute, Heinelt, H. and Vetter, A. (eds.) Wiesbaden: VS Verlag für Sozialwissenschaften, pp. 127-163. DOI: 10.1007/ 978-3-531-91111-3_6.

Blotevogel, H.H. (2005) Metropolregionen. In: Handwörterbuch der Raumordnung (4th ed.), ARL (ed.) Hannover: Verlag der ARL, pp. 642-647.

Blotevogel, H.H. and Schmitt, P. (2006) "European Metropolitan Regions" as a new discursive frame in strategic spatial planning and policies in Germany. Die Erde, 137(1-2), 55-74.

Blotevogel, H.H. and Schulze, K. (2010) 1 oder 2 oder 3?: Zur Konstituierung möglicher Metropolregionen an Rhein und Ruhr. Raumforschung und Raumordnung, 68(4), 255-270. DOI: 10.1007/s13147-010-0040-8.

Brenner, N. (2004) Urban governance and the production of new state spaces in Western Europe, 1960-2000. Review of International Political Economy, 11(3), 447-488. DOI: 10.1080/0969229042000282864.

Bundesinstitut für Bau-, Stadt- und Raumforschung (BBSR) (2005) Raumordnungsbericht 2005. Bonn: BBSR.

Bundesinstitut für Bau-, Stadt- und Raumforschung (BBSR) (2012) Raumordnungsbericht 2011. Bonn: BBSR.

Bundesinstitut für Bau-, Stadt- und Raumforschung (BBSR) (2017) Raumordnungsbericht 2017. Bonn: BBSR.

Domhardt, H.-J. and Hilligardt, J. (2011) Der Regionale Flächennutzungsplan als Lösungsansatz für die Herausforderungen in metropolitanen Stadtregionen? Überlegungen zur Aufstellung im Ballungsraum Frankfurt/Rhein-Main. Raumforschung und Raumordnung, 69(6), 397-411. DOI: 10.1007/ s13147-011-0128-9.

Durchdenwald, T. and Schwarz, K. (2019) Wer wird Neuer Regionalpräsident? Stuttgarter Nachrichten from 27 May 2019. Stuttgart.

Ebert, R. (2016) Abschlusspräsentation. Raumtypen zur Entwicklung der Metropolregion FrankfurtR heinMain. Dortmund: StadtART. 


\section{Germany}

Europäische Metropolregion Stuttgart (2008) Gemeinsames Regionalentwicklungskonzept für die Europäische Metropolregion Stuttgart. 12 September 2008.

Frank, A. and Marsden, T. (2016) Regional spatial planning, government and governance as recipe for sustainable development? In: Metropolitan Ruralities. (Research in Rural Sociology and Development, Volume 23), Andersson, K., Sjöblom, S., Granberg, L., Ehrström, P. and Marsden, T. (eds.) Bingley, UK: Emerald, pp. 241-271. DOI: 10.1108/S1057-192220160000023011.

FrankfurtRheinMain GmbH international marketing of the region (2018) FrankfurtRheinMain 2030: Zukunftsbild und Maßnabmenkatalog für eine attraktive, zukunftsfähige und internationale Metropolregion. Frankfurt: FrankfurtRheinMain GmbH.

Freund, B. (2003) The Frankfurt Rhine-Main region. In: Metropolitan Governance and Spatial Planning, Salet, W., Thornley, A. and Kreukels, A. (eds.) London, New York: Spon Press, pp. 125-144.

Fricke, C. (2017) Metropolitan regions as a changing policy concept in a comparative perspective. Raumforschung und Raumordnung, 75(3), 291-305. DOI: 10.1007/ s13147-016-0450-3.

Fricke, C. (2020) European Dimension of Metropolitan Policies. Policy Learning and Reframing of Metropolitan Regions. Cham: Springer (Springer Geography). DOI: $10.1080 / 17535069.2020 .1843334$.

Fürst, D. (2005) Metropolitan governance in Germany. In: Metropolitan Governance, Capacity, Democracy and the Dynamics of Place, Heinelt, H. and Kübler, D. (eds.) London: Routledge, pp. 151-168.

Hager, G. (2016) Metropolitane Grenzregionen in Aktion: Der IMeG. Informationen zur Raumentwicklung, 5, 559-564.

Harrison, J. and Growe, A. (2014) From places to flows? Planning for the new 'regional world' in Germany. European Urban and Regional Studies, 21(1), 2141. DOI: $10.1177 / 0969776412441191$.

Heeg, S. (2003) Governance in the Stuttgart metropolitan region. In: Metropolitan Governance and Spatial Planning. Comparative Case Studies of European CityRegions, Salet, W. G. M., Thornley, A. and Kreukels, A. (eds.) London, New York: Spon Press, pp. 163-174.

Heinelt, H. and Egner, B. (2011) Germany. In: Second Tier of Local Government in Europe: Provinces, Counties, Départements and Landkreise in Comparison, Heinelt, H. and Bertrana, X. (eds.) London: Routledge, pp. 106-125. DOI: $10.4324 / 9780203180846$.

Heinelt, H., Razin, E. and Zimmermann, K. (2011) Metropolitan Governance. Different Paths in Contrasting Contexts: Germany and Israel. Campus: Frankfurt am Main/Chicago University Press.

Heinelt, H. and Zimmermann, K. (2016) Cities in the multi-level system of German federalism. In: Cities as Political Objects. Historical Evolution, Analytical Categorisations and Institutional Challenges of Metropolitanisation, Cole, A. and Payre, R. (eds.) Cheltenham, UK: Edward Elgar, pp. 156-174.

Heinz, W. (2007) Inter-local cooperation in Germany. The mismatch between existing necessities and suboptimal solutions. In: Inter-Municipal Cooperation in Europe, Hulst, R. and van Montfort, A. (eds.) Dordrecht: Springer Netherlands, pp. 91-115.

Hemberger, C. and Kiwitt, T. (2018) Wohnraumbereitstellung im Stadt-regionalen Maßstab. Das Aktionsprogramm Wohnen des Verbands Region Stuttgart: Kleinund Mittelstädte als Leistungstrager. RaumPlanung, 195, 34-39. 
Hesse, M. and Leick, A. (2013) Wachstum, Innovation, Metropolregionen. Zur Rekonstruktion des jüngeren Leitbildwandels in der Deutschen Raumentwicklungspolitik. Raumforschung und Raumordnung, 71(4), 343-359. DOI: 10.1007/s13147-013-0243-x.

Hoyler, M., Freytag, T. and Mager, C. (2006) Advantageous fragmentation? Reimagining metropolitan governance and spatial planning in Rhein-Main.' Built Environment, 32(2), 124-136.

Hoyler, M., Freytag, T. and Mager, C. (2008) Connecting Rhine-Main: The production of multi-scalar polycentricities through Knowlegde-intensive business services. Regional Studies, 42(8), 1095-1111.

Hunds, M. (2011) Außenpolitische Aktivitäten der Metropolräume Àrea Metropolitana de Barcelona und Region Stuttgart. Schriftenreihe Studien zur Stadt- und Verkehrsplanung, 13. Hamburg: Kovač.

Institut für Landes und Stadtentwicklungsforschung (ILS) (2019) Stadt oder Umland? Aktuelle Trends des Bauens und Wohnens in Deutschen Stadtregionen. ILS-Trends 2/2019. Dortmund: ILS.

Jessop, B., Brenner, N. and Jones, M. (2008) Theorizing sociospatial relations. Environment and Planning. Part D, 26(3), 389-401. DOI: 10.1068/d9107.

Kawka, R. and Staats, J.-U. (2016) Metropolregionen und Bundesraumordnung. Informationen zur Raumentwicklung, 5, 535-541.

Klinkenberg, S. (2010) Regional Governance der in Europäischen Metropolregion Stuttgart - über Machtansprüche und die Suche nach der richtigen Organisationsform. In: Jahrbuch des Föderalismus 2010, Europäisches Zentrum für Föderalismus-Forschung Tübingen (ed.) Baden-Baden: Nomos, pp. 389-402. DOI: $10.5771 / 9783845225388$.

Kübler, D. (2012) Governing the metropolis: Towards kinder, gentler democracies. European Political Science, 11(3), 430-445. DOI: 10.1057/eps.2011.44.

Land Hessen (2018) Gesetz über die Metropolregion Frankfurt/Rhein-Main (MetropolG). Wiesbaden: Land Hessen.

Landeshauptstadt Stuttgart and Verband Region Stuttgart (VRS) (2019) Mobilitätskongress 22. Januar 2019 Europäische Metropolregion Stuttgart. Veranstaltungsdokumentation. Stuttgart: VRS.

Lefèvre, C. (2001) Metropolitan government reform in Europe: Current trends and challenges. Swiss Political Science Review, 7(3), 16-21.

Mayer, M. (1996) Postfordistische Stadtpolitik. Zeitschrift für Wirtschaftsgeographie, 40(1-2), 20-27. DOI: 10.1515/zfw.1996.0002.

Ministerium für Wirtschaft, Arbeit und Tourismus Baden-Württemberg (2002) Landesentwicklungsplan. Stuttgart: Land Baden-Württemberg.

Ministerkonferenz für Raumordnung (MKRO) (1995) Raumordnungspolitischer Handlungsrabmen. Beschluß der Ministerkonferenz für Raumordnung in Düsseldorf am., 8 März 1995. Bonn: Bundesministerium für Raumordnung, Bauwesen und Städtebau.

Ministerkonferenz für Raumordnung (MKRO) (2016). Concepts and Strategies for Spatial Development in Germany. Berlin.

Nagel, M. and Satoh, K. (2019) Protesting iconic megaprojects. A discourse network analysis of the evolution of the conflict over Stuttgart 21. Urban Studies, 56(8), 1681-1700. DOI: 10.1177/0042098018775903.

Nelles, J. (2012) Comparative Metropolitan Policy: Governing Beyond Local Boundaries in the Imagined Metropolis. London: Routledge. DOI: $10.4324 / 9780203126745$. 
Niemann, L., Polivka, J. and Schauz, T. (2011) Die Zukunft internationaler Bauausstellungen. Erkenntnisse aus der Forschung. In: Internationale Bauausstellung Emscher Park: Impulse. Lokal - regional - national international. Reicher, C., Niemann, L. and Uttke, A. (eds.) Essen: Klartext, pp. 314-345.

Priebs, A. (2019) Die Stadtregion: Planung, Politik, Management. Stuttgart: Eugen Ulmer Verlag. DOI: 10.2478/rara-2020-0001.

Prognos, A.G. (2010) Gutachten zu den funktionalen Verflechtungen in der Metropolregion FrankfurtRheinMain (FRM). Stuttgart/Berlin.

Pütz, T. (2016) Empirische Zusammenschau der europäischen Metropolregionen in Deutschland. Informationen zur Raumentwicklung, 5, 543-553.

Regional Authority FrankfurtRheinMain (FRM) (2014) The Regional Preparatory Land Use Plan: Tasks and Objectives. Frankfurt: Regionalverband FRM.

Regional Authority FrankfurtRheinMain (FRM) (2020). Die Gremien des Regionalverbands. Frankfurt: Regionalverband FRM.

Regionalverband FrankfurtRheinMain (FRM) (2017) Flächenmonitoring Jahresbericht 2017. Frankfurt: Regionalverband FRM.

Scheller, J. and Langhagen-Rohrbach, C. (2004) Rhein-Main: Interkommunale Planung und Regionalmanagement unter Bedingungen einer Kultur der Konkurrenz? In: Raumentwicklung und Raumplanung in Europa, Tharun, E., Berge, T. and Langhagen-Rohrbach, C. (eds.) Frankfurt am Main: Johann Wolfgang Goethe-Universität, pp. 73-96.

Schmidt, M. (2013) Regional governance und Infrastruktur. Kooperationen in der Wasserver- und Abwasserentsorgung am Beispiel der Stadtregionen Frankfurt/M, Berlin und Ruhr. Detmold: Rohn Verlag.

Schmidt, S. (2009) Land use planning tools and institutional change in Germany: Recent developments in local and regional planning. European Planning Studies, 17(12), 1907-1921. DOI: 10.1080/09654310903322397.

Schmidt, S., Siedentop, S. and Fina, S. (2018) How effective are regions in determining urban spatial patterns? Evidence from Germany. Journal of Urban Affairs, 40(5), 639-656. DOI: 10.1080/07352166.2017.1360741.

Stark, S. (2009) Steuerung durch Regionalpläne. Anspruch und Wirklichkeit der Steuerungswirkung des Regionalplans am Beispiel der Wohnbauflächen in der Region Stuttgart. Berlin: Univ.-Verl. Der Techn. Univ.

Tomàs, M. (2019) Metropolitan revolution or metropolitan evolution? The (dis) continuities in metropolitan institutional reforms. In: Metropolitan Regions, Planning and Governance, Zimmermann, K., Galland, D. and Harrison, J. (eds.) Berlin: Springer, pp. 25-39. DOI: 10.1007/978-3-030-25632-6_2.

Verband region Stuttgart (VRS) (2004) 20 Jahre. Rückblicke, Einblicke, Ausblicke. Stuttgart: VRS.

Verband region Stuttgart (VRS) (2016). Regionalentwicklungsbericht der Region Stuttgart. Stuttgart: VRS.

Verband region Stuttgart (VRS) (2018) Beteiligungsbericht 2017 des Verbands Region Stuttgart. Stuttgart: VRS.

Verband region Stuttgart (VRS) Regionalverband Heilbronn-Franken and Regionalverband Neckar-Alb (2003) Strategiepapier zur Weiterentwicklung der Kooperation in der Europäischen Metropolregion Stuttgart. 09 October 2003. Stuttgart: VRS. 
Wahl, R. (1998) Landkreise, Regionen, Regierungsbezirke - Zu viele Ebenen? Der Bürger im staat, 48(4), 209-213.

Walter-Rogg, M. (2018) What about metropolitan citizenship? Attitudinal attachment of residents to their city-region. Journal of Urban Affairs, 40(1), 130-148. DOI: 10.1080/07352166.2017.1355664.

Website Statistisches Landesamt Baden-Württemberg. Available at: https://www. statistik-bw.de/ (accessed 22 January 2020).

Website IKM. Available at: http://deutsche-metropolregionen.webseiten.cc/ monitoring/ (accessed 22 January 2020).

Wirtschaftsförderung Region Stuttgart (WRS) (2016) Memorandum IBA 2027 StadtRegion Stuttgart. Ergebnisse des IBA-Plattformprozesses. Stuttgart: WRS.

Zimmermann, K. (2011) Metropolitan governance in Stuttgart. New Regionalism par excellence? In: Metropolitan Governance. Different Paths in Contrasting Contexts: Germany and Israel, Heinelt, H., Razin, E. and Zimmermann, K. (eds.) Frankfurt am Main: Campus (Interdisziplinäre Stadtforschung, Volume 9), pp. 189-205. DOI: 10.1080/09654313.2012.680743.

Zimmermann, K. (2014) Democratic metropolitan governance: Experiences in five German metropolitan regions. Urban Research and Practice, 7(2), 182-199. DOI: $10.1080 / 17535069.2014 .910923$.

Zimmermann, K. (2017) Re-scaling of metropolitan governance in Germany. Raumforschung und Raumordnung, 75(3), 253-263. DOI: 10.1007/s13147017-0480-5.

Zimmermann, K. (2020) Kommunalpolitik seit 1945. In: Stadtsoziologie und Stadtentwicklung. Handbuch für Wissenschaft und Praxis, Breckner, I., Göschel, A. and Matthiesen, U. (eds.) Baden-Baden: Nomos.

Zimmermann, K. and Heinelt, H. (2012) Metropolitan governance in Deutschland. Regieren in Ballungsräumen und neue Formen politischen Steuerung. Regieren in Ballungsräumen und neue Formen politischer Steuerung. Wiesbaden: Springer VS. DOI: 10.1007/s13147-012-0187-6. 


\title{
5 Cross-country comparison
}

\author{
P. Feiertag and K. Zimmermann
}

After the presentation of six city-regional case studies and the internal comparison of the two cases per country in Chapters 2 to 4, we draw conclusions about the drivers of reforms and the results in terms of institutions, functions and spatial relationships by making a cross-country comparison. This includes national policy frameworks in a cross-country perspective as well as a comparison of the six case studies.

National frameworks and administrative cultures continue to matter for metropolitan governance due to different state structures (federal, regionalised, unitary), socio-economic development paths and country-specific discourses on state modernisation and spatial development policies. Besides the relevance of national frameworks, the empirical evidence shows regional differences within nation states as well as similarities across country boundaries, e.g. regarding the issue of the direct election of the metropolitan council. The fact that European city-regions are well connected to each other via institutionalised networks, personal contacts and shared experiences contributes to these cross-national similarities. However, despite this travelling of ideas and shared challenges of European city-regions, there are only weak signs of homogenisation of city-regional governance across the three countries and six case study regions.

\subsection{Institutions}

The selected case studies all have an institutionalised city-regional authority but only in Italy are these institutions mentioned in the constitution, because they substituted for an existing jurisdiction. This substitution also happened in Lyon as the métropole gained the status of a département. The three other metropolitan institutions are additional levels added to the multi-level system without replacing the second tier of local government.

In Germany, the term "region" is used in a variety of ways and it is common to call city-regional institutions "region", whereas the French régions and Italian regione are higher level governments and more comparable to the German state governments. Thus, "region" in the German terminology refers to much smaller entities (city-regions or metropolitan regions) than 
in the European understanding (Fricke 2020a, 155; Wahl 1998, 210). In contrast to France and Italy, regions exist in formal terms only as statutory planning regions for regional planning (see Figure 4.5) and as government offices of the regions (Regierungsbezirke), i.e. regional branches of the state governments (often also referred to also as "districts") (Zimmermann 2017, 254). The term "region" is also used for informal formats of cooperation such as the agglomeration concept Cologne/Bonn producing a spatial image of the region or within the funding programme REGIONALE in NorthRhine Westphalia (Reimer 2012). The terms "città metropolitana" and "métropole" are more clear in the sense that they refer to a distinct institutional form framed by national laws. However, the French term "métropole" existed before these laws and is linked to specific connotations and imaginations of a city, and is not only used to signify the legal institution. To increase the ambiguity further, some municipal groupings without the legal status of a métropole use it as a name (e.g. CU Angers Loire Métropole or even CA Châteauroux Métropole) to underpin the relevance of the respective city-region.

Compared to the history of the modern nation states, metropolitan authorities are relatively recent phenomena, in particular when compared to the second tier of local government in France and Italy. Their raison d'être depends much on their performance and the need for city-regional solutions. In France, the métropoles have gradually evolved and are now a crucial institution for the provision of many public services. Thus, it is difficult to imagine that their reason for existing will be questioned again, or that they will be abolished and their functions redistributed to other levels of the state. It is more likely that more tasks from municipalities and départements will be assigned to them and the question is rather to what extent the partly criticised power concentration will continue and how horizontal and multi-layered cooperation will be institutionalised in the future.

The two German cases, Stuttgart region and Frankfurt/Rhine-Main region, have stabilised and have gained a good reputation among municipalities and counties as useful service providers and moderators. Because of the performance of the current arrangements that are able to deal at least with some of the city-regional issues, both regional authorities are not likely to vanish. In the future, it may happen that they extend their role as core institutions and/or moderators at the city-regional level slightly, if the state governments or local actors assign additional tasks. However, municipalities and counties defend their constitutional right of local self-government and give the subsidiarity principle and proximity to the citizens as reasons. Thus, in both cases, the regional authorities have to prove that the cityregion is the more appropriate level for problem-solving. In Italy, the CM are quite young compared to the other metropolitan authorities in Europe and are still building their reputation, mainly via strategic planning instruments. Performances differ and for future development, it will be decisive how they fill the niche between the cities and the regions. 
The question of whether city-regions increased in relevance as institutional sites of problem-solving or service provision can be answered positively for all the six case studies but there is certainly variation. They have some autonomy vis-à-vis higher levels of government as well as vis-à-vis local authorities, and partly meet the criteria of adequate financial (and human) resources and significant powers to intervene in metropolitan affairs (Demazière and Sykes 2020b, 199). Financial autonomy is highest in the case of the French métropoles with a share of direct tax income (see Table 5.1). Political legitimacy by direct election has been established only in Stuttgart Region (since 1994) and the Métropole de Lyon (since 2020). Both are exceptions in their national contexts and became possible due to a window of opportunity. With regard to leadership, three out of six presidents of metropolitan authorities are mayors of the core city (in Italy prescribed by national law). The reason for this double position is on one hand to synchronise the policy of the core city and the metropolitan authority and on the other hand to have a powerful leader who is able to defend the interests of the city-region, e.g. in negotiations with higher levels. In Italy, this is also a measure to save expenditure as the position of the head of the second tier (former province) no longer exists. In France, being mayor of a large city used to be the foundation of many national political careers (see 2.2.1). In Germany, the argument to avoid the coupling of the position as president of a regional authority and mayor is that it would harm the role as neutral moderator within the region by accentuating the dominance of the core city. In the case of the Frankfurt/Rhine-Main region, the current director of the planning authority is a former mayor of a medium-sized town adjacent to Frankfurt/ Main.

Regarding budget and staff, Table 5.1 shows striking contrasts. As the city-regional authorities have different sources of income (including temporary funding) and assets, these global numbers have to be interpreted with caution to avoid misunderstandings and can only be compared in a differentiated way by looking in detail into the budgets and staff schemes. The lion's share of the budget of Stuttgart region for example is dedicated to public transport $(90 \%$, including the purchase of new light rail trains, see 4.3.1); after subtracting this budget position, the difference between the budgets of Stuttgart and Frankfurt/Rhine-Main region appears less significant. Still, the figures give an impression of the strength and performance of the city-regional authorities and the rough indication of whether a hundred (or less) or several thousand employees work for an organisation gives a clue to the functional relevance of a city-regional institution. Some explanations are related to the distribution of functions (see 5.2). The huge discrepancy points to the role of the institution, meaning if it is mainly strategic and coordinative and therefore less cost-intensive or also operational and managerial. This difference determines the budget and influences what kind of staff are needed to fulfil these functions. To give an example, the seven pôles de proximité of Nantes Métropole have about 200 employees each 
Cross-country comparison 265

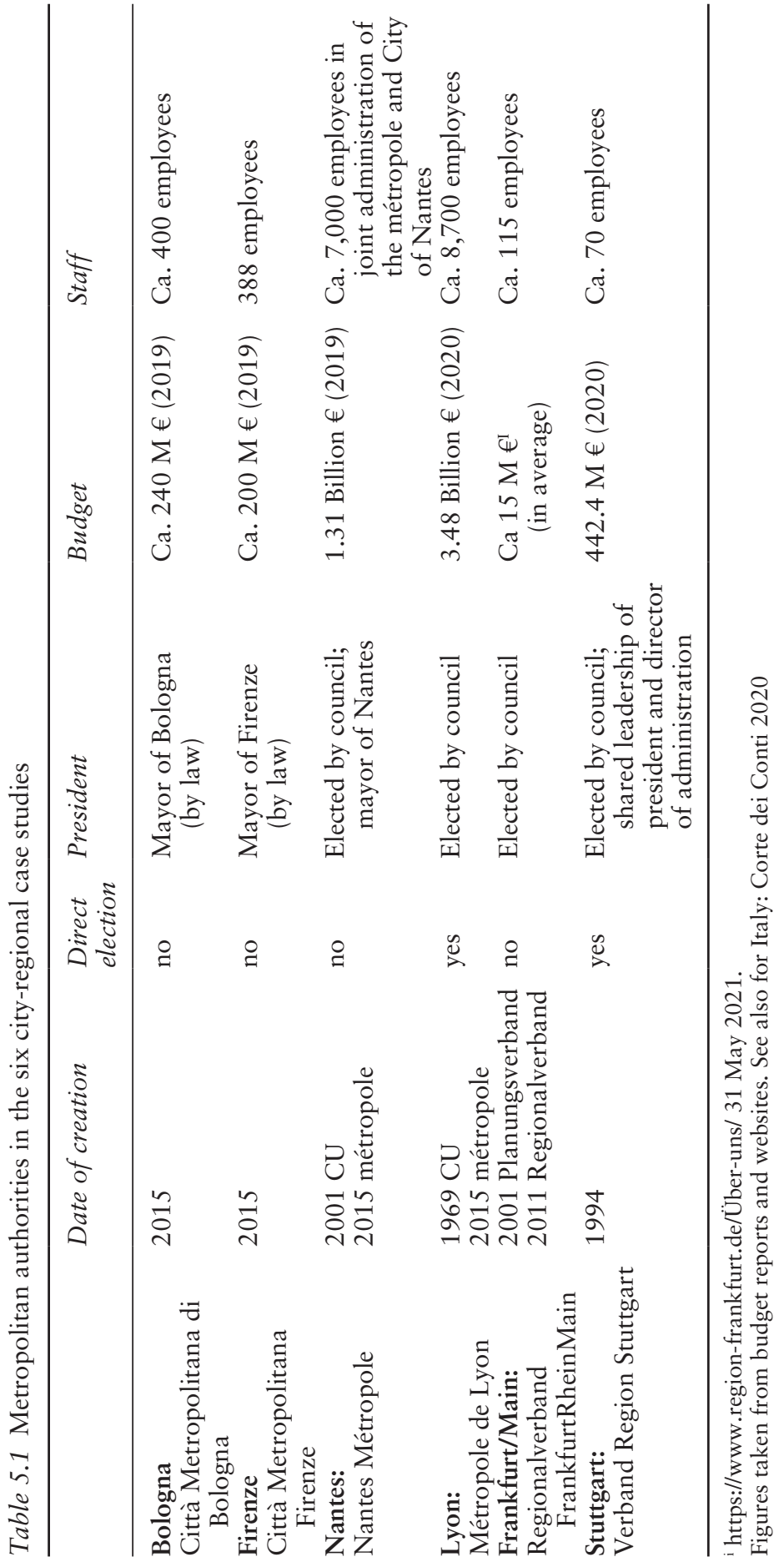


and deal e.g. with the maintenance of municipal streets, and include the construction teams that repair potholes (see 2.2.1). The provinces and città metropolitane in Italy had to make a significant contribution to the fiscal consolidation of the Italian public sector in 2015, 2016 and 2017 and this hampered the start the of città metropolitane as strategic planning agencies (Corte dei Conti 2020).

The human resources also point to the position in the multilayer system. The CMs are former provinces and kept part of their staff along with the tasks (provincial streets, schools and planning in particular). French métropoles have taken on staff from the municipalities or even merged both administrations in the case of Nantes. The administration of Lyon is ever larger, because it includes a substantial number of employees transferred from the Département Rhône (see 2.3.1). In Stuttgart region and the region Frankfurt/Rhein-Main, this kind of transfer has not taken place. Rather than partly replacing counties and municipalities, these regional associations fulfil additional strategic tasks with the aim of increasing coordination of public policies and public-private initiatives. Both organisations are in principle planning authorities, a public policy that is less cost-intensive compared to social housing, urban regeneration, public transport or maintenance of school buildings. The balance between county-exempt cities and regional authorities in Germany in terms of functions, territory and finances is completely different than that between French core cities and métropoles: as an example, Frankfurt/Rhine-Main region has less than $1 \%$ of the budget and staff of the city of Frankfurt/Main, whereas the budget of the city of Lyon is less than one-quarter that of the métropole and it has slightly less staff (Demazière et al. 2022). In order to give a more balanced picture of the weakness of German regional authorities in terms of staff and budget (see Table 5.1) we need to take into consideration that German county-exempt cities (such as Frankfurt, Stuttgart) are bigger in terms of territory (due to annexations that happened decades ago) than their Italian and French counter parts. Hence, the French métropoles are in a way a functional equivalent of German county-exempt cities.

These numbers also point to different ways to organise the functions. Stuttgart region can be seen as prototype of a lean organisation with the core task of regional planning. Many other tasks, including economic development or tourism, are organised in limited liability companies $(\mathrm{GmbH})$ and the regional authority is a significant shareholder. The directly elected regional assembly supervises these partnerships and takes strategic decisions, but they operate autonomously at arm's length distance and also have their own budget (see 4.3.1). In Bologna, the administrations of the CM and the core city collaborate closely (joined offices), although not as closely as in Nantes, where mergers took place. This is primarily done for reasons of cost-efficiency. This phenomenon of close administrative ties between the regional authority and the core city is not observable in Germany, where the two bodies keep a distance. 
Looking at the evolution of city-regional policies in the six city-regional cases and three countries, we rather see context-specific institutional solutions how to organise metropolitan governance than convergence towards a unified model. Recent changes in France are not path-breaking changes but show a pattern of management of adaptations. This applies also to Italy although the introduction of the citta metropolitana changed much in terms of legitimacy and territorial political representation of the second tier of local government. France shows a sequence of adaptations and complementary measures with regard to the creation of new city-regions, their size and functional portfolio. In Germany, we see a decentralised and nonuniform way of dealing with problems of metropolitan development. The governance arrangements that emerged in different city-regions at different moments in time are specific to the local context, but are also influenced by the respective Zeitgeist.

\subsection{Functions}

The repartition of functions in the multi-level system differs among the federal state of Germany, the regionalised state of Italy and the unitary state of France. The German city-regions Stuttgart and Frankfurt/Rhine-Main have a rather narrow functional profile compared to the responsibilities of the local governments and the Länder and therefore cannot be regarded as representing a full-fledged level of public administration. This is different in Lyon and Nantes, where the métropoles have broader tasks. French métropoles are as powerful as régions and have gained problem-solving capacities at the expense of départements and municipalities in the last decade. The Italian CM Bologna and Florence are somehow in an intermediate position between a hollowed-out province and a city-regional agency for strategic planning. Compared to the former province, expectations are high with regard to strategic coordination of socio-economic development. Note that in France, the definition of functions and roles for the métropole was negotiated by the municipalities, the existing CU and the départements. In Italy the functional profile of the CM was rather decided top down by the regional governments.

In many policy fields, the city-regional institutions in all three countries do not have exclusive functions, but share them with other levels, in particular with the local governments. Therefore, close coordination is needed. The German regions represent a specific case as they use a range of collaborative arrangements with public and private actors and this makes them appear larger than they are.

Across our six cases, there are some policy fields addressed by all cityregions. All regions are meant to coordinate the spatial development through different kinds of strategic and statutory spatial plans. The CMs Firenze and Bologna are responsible for the Piano Strategico Metropolitano, the Piano Territoriale Metropolitano and a city-regional mobility plan. The 
métropoles Lyon and Nantes have established the inter-municipal land use plan PLUi and have approved the strategic SCoT. Stuttgart Region has the responsibility for the statutory regional plan and Frankfurt/Rhine-Main region for a regional land use plan (regionaler FNP), the latter replacing the regional plan and municipal preparatory land use plans. Both authorities are also responsible for landscape plans. In contrast to the French métropoles and Frankfurt/Rhine-Main region, local land use planning has remained a municipal task in Stuttgart and the Italian cases. However, in both city-regions, Florence and Bologna, inter-municipal land use plans are getting more and more relevant. Inter-municipal land use planning is possible according to national law in Germany as well, but rarely takes place for more than two or three municipalities. All six city-regions accomplish mobility planning (though to different degrees with the mobility concept of Frankfurt/Rhein-Main being the document with the lowest binding quality). Stuttgart region is also responsible for intermodal mobility and regional trains (S-Bahn), whereas in France this is a task accomplished by the région. In the Italian city-regions, mobility is a pressing issue but the task is shared among the $\mathrm{CM}$, the regions, the municipalities and transport providers. Compared to the former province, the sustainable mobility concept has gained more weight and this finds repercussions in national regulations that make city-regional sustainable mobility plans (SUMPs) more or less obligatory. This is not the case in the German city-regions. The case of Bologna demonstrates how the combination of strategic planning, sustainable mobility policy and national funding dominates the agenda.

All city-regions plan or manage some infrastructure of city-regional importance, e.g. the trade fair in the case of Stuttgart region and, as a more recent phenomenon, they are in charge of the expansion of digital infrastructure, broadband access in particular (Frankfurt, Stuttgart). The French métropoles and German regional authorities also carry out functions related to competitiveness, such as tourism and city-regional marketing as well as economic development. In Italy, coordination of socio-economic development is the core task as defined by the law but remains vague in operational terms. The Métropole de Lyon and Stuttgart Region are particularly active regarding external representation and marketing, including a European liaison office in Brussels. The planning authority Frankfurt/Rhein-Main has a liaison office in Brussels which is still part of the planning authority but serves the whole metropolitan region. Bologna participated in a high number of European projects (URBACT, ESPON, Partnerships of the EU Urban Agenda).

Along with strategic planning and functions related to competitiveness, the city-regional level is also relevant for reproduction functions. French métropoles provide a broad range of services of general interest including electricity, heating networks, gas, waste management, water distribution and wastewater treatment, cemeteries and crematoria, slaughterhouses and wholesale markets, fire brigade and charging devices for electric vehicles. 
These services are usually not implemented at the city-regional level in Germany but are the responsibilities of the county-exempt cities and counties or delivered by inter-municipal single-purpose associations for a few neighbouring municipalities. This difference can be explained by the small size of French municipalities. In Italy, the picture is more mixed and eventually the general hollowing out of the provincial level is more relevant in this regard. The purpose of the CM, according to the law, is one of strategic planning and coordination of territorial development and not one of provision of technical infrastructure and services for water or energy supply. Still, the $\mathrm{CM}$ are responsible for provincial streets (and some regional streets) and secondary schools.

No or very limited functions related to social policy, education and health are carried out by the studied CM, regional authorities in Germany or Nantes Métropole. The Métropole de Lyon is an exception in this regard, also compared to all other French métropoles, because its status as a département includes various functions related to social policy as well as for the secondary schools for grades 6-9 (collèges). In all cases, culture and sports are only targeted when related to festivalisation, i.e. large events as well as sites of regional or even national importance (stadiums). To name a few examples, Stuttgart Region applied to host the Olympic Games 2012 (without success) and Nantes Métropole is responsible for the football stadium (one of the arenas for the world championship 1998) and the opera house. These activities contribute in a way to city-regional competitiveness, whereas infrastructure for local neighbourhoods, such as sports fields, are built and maintained by the municipalities in all six cases. Cooperation in cultural policies is a specific development in the Frankfurt/Rhine-Main area and is much more pronounced than in the other city-regions.

A difference between Germany on the one side and France and Italy on the other is the openness to a combination of different forms of city-regional cooperation in different sectors. There is not just one organisation, but a mix of different organisational forms and in the case of Frankfurt these sector-specific organisational forms also refer to different spatial scales. That is to say, place-based and sectoral principles compete in Frankfurt more strongly than in the other regions.

In our six case study regions, we can observe that more functions have been shifted to the city-regional level and that the fields of activity have become broader. This is most pronounced in France. The shift of responsibilities from municipalities to the inter-municipal level is a decades-long process that has not ended yet. More recently, some (Nantes) or all (Lyon) functions of the départements have been shifted to métropoles as well, further increasing the relevance of this level of the state. In Bologna and Florence, the CM have gained strategic planning functions. However, the CM have also lost substantial functions, in particular environmental planning. In Stuttgart, the repartition of functions between counties and region was an issue at the beginning of 2010. As an outcome, Stuttgart Region has gained additional 
functions regarding public transport (express busses). However, the counties as such were not put into question and in contrast to the French départements or the Italian provinces it is unlikely that this will happen in the near future. The regional assembly of Stuttgart Region has also adopted an action programme for housing, without having formal responsibility in the field. Frankfurt/Rhine-Main region adopted additional tasks in 2018 including an energy concept and a digitalisation strategy for the region.

The shift of functions to the city-regional level can take place in a topdown manner by national or in the case of the federal state Germany by state law, or in a bottom-up manner by voluntary transfer of member municipalities. In case of the two Italian city-regions Bologna and Florence, all responsibilities have been defined by regional law, within the framework of a national law. In the French city-regions Nantes and Lyon, the bundle of functions is the result of a combination of the minimum requirements for all métropoles defined by the national law and additional responsibilities transferred by member municipalities. The same principle of a mix of topdown and bottom-up definition of tasks also applies for Stuttgart region. However, there is no national framework law, but instead a federal law of the state Baden-Württemberg regarding the creation of Stuttgart region. In the case of Frankfurt/Rhine-Main, the state sets tasks that have to be addressed regionally, either by the planning authority or another voluntary arrangement. This represents the most flexible approach, as local actors negotiate about the most suitable arrangements regarding institutional form and spatial dimensions.

We can observe a heterogeneity of functions within the city-regions in one country, meaning that functions can be adapted to local needs. The diversity is most pronounced in Germany due to a lack of a national framework for all German city-regions. But also in the unitary state France, there are variations between the functions of the métropoles, even more than between the città metropolitane in the regionalised state of Italy. This can be explained by the long trajectory of inter-municipal groupings in France before the transformation into métropoles took place, which was strongly shaped by the local context. In Italy on the other hand, CM are transformed provinces with a defined set of uniform functions defined by national law. The regions, however, have the legal responsibility to add functions and establish a variety of institutional relationships with the new entity. In Nantes, the administration of the métropole is becoming more and more interwoven with the administration of the City of Nantes. In addition to the formal responsibilities, the métropole and interested municipalities conclude individual arrangements for the pooling of municipal tasks. This means that some heterogeneity can also arise within the city-region. The latter happens to a limited degree also in Bologna where $\mathrm{CM}$ and core city collaborate through joined offices.

Overall, we can trace ongoing debates and constant adaptations of the distribution of functions in the multi-level systems. In Germany, this is 
particularly true for the balance between national level and state governments. In France, territorial reforms have touched all levels of the state and have aimed to reduce overlapping responsibilities. In Italy, the long-envisioned creation of metropolitan cities was made possible as a result of the fiscal crisis and this has had an influence on the reform agenda. At the same time, we would say that even in France and Italy, city-regions are not at the centre of debates on state modernisation, but with regard to their functions we can nevertheless observe an increase in the relevance of city-regions as institutional sites of problem-solving in France. Despite institutional differences, some functions are carried out at the city-regional level in all six cases, including regional planning. The question of whether the respective métropole, $\mathrm{CM}$ or regional authority is the appropriate level for problemsolving, or either too small due to functional interrelations or too large due to reasons of subsidiarity and proximity also greatly relates to their spatial dimensions.

\subsection{Ideas}

City-regions are considered as relevant sites for innovation and economic growth in the urban age, and are crucial for the global competitiveness of national economies (Rodríguez-Pose 2009). This way of thinking is visible in the rhetoric of policy documents in the three European countries Germany, France and Italy, and is used as justification for metropolitan policies. However, the competitiveness of city-regions has not been the key driver for territorial reforms in any of the three countries. Territorial reforms were justified by an improvement in the multi-level system of public policy-making and a shift to the intermediary level. Regarding the rhetoric of the reform, key words were simplification, efficiency and effectiveness in the public sector as well as decentralisation and regionalisation.

The idea of competitiveness has been most prominently mobilised in the German discourse around "European metropolitan regions in Germany". This joined initiative of the federal states was meant to compensate for the lack of a global city such as London or Paris, and highlights the polycentric character of the German urban system. The label was used for networking and international marketing, but did not result in any territorial or functional reform that would have attributed more formal responsibilities, tax share, direct representation or the like to those metropolitan regions. In addition, the rhetoric of highlighting the metropolitan regions provoked resistance from rural areas and towns and the national spatial vision from 2006 attempted to reconcile both principles of competitiveness and equal living conditions with the concepts of urban-rural partnerships and large-scale communities of responsibility (Fricke 2020b, 173). Since the mid-2010s, the national attention to metropolitan regions in reports on spatial development, model projects and applied research founded by the ministry (Ressortforschung) has become lower. None of the federal states 
has strengthened their metropolitan regions considerably but in the case of Frankfurt/Rhein-Main the initiative facilitated a continuous dialogue among four federal state governments and a range of local actors.

In Italy and France, territorial reforms did take place, but the competitiveness of city-regions was not the key driver behind them. In Italy, reforms were mostly driven by austerity measures (Longo and Mobilio 2016; Bolgherini and Lippi 2016). The creation of the CM, however, also opened the door for sustainable transport policy (SUMPs) and urban regeneration (in particular in Bologna) but this differs from region to region. In general, we can say that there is still a lack of territorial coherence (see below).

In France, the main idea was to make the complex multi-level system more efficient, which is a long-standing theme for French governments (Kuhlmann and Wollmann 2014). City-regions and their position in the multi-level system have not been the main concern in the state modernisation process. However, the creation of métropoles along with the enlargement of régions symbolises neoliberal, growth-oriented thinking in the eyes of critical voices. There is a growing criticism of metropolitan systems illustrated by titles such as "les métropoles barbares" (Faburel 2018). Faburel criticises both the French territorial reforms aiming to create larger competitive regions as well as urban development policies based on the touristification of city centres through the "guggenheimisation" of cultural facilities and the festivalisation of public spaces as neoliberal strategies leading to social and environmental damage (Faburel 2020). Others see a causal link to the yellow vest movement due to the feeling of the withdrawal of the state from peripheral or rural territories (Bourdin and Torre 2020). The criticism does not go into detail regarding the reform of inter-municipal groupings and the creation of stronger groupings of municipalities (CC or CA) in less urbanised areas. Just as in Germany, the current national policy focuses much more on small and medium-sized cities in decline and the proximity of public services (Demaizière and Sykes 2020a). However, in France, metropolitan cities are criticised for being a symbol of power concentration and for producing leftover territories, underlining conflicts and opposing the categories of space to each other rather than emphasising their functional interrelation and interdependence as part of a networked space.

Democracy and citizen participation had a weak influence in the debates in all three countries. In Italy, the fact the mayor of the core city is automatically the political and administrative head of the CM has raised concerns about legitimacy and territorial representation. The direct election of the council of the CM has been considered in the national law but as the necessary legislative steps are pending the realisation is not very likely. At least the statutes of the largest three CM (Rome, Milan, Naples) indicate that the direct election of the council would be introduced once the national law allows this. A direct election of the metropolitan assembly was introduced in Lyon, one of the six city-regional case studies. This strengthens the democratic legitimacy of the Métropole de Lyon. Having said this, we need to 
point out that it was a by-product of the change of status, taking the overall responsibilities of the département in its territory and therefore having a directly elected representation like all départements. Thus, the driver was the aspiration of the mayor of Lyon of that time to strengthen Lyon in line with the idea of competitiveness. Some French scholars such as Demazière (2018) favour expanding the direct election to other French métropoles, arguing that broadening the functions of the métropole has further increased the democratic deficit. In Stuttgart, the direct election of the regional assembly was an essential element of the reform in 1994, strengthening the implementation power of the regional planning authority. The principle of territorial representation is much stronger France and in Germany than in Italy.

\subsection{Spatial relationships}

Functional urban regions have become a category for spatial observation, both in academia as well as national and European statistics. Statistical definitions of urban regions seek to grasp functional interrelations and the settlement pattern. The spatial delimitation results from a statistical rule and is reviewed from time to time. It is necessarily dynamic and the functional descriptions of urban regions have become ever larger. In France, there is a nationwide statistical definition of functional urban areas defined by commuter relations (aire urbaine) and urban agglomeration (unité urbaine) based on settlement patterns. In Germany, the federal institute BBSR has established different kinds of functional regional definitions for purposes of spatial observation such as large city-regions (Großstadtregionen), urban rural regions (Stadt-Land-Regionen) based on commuter patterns and accessibility as well as labour market regions and housing market regions. The state plans combine statistical definitions (such as density) and other considerations to define agglomerations (Verdichtungsräume). These are target areas of specific aims and planning principles (see 4.3.2 for Baden-Württemberg). In Italy, the notion of aree vaste (wider areas) is used to describe larger cooperation areas for public policies that would reach beyond the boundaries of the CM. In addition, the Atlas of Post-Metropolitan Territories produced by nine universities used squares of $100 \times 100 \mathrm{~km}$ to create regional profiles of Italy's largest cities and to provide an alternative view on contemporary urban patterns as polynucleated, networked city-regions (Balducci et al. 2017).

The spatial delimitation of city-regions is multi-faceted and ambiguous all three countries. The six city-regions under study in this book all have to face the mismatch between jurisdictional boundaries and functional urban regions that are much more relational, polycentric and fluid. The relational spatial dimension of city-regions did not play any role in the territorial reforms in either Italy or France.

In contrast to functional descriptions, the institutional boundaries have been remarkably stable in our case study regions. From our six case 
study regions, the Métropole de Lyon has the narrowest spatial delimitation as compared to its area of influence. Thus, a balancing of interests between urban and rural areas cannot be solved within the strong institution Métropole de Lyon but has to be negotiated in voluntary agreements between the métropole and much smaller municipal groupings within the wider metropolitan area. In the Italian CM Firenze and Bologna, the boundaries are inherited from the former provinces and have not been altered at all. In France, the boundaries of métropoles are flexible in theory as they can be defined and expanded at the local level. In practice, they have been very stable in the cases of both Lyon and Nantes. In Lyon, minor extension of the municipal grouping took place: four small municipalities have joined since 1964. In the case of Nantes, the territory has been stable since the creation of the CU in 2001. The same applies for Stuttgart region. Its perimeter has not been altered since 1971. Frankfurt/Rhine-Main region shows more flexibility and tendencies to expand. First, the catchment area of the planning authority is much wider than its predecessor UVF (it has increased from 43 to 80 municipalities since 2001), even if this geographic extension went hand in hand with less powers. Second, accession is possible for municipalities that share a border with the planning region. This took place for the first time in 2021, when five municipalities joined the region.

The concept of flexible geographies of cooperation has been followed in the Frankfurt/Rhine-Main region very strongly since the beginning of the 2000s due to the preferences of the state government. The desire for flexible geographies, i.e. juxtaposition of larger and smaller scales and a preference for sectoral rather than place-based approaches is also shared among municipalities and the private sector. Today, the region shows a pragmatic approach of metropolitan governance with voluntary collaboration in different constellations and formats, depending on the task. This contrasts with the approach of the French territorial reform, aiming to regroup singlepurpose associations within municipal groupings with a broad portfolio of tasks with the argument of simplicity. Task-specific voluntary cooperation beyond the métropole does exist, but is weakly institutionalised. In Nantes, local actors have established the metropolitan region of Nantes-Saint Nazaire as a second scale for strategic decisions and joint action. In Stuttgart, the regional planning authority has a central role and most city-regional tasks are addressed within the same space of action. However, the region uses an organisation model as a joint limited liability company for many tasks and this allows the involvement of both private partners as well as municipalities and counties outside the region, e.g. for touristic marketing.

There is a greater offer of flexible instruments for territorial cooperation in Germany and in France, and these follow the idea of multi-scaled arrangements. Still, the métropole in France is certainly the institutional core with significant legal power and financial resources. In France, the government preferred the métropole as a hard institution from the beginning in order to consolidate local governments, but due to resistance of the local 
actors the French government also offered softer forms city-regional collaboration. As the latter was not very successful, the central government made the métropole obligatory.

\section{References}

Balducci, A., Fedeli, V. and Curci, F. (eds.) (2017) Post-Metropolitan Territories: Looking for a New Urbanity. London: Routledge.

Bolgherini, S. and Lippi, A. (2016) Italy. Remapping local government. From re-allocation and re-shaping to re-scaling. In: Theoretical Foundations and Discussions on the Reformation Process in Local Governments. Sadioglu, U. and Dede, K. (eds.) Hershey: IGI Global, pp. 265-288.

Bourdin, S. and Torre, A. (2020) The territorial big bang: Which assessment about the territorial reform in France? European Planning Studies, 1-18. DOI: 10.1080/09654313.2020.1777943.

Corte dei Conti (2020) Relazione sulla gestione finanziaria degli enti locali. Comuni, Province e Città Metropolitane. Esercizi 2018-2019. Deliberazione, N. 7/ SEZAUT/2020/FRG. Roma.

Demazière, C. (2018) Le sacre des métropoles? L'institution d'un nouveau palier de gouvernement local dans trois pays européens (Angleterre, France, Italie). Bulletin de la société de géographie de Liège, 71(2), 27-46. DOI: 10.25518/07707576.5659 .

Demazière, C. and Sykes, O. (2020a) Acting for cities and towns? The perpetual reinvention of categories and tools of national urban policies in France. In: The Modern Guide on National Urban Policies in Europe, Zimmermann, K. and Fedeli, V. (eds.). Cheltenham, UK: Edward Elgar, pp. 34-57.

Demazière, C. and Sykes, O. (2020b) The rise of the metropolitan city region? Exploring the establishment of new levels of local government in England and France. In: Foregrounding Urban Agendas, Armondi, S. and Gregorio Hurtado, S. de (eds.) Cham: Springer International Publishing, pp. 185-209. DOI: 10.1007/978-3-030-29073-3_9.

Demazière, C., Feiertag, P., Paris, D., Zimmermann, K. and Dubois, J. (2022) Métropoles et organisation du développement métropolitain en Allemagne et en France. In: Villes et métropoles en Allemagne et en France: Les défis actuels pour l'aménagement du territoire et l'urbanisme, Gustedt, E., GrabskiKieron, U., Demazière, C. and Didier, P. (eds.). Hannover: ARL Akademie für Raumentwicklung in der Leibniz-Gemeinschaft. In print.

Faburel, G. (2018) Les métropoles barbares: Démondialiser la ville, désurbaniser la terre. Neuvy-en-Champagne: Passager clandestin.

Faburel, G. (2020) Les métropoles: Entre grandeur imaginaire et projets écocidaires. Cause Commune, 16, 80-82.

Fricke, C. (2020a) European Dimension of Metropolitan Policies: Policy Learning and Reframing of Metropolitan Regions. Cham: Springer.

Fricke, C. (2020b) Locating urban issues in German policy-making: Metropolitan regions and urban development policies in a multi-scalar context. In: Foregrounding Urban Agendas, Armondi, S., Hurtado, Gregorio S. de (eds.) Cham: Springer International Publishing, pp, 167-184. DOI: 10.1007/978-3030-29073-3_8. 


\section{Cross-country comparison}

Kuhlmann, S. and Wollmann, H. (2014) Introduction to Comparative Public Administration. Cheltenham, UK: Edward Elgar.

Longo, E. and Mobilio, G. (2016) Territorial government reforms at the time of financial crisis: The dawn of metropolitan cities in Italy. Regional and Federal Studies, 26(4), 509-530. DOI: 10.1080/13597566.2016.1210603.

Reimer, M. (2012) Planungskultur im Wandel: Das Beispiel der REGIONALE 2010. Detmold: Rohn.

Rodríguez-Pose, A. (2009) Are city regions the answer? In: The Future of Regional Policy, Tomaney, J. (ed.) London: The Smith Institute, pp. 50-59.

Wahl, R. (1998) Landkreise, Regionen, Regierungsbezirke: Zu viele Ebenen? In: Über den Kirchturmshorizont hinaus: Überlokale Zusammenarbeit. Bürger im Staat 48 (4). Landeszentrale für politische Bildung Baden-Württemberg (LpB) (Ed.) Stuttgart, pp. 209-213.

Zimmermann, K. (2017) Re-scaling of metropolitan governance in Germany. Raumforschung und Raumordnung, 75(3), 253-263. 


\title{
6 Conclusion
}

\author{
K. Zimmermann and P. Feiertag
}

\subsection{The three countries in a European context}

City-regionalism is a global phenomenon. Most states and subnational governments still struggle to find appropriate governance mechanisms to solve issues of sprawl, overstrained mobility infrastructure, protection of green spaces, management of climate-related risks and spatial allocation of affordable housing (Rosan 2016; Zimmermann 2018; Miller et al. 2018). As our empirical study is bound to three western European states, this section seeks to put our results into an international context. Are the trends that we observed also recognisable in other parts of the world? With regard to the coverage of this section, time, language and the page limit of this book are the restrictions.

The countries and cases chosen for this section are Portugal, Spain, the Netherlands, the UK, Poland, Denmark and Norway. This selection presents a requisite variety of ways of dealing with city-regional problems in federal, non-federal and regionalised states as well as in small states and large states with and without national policy frames for metropolitan governance. We also considered those states where novel ways of dealing with city-regions emerged, i.e. the combined authorities in England and the use of contracting in Norway. Still, the exceptionality of France, Italy and Germany stands out as there are only a few states where there is a critical mass of cases of city-regional governance. In many states only a few exceptional cases exist, usually the capital city-regions or the largest agglomeration.

\subsubsection{The Netherlands}

Specific governance arrangements for city-regions used to be an ongoing topic in the Netherlands but a more stable establishment of city-regions suffered from the unclear - if not competitive - relationship of eventual cityregional institutions with the provinces. In the city-regions of the country, the Randstad Regio in particular, forms of cooperation experienced some drawbacks and during the 1990s, continuous efforts were made to address the governance issues at the metropolitan level by the state (Janssen-Jansen 2011). 


\section{Conclusion}

In the mid-1990s, attempts to establish city-provinces as formal, legal entities to replace individual city administrations (i.e. to turn adjacent cities into one singular administrative body) failed due to the resistance of citizens and local governments (failed referendum in Rotterdam). In 2006, a national law came into force and introduced eight weaker city-regions that were defined as WRG-plus regions (partly called Stadsregios) (Spaans et al. 2019). Thus in 2006, the cooperative arrangements in major Dutch urban areas received permanent juridical status "as obligatory cooperation associations between the core cities and their immediate periphery" (Janssen-Jansen 2011, 264). These city-regions were supposed to act as a fourth layer of government and were important actors in the area of public transport for which they received a considerable budget from the national government. Most of the WRG-plus regions covered only parts of provinces in terms of territory but represented large parts of the population and economic power. Later on, the city-regions were also responsible in the areas of spatial planning, economic affairs and environment (Janssen-Jansen 2011). The responsibility for the binding structure plans did not last very long as the Dutch Spatial Planning Act of 2008 took away the planning responsibilities (Janssen-Jansen 2011, Spaans et al. 2019). There was also criticism because of a lack of legitimacy since the WRG-plus regions were managerial bodies without elected councils. As a result, in January 2015 the eight WRG-plus regions were abolished and the responsibilities shared between the municipalities and the provinces. The central government hoped this would increase flexibility in the lower tiers of governance because the municipalities would be able to opt for the best form of cooperation. So in terms of governance, city-regions as administrative bodies ceased to exist in the Netherlands but exceptions were made for two provinces: South Holland and North Holland. In South Holland the former WRG-plus city-regions Rotterdam and The Hague merged and the new city-regional body Metropolitan Region Rotterdam The Hague (MRDH) came into being. MRDH has two main functions: public transport and economic development, the former being more relevant (not least in terms of the budget). The MRDH was the result of a political power play between the province of South Holland on the one hand and the cities of Rotterdam and The Hague on the other hand. The mayors of Rotterdam and The Hague wanted to keep control of the funding for public transport tasks. The new law only stated that the transport authority should cover the geographical area of the metropolitan region Rotterdam and The Hague and the exact details were left to the municipalities and the provinces. Twenty-four municipalities are members of the MRDH.

In the Amsterdam area, the arrangement took a different shape (Schipper and Gerrits 2015). After the dissolution of the WRG-plus region, a special purpose body took over the function of the transport authority (TAA). TAA covers parts of the province ( 15 municipalities). In addition, in a more voluntary and informal manner and as a follow-up of the North Wing Conference, the Metropoolregio Amsterdam came into being in 2017. This 
is an association of 32 municipalities, two provinces and the TAA, largely being a platform for consultation on issues such as economic development.

Metropolitan government has lost its appeal in the Netherlands. Instead, there is a preference (and need) for flexible, project-based and sectoral cooperation. This is not to say that inter-municipal cooperation is not well established in the Netherlands. Like in Germany or France, inter-municipal cooperation is the preferred solution for efficient and effective provision of public services on a smaller territorial scale. According to Klok et al. (2018) who identified 779 IMCs in the Netherlands, these forms of cooperation have developed organically and on average have 16 member municipalities.

\subsubsection{Portugal}

Portugal experienced a number of reforms changing the status of local government and the inter-institutional relationships of cities, regions and central government (Teles 2016). Fiscal consolidation pressures, amalgamation of local governments and inter-municipal cooperation as well as decentralisation are high on the agenda. The largest metropolitan areas, Lisbon and Porto, received special treatment but these attempts have been evaluated as inconsequential (Rayle and Zegras 2013).

In 1991, the Portuguese national government created an intermediate scale for metropolitan governance (law 44/1991). This law defined the metropolitan areas in terms of their size and legal status (Pereira and Nunes da Silva 2008, 115; Rayle and Zegras 2013, 872). Apart from the capital city of Lisbon, which is embedded into a metropolitan area (Área Metropolitana de Lisboa = AML), also the second largest city of Portugal, Oporto, is part of a larger metropolitan region (Área Metropolitana do Porto $=$ AMP). Since its foundation, the legal framework has been adjusted and changed several times (Oliveira and Breda-Vázquez 2015, 15). In 2008 , law 46/2008 introduced some significant changes, again only targeting AML and AMP. The new law defined these two metropolitan areas as obligatory entities, territorially congruent with the European NUTS III regions (AML 2016, 20; Oliveira and Breda-Vázquez 2011, 72). In the case of Lisbon, the AML consisted and still consists of the two NUTS III regions Grande Lisboa and Península de Setúbal (cf. ibid.). The AMP on the other side was made up of Grande Porto and Entre Douro e Vouga region and parts of Tâmega until 2015 and now corresponds with the eponymous NUTS III region AMP.

The AML is composed of 18 municipalities of the Lisbon and Tagus Valley Region and had a population of about 3 million inhabitants in 2014 (Balsas 2017, 85). The AMP initially only consisted of nine municipalities in the urban core of the Greater Oporto region (Law 44/1991). Over time several neighbouring entities have joined the metropolitan area (Balsas 2020). Today the AMP integrates 17 municipalities in the north-western part of mainland Portugal (Website AMP I; Balsas 2017, 85). All in all, it includes 
an area of about 2,040 $\mathrm{km}^{2}$ with ca. 2 million inhabitants in 2014 (Website AMP II; Balsas 2017, 89).

With regard to the institutional set-up, from 1991 until 2013 there was a dual structure in place: a council, indirectly elected by the councillors of the municipalities (18 in Lisbon, 17 in Porto) and an executive body, composed of the mayors. This arrangement changed in 2013 when the executive body of mayors became the council while it was decided that the new metropolitan executive commission would be elected by the councillors. The candidates, however, are proposed by the mayors. So, this new arrangement is under strong local leadership. The direct election of the metropolitan councils has been under discussion for a longer period but has been postponed several times due to tactical reasons and constitutional concerns.

In terms of functions, the metropolitan bodies would be responsible for a range of supra-municipal services and central government investments (including EU funds) but the mayors of the constituent municipalities have refused so far to delegate these functions. The most recent change happened in the course of the introduction of a law on public finances in 2018. This law implemented a decentralisation strategy that also encourages intermunicipal cooperation and the consolidation of the two metropolitan areas in the functional realm of social services, tourism and public transport. This law made a great difference and led to more integrated metropolitan policymaking. Hence, the responsibility for the EU funds and transport changed the situation greatly. There is now also a consultative body composed of public and private actors.

\subsubsection{Spain}

Much of the academic work on Metropolitan Governance in Spain focuses on the Barcelona metropolitan area and in fact the governance arrangement of this region is the one with the highest degree of institutionalisation, though having experienced turbulent times (Tomàs 2017b). There are, however, other cases such as Valencia and Vigo that are worth considering. In principle, the possibility to create Areas Metropolitanas has been included in the national law since 1985 . However, according to the law the regional governments are "responsible for creating, modifying and abolishing metropolitan areas by their own Statutes of Autonomy" (Tomàs $2017 \mathrm{~b}, 246)$ and these regions have been very reluctant to give power to city-regions, especially so soon after gaining their status of autonomy. On the contrary, the regions have used their responsibility regarding metropolitan governance to abolish former metropolitan institutions (Corporaciones metropolitanas) inherited from the Franco regime in the case of Madrid, Bilbao, Barcelona and Valencia, and have replaced them with several sectoral agencies covering different spaces (Barcelona, Bilbao, Valencia) or assumed by the regional government in case of Madrid (Hildenbrand Scheid 2017, 71; Tomàs 2017b). The former metropolitan governments 
were mostly abolished in the 1980s (Corporation of Greater Bilbao 1980, Commission for Planning and Coordination of the Madrid metropolitan area 1983, Barcelona Metropolitan Corporation 1987). In the case of Valencia, a multi-purpose metropolitan authority persisted as the Gran Valencia Metropolitan Corporation was first transformed into the Consell Metropolità de l'Horta responsible for transport and spatial planning, water and sewage in 1986 and was only abolished in 1999 (Tomàs 2017b, 248). The capital region Madrid is a specific case, because (a) the city was enlarged via annexations (between 1948 and 1954) to a size equivalent to the Metropolitan Area of Barcelona, and (b) because the regional government of Madrid does not have supra-municipal entities (neither disputationes provinciales nor comarcas) and its spatial outline is similar to the city-region (Tomàs 2017b, 248).

There is no national policy of metropolitan reforms and the central government has not given any incentives to create metropolitan governments either (Medir et al. 2018, 137). However, austerity measures support the amalgamation of local government and inter-municipal cooperation in general.

Barcelona searched for a long time for an appropriate arrangement. In the 1980s, the existing metropolitan government was weakened due to political conflicts between the regional government and the local governments of the Barcelona city-region (1987). Key functions (metropolitan transport, waste management) were organised in single-purpose associations. During the 2000s, however, the metropolitan initiative experienced a revival and as a result of a strategic planning process a new inter-municipal consortium was founded in 2009.

In addition to the strategic plan, the municipalities of the metropolitan area decided voluntarily in 2009 to create the Consortium of the Metropolitan Area of Barcelona, which joined together the three existing metropolitan entities so as to prepare the institutional transition to the Metropolitan Area of Barcelona. (Tomàs 2017a, 325)

The Area Metropolitana de Barcelona (AMB) was established in 2011 and has a broad portfolio of functions, both in terms of strategic functions and of joint service provision. Its functions include territorial planning and urbanism, public transport and mobility, housing policies, environment, economic development and social cohesion as well as international relations (Tomàs 2017b, 247; Geróházi und Tosics 2018, 13). However, the metropolitan authority shares its implementation powers with local and regional governments. Social reproduction functions such as social housing, education and culture have remained the responsibility of the region and the municipalities (Tomàs 2017a, 331). On the other hand, production functions such as economic development strategies or strategic projects have so far been handled by the City of Barcelona, voluntary mechanisms of 
inter-municipal cooperation or the regional government of Catalonia rather than by the metropolitan authority (Tomàs 2017a, 329-330).

Still, the AMB is the metropolitan institution with the greatest degree of institutionalisation in Spain. It can be classified as a metropolitan government, but does not fully correspond to the ideal model of the metropolitan reform school, because "it is indirectly elected, has little fiscal autonomy and its responsibilities are not exclusive but shared both by local and regional governments" (Tomàs 2017b, 247).

The definition of the city-region of Barcelona is elastic, meaning that three different definitions of what is considered the Barcelona urban region coexist: (1) the province of Barcelona $\left(7,728 \mathrm{~km}^{2}\right),(2)$ the metropolitan region $\left(3,239 \mathrm{~km}^{2}\right)$ and $(3)$ the metropolitan area $\left(634 \mathrm{~km}^{2}\right)$. Each of them corresponds to a different conception of the territory, is formed by different institutions and supported by different actors (Tomàs 2017a, 320-327).

In Vigo, the process of installing a metropolitan authority came to a standstill. In Valencia, a recent initiative launched a discussion process on the future constitution of the city-region in autumn 2020. Currently, service provision at a metropolitan scale takes place in the form of three sectoral agencies with variable geometries: the Metropolitan Water Services (formed by 51 municipalities), Metropolitan Waste Treatment (formed by 45 municipalities) and the Public Metropolitan Transport Association (60 municipalities). The latter entity has developed the Metropolitan Plan of Transport of Valencia, including integrated fare management and administrative services. It collaborates with other transport agencies (Railways of the Generalitat Valenciana and Municipal Transport Companies) and the Valencian Metropolitan Mobility Authority. The three agencies are governed by indirectly elected representatives of the municipalities, according to their population. The current situation is summed up in the following quote:

In short, today the metropolitan area of Valencia is institutionally organised by sectoral agencies covering a different number of municipalities. The metropolitan dimension is recognised and metropolitan agencies manage some essential metropolitan services (transport, waste, water). However, a common understanding of the metropolitan reality does not exist, since each agency covers a different territory. Moreover, the relationship between the City of Valencia and some of the metropolitan municipalities has been characterised by political conflicts, which has not helped to build a shared metropolitan vision. (Tomàs 2017b, 248)

\subsubsection{The UK (England)}

The most recent change with regard to metropolitan policies in England was the introduction of the option of combined authorities in 2011 (Shaw and Tewdwr-Jones 2017; Sykes and Nurse 2021). Metropolitan councils 
existed in the larger agglomerations (Birmingham, Manchester, Liverpool, Greater London, etc.) until they were abolished by central government in 1986. They were replaced by sector-specific collaboration for policies such as public transport, sewage, waste management and metropolitan police. The city-regional scale has not been addressed since then as either larger (the regions until 2011) or smaller scales were at stake (i.e. the Local Economic Partnerships post-2011, which were much smaller and limited to intermunicipal cooperation for economic development).

The growth strategy for the north (the Northern Way) included some prescriptions for city-regions but the resonance was rather weak (Sykes and Nurse 2021). This void has been partly filled by voluntary collaboration, and the Manchester city-region is a much discussed case in this regard (AGMA Association of greater Manchester Authorities). In fact, the Manchester case is seen as a role model for what followed when central government introduced the combined authorities.

The combined authorities are a new type of intervention, a sort of placespecific central-local arrangement. In terms of territory, the existing combined authorities differ in size and do not necessarily cover a functional urban region, as the composition of municipalities is the result of political negotiations and opportunities. As a result of negotiations between central government and the municipalities involved, the portfolio of tasks differs and as a legal entity they are responsible for tasks such as public transport, economic development, health and urban regeneration. ${ }^{1}$ The negotiations between central government and the combined authorities were in part problematic as the government rejected proposals of some combined authorities. So, there is great difference between Manchester where local leaders were able to design the process in a very favourable way and the others where this was less the case. The establishment of a combined authority implies additional funding. At the same time local governments had to face large budget cuts in many other areas (Sykes and Nurse 2021). Hence, the combined authorities are seen by many observers as part of a national austerity agenda (Hambleton 2016; Shaw and Tewdwr-Jones 2017; Sykes and Nurse 2021). The implementation differs greatly between the city-regions (see Lowndes and Lempriere 2018 for the West Midlands and Greater Manchester; see Sykes and Nurse 2021 for Liverpool). There are currently ten combined authorities in place. They were established in 2011 (Greater Manchester), 2014 (Liverpool, North East Combined Authority, West Yorkshire, Sheffield City-Region), 2016 (West Midlands/Birmingham, Tees Valley), 2017 (West of England, Cambridgeshire and Peterborough) and one more in 2018 (North of Tyne).

Combined authorities - as a result of the so-called devolution deals in 2016 - usually have a directly elected metropolitan mayor but these were elected stepwise (2017: Manchester, Liverpool, Tees Valley, West of England, West Midlands; Cities and Local Government Devolution Act 2016). Sheffield followed in 2018 and the North East Combined Authority is still pending. 


\section{Conclusion}

\subsubsection{Norway}

The debate on city-regions in Norway largely focuses on the Oslo metropolitan area (Hanssen 2021a; ESPON Spima 2018). There are some inter-municipal arrangements in place and one innovative and facilitating instrument was contracting between central government and local governments in order to give incentives for collaboration. These contracts were initially made in the field of public transport in the 1980s but were subsequently used for other policies as well (Hanssen 2021a, 138-139). Today, they are formulated in a more comprehensive way and are called Urban Growth Agreements.

In Norway, it was the need to coordinate the efforts and investments in metropolitan areas that spurred the emergence of a new multi-levelgovernance contractual management tool. These are called "Urban Growth Agreements”, and they coordinate the land use measures of the local government with the large transport investments of regional and national authorities. These contracts/agreements are now one of the main incentive arrangements for multi-level coordination between national, county and municipal authorities on transport and land use policies for the larger urban regions.

(Hanssen 2021a, 138)

In the Oslo city-region, collaboration largely affects the core city of Oslo, the county municipality of Oslo and the county of Akershus. In fact an amalgamation was debated in the late 1990s but never accomplished. As a result, a number of multi-level collaborative arrangements exist but a certain degree of fragmentation is still in place as most of these arrangements are sector-specific.

In 2004, a voluntary arrangement of Oslo and Akershus emerged (The Oslo Region Alliance). Today the alliance consists of five county municipalities and 78 municipalities and its main purpose is marketing and competitiveness.

\subsubsection{Denmark}

As in Norway, the metropolitan governance discourse in Denmark primarily concerns the capital city-region: the Greater Copenhagen Area (region Hovedstaden). Despite the widely recognised need for metropolitan governance, metropolitan authorities in the Greater Copenhagen Area never had a stable position because of a lack of acceptance both by local authorities and the central government (Andersen et al. 2002, 43). On one hand, the affluent suburban districts in the north and north-west with conservative majorities rejected a metropolitan reform that would reduce their independence from socio-democratic Copenhagen. On the other hand, central government 
and the counties did not support a strong metropolitan government due to the dominant political and economic power of such a unit (Andersen et al. 2002, 48).

The Greater Copenhagen Council (Hovedstadsrådet 1974-1989) was the first formalised attempt to coordinate activities at the metropolitan level, but had limited powers (Galland und Enemark 2015, 346; Andersen et al. $2002,43)$. Its construction was similar to the pre-existing voluntary planning association Regional Planning Council (Egnsplanrådet), but with a formal status (Andersen et al. 2002, 48). In addition, it gained responsibilities beyond regional planning, notably public transport, environmental issues and public hospitals. The council was composed of mayors as well as representatives of the counties. It was financially dependent on contributions of the counties and municipalities (Andersen et al. 2002, 49). Due to the lack of direct elections and of its own financial resources, it remained a weak institution limited to consensus finding between the local authorities. As a second element, a special equalisation scheme for the metropolitan area was introduced on top of the already existing financial equalisation mechanisms for the whole of Denmark. However, the new council-controlled public transport company for Greater Copenhagen greatly improved public transport. The council also had greater regional planning powers than its predecessor and could put some pressure on local planning (Andersen et al. 2002, 49). Despite these successes, the council was abolished in 1989. Its responsibilities were transferred to the counties or to independent single-purpose organisations (the Regional Statistic Office and the Regional Transport Company, Hovedstadens trafikselskab) (Andersen et al. 2002, 49). The abolition of Greater Copenhagen Council led to the creation of a multitude of organisational forms, some of which covered the same area as the former Greater Copenhagen Council (Andersen et al. 2002, 50).

The next wave of formalised city-regional governance came rather late compared to other European countries due to a lack of consensus both at the national and the local levels. Debates about the best form of metropolitan governance took place throughout the 1990s but remained fruitless (Mouritzen 2011, 58; Andersen et al. 2002, 51). During that time, three counties, together with Copenhagen and Frederiksberg municipalities, continued their collaboration on regional planning (Geróházi und Tosics 2018, 39).

A new metropolitan authority was then created in July 2000, the Metropolitan Council of Greater Copenhagen (Hovedstadens Udviklingsråd, HUR). It had different objectives than the former Greater Copenhagen Council, with much more emphasis on competitiveness and economic development instead of services of general interest (Andersen et al. 2002, 44). Part of the motivation to create this new body was "to manage the complex coordination and development challenges faced by the Øresund area during and after the opening of the Øresund Bridge in July 2000" (Geróházi und Tosics 2018, 37). Its tasks were regional planning, transport planning, the operation 
of busses and of some local train lines, the coordination of economic development, tourism and culture (mostly theatres ${ }^{2}$ ) as well as cooperation across the Øresund (Andersen et al. 2002, 51). The HUR did have five members: the counties of Copenhagen, Frederiksborg and Roskilde and the municipalities of Copenhagen and Frederiksberg. Decision-making took place in a board of 11 politicians appointed by the members (Andersen et al. 2002, 51). Just like the preceding bodies, it was a rather weak metropolitan authority without its own financial resources or direct democratic legitimation. It was abolished in 2007 in the course of a wider local government reform in Denmark. Although the reform established regions as formal jurisdictions, this step did not result in a strong institution at the metropolitan level. Quite the opposite, it led to splitting up of functions due to the inadequate size of the region for regional planning, regional transport and economic development.

Regional planning had been carried out at the metropolitan level by the Metropolitan Council of Greater Copenhagen up to 2007, when responsibility for the regional plan covering the capital region shifted to the national level. The newly created five regions do not have responsibility for a binding regional plan in other parts of Denmark either, only for economic development plans. The responsibility for Greater Copenhagen's regional plan was first assigned to the Ministry of the Environment and moved to the Ministry of Economy after the 2015 election (Geróházi und Tosics 2018, 39). Since then, three versions of the fingerplan have been adopted: in 2007, 2013 (both by the Ministry of Environment) and 2019 (by the Ministry of Economy). Since the introduction of the Planning act of 2012, the plan has become a national planning directive, thus strengthening its legal power (Geróházi und Tosics 2018, 39).

Apart from this, social reproduction functions are the responsibility of the municipalities. Inter-municipal cooperation for technical services such as fire protection, waste disposal, water supply, energy, electricity and gas and for schools and culture as well as specialised social services does exist in Denmark. Single-purpose associations (kommunalt fællesskab) for these purposes were frequently formed in the 1990s (Henning 2001, 37), but were much reduced by municipal mergers in 2007.

Public transport is operated on a regional level and jointly steered by the municipalities, the regions and the state. The Greater Copenhagen Area does not have a strong metropolitan authority that bundles functions and power. The region has a jurisdictional status with a directly elected council, but with very limited functions. A range of other organisations carries out tasks of city-regional coordination at the same scale or beyond. In addition, the central state intervenes in the capital region due to its high relevance.

\subsubsection{Poland}

In Poland, there was no clear national priority to enforce metropolitan governance for quite a long time. Some weaker and largely voluntary forms of 
cooperation exist in several city-regions, the more established ones being Upper Silesia (Katowice), Poznan, Szczecin and the so-called Tri-City (Gdansk, Sopot, Gdynia) on the Baltic coast (Krukowska and Lackowska 2017). All these came into being in the 2000s (Katowice in 2007) but were not very powerful.

On a national level, the Act on Metropolitan Associations (2015) gave a legal framework for metropolitan initiatives but there was no obligation to use the format of metropolitan associations in that period. At least the existing law made clear that inter-municipal cooperation in city-regions was possible and that there were legal formats for this. Nevertheless, in Upper Silesia, Poznan and to a slightly lesser degree in the Szczecin agglomeration, bottom-up initiatives emerged in the period 2000-2010. The Poznan Metropolis Association has been active since 2011 (from 2007 to 2011 the name of the organisation was Poznan Agglomeration Council) (Mikuła and Kaczmarek (2017). Szczecin Metropolitan Area Association, founded on the basis of the Local Governments Association for Regional Cooperation operating in 2005-2009, has been active since 2009.

The Katowice city-region is an outstanding case because of its stronger institutionalisation. Katowice established a Metropolitan Joint Committee in 2007 but the major change came about in 2017 when the Metropolitan Association of Upper Silesia and Dąbrowa Basin, shortened to "Metropolis GZM" (MGZM) was founded based on the Metropolitan Act approved by the state government. It is an association of several cities and towns (41) with 2.3 million inhabitants (50\% of the Voivodship). MGZM has a certain degree of operational autonomy and financing and manages a solidarity fund. Its main responsibilities are public transport, waste management, economic development, voluntary master plans and IT services.

City-regional cooperation in the Tri-City area was more cumbersome, mainly because of the competitive orientations of local leaders of the three cities. The Metropolitan Council of the Gdansk Bay came into being in 2003. It is an informal forum of mayors and local leaders, with the three cities Gdansk, Sopot and Gdynia being the main actors. On the initiative of the Council, the Metropolitan Association of Gdansk Bay was established in 2006. In 2011, however, two new organisations were established: the Gdansk Metropolitan Area Association founded by Gdansk, and the Metropolitan Forum of Mayors NORDA founded by Gdynia.

The situation changed in the EU funding period 2014-2020 when the Polish government made the use of Integrated Territorial Investment (ITI) obligatory in the 17 city-regions of the capital cities of voivodships. Though being an episode bound to the ERDF funding period, it caused a vivid period of metropolitan cooperation with diverse outcomes (Krukowska and Lackowska 2017). It was more successful in those city-regions with some previous experience of inter-municipal collaboration but in some city-regions the ITI co-existed next to established city-regional bodies (i.e. Katowice). In terms of size, the national government made a suggestion 
(varying between five and 50 municipalities in the case of Warsaw), but in the course of ITI implementation the boundaries were changed due to local initiatives (usually they got larger).

In the Tri-City region, the obligatory use of ITI had a major institutional impact but did not result in a territorially coherent arrangement. In 2015, a new institution for the implementation of ITI Integrated Territorial Investment was created: the Metropolitan Area Gdansk-Gdynia-Sopot incorporated the former Gdansk Metropolitan Area, whereas NORDA remained a separate body.

\subsection{City-regions and the consolidation state: what drives reforms and what are the results in terms of institutions, spatial relationships and functions?}

In a contribution to a book entitled "The Future of Regional Policy", Andrés Rodrigues-Pose critically discusses the question whether we observe a rise of the city-region as a relevant political and/or economic scale or not (Rodríguez-Pose 2009). There are in fact good reasons for the establishment of city-regions as cross-municipal cooperation promises higher effectiveness of public policies, innovative solutions for all kinds of problems and supports economic agglomeration effects. Institutionalised city-regions may also have a balancing effect with regard to social and territorial disparities as well as fiscal imbalances between municipalities (Kübler and Rochat 2018). Parochial attitudes of local governments or "defensive localism" (Barron and Frug 2005) instead are rather seen as costly and dysfunctional.

According to the empirical results of this book, the assumption of the rise of city-regions as political or economic scale is half true and half wrong. In any case, we can state that the rise of city-regions as it is described in a number of publications is not backed by our results. In the recent period we have seen a number of reforms targeting the city-regional level in many states - not only in Europe - but this does not constitute a new wave of metropolitan reforms following a coherent set of ideas. At least if we consider the conventional wisdom of periodisation that argues that the rise of metropolitan governments in the late 1960s/early 1970s was followed by a cross-national trend of abolishing metropolitan councils in the mid 1980s and the new regionalism in the 1990s, the current situation is more diverse. Although some examples mentioned in this book may indicate a revival of the metropolitan reform model (France, Italy, to a limited degree Spain), the broader picture shows a collection of disparate and opportunistic practices. Interventions of national governments are sometimes half-hearted, and sometimes clearly show centralistic patterns.

In France and Italy, but also in Poland and Portugal, there were clear attempts of the national governments to support city-regions, although the initiatives in many states are fragile (if not temporary) or concentrate on the biggest agglomeration of the country (Portugal). In England, the evaluation 
of the combined authorities is rather difficult as the whole process is characterised as "disorganised" (Shaw and Tewdwr-Jones 2017) and driven by a mixed-motive of austerity measures and a pro-development agenda. The use of the notion city-region is less common in England and there are great differences between the realised combined authorities (Lowndes and Lempriere 2018; Sykes and Nurse 2021). In fact, the practice of city-regional governance in some states requires new notions.

Institutionalised city-regions or regional authorities do perform functions related to the international competitiveness of the city-region and engage in the external representation and marketing of the city-region in partnership with the (still important) core city. In France, economic development and competitiveness is relevant - in particular for the local leaders who try to implement flagship projects and infrastructures and use city-regional institutions as a vehicle to promote this. The joint external representation of the core city and the city-region is either secured by a double leadership of the mayor of the core city (Bologna) or with joint shareholdings such as in the case of the agency for tourism and regional marketing in Stuttgart. However, city-regional agendas are much broader and range from climate change and affordable housing to sustainable mobility issues, digitisation and urban regeneration. In principle, we see a greater concern for public policies, services of general interest (such as planning, sustainable transport) and the recognition of peripheries. On the national level the agenda is more balanced: effectiveness and efficiency of the public sector and fiscal consolidation go hand in hand with other motives such as the relaunch of the economy following a recession. In particular, the reforms in Italy and France are mostly driven by austerity goals and the quest for higher efficiency in the public sector and less by the idea of turning the city-regions into engines of the economy (the latter is in particular true for Italy). The consolidation state (Streeck 2017) may open windows of opportunity for the stronger political and institutional integration of city-regions in terms of governance. Austerity policies may initiate reforms but leave the new entities more or less alone. Hence, the results differ: in Italy the city-regional level has been hollowed out and equipped with a questionable system of political representation. In France, métropoles such as Lyon are definitely a highly relevant layer for public policies but are limited in terms of territory. In the majority of states, city-regions are the weakest level in the multi-level system of governance.

Greater territorial coherence still is an issue in most of the European cityregions but often this is not the core driver for reforms. In France, the cityregions are a genuine layer of public policies but they are on average too small. The management of territorial interdependencies is difficult and unsolved in Lyon. Territorial fragmentation continues to exist beyond the boundaries of the métropole and in some cases this is a cause for conflicts. As contemporary metropolisation processes concern vast territories (Cardoso and Meijers 2021), the metropolitan scale is well above the scale of municipalities, meaning 
that their amalgamation cannot solve the metropolitan question anymore (in contrast to the beginning of the 20th century, e.g. Groß-Berlin). The creation of a metropolitan government either means to add one more level to the multilevel system (as the planned Dutch city-provinces in the 1990s) or to suppress another one (as the provinces in Italy or the counties in Denmark). Thus, the metropolitan reforms are related to the fate of the second tier of local government, i.e. provinces, counties, départements or Landkreise. Abolishing the second tier of local government has been discussed in several European countries. The main argument is that these entities - created in the 19th century (French départements, Spanish provinces, Italian provinces, Denmark) - are seen as outdated due to their limited spatial dimension. The Napoleonic logic of uniform administrative subunits of the state that are of similar size does not correspond to contemporary patterns of mobility and metropolisation. However, putting the second tier of local government into question causes much resistance (Italy, France). In Spain, the region of Catalunya would like to replace the provinces by veguerias, but there is disagreement of the central state wishing to preserve a similar administrative structure in all regions. Denmark is one of the rare examples where the second tier of local government has been entirely eliminated. The new regions in Denmark are much larger but less relevant in terms of functions. This was politically possible due to the consent of local authorities and their umbrella organisations; it was secured with the argument to increase local autonomy as part of the functions of the counties was shifted to the enlarged municipalities. The following quote gives an appropriate summary:

Elements that are more intangible, related to political culture and to the attitudes and values of local representatives towards metropolitan governance, influence the final model. For example, in some countries there is a greater tradition of institutionalizing metropolitan cooperation through the creation of new structures (such as in France), whilst in others reforms move towards the reduction of the number of structures (such as in Denmark).

(Tomàs 2017b, 245)

Coping with existing administrative boundaries and institutional fragmentation in city-regions is still a major challenge. In more theoretical terms we see the two competing principles for the design of institutional solutions:

a) higher effectiveness of sectoral cooperation (single-purpose organisations or issue-based cooperation); and

b) territorial integration and representation (multi-purpose organisations for one territory).

The latter one seems still to be very present in the mindsets of the actors involved in metropolitan reform processes. Our results show, however, that 
this institutional idea does not work well in any case. The much-appraised combination of variable geometry of governance and multi-scaled arrangements is a compromise that combines an organisational core with additional issue-based forms cooperation on different territorial scales. Though being an appealing idea, these kinds of arrangements are rare. The two German cases represented in this book are in a way following this idea with Stuttgart being a case of stronger territorial integration and Frankfurt representing the second principle of a variety of sectoral cooperation on different scales. Some are stronger attached to the core region (i.e. the planning authority FrankfurtRheinMain), others less and the board of the region is seen as the integrating mechanism.

A new pattern is certainly the close cooperation of core cities and cityregional authorities observable in France (Nantes) and Italy (Bologna). The emergence of territorial subunits within city-regions such as the pôles de proximité, zone omogenee, unioni di comuni is a specific pattern for France and Italy.

A striking insight is the neglect of addressing issues of territorial representation in many cases. The introduction of the direct election of regional councils is usually justified by referring to the bundle of functions. As soon as a critical mass of (local government) functions is transferred to a cityregional authority, the direct election of the regional council is inevitable. The introduction of the directly elected metropolitan mayor follows the argument of greater visibility and leadership. Both arguments tend to miss the role of citizens and city-regional citizenship for metropolitan governance (Lidström and Schaap 2018; Strebel and Kübler 2021). The body of work on city-regional citizenship is still small but at least indicates that citizens do not necessarily think local or ignore what is happening beyond the border of their jurisdiction.

\subsubsection{The impact of national role models}

National role models for metropolitan reforms have a considerable influence and this is visible in England (Greater Manchester), France (Lyon) and - to a lesser degree - in Spain (Barcelona). Sometimes the institutional design of these role models is the result of direct negotiations between local political leaders and central government. In Italy, it's less appropriate to speak of a national role model although Bologna is a widely considered case. France and Italy are the two states that implemented nationwide reforms that more or less prescribed a uniform solution and both states clearly show the fallacies of implementing nationwide institutional models. During the implementation adjustments were made in order to meet the requirements of a variety of local contexts. In Germany, the heterogeneity of models is high and depends on local conditions and preferences of the state governments at the time of creation. Stuttgart Region is one of the cases that is much cited internationally as a role model for metropolitan governance. 


\section{2}

But within Germany, it is not necessarily the blueprint for other regional authorities.

Only some of the European states actually have a critical mass of cases of city-regional governance. This applies to France, Italy and Germany and also to England and Poland. Whether there is more than one institutionalised city-region depends on the urban system and on the area, but also on the historic evolution of the intermediary territorial authorities. In Spain, there is a high number of functional city-regions. Nevertheless, due to historic reasons related to the autonomy of regions after the Franco regime, there is so far only one fully developed metropolitan authority. In the Nordic countries, the capitals are by far the dominant city-regions and receive a specific treatment. To strengthen their role and autonomy is ambivalent from a national perspective. On one hand, they are the main engines for the national economy. On the other hand, internal migration towards the capital region threatens territorial cohesion within the country. Thus, Finland currently seeks to support a network of the largest finish cities (the six cities strategy Aika 6, an open innovation platform for Helsinki, Oulu, Espoo, Tampere, Turku, Vantaa) rather than creating a powerful metropolitan authority for Helsinki region (Anttiroiko 2016; Raunio et al. 2016).

\subsubsection{Asymmetric treatment}

In countries where strengthening of city-regions is part of a national reform, the debate about what power shall be given to city-regions is related to the fundamental question of the equal treatment of territories. City-regions gaining more autonomy and access to more resources than rural regions and small and medium sized towns may cause distribution conflicts and trigger the wish of adjacent municipalities to become part of the city-region in institutional terms (as has happened in Frankfurt-Rhein Main in 2021 and was suggested by one municipality in Florence). The dominant justification to strengthen metropolitan governments has recently been global economic competitiveness both of the city-regions and of the national economy. This triggers conflicts, including the accusation of pursuing neoliberal policy and to neglect the aims of equal living conditions and cohesion. The question behind is: are strong metropolitan governments only an advantage for the city-region or for the entire country? These conflicts are visible in France (Faburel 2018; Bourdin and Torre 2020) and, to a lesser degree, in Germany (European Metropolitan Regions). In reaction, the political attention turned towards the fate of small and medium sized cities. There are distributional conflicts within city-region as well as between city-regions and left-over spaces. In Italy, the budgets of the remaining provinces have been cut considerably due to austerity measures and have therefore much less possibilities to act than the CM. 


\subsubsection{Institutional models}

With regard to institutional trends there are certainly no uniform models observable but we can identify basically two trends. In some European states there is a very flexible way of dealing with city-regions, i.e. making place-specific deals or giving specific treatment to some city-regions but not all (Netherlands, England, Portugal, Spain). Multi-level contracts for project financing between the state and city-regional authorities are used as steering mechanism in Norway (Hanssen 2021b), but also in France (including the région) and England. This steering mechanism is absent in Germany. These place-specific deals and arrangements are not in line with the new regionalism but rather represent a mix of more control of city-regions by upper-level governments and flexible cooperation. Certainly, these arrangements are easier to abolish if no longer wanted.

In other states, the metropolitan reform idea is still prevalent but implemented in a light way. The metropolitan reform model implies a strong metropolitan authority with its own competences, direct election of a council and own taxes. This model is not fully realised but still seen as an ideal in France, Italy and recent initiatives in Spain. However, the organisational autonomy (in terms of politics and financing) is not as high as the ideal model prescribes.

There are also differences between regional, unitary and federal states. In many states laws creating (or abolishing) city-regional authorities have to pass the national parliament (France, Denmark), the federal states level (Germany) or the government of regions (Spain) (the latter with a high degree of autonomy). In Italy, the national framework law required a concretisation by the regional governments which explains some of the variation. In Germany, only small changes and incremental adjustments happened over the last decade. In contrast we see much more dynamic in centralised and non-federal European countries. Still, each country has its own specific trajectory, and national framework conditions seem to matter a lot regarding the power and shape of metropolitan governance arrangements. The success of metropolitan governance and sometimes also the opportunity to create a strong institution depends on a consensus of local actors and the support of a shared strategy for territorial development as visible in often cited cases such as Barcelona. However, purely voluntary inter-municipal agreements have their limitations.

\section{Notes}

1 https://www.local.gov.uk/topics/devolution/devolution-online-hub/devolutionexplained/devolution-register (7 June 2021)

2 The Copenhagen Theatre Cooperation (Det Storkøbenhavnske Teaterfollesskab) was financed by the five members of the HUR as well as the central state (Henning 2001, 38). It was abolished in 2005. 


\section{4}

\section{References}

Andersen, H.T., Hansen, F. and Jørgensen, J. (2002) The fall and rise of metropolitan government in Copenhagen. GeoJournal, 58(1), 43-52. http://www.jstor.org/ stable/41147730

Área Metropolitana de Lisboa (AML) (2016) 40 anos poder local democrático. Metrópole - Revista da Área Metropolitana de Lisboa. Lisboa: AML.

Anttiroiko, A.-V. (2016) City-as-a-platform: The rise of participatory innovation platforms in Finnish cities. Sustainability, 8(922). DOI: 10.3390/su8090922

Balsas, C.J.L. (2017) When markets reset, will we regain? Planning lessons from across the Atlantic Ocean. Land Use Policy, 65(June), 78-92. DOI: 10.1016/j. landusepol.2017.03.033

Balsas, C.J.L. (2020) A study of Porto's polycentric metropolitan development and governance at the turn of the millennium. International Journal of Regional and Local History, 15(2), 131-145. DOI: 10.1080/20514530.2020.1835060

Barron, D.J. and Frug, G.E. (2005) Defensive localism: A view from the field. Journal of Law and Politics, 21, 261-291

Bourdin, S. and Torre, A. (2020) The territorial big bang: Which assessment about the territorial reform in France? European Planning Studies, 1-18. DOI: 10.1080/09654313.2020.1777943

Cardoso, R. and Meijers, E. (2021) Metropolisation: The winding road toward the citification of the region. Urban Geography, 42(1), 1-20. DOI: 10.1080/02723638.2020.1828558

ESPON Spima (2018) Final Report Annex II. Profiles of the Metropolitan Areas. Luxembourg: ESPON.

Faburel, G. (2018) Les métropoles barbares: Démondialiser la ville, désurbaniser la terre. Neuvy-en-Champagne: Passager clandestin.

Galland, D. and Enemark, S. (2015) The Danish national spatial planning framework: Fluctuating capacities of planning policies and institutions. In: Planning for States and Nation-States in the U.S. and Europe, Knaap, G.; Nedović-Budić, Z. and Carbonell, A. (eds.) Cambridge, MA: Lincoln Institute of Land Policy, pp. 339-380.

Geróházi, É. and Tosics, I. (2018) Addressing Metropolitan Challenges in Barcelona Metropolitan Area: Lessons from five European metropolitan areas: Amsterdam, Copenhagen, Greater Manchester, Stuttgart and Zürich. Barcelona: Àrea metropolitana de Barcelona

Hambleton, R. (2016) English devolution: Time for a radical rethink. Town and Country Planning: the Quarterly Review of the Town and Country Planning Association, 85(9), 350-352.

Hanssen, G.S. (2021a) Becoming urban: The emergence of an urban policy in rural Norway. In: The Modern Guide on National Urban Policies in Europe, Zimmermann, K. and Fedeli, V. (eds.) Cheltenham, UK: Edward Elgar, pp. 127-148.

Hanssen, G.S. (2021b) Core-city climate leadership in metropolitan contractual management agreements. Paper for the EURA conference 2021, Oslo Metropolitan University.

Henning, R. (2001) Regional Governance in the Nordic Capital Areas (Nordregio Working Paper No. 2001:8) Stockholm: Nordregio. 
Hildenbrand Scheid, A. (2017) Gobernanza y planificación territorial en las áreas metropolitanas: Análisis comparado de las experiencias recientes en Alemania y de su interés para la práctica en España. Publicaciones de la Universidad de Valencia.

Janssen-Jansen, L. (2011) From Amsterdam to Amsterdam metropolitan Area: A paradigm shift. International Planning Studies, 16(3), 257-272. DOI: 10.1080/ 13563475.2011.591145

Klok, P.-J., Sanders, M., Denters, B. and Boogers, M. (2018) Intermunicipal cooperation in the Netherlands: The costs and the effectiveness of polycentric regional governance. Public Administration Review, 78(4), 527-536. DOI: 10.1 111/puar.12931

Krukowska, J. and Lackowska, M. (2017) Metropolitan colours of Europeanization. Institutionalization of integrated territorial investment structures in the context of past cooperation in metropolitan regions. Raumforschung und Raumordnung, 75(3), 275-289. DOI: 10.1007/s13147-016-0447-y

Kübler, D. and Rochat, P. (2018) Fragmented governance and spatial equity in metropolitan areas: The role of intergovernmental cooperation and revenuesharing. Urban Affairs Review, 55(5), 1247-1279.

Lidström, A. and Schaap, L. (2018) The citizen in city-regions: Patterns and variations. Journal of Urban Affairs, 40(1), 1-12. DOI: 10.1080/07352166.2017.1355668

Lowndes, V. and Lempriere, M. (2018) Understanding variation in processes of institutional formation. Political Studies, 66(1), 226-244.

Medir, L., Magre, J. and Tomàs, M. (2018) Mayors' perceptions on local government reforms and decentralization in Spain. Revista Española de ciencia politica, 45(45), 129-155. DOI: 10.21308/recp.46.06

Mikula, L. and Kaczmarek, T. (2017) Metropolitan integration in Poland: the case of Poznan metropolis. International Planning Studies, 212(1), 30-43. DOI:10.10 80/13563475.2016.1256191

Miller, D., Nelles, J., Dougherty, G. and Rickabaugh, J. (2018) Discovering American Regionalism: An Introduction to Regional Intergovernmental Organizations (1st ed.) London: Routledge. DOI: 10.4324/9781351242653

Mouritzen, P.E. (2011) Denmark. In: Second Tier of Local Government in Europe: Provinces, Counties, Départements and Landkreise in Comparison, Heinelt, $\mathrm{H}$. and Bertrana, X. (eds.) London: Routledge, pp. 56-72

Oliveira, C. and Breda-Vázquez, I. (2011) Territorial governance in Portugal: Institutional change or institutional resilience? disP: The Planning Review, 47(186), 64-76. DOI: 10.1080/02513625.2011.10557145

Oliveira, C. and Breda-Vázquez, I. (2015) Beyond institutional change: The apparent transformations of Portuguese urban and territorial policies. Paper for the EURA conference 2015, in Sibiu.

Pereira, M. and Nunes da Silva, F. (2008) Modelos de ordenamento em confronto na área metropolitana de Lisboa: Cidade alargada ou recentragem metropolitana? cadernos metrópole, 20(sem. 2008), 107-123.

Raunio, M., Nordling, N., Ketola, T., Saarinen, J.P. and Heinikangas, A. (2016) 6Aika. Open Innovation Platforms: An Approach to City-Development. Handbook for Developers Tampere: University of Tampere; Tampere Region.

Rayle, L. and Zegras, C. (2013) The emergence of inter-municipal collaboration: Evidence from metropolitan planning in Portugal. European Planning Studies, 21(6), 867-889. DOI: 10.1080/09654313.2012.722932 


\section{6}

Rodríguez-Pose, A. (2009) Are city regions the answer? In: The Future of Regional Policy, Tomaney, J. (ed.) London: The Smith Institute, pp. 50-59.

Rosan, C.D. (2016) Governing the Fragmented Metropolis. Planning for Regional Sustainability Philadelphia, PA: University of Pennsylvania Press.

Schipper, D. and Gerrits, L. (2015) The Emergence of Metropolitan Governance: A coevolutionary analysis of the life-and-death cycles of metropolitan governance in the Amsterdam metropolitan region. Complexity, Governance and Networks, 1(2), 57-78. DOI: $10.7564 / 14-C G N 13$

Shaw, K. and Tewdwr-Jones, M. (2017) "Disorganised Devolution": Reshaping metropolitan governance in England in a period of austerity. Raumforschung und Raumordnung, 75(3), 211-224. DOI: 10.1007/s13147-016-0435-2

Spaans, M.; Zonneveld, W. and Stead, D. (2019) Governance and power in the metropolitan regions of the Randstad. Paper presented at the AESOP Conference 2019, IUAV Universita di Venezia.

Strebel, M.A. and Kübler, D. (2021) Citizens' attitudes towards local autonomy and inter-local cooperation: Evidence from Western Europe. Comparative European Politics, 19(2), 188-207.

Streeck, W. (2017) A new regime: The consolidation state. In: Reconfiguring European States in Crisis, King, D. and LeGalès, P. (eds.) Oxford: Oxford University Press, pp. 139-157.

Sykes, O. and Nurse, A. (2021) The scale of the century?: The new city regionalism in England and some experiences from Liverpool. European Planning Studies, 1-23. 27 May 2021. DOI: 10.1080/09654313.2021.1931044

Teles, F. (2016) Local Governance and Inter-Municipal Cooperation. London: Palgrave.

Tomàs, M. (2017a) Building narratives of city-regions: The case of Barcelona. In: Governing Cities through Regions: Canadian and European Perspectives, Hamel, P.; Keil, R.; Kipfer, S. and Boudreau, J.-A. (eds.) Waterloo, ON: Wilfrid Laurier University Press, pp. 319-335.

Tomàs, M. (2017b) Explaining metropolitan governance. The case of Spain. Raumforschung und Raumordnung, 75(3), 243-252. DOI: 10.1007/s13147016-0445-0

Website AMP I: http://portal.amp.pt/pt/4/territorio/\#FOCO_4 (accessed 15 November 2019).

Website AMP II: http://portal.amp.pt/pt/4/stats/\#FOCO_4 (accessed 15 November 2019).

Zimmermann, K. (2018) Politicising the regional scale? The Politics of Metropolitan Governance in in the three federal states Germany, Brazil and Canada. In: Politics and Conflict in Governance and Planning. Theory and Practice, Eraydin, A. and Frey, K. (eds.) Milton: Routledge, pp. 151-168 


\section{Annex}

Expert interviews for the case Nantes

\begin{tabular}{|c|c|c|c|}
\hline & Institution & Position & Date \\
\hline 1 & $\begin{array}{l}\text { Nantes Métropole and } \\
\text { municipality }\end{array}$ & $\begin{array}{l}\text { Vice-president of } \\
\text { métropole, mayor }\end{array}$ & 18.4.2018 \\
\hline 2 & Nantes Métropole & Head of department & 18.4.2018 \\
\hline 3 & $\begin{array}{l}\text { Pôle Métropolitain Nantes } \\
\text { Saint-Nazaire }\end{array}$ & Director & $\begin{array}{l}23.5 .2018 \text { (via } \\
\text { phone) }\end{array}$ \\
\hline 4 & $\begin{array}{l}\text { Pôle Métropolitain Nantes } \\
\text { Saint-Nazaire }\end{array}$ & Project manager & $\begin{array}{l}23.5 .2018 \text { (via } \\
\text { phone) }\end{array}$ \\
\hline 5 & $\begin{array}{l}\text { Conseil de Développement of } \\
\text { Nantes Métropole }\end{array}$ & General secretary & 19.4.2018 \\
\hline 6 & $\begin{array}{l}\text { Conseil de Développement } \\
\text { of Nantes Métropole and } \\
\text { Conseil de Développement of } \\
\text { a municipality }\end{array}$ & $\begin{array}{l}\text { Head of a working } \\
\text { group, President }\end{array}$ & 19.4.2018 \\
\hline 7 & $\begin{array}{l}\text { Société d'Aménagement de la } \\
\text { Métropole Ouest Atlantique } \\
\text { (SAMOA) }\end{array}$ & Director & 20.4.2018 \\
\hline 8 & $\begin{array}{l}\text { Agence d'Urbanisme de Nantes } \\
\text { (AURAN) }\end{array}$ & Head of division & 18.4.2018 \\
\hline 9 & Région Pays de la Loire & Head of division & 20.4.2018 \\
\hline 10 & Région Pays de la Loire & $\begin{array}{l}\text { Project manager } \\
\text { SRADDET }\end{array}$ & $\begin{array}{l}5.3 .2019 \text { (via } \\
\text { phone) }\end{array}$ \\
\hline 11 & $\begin{array}{l}\text { Institut de Géographie et } \\
\text { d'Aménagement Régional } \\
\text { de l'Université de Nantes } \\
\text { (IGARUN) }\end{array}$ & Academic & 19.4.2018 \\
\hline
\end{tabular}


Expert interviews for the case Lyon

\begin{tabular}{|c|c|c|c|}
\hline & Institution & Position & Date \\
\hline 1 & $\begin{array}{l}\text { Métropole Lyon and Ville de } \\
\text { Lyon }\end{array}$ & $\begin{array}{c}\text { Vice-president of métropole, } \\
\text { member of city council }\end{array}$ & 17.10.2018 \\
\hline 2 & $\begin{array}{l}\text { Métropole Lyon and } \\
\text { municipality }\end{array}$ & $\begin{array}{l}\text { Vice-president of métropole, } \\
\text { mayor }\end{array}$ & 16.10.2018 \\
\hline 3 & Planning association SEPAL & Director & 16.10.2018 \\
\hline 4 & Pôle Métropolitain & Director & 17.10.2018 \\
\hline 5 & $\begin{array}{l}\text { Conseil de Développement of } \\
\text { Métropole }\end{array}$ & Vice-president & 16.10.2018 \\
\hline 6 & Agence d'Urbanisme UrbaLyon & Project manager & 18.10.2018 \\
\hline 7 & Région Auvergne Rhône-Alpes & Head of division & 18.10.2018 \\
\hline 8 & $\begin{array}{l}\text { Institut d'Urbanisme de Lyon, } \\
\text { Université Lyon } 2\end{array}$ & Academic & 17.10.2018 \\
\hline
\end{tabular}

Expert interviews for the case Stuttgart

\begin{tabular}{llll}
\hline Institution & Position & Date \\
\hline 1 & Region Stuttgart & $\begin{array}{c}\text { Head of planning } \\
\text { department }\end{array}$ & 09.07 .2019 \\
2 & $\begin{array}{c}\text { Wirtschaftsförderung Region } \\
\text { Stuttgart GmbH }\end{array}$ & $\begin{array}{l}\text { Head of division } \\
\text { Regional planner }\end{array}$ & $\begin{array}{c}18.09 .2019 \text { (via } \\
\text { phone) }\end{array}$ \\
4 Cegionalverband Neckar- Alb & City of Stuttgart & $\begin{array}{c}\text { Head of planning } \\
\text { department }\end{array}$ & $\begin{array}{c}13.09 .2019 \\
5\end{array}$ City of Stuttgart \\
6 City of Remseck am Neckar & $\begin{array}{c}\text { Head of division } \\
\text { department }\end{array}$ & $\begin{array}{c}13.09 .2019 \\
29.10 .2019\end{array}$ \\
7 & City of Welzheim & $\begin{array}{c}\text { Mayor and member or } \\
\text { regional council }\end{array}$ & 30.10 .2019 \\
8 & City of Leinfelden-Echterdingen & $\begin{array}{c}\text { Head of Department, } \\
\text { County Councilor, } \\
\text { and County of Esslingen }\end{array}$ & $\begin{array}{c}\text { General secretary of KAF } \\
\text { phone) }\end{array}$ \\
\hline
\end{tabular}

Expert interviews for the case Frankfurt/Rhine-Main

\begin{tabular}{|c|c|c|c|}
\hline & Institution & Position & Date \\
\hline 1 & Regionalverband & Head of planning department & 11.03 .2020 \\
\hline 2 & Regionalverband & $\begin{array}{l}\text { Head of department regional } \\
\text { development }\end{array}$ & 10.06 .2020 \\
\hline 3 & City of Frankfurt am Main & Head of planning department & 07.05 .2020 \\
\hline 4 & City of Bad Homburg & Head of planning department & 08.10.2020 \\
\hline \multirow[t]{2}{*}{5} & Municipality of Raunheim & Mayor & 02.11 .2020 \\
\hline & & & (Continued) \\
\hline
\end{tabular}




\begin{tabular}{llll}
\hline Institution & Position & Date \\
\hline 6 & $\begin{array}{c}\text { Chamber of Commerce and } \\
\text { Industry Frankfurt am Main }\end{array}$ & $\begin{array}{c}\text { Head of department } \\
\text { Metropolitan }\end{array}$ \\
$\begin{array}{l}\text { Development + employee } \\
\text { City of Erlensee }\end{array}$ & 28.10 .2020 \\
\hline
\end{tabular}

Expert interviews for the case Florence

\begin{tabular}{|c|c|c|c|}
\hline & Institution & Position & Date \\
\hline 1 & $\begin{array}{l}\text { Municipality San Giovanni } \\
\text { Valdarno }\end{array}$ & Mayor & 08.10 .2018 \\
\hline 2 & $\begin{array}{l}\text { Regional government of } \\
\text { Tuscany }\end{array}$ & Two regional planners & 10.10.2018 \\
\hline 3 & $\begin{array}{l}\text { City of Florence / Città } \\
\text { Metropolitana of Florence }\end{array}$ & Segretario Generale & 09.10 .2018 \\
\hline 4 & Municipal union Mugello & Planner & 19.02.2019 \\
\hline 5 & City of Scandicci & $\begin{array}{l}\text { Mayor, head of planning } \\
\text { department, staff member }\end{array}$ & 09.10 .2018 \\
\hline 6 & City of Sesto Fiorentino & Head of planning department & 19.02.2019 \\
\hline 7 & $\begin{array}{l}\text { Città Metropolitana of } \\
\text { Florence }\end{array}$ & Head of planning department & 18.02 .2019 \\
\hline 8 & Università di Firenze & $\begin{array}{l}\text { Prof. for urban and regional } \\
\text { planning }\end{array}$ & $\begin{array}{l}09.10 .2018 \\
19.02 .2019\end{array}$ \\
\hline 9 & Università di Firenze & Prof. for public law & 21.06 .2021 \\
\hline
\end{tabular}

Expert interviews for the case Bologna

\begin{tabular}{|c|c|c|c|}
\hline & Institution & Position & Date \\
\hline 1 & Municipality of Minerbio & $\begin{array}{l}\text { Former mayor and city- } \\
\text { regional Councilor }\end{array}$ & 27.06.2019 \\
\hline 2 & $\begin{array}{l}\text { Regional government of Emilia } \\
\text { Romagna }\end{array}$ & $\begin{array}{l}\text { Head of regional } \\
\text { planning unit }\end{array}$ & 27.06.2019 \\
\hline 3 & City of Bologna & Head of planning department & 26.03.2019 \\
\hline 4 & City of Casalecchio di Reno & Head of planning department & 28.06.2019 \\
\hline 5 & Città Metropolitana of Bologna & Head of planning department & 26.03.2019 \\
\hline 6 & University of Bologna & $\begin{array}{l}\text { Prof. for law and public } \\
\text { administration }\end{array}$ & 25.03 .2019 \\
\hline 7 & University of Bologna & $\begin{array}{l}\text { Prof. for law and public } \\
\text { administration }\end{array}$ & 14.11.2019 \\
\hline
\end{tabular}




\section{Index}

Note: Page numbers in italics indicate figures, bold indicate tables and page numbers with " $\mathrm{n}$ " indicates the end notes in the text.

Accordi di Programma 151

Accordi Territoriali 151

Act on Metropolitan Associations (2015) 287

Agence d'Urbanisme de la région de Saint-Nazaire (ADDRN) 111n29

Agence d'Urbanisme de la Region Nantaise (AURAN) 68, 111n29

Agence d'Urbanisme de la Région Stéphanoise (EPURES) 111n29

Agence d'Urbanisme pour le développement de l'agglomération lyonnaise (UrbaLyon) 89, 96, 111n29 agglomeration 19, 20, 44, 63-64, $68,86,107,187,200,205,245$, 253, 263, 273, 277, 283, 288; attractiveness of 59; of BadenWürttemberg 225; of Lyon 70, 82, 84, 86, 101; of Nantes 53, 60; of north-western France 69; SaintÉtienne 87, 97, 98

Aguiar Mol, N. 93

aire métropolitaine 48, 81-82, 85, 105

aire urbaine 43, 63-64, 63, 81-82, 98, 107

Alto Reno Terme 141

Área Metropolitana de Barcelona (AMB) 281-282; see also Barcelona

Association for the Promotion of the Frankfurt Rhein/Main region 218

Association pour le developpement economique de la region lyonnaise (ADERLY) 72, 97-98

asymmetrical regionalism see differentiated regionalism austerity policies $6,8,11,25,281$; in France 52, 272, 289; in Italy 134, 154, 272, 289; in UK 283, 289

Autorita di ambiti territoriali ottimali (ATO) 135-136, 145, 146

Ayrault, Jean-Marc 52, 66, 104, $105,110 \mathrm{n} 13$

Baccetti, C. 120

Baden-Württemberg 194, 222, 225, 227-230, 233, 242, 245, 254, 256n13

Baldersheim, H. 11

Balladur commission 43

Ballungsraumaufgaben 210

Barcelona 280-281, 291, 293; definition of city-region 282

Barre, Raymond 72, 75, 93

Bassanini Acts (1997) 119, 120

Ben Mabrouk, T. 82

Bernard, Bruno 75, 78

BioRegion STERN 248

Blatter, J. 195

Bolgherini, S. 137

Bopp, Thomas 230, 250

Bundesinstitut für Bau-, Stadt- und Raumforschung (BBSR) 199

bureau $37,58,81$

Cabanne, Claude 64

Caen-Le Havre-Rouen 19

case studies: document analysis 24-26; interviews with experts 23-24; selection of 23

Charta Bologna 150 
città metropolitana 19, 21, 118-126, 126, 127, 266; functions and competences 130-133; homogeneous zones 137; institutional models for 128; legitimacy of 128-130

Città Metropolitana di Bologna 137-154; administration of 266; budget and staff 265 ; case of 124; compensation fund 152 ; coordination of public policies 147-153; councilors 140; Delrio Law in 139-140; expert interviews 299; vs. Firenze 175-176; forms of cooperation between municipalities 142-144, 143; functional profile 267; housing policy and urban regeneration 153; inter-institutional relationships 144-145; intermunicipal planning 137; local land use planning 268; mayor 139 , 140, 142; metropolitan railway system 148; metropolitan strategic plan (PSM) 149-151, 178n35; metropolitan territorial plan (PTM) 151-153; mobility policies $148-149$; polycentric development 138 ; regional law no. 21/2012 145-146; reintroduction of tram 149; socioeconomic development 147; spatial relations 145-147; strategic planning 269; Sustainable Urban Mobility Plan (SUMP) 133; tourism and rural development 147; tourism project 149; transport infrastructure 153

Città Metropolitana Firenze 154-172, 174; vs. Bologna 175-176; budget and staff 265; cooperation with CM Bologna 166; coordination of public policies 166-172; Delrio Law 156-157; environmental and nature conservation policies 158 ; forms of cooperation between municipalities, municipal unions and CM 158-159; functional profile 267 ; history of $155-156$; integrated metro ticket for 171 ; intercommunal land use planning below CM 166; inter-institutional relationships 159-160; inter-municipal planning and cooperation in 155-156; local land use planning 268; mobility plan 170-171; municipalities and municipal unions in 158-159, 160; Piana Fiorentina project 163-166,
164; population 156; regional rail transport 171; re-introduction of tram system in 171; spatial dimension 162-163; spatial relations 160-166; special funding 171-172; strategic plan 167-168, 269; territorial plan 168-170; see also Florence

city-regional governance: conceptual approaches for 12; in France 5; in Italy 5

Collomb, Francisque 75

Collomb, Gerard 74, 75, 77

Comitato Promotore 150

communauté d'agglomération (CA) 34,40

communauté de communes (CC) 34, 40 communauté urbaine (CU) 34, 40, $51-53,71,86$; key role of 72

Communaute Urbaine de Lyon (COURLY) 71, 72-73, 75, 83, 84, 93; transformation of 74

communautés de communes 39, 47, 85 communautés urbaines 18, 34, 51, 54 conférence métropolitaine 37, 60, 66 Conferenza di Copianificazione 169 Conferenza Metropolitana 124, 136, 140, 156, 157

Conferenza pianificazione territoriale dell'area 155

Confluence Museum 74

connectivity 9, 148, 223

conseil de développement 23, 37

conseil de la métropole 37

Consiglio 118, 157

consiglio di sviluppo 150

Consiglio Italiano per le Scienze Sociali 135

consolidation approaches, in metropolitan governance 10

Contrat de Développement Métropolitain (CDM) 54 contrat de réciprocité 37,68 Contrats Territoires-Région (CTR) 54 Covid-19 crisis 151

cross-country comparison: functions in multi-level system 267-271; ideas 271-273; institutions 262-267, 265; spatial relationships 273-275

Cultural Initiative Frankfurt/RhineMain 216-217

Cultural Region 216

"Daseinsvorsorge sichern" 200

DATAR 19 
decentralisation 3, 43; asymmetric 6; decentralised agencies 215; and Delrio Law 137; in Florence 173; in Frankfurt/Rhine-Main region 215; in Germany 267; in Italy 129-130, 174; by Länder governments 194; in Lombardy 175

Delrio Law 121, 124-126, 129, 132, 134, 137; in Bologna 139; direct election 129; in Florence 156-157

democracy 11, 25; in France 43, 273; in Italy 272; in Lyon 272-273; in Stuttgart 273

Denmark 284-286, 290; debates 285; decision-making 286; direct elections 285; financial resources 285; Greater Copenhagen Area 284-285; Greater Copenhagen Council 285; metropolitan authority 285-286; metropolitan governance 284; public transport 286; regional planning 286; social reproduction functions 286

Département Ain 84, 93

Département Isère 84, 93

Département Loire-Atlantique 53, 60, 62,67

Département Rhône 41, 74, 77, 84, 93, 266

départements $8,18,19,33,41,70$, 76, 84, 93, 95, 96, 101, 263, 267, 270,290

devolution 3, 118; in Italy 118; public policies 5; in UK 283

differentiated regionalism 120

digitalisation 4, 20, 21, 151, 158, 169, 196, 213, 215-216, 222

direct election, of metropolitan council 79-81, 80

directive territoriale d'amenagement (DTA) 48, 54; Lyon 87-92; Nantes

Saint-Nazaire 62

document analysis 24-26

Doucet, Gregory 75

Dugua, B. 86

Dutch Spatial Planning Act (2008) 278

EcoCité 50, 60, 67, 104

economic crisis 86, 122, 134

economic development 9; ADERLY agency 72, 97; advisory board for 150; in Denmark 285-286; in France 18, 38, 41-42, 52, 54-56, 72, 76, 89, 103, 105, 289; in Frankfurt/RhineMain region 222, 255; in Germany
208, 211, 217-218, 222, 226, 237, $238,240,248,268$; in Italy 122 , 131-134, 136, 143, 147, 158, 165, 193, 195, 197; Métropole de Lyon 75; municipal and regional 10-11; in Netherlands 278; in Poland 287; in Spain 281; in Stuttgart region 224, 255, 266

Economic Development Agency for the Region of Frankfurt/Rhine-Main 217, 256n11

Economic Initiative 208, 217, 218, 221 economisation 253

Emilia Romagna 138, 145, 147, 154, 175,177 n17; new spatial planning law of 151

environmental planning 119, 122, 132, 155, 163, 170, 174, 269

EPCI (Établissements publics de cooperation intercommunale) 18-19, 38, 43-44, 45, 48, 60-62, 70, 85, 91, $96,98,102$; responsibilities of 39 ; $v$ s. technical multi-purpose unions 34

Espace métropolitain Loire-Bretagne 69 EU structural funds (2014-2020) 133

"Europäische Metropolregion in Deutschland" 190

Europäische Metropolregion München (EMM) 193, 197

Europäische Metropolregion Stuttgart 225, 230, 245, 250-252

European metropolitan regions, in Germany 21, 189-193, 191, 195, 203, 245; ideas behind concept of 197-200

European Union see specific countries

Europeanisation 6, 8, 11

Federal Institute for Research on Building 199

federalism 7, 118, 129, 134; see also fiscal federalism

financial crisis (2008-2009) 2, 6, 11

"Firenze 2010: Associazione per il piano strategico dell'area fiorentina" 162

fiscal federalism 5, 8, 129, 134

Fiscal Federalism Act 125

Fondazione per la Ricerca e l'Innovazione (FRI) 168

Forum Region Stuttgart 238

France: adaptations and complementary measures 267; asymmetric treatment 292; case study 18-19; city-regional 
cooperation 269; city-regions 17 , 262-263; diversity 270; financial autonomy 264; human resources 266 ; impact of national role models 291-292; inter-municipal associations 5; inter-municipal cooperation 17-19; national reforms in 2; reterritorialisation in 6 ; second tier of local government 263; shift of functions 270; social reproduction functions 55; territorial cooperation 274; territorial reforms 271; see also cross-country comparison

France, city-regional governance in 33-49; coordination of public policies beyond métropole 65-70; Lyon 70-98; métropoles 36; metropolitan institutions 33-39; multi-scaled governance of Nantes 49-65; recent changes 98-109; redistributing responsibilities within multilayer system 39-42; regional plans 48; spatial relationships 44-49; territorial reforms 41-44

France, municipal groupings in: from 2007 to 202035 ; city-regions as 34; communauté d'agglomération 34; communauté de communes 34; communauté urbaine 34; in French 34; Metropole de Lyon 85-86; métropoles 34, 36; Nantes 52; responsibilities of 40

Frankfurter Paulskirche 220

FrankfurtRheinMain International Marketing of the Region 217

FrankfurtRheinMain International Office 218

Frankfurt/Rhine-Main region 203-220, 206; administration 266; budget and staff 264; coordination of public policies within and beyond planning authority 212-220; "council of the region" 209, 210; cultural policies 216-217; current structure 210; digitisation 215-216, 222; economic development 222; Economic Development Agency for 208; economic development and marketing 217-218; energy 220; expert interviews 298-299; federal state intervention 209; FRM 2030 project 218; functional profile 267; governance of 207; Hesse parliament elections 208; infrastructure planning 220; initiatives 211; institutional arrangement 205-211; local land use planning 268; masterplan of 2011 219; mobility 218-222; in multilevel system 214; networks and initiatives with participation of planning authority 221; new regional land use plan 215; organisation for economic cooperation 208; planning authority 254; private sector activities 207 ; regional land use planning 213-215; regional landscape park 215; regional planning and inter-municipal cooperation 205; spatial relations within the metropolitan region of 211-212, 254-255; strategic territorial development 221-222; vs. Stuttgart region 253-255; treaty on metropolitan region 220; voluntary collaboration 221

French Post 50

Fricke, C. 191

FRM 2030 project 218

functions: defined 8 ; dimension of 9 , 13; exemplary 9; fourfold definition 9 "The Future of Regional Policy" 288

Galland, D. 7

gateway-functions see connectivity Gemeinsame Landesplanung BerlinBrandenburg 196

Geppert, A. 86

German Trade Union Federation 210

Germany: amalgamated city-regions 16-17, 197, 262-263; asymmetric treatment 292; city-regional cooperation 269; collaborative arrangements 267; cultural/sports events 197; digitalisation 196; diversity 270; economy 253 ; election 253; emergence of multi-scaled arrangements 253; e-mobility 196; European metropolitan regions 189193, 191, 197-200, 202; evolving delimitation of metropolitan regions 202; federal states responsibility 194; Frankfurt/Rhine-Main region 203-220; Hamburg metropolitan region 195-197; impact of national role models 291-292; inter-municipal associations 5, 188, 252-253; inter-municipal cooperation 17 , 20-21; local land use planning 197; 
local self-government 263; map competitiveness in updated spatial vision 2016 192; metropolitan governance in 187-203; metropolitan institutions 187-194, 190; multiscaled governance 193-194; national spatial vision 198-199; new map of 199; planning law 208-209; planning regions for regional plans 204; polycentric metropolitan region 200; production functions 194-197; public-private partnership 197; regional authorities in 269; regional planning and mobility 194-197; representation of metropolitan regions in 201; shift of functions 270; social reproduction functions 195 ; spatial relationships 200-203; state governments 252; steady relevance of city-regions 252-255; Stuttgart 222-252; territorial cooperation 274; territorial reforms 188-189, 271-272; transport in 253; waste disposal 195-196; wastewater treatment 195-196; water supply 195-196; see also cross-country comparison

Gigabit region 215-216, 222

Gigabit Region Stuttgart GmbH (GRS) 238-240

Giunta regionale 118

globalisation 2, 6, 8, 42, 195, 198

Grand Lyon see Communaute Urbaine de Lyon (COURLY)

Greater Copenhagen Area 284-285

Greater Copenhagen Council 285

Green Party 75, 81, 99, 104, 209, 232

Hall, P.A. 11

Hamel, P. 4

Harrison, J. 7

Heinelt, H. 12

Hertzog, R. 39

Île de Nantes 50, 59-60, 98, 105, 106; planning process of 59

infrastructure planning 119, 122, 132, 220,222

innovation 2-5, 9, 38, 42, 105, 108, 250, 271, 292

INSEE (Institut national de la statistique et des etudes economiques) 63-64, 82

institutional reforms, in Italy 118-137 institutions: defined 10; dimension of 9, 13; and governance 9-11; see also specific types

Integrated Regional Spatial Planning and Landscape Plan 159

Integrated Territorial Investment (ITI) 287-288

inter-institutional conference 144, 145

inter-municipal cooperation: in Bologna 139, 175; in Denmark 286; in Emilia Romagna 139; forms of 143; in France 18-19, 34, 124; in Frankfurt/ Rhine-Main region 205; in Germany 20-21, 196, 217, 249, 252-253; in Italy 19-20, 123, 126-128; in Nantes 56-57; in Netherlands 279; of Nuovo Circondario Imolese 142; in Portugal 279; single-purpose 196; in Stuttgart region 225-226, 246-247; in Tuscany 166

Inter-SCoT dialogue: Lyon 88-91, 88, 90; Nantes 67-68, 87

international building exhibition (IBA) StadtRegion Stuttgart 2027 238-240

International Journal of Urban and Regional Research 3

internationalisation 6, 52, 72, 195

interviews, with experts 23-24

Istituto Regionale Programmazione Economica Toscana (IRPET) 168

Italy: administrative simplification 134; asymmetric treatment 292; austerity measures 137 ; central government 120; città metropolitana di Bologna 124-126, 126, 127, 137-155; city-regional cooperation 269 ; city-regions role in multilevel governance system 122-130; city-regions/metropolitan regions 17, 262-263; competitiveness 133-134; constitutional reform (2001) 118-119; Delrio Law 124-126; discourse on services of general interest 133-134; diversity 270; Firenze 154-172; impact of national role models 291-292; institutional reforms in 118-137; inter-municipal cooperation 19-20, 126-128; inter-municipal initiatives 124; local government system 17 , 120; metropolitan institutions 262; metropolitan policies 118-137; milestones in metropolitan policy 123; multi-level governance system in 
120, 122-130, 174; national reforms in 2; PeriMetro programme 172; planning system 135; PON Metro programme 171-172; provinces role in 120; public administration in 135-136; reterritorialisation in 6; second tier of local government 263; separation of powers 118-119; shift of functions 270; sources of income 129; spatial relationships 135-136; state defined in 2001 119; territorial and functional reforms 133-134; territorial reforms 126-128, 271272; two-tier urban planning system 121-122; union of municipalities $177 \mathrm{n} 7$; see also cross-country comparison

Jessop, B. 12

Jonas, A.E.G. 4

Jouve, B. 82

Kantor, P. 4, 14

Keil, R. 4

kommunale Zweckverbände 188

Kommunaler Arbeitskreis Fildern (KAF) 246-247

Kommunalverbund Niedersachsen Bremen e.V. 196

Kuhn, Fritz 232, 251

Kulturfonds Frankfurt Rhein-Main GmbH 216

"Laboratorio per l'Operatività del Piano Strategico Metropolitano" 168

Laboratorio Regional Design del Dipartimento di Architettura (Re-DLab) 168

Le Saout, R. 59

Lefebvre, Henri 12

Lempriere, M. 10

l'expérience métropolitaine lyonnaise 81

Lippi, A. 137

Lowndes, V. 10

Lyon 70, 81-82; administration of 266; budget and staff 265 ; coordination of public policies beyond métropole 87-98; expert interviews 298; high fragmentation of institutional perimeters 83-86; inhabitants 70; in multilevel system 84 ; perimeters for regional planning 86-87; pôle métropolitain as alternative to RUL
94-97; Region Urbaine de Lyon 92-94; regional planning 87-92, 88, 89; Saint-Étienne 97-98; spatial relations $81-87,82$; unité urbaine 81-82; see also Métropole de Lyon Lyon Villeurbanne 79

Masson, P. 59

MedienInitative Region Stuttgart 237

Memorandum of Understanding (MoU) 166

Mercier, Michel 74

Métropole de Lyon 71, 83; direct election of metropolitan council 79-81, 80; extensive functions of 75-77; inter-municipal cooperation and planning 71-73; production functions 75-76; social reproduction functions 76 ; special status fixed by national law 74-75; substantially enlarged administration 77-78 métropoles 19, 21, 24, 34, 36, 39, 40 ; coordination of public policies beyond 65-70; enlargement of 46; legal status of 43; map of 45 ; population 44 ; for social reproduction 43

Metropolitan Association of Upper Silesia and Dąbrowa Basin 287

Metropolitan Conference 129, 139, 140

Metropolitan Region Rotterdam The Hague (MRDH) 278

metropolitanisation 2-3, 5

Metropolticket 250-251, 251

Metropoolregio Amsterdam 278-279

Ministerkonferenz für Raumordnung (MKRO) 24, 25, 200

Modellprojekte der Raumordnung (MORO) 193, 255n2

Modernisation de l'action publique territoriale et d'affirmation des metropoles (MAPTAM) law 24, 25, 42, 43, 52-53, 74, 77; responsibilities of municipal groupings according to 40

Monti, Mario 121, 125

municipal councilors see conseil de la métropole

Nantes: budget and staff 264-266, 265; culture and sports 269; department 53; double leadership 56; economy 50; expert interviews 297; as harbor city 66; inter-SCoT area of Nantes 
63; layers of planning documents 62; metropolitan governance and planning 50; in multilevel system 61, 61; municipal grouping 52; overcoming boundaries 67-70; pôles de proximité 50; rules of collaborative governance 51-52

Nantes Métropole 51-60; from communauté urbaine to métropole 51-53; functions of 55-56; inter-municipal administration 56-57; in multilayer system 53-54; representation of municipal interests 58-59; SAMOA 59-60; territory of 60-62

Nantes Saint-Nazaire, pôle métropolitain 60, 65-67; aire urbaine 63-64; boundaries 64-65; institutional perimeters 60-63; space for regular exchange 67; spatial relations 60-65; unité urbaine 63-64; weaknesses of 68

national planning law: in Germany 197 , 208-209; in Italy 121, 122, 152

Netherlands 277-279; economic development 278; intermunicipal cooperation 279; mayors of 278; metropolitan government 279; national law 278; planning responsibilities 278; public transport 278

Network of European metropolitan regions and areas (METREX) 236

Noir, Michel 72, 75, 104

Norway 277, 284

Nuovo Circondario Imolese 140, 142

Ostrom, Vincent 10

Parnet, C. 73

Pavageau, Benoist 56

Perform, open online platform 218

PeriMETRO 172

Piana Fiorentina 18, 155, 160, 161, 162; project $163-166,164$

Piano di Commercio 151

Piano di Localizzazione delle Emittenti RadioTelevisive (PLERT) 151

Piano Intercomunale del Comprensorio Bolognese 137

Piano Regolatore Generale (PRG) 121

Piano Strategico Metropolitano 149-151, 167, 168, 267
Piano Territoriale di Coordinamento Provinciale (PTCP) 122, 132, 143, 147, 151, 170

Piano Territoriale Metropolitano (PTM) 145, 147, 151-153, 157, 160, 166, 167, 168-170, 176, 178n29, $178 \mathrm{n} 33$

plan d'aménagement et d'orientation générale (PADOG) 73, 86, 97

plan local d'urbanisme intercommunal (PLUi) 47, 76, 78, 100, 109, 110n27; legal possibility of 48

plan local d'urbanisme métropolitain (PLUm) 57, 59, 60, 62, 110n27

Poland 286-288; Act on Metropolitan Associations (2015) 287; cityregional cooperation 287; EU funding period 2014-2020 287; impact of national role models 292 ; institutionalisation 287; metropolitan governance 286-287

pôles de proximité 56, 57

pôles métropolitains 19, 37-39, 42; as alternative to RUL 94-97; creation of 44

pooling of staff 57

Portugal 279-280; law on public finances 280; metropolitan governance 279; municipalities 279-280; recent changes 280; supramunicipal services 280

positive catalogue 118 post-suburbanisation 13

Poznan Metropolis Association 287

Pradel, Louis 75

Progetti integrati territoriali (PIT) 132 , 159, 163, 165, 170

Progetto 80 (Project 80) 122

Programma operativo nazionale plurifondo Città metropolitane 2014-2020 (PON Metro) 133, 148, 154, 171-172, 175

programme for housing (PLH) 77

proximity, principle of 57

public administration science 12

public choice, in metropolitan governance 10

PUMS see Urban Sustainable Mobility Plan

Randstad Regio 277

re-urbanisation 13

Reforme des collectivites territoriales (RCT) law 24, 25, 37, 42, 83 
Regierungspräsidien 229

Regio Stuttgart Marketing- und

Tourismus GmbH 248-249

Region Hannover 196

Region Pays de la Loire 53, 54, 60, 69, 70; territorial conferences of 70

Region Urbaine de Lyon (RUL) 82, 86, 87, 92-97

Regional Development Programme 159

Regional Planning Association Untermain 205

Regional Planning Law (2014) 169, 170

regionalisation 3, 218; in Frankfurt/ Rhine-Main region 222; in Italy 118, 120; in Stuttgart region 225, 250

Regionalverband Ruhr 193, 196

Regionalverbände 21, 188, 190

Remstal Gartenschau 249

Renard, Jean 64

Rhein-Main-Verkehrsverbund (RMV) 210, 219-220, 222

Rimbert, Patrick 52

Rodrigues-Pose, Andres 288

Rolland, Johanna 52, 105, 110n13

Rose, L. 11

Rural Regional Development Plan 165

Sachsendreieck 200

Saint-Étienne 46, 70, 82, 84, 89, 93, 97-98

Salva Italia decree 134

SAMOA (Société d'Aménagement de la Métropole Ouest Atlantique) 50, 59-60, 66, 67, 98, 106

Savitch, H. 4, 14

schéma de cohérence territoriale (SCoT) 42, 47-48, 109n4; de l'agglomération lyonnaise 87; Nantes Saint-Nazaire 62; second generation of 67-68

schéma départemental de coopération intercommunale (SDCI) 47, 64, 85

SCoT see schéma de cohérence territoriale

Scott, A. J. 7

Sellers, J. 15

SIMAN (Syndicat intercommunal à vocation multiple) 51

SNCF (Société nationale des chemins de fer) 50

Social Democratic Party (SPD) 209

space, categories of 12

Spain 280-282; Área Metropolitana de Barcelona 281-282; austerity measures 281 ; impact of national role models 291-292; metropolitan governance 280-281; regional governments 280; social reproduction functions 281; spatial planning 281; strategic planning 281; transport 281 spatial relations 12-13, 13; Bologna 145-147; Firenze 160-166; in Germany 200-203; Lyon 81-87; Nantes Saint-Nazaire 60-65

Spending Review Act (2009) 135 sportello unico delle attività produttive (SUAP) 173

SRADDET (Schéma régional d'aménagement, de développement durable et d'égalité des territoires) 42, 48, 54; development of 69-70; Lyon 87-92

St-Leger-les-Vignes 58

Stuttgart 222-252, 223; administration 236-238, 266; budget plan 237, 264; culture and sports 269; delimitation of German regional plans 244; development agencies 237; direct election 264; economic actors 238; economy 224; emergence of unique governance model 225-227; European activities 236; evolving spatial definition of metropolitan region 245-246, 246; expert interviews 298; first regional plan 225-226; vs. Frankfurt/Rhine-Main region 253-255; functional profile 267; governance arrangement in 224, 225; head office 237-238; history of 222-223; infrastructure 240 ; institutional arrangement 225-240; institutional ideas 254; inter-municipal landscape planning 247; key principles for settlement development 247; Key projects (trade fair, Stuttgart 21, IBA 2027, Gigabit Region) 238-240; Kommunaler Arbeitskreis Fildern (KAF) 246-247; land consumption 224; land use conflicts 239; layers of planning documents 243; leadership conflicts 250; METREX 236; morphological and functional definitions 244-245; in multilevel system 241-244, 242; municipal councils of rural municipalities 241; planning regions 245-246; population 223-224; public policies 229; regional planning and inter-municipal 
cooperation 225-226; regional transport 250-251; relocation of trade fair 239; repartition 269; shareholdings of 234-235; singlepurpose associations 240; spatial relations within metropolitan region 241-247, 254-255; statistical data 224; Steering Committee 250; suburbanization 224; see also Verband Region Stuttgart (VRS) suburbanisation 2, 13, 138, 160, 224 sustainability goals (SDGs) 150 Sustainable Urban Mobility Plans (SUMP) 131-133, 148

symbolic power 5, 9

Syndicat d'Étude et de Programmation de l'Agglomération Lyonnaise (SEPAL) 73, 75

Syndicat Mixte du SCoT 60, 66

Tangentopoli crisis 120

Thery, Laurent 60

Tiebout, Charles 10

Tilly, C. 15

TPSN-framework 12, 212

The UK: combined authorities 283; growth strategy 283 ; impact of national role models 291-292; metropolitan governance 282-283; negotiations 283; policy collaboration 283

Umlandverband Frankfurt (UVF) 205-207; criticism of 207; mobility 218-219; responsibilities of 205-206

Unioni di comuni 121, 124, 128, 136; in CM Bologna 140-142, 141; in CM Firenze 159

unité urbaine 63-64, 81-82

Urban Sustainable Mobility Plan 148, 150, 153, 154, 170-171

Val de Saone 79

Verband Region Rhein-Neckar 196

Verband Region Stuttgart (VRS) 196, 223; administration 227,
229; agreement ÖPNV-Pakt 2025

227; capacity of self-government 227, 229; city-regional level 227; coordination of public policies beyond perimeter of 248-252; debates about extending regional authority 227; decision-making and leadership 230-232; disputes 227; election 231; environmental issues 229; Europäische Metropolregion 250-252; functions of 232-236; governance arrangement of 226; governance model of 248; head office 227; history of 230; housing policies 236; informal development strategy 226; institutional reforms 230; inter-municipal cooperation 249; large infrastructure projects 230; leadership conflicts 250; in multilevel system 227-230, 228; municipalities 227, 229-230; networks with variable geometries 248-249; production functions 232-233; public transport 229; public-private partnership 239; regional assembly 230-231; regional business development 229; regional planning 233; representative of city region 236; social reproduction functions 233; strong position of 226 ; today's regional authority 226-227; tourism 248

Verdichtungsräume 245

Walter-Rogg, M. 231

Ward, K.G. 4

welfare policies 4, 15, 33, 74, 118, 151

Wirtschaftsförderung Region Stuttgart $\mathrm{GmbH}$ (WRS) 229, 231, 232, 237-238, 240, 248, 249, 255

Working Party of Regional Associations 220

\section{Zimmermann, K. 12} zone omogenee $(\mathrm{ZO}) 129,130$, 136, 291 